\title{
The Diary of Heinrich Witt
}

\author{
Volume 8
}

\author{
Edited by
}

Ulrich Mücke

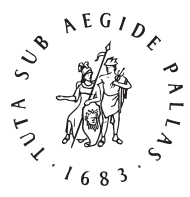

B R I L L

LEIDEN | BOSTON 


\section{[1] Volume VIII}

\section{Commenced in Lima on the $22^{\text {nd }}$ February 1879 by Mr. James Bryson. [2]}

\section{[_]ence in Lima.}

Friday, $27^{\text {st }}$ of January 1876 . I was up at an early hour, and in the water by half past seven. My wife was so well that she called her sudden improvement a real miracle. Before I left by the 9 train Garland and Enriqueta had arrived.

By 3 O'clock I was at the meeting of the Directors of the Insurance Company "Lima". Moscoso Melgar presided. The gerente Elizalde asked what was to be done with pagarées of various people which would shortly fall due. Peña said, "Get the money"; I replied, "That is more easily said than done, and after some talking we came to the natural conclusion to authorize the gerente to do the best he could in conjunction with the Director de Turno. Moscoso Melgar was chosen President, Michael Carrol Vice. Before we had risen I was called to the Banco de Lima. Lembcke presented himself, and laid before us the closing entries in the books, which could not be made without the authorization of the Directory. Several decidedly bad debts were written off to Profit and Loss account, to the debit of which account were likewise carried heavy sums for premiums paid and commissions charged by the London Bankers, and for charges - in Spanish "Gastos Generales" - not less a sum than S/59,00o of which more than $S / 10,000$ for patente and stamp duty, and $S / 9600$ to the two gerentes. The question was also raised whether shares in other banks, such as the Hipotecario, Perú, etc. which the Banco de Lima had been obliged to take at par, should be left standing at par, or be valued. I was decidedly for the latter course, and the majority agreed with me, but in order somewhat to diminish the fresh loss arising from this valuation, I had to give way so far as to value them some per cent above their actual market price. Then Lembcke left, and a long discussion began respecting dividend. We all agreed that in reality there was no profit, and that no dividend ought to be given, but that prudence obliged us to swerve a little from this straight road, and we finally resolved to give $41 / 2 \%$ for last year, Cucalon being of course opposed to it. Then Barrios presented a motion to the effect that we should not admit Lembcke's resignation. This again gave rise to a long debate and with the exception [3] of Cucalon and Bernales who voted for a provisiona[_] ger [...] who had left the room, the remainder, viz.: Castillo, Barrios, and Armero, Sagastabeyta and I, gave our adhesion to a motion of Aliaga, which merely said that as the relation between the bank and the Salitrera was now exactly the same as it had been all the time that Lembcke had been Gerente, our negotiations with the Salitrera were no motive for Lembcke's resignation and consequently he might withdraw it.

(C) KONINKLIJKE BRILL NV, LEIDEN, 2016 | DOI 10.1163/9789004307247_002 
Aliaga had first written "la renuncia se debe retirar", which was altered into "se puede". Now a few words containing a copy of this motion, approved by the majority, were addressed to Lembcke. It was 6 when we broke up. I took a quick and cold dinner; then Bryson came, and by 10 I was in bed.

Saturday, $22^{\text {nd }}$ of January 1876 . Once more up early. By the 8 O'clock train to Chorrillos, then a sea bath, breakfast, and back by 11 train. My wife was up: she felt well but extremely weak. In the evening whilst Bryson was reading to me, Enriqueta called me out, and told me that she had heard from the mother or her black servant girls, who had just come from Chorrillos, that my wife had had, in the course of the day, a dispute with the cook Achipe. I, afraid something might be wrong, went down by the 8.45 train. Enrique went with me. We found my wife, Doña Angela, and Felicita quietly conversing. There had certainly been a row with Achipe, but he had been pacified by Mariquita giving him not less than 8 Soles for tomorrow's marketing. When at 10.30 we retired to rest, her diarrhoea again came on, which we attributed to the annoyance which the dispute with Achipe had caused her.

Sunday, $23^{\text {rd }}$ of January. I had again to call Dr. Aranda, and his medicines, I feared mere palliatives, had a calming effect upon my wife, who however remained in bed the whole day. I bathed, after breakfast Alejandro talked with me for a long time. Then came Guillermo with his wife Eliza; and from 2.30 till 5 I made several calls: upon General Pezet and family, where nobody was in; upon Doña Fidelia, Minister La Torre's wife, who gave herself great airs; upon Jose Canevaro, where of course rocambor was being played; Garland, Anibal de La Torre, General Aparicio, Admiral Montero, made up the party [4] [...] with Don José, always very polite; his wife [...] gone to her sister Mercedes, whose husband, George Elster, just returned from Europe, was again suffering from asthma, a complaint of which he had been completely free whilst in Europe. With Macandrew and his lady I remained a long while. About fifteen minutes I was with Doña Isabel Elias. Ruden was not in. My last visit was to Corso, the brother of the vocal; this vocal and his wife, Dr. Pró, and the other Corso's wife were together. I stayed with them a considerable while, and was much pleased with them all. To our dinner, which was well cooked, but not so abundant as eight Soles warranted, sat down Guillermo and Eliza, Enrique, I, Doña Angela, and Felicita Velarde. The evening passed quickly enough. The young folks went out to hear the retreta - the military band - play on the malecon. I for the greater part was in my wife's bedroom. The temperature, though this was the first day of La Canicula (dog-days) was uncommonly cool. Alejandro sold to Manuel Candamo silver bars at S/14 the mark which, I was told, gave in Europe an exchange of 29 to $30 \mathrm{~d}$ the sol. 
Monday, $24^{\text {th }}$ of January. I was up at six, before seven in the water, and in Lima by half past nine. In the evening a meeting of the shareholders in the Banco de Lima took place. A good many were present; I was in the chair, to my right the secretary Pedro Bernales, to my left, John Gallagher. At 8 the proceedings commenced. The calling over of the names, and the reading of the last "acta" went off quietly. When I was on the point of stating in a few words, the object of this extraordinary meeting J. M. Cardenas intruded with a written motion of his own signed by many shareholders. What it was about I did not know. After a violent debate, which degenerated into a row, the motion was not admitted, because according to statutes in an extraordinary meeting only those points could be treated on, for the discussion of which the shareholders had been convened. I gave a short account of what we had done with the Salitrera "Esperanza", and after some detailed explanations given by Dr. Aranivar we passed to the second point: the resignation of the gerente Lembcke. The actas treating on his resignation and his letters were read to the shareholders and after a great deal of loud and violent [5] talking I proposed to the shareholders whether the [...] should be voted publicly or secretly, that is to say, whether each present should give his opinion, yes or no, by word of mouth or write it on a piece of paper. The majority in favor of the latter way of proceeding was no more than ten. I then asked the shareholders to give their votes in the manner agreed upon - whether they admitted Lembcke's resignation or not: two hundred and odd were for the affirmative, four hundred and odd were for the negative. Consequently I declared in a loud voice that Lembcke continued to be gerente of the Banco de Lima. It was eleven when we broke up, and Cardenas' affair was again left untouched. At home Garland and Enriqueta were in bed, but still awake. They had come in from Chorrillos, and told me that they considered my wife to be very unwell, and we decided to call in Dr. Middendorf. In the forenoon of this day the Supreme Court had voted unanimously that Schutte \& Co. had to pay to Francisco Garcia Calderon the remuneration of $S / 20,000$ offered by the former and refused by the latter. The Juez de $1^{\text {a }}$ Instancia had sentenced that this remuneration was to be $10 \%$ upon two hundred and odd thousand pounds sterling; amount paid by Balta's administration to Schutte \& Co., Guano Consignees to Germany, in cancelment of all their claims. The Superior Court had reduced the 10, to $4 \%$, and the Supreme Court brought it down to S/20,000. The Vocales were: Cossio, Muñoz, Alvarez, Manuel Cisneros, Arenas, Sanchez, and Alzamora. The President Vidaurre and Ribeyro had not voted. Felicitations came in from all sides.

Tuesday, $25^{\text {th }}$ of January 1876 . By seven I was with Dr. Middendorf who promised to go down to Chorrillos by the 10 train. Enriqueta and I went at 
eight. My wife was certainly not well. I had time to bathe. Middendorf came, breakfasted with us, and after a close investigation of the symptoms of my wife's illness, he merely prescribed a very light opening medicine. I returned to town by the 1 O'clock train and sent in to the Gerentes of the Banco de Lima my resignation of the post of Director of the bank, in the following terms: [6]

[...] Banco de Lima

Señores Gerentes.

Tengan Uds. la bondad de poner en conocimiento de los Señores Directores de ese Banco como tambien de los accionistas en general, que desde el dia de hoy hago renuncia del cargo de Director que me fué confiado al fundarse el Banco.

Sirvanse Uds. al mismo tiempo manifestar a los Señores que fueron mis Colegas, mis mas sinceros agradecimientos por la indulgencia y amistad que me han dispensado durante el tiempo que hemos trabajado juntos.

Me suscribo de Uds. con la mayor consideracion, etc.

My reason for writing this letter were manifold; firstly, the bad state of the affairs of the bank which I feared would not be able to extricate itself from its present difficulties; secondly, the disapproval by the shareholders of a step taken by the Directory: We accepted Lembcke's resignation, and they did not; and thirdly, the conviction that Lembcke, now considering himself indispensable, would become insupportable, and still more overbearing than hitherto. Enriqueta, who had again been in Chorrillos, told me in the evening that the opening medicine had had its desired effect, and that her mother was decidedly better, though very weak.

Wednesday, $26^{\text {th }}$ of January 1876 . I was again up by six; came too late for the 8 train, and together with Middendorf went down at 10. He was satisfied with my wife's state of health, and prescribed a tepid bath with bran which she should take at about two. Enriqueta arrived with the little ones, and I after having taken a bath returned per train to Lima, where I had to attend to the captain of a Danish vessel, the "Conrad", arrived from Chile with grain. For nearly eighteen months no Danish vessel had made her appearance in the port of Callao. At 3.30 I was in the Chorrillos terminus, where Dr. Middendorf, Juan, and Ricardo were already waiting for my wife, whom on her arrival Middendorf and I assisted to a coach, in which we drove to our house. She was extremely weak, and went to bed without loss of time. In [7] In the evening however she managed to [...] of her friends who gathered round her bed. We intended to remain only a short time in Lima, and then to return to Chorrillos, where in the meanwhile Angela Villena with the cook and servant Serapio kept our rancho open.

Thursday, $27^{\text {th }}$ ofJanuary 1876 . Mariquita had passed a very bad night; however the diarrhea was gone, and Dr. Middendorf now prescribed some tonic pills. I 
went to La Merced to be present at the exequies of Manuel Ferreyros, whose corpse his brother Carlos had brought with him from Puno.

The remainder of the day I spent quietly.

Friday, $28^{\text {th }}$ of January. I went to Chorrillos by the 8 train and took my usual bath. The two ladies Angela and Josefa seemed well pleased. Achipe, to whom I paid his weekly wages, they said was behaving admirably; for two Soles daily he found them breakfast and dinner. I breakfasted with them and returned by the 11 train. Dr. Middendorf said that my wife's pulse was strong, but she still felt very weak. At 2.30 I entered the Bolsa just at the moment that the shareholders in the South American Insurance Company took their seats. Alexander Ruden presided. Calixto Pfeiffer was the gerente. The acta of last meeting was read, then the memoria, which showed a dividend of $50 \%$. Both documents were approved. Then Macandrew made a motion to pay a remuneration to the Directors of S/500o for the year 1875. Leuthold of Canevaro \& Co. was the first who spoke, and said he was opposed to a grant for the preceding year, but not to a remuneration for the future. I said I had always been averse to remunerate any Directors, that it had not been the custom in Lima that the National Bank had been the only one which made an exception, and that I persisted in my idea. Many others spoke, and the remuneration for last year was negatived almost unanimously. I believe Carlos Elizalde was the only one in its favor. I then rose, and quietly left, for I had the conviction that the remuneration for the future would be moved and carried, and I did not like to be the only one in the opposition. Riva Agüero embarked this day for Europe [8] [...] the Courts of Paris and Brussels.

Saturday, $29^{\text {th }}$ of January. My wife was considerably better. I received from the South American Insurance Company my dividend of $50 \%$ say $S / 800$. In the Banco Hipotecario Oyague, Jimenez, Aliaga, and I, with the two gerentes were assembled at somewhat past four. Only two points of importance were discussed; the one, whether the $5 \%$ to be paid to the shareholders in Cedulas should be given at par (this was the opinion of Jimenez and myself) or at $75 \%$ which Oyague insisted upon. With him sided Aliaga. I then withdrew my opposition, though, as I said, reluctantly and against my conviction. Jimenez said nothing. Then Garland, Gallagher having left for Chorrillos, read aloud part of the informe drawn out by the lawyer Forrero, which showed that the three gerentes, Riva Agüero, Garcia Calderon, and Escudero, had respectively calculated their $5 \%$ commission upon the gross gains, whilst at all events the $10 \%$ interest to the shareholders should have been deducted from the profits before they made this charge. This, if I was not wrong in my calculation, made a difference of between forty and fifty thousand Soles taken out by them more than they ought to have done. Jimenez, Aliaga and I opined that we should sue 
them for this surplus, because, though the result of the suit might be doubtful, our duty towards the shareholders demanded our doing so. Oyague thought we ought not to touch it because we had already sufficient law-suits on our hands. It was resolved to leave it to the decision of the shareholders but to give our respective opinion should it be asked for. In the evening when Bryson was gone I was with my wife till we retired to rest. At 9 she felt very unwell and feared that her end was near. She recovered afterwards. Enriqueta had a jowl killed, and gave her the broth at about eleven O'clock. She lay down on the sofa in our room half dressed. Also the black women Aurelia and Virginia were at hand the whole night.

Sunday, $30^{\text {th }}$ of January. This morning my wife felt again somewhat better. Dr. Middendorf was of opinion that her debility was very great, and that it would take a very long time for her to recover her strength. Numerous visitors came in and took up [9] much of Enriqueta's time.

Within the last few days Pardo had given a decree in [...] of which nearly all the employees in the Callao Custom House had been turned off, and new ones come in. Instead of one "administrador" as hitherto, there was now a board of five Directors. The revenue of the Callao Custom House had fallen off in an extraordinary manner which arose mainly from the great diminution of imports. I was told that its receipts were now equal to those of 1839. I remained at home the whole day. When Bryson was gone at 2 O'clock I had to receive visitors; and after dinner, always taken at Enriqueta's, I, some of the Velardes, Enriqueta, and Eliza were in my wife's bedroom. Enriqueta passed the night on the sofa. Our old deaf black servant Peta made her reappearance to my wife's great joy.

Monday, $33^{\text {st }}$ of January 1876. By the 8 train I went to Chorrillos, and gave orders to Doña Angela, Felicita and the servant Serapio to get everything ready for our return to Lima on the following day because there was very little probability that my wife would shortly recover so far as to be able to remove to Chorrillos.

I bathed and breakfasted, which over Serapio called my attention to the low mud wall which enclosed my property towards the sea side, built upon the loose ground of the cliff; it had in course of time given way a little, and a rent has become visible. Our next door neighbour, Doña Jancinta Sotomayor, with whom since the lawsuit we had not been on speaking terms, was very friendly towards me, allowed me to pass over her yard in order to have a better look at the wall, and even called a bricklayer who was at work for her. To him I pointed out what was to be done and agreed to pay him $\mathrm{S} / 45$ for making the necessary repairs. 
My wife continued beyond measure weak. About 9 or 10 p.m. she was again very unwell, nearly as bad as on Saturday. We sent for the Doctor who strictly prohibited any visitors coming near her. Their conversation, he said, caused her excitement, and then came the reaction. The principal enemy which she had to overcome [10] [...] Enriqueta did everthing, and attended and nursed [_] mother in a wonderful manner. She again slept on the sofa.

Tuesday, ${ }^{\text {st }}$ of February 1876. My wife continued as weak as ever. Middendorf came and was satisfied with the pulse. By the 12 train I went to Chorrillos, and found almost everything packed up, and the inmates ready to start. Something or other however still remained to be done, so that I had no time to bathe. All being shut up and locked, by the train of 2.45 we returned to Lima; we, that is to say, Doña Angela, Felicita Velarde, and I, the servant Serapio, and Isabel, Doña Angela's domestic. Achipe had come the previous day. To my great surprise I found my wife much better than we had anticipated. At 8 p.m. there was a numerous meeting of the shareholders of the Chilete Mining Company, J. P. Escobar President, Malinowski and Derteano, Directors. I sat next Derteano; next to me Rufino Echenique, then Ford, who seemed to be in the wind, Ruden, Oyague, Bryce, Maître of Gautreau's house, formerly Thos. Lachambre \& Co., Polis of F. S. Isaac \& Co., Leuthold of Canevaro's, and several more. Escobar, after the last acta was read and approved, stated that to put up the machinery, more than $\mathrm{S} / 100,000$ were required, as per estimate made by White \& Co., that the Company owed some other amounts, and that at least S/120,00o were wanted to carry on the business. Ford inculpated the Directory, with justice, for not having presented their accounts on $30^{\text {th }} \mathrm{June}$, as the statutes prescribed; and secondly, that last time the Directory had asked for S/6o,ooo and had assured the shareholders that this would suffice. Now they asked for $\mathrm{S} / \mathbf{1 2 0 , 0 0 0}$ more, and who knew, he said, whether these being spent they would not make fresh calls upon the shareholders. The Directors excused themselves with their ignorance, with erroneous information etc., assured us that they had done the best they could, and even requested the shareholders to pass a vote of censure so that they in a body might throw up the direction of the company. These discussions took a long time, without leading to any result. Then Escobar made known that he entertained great hopes to come to an understanding with a mercantile establishment, which was willing, according to him, to advance the $S / 120,000$ required, at $1 \%$ [11] monthly interest, on condition to be repaid for [...] of the proceeds to be calculated at $40 \mathrm{~d}$ the sol, and asked whether [_] shareholders would authorize the Directory to make such an arrangement, they giving of course to the merchant every possible security. Polis moved that before this could be done it would be advisable that the shareholders should 
have a complete and correct idea of how the affair stood. Before all these details could be given, four or six weeks would elapse, and consequently I, considering that such an arrangement as that proposed, if it could be carried out, would be the only means to save the money already laid out, voted with the majority. I learned that one quintal of silver ore yielding from 45 to 50 marks the cajon of quintals, the cost of which on board, I was not told, had on an average netted in England $£ /$. . It was eleven when I came home, where I found Enriqueta, Guillermo, and his wife Eliza taking their tea. My wife was pretty well.

Wednesday, $2^{\text {nd }}$ of February. Candlemas. My wife rose from her bed. Enriqueta read to us Juan's letter from Nizza, written towards the end of December. He repeated that the circumstances of C. W. Schutte were distressing; his house in Paris had cost him fcs 1,500,000, that he had now necessarily to sell it, and that the highest offer hitherto made had been one million. Juan in Nizza had withdrawn from all society and had reduced his expenses, everything included, to 20 francs daily. To Dreyfus he still owed seventy thousand francs.

I went to see Don Juan Bazo in the house of the widow Doña Mariquita Lastre. He was very sad, and well might he be so: he had lost his wife Irene, of whom he was extremely fond, and his fortune into the bargain, owing mainly, I believe, to the failure of his brother-in-law Gonzales. He told me that Schutte's losses came to seven million francs, and I verily believed that after he had paid everything of his fortune, which when he left Perú in 1868 did in my opinion not fall short of two million pesos, only his shares in the Lima Gas Company, S/200,00o and S/60,000 paid up capital on his 120 shares in the Banco del Perú, remained to him. I was by myself with Bazo nearly an hour and rose when Aurelio Garcia, Minister of the Interior, entered. I also called upon Julia Cavencenia who, notwithstanding her pretended intimacy with [12] [...] me nothing certain of the stat[_] of my law-suit. Towards evening my wife again felt worse. In our corredor a numerous tertulia remained together till eleven O'clock.

Thursday, $3^{\text {rd }}$ of February. We determined to give up the two inner rooms, which I occupied, to Doña Angela Villena, in order that she might always be at hand when my wife required her services. Consequently I again removed to my old room, the windows of which look out upon the ayres of Leyva's house, which were the bone of contention between him and me.

There was a meeting of the shareholders of the Banco Nacional at which I attended. Derteano presided, and Echenique, one of the Gerentes, read a long, but very interesting account of the many negotiations, and final contract with the Supreme Government, the particulars of which have in due time been given in this my diary. The "memoria" was short; $\mathrm{S} / 100,000$ had been written off to a new reserve account, and this being done, the remainder was just sufficient 
to pay to the shareholders $9 \%$ upon the paid up capital. Three Directors who went out by lot were reelected: Ford, Westphal, and Meiggs. My wife was much better.

Friday, $4^{\text {th }}$ of February 1876 . I was busy removing to my room and assisted by Bryson re-arranging my library, which was a troublesome job. At 1.30 I went to the insurance Coy. "Lima". Present were: Moscoso Melgar, President; Carlos Elizalde, Gerente; Robertson Chavez, Gil and I, Directors. Elizalde made known that the company had lost the suit against the widow of Abril who claimed as her property the Banco de Lima shares which Mazzini had placed in the company's hands as security for a loan of $S / 14,000$ which were now a loss to the company, and had to be written off to the debit of reserve fund. By the wreck of the German steamer "Karnac" in the Straits of Magellan the company lost $\mathrm{S} / 75^{0}$; and $\mathrm{S} / 125$ owing to a strange accident in Callao. In the house of a brother of Elizalde insured in the company, a servant, if I understood rightly a Chinese, had made an attempt to blow up the house, by throwing a torpedo, or something similar under the staircase. It exploded, and did some injury, which however the party insured only valued at the said S/125.

Saturday, $5^{\text {th }}$ of February 1876 . The Directors of the Banco Hipotecario [13] except Mendoza, met at 4 O'clock; nothing of [...] was transacted. My wife was again worse.

Sunday, $6^{\text {th }}$ of February 1876. Garland told me that Middendorf was desirous to call in another medical man; he seemed to be at a loss how to impart strength to my wife's system.

After Bryson had read to me as usual I went by the 1.30 train to Chorrillos, accompanied by the Servant Serapio. Our object was to examine the bricklayer's work spoken of on the $31^{\text {st }}$ ulto. It was not yet finished. I had time to take a bath, and returned by the 4.15 train. In Lima I called upon Mrs. Henry, who with her husband and children had returned from Chile a few days back. Mr. Pinto was with her, and she told us that though her husband believed himself to be quite well, she herself was not of that opinion, and she expressed the regret that they had not prolonged their stay in Chile. They had passed a few days in Arequipa, where however the verified air had not at all suited the asthmatic disposition of Mr. Henry. J. F. Johnson had once more come out from England on a visit, and had been very ill of dysentery in Arequipa. At home I found my wife pretty strong, and she continued so the whole day. Enriqueta again passed the night lying on the sofa in her bedroom.

Monday, $7^{\text {th }}$ of February. A very quiet day. My wife's health improved a little, owing I believe to some pills containing musk and quinine, prescribed by the Doctor. In the Supreme Court Garland for C. W. Schutte lost the suit carried on against the latter by a Bolivian called Zavala, defended here by the lawyer 
Ramon Ribeyro. Only Gervacio Alvarez voted for Garland. Many many years back Schutte made a contract with old lldefonso Villamil, for a quantity of bark, upon which he made him some advances. Villamil did not fulfil his part of the contract, and did not return the money he had received. Schutte dispatched J. F. Johnson to La Paz to recover the debt. Villamil gave in payment an estate purchased by him some years previously in a public sale; this estate Johnson sold to Zavala. After a lapse of years some persons, minors at the time when Villamil made the purchase of the estate, commenced a suit against Zavala, because at the time of the sale to Villamil, irregularities had occurred arising, I believe, mostly from their not having been of age at the time. In the Bolivian Courts of Justice Zavala was condemned to return [14] [...], and he now made his suit against Schu[_] having sold him a property which was not legally his. The amount demanded came with interest to about S/30,000.

Tuesday, $8^{\text {th }}$ of February 1876 . By the 8 train I once more went with Serapio to Chorrillos to have a look at the mended wall, which I thought would now stand for some years. I took a bath, and was back in Lima by twelve. At 2.30 the shareholders of the South American Insurance Company again assembled. Last time after I was gone it had been resolved that to the seven directors a remuneration of $10 \%$ should be allowed annually upon the "gananciales liquidas repartibles". After the last acta had been read I said that I supposed the meaning had been that before the repartition of $10 \%$ were made, interest of $9 \%$ on the paid up capital of $\$ 200,000$ should be deducted in favor of the shareholders. This, I understood from all sides, had by no means been the intention, whereupon, before I could make my motion, it had first to be determined whether the resolution taken last time should be reconsidered; then I moved this reconsideration, which was negatived by all present, except Henry and myself. I then left the room and went to the Banco Hipotecario, where I found Oyague, Mendoza, Jimenez, Dr. Forero, the two gerentes, and Jose Canevaro who was on his legs proposing to the Directory the purchase of a considerable debt due to the bank by the Monteros. When he was gone we resolved to cede to him the penal interest of $3 \%$ monthly, but not the common interest of $1 \%$. If he would engage to pay this interest, and the capital we were quite ready to allow him some short time for making the payment. My wife was up several hours in the course of the day. Enriqueta slept this night in her own bedroom. I received a letter from Pedro Bernales, secretary of the Banco de Lima, in which he informed me that on Saturday last my renunciation had not been admitted by the shareholders. Sagastabeytia assured me that all had been unanimous. Dr. Middendorf said that at present he considered my wife out of danger, but that three or four days ago he had felt very uneasy, because 
then, though the pulse still beat pretty strong, the weakness was increasing from day to day. [15]

Wednesday, $9^{\text {th }}$ of February 1876. A very busy day. [...] other things I paid to Dreyfus S/50oo on account of Juan, and answered Pedro Bernales letter saying that I submitted to the decision of the shareholders. Both his letter and the copy of my answer go affixed in appendix under $\mathrm{N}^{\circ \mathrm{s}} 1$ and 2 . At a later hour I together with Oyague, Mathison, Garland and the Gerente Marriott was for some time in the office of the Gas Company. The letters received from Prentice were of interest; according to him hitherto the making of gas out of petroleum had nowhere succeeded, but he was confident that some day or other a discovery would be made to make this article available. I left at four, and hastened to the justice hall where I learned that my suit against Leyva was not yet decided: thence to Dr. Domingo Mendoza, who was not in and to Dr. Corso, who was with his family in Chorrillos, and thus all my running about was fruitless. My wife was up two or three hours in the course of the day.

Thursday, $10^{\text {th }}$ of February. At 10 I was at Dr. Domingo Mendoza's and had to wait for him till near eleven; he was very friendly, and promised to do his best to have my case decided either this or the following day, but how he was inclined I could not discover. Basagoytia wrote a few words to Dr. Gorzo to the same effect. Dr. Palacios told me that he had been with the vocal Galindo, who, he said, was leaning towards Leyva; Rafael Velarde affirmed the contrary. I sold my S/58,ooo Deuda Interna to Alejandro Cox at 59\%; Cedulas del Banco Hipotecario were up to $72 \%$, premium on coined silver to $54 \%$.

Friday, $17^{\text {th }}$ of February. At about two the shareholders of the Banco del Perú met in the locality of this bank. Ruden presided. The names were called over, and the last acta and the memoria for last year were read by Escobar. The Directory proposed to pay $9 \%$ to the shareholders, to which Ruden added that the shareholders should bear in mind "que la cartera no se habia castigado". After a short silence I was the first to speak, and said that no deduction being made for the depreciation of bad or doubtful debts, it would be more prudent to give a smaller dividend. Various shareholders who spoke took the contrary view. Calderoni, one of the Directors, observed that between four and five hundred thousand Soles stood already to the credit of reserve fund to meet a [16] [...], also Villemars, the Belgian, late manager of [_] Sociedad Maritima, spoke in favor of the repartition of $9 \%$; another observed that the interest of $9 \%$ upon the capital had to be paid to the shareholders, to which I replied that if actually there was no gain, no interest could [_] paid, even though the estatutes ordered this payment. After these discussions the memoria was aporoved as it stood, and the $9 \%$ would be distributed. Next was read a written 
motion of a French carpenter Fabre, who accused the Directory of secret and underhand dealings, and demanded that a commission should be named to investigate the affairs of the bank. A shout of indignation rose from all sides, and this motion was unanimously disapproved. Finally came the election of seven new Directors. I had no time to remain any longer, gave my verbal power to Polis head of the house of F. S. Isaac \& Co., and hastened to the Justice Hall, where the secretary of the second chamber of the Superior Court received me with the word "revocaron", which means that the sentence given in my favor by the Juez de $1^{a}$ Instancia Puente Arnao, had been annulled by the Superior Court, whose members, as said more than once, were: Corso, Mendoza, and Galindo. Dr. Palacios read to me the sentence, which was founded upon the circumstance that on the testament of El Conde de Querejazú, the Ayres of Leyva's house were not mentioned as being his property, and I much feared that this would be a weighty argument against me in the Supreme Court, to which I intended to appeal. Thence I hastened to the Banco Hipotecario, where all were assembled except Jímenez. Oyague read to us what he as President in the name of the Directory intended to say to the shareholders in the meeting of next Tuesday. We approved what he had written, and I for my part thought it very well done. My wife was up for a great part of the day. Late in the evening I went for an hour or so to Basagoytia's to bid them good by as on the following day they intended to leave for Ancon. The papers gave the news that on board of the "Tagus", run down in the port of Colon, and again raised not less than 700,00o Soles in silver had been found which it was supposed had been embarked in Callao. Evil tongues said that Albarracin had been the shipper, and that Manuel Pardo was the owner. In Callao investigations were being $[17]$ made to discover the truth.

Saturday, $12^{\text {th }}$ of February 1876 . Nothing occurred worth mentioning.

Sunday, $13^{\text {th }}$. By the two train I went to Chorrillos; before taking my bath I looked in at Doña Juana Tirado's, wife of General Pezet. With her were Charles Wheelock of the house of Duncan Fox \& Co., young Basadre, just returned from Paris, son of the well known Don Modesto, at present employed by the Banco Nacional to look after their interest in the province of Tarapacá, and Dr. Ladislao Rospigliosi, son-in-law of Doña Paula Benavides. Wheelock related he had heard that the instructions received by Riva-Agüero from Pardo, were to offer to the holders of the Anglo Peruvian Bonds the reduction of the capital to $25 \%$, and Wheelock added that as the greater part of the present owners of the bonds had bought them at less than $25 \%$, they would be the gainers by such an arrangement. I did not believe in such an infamous plan. Garland was the whole day in Chorrillos, dined with Oyague and did not come home much 
before midnight. Maria and Corina, accompanied by Eliza, Guillermo's wife, were at a dance given in the college by Madame Beausejour, with whom Doña Catalina, a north American lady, who gave private lessons to Maria, was the first teacher. Guillermo kept us company. My wife had an indigestion, vomited and was again very unwell.

Monday, $14^{\text {th }}$ of February 1876. At 1 O'clock I went to a meeting of the Directors of the Insurance Company Lima. Present were Moscoso Melgar, who presided, Elizalde, Gerente, Chavez, Gil, Robertson, and I. The house of Gibbs had proposed to insure the wool establishment in Arequipa valued at $\mathrm{S} / 5^{0,000}$, at a premium of $1 \%$ annually. Though we all considered it a good risk, we refused it, in order not to break through the rules hitherto observed, which were, not to insure in any other department than that of Lima, because were we to do so, we should require an agent there, who would cause an extra expense. The Banco de Lima wanted a loan of $S / 50,000$ giving as security $S / 83,000$ in the United States Guano Coy's shares. The matter was discussed, and the loan granted. José Vicente Oyague had called together the Directors of the Banco Hipotecario. The only thing we did was to call over the list of shareholders, and to fix upon the names of those whom we [18] [...] rors. My wife's health was improving, though weakness continued.

Tuesday, $15^{\text {th }}$ of February 1876 . For the last few years there had been hardly any alteration in my daily occupations. The following minute account of this day may give an idea of how I was in the habit of spending my time on week days. I rose about half past seven, then, unable as I was to occupy myself, walked about in the corredor, sat down, made an attempt to calculate in my head, went to my wife's bedside, conversed with her, and so the time passed away till nine, when Ricardo read to me for an hour, an interesting work in German, called "The Two Imperial Crowns". It treats on the political events of 1868, and is the continuation of "Crown and Sceptre" and "Mines and Counter Mines" already read to me. Somewhat past ten Doña Angela Villena and I, sat down to breakfast. My wife took hers in bed. Between half past ten and eleven Bryson came. We occupied ourselves with remodelling my old diaries and from one of the Eclectic Magazines he read to me part of a pretty article on the campaign of 1864 in Georgia, between the Federals commanded by Sherman and the Confederates commanded first by Jackson, called "Stonewall Jackson", also "the Cunctator", and then by Hood, bold in the extreme, the very reverse of the former. At 1 I went into the street. I met Jose Basagoytia, who agreed with me that the best thing I could do was to endeavour to purchase Leyva's house, and he offered to be the mediator, but we were both of opinion that it would be prudent to let a few weeks pass by before making the attempt. I next 
looked in at the South American Insurance Company's office where Ruden was expecting me. He told me that on Sunday last he had had a conversation with Manuel Pardo on the subject of the $S / 100,000$ privileged obligations of the Pasco Mineral Railway Company of which Pardo himself held S/20,00o; the South American Insurance Coy. S/20,000; the heirs of José Maria Varela S/20,000; Nicolas Rodrigo S/18,000; I S/12,000 and the heirs of General Iturregui $\mathrm{S} / 10,000$. Pardo had expressed his surprise that we had taken no judicial steps to obtain from the Directory of the Company the Cedulas and the money which they held amounting one with another to S/50,00o. Accordingly, Ruden had determined to place their $S / 20,000$ into the hands of the company's lawyer. [19] I told him that quite willing to go hand in [...] to pay my share of the judicial expenses. Thence I went to the office of the Banco Hipotecario where at about 2 O'clock a number of shareholders were assembled, sufficient to allow the proceedings to commence. Oyague, who presided sat behind the table, I to his right, to my right Mendoza, to his left, Jimenez, then Garland; Gallagher on the one side of the table just before me. After the last acta was read by Gallagher, and approved of, la memoria, drawn up by Garland was not read, because all were acquainted with its contents, whereupon Oyague read a short speech which in some measure condensed the contents of the memoria. The first who spoke was Col. Torrico, who made the motion that a commission should be named to investigate the affairs of the bank; this Oyague violently and angrily opposed; he and Torrico came to personalities, and the latter withdrew the motion. Next came that point of the memoria which proposed that the redemption of the cédulas should be reduced to $3 \%$ annually. Many spoke on the subject: Bohorquez, Forero, Varela, Noel, Escudero; and after a long discussion and the adduction of many very proper arguments, it was agreed that the Directory should withdraw this proposal, and was authorized "para amortizar lo que correspondiese". A more ample authorization we could not wish for. The other proposal of the Directory, though opposed by some, were approved by a majority, viz.: firstly, that of the nominal gain of $S / 433,715-75 \mathrm{~d}$ of $1874 \mathrm{~S} / 150,000$ be applied to the $5 \%$ which the shareholders still owed upon their shares, 95\% hitherto being paid up. Secondly, the gain of 1875 amounting to $S / 262,836.20$ should be divided amongst the shareholders, viz.: $33 / 4 \%$ on the capital of 3,000,000 Soles, in cash on the $1^{\text {st }}$ March, and $5 \%$ in Cedulas, not at par, but at $75 \%$. This repartition would leave a small balance of S/336 to the credit of Profit and Loss, to be carried on to next year. We had still time to draw the names of Directors who went out by lot; the names of Oyague and Aliaga were drawn, and as Mendoza had to go out by vote he having been Director for two years, in the next general meeting three Directors had to be chosen. It was nearly 5.30 when I got home. My wife, though she ate nothing was well enough 
to sit down to dinner with Doña Angela and myself. After dinner I took the fresh air in the corredor and conversed with Garland till [20] [...], who read till past eight the Life of Anne of Cleves, [_] Miss Strickland's work. We took tea in the bedroom, my wife in bed. Diego Masias came and whilst we conversed she fell asleep. We withdrew to the corredor, and at 10.30 I went to bed, and so the day was spent.

Wednesday, $16^{\text {th }}$ of February. My wife had passed a very bad night and was beyond measure weak this morning; she perspired profusely, wept and expressed a doubt she would ever recover. Dr. Middendorf had again recourse to his pills of musk, quinine and Valeriano. By me the day was spent like the previous one, with the only exception that instead of attending at a meeting, I was nearly two hours in the Banco del Perú where I collected $9 \%$ dividend upon my son Juan's $S / 53,000, C$. W. Schutte's $S / 60,000$ and my $S / 10,000$. The amount, $\mathrm{S} / 10,170$ I took to the "Providencia".

My wife continued very weak, and at Rafael Velarde's earnest request we sent for Dr. Bravo. He came, and approved of the pills prescribed by Middendorf. In the evening Rafael and his family, Melchor, and several others were with us.

Thursday, $17^{\text {th }}$ of February. Though my wife had spent a good night, Enriqueta again on the sofa, she continued extremely weak. At 1o O'clock Dr. Bravo and Dr. Middendorf held a long consultation; they called me in and Dr. Bravo told me that my wife was very dangerously ill, because she could not digest her food, and thus her recovery might take a very long time, and was even problematic. Such an attack as that of yesterday morning and on previous occasions, which the Doctor called Syncope, might carry her off at once, and both Doctors therefore advised me that my wife should arrange her temporal and spiritual affairs. I told them that her will was made long ago and that as to taking the last sacrament I really thought that it was indifferent, and that I did not wish to frighten her by speaking of it. The Doctors were of a different opinion: I mentioned to Enriqueta what they had said, who replied that she would beg her friend Isabel Coloma to introduce the subject to my wife in the gentlest manner possible. It was now twelve, my wife had taken her broth, tea and a little Malaga Wine with water, which for the moment fortified her. The remainder of the day till past five she was up, and pretty [21] strong. In the evening we had again many visitors who [...] outside in the corredor.

Friday, $18^{\text {th }}$ of February 1876 . Though my wife had spent a pretty fair night, she was this morning very weak and low spirited. The Doctors came again and made a trifling change in the prescription. She had resolved to make a small alteration in her will, and this in favor of little Maria and Corina. She would also take the sacrament perhaps today, perhaps tomorrow. Fortunately Dr. Bandini came in who, a Canon of the Cathedral, was a rational and clever man. 
He was a long time with my wife. She confessed to him; the Inter from the Cathedral was called, my wife took the communion; and los santos oleos were administered. All this was done so quietly that I in my office did not observe anything. I then went into my wife's bedroom and still found Bandini with her: I showed him the rough draft of my wife's will which he much approved as being drawn out in a very clear and straight forward manner.

Middendorf said that for the moment there was no actual danger, but he feared, and I was of his opinion that my wife would become weaker and weaker till the last hour came, like a lamp which gradually burns out. The whole day I was in the most desponding state of mind and could not do anything. Dr. Palacios at my request drew out a rough draft of the codicil which my wife whished to be added to her last will and testament. The shareholders of the Banco Hipotecario had a meeting at which I did not attend. Three Directors were chosen: José Vicente Oyague, Evaristo Barrios, and Francisco Sagastabeytia; with the choice of the two latter I was displeased, because they were sayers of "yes", and had no spirit to object to any suggestion of Oyague's. I for my forty shares had given orders to vote for Oyague, Diego Lopez Aliaga, and Clemente Nöel. The suplentes were more to my liking: Lorente, and the lawyer Galvez, son-in-law of Nicolas Rodrigo.

In the evening we had again many visitors, who in my opinion only annoyed and mortified us, though they came with the very best intention.

Saturday, $19^{\text {th }}$ of February. Last night Enriqueta, Goya, the widow of Manuel Velarde, and Josefa Velarde had hardly had a wink of sleep. My wife slept till one in the morning, but from one till three was [_] [22] [...] day she was somewhat better, and I flattered myself [_]ough I hardly expected, that she would get through. She consulted with Rafael, and yesterday's codicil was again altered. I was not satisfied with the alteration now made in the original will, for having once made a promise to Juan, I did not think it right to make an alteration to his prejudice, though it were in favor of Enriqueta. The law of the country says that a testator may "mejorar" one of his heirs, with one third of his property. Of this liberty my wife had availed herself in her original will and divided this one third between Enriqueta and Juan, giving to the former $2 / 3^{\text {rds }}$ to the latter $1 / 3^{\text {rd }}$ of the third. By doing this, Rosa would have been the only one prejudiced, Enriqueta the only one favoured, and Juan would have recived exactly the third which corresponded to him as will be seen by the following caculation. Suppose my gains since my marriage had been $\mathrm{S} / 600,000$, my wife would have had a right to dispose of one half, say S/300,000 and had she disposed of this sum equally between her chidren, each would have received S/100,00o; but as she did not do so, and made the distribution as above said, the calculation stood as follows: 
Of $S / 300,000$ one third was deducted

$\mathrm{S} / 100,000$

remain $S / 200,000$ divided by 3

came to Rosa

S/66,666.67

to Juan

and $1 / 3$ of $S / 100,000$

S/66,666.67

and to Enriqueta

$\mathrm{S} / 33,333 \cdot 33$

S/100,000.00

and $2 / 3^{\text {rds }}$ of $S / 100,000$

S/66,666,67

S/66,666.67

$\mathrm{S} / 133,133 \cdot 33$

$\mathrm{S} / 300,000.00$

In the Codicil, of which as already said, I did not entirely approve she allotted the whole third to Enriqueta, and consequently the calculation was the following:

to Rosa

to Juan

and to Enriqueta

and
$66,666.67$

$66,666.67$

$66,666.66$

$100,000.00 \quad 166,666.66$

[23] Mariquita did so, because of the original will had stood go [...] share would not have come up, to a sum sufficient to cover the value of our house 96 Calle de Zarate with its appurtenances, and that this should become hers had always been my wife's earnest desire. Rafael Velarde drew out the codicil in rough, and Francisco Palacios, the notary, copied it in my room. As witnesses were called in Gregorio Benavides, Enriqueta Cox, and a certain Lesandro Prieto unknown to me. My wife sitting up in her bed affixed her signature, and the thing was done. She felt so well that I resolved to go to the Banco de Lima to be present at the meeting of the Directory. Since the $24^{\text {th }}$ ulto. I had not been there. The meeting was more numerously attended than ever. We were: the two Gerentes; Cucalon; Diego Lopez Aliaga; Bernales, the Secretary; Luis B. Cisneros, Vice; I; Castillo, J. M. Cardenas; Focion Mariategui; Evaristo Barrios; Julio Armero, and Gallagher. The arm chair at the head of the table stood empty. I begged Cisneros as Vice, to occupy it; he refused, and urged me to take the seat. I declined, and earnestly begged my colleagues not to elect me as their President; I was however over-ruled, and J. M. Cardenas most particularly explained to me that the credit of the bank would suffer if it became known that I, their Senior, had refused to preside; and thus I had finally to give way. Next, Cisneros and Bernales were chosen by a majority, the former Vice; the second secretary. All this being over, the gerentes informed us that José Vicente Oyague had not admitted his election as Director. I opined that we might beg him to reconsider 
his refusal; but the majority resolved that we should simply acknowledge his negative answer. The Gerentes finally communicated to us that Henry Meiggs wanted to postpone the payment of a debt amounting to $S / 178$,0oo partly overdue, partly due within a few days. He offered very advantageous terms in order to obtain this new respite, but we resolved not to grant it, because the bank stood in need of money. We also discussed whether we could put off any longer the payment of last year's dividend, and decided to pay it without any further delay. It was 5.30 when I came home, and I found my wife better than I had expected.

Sunday, $20^{\text {th }}$ of February 1876 . My wife slept soundly the whole night and [24] [...] Doña Goya and Doña Josefa had also been able to make [_] for the want of the preceding night's rest. Bravo and Middendorf came at about ten; they found my wife better, but Middendorf would not yet take upon himself to affirm that the cure was complete. After Bryson had been with me, I went out to pay two visits, the one to Dr. Muñoz, the other to Dr. Alvarez, both Vocales of the Supreme Court. With the former I was but a few minutes; he was on the point of giving out and told me that a few days back his son had once more been at death's door, but that he had again got over it. Dr. Alvarez was very friendly; he himself began to speak about my suit against Leyva, of which Dr. Palacios had given him the particulars. I also did my best to explain the matter to him, but though I was sure he would do his utmost to favor me, yet it was impossible to foresee whether the result would be for, or against me. He was of my opinion that the best I could do would be to purchase Leyva's house, if he did not ask too high a price.

My wife remained pretty well the whole day; in the evening there was again a large circle assembled in our corredor: Rafael Velarde and family; Francisca Cardenas de Benavides; the son of Manuel Francisco Benavides; Guillermo and Eliza, and young Chilian Urquhart, the same who had sat next to me when we dined at Guillermo's. Once more Enriqueta, Doña Goya, and Josefa kept watch. They lay down, dressed, to be ready at a moment's notice.

Monday, ${ }^{2} 7^{\text {st }}$ of February. My wife had not slept well; this morning she was very weak. As Dr. Middendorf had told us that he had to accompany Westphal and his wife to Callao, I went for him at seven. He came and said that I must be prepared for such repeated ups and downs. Dr. Bravo did not come. I have already said that the firm of Huth Gruning \& Co. had closed their office at the end of last year. Graham Rowe \& Co. had taken upon themselves the collecting of the outstandings, and the sale of the few articles which were still on hand. Dr. Middendorf told me that Mr. and Mrs. Westphal would probably not return to Perú, but that Westphal's [_] tract with the firm of Huth did not expire till 1878. My [25] wife got up, sat down on the sofa, and one with another spent 
[...] day. In the evening, visitors as usual. The number of persons who sent to enquire for her health was very considerable.

Tuesday, $22^{\text {nd }}$ of February 1876 . My wife had had a very good night's rest, and felt this morning better than she had done for several weeks. I myself did not awake a single time from 11.30 to 6 this morning, a thing which had not happened to me since our coming in from Chorrillos. On the other hand, the three ladies mentioned more than once, had always been on the alert to give my wife broth and pills as soon as she awoke. The papers said that the English Government had bought from the Viceroy (Khedive) of Egypt his share in the Suez Canal for four million pounds sterling.

Don Valentin Gil, who at the utmost two years back built a very handsome and large house exactly opposite ours in the Calle de Zarate, was now offering it for sale, and Alejandro and another gentleman, whom I did not know, were acting as brokers. Gil asked S/160,00o and said that he had already refused S/140,00o. The ground which this house occupied, with the old building then standing upon it, was in former times the property of the family Mendoza. The father of the present Mendoza y Bozas sold it, perhaps forty years ago to Achiles Allier, who through the medium of his agent Valdeavellano resold it to Gil for $\$ 60,000$. Gil demolished the entire old building, only making use of the earth of which the walls consisted, and built the present, which, he said, yielded a monthly rent of $S / 1600$.

At 3.30 the Directory of the Banco de Lima was assembled. Gallagher was wanting. Aranivar, the lawyer of the bank, attended. The informe, drawn out by the lawyers Ribeyro and Villarán named by the Government to examine the title deeds of the "Esperanza", was read. It entirely invalidated the objections which A. Almonte, the owner of the ground, had endeavoured to raise in his escrito, in order to prevent the sale being made by the Directors of the "Esperanza" to the Government of the lease of 10 years granted to the same by Almonte, and of its entire establishment including machinery, railway, houses etc. On the other hand the Minuta of the Escritura which the Government as purchaser, the Esperanza as seller, and the bank as creditor had to sign [...]. [26] [...] had obtained a copy in the greatest confidence, contain[_] clause which we looked upon as detrimental to our interest. Aranivar proposed another should be substituted, and for the purpose of attaining this object, after a very long and animated discussion, two Directors were named, who jointly with Aranivar should ask for an audience with Pardo and represent the matter to him. I fixed on Cardenas and Cisneros, but this latter begged so earnestly to be excused that I named Lembcke in his stead. It was 5.30 when we broke up. My wife was pretty well the whole day; nevertheless on 
Wednesday, $23^{\text {rd }}$ Middendorf still continued with the pills, the number of which to be taken daily it was his intention gradually to diminish, and finally to leave off entirely. The whole day she continued apparently pretty strong, but towards evening she once more suffered from extraordinary debility, so much so that Middendorf said he would remain here till a late hour to observe her. To while away the time he proposed to Garland to call in one or two of the rocambor players; Seminario, young Valle, son of the late vocal and Catalina Osma, and Melchor Velarde came. It was past one before they left off, and I could go to bed. Mariquita was fast asleep.

At 3.30 in the afternoon the Directory of the Banco Hipotecario had been cited. I was there at the appointed hour. The two new Directors, Barrios and Sagastabeytia, joined me. José V. Oyague's letter in which he refused to admit his election as Director was read. It was written in such a determined manner that we were all of opinion that it would be quite superfluous to request him to reconsider his refusal. The only thing of importance we did, was to settle in what manner the Cedulas for redemption should be drawn on the following day, we having been authorized by the shareholders to act on the manner we might think proper. I was named President; Jimenez Vice, and the Gerentes were instructed to call in the suplente Galvez to attend our meeting in future.

Thursday, $24^{\text {th }}$ of February. My wife was this morning beyond measure weak, and sad. Middendorf however assured me that there was no immediate danger. For the first time during her illness he administered a little [...] ther. I left my office at 12.30 and did [27] not come back till near six. Firstly, I went [...] Becker, formerly clerk of H. Witt \& Schutte, since 1868 partner of Johannes Limpricht in a cigar shop, Calle de Mercaderes, to the German Chargé Dr. Lührsen for the purpose of having his certificate added to two signatures of mine; the one to a letter directed to F. Köpcke \& Co., the other to Mr. B. Grönewold, both of Hamburg, with the former of whom I opened a credit for Limpricht \& Becker to the extent of 25,00o Reichs Mark, with the latter for 27,500. This I did because Messrs. J. H. and G. F. Baur with whom Limpricht \& Becker had hitherto had a credit under my guarantee for 35,00o Banco Marks, had of late made some difficulties, for which reason Limpricht \& Becker and I were desirous to close our account with them. Thence I went to the Banco Hipotecario, where at about 2.30 we began drawing the numbers of the Cedulas to be redeemed on the $30^{\text {th }}$ June next. Present were: the two Gerentes and the three Directors, Barrios, Galvez, and I. The notary Selaya, though cited, did not come. Of the public perhaps six or seven attended, of whom I knew Pedro PazSoldan Jr. Gallagher called out the numbers; I put them down in due order, and Garland, the bookkeeper, and one or two other persons noted them down. Gallagher told me that he had spoken to Oyague in the morning and from what Oyague had said he drew the inference that he would not object to return to 
the bank after the lapse of a few months and we therefore decided that our answer to him should be written in conformity. From the Banco Hipotecario Gallagher, Galvez and I went to the Banco de Lima where a weighty matter had to be discussed viz.: the draft of the contract between the Government and the four banks relative to the salitreras, which when bought by Government were to be administered by them. Clause after clause was read aloud; some passed without any remark, whilst others caused a well sustained and in some instances well founded discussion. The observations made were noted down by Bernales and Cardenas, and were again to be gone over this evening in a meeting of the Directories of the four banks who were cited to meet at 8 O'clock in the premises of the Banco Nacional. I did not go, and excused myself with the bad state of my wife's health, though in reality she was better than she had been for a long time. I was glad we had no visitors. Dr. Lührsen told me in the forenoon that the [_] of Arequipa [...] [28] [...] the duties in Mollendo should be paid in coined silver.

Friday, $25^{\text {th }}$ of February 1876. My wife was uncommonly well; I even heard her laugh, which she had not done for a long time. Prado arrived in Callao from the South, and many went down to receive him. When he passed through the streets of Lima, flowers and garlands were showered upon him. He alighted as it was his habit in the house of Pablo Vivero and in the evening fireworks were let off in the Plaza. I spent a very quiet day; the only thing worth mentioning was my payment of S/680o to Dreyfus, account Juan, for whom I had collected within the last few days $9 \%$ upon his $\mathrm{S} / 53,000$ in the Banco del Perú, and from Dreyfus $5 \%$ on the $S / 40,000$ for which he was interested in their contract with the Peruvian Government.

Saturday, $26^{\text {th }}$ of February. My wife, though free from pain, hardly slept at all during the night, and consequently felt this morning less strong than yesterday. The heat had much increased within the last few days. Thermometer in my office at 11 a.m. $80^{\circ} \mathrm{F}$. This day the Tribunals closed, and would not open till Wednesday after Easter. Don Manuel Pardo, the President, embarked on board the Chalaco for the North, to spend the Carnival days in his and his own friends' estates in the neighbourhood of Chiclayo. My wife passed a rather bad day, and Dr. Middendorf as he intended to make an alteration in his prescription, was desirous to have a consultation with Dr. Bravo.

Sunday, $27^{\text {th }}$ of February. My wife having slept soundly, awoke this morning uncommonly well, and continued so the whole day. To me on the other hand it was beyond measure tedious. When Bryson was gone Ricardo read a little to me, which done I did not know how to while away the time.

Monday, $28^{\text {th }}$ of February. Again my wife awoke pretty well, after a good night's rest. It being Guillermo's birthday he and his wife came to breakfast with their parents. Bryson remained till 1.30. Without being wetted I reached 
the Chorrillos terminus, and went by the 3.30 train to Chorrillos, where I bathed and returned to town at 5.45. This day passed somewhat less heavily than the previous one.

Tuesday, $29^{\text {th }}$ of February. My wife rose early, even ventured out to the [...] and remained up till nearly five. Guillermo and Eliza came [29] at an early hour, afterwards Rafael Velarde with his daughter [...] remained with Enriqueta. She and Eliza, the former's sister Sofia, Maria and Corina, some of Garland's sons, the boys of Melchor Velarde, Dr. Middendorf, Diego Masias, and perhaps some others whom I did not recollect, altogether made a great noise in the corredors, wetted each other with fresh, and with scented water, and certainly enjoyed themselves. To me it was beyond measure tiresome. On going to the terminus water was thrown upon me from four or five houses, but did not wet me much, for my broad brimmed straw hat kept it off. In Chorrillos I bathed, had time to look in at Doña Dolores Puente's, who resided with Marriott and her sister, and at General Pezet's. I returned by the 4.15 train. Rafael and his wife took tea with us whilst with Enriqueta dined Middendorf and Seminario, with whom, and after dinner with Terrazas, the Bolivian Chargé, Garland played rocambor the whole day long.

Wednesday, $7^{\text {st }}$ of March. Ash Wednesday. Carnival over, the usual occupations were resumed. It was a strict fast day. Da. Angela abstained from everything; she would not come to breakfast, and Dr, Middendorf took her place.

About noon I called upon General Prado at Pablo Viveros. Vicente Gonzales with his son just arrived from Europe entered with me. Prado was sitting with General Silva on the sofa. All besides myself were in black, I in my usual lightcolored summer clothes. The General was particularly polite towards me as it was his custom. Not four hours had elapsed before he returned the visit, merely for the purpose of seeing Mariquita, who was however too unwell to receive him.

Thursday, $2^{\text {nd }}$ of March. The object of Prado's great politeness came to light. Through Rafael he requested us to let him our Rancho in Chorrillos. Of course we could not say "no", nor would we take any money from him. My wife continued weak the whole day. In the forenoon I received in the Banco Hipotecario the dividend for 1874 and part of that for 1875 , looked in at the insurance Company Lima, where this month I was Director de Turno, and then, as usual, presided the Directory in the Banco de Lima. Garcia Calderon, president of the 8 Delegados, had cited the Directories of the four banks to meet this day at 2 O'clock. The letter to me containing [30] [...] came to hand yesterday at 5 , consequently too late for me to cite [_] Directors, and I thus answered Garcia Calderon's letter telling him that we could not attend, and begged him in future to let me have twenty-four hours anticipated notice. This 
was the first thing I laid before my colleagues. Luis Cisneros then said that next Monday at 1 p.m. the four Directories would meet, of which due note was taken. Once more the contract between the Government and the four banks, relative to the administration of the Iquique Salitreras, formed the subject of an animated debate, in which Lembcke and Cardenas, who were now again very intimate, took the lead. This over the usual statement of the monthly accounts was read by Lembcke, whereupon Cucalon mooted the question of the necessity of more economy on the expenses of the bank. I seconded him, as we had previously agreed upon. The greater number seemed however opposed to any reduction, and when Lembcke rose, begging to be excused, as he wished to pass this his birthday in Chorrillos, Cucalon postponed his motion till our next meeting, which I fixed upon for next meeting, which I fixed upon for next Thursday, when the "reglamento interior" had to be discussed. The North steamer arrived, on board of which came Emilio Althaus, one of the two commissioners lately sent by Pardo to Europe. Juan informed me in his letter that he held $£ 26$,ooo Peruvian Bonds, which cost him $58 \%$, and that Schutte's pecuniary affairs stood really very bad. There was however some probability of his finding a purchaser for his house.

Friday, $3^{\text {rd }}$ of March 1876. Dr. Middendorf ceased prescribing any medicine for my wife, who was up the greater part of the day, and quite capable of giving her instructions as to the various articles, which were to be taken out to Chorrillos for Prados use. At 12 I went to the Insurance Coy. Lima. I received from Chavez, the Director who went out, all the documents which the company held as prenda pretoria, and which were deposited in a new iron safe, of which the Director de Turno kept the key. Alejandro paid me the balance of the $S / 58,000$ Internal Debt, sold him by me at $59 \%$. At 3.30 I was in the Banco Hipotecario, where besides myself the two Gerentes and Dr. Galvez were present. Instead of admitting Oyague's resignation, we merely gave him licence to absent himself for some time. He continued President, and I Vice. A [_] point was discussed. The Insurance Company Lima demanded [31] from the Banco Hipotecario the payment of the dividend on a con[_] amount of shares which Riva Agüero had placed into the hands of the same as security for a large sum he had taken up on interest, but as Riva Agüero was also a debtor to the Banco Hipotecario, the Gerentes refused making any payment to the Insurance Coy. I gave it as my opinion that the Insurance Company's right had the preference. The lawyer Galvez opined that we would act in a prudent manner if we were to leave the decision to the tribunals and in the meanwhile refuse payment.

Saturday, $4^{\text {th }}$ of March 1876 . Having put up the various things which my wife was of opinion Prado would require in Chorrillos, Enriqueta and I drove to the terminus. We however came too late for the 10 train; she walked to Melchor 
Velarde's there to breakfast and I returned home. For the 11.45 train we were in time, and took the servants Aurelia and Ayao with us: Hardly had we arrived in our rancho when we were joined by Gregoria Velarde and her married daughter Adela. We then set to work. Enriqueta gave her directions, the servants swept, Goya and Adela washed the glasses and tea service. We all carried in and out from one room to the other. Only the despensa we kept locked and stowed away in the same a number of useless articles. I called one of the Chorrillos porters to put up the curtains, paid the gas account which I owed since our last stay in Chorrillos, had time to take a bath, made a detailed list of everything which we left out for Prado's use; and had done just in time to return to Lima by the 5.45 train, all very tired. Goya and Adela remained in Chorrillos in their own rancho. My wife had passed a very good day; it was nearly 10 before she went to bed. When Bryson had done reading to me in the evening, I went to the house of Dr. Palacios, who had been looking for me in the course of the day. He read to me an article in the Codigo Civil, which prohibited the "bettering" (mejorando) one heir to such an extent as to make him receive twice as much as any of his coheirs. This my wife had done by the last codicil, as will be seen by the calculation on page 22 .

Sunday, $5^{\text {th }}$ of March 1876. My wife rose at 8, and Dr. Middendorf declared he considered her quite well now, however in her [_] [32] [...] to be taken. She remained up till 8 or 9 in the evening, and my opinion was that she had recovered her health not her strength. The day passed to me quite as tediously as the late carnival days if not more so. When Bryson was gone I first thought of going to Chorrillos, altered my mind, thought of paying visits, then did not like to put on my black clothes in the present hot season, and thus I remained at home, doing nothing the whole day long; even Ricardo did not read to me. My wife had a long visit from José P. Escobar, another from Doña Juana, widow of Salaverry; I myself received Manuel Rosa O'Phelan and his son Daniel, and in the evening Macandrew and his wife made a short call. Manuel Pardo returned from his trip to the North on the "Chalaco", and landed in Chorrillos. José F. Canevaro gave a lunch in the sugar estate of Caudevilla, which not many months back his firm bought from Mariano Laos, Rafael Canevaro's father-inlaw, who one or two years ago purchased it from the Monteros for $\$ 1,200,000$ of which sum the Banco Hipotecario advanced $\$ 1,000,00$. Caudevilla is a league, or somewhat more distant from the estate of Infantas, where the train to Chancay was in the habit of stopping, and from which point the guests, two hundred in number, had to go on horseback. This lunch was given to the Colegio Electoral of Lima, but General Prado was of course the lion. Rafael Velarde and Escobar who had been invited, had declined going. 
Monday, $6^{\text {th }}$ of March. I made my excuses to Andrés Rey for not being able to be present at a meeting of the Directors of the Water Company, and then went to the Banco Nacional, where I had to wait till long past two before the meeting of the Directories of the four Banks "Nacional", "Peru", "Providencia" and "Lima" could be opened by Garcia Calderon, who presided. The actas of the three last meetings, not yet written in clean, were read by the secretary Climaco Basombrio in a slovenly, unsatisfactory manner, he then renounced his post as secretary because his time did not allow him to do his duty in a proper manner; his resignation was not admitted. Then Garcia Calderon read the draft of the contract between the banks and the Government relative of the nitrate of soda business which we had already twice discussed in the Directory of the Banco de Lima. Clause after clause was read aloud, some immediately approved of, others violently debated, modified, and then approved. The [...] [33] The approval was given by the president of each Directory on [_] Garcia Calderon's question; he invariably made the beginning with the Banco de Lima, and thus I had always to speak first. The spokesmen in defence of the interest of the banks were: Lembcke, Althaus, Calderoni, and Cardenas, whilst Garcia Calderon and Moscoso Melgar were rather averse to introduce any alterations in the draft. Schell also spoke a few words, but I could not make out what were their tendency. We broke up at 4.45, and not having yet finished were cited for the next day. I learned that yesterday's lunch in Caudevilla had not given general satisfaction.

Tuesday, $7^{\text {th }}$ of March 1876 . A day very much like the previous one. At 1 I went to the Insurance Company Lima, where some of the Directors had already been before me. Elizalde communicated to me what had been transacted, which was of little importance except the Insurance of an ironmonger's store against fire, in the Calle de Lescano, valued in S/6o,ooo. I approved of what had been done and we agreed that the acta should be drawn out as if all had been present at the same time. Thence Elizalde and I went to the Banco Nacional where yesterday's discussion was continued, not yet concluded. My wife might be considered well in health, but still wanting in strength.

Wednesday, 8 $^{\text {th }}$ of March. The discussion in the Banco Nacional, with a very limited attendance of the Directors, was once more continued, and again not brought to a close. The large house over the way, Gil's, was purchased by Carlos Maria Pflücker \& Brothers. I had thought of lending him S/80,0oo upon the same to enable him to pay off debt to Varela, but when I went to make him the offer, the bargain with Pfücker had already been struck, and I did not regret that it was done for if I had lent $\mathrm{S} / 80,000$, I should have remained with a very small balance to my credit in the banks "La Providencia" and "Lima". 
Rafael Velarde and family, Guillermo, and Eliza, were with us in the evening. Rafael told us that there was the greatest probability of Prado's leaving on the $14^{\text {th }}$ for Europe, accompanied by José Canevaro, in order to negotiate the long spoken of loan.

Thursday, $9^{\text {th }}$ of March 1876. Again a meeting in the Banco Nacional with a still more reduced attendance. The main point in [34] [...] occupied nearly the whole time for 2 till 4.30 , was [...] profits expected to be made on the Nitrate, as well as the sixty cents per quintal export duty, to be paid by such as had not sold their salitreras to the Government, were to be applied. Garcia Calderon and Moscoso Melgar defended, though faintly, the clause as it stood in the projected contract, which was attacked, and finally completely altered, consequent upon the speeches of Cardenas and Althaus, to which I gave my implicit assent, and in which debate, towards the end, I took a small share. Lembcke gave explanations, and acceded to the motion of Althaus, which at last all four banks did through the mouth of their Presidents, I, as always, the first called upon for "Lima", Scheel for "Nacional", Albarracin for "La Providencia" and Ruden for Perú. The said profit and export duty we proposed to apply as follows:

Firstly, to the payment of Interest on the Certificates to be given to the sellers of Salitreras; secondly, to that of the Interest due to the banks on the $\mathrm{S} / 18,000,000$ which the banks were bound to lend to the Government as per agreement of September. Thirdly, the balance there might be to be left by the Government in the hands of the banks as part payment of the capital lent, until the Government placed into the hands of the banks the $31 / 2$ million Soles in Bills on Europe which it had promised to do in the September contract, but had not done. Garcia Calderon insisted that the banks should bind themselves "de hacer el servicio" on the Internal debt after the $30^{\text {th }}$ September, until which date they were obliged to do it, in virtue of said contract. This Althaus strongly opposed, and I agreed with him, because my conviction was that after the interest on the certificates, and on the debt to the banks was paid, there would be no surplus left from the profits and the export duty, and consequently the banks would have de "hacer el servicio" out of their own funds, without the probability of ever being repaid. Now it remained to be seen whether Pardo would accede to these important and vital alterations made by us. After we had broken up I went per train to Miraflores. Cardenas took his seat next to me, and of course we had a long talk. When I alighted in the Miraflores station I found Dr. Lührsen and Scheel, with their respective wives. Schell showed me the house of the Canon Bandini with whom my wife was desirous. I should speak a few [35] words about the shops under my house Calle de Correo, of which [...] 
through his influence with the nuns of la Concepcion, would in all probability be able to produce me a new long lease. I remained with him a quarter of an hour, and waited in the terminus till exactly six when the train from Chorrillos to Lima passed by. Whilst I had been absent, Prado had paid my wife a long visit, and thanked her for having placed our Chorrillos rancho at his disposal.

Friday, $10^{\text {th }}$ of March 1876 . Dr. Middendorf assured me that my wife was getting on famously, and that even her extreme thinness was decreasing. By Ricardo I sent him a cheque for S/400. At 1.30 I was in the Banco Nacional, and it was very late before we took our seats. Perú and Lima were sufficiently represented. Providencia and Nacional very poorly. Basombrio, the secretary, read a letter from Garcia Calderon, in which he threw up the Presidency hitherto filled by him at the meetings of the Directories of the four banks. Now nobody was in the chair, or more properly speaking, on the sofa which stood at the end of the saloon below the window and before the table at which the secretary also sat whilst the Direcotries were ranged alongside the wall, Lima and Nacional to the right, Perú and La Providencia to the left. I called upon Ruden to take Garcia Calderon's place; he returned the compliment, when I, not to lose time, took the seat. I merely asked those assembled whether the resignation of Garcia Calderon was admitted; it was not. Then whether a commission should be named requesting him to return, to which they answered in the affirmative. My choice fell on Calderoni and Rufino Echenique, who immediately started on their errand. I hasted back to my customary place, the first on the right side. After a quarter of an hour or so Calderoni and Echenique returned, and said that Garcia Calderon would not withdraw his resignation. I then again occupied my seat on the sofa, and proposed that Calderoni should preside; he excused himself with his many occupations, then the general call was for Althaus, for whom I readily made room. We now came to an end with the contract, without any new important alterations having been made. One or two clauses remained pending, which at Althaus' suggestion we left to be remodelled by the eight Delegates. We broke up at the usual hour [36] [...].

Saturday, $17^{\text {th }}$ of March 1876 . Somewhat more than an hour and a half I was in the Banco de Lima, in order to present whilst one of the clerks put my signature to 1000 of the new shares with a stamp which had been sent to me at the time of the bank's foundation. Melchor Velarde proposed to me to make an emphytentic purchase for 135 years of twelve small houses not far from Balta's bridge, the back part of which looked towards the river. The seller asked forty Cedulas of the Banco Hipotecario of S/10oo each, the purchaser paying every expense; and as the broker asserted that at present the twelve houses paid monthly four hundred and eighty dollars rent, I thought it might be a 
profitable bargain. Melchor did not make the purchase, because he had not the means; perhaps I would give him a small interest. Through the medium of Alejandro I purchased two bars silver, for which I paid with the coined Soles I bought towards the end of last year, and, which bars I now intended to send to Gibbs, to buy with their proceeds some more Anglo-Peruvian 5\% Bonds.

Sunday, $12^{\text {th }}$ of March. General Prado gave a lunch to a numerous party of his adherents, in the large garden of Juan Rivera, the very locality in which Pardo had given a similar entertainment to his friends about four years back.

I took the 1.45 train for Chorillos. On my arrival there I walked to the rancho of Baltasar Aranivar, situated outside the village in the direction towards Lima. I congratulated his mother in law, Doña Goya, on her saints day, and handed her a small present from my wife. Don Baltazar showed me all over the house, which was very extensive and in the construction of which marble and cedar had been used in profusion, but which was not yet finished, and would probably never be by the present owner, B. Aranivar, for want of money. The Goyeneches some years back, made him a present of the ground; he then took it into his head to build a rancho, and to procure the money wanted having obtained a full power from his mother-in-law, partly sold, partly mortgaged the pretty immovable property left by Manuel Velarde. The money raised in this manner he laid out in the building of the rancho and this not having been sufficient he still owed to the carpenter [37] S/14,00o for which he gave him a mortgage on the rancho [...] S/500o to Simon Soyer, also settled on the building, which he had bound himself to return within two years. Soyer made over these S/500o to the Banco Hipotecario, and thus after the lapse of the two years, the rancho would fall into the hands of the carpenter and of the Banco Hipotecario, Soyer's representative. I passed the new Church in the building of which the mother of the President took a great interest. The walls were perhaps three varas above ground. Then I wended my way to the rancho of Vicente Gonzales, with whom I remained a very long time; neither his wife nor daughter made her appearance; then to Anibal de la Torre's, with whom I found Malinowski; other gentlemen came in and I soon left; my fourth call was upon the very agreeable wife of Jose Canevaro, Luisa Soyer. Her husband was of course at Prado's lunch. It was near five when I went below to bathe. By the 5.45 train I returned to Lima, quickly dispatched my dinner, and then went to Dr. Jervacio Alvarez to pay my respects to his son Benjamin, late Peruvian Consul in Hamburg, just returned with his French wife and a babe. They were not in, having gone to dine with Luis Cisneros, but with the Doctor, his wife, his daughter Asuncion, and an Italian gentleman, I remained nearly an hour. At home we had a certain Villacampa, whose acquaintance Enriqueta had made at the Basagoytias, Dr. Middendorf, Guillermo, and Eliza. 
Monday, $13^{\text {th }}$ of March 1876. From the German book, the Two Imperial Crowns, which Ricardo read to me in the morning, I learned, firstly, that Count Walewski, a natural son of the first Napoleon by a Polish Countess, died in the autumn of 1868, of apoplexy, in Strasburg, exactly at the time that Queen Isabel of Spain sought refuge in France, where the castle of Paw was placed at her disposal and secondly, that Alfonso, the eldest son of the queen, since January last King of Spain, was born in November 1857, and was consequently twenty months younger than the so called Prince Imperial of France, son of Louis Napoleon and Eugenia Montijo. It was said that Prado would not embark before the $22^{\text {nd }}$, and that yesterday at a lunch many of his friends expressed themselves aver[_] [38] [...]

Tuesday, $14^{\text {th }}$ of March 1876. Meeting of the Directory of the Banco de Lima. Lembcke asked whether the Salitrera "Esperanza" should be delivered to the agents of the Government before the escritura or even the minuta of the sale were signed. He added that the obnoxious clause referred to on the $2^{\text {nd }}$ January had in the conference between some of the Directors and the President of the Republic, been declared unjust by the latter, been substituted by another, drawn out by the lawyer Ramon Ribeyro, who, jointly with a certain Villarán acted on the part of the Government, and finally been approved by Aranivar, the bank's lawyer, but that this substituted clause had not yet been approved by the Minister of Finance or by the President. Lembcke further said that a great many other salitreras had been delivered in the province of Tarapacá without any minuta being signed. The opinions of the Directors were much divided; some thought that the "Esperanza" should be delivered without loss of time, others that the minuta should first be signed, and the third party that the corrected clause should at all events be inserted in the minuta before the delivery could take place. Finally, a commission was named to give their opinion in writing before we would come to a decision; I named Cardenas and Sagastabeytia. Lembcke also laid before us a statement of the affairs of the bank, which were in the worst condition imaginable. It was evident that after making one monthly payment more to the Government the bank would have exhausted all the notes which it was allowed to issue. Nevertheless, we resolved to make payment, because if we did not do so, Pardo might raise some difficulties about receiving the Salitrera.

In the evening were with us a certain Palacios with his wife, daughter of Villacampa, both nice people, particularly he, who had formerly been in the navy, and now turned chacarero. Several years back he had been round the world in the Peruvian man-of-war "Amazonas" and quite lately he had again been to Europe. He, José Vicente Oyague, the Delgados, and J. A. Garcia y Garcia had some years back entered into a joint speculation for the importation 
of Chinamen; the management they had left to Garcia, who with his usual dexterity had caused a loss to Oyague and to Palacios, of $\$ 80$, ooo each less about £9oo which Palacios saved from the total wreck when last in Europe. [39]

Wednesday, $15^{\text {th }}$ of March 1876 . Yesterday's meeting [...] was continued. The commission gave in its report, more or less on the terms which had been the opinion of the third party yesterday spoken of; the debate was animated, nay violent, and lasted long. In the course of the discussion it came to light that the minuta cancelled all previous obligations of the Esperanza towards the bank and as in a previous escritura, the Esperanza had bound itself to pay to the bank, part of what hereafter they might receive form the Government over and above the $\mathrm{S} / 900,000$, Cardenas opined that the cancelment would also annul this previous obligation which the "Esperanza" had taken upon itself. Gallagher and Aliaga were of opinion that this former obligation would always remain in force, and it being impossible to come to terms and to calm the agitation which prevailed, Mariategui was added to Cardenas and Sagastabeytia and the three were commissioned to give in a reconsidered report on Friday.

Melchor Velarde told me that the owner of the twelve houses above spoken of, General Francisco Diez de Canseco, with whom he had had several conferences on the subject, had changed his mind, and would not sell them. In the evening I was so sleepy that as soon as Bryson was gone I went to bed. Dolores Puente, Rafael Velarde, Felis Dibos with his wife Ernestina Pflücker, kept the family company.

Thursday, $16^{\text {th }}$ of March 1876 . The Directories of the four banks were cited to meet at twelve in the large saloon in the Banco Nacional. I had mistaken the hour, and did not go till past one, but was still in time. The Banco de Lima was fully represented. El Nacional, and La Providencia had the number required, whilst in the Banco del Perú one was wanting, and had to be sent for. At last when all were ready Althaus, who presided, said that the President of the Delegados, Garcia Calderon, whished to be heard. He from his seat, amongst the Directors of La Providencia made a long and lucid speech in which he explained the necessity of naming without loss of time four paid Directors for managing the salpetre business with the Government. Lembcke first rose, and opposed it, saying it was hightly irregular to take all these provisional steps without having first signed an escritura of the partnership of the four banks as far as regards the [40] [...] with the Government, and the various business emana[_] from the same. Garcia Calderon replied that there was no immediate necessity for such an escritura; Derteano, no doubt in conformity with Calderon's wishes made a pretty speech in which he proposed not only that the four Directors should be immediately named, but that the Delegates should name them. 
This was violently opposed by Cárdenas, in more moderate terms by Lembcke, with great clearness by Althaus, whilst Derteano's motion was defended by Garcia Calderon, Calderoni, Moscoso Melgar, and Echenique. Mariategui had suggested that one gerente of each bank without an increased pay should form the Directory for the Nitrate business. I made this proposal in a loud voice, but it passed unheeded. When Althaus asked my vote as President of "Lima", whether I was for or against Garcia Calderon's original proposal I answered that I had first to deliberate with my colleagues; we passed to an adjoining room, and returned after a few minutes, when I answered that the Banco de Lima was against the motion; so were the three other banks. The Nacional was represented by its President, Derteano not by Scheel, its vice. Now Derteano's motion came under discussion. Some were of opinion, I amongst them, that the clauses pending in the draft discussed last week, and the remodelling of which we had left to the Delegates, should first be approved, or disapproved. Althaus very properly considered this as a postponement, or aplazamiento of the discussion of Derteano' s motion; he put it to the vote: The Banco de Lima was for it, the three other Banks against it. Then Derteano's motion came to the vote; the result was the same: Lima against, the three other banks for it, and now we were all delivered up, bound hand and foot to the eight Delegates, who named the Directors whom they liked, they had done so for the guano, and now did so for the nitrate business. In the evening we had a visit from Pinto and Asambuja, the Brazilian Minister, whose only object was to play rocambor, but Garland not being in, they did not remain long. My wife went to bed early: probably she did not feel quite well.

Friday, $17^{\text {th }}$ of March 1876 . This morning before eight I went to the small church of Jesus Maria, where the funeral of the eldest child of Federico Bergmann and Julia Cavenecia was celebrated. Hardly [41] thirty gentlemen attended. There was vocal and instrum [...]. Nosegays were handed round to all, and, as far as I could distinguish the coffin was not closed, but a transparent gauze covered the corpse. When I came home at nine, my wife was up, but very sad, she actually wept. Since yesterday and the day before, her feet higher up than the ankle were considerably swollen, which was certainly no good sign. Immediately went to Middendorf, who, when he came put himself a bandage round each foot, the left being more swollen than the right, and this he attributed to the shifting of one of the tumours from which my wife was suffering for the last twenty years. I much feared, and Enriqueta was of the same opinion, that Mariquita would never again completely recover her health; she would not be obliged to keep her bed but always be ailing, and be unable to leave the house. At about one I went to the Banco de Lima where I was present at the affixing of my signature 
to about five hundred new shares of S/100o each. The meeting of the Directory was fixed at two, but it was three before we could sit down. Julio Armero and Diego Lopez Aliaga did not attend. Cárdenas, Mariategui and Sagastabeytia gave in their report; the first clause of which said that the Salitrera Esperanza should not be given up to the Government until the clause drawn out by Ribeyro was subsituted for the obnoxious one; the second that meanwhile an escrito should be presented to the Government declaring our willingness to deliver the Salitrera with the preceding proviso; and thirdly, that in order to secure ourselves against the danger of cancelling escrituras, as explained on the $15^{\text {th }}$, the "Esperanza" should sign a new one revalidating the previous one which related to the payment to the bank of any surplus they might receive from th Government. To me it appeared at first sight that this embraced everything and could not but be approved by all. But Gallagher then spoke and demonstrated in the clearest manner the enormous risk the bank would run if we put off the delivering of the "Esperanza" for an indefinite time. He completely convinced me, and so I told Cardenas. Lembcke then read an escrito ready to be given in to the Government. I proposed that Lembcke should take this immediately to the Ministry and that we should suspend our discussion till his return, this was agreed to, but [42] [...] back he told us that he had not seen the Minister for Finance, but only the Director de Rentas, who could not give him a decided reply. The report was again discussed in an actually passionate manner. When put to the vote, I in the minority voted against the first clause. The two others were unanimously approved. Cardenas gave in another written motion to the effect that another general meeting of shareholders should be convened to demand their authorization for our transferring the power received from them to the commission of Delegates. It was opposed by Gallagher, and then referred to a commission to report on the same. I named for the purpose Gallagher, Cucalon, and Mariategui; it was a very disagreeable session. We broke up at five. In the evening only Guillermo and Eliza were with us.

Saturday, $18^{\text {th }}$ of March 1876 . The temperature had suddenly become cooler. At half past eleven in my office, thermometer $73^{\circ} \mathrm{F}$. I called at the Basagoytia's where both father and mother, and Juana Rosa, Jose's wife, were lying ill. In the Banco Hipotecario only I, Dr. M. M. Galvez, Evaristo Barrios, and the two gerentes were present. Nothing of great importance was discussed; we took however various resolutions and everything went off very pleasantly. Oyague had decidedly refused again to join the Directory, and thus I had necessarily to preside for the future, and Jimenez would do so in my absence as Vice.

Dr. Galvez, a lawyer, was a very useful member. I learned from Gallagher that Lembcke, acting for the Banco de Lima, had again been with the Minister for Finance on the subject of the "Esperanza", but that he had not obtained 
any answer, the entire cabinet being occupied with dispatching General Prado, who, they said, would leave this evening in the "Chalaco" for Panamá. I received Juan's letter from Nizza, dated $12^{\text {th }}$ February, in which he repeated that Schutte was totally ruined, and accordingly I resolved to make a present of $S / 10,000$ to Rosa, to which my wife did not object. Schutte, when he left Lima in April 1868, had at least two million dollars. John Hegan had died in England. On the $24^{\text {th }}$ December 1851 I settled with him in Liverpool the claim Joseph Hegan \& Co. on C. W. Schutte.

Sunday, $19^{\text {th }}$ of March. My wife had an excellent night's rest, and was this morning in good spirits. The temperature was much warmer [43] than it had been for a few days past. I went to Chorrillos [...] 1.45 train, and on arrival hastened down to the bathing place. The attendance had gradually become very bad; hardly a single room had a key to its lock, the shoes were torn and today they gave me only a sheet, not a sheet and towel, to dry myself with. The sea was high, and much agitated, its temperature far from cold. I was dressed by about 3.30, and went first to my own rancho, where however General Prado was not in. There were several gentlemen in the saloon and I left my card; it was now certain that he would embark on the $22^{\text {nd }}$. I next called upon Doña Josefa, for this was the day of San José, the wife of Corso, the Vocal's brother. Then upon Dr. José Maria Perez, Vocal of the Superior Court, and his lady Cora Barrera. He was somewhat more talkative than it was his habit. My third visit was to Doña Josefa Torre Tagle, the wife of Dr. Zevallos; there were a great many visitors. I hardly said a word and left soon. Also at Jose Vicente Oyagues I did not remain long, though here they were always very polite. Next door at Doña Carmen Osma's, wife of Felipe Barreda, I was best pleased. She was particularly communicative, and as she often did, praised the amiability of Corina Schutte, and the wonderfully youthful appearance of Enriqueta. I told her that I had also come to see her brother Manuel, just arrived from Europe and particulary recommended to me by Juan. Mercedes Soyer, Elster's wife, had gone out, and Doña Dolores Puente seemed to me not quite so friendly as usual, which change in her comportment I could only attribute to Guillermo's report on the Gas Company, which was not favourable to the manager Frederic Marriott, the husband of her beloved sister Petita. I returned by the 5.45 train, dined by myself, and at a later hour Guillermo and Eliza, Rafael and family kept us company.

Monday, $20^{\text {th }}$ of March 1876. When I went to the Banco de Lima, where about 500 of my signatures were again affixed to new shares, Lembcke who was out of humour gave me a bad piece of news. Not only had he not yet been able to obtain an answer from the Minister for Finances to the escrito of the bank spoken of on Friday last, but he had just received a letter from Iquique in 
which he was inf[_] [44] [...] persons sent thither by Government to receive the [_] treras were on the point of returning to Lima, so that now there would be nobody to receive the "Esperanza" when at last we should determine to give it up: and consequently the delivery of the certificates for S/90o,ooo amount of the purchase money which the government had to give - would also be deferred for an indefinite time. I dictated a letter to Rosa in which I promised to send her by the steamer of the $28^{\text {th }}$ Silver bars for the $\mathrm{S} / 5400$ which I had received for her husband on his shares in the Banco del Perú, and for the S/10,00o more, of which my wife and I made her a present.

Tuesday, $2{ }^{s t}$ of March. A very quiet day. My wife was fast getting better. In the Banco de Lima my signature was again affixed to six or seven hundred shares. Sagastabeytia told me that the escrito yesterday spoken of had been passed by the Minister to the President.

In the evening I went to Dr. Palacios to consult with him on my wife's codicil. Wednesday, $22^{\text {nd }}$ of March. At about 9 a.m General Prado looked in in the greatest haste, to bid us good by, for this day he embarked for Panamá. Mariquita and Enriqueta were still in their bed rooms. He embraced Garland and myself, and then hurried off. By the 12 train, I, accompanied by Angela Villena and the Chinese Ayao, went to Chorrillos to look after our rancho, some keys of which had been returned to me by Prado through Rafael Velarde. I went to the office of the Gas Company where I was told that that the General had paid for the gas consumed in the rancho during his stay; then to the rancho, where Doña Angela and Ayao were standing in the corredor whithout being able to get into the house. A new lock it would seem, had been put on the first door, but I had no key wherewith to open it. Off I started again, first to Doña Trinidad Cisneros who recommended to me a smith living opposite the house of Francis Bryce. The master was lame, but gave me one of his journeymen, who took nearly an hour to open the lock. In the interior we found everything in good order, nothing wanting. Ayao took down the curtains in the corredor. Doña Angela and I put everything in order, and filled [45] the trunk with things which we intended to take back [...] was 3.30 when we had done, and by the 4.15 train we returned to town. The railing of the corredor was closed with a padlock, but the first two doors were left open for want of keys. I was much tired when we came home, for I had really worked hard, and went to bed at half past nine. Felix Dibos gave a ball to the naval officers of a French man-of-war in the port. Enriqueta and Garland were invited, but did not go. Rafael Velarde and family, also Guillermo and Eliza went. This being the day called I do not know why, La Vieja, the middle of Lent, in Chorrillos also balls were given one by Freundt, partner of Albarracin, the port agent, and another by Celso Salinas, one of the sons of the late Don Antonio, and husband of Jesus Rabago. At Freundt's, Juan and Antonio Garland; at Dibos', Enrique danced. 
Thursday, $23^{\text {rd }}$ of March 1876 . When I went to the Banco de Lima to have my signature affixed to another parcel of shares, I learned from Sagastabeytia, to my great satisfaction, that the affair of the "Esperanza" was on the point of being favourably settled. The Salitrera with all its appurtenances was to be delivered to the Government, and the certificates for $\mathrm{S} / 900,000$ would be handed to the bank.

Friday, $24^{\text {th }}$ of March. At 12 O'clock I went to the office of Dr. Palacios who handed me a draft of the codicil to my wife's will, which he recommended to me should be substituted for that drawn out by Dr. Bandini and Rafael Velarde, and which had already been signed. He showed me by the Codigo Civil that it was contrary to law that one heir inherited double as much as one of his coheirs, and therefore this new document merely expressed a hope that the heirs would respect the wishes of their mother, which was that one third of the gananciales should be laid aside for her daughter Enriqueta, and that the remaining $2 / 3^{\text {rds }}$ should be distributed in equal parts between the three. Should however any objection be raised to the will of the testatrix, then the half of the third should go to Juan of whom it was expected that he would act in conformity with his mother's desire, which was that he should cede this one half to Enriqueta. Of this draft, the result of Dr. Palacios lucubration's - I say so in March 1879 - no further notice was taken and Juan, who acted for himself and his sister [46] [...] the slightest demur the codicil signed by his mother. the $19^{\text {th }}$ February and the repartition of her gananciales was made accordingly. From Palacios office I went to the apothecary's, and bought pills for my wife; thence to the Banco La Providencia, where I paid in some money, to the Banco de Lima to see my signature affixed to a number of shares, and finally to the Banco Hipotecario. Thus the whole forenoon passed. In the last named bank Gallagher read to the Directors a letter from Morales Brothers, owners of the sugar estate of San Antonio in the valley of Chicama near Trujillo, in which they explained how the canals for irrigating their grounds, had fallen in, how they were in want of water, could therefore not properly attend for the present to the working of their plantations, and therefore begged the bank not to push them for payment till the $1^{\text {st }}$ of July. We acceded to their wish, for we did not see that anything better could be done; this was the question of most importance which was laid before us. Somewhat before 10 p.m. I went to the house of Dr. Muñoz to accompany the corpse of his son, who after dreadful sufferings had died of consumption, to the Church of La Merced. About 20 persons formed the cortège.

Saturday, $25^{\text {th }}$ of March. La Encarnacion. At the usual hour, say eight, I was in the Merced at the funeral service of young Muñoz, which was over before nine. To Bryson I dictated a letter to Juan, and went with the 1.45 train to El Barranco, which place of campestrian resort was increasing in size in a wonderful manner. 
There were a great many new houses, small, neat and comfortable, different from the palace-like building in Chorrillos; the footpavement was boarded, and there was even a small market place. I went first to the Ribeyro's where I found the Doctor with two gentlemen, Espinosa of the Banco Territorial, and Nataniel Sanchez a well known character, Deputy and looked upon as a good accountant. With this latter I had hitherto not been acquainted; he and the Doctor were engaged in such an earnest conversation about politics that the latter took but little notice of me. The daughters and Don Nataniel's wife were very quite. Doña Eulalia, the mother, did not make her appearance. I heard that Prado would first visit the United States, and go to Philadelphia in hopes that he would be allowed to see the interior of the [47] buildings intended for the exhibition. According [...] Agüero had a great chance of being elected Vice President. There were three candidates: Riva Agüero, Buenaventura Elguera, and General La Puerta. None of them would have the majority required and then the Congress would have to decide between the two who had most votes. Two doors off lived José Maria Peña, who was extremely agreeable, and invited me to dine with him. He told his Cholo boy to accompany me to the bath, the descent to which was long and gradual. On both sides were high cliffs, partly overgrown with bushes. There was a shed in the middle of the road, covered with vines, and the whole had a pretty, not to say picturesque appearance. Peña had a small room made of boards for undressing while the other huts were of mats. The bathing was far from pleasant; to reach the sea I had to pick my way over big stones; stones covered the ground, and the waves came rolling on with such violence that with difficulty could I keep on my legs. After the bath I looked in at José Pablo Escobar's, always very polite. With him were his wife, her unmarried sister, and another sister married to Arosomena, formerly book keeper of the Constructora, at present with Chavez. Escobar said that the Nitrate consignment was on the point of being arranged with Gibbs, but I did not believe that this was as yet in a state of such forwardness as he pretended. I dined at Peña's, with his wife, daughter, son, and his brother-in-law José Maria Costas. The two gentlemen were very nice persons, and I was well pleased. Past seven Peña accompanied me to the station where a military band had just arrived from Lima merely for the purpose of diverting the dwellers of El Barranco with their performance. I returned to Lima by the train which left Chorrillos at 7.30. Lizardo Montero arrived this evening from the North, where he had been canvassing for the Presidency, but with little success. Fireworks were let off, and about eight he held a speech from the balcony of the house where he resided, that belonging to the widow of the late President Balta in the Calle de Negreyros, close to Rafael Velarde's. The concourse of people was small; he spoke however as if his triumph was certain. 
Sunday, $26^{\text {th }}$ of March. At 1.45 I went by train to Chorrillos [48] [...] Frederic Marriots whom his sister in law Dolores [_] uente stayed. My visit was especially to her, and she was as friendly as [_]. There was at present here in Lima a young Spanish girl who called herself Esmeralda Cervantes, who excelled on the harp. On Thursday of last week she played in the President's rancho in Chorrillos; to hear her Pardo had invited some ladies of those nearest related to him, and about thirty gentlemen, amongst whom Frederic Marriott, who told me that one of the guest had been the son of the Prince de Joinville, midshipman on board of the French man-of-war in the Port, and who, according to Marriott, had all the appearance of a booby, tall, lank, and without any manners; in such a party as this he had appeared whithout gloves. From Dolores Puente I went to Juana Rosa Moreyra, wife of General Freyre, who was still dressing; then to the rancho of Emilio Althaus where I merely found his sister-in-law Georgina Dartnell. Macandrew whom I met in the street said that his wife was still en négligé, thus I did not go to her. With Mrs. Henry I stayed a long while. I concluded my round with Doña Juana Guise and her family, had time to take a long bath and return to Lima by the train of 5.45. In the evening I was beyond meausure sleepy, and though Federico Palacios, Isabel Coloma, her two daughters, and Zoila Velarde were with us, I went to bed at 9.30. When my wife came to our bedroom I had to rise again to shut all the doors, and thus after all I slept but poorly.

Monday, $27^{\text {th }}$ of March 1876. Alejandro had only been able to purchase two bars from Bamberger Kastendyk \& Co. at S/14 the mark which I sent per steamer to Rosa Schutte in Paris. Whilst I was in the Banco de Lima to have my signature affixed to shares Gallagher called and begged me to go with him to the Banco Hipotecario. José Canevaro had proposed some time back to pay $\mathrm{S} / 45,000$ due by the Monteros, if we would waive the penal interest. We then determined that we would be satisfied with $1 \%$ monthly penal interest. He now renewed his proposal, and offered a round sum of $\mathrm{S} / 500$ in cancelment of all such interest. My opinion was that the Gerentes might settle with him for $\mathrm{S} / 3000$ in the very last case for 2000 . Sagastabeytia and Dr. Galvez were sent too after I was gone and they coincided whith me. [49]

Tuesday, $28^{\text {th }}$ of March of 1876 . A great part of [...] I spent in the office of the Gas Coy., jointly with Oyague, Mathison, Ruden, Garland and the Gerente F. Marriott. The time was taken up with reading various reports to be laid before the shareholders in the next general meeting. Mathison, Ruden and Garland had drawn out a report, in which they touched on several abuses and Marriott seemed much inclined to have it quietly laid aside; but I agreed with the said three gentlemen that it should be printed and made public; and thus it was resolved. Oyague kept neutral. Last year about 109,000,00o Spanish cubic feet 
of gas had been produced, of which about 21,000,000, between 19 and $20 \%$, had been lost, and the balance of $88,000,000$ consumed. Each ton of coal had on an average produced about 11,000 cubic of gas.

In the evening José Basagoytia came, and gave me the bad news that he having proposed to my neighbour Leyva the purchase of his house, ostensibly for himself, Leyva had declined selling it. The sentence of the Superior Court in his favor, had very naturally raised his expectations to obtain hereafter a very high price from me or my heirs. In Callao had died Joaquin Soroa, one of the most respectable and oldest port agents.

Wednesday, $29^{\text {th }}$ of March. About three in the afternoon died José Baron, for many years clerk, afterwards partner of the house of José Canevaro; he had also been for a considerable time sindico of the Convent of La Concepcion. At 7.30 in the evening I went to the house of Dr. Muñoz to pay him my visit of condolence for the loss of his son. He was by himself, received me in his library, and I remained with him nearly half an hour.

Thursday, $30^{\text {th }}$ of March. At the meeting of the Directory of the Banco de Lima, Armero and Castillo were the only two wanting. The affair of the Salitrera "Esperanza" seemed to be satisfactory arranged. The Government engineer Arancibia had to return to Iquique to receive it, but hitherto he had been prevented from going. The commission of Delegates had also closed with Gibbs for the consignment of nitrate to their London house for at least three months; they at once advanced $£_{40,000}$ wherewith to pay the interest on the certificates. Two members of the commission [50] [...] on the [_] inst., had given in their report; Gallagher was opposed [_] Mariategui in favor of the meeting of shareholders. Cucalon had not affixed his signature. It was therefore decided, notwithstanding the strenuous opposition of Cardenas, to request him to give in his report by Tuesday next, on which day, with or without his written opinion, the Directory would resolve what was to be done. This evening took place the marriage of the lawyer Felipe Varela, one of the sons of the late José Maria, with Rosa, second daughter of the late Pedro Orbegoso and his widow Rosa Mercedes Riglos.

Friday, $3^{\text {st }}$ of March 1876. I carefully examined the sentence given by the Superior Court against me, and in favor of Leyva, and found it based on such irrefutable arguments that I much feared that it would be quite impossible for me to gain the cause in the Supreme Court. I dictated to Bryson some observations, and took them with the copy of the sentence to the office of Dr. Palacios, who fixed upon next Tuesday night to confer with me on the subject. Only Barrios and I were in the Banco Hipotecario, consequently there was no meeting of the Directory. When I came home, I once more found my wife unwell. A feeling of cold, and pain in the legs, had made her seek her 
bed. However Dr. Middendorf, when he came, did not think it necessary to prescribe any medicine.

Rosa's and Juan's letters by the North steamer were extremely disheartening as regards Schutte's affairs. Rosa asked me for a loan "for" said she "as we cannot sell the house, and Vega \& Ibañez will not continue any longer with their monthly pecuniary assistance, within two or three months the family will actually be without the mean of subsistence." Page 274, Volume VI, I mentioned a certain Vega, who in 1856 was our fellow passenger from Southampton to Callao. In later years he, whether Chilian or Spaniard I do not know, married a Chilian lady, and then settled over to Paris, where with a relation of his as his partner he formed a mercantile establishment under the firm of Vega \& Ibañez. It was perhaps owing to his acquaintance with Amalia Schutte, whose fellow passenger as already said he had been in 1856 , that he became known to her father. Mr. Schutte, notwithstanding his intellectual capacity which nobody can deny [51] him, has always been open to flattery, and can easily be [...] by anyone, who works upon this his weak side. Vega \& Ibañez were not long in discovering this, and wormed themselves into his confidence to such a degree that nothing could be done without them. They became his factotum, and his agents in his extensive transactions on the Paris Stock Exchange; he lost, they gained, and finally when el patron found himself in straightened circumstances they, as is evident from Mrs. Schutte's letter, tendered him for some time a helping hand.

Juan wrote that politics in France wore a threatening aspect. In the elections Gambetta, the reddest of the red, and his partizans had triumphed everywhere. They would have the preponderance in the next French Parliament, and in all probability the first thing they would do would be to pardon those of "La Commune" and to recall them from their place of Banishment in New Caledonia.

Saturday, $7^{\text {st }}$ of April 1876. My wife continued unwell. Dr. Middendorf prescribed some tonic pills to be taken if she should again suffer from diarroeha. Ilent to the Banco Hipotecario $S / 40,000$ - which they wanted to pay the interest now due on Cedulas. They had in cash $\mathrm{S} / 70,000$ - a sum which did not suffice. They paid $1 \%$ monthly interest, and bound themselves to return the money on or before the $30^{\text {th }}$ June. At 3.30 the two Gerentes, Barrios, Sagastabeytia, and I were assembeld. The following came under consideration: five or six years ago the then Directory resolved, following the advice of Riva Agüero that a considerable quantity of Cedulas should be remitted and sold in Paris, there to be redeemed and interest to be paid on them on a fixed exchange, equal to 45 pence on London. Ventura Marcó was named the bank's agent. Already in 1874 the remittances were not made to him and he could not hacer el servicio. 
When in March of last year the new Directory came in, it was decided to stop the payments in Paris, because the loss to the bank, paying at $45 \mathrm{~d}$ and making remittances at an exchange which had gone down to $28 \mathrm{~d}$, would be ruinous. Of course the holders of the Cedulas in Paris protested [52] [...] the one and the other amicable arrangements were made, whilst Chavez, in the name of Gordillo in Paris, presented himself to a Juez de $1^{\mathrm{a}}$ Instancia here in Lima, where the case now lay. Manuel Osma, just arrived from Europe, who was holder of 32 shares bought in Paris applied to the Gerentes, and expressed his willingness to waive his right to the exchange of $45 \mathrm{~d}$ if the banks would give him in lieu of the amount which he might have to receive, six cedulas of S/10oo each. The Directory negatived his request, and authorized the Gerentes to make some trifling concessions; and if not satisfied with the same, he might go to law. When we had broken up, Sagastbeytia communicated to us of the Banco de Lima that though the tribunals were still shut, the Monteros had presented themselves to the judge Velis, with an escrito protesting against the sale of "La Esperanza", because, according to them, the railway by a previous arrangement was theirs and could therefore not be sold by the Directors of the Salitrera. Velis ordered this escrito to be made known to the Banco de Lima. This, I feared, would once more embarass the sale of the Salitrera to the Government.

The Committee of Delegates had published this day in "El Comercio" that they would pay the interest of $2 \%$ on the Certificates given by the Government to the sellers of the salitreras in bills at $90 \mathrm{~d} / \mathrm{st}$. on A. Gibbs \& Sons of London, at $44 \mathrm{~d}$.

Sunday, $2^{\text {nd }}$ of April. I went to Chorillos at 1.45 , bathed, looked in at Mariano Felipe Paz-Soldan's, and was back in Lima by 5 . My wife went to bed at as early an hour as 8 p.m. I thought of following her example, being very sleepy, owing to the bath, when at about nine Federico Palacios came, accompanying Maria and Corina, who had spent the day with his children in the garden huerta, the property of his father-in-law Villacampa, near the portada the Guia. Palacios told us that the fanegada of good land generally produced 500 quintals of sugar. The famous estate of Caudevilla, now Canevaro's, had about one hundred fanegadas planted with sugar cane; thus it produced annually fifthy thousand quintals which at the present exorbitant price of $S / 5$ per quintal of brown sugar gave annually $S / 250,000$ gross, [53] not corresponding to the cost of the estate, and the heavy [...] which were incurred. Santa Clara, Bryce's property on the Oroya line gave sugar of first rate quality, but the ground was so sterile that the cane reached but a small height, and the quantity annually produced was very limited, so that this plantation left a decided loss. Even Derteano from his ernormous estate near Santa, according to Palacios, was not likely to obtain any adequate returns. The exchange on Europe, 28 to 3 od per 
Sol, was of course extremely favourable to owners of sugar estates, for now they sold their produce at an extremely high price, but, should the exchange again go to $40 \mathrm{~d}$ or thereabouts, then no sugar planter could possibly make $8 \%$ upon the capital invested. Labourers would also be wanting in course of time, not exactly because the eight years contracts would gradually expire, for the Chinese Coolies, if free, might and most likely would work, but the danger lay in the probability of the total extinction of the Chinese introduced into Perú, who for the greater part are of the most vicious habits. They intermix but little with the other Peruvian races, the Cholas, the Sambas, and the negresses, and thus, instead of multiplying as is generally the case with human kind, there was every appearance of their gradually decreasing in number, and finally dying out. He also gave it as his opinion that there was some truth in the rumours which had been afloat some time ago as to a far spread conspiracy amongst the Chinese, their plan having been to poison the provisions a large proportion of which went through their hands. Their leader had been apprehended, and was at present in prison. At 10 Palacios left, Garland and Enriqueta went to Doña Pancha, wife of Gregorio Benavides, whose birthday it was, and I retired to rest.

Monday, $3^{\text {rd }}$ of April. Dr. Middendorf prescribed for my wife a slight purge, which had its due effect. I collected $2 \%$ for the last 3 months on my shares in the Water Company, Cedulas del Banco Hipotecario, and Cedulas del Banco Territorial. Towards the latter end of March there had been some disorder in Chuquibamba which had been easily put down with the loss of some lives. The Comercio made known that a telegraphic dispatch had been received from Europe which brought the news that a contract had been concluded with La Société [54] [...] was not said in virtue of which, if approved by the [_]dholders, La Société bound itself to hacer el servicio for three half years and to place at the disposal of the Peruvian Goverment $£ 700$, ooo annually. This evening Esmeralda Cervantes was to perform on the harp in the Club de la Union, and a numerous concourse was expected.

Tuesday, $4^{\text {th }}$ of April 1876. In the Banco de Lima the Directory was well represented, only Aliaga and Castillo being absent. Cucalon was present, but did not give in his written opinion on Cardena's motion of the $17^{\text {th }}$ for a general meeting of the shareholders. Gallagher's and Mariategui's reports on the same subject were once more read. The former was opposed, the latter in favor of the meeting. Mariategui's argument was that the Directors had no right to transfer the power given them by the shareholders to two of their members who had been named the representatives of the Banco de Lima in the commission of the Delegation of the four banks, and that consequently the shareholders ought to be convened, in order that they might confirm or disapprove the nomination made by the Directory. A short discussion ensued, the result of which was that 
the majority, I of the number, and including Cucalon, sided with Gallagher and thus the convening of a general meeting was negatived. Dr. Cisneros, one of the two Delegates of the bank, made known that five or six persons had presented themselves to the Government to impede the sale of the Salitrera "Esperanza", pretending to have claims on the same preferable to those of the Banco de Lima, they were: the estate of Zaracondegui, Almonte, the proprietor of the ground, Montero, who claimed the sleepers and rails not paid for, and two or three more. Lembcke being asked assured us that Arancibia, the government's engineer, would leave next Monday for Iquique, to receive the "Esperanza". In the evening after [_], my wife having already gone to bed, for she was not well, I went to Dr. Palacios and conferred with him about the lawsuit against Leyva: he did [_] yet despair. Last Wednesday nine persons embarked in Ancon on board of a small sailing boat to make a short pleasure trip. None of them understood anything about managing such a [55] boat. They had with them a fair stock of spirituous [...]. Nothing had since been heard of them, and it was said that the steamer "Limeña" had found the boat keel uppermost.

Wednesday, $5^{\text {th }}$ of April 1876 . Dr. Middendorf regularly attended my wife, who after the last slight attack of diarrhea was again complaining of debility. Towards 2 O'clock I went with Rafael Velarde to General La Puerta, whose influence with the vocals of the Supreme Court we might need in our suit against Leyva. He was an elderly man, and had his room very prettily furnished; towards me he was polite, but not particularly attentive, for he, Rafael, and Dr. Quimper, who joined us, were immediately engulphed in their political discussions in which I took no share. At about 4.30 the Directory of the Banco de Lima took their seats; all were present except Castillo, whose eldest daughter was dangerously ill of consumption. After the acta of the last meeting, and the usual monthly statements had been read Cucalon again enquired about the accounts of the "Esperanza", and then it came to light that the Gerentes could not account for 90,00o Soles and more, sent to the Salitrera by the Banco de Lima. Lembcke even said that it had been absorbed by expenses, and then read the last letters he had written to his son-in-law Juan Juiroz, who since Sterlings withdrawal had had the management, and from which letters it appeared that in the production of nitrate there was a deficiency of four thousand quintals. This was not to be borne; I got very angry and said that if there really turned out to be a deficit of 90,00o and odd Soles, the Directory could only be responsible for the orginal 20,000 which we had agreed to advance over and above the $S / 1,200,000$ permitted by the shareholders, and that for any amount exceeding the $S / 20,000$ the gerentes alone were responsible. Sagastabeytia endeavoured to exculpate the Gerentes by referring to actas of October and November last, and Lembcke was offended at my having expressed myself in such clear terms; 
however when we left several of the Directors, amongst whom Gallagher and Cardenas, told me that they were glad I had spoken in the manner I had done. Bernales moved that one of the Directors should go to Iquique to deliver the "Eperanza" to the Engineer Arancibia, and examine [56] [...] carry out this commission we fixed upon Cucalon [...] o replied that tomorrow he would give his answer whether he could go or not. Cucalon moved that the guarantees given by the clerks of the bank should be examined; of course all agreed to it, and I named Cárdenas for this object who accepted the nomination. Besides La Puerta and Buenaventura Elguera, Riva Agüero was again in the field for the Vice Presidency, and even J. A. Ribeyro of the Supreme Court, had started up.

Thursday, $6^{\text {th }}$ of April 1876. The Directory of the Banco de Lima met once more; when the acta of yesterday had been read, Cucalon complained that his words had not been faithfully given, and presented a long written paper, containing as he pretended an exact account of what he had said. Lembcke observed that these were not the expressions which he had made use of on the previous day, whereupon a violent altercation ensued, which was put an end to by Cárdenas proposing that in today's acta, Cucalon's alteration, and the answer of Lembcke and Sagastabeytia, should be noted down. I then asked Cucalon whether he was inclined to go to Iquique as yesterday proposed; [_] declined, on the plea that his wife was near her confinement and that therefore he could not leave her. I then enquired Mariategui whether he would take upon himself the commission, and before he had time to reply, Aliaga proposed Lembcke. The general opinion however was in favour of Mariategui, who after some demur acceded and said that he was ready to go on Saturday. Instructions were to be given to him signed by me, which Cardenas at my request promised to draw out. When we broke up, and I begged Sagasta[_] to give me the stamp with my name, which was no more used, he told me that he was much hurt at what I had said yesterday and that he had not expected such words from me, whom he believed to be his friend; he was, he said, no encubridor de fran[_] to which I answered that I had never said, he was, but that I was of opinion that there had been some negligence on the part of the gerentes. This however they would not admit, and tried to [...] and perhaps actually proved they had beed deceived by J[_]z, the manager of the Esperanza. When I left at about five, there was [57] still the cloud hanging over Sagastabeytias countenance.

Friday, ${ }^{\text {th }}$ of April 1876. At somewhat past one in the office of the insurance Company "Lima", the Gerente Elizalde, the Vice, Chavez, Gil, Robertson and I were assembled, and though one was wanting to form the quorum, we approved the usual monthly accounts laid before us by Elizalde. I then looked in in the Banco de Lima, where I found the two gerentes with a less severe aspect than on the previous day, and Mariategui. Arancibia, the Government's engineer, 
had made difficulties about his going to Iquique. Mariategui had explained to him the importance to the bank of his going without loss of time. Arancibia had then applied to the bank for a loan of $S / 2000$ which were paid him, and which would probably never be returned, and then promised to embark for Iquique on Wednesday next. Mariategui put off his departure till the same day. Cárdenas had drawn out the instructions which Lembcke read to Mariategui and myself; they were approved and would be copied in clean. I then went to the office of the Gas Company where some of the shareholders were in sufficient number to proceed to business. Oyague presided. The last "acta" was read; next it was proposed that the informe, or report, should not be read, because all the shareholders were acquainted with its contents. I observed that the informe of Mathison, Ruden and Garland was of such consequence that it well merited to be read again. This was done, but instead of being discussed, it was agreed that the Directory should attend to the alterations and improvements therein recommended; in other words nothing would be done. Then at Oyague's request a protest signed by José Sevilla, and José Sebastian Goyeneche in Paris was read in which they found fault with the statutes and everything done by the Company. Oyague was principally alluded to. Then the counter-protest, signed by Oyague, Mathison, Ruden, Carrol, Garland, and Francis Bryce was read. Gallagher was the $7^{\text {th }}$ Director, but as he held Sevilla's power, the protest drawn out in Paris had not been notified to him, nor had he signed the counter-protest. Henry moved that shareholders should declare themselves satisfied with what the Directors had done [58] [...] of the counter protest. According to statutes [_] the Directors went out, and new ones had to be chosen, but before we proceeded to the election, Garland observed we ought first to decide whether they were to be paid or not, for a motion to this effect made by Henry at the last meeting was still pending. I rose, and proposed that a remuneration should be given to the Directors, but only after the shareholders had received $9 \%$ interest on the capital. Dr. Arosamana considered my motion a very proper one. Ruden, the great defender of paid Directors, called it a burla, which it certainly was for the profits were usually so small that after $9 \%$ interest was deducted, not much would remain upon which the remuneration for the Directors had to be calculated. A great deal was talked the one way or the other and at last Garland's motion was postponed till next meeting. I again rose, and observed to Oyague that the payment or non-payment of the Directors ought first to be decided, because there might be some gentlemen who would be Directors if paid, but who would not be if not paid. This was considered derogatory to the honorability of the gentlemen assembled, and it was not even put to the vote, which I had not expected either. Finally the election was proceeded with, but as it was time for many members to go to Chorrillos by the five train, the result was not yet made known. Melchor [_] 
told me in the course of the day that General Francisco Diez de Canseco would not sell the houses spoken of several weeks back for less than 46 Cedulas of S/1000 each.

Saturday, $8^{\text {th }}$ of April 1876. The gerentes of the Banco Hipotecario lent me the title deeds of general Canseco's houses above spoken of for they were mortgaged to the bank. I took them to Dr. Palacios who looked them over, and found them in order; but Guillermo whom I had requested to examine their structure, gave me a discouraging report. They were built, he said, in an extremely slight manner, and wou[_] probably soon require repairs. Canseco's wife bought them in 1869 from Cluseau for S/16,0oo. Rivarola, Guillermo's partner, had told him that he knew these houses to be unhealthy, owing to their proximity to the river, and thus I resolved not to purchase them. In the Banco Hipotecario, the Directors met except Sagastabeytia who was busy [59] on the Banco de Lima. Gallagher brought again under [...] the more than once referred to offer of José Canevaro who proposed to pay all the arrears of the Monteros, not $S / 45,000$ but $S / 50,000$ if the interest were waived. Last time we did not accede to this last condition; we now changed our mind, taking into consideration the reasons which Gallagher adduced, and which had been corroborated by the lawyer Dr. Aranivar, one of the shareholders of the Banco Hipotecario. We then began to discuss the reformed Statutes with which we made some progress, till Dr. Galvez had to leave, when we broke up.

Sunday, $9^{\text {th }}$ of April 1876. A little past 6.30 a.m. I left my house, crossed the bridge of Balta, and ascended San Cristoval from the Lurigancho side. I did it without stopping, but very slowly. When I reached the summit, I sat down for a few minutes on the big stone. The sun now began to pierce the clouds. When I returned over the bridge it struck nine, and the sun was out in all its brightness. At home I lay down for about half an hour, and at a quarter to two I went per train to Chorrillos, where I bathed, and whilst in the bath felt an earthquake; not exactly the shaking, but an unusual noise which I could not account for, until I was told in Lima that an earthquake had been experienced. I had time to look in at Macandrews, who and his wife were by themselves both reading in the corredor. I returned by the 4.45 train.

Garland, Enriqueta, part of their family, and Guillermo with Eliza dined at Villacampa's in their huerta. Dolores Puente kept my wife company. I as usual accompanied her home, and notwithstanding my great sleepiness remained up till Enriqueta came, who read to me a letter from Rosa, just received per French Steamer dated $5^{\text {th }}$ March; it contained nothing new, being merely a confirmation of the previous letters. They had received the sentence of the Supreme Court in the suit against Calderon, and seemed to be satisfied with the result. 
Monday, $10^{\text {th }}$ of April 1876. Again in the Banco de Lima. Castillo sent word that he could not come because he had to take his sick daughter [6o] [...] agher could not remain, being too busy in the Banco [_]potecario; Armero and Aliaga did not make their appearance. Firstly. The instructions given to Focion Mariategui for his trip to Iquique were read and approved. Secondly. A copy of the contract made between the Delegates representing the four banks, and William Gibbs \& Co. was read. The original was already signed by the eight Delegates; consequently, though we might discuss it, we could not alter it. Its principal conditions were: in order to enable the Government to pay the interest on the certificates, due $1^{\text {st }}$ April, Gibbs advanced to the four banks, de mancomun et insolidum up to $£ 40,00090 \mathrm{~d} /$ st., the drafts for which amount, upon Gibbs in London would be signed by Garcia Calderon, President; and Luis Benjamin Cisneros, Secretary of the Committee of Delegates. On this advance $6 \%$ annual interest was to be charged. During the months April, May and June the banks consigned to Gibbs of London all the nitrate which they might produce in the course of these three months. Gibbs of Lima advanced on each quintal when shipped S/1.70 and the surplus which the nitrate was expected to leave in London when sold was to cover Gibbs for the advance which they might have made on account of or the total $£_{40,000}$. Gibbs charged [?]\% sales commission, and customary expenses; also $21 / 2 \%$ commission for chartering vessels; of this last $21 / 2$, they returned the half to the bank. If on the $30^{\text {th }}$ June they were not covered for the advance made they might ship and sell till covered. As a further security the banks placed into the hands of W. Gibbs \& Co. S/60o,ooo Noml. of the Internal debt, which in case of need they might sell at the market rate. The principal fault which we found with this agreement was that the selling price was left completely to Gibbs of London, without the slightest interference on the part of the Government or the banks. In the letter which Garcia Calderon wrote to the bank enclosing a copy of the contract, he demanded that the bank should contribute immediatly [_] share of the Vales de la Nueva Consolidacion which were to be handed to Gibbs. Lembcke asked the Directors to authorize the Gerentes to make this delivery; we had necessarily to give it, but withdrew it when we learned to our utter surprise from Cisneros that Manuel Pardo [61] [_] the Government had come forward with a fresh request [...] monthly from the four banks, which had however been decidedly refused by the Delegates. This affair became more complicated from day to day. Mariategui would always leave for Iquique on the following day, and Arancibia promised to do the same.

Tuesday, $11^{\text {th }}$ and Wednesday, $12^{\text {th }}$ of April 1876 . Two dull and tedious days. In the evening of Wednesday Rafael Velarde came to tell us that he had had a long conference with General La Puerta, who had refused to take any steps in our 
favor in the law-suit against Leyva. About a month back Leyva, and his fatherin-law Col. Deustua, a particular friend of the Generals, had been with him, had represented to him the suit in their light; Leyva had spoken of his large family etc., and accordingly La Puerta had resolved to keep completely neutral, and do nothing either for the one or the other party.

Thursday, $13^{\text {th }}$. Holy Thursday. I went to Chorrillos after Bryson had left me and looked in at Doña Isabel Coloma's, who was not at home. I remained a short time with her eldest daughter Juanita, took my bath, and returned to her rancho; she was now in and told me that she had done everything in her power to influence some of the Vocales of the Supreme Court. At General Pezet's the doors were locked, and it being now too late for the 4.45, and too early for the 5.45 train, I walked on the railway as far as the Barranco station, where I had still to wait a considerable while for the train from Chorrillos, which took me back to Lima. In the evening we had a short visit from Henry Higginson. His daughter Eliza was about this time in the habit of spending now and then an entire day with her mother-in-law, my daughter Enriqueta; her husband Guillermo was interested with two Italians in a coal business, which he thought would in course of time leave him a fair profit, but as according the agreement none of the three partners was allowed to take out any part of the gains until their joint capital had reached a certain amount, it was very natural that he found himself often much straightened for want of ready money. Alejandro, who resided with his wife in Chorrillos, earned his daily bread by dealing in all descriptions of public securities [62] [...] worked in my office when I was in Chorrillos and balance[_] my books till the $29^{\text {th }}$ February last. By tomorrow's steamer José Canevaro would embark for Europe, but being the candidate for the second Vice Presidency, had necessarily to be back within three months, before the opening of the Congress.

Friday, $14^{\text {th }}$ of April 1876. Good Friday. I did not leave the house the whole day. From noon till five Alejandro and I were occupied with my books. The result of last year till $29^{\text {th }}$ February 1876 was the following: notwithstanding my having received in the course of the year the $\mathrm{S} / 5^{0}$,ooo due to me by the Pasco Railway Company, the valuation of my property had once more deteriorated $S / 13,000$ which deterioration added to $\mathrm{S} / 8519.25$ housekeeping expenses, $\mathrm{S} / 1240$ lectors, and between 4 and $S / 5000$ extraordinary expenses, reduced my gross gain of $S / 68,000$ to $S / 41,000$. This would not have been a bad result, if owing to the depreciation of the Lima Bank notes, and the consequent rise of exchange on Europe, my fortune had not really decreased in its actual value, more than $331 / 3 \%$, nay more than $50 \%$ in the course of the last twelve months for the exchange on London which was 43 , was now 28 and the difference of 15 is more than $50 \%$ upon the $28 \mathrm{~d}$. 
Saturday, $15^{\text {th }}$ of April. Sabado de Gloria. Though no actual holiday, I, at my wife's particular request, went out to Chorrillos to ask General Pezet for this influence with the Vocales. I took my ticket only as far as the Barranco, where I got out, and went to the house of the Vocal Ribeyro; he was not at home, but his wife Doña Eulalia was, whom I begged to do all she could with her husband to induce him to sentence in my favor. I then walked along the railway to Chorrillos, to General Pezet's house, who had gone to Lima, and his wife was ill in bed. I was however received by a young lady who told me that the General would be back by the 4 O'clock train. I then took my bath, and was again in Pezet's house somewhat before 5 . I explained to him all that was necessary; he noted down the names of the Vocales, and promised to speak to the greater part of them. This being settled, I conversed with him on the topics of the day, when he told me amongst other things that he had been informed that the conclusion of the loan contract had been once more postponed, this time owing to the machinations of the [63] clever, but imprincipled Pole Lazky, who as a pr[_] had succeeded in inducing the London holders of Peruvian Bonds to retract the concessions previously made by them to the Peruvian agents. Lazky's sole object, according to Pezet, was to take the contract out of the hands of La Société Générale of Paris, and to put it in those of the firm of Thomson Bonar \& Co. of London, in whose business he had an interest. From Pezet's I walked back to the Barranco station where I had to wait at least a quarter of an hour before the train came which conveyed me to Lima, where I arrived at a quarter, and was in my house at half past six. We had a visit from José Basagoytia who also promised to use his influence with various persons. Felix Dibos and his wife Ernestina Pflücker took tea with us.

Sunday, $16^{\text {th }}$ of April 1876. Easter Sunday. I did not go to Chorrillos because I thought it better to pay some visits, which I had not done for a length of time. I first looked in at Dr. Manuel Morales, a very honest and upright man, but of limited capacity, who Fiscal of the Superior Court, had since the death of the two Fiscales of the Supreme Court, Drs. Ureta and Paz-Soldan, been entrusted with the Fiscalia of everything relating to the Government, whilst the cases to be decided in the Supreme Court were distributed between various lawyers who for this sole object had been named provisionally "Fiscales adjuntos". Next, I went to Dr. Muñoz and his wife who received me kindly; with the Doctor I spoke a few words about my law-suit, then to the Masias, and Rafael Velarde with both of whom I remained a very short time. Neither did I stay long at the Basagoytia's. Doña Josefa, the widow of Dr. Prada, now married to Andrés Zavala, was not in; with Augusta Bergmann, Miceno Espantoso's wife, I had a very long chat. At Dr. Alvarez only he and his wife were in, but visitors being with them I could only, when taking leave, say a few words to the Doctor 
about the suit. With Doña Cristina Bustamante, grand-daughter of Dr. Alvarez, I was perhaps a quarter of an hour; her husband, Dr. Luis Cisneros whom I particulary wished to see, that he might speak in my behalf to his brother, Don Manuel the Vocal, was absent on a trip to Ica. At the Pintos I was received by one of the youngest daughters, who of course had not yet so much to say for herself as her two elder sisters [64] [...] after dinner we had a visit from Col. Diego Mas[_] and at a later hour Rafael Velarde with his family, Doña Francisca Cardenas de Benavides, and her pretty niece Rosaura, came in and kept us company.

Monday, $17^{\text {th }}$ of April. Easter Monday. I continued the visits begun on the previous day. Dr. Bandini, the Canon of the Cathedral, was not in, neither was Dr. Teodoro de la Rosa at home, I was received by his wife, a lady certainly not of great intellect or pleasent manners. Somewhat more agreeable than she was Doña Josefa, the daughter of old Anselmo Centeno, and widow of Fermin Miota. With Doña Manuela Portillo I always spent a very pleasant half hour or so. Melchor Velarde's wife and daughters were very nice persons; I was with them perhaps twenty minutes. My last call was upon Doña Josefa Bazo, the wife of Anibal Gonzales, who had taken up abode in the huerta of Gamboa, not far from the Callao gate. Several years back she had had her right arm amputated. When sewing she pricked her finger with the needle. This slight wound assumed a cancerous character; the poison spread across the wrist, up the arm, and to save the body the limb was cut off. Whilst in London her husband had for some years been gerente of the South American Company; he then established himself on this own account, and failed. Her beloved Irene, wife of her brother Juan had also died in London. Don Juan himself had lost nearly all his fortune by speculating in Peruvian Bonds, and thus it was not to be wondered that the poor woman was at present very low spirited. At first she was rather taciturn, but became more lively when she related to me how happy she had been in London after she had conquered the difficulty of the language, and how gladly she would return thither. My wife, Doña Angela, and I dined with Enriqueta, her son Juan, and her two little girls. The remainder of the family were all out in different directions.

Tuesday, $18^{\text {th }}$ of April. I saw Dr. J. A. Rybeyro about our law suit against Leyva; also, at my wife's earnest request, Mr. Pinto who promised me that indirectly he would do his best to [65] influence some of the Vocales.

Last Sunday Alexander Robertson, partner of the firm of Sawers Woodgate \& Co., my colleague in the Directory of the Lima Insurance Company, and husband of Fanny Meiggs, met with an accident which very nigh put an end to his existence. In Chorrillos, close to the bathing place in the sea itself, stands a building which goes by the name of the hotel; the property of one of the Terrys. 
From a gallery which runs round it, some young men, expert swimmers, were in the habit of jumping into the water. Peter Gallagher did so this day but observing that the water was uncommonly low jumped off in a slanting direction, and fell into the water, without touching the bottom. Robertson, who jumped in after him, did not take this precaution, but threw himself straight down, his hands and head foremost. With his head he struck into the sand; fortunately there were no stones. The lookers on, amongst whom Geraldo Garland Jr., saw what had happened, and shouted to Peter Gallagher who without loss of time took hold of Robertson and pulled him on shore. He had swallowed a good deal of water, and had lost his consciousness. Doctors were sent for. Robertson soon recovered himself; no part of his body was fractured, but it was doubtful whether the severe concussion which the brain had necessarily experienced would affect his intellect.

Wednesday, $19^{\text {th }}$ of April 1876. In the Banco de Lima the Directory was cited for 2 O'clock; we had no meeting for want of number, but bad news came in fast. The engineer Arancibia had not gone to Iquique to receive the Esperanza, having received express orders from Pardo, to remain here, as at present there was no necessity for his going. Lamarca, the Chilian, who was said to be engaged to the eldest daughter of Jose Vicente Oyague had some time back made a loan to the Government of three hundred thousand Soles or more at 9\% interest, for which he was to be paid in drafts on Europe at 40 pence, but until these drafts could be drawn, Pardo had given him drafts on the Banco Nacional, del Perú, and Lima on account of the monthly payments these banks had still to make [_] the [66] [...] for May, June and July. La Marca had presented a dr [...] the Lima Bank, with a letter of advice from the Government, and now the Gerentes wished to know from the Directors whether they should accept it or not. My opinion was not to accept it, for which I intended to give my reason in the next meeting.

Thursday, $20^{\text {th }}$ of April. Last night at about 2 I was called by my wife, who told me that she felt a severe pain in her intestines. I rose, and from a small flask of laudanum which we had always at hand, she poured three drops into a little cold water. This she took; her pain was assuaged for the moment, and she fell asleep. The whole day long she was unwell, and went to bed at nine p.m. She again felt pain; all kinds of home remedies were applied and at 10.30 p.m. Middendorf was sent for, who did not come. Enriqueta and I remained up till midnight, when my wife being asleep Enriqueta retired to her apartment, and I went to bed. In the course of the day Pinto came to tell me that he had done what I had requested him to do the other day, and that he had been very well received by those to whom he had applied. He remained to play at rocambor with Garland and young Jorge Valle. The Directory of the Banco Hipotecario 
met at the usual hour present: I, Dr. M. M. Galvez, Evaristo Barrios, José Jimenez, the two gerentes, and Dr. Ramon Ribeyro, one of the two lawyers of the bank Graña who was in arrears with his 3 monthly payments asked for a new loan with which he would paid off his debt to the Banco Nacional, and increase his debt to the Hipotecario to $S / 400,000$. His request was negatived. Dr. Fernando Palacios, who owed nearly $S / 80,000$ principal, and was in arrears with his three monthly payments for about $S / 10,000$ proposed to capitalize the $S / 10,000$ and consider them as a new loan made to him or make over to the bank his house Calle de Gallinacitos in part payment. He had spoken to me on the subject, and begged me to interest myself in his behalf. We found ourselves however under the necessity of declining both proposals. Finally came the principal object for which Ribeyro had been cited under discussion. What was to be done with those individuals who resident in Paris were holders of Cedulas upon which they asked the payment of cupones as well as that of the redeemed Cedulas, at the [67] exchange of 4 francs $65 \mathrm{c}$ the Sol, which in 1873 at the recomm[_] of Riva Agüero the Directory had promised to pay, and which arrangement when made known to the shareholders in a general meeting had not been found fault with. Now that exchange was fcs 3.10 the sol, such payments left a frightful loss; but on the other hand the Paris holders of Cedulas had a right to claim what had been promised to them. In November last the present Directory advised Marcó, who hitherto acted as their agent in Paris, that hencefroth the payments would no more be made at the fixed exchange of fcs 4.65 the Sol, and we consequently resolved that up to that day, November 1875 all Cupons and redeemed Cedulas should be paid at fcs 4.65 but after that day not.

Friday, $27^{\text {st }}$ of April 1876. Dr. Middendorf came in the morning and prescibed to my wife a slight opening medicine which did her good, though she remained in bed the whole day; the Doctor returned in the evening. Rafael Velarde, wife and daughters, also two young men, Urquhart and Julio, the son of Manuel Francisco Benavides, were with us. The latter two, whose visit was intended for Enriqueta, not for us, remained till 11.30.

Saturday, $22^{\text {nd }}$ of April. The temperature was getting considerably cooler. Thermometer at 11 a.m., in my office $71^{\circ} \mathrm{F}$. My wife was again pretty well, and out of bed. The financial and commercial state of the country wore the most gloomy aspect imaginable; the negotiations in Europe regarding a new loan had not yet led to any result, at all events for the last week or thereabouts nothing was known here in Lima on the subject. By last steamer the $5 \%$ Anglo Peruvians came quoted at $21 \%$. Garland told me that telegraphic dispatches had brought them at $16 \%$, which however I did not believe. The President Pardo had continual meetings with the Delegados of the banks; he asked for the money, which they could, and would not give. Consequently the business 
of the Salitreras remained in Suspense, and the Salitrera "Esperanza", the sheet anchor of the Banco de Lima, was not yet delivered up to the Government, because, as already said, Pardo had ordered his engineer Arancibia not to go. From the Callao Custom-House no money entered into the Treasury for only by orders on this [_] [68] [...] treasury was capable of making some payments. Meiggs, who made large claims on the Government, was not paid, whence followed that he did not pay either; for the rent which was due to me from La Empresa de Obras Publicas, I received on the $1^{\text {st }}$ inst. an order for S/540 on Meiggs, which up to this day had not been honored. Yesterday the interest due to me by the United Stated Guano Coy. fell due and was not paid; José Paredes, the usurer, who occupied № 20 Calle del Correo, and who usually paid with great regularity, had not paid his rent due $17^{\text {th }}$. Exchange on London was $28 \mathrm{~d}$. Only Dreyfus and the Banco Nacional drew small amounts at 33d. Derteano of Dreyfus house refused giving me anything; from Scheel I obtained the promise of $£ 100$ at 33d. Silver bars were at S/14 the mark. Coined Silver again up to $40 \%$ premium. Diego Masias who on this day was to leave with his wife for New York, to pay there a visit to two of their boys who were there for education, told me that he had paid to the Banco de Londres for an order for 3000 North American Dollars in Gold S/560o in Lima Bank notes. In the shops, all articles of European manufacture were exorbitantly dear.

Sunday, $23^{\text {rd }}$ of April 1876. At 2.15 I went to Chorrillos, and met in the train José Maria Romero, who had hitherto been collecting clerk for the convent of La Concepcion, and had now, after Barron's death, been raised to the lucrative post of Sindico of this convent. I told him that on the $15^{\text {th }}$ January 1878 , the lease which I had of the five shops Calle del Correo would expire, and that I was desirous to have it renewed; he was of opinion that this might be done, but only when the present Abbess, who was opposed to granting leases, had retired from her post, which would not be the case before the end of 1877 . In Chorrillos I called upon Dona Isabel Coloma, who assured me that she did not neglect our interest in the law-suit against Leyva, but that only three Vocales, Alzamora, Arenas and Cisneros were within her reach, and this only indirectly by means of her friends. She entreated me to procure some situation or other for her son Arturo, hitherto in Camogli's counting-house, but with my best will I did not see I could do anything for him. I then took my bath [69] and had time to look in at General Pezet's, who was [...] busy, for, as he told me, he had invited a large party to his house in the evening, to hear the Repetto sing; he also asked me, but I declined. Hitherto he told me, he had only spoken to Oviedo, but promised to do the same in the evening with Ribeyro and Vidaurre. At about 5 I was back in Lima. Doña Angela, my wife and I dined with Garland, Enriqueta, 
Enrique and Ricardo. This was the last time Mariquita dined with the family Garland ( $27^{\text {th }}$ March 1879). In the evening we were by ourselves.

Monday, $24^{\text {th }}$ of April 1876. Last night a robbery was committed in the store of José Lucas Oyague, natural son of Don José Vicente. The burglars broke open a door which from the patio led into the store, opened the lock of the ironchest by firing a ball into it, and stole many shares in Insurance Companies and banks, a small amount in money and some jewels of little value. In the forenoon I went to Luis Cisneros, and requested him to interest himself with his brother Manuel, the Vocal of the Supreme Court, in my behalf. I had also a very long talk with him about the Banco de Lima, of which he had a bad opinion to be sure though not so bad as that which I had. In the Banco Hipotecario the Directors, Jimenez expected and the Gerentes being present, we continued revising the statutes. The family of the Dulantos in Callao wanted a new loan of $\mathrm{S} / 20,000$ which we were not averse to grant, in case the security offered were sufficient. The Government had made a contract with La Compañia de Obras Públicas y Fomento for building a new post office on the same site as the present one. The payment was to be made in bonds bearing $8 \%$ interest, and $4 \%$ annual redemption. I wondered who would buy such bonds. In the meanwhile the offices had been transferred to the house formerly occupied by Huth. The new postmaster, it was said, would be Dr. Selaya, engaged to marry Juanita Valle Riestra, but the Nacional affirmed that the choice would fall upon a certain Pedro Castro.

Tuesday, $25^{\text {th }}$ of April 1876. Nearly the whole forenoon passed in running out from one place to the other; three times I went to Dr. Palaci[_] [70] [...] me when I found him in I arranged with him that in [_] evening he would draw up the escrito "fundando la apelacion" in the suit against Leyva, and after all I received a note from him that the procurador had not brought him the autos, and that nothing could be done this evening. At Basagoytia's I was received by the old gentleman who suffered from a bad cold. In the South American Insurance Company Ruden the President, Felipe Varela, Nicolas Rodrigo and I, had a meeting to determine what steps we should take in order to make the Pasco Railway Coy. pay us the interest long over due upon our "obligaciones de preferencia". Ruden held a power from Manuel Pardo; Böhl as representative of Gibbs' house which firm had full power from the widow of General Iturregui approved what we resolved, viz.: to give full power to Calixto Pfeiffer secretary of the Insurance Company, who without loss of time should order the company's lawyer Alejandro Arenas to call the company or its representatives before the Consulado, and to demand immediate payment. Carlos Elizalde, the Gerente of the Insurance Company Lima, was ill of dysentery. I therefore went 
everyday to the office to see what was doing there. The hacendado Baltazar E. Izaguirre who owed largely to the Banco Territorial, and whose two estates were about being brought to the hammer, came to me, and asked me for a large loan, which of course I refused granting him. It was past four when I made my appearance in the Banco de Lima; the greater part of the Directors were assembled: Dr. Luis Cisneros as Vice in the chair, which he ceded to me when I entered. The contract of the Salitreras with the Government was not yet signed, consequently everything referring to it remained in suspense. Lembcke read letters received from Focion Mariategui, who was anxiously awaiting a Government engineer, to whom the Esperanza was to be delivered up by him. Lembcke had not been inclined to communicate to the Directory the letters received by the last steamer from Huth \& Co. and the International Bank of London. He however read them at my request. In them mention was made of some securities placed by the bank into the hands of Huth Gruning \& Co. of Lima. Cucalon pretended to know nothing about it, and asked what this meant, when Lembcke [71] answered that many months back the Gerentes, with the [...] the Director de Turno, John Gallagher, and the President of the Directory; had placed into the hands of the said firm as security for the banks debt to the above London establishments, Government Bonds, and bonds of the Internal Debt. Now the storm broke loose. Cucalon said that those who had done it, had no right to do so without the knowledge of the entire Directory, and went so far as to call it an abuso de confianza. I said that instead of being blamed I expected to have received thanks for having approved what the Gerentes had done for nothing was more correct than to place securities into the hands of one's creditors. Other Directors seemed to approve of what had been done, but not in the manner in which it had been done. Cucalon and Lembcke had high words. The two gerentes went out and also called me, because I was included in the accusations. I however remained and took the whole very cooly. Cucalon reiterated his motion that what the four above named persons had done should be disapproved, and the bonds be returned to the bank. I said, "bien Señores desaprueban Uds. la forma, aprueban el fondo." Cardenas said, that he was so little acquainted with the details that he counselled not to come to the vote, and suggested that a commission should be named to investigate the affair. I fixed up[_] Aliaga and Barrios who accepted the nomination. It was past six when I came home.

Wednesday, $26^{\text {th }}$ of April 1876. Having learned from Rafael Velarde that old Mr. Basagoytia had been taken ill yesterday at 4 p.m. I went immediately to the latter's house where I spoke with his daughter in law, who told me that he was really very poorly; he had been delirious, been spitting blood, and was extremely weak; her mother in law Doña Antonia also kept her bed, owing to 
indisposition. In the evening I returned thither, and was told that both father and mother were a little better. Rafael Velarde was with us till near eleven.

Thursday, $27^{\text {th }}$ of April. I remitted by the steamer to Rosa $£ 100$ on Dreyfus at $33 \mathrm{~d}$ and one bar silver bought through Alejandro from the Pflückers or nearly 300 marks, at $\mathrm{S} / 14$ the mark.

This day was proclaimed with due solemnity the convocation of the Congress, for the $28^{\text {th }}$ July. Though Garland had not told me an[_] [72] [...] had learned from other sources that Garcia Calderon had received from the Gas Company on account of the $S / 20,000$ awarded to him, about $S / 15,000$ dividends paid by the Company on Schutte's shares hitherto embargoed. From 8 till past ten in the evening I was with Dr. Palacios in his study in his own house, where he dictated the first part of the escrito to the Supreme Court in my suit against Leyva.

Saturday, $29^{\text {th }}$ of April. My wife again kept her bed owing to a bad cold. There was little chance of old Mr. Basagoytia's recovery; he was beyond measure weak, suffered from fever, and was at times delirious. From 8 till 10 in the evening I was again with Dr. Palacios, who did not finish dictating the escrito.

Sunday, $30^{\text {th }}$ of April. Old Basagoytia lay in a continual lethargy. I did not go to Chorrillos, but remained in Lima in order to pay some visits; neither Dr. Muñoz nor his wife, both of whom I was anxious to see, was at home. At Transito Abrils, whose sister and brother-in-law Mrs. and Mr. Masias had gone to New York, the doors were shut. With Ernestina Pflücker, Dibos' wife, I remained a long while; she was a rather plain woman, but very agreeable, and showed me this day a great many Indian curiosities, not only such as date from the time of the Incas, but various ornaments, particulary collars, worn by the wild Indians on the other side of the river Chanchamayo, black and white beads, which appeared to be small fruits of a round shape, were stru[_] upon threads, the material of which I did not learn; and to them were fastened small birds with beautiful plumage of various colors; to another collar were fastened the claws of a wild beast, which made a rattling noise when shaken. Snakes, a viper, and lizards, she showed to me preserved in spirit of wine. It was getting late, and so I had to break off our conversation, and went to Dr. Alvarez whose daughter Asuncion told me that in conformity with my wife's request she had through the medium of her sister, interested herself with the wife of the Vocal Cossio to make her speak to her husband in favor of our suit. I concluded my round with a call on Doña Dolores Puente, with whom I found Don Anselmo Centeno, who told us that he had completed last week his $90^{\text {th }}$ year, and who was beyond measure tedious and prosy. My wife in bed the whole day. Doña Angela and I dined with Garland, [73] Enriqueta, Guillermo, Eliza and Ricardo; all the $[\ldots]$ at the regatta in Chorrillos. Eliza went to the play where there was 
at present a French Opera Bufa; Garland and Guillermo to the house of Doña Catalina Osma, widow of the Vocal of the Superior Court, Dr. Valle, where the marriage of her pretty young daughter Catalina, with a young Julio Carrillo de Albernoz y Mendoza was celebrated. Dr. Bandini performed the ceremony. This was looked upon as a connection between two high aristocratic families of Lima. On the one side the Osmas with the Barredas, and consequently the President Pardo, who was one of the witnesses; and on the other, the Mendoza y Bozas, who believed themselves of "la sangre mas azul de Lima". The mother of the bridegroom was Doña Catalina, sister of Manuel and Domingo Mendoza, and daughter of Doña Manuela who lived opposite to us. She had been twice married, the first time with El Conde Carrillo de Albornoz, with whom she had led no happy life, and secondly with General Manuel de la Guarda. She was very rich, having inherited a large property from her husband the Count, and from an uncle Dr. Galdeano; but on the other hand very plain, and - like all the Mendoza's - of a limited understanding. In the course of last week Frederic Marriott communicated to me that I had been re-elected one of the Directors of the Gas Company, which post I declined to accept under pretence of being too much occupied, in reality because when last Director I had come to the conviction that the Directors could do nothing, that they were and would be mere cyphers, as long as José Vicente Oyague, the largest shareholder continued to preside, and Frederic Marriot to be the Gerente, because these two united offered a passive, but most effective resistance, to every alteration, every improvement, every diminution in the expenses, which had been frequently recommended both by the Directors and shareholders.

Monday, $7^{\text {st }}$ of May 1876 . Old Don Manuel Mariano Basagoytia died this day at 11.15 a.m. At a few minutes past eight I had been a short time with his son José, who was by himself bitterly weeping. We had a long sitting in the Banco Hipotecario, all be[_] present except Sagastabeytia, and concluded the revision [74] [...] statutes which were now to be printed and to be distributed amongst the shareholders that they might look them over and give their opinion upon them in the next extraordinary general meeting. In the evening I was from eight to eleven with Dr. Palacios who concluded the escrito; my wife was up this day, but on

Tuesday, $2^{\text {nd }}$ of May she again kept her bed. This day, the anniversary of the battle between the Spanish fleet and the Callao fortifications in 1866, though in fact no holiday, was made one by the shopkeepers who kept their shops closed; also horse races were held, but in the town itself everything was quiet, and not a single rejoicing was heard. There were three things which caused my present sadness and despondency: firstly, and mainly, the continual indisposition of my wife; secondly, the lawsuit against Leyva, which I much feared we should 
lose; and thirdly, the beyond measure bad state of the affairs of the Banco de Lima. Mariquita remained in bed the whole day. At 2 Bryson left me, and I resolved to ascend San Cristoval which, notwithstanding the heat, for the sun shone from an unclouded sky, I accomplished with a facility which really astonished me. It struck 2.30 when I was in the second Alameda de Acho and four when I was back in the street which runs behind the palace from Los Desamparados to San Francisco. At home I slept for half an hour took a quick dinner together with Doña Angela; Bryson came at seven, when having finished the life of Queen Anne of Denmark we commenced reading Scott's History of Scotland. It was 8.30 when he left; I took tea as usual, and Enriqueta read to me the letters received from Europe; a very long one from Juan, who complained of his extreme costiveness which increased from day to day, and another, very polite from C. W. Schutte. In the letter which I had written to Rosa at the time of my wife's dangerous illness, I had sent him a salute in my own and Mariquita's name, and of this he now availed himself, no doubt for the purpose of making up matters after a total estrangement of about ten years. Towards ten I went again to the house of the Basagoytia's, where a great many gentlemen were assembled who accompanied the corpse to the Church of La Merced. I walked arm in arm with Dr. Luis Cisneros and conversed with him on the affairs [75] of the Banco de Lima.

Wednesday, $3^{\text {rd }}$ of May 1876. At 8 a.m. I was in the Church of La Merced at the funeral of M. M. Basagoytia, I drove out to the pantheon in a carriage with two gentlemen unknown to me, apparently Arequipeños. When we arrived at the pantheon another funeral, that of a certain Villegas, in which the principal mourners were General Lafuente and Ramon Lafuente, was just entering. I, owing to my want of sight, mistook them for my party, joined them but discovered my error in time to be present at the moment when poor Basagoytia's coffin was deposited in its niche. I was home in time for breakfast.

The Directory of the Banco de Lima was cited for 1 O'clock, but it was nearly half past two before the necessary number was together. Julio Armero, a very useless member, did not remain long. Aliaga, Bernales, and Castillo were wanting. It was, as it had always been of late a very disagreeable and boisterous session. Cucalon made use of some improper language, which we induced him to retract, but at the bottom he was in the right, for Lembcke refused to present documents which he asked for. Cucalon called the Gerentes subalterns, when Lembcke jumped up crying; "alto hay tan Director como Ud." Lembcke also gave satisfaction to Cucalon but there seemed to be much ill-will, not only between these two, but between various other members of the Directory. All this arose from the Gerentes having placed into the hands of F. Huth Gruning \& Co. a large amount of securities as a guarantee for the 
bank's debt to their London house, and the International Bank of London. The opinion given by the Commission Barrios and Aliaga was read and approved of by the Directors. It said that the gerentes had been quite correct in giving the security, but were to be blamed for the manner in which they had done so, because such a step they ought not to have taken whithout the consent of the Directory. We authorized the Gerentes to hand to the Banco Nacional the proportion of Vales de la Nueva Consolidacion which corresponded to the bank and the total of which the four banks had to place into the hands of Gibbs as a security for the advance, which this house had [_] [76] [...], as I explained detailedly on the $10^{\text {th }}$ April. Arancibia had not yet embarked for Iquique, where as so often mentioned, he was to receive the Salitrera "Esperanza" on account of the Government. We agreed to meet again on the following day. Before this meeting I had been in the Insurance Company Lima, where I had been Director de Turno for two months, and where I now gave up my charge to Carrol who told me that he was not at all pleased with the loan of $\mathrm{S} / 5^{0}, 000$ which during his absence this company had made to the Banco de Lima. In the evening I had a long and agreeable visit from 8 to 11 from Federico Palacios, whilst his wife Mercedes Villacampa, together with Enriqueta was keeping my wife company. The rich Mr. Stewart of New York had died, leaving, as it was said, a fortune of two hundred millions American Dollars.

Thursday, $4^{\text {th }}$ of May. This morning I was again at a funeral in the Church of El Sagrario, viz.: at that of a young daughter of Amancio Castillo who had died of consumption.

Mariquita, who had suffered from fever on the preceding day felt this day somewhat better, rose at a late hour, and remained up till about 9 p.m. when a slight fever again came on. We were gradually progressing in our suit against Leyva, whether we should gain it was doubtful. At about three the Directory of the Banco de Lima was again assembled. Absent were Aliaga, Armero, Castillo, Bernales and Cisneros. Cardenas acted as secretary. I opened the proceedings with saying that at the time the Gerentes asked the opinion of Gallagher and myself about giving up the securities we had authorized them to place into the hands of F. Huth Gruning \& Co., not into those of J. F. Lembcke \& Co., and I thought it my duty to make this statement because it would not be correct that we two should be considered responsible for a step which we had not sanctioned. As these few words elicited no reply, and as the motion of Cucalon that the securities should be returned to the bank was still pending, it had now to be discussed. Again the same silence reigned as before, when I took courage and expressed myself in the following terms: "I know I speak the mind of all the Directors when I say that they wish the securities to be taken out the hands of J. F. Lembcke \& Co. and to be placed into those of the [77] representatives of 
F. Huth Gruning \& Co. because we do not [...] it correct that J. F. Lembcke \& Co. should hold documents belonging to the bank, represented by J. F. Lembcke \& Co." This gentleman though certainly hurt after the pause of a few moments merely said that he was ready to speak to the head of Graham Rowe \& Co. place the documents into their hands, and obtain a receipt for them in the name of F. Huth Gruning \& Co., and on account of the London creditors. This was agreed to by all except Cucalon who insisted upon the devolution of the securities. Gallagher and Cardenas expatiated on the property of the step, which had been taken when the securities were given to the representatives of the London creditors. (This was agreed to by all except Cucalon who insisted upon the devolution of the securities.) Letters from Mariategui in Iquique were read; he, very naturally, was anxiously looking out for the arrival of the Government's engineer. Accordingly, the Gerentes were instructed to hasten Arancibia's departure as much as lay in their power. Cardenas moved that henceforth all prolongations of credits should be granted by the United Directory, not as hitherto by the Gerentes and the Director de Turno. Of course this was agreed to. This same gentleman's motion for a reduction of the expenses by the dismissal of clerks, in which I had coincided with him, was put off by the majority. We had then a desultory conversation, when Cardenas said that the "Banco era desorganizado", of which expression Lembcke availed himself to make an appeal to Cucalon, and to ask him why he showed such an opposition to everything he, Lembcke, did; to which Cucalon replied in a friendly way; they shook hands, and thus apparently matters were made up between them.

Friday, $5^{\text {th }}$ of May 1876. In the office of the Banco de Lima, the following met: I, president, the two Gerentes; Cardenas, provisional secretary; Armero;Barrios, and Cucalon. After the reading of the actas of the two last days, Lembcke made known that he has spoken to the President about the departure of the Government's engineer for Iquique, and that he had expatiated on the injury which the bank would suffer by further delay in the delivery of the Esperanza to $[78][\ldots]$ esident had replied that for the present he could not send any engineer to Iquique, and that if the bank suffered any loss, the Directors themselves were to blame. Lembcke further said that he had spoken to Macandrew of Graham Rowe \& Co., that this firm was quite willing to receive any documents which we might deliver to them on account of Huth Gruning \& Co., but that they could only give them up if they received order from Huth \& Co. to do so, and consequently that the clause inserted in the original receipt of Huth Gruning \& Co., and copied in that given by J. F. Lembcke \& Co., which said that in proportion as remittances were made, part of the documents should be returned to the bank, ought to be omitted in the receipt given by 
them. This clause was of such importance to the bank that we could not accede to its omission. Now we spoke some time on what was to be done. At last Cucalon came out with the following proposal: "The receipt of J. F. Lembcke \& Co. remains in force until some arrangement can be made with the creditors in London, but meanwhile the documents are deposited in the iron chest of the bank." This was exactly what we all desired, but Cárdenas, to sweeten the pill to Lembcke added that in the acta it ought to appear as if this proposal had been made by Lembcke himself and not by one of the Directors. We were all of the same opinion, and thus this disagreeable affair was at last brought to a close.

My wife was in bed the whole day long. Dr. Middendorf came daily to see her, sometimes twice a day. Col. Joaquin Torrico had published a broad sheet on the affairs of the Pasco Mineral Railwail Coy. which I had not read, but in which as I was told, he handled very severely the various directories, especially the first, consisting of Manuel Pardo, José de la Riva Agüero, Nicolas Rodrigo, Francisco Sagastabeyta and myself.

Saturday, $6^{\text {th }}$ of May 1876. Long before breakfast I walked out to have a look at the edifice which went by the name of Santa Sofia and which was being built on account of Augustus Dreyfus of Paris to the memory of his late wife Sofia Bergmann. In the centre of the inner yard stood the statue of the deceased, completely covered over, apparently in a reclining posture, upon a high pedestal of [_]lished granite. Otherwise the work had progressed but little [79] since my last visit and if the number of workmen was not [...] many years would certainly elapse before its conclusion. If ever concluded I calculated that its cost could not fall short of half a million Soles.

In the Banco de Lima at 3 O'clock only the two Gerentes, Cucalon, Cardenas and I were present. We went to the inner Room; the account-current book was brought, and one account after the other was examined by Cucalon and Cardenas who had taken their seats to the right and left o Lembcke. I, not able to see, sat opposite, listened, and now and then asked a question. Cardenas noted down the outstandings, to each of which some observation was added. Barrios and Bernales joined us; we left off at 4.30 without having finished.

Sunday, $7^{\text {th }}$ of May. My wife was much better, but still kept her bed. I left my house at 7.30 and ascended San Cristoval without difficulty; it was a foggy morning. When approaching the summit I heard a few drops of rain fall, but on the top where I rested for a few minutes on the big stone, for several yards around me all was clear; further down thick fogs concealed every object. When I began the descent the sun gradually shone out.

Last night's "Comercio" contained a telegraphic dispatch from Chile of $4^{\text {th }}$ inst., which spoke of the probability of a war between Russia and Austria, arising from the troubles in Herzegovina. When Bryson was gone, I went out 
to make a few visits; firstly, over the way to the sister of the two brothers Cox, the widow of a German Charles Minx, an agreeable young lady, whilst the same could not be said of her mother, the widow of William Cox, many years back partner of John Hoyle of Trujillo; secondly, to Doña Manuela Mendoza who could speak of nothing else but of the greatness of her family. Whilst I was with her, Dr. Muñoz came in, when she turned all her attention towards him, and hardly vouchsafed to address a word to me. I learned afterwards that Muñoz had then called upon my wife, whom she had received though she was in her bedroom, and who had been quite as polite and friendly as on former occasions. I myself called upon his wife, the really good-looking Irene who [8o] [...] marriage did not enjoy the best of reputations, now behaved very properly, and all at all events affected, if she did not really feel affection and gratitude for her elderly husband. Transito Abril being unwell, I was received by another lady with whom I remained a short time. Also with Rafael Velardes wife and daughter I did not stay long, Here I learned that the electors for the Province of Lima assembled in the Cabildo had just finished their work and that the result had been the following: for president of the Republic General Prado had had 111 votes, 1 blank; for Vice-President, Buenaventura Elguera 88; General La Puerta 16; Vocal Ribeyro 2; Dr. Bambaren 1; an apothecary, Zuleta 1, and so on; for Second Vice President, Jose F. Canevaro 54; Jose Feliz Garcia, Director de Contabilidad in the Finance Ministry 52, which the friends of Canevaro had certainly not expected. With Ignacio Tavara, arrived from the North not long ago, I left my card; and finally I went to Isabel Coloma, with whom and her two daughters, I stayed a very long time. In the evening I went to the Basagoytias, where I met José Maria Peña, wife, and daughter, all, like myself, dressed in deep mourning. We conversed on many subjects, and I learned that José Sevilla, resident in Paris, was not actually deranged, as had been said, but had suffered from a severe attack of brain fever, which it was generally supposed had been caused by the loss of half a million dollars which he had sustained owing to the failure of a North American firm. Peña added that Sevilla could well bear this loss, heavy as it was, for his fortune was estimated to be five or six times as much.

Monday, $8^{\text {th }}$ of May 1876. I had a visit from a young naval Danish officer A. C. de Fine Skibsted who served on board of an Italian man of war, just arrived in Callao. He had come up, merely to present himself to his Consul, and stayed with me somewhat more than half an hour. We conversed in English, and I understood from him that the dispute between Denmark and Prussia relative to a small tract of land, the most northern part of the Duchy of Slesvic, was not yet arranged, and according to him was not likely to be so until a war were to break out against Germany when [81] Denmark would certainly take a part by 
means of $[\ldots]$ block up the three outlets from the Baltic, the Sound and the two Belts. I told him that my wife was ill, and as the man of war would sail on Wednesday or Thursday, I should probably not have the pleasure of seeing him again. Neither in the Banco de Lima nor Banco Hipotecario did the Directors meet in a regular session; many of the former were however together and earnestly conversed on a new demand of money made by the President Pardo.

My wife was always in bed; she took some quinine and though the fever just came in at 8 p.m. it did not declare itself.

Already in the evening of the previous day, the electric wire had brought no the result of the elections in Callao and Trujillo. In the former place Lizardo Montero had a few votes for the Presidency; Riva-Agüero for Vice; whilst in Trujillo Prado and La Puerta had been elected almost unanimously. In the course of the day advices from the other parts of the Republic came in thick and fast. Prado was the general favourite. Lizardo Montero could boast but of a few votes. For the Vice Precidency on the contrary, the votes were much divided between Buenaventura Elguera, La Puerta, and Riva Agüero. In Chiclayo even J. A. Garcia y Garcia had a few. As to yesterday's elections in Lima, several persons were of opinion, which was even taken up by the "Comercio", that they were ilegal, because the Electors of the entire province numbered above 200, and only 112 had been present, less than $2 / 3^{\text {rds }}$ the number required to form a quorum. On the other hand, there were others, and these were no doubt in the right, who affirmed that the proceedings had been quite legal, because the electors numbered only 163 , and $2 / 3^{\text {rds }}$ of these were 109 , less than the number actually present.

Tuesday, $9^{\text {th }}$ of May 1876. My wife continued to keep her bed. Middendorf came twice a day. I was by two in the Banco de Lima, but it was three before we sat down; only Bernales and Castillo were wanting. Two actas were read, approved [_] [82] [...] In the last agreement or contract between the Delegates and the Government regarding the salitreras, the $10^{\text {th }}$ article said that if the Government should require money for various expenses connected with the receiving of the Salitreras the banks would advance this money, on condition that it did not exceed half a million Soles. In virtue of this clause, of which by the by I myself was ignorant, the Government had demanded from the banks $\mathrm{S} / 300,000$ of which about $\mathrm{S} / 60$,ooo corresponded to the Banco de Lima, and the question was now whether we should deliver them to the Banco Nacional or not. Cardenas was opposed to it; the majority was of opinion that we could not avoid paying, though there was not one of us who did not clearly foresee that by this extra payment, and other payments which we had to make, the bank would very shortly have issued all the notes it had a right to issue, and in that case we should perhaps be obliged to liquidate. This no one denied, but on the 
other hand Gallagher opined, and I went with him that if we did not pay our share Pardo would not send Arancibia to receive the Salitrera "Esperanza"; we should not receive certificates for the S/900,00o and our ruin would be still more certain. Lembcke was rather silent; Armero, Barrios and I did not say much, nor was Cucalon, who acted as secretary in the absence of Bernales, so talkative as usual. He and Cárdenas finally proposed that the affair should be referred to a commission. I saw no use in such a delay; however, the majority agreed with them and I named Aliaga and Cardenas, who should have ready their report by tomorrow when we would meet again. I learned that through the medium of Meiggs, the Peruvian Government had rented for a number of years from the Bolivian Government their Salitreras which was a very wise step, for otherwise the Bolivians could and would interfere with the producers in the province of Tarapaca.

Wednesday, $10^{\text {th }}$ of May. At 3 I was in the Banco de Lima, but nothing was done, for Cárdenas and Aliaga had not yet drawn out their written opinion as they had promised to do. [83]

Thursday, $17^{\text {th }}$ of May 1876. My birthday, not a merry [...]. My wife had diarrhea during the night, coughed in the morning, felt extremely weak, and was much dejected. When I went to her bedside, she embraced, kissed me, and wept bitterly. (Perhaps it was already a presentiment of her approaching end. $3^{\text {rd }}$ April 1879.) I need hardly say what my feelings were, when I saw the tears run down her cheeks. My love for her had certainly not decreased; what in October 1832 had been a youthful passion, had in course of time become the sincere, constant, and steadfast affection of an old man. Little Maria and Corina brought me each a large nosegay also some trifling presents, and recited a few verses which they had learned by heart. Enriqueta also presented me with two pairs of gloves, and a bottle of Eau de Cologne, which latter I immediately passed over to my wife, for I never use any scented water or other perfume. Enrique, Geraldo, Juan, and Ricardo congratulated me, but I was glad they made me no presents, for I knew that none of them was flush of cash. Dr. Middendorf, who came at his usual hour of nine, did not find my wife so ill as we believed her to be, and prescribed pills containing quinine; yesterday's prescription, a tonic beverage, had done my wife no good. At 3 Galvez, Barrios and I were in the Banco Hipotecario with the two Gerentes. Gallagher took our opinion on various subjects, and everything went off quietly and smoothly. The most important thing was a new loan of $S / 20,000$ which we agreed to make to the family of Dulanto of Callao; the property which they had mortgaged to us, had undergone extensive repairs, and we thus considered ourselves warranted to make the new loan; by disposing of the Cedulas which we gave them, they would raise the funds required to pay off their arrears; it was past four when 
Gallagher, Barrios and I went from the Banco Hipotecario to the Banco de Lima. Here all were present, except Castillo and Aliaga. The report of Cardenas and this last named Director, was decidedly opposed to our paying the money of which I spoke on the $9^{\text {th }}$ inst. The discussion was extremely animated [84] [...] past six. Cardenas was not exactly opposed to [_] payment of the $S / 60,000$ but he found fault with the committe[_] of Delegates, who had taken upon themselves to administer the salitre or nitrate of soda business, and in virtue of this administration ask for the money. His principal opponent was Luis Cisneros who affirmed, and proved by copies taken on the spot that in the last meeting of the four Directories, the three banks Nacional, Perú, and La Providencia had authorized the Delegates to administer the business, and that the Banco de Lima, though voting against it, had to give way to the majority. Cardenas asserted that there was some misunderstanding. Bernales spoke a few words, but in such a low voice that I could not understand them. Lembcke, in a quiet and moderate manner tried to convince Cardenas. Gallagher did not see how we could avoid paying. I said that if we did not pay I was sure that Pardo would not receive the Salitrera "Esperanza". Cardenas opined that the payment of the money and the delivery of the Esperanza, had nothing to do the one with the other. At last, to put an end to the discussion I said that though, as President, I ought to be the last to give my vote, I thought proper to break through this general rule, and at once declare my opinion, which was in favor of the payment, because prudence counselled us to make it. All except Cardenas sided with me, and every one gave a different reason for his vote. When I came home, the Garlands had been waiting for me, for it being my birthday, Enriqueta insisted upon Doña Angela and I dining with them. All the children were present, Alejandro excepted; also Eliza, Guillermo's wife. Rafael Velarde came at a late hour and remained till eleven; he was positive that Prado would be elected President; La Puerta, first; and Garcia, second Vice President. The last telegram from Europe of the $25^{\text {th }}$ April did not yet advise Prado's arrival.

Friday, $12^{\text {th }}$ of May 1876. My wife was considerably better. She remained up till 7.30 p.m.

Dr. Palacios told me that Dr. Ignacio Távara, one of the fiscal adjuncts to the Supreme Court, had been named by [85] the President to give his vista in my suit against $[\ldots]$ attributed this nomination to his influence with the relator; Alejandro Garland thought it was owing to his intimacy with young Arenas, son of the President, to whom he had spoken on the subject; but whether I was indebted to the one or to the other, glad was I that Ignacio Tavara was named. Not only was he acquainted with the whole family, but to Garland in particular he was under more than one obligation, and I therefore flattered myself that his vista would be favourable to me. In this my belief I was confirmed a few 
hours later by the Doctor, from whom I learned that Tavara had already been with him, and enquired about the particulars of the case, when he had replied that he wished him to study the autos, and when he had done so he was at his commands to give him any further explanation. I need hardly add that it was highly improper for a judicial character to consult with the lawyer of one of the litigants. However that Tavara did so, proved that he was not over delicate, and well inclined towards me; nevertheless, though the suit now wore a favourable aspect, I continued to have my doubts as to the result. I bought through Alejandro from Ricardo Zevallos, four shares in the Banco Hipotecario of $\mathrm{S} / 1000$ each at $45 \%$

Saturday, $13^{\text {th }}$ of May 1876. Dr. Palacios had persuaded me that the most judicious step to ensure the favourable issue of my suit was to have his last escrito to the Supreme Court published in the shape of a pamphlet, and to distribute these pamphlets to the Vocales of this tribunal, after the pleading of the two lawyers was over. He said that this way of proceeding had answered extremely well in Garland's suit against Garcia Calderon. He as appellant had to plead first and if he were to come forward with all his arguments Leyva's lawyer would of course refute them, and his (our opponent's) speech would remain fresh on the minds of the Vocales. He would therefore only make a general and superficial defence, so as to leave his opponent in the dark as to what was our vulnerable point. As to the escritos contained in the autos, Palacios said I need not trouble my head about them, for they were hardly ever read by the Vocales. [86] [...] of this day, the printer brought me these papers and [_] wife, though in bed, had of the pamphlets read to her from beginning to end. She listened attentively, and expressed herself well satisfied though generally she was no friend to Palacio's style.

Sunday, $14^{\text {th }}$ of May. My wife rose after breakfast, but feeling great cold in her feet, she lay down again, and remained in bed the whole day.

In the course of the forenoon I made many calls but all of them of such an insignificant nature that I need not specify a single one of them.

In the evening we were all quietly at home, and had pleasure to hear my wife say that she felt uncommonly well.

Monday, $15^{\text {th }}$ of May. My wife again kept her bed. In the forenoon I had to run about a great deal so that when at 2.30 I went to the Insurance Company "Lima" I found all the Directors and the Gerente Elizalde assembled with the exception of young Robertson, who had not yet recovered from the injuries he had received when bathing in Chorrillos several weeks back. I proposed that in order to decrease our capital, which we found great difficulty in laying out at interest with good security, we should on the $30^{\text {th }}$ June pay $6 \%$ dividend to the shareholders. This was not yet finally agreed upon, but the idea was well received, particularly by Carrol. At 8 in the evening I went to the Banco de 
Lima, where the Directory, complete, Cardenas and Castillo excepted, had a very important session. Just before we rose, somewhat past ten, it was resolved that the acta should be copied, not by one of the clerks, but by one of the Directors, in a special book for actas secretas, for which reason I did not give the particulars in my rough diary.

Tuesday, $16^{\text {th }}$ of May. My wife though up the greater part of the day, was far from well, and in the evening she suffered again from fever.

I had very little to do in my commercial affairs, and attended no meeting. By a bando, or public proclamation, attended by troops of all arms, a Congress Extraordinary was [87] [_]nvoked to meet on the $15^{\text {th }}$ June, its exclusive object [...] the export duty on the Nitrate of Soda. The newpapers contained a Government's decree dated this day which said that as the Government had to pay for the expropriated salitreras in bills on England at 44d the sol, it would be incorrect if the export duty on Nitrate, which in some measure guaranteed the interest on the capital employed in the expropriation, were to be paid in a manner different from that in which the capital was paid; and therefore, from the $26^{\text {th }}$ inst. the export duty had either to be paid in good bills on London at 44 pence per Sol, or, if the exporters preferred it, in current bank notes with an increase corresponding to the difference between $44 \mathrm{~d}$ and the current exchange of the day, and as this would be calculated more or less at $40 \%$ prem., this decree raised the export duty from six rials hitherto paid, to $82 / 5^{\text {ths }}$ rials more or less. In the same paper we read a sentence of the second chamber of the Superior Court consisting of the Vocales Mariategui, Corso and Figueredo, which said that as the legal circulating medium in Perú was the silver Sol, the Banco de Londres which bought from Pedro Areze in public sale the house of the latter in the Calle de la Coca, had to pay to him the purchase money of $\mathrm{S} / \mathbf{1 0 4 , 0 0 0}$ in Silver, or if in banks notes with an increase in price corresponding to the depreciation of the notes. Mr. Dawson, the Manager of the said bank, had appealed to the Supreme Court. On the $4^{\text {th }}$ May a revolution broke out in La Paz; General Hilarion Daza deposed the constitutional President, Tomás Frias, and arrested him and all his Ministers. He named Jose Oblitas, his Secretary - General and General Carlos de Villegas Chief of the Staff. No blood was shed. In China near Shanghai, the first locomotive had been running on a railway, and an iron-clad steamer had been launched called "The Terror of the Western Powers". There seemed at present to be some probability of the long spoken of plan of a submarine railway from Dover to Calais, being actually carried out; the depth of the sea was nowhere more than 60 metres, and the railway when laid would be 31 kilometres long. Thus upon 31,00o the [_] [88] [...] ascent, would be no more than 6o, a percentage [_] perceptible in any railway. 
Wednesday, $17^{\text {th }}$ of May 1876. No alteration in the state of my wife's health.

I had no meeting to attend, and spent a quiet, rather lazy day. Bryson made good progress in the copying of my old diaries. We had now come as far as the end of 1860 but a great chasm had still to be filled up, including my absence from Lima from August 1854 to June 1856.

Thursday, $18^{\text {th }}$ of May 1876. My wife was getting better.

The Directory of the Banco Hipotecario met at 3 O'clock, all were present. We treated on various subjects, the only one of which of some importance was the settlement of accounts whith John Anselmo Hoyle of Trujillo. When Garcia Calderon made the loans to him a great many irregularities were committed by him, all which Hoyle had explained to the present Gerentes, and accordingly we agreed to make considerable concessions to Hoyle, rather than begin a lawsuit against him. This Hoyle was the eldest son of the late John Hoyle, a young boy when in 1844 I resided for a short time with his father in Trujillo. In the evening from past 8 till past 11 the Directors of the Banco de Lima, Castillo excepted, were assembled; it was again determined that the acta should be copied in the private book.

When I came home I found letters from Juan dated Paris and from Limpricht, Hamburg, both of the middle of last month. Limpricht's nephew Paul Bobertag, who for some years had been suffering from weak lungs, and had of late, for the pure air been residing at Meran in the Tyrol, had fallen suddenly so ill as to require his mother's assistance, who had hastened thither. Gibbs had bought for me $£_{3000}$ noml. Anglo-Peruvian Bonds at $161 / 16^{\text {tho }} \%$ whilst others quoted them as low as $14 \%$. In appendix under $\mathrm{N}^{\circ} 3$ goes affixed a cutting from The Times, which gives an account of the conditions of the last contract concluded between Riva Agüero and the Societé Générale, which the Lima Government considered so disadvantageous to the country, that it did [_] ratify it. Lembcke said this evening, whether his information [89] [-] correct, I could not say that the late fall on the [...] Turkish, and Peruvians Bonds had caused to the European mercantile world, a loss of 95,000.000£ Stg.

Friday, 19 ${ }^{\text {th }}$ of May 1876. At 12, we in the Banco Hipotecario, Galvez, Barrios and I present, continued our yesterday's session and instructed the Gerentes as to the amount which, if better could not be done, they might concede to J. Anselmo Hoyle. My wife continued in a fair state of health; she no more kept her bed in the day time, and was lying on the sofa, the fever seemed to have left her. She told Enriqueta: "Si tengo dos dias tan buenos como ayer y hoy, ya me consideraré buena, y fuera de todo riesgo." (If I have two days like yesterday and today I shall consider myself well and out of danger.)

Aguiles Allier had died in Paris at the age of 82. Notwithstanding his advanced age he was still so robust that he might have lived several years longer, had he 
not exposed himself to a sharp wind by sitting for more than two hours in the open air, which brought about a severe cold, the cause of his death.

The following is with some trifling alterations a literal copy of what is written in my rough diary.

Sunday, $27^{\text {st }}$ of May 1876. At last the fatal day has come which has taken from me my dearly beloved Mariquita. On Friday, early in the morning, Enrique Garland, the best beloved of her grandsons, went to her bedside to bid her good by, as he was about leaving for his mine on the Oroya line, and though his absence would last only a few days, Mariquita was much more affected than such a short separation warranted. She then breakfasted in bed, as it was her habit and seemed to enjoy her meal. A few moments later she said "esas pildoras (those of quinine) me han dado la vida." Dr. Middendorf came, found her very well without fever, and said that she should take the two remaining pills next morning. She afterwards rose, and Enriqueta was quite astonished to find her walking about and busying herself with the contents of the [90] $[\ldots]$ in the bedroom. Somewhat later she sitting [...] the sofa ocuppied herself with cutting prettily a sheet of paper wherewith to cover some sweetmeats which she sent as a present to the wife of the judge Cossio. Ayao was to take them, and Doña Josefa Velarde to show him the house. I found her so well that I did not hesitate to take a walk to the Alameda before dinner. On my return at about five she told my that she felt well, but not quite so well as on the previous day, and on Sunday last. She however complained of feeling cold from her waist downwards, when I counselled her to go to bed, which she did, and as the servant girl was not present I opened the bed for her, and when she lay down covered her up with blankets, a church carpet, and a cushion on the top, and in few moments she was quite comfortable. This was the last service I rendered her whilst alive. She dined with appetite, and declared herself quite "incorporada". I was with her till about seven, when she fell asleep, and I went to my room to hear Bryson's reading. At about eight Doña Angela had awakened her that she might not spoil her night's rest. A few minutes later Melchor Velarde came, with whom she talked quite animated, and told him laughingly that little Ricardo Zevallos had been in the morning with Enriqueta and requested her to send little Maria and Corina to his house to-day, Sunday, because he wanted to marry Corina to whom he was engaged and that he would not wait any longer. When Melchor left for the Consejo Departamental he felt his cousin's pulse and pronounced it to be as good as could be desired. When I came we took tea, Mariquita asked me whether Tavara had not yet given his Vista-fiscal; she found fault, and very justly so with Ricardo who when he came too late was angry that the tea things had already been taken away. Afterwards both she and Enriqueta scolded Garland for not having given his 
vote to Melchor Velarde when he wished to be elected Director of the Banco Hipotecario. I mention these trifles to shew that my wife had the use of all her intellectual faculties, and took an interest in all that was going on. Enriqueta when she left at a quarter past ten said: "Mamá Ud. [91] está tan buena que mañana puedo levantarme [_] a misa y comulgar." Previously Mariquita had told me to take out of her desk $\mathrm{S} / 10-80$ to purchase twelve varas of a certain article at nine rials, and twenty cents being short, I said "tomorrow I will add them." "Bien", she replied "saca dos Soles más que necesito para menudencias, botones, etc." I put the paper under a small watch standing upon her night table, and explained to her how much money was still in her desk and in what drawer it was lying. Garland remained about ten minutes longer than Enriqueta, conversing with me in Spanish about the Banco Hipotecario, to which my wife apparently listened; now Doña Angela came and brought her for supper some broth and a glass with wine which she emptied, contrary to her habit, saying in a jocular manner to Doña Angela "lo hago para que Ud. no se enoja conmigo." When we were by ourselves, I, as usual, shut and barred the doors, and put out the gas lights, when Mariquita said "ten cuidado de cerrar el gas." I believe, tough I am not certain, that these were the last words she ever addressed to me. In the adjoining room we had an oil lamp burning. I had previously mentioned to her that on Sunday I intended to pay a great many visits, when she recommended me not to omit the principal ones, that is to say the Vocales of the Supreme Court, amongst whom she specified Cosio and Alzamora. I of course said I would go. I undressed, as I was in the habit of doing, sitting on the sofa covered with green maroquin and if I remember correctly went at once to my bed, without going to hers, to bid her good night. I do not remenber either whether when I was in bed we exchanged a few words as we occasionally did. When in bed, my wife being so well, I recommended her health and her life to my Creator, in a slight superficial manner without insisting, as I had done on previous occasions when I had thought her dangerously ill. Shortly after I fell asleep. Whether Mariquita already slept I cannot say. In the middle of the night I was awakened by hearing something [_]ll [92] [...] that it was the heavy cover of an ordinary cham[_] which we had bought this very day; then I heard some groans. I called out "Mariquita, Mariquita" - no answer. I jumped out of bed and ran to hers; the bed was empty, and on the oppsite side, just at the foot of the bed, between the same and the wall, the poor woman was lying not stretched out, but rather doubled up, her head close to the post of her bed, not touching it, and with the face turned towards the wall. I knelt down near her, and called out like a madman "Mariquita, Mariquita" - no answer. I lifted up her head, which was bathed in perspiration. Her false teeth had got loose; I took them out of her mouth. For a moment I had to let go my hold and call 
Doña Angela. We two were too weak to lift my wife up. Isabel, Doña Angela's servant girl, for just at the time my wife had none of her own, called Enriqueta and Garland. In the winkling of an eye they were on the spot, as well as Juan, who was strong enough to lift my wife on the bed placing her head towards the footrails. She was still alive; at least I heard her breathe. The Inter belonging to the Sagrario was called; he came in a few minutes and read some Latin prayers; I heeded him little for I had lain down alongside my wife. I thought she was still alive. Now Enriqueta made me observe that I was undressed merely in my long night shirt, and a comforter around my neck. I sat down on the sofa, and dressed quickly, but in this short interval it was that my wife breathed her last; at least Enriqueta, who was close to her, heard a breathing, felt a shivering of the whole body and saw one tear start from her eye. My wife had expired. Dr. Middendorf came, for Enriqueta had sent her boys in various directions, $\mathrm{He}$ at once declared that Mariquita was no more, and inmediately tied up her nether-jaw. I think it was now about 4.30; the gas had been lighted, which Aurelia, Enriqueta's excellent black woman, had done. When I heard the first fall it was a quarter to four. By Middendorf's order I was turned out the room; when I re-entered I found that they had cleared out the room in which my wife and I were in the habit $[\ldots]$ leaving only the presses and the chest of drawers. [93] In the middle of the room stood a table upon which [...] wife, her head a little raised, her arms folded upon her breast, they had left her her entire nightdress, with drawers and stockings and above the body as far as the head, a sheet sewn together over her legs; the Doctor had shut her eyes, and she looked as calm and placid as if she were asleep. It was now broad daylight."

"The bed clothes, that is to say the coverlid and blankets, we had found carefully turned over, from which we inferred that when my Mariquita awoke she did not feel any pain and merely rose because she stood in want of the chamber. The very moment she descended from the bed, a stroke of apoplexy must have felled her to the ground. We found another confirmation of this our supposition in the circumstance that the ground between the bed and the wall was somewhat wet, and her shift a little soiled. I have said more than once that she frecuently had complained of a coldness in her feet and legs; to keep them warm she had also this night slept her drawers, stockings, and slippers on. She had been cured of her catarrh, of her fever; of late she had but seldom complained of the tumours, of the cramp in her legs, of the numbness in her feet, thus in fact her various ailings were gone, but, as Dr. Middendorf said, and I agreed with him, her time had come, the machine was worn out, there was no more oil in the lamp. Her exact age I never learned, but suppose that she must have reached her eightieth year. 
Saturday, $20^{\text {th }}$ of May 1876. I can hardly say how I spent this day. I walked from the one room to the other, sat down, rose again, talked, wept, and gave my wife many, many kisses upon her fine forehead, cold, without a wrinkle. Many people say, even Mariquita said so, that they fear to approach a human corpse, certainly those who say so must not have loved the deceased. At an early hour the Velardes came, other acquaintances in the course of the day; who they all were, I knew not. Guillermo and Eliza did not leave till late in the evening. [94] [...] Velarde's widow, and Josefa Velarde, one of my wife's cousins, whom we called "the poor" to distinguish her from Josefa de la Barrera, Rafael's wife, were the two who made themselves most useful. Rafael stood about and talked big; once I did not even recognize him. Another time - and this I learned afterwards from Dr. Middendorf - when he came to me with the common places of consolation, I stopped him with the words "don't talk nonsense", which rough expression of mine, good natured man as he is, he did not take amiss. The silly girl Zoila when I went into the room where my dear wife lay stretched out called to me "do not enter". I shall not forget, nor forgive her these stupid words. Alejandro always lent his assistance: through him Dreyfus' house sent a telegraphic dispatch in Garland's name to my son Juan in Paris; another telegram went off to Enrique in his mine. To Garland I gave a cheque for $\mathrm{S} / 1000$ on La Providencia to defray all necessary expenses. I breakfasted very little; my dinner consisted of a piece of beef, a potato, half a glass of wine and water. Doña Goya, Doña Josefa, Doña Angela and Ricardo took their meals in the dinning room. Middendorf, who came in the evening, obliged me to go to bed at about eight; they had placed my bedstead in our parlour; it was however impossible for me to sleep. I was in a dreadful state of excitement, and requested Alejandro or Guillermo to keep me company. Alejandro did so for poor Guillermo had an attack of asthma; and at last about midnight I fell asleep, and without dreaming slept till half past two, and again from three till half past five.

Sunday, $27^{\text {st }}$ of May 1876. I rose at about seven; as soon as dressed, and washed, which I had not been able to do on the previous day, I went to see my Mariquita; her forehead upon which I imprinted my kiss, was as hard and cold as marble.

Yesterday we cut off a little of my wife's hair part of which I intended for a ring for myself.

Garland wrote by this day's steamer to Juan [95] requesting him to come immediately $[. .$.$] a full and ample power from his sister. Enriqueta had ordered$ my bed to be made in the room which goes by the name of Garland's study, and which adjoins his and Enriqueta's bedroom; I was glad she had done so, 
for these large apartments, occupied by me and my wife, are to me void and desolate without her. Enriqueta herself had yesterday a severe nervous attack, convulsions; she lay down at 3 and remained in bed for three or four hours. I may say here that my wife was called by all the children of Enriqueta "Mama Qui" and this arose from Enrique not being able to say Mariquita when an infant; he called her Mama Qui, and with this name she remained. Maria and Corina when they wanted to cajole her, and to get something from her used to say Mama Quicita.

I spent the day after Bryson was gone, in the same way as yesterday; I did nothing, walked to and fro, spoke with Enriqueta a few words, then went to where my wife was lying, sat down on a chair which stood just behind her her head, kissed her forehead many a time, and so the time passed by. At about five the coffin was brought. The lid at the upper end had according to my orders a piece of thick glass fixed in, so that the face might always be seen, but as it is the custom, which I did not know, to solder a large piece of tin plate or zinc to the lower part of the coffin before the lid is closed and locked, this my precaution was of no avail, because it of course covered the face, and when looking through the glass you only saw the tin plate; it was half past five when I kissed her for the last time. Enrique arrived. He had received the telegraphic dispatch yesterday at about 8 in the evening, had immediately made his arrangements and started this morning on horseback about 3.30. He rode as far as the nearest railway station, where through his influence with the employés, particularly with Mr. C[?]ill [96] [...] car was put at his disposal and going $[\ldots]$ incredible speed, he reached Lima in about five hours not without danger. When we had dined he and I went to see his Mama Qui; she was already in the coffin, which was not yet closed. He told me that her nether-jaw had given way, and the mouth was open, the upper part of her face was intact." So far the literal copy.

Monday, $22^{\text {nd }}$ of May 1876. Last night, a little past nine, Dr. Middendorf came; I well knew what was his object; to keep me in conversation whilst the coffin was being taken out. We talked on many things; however, when I knew that the time was come I looked out of the large rosette window from which out of my inner room the stair case is seen; the bearers of the coffin had already descended, but I noted the large number of gentlemen who followed. I heard to my surprise, and to my joy that Federico Sotomayor had been amongst them; he when in France had lost his beloved wife; he had suffered as I suffered now, and probably he wanted to show by this act that the ill-will which he and his family had had against us on account of the law-suit, did no more exist. When Garland and the young men returned from San Francisco we retired to rest, I to my new quarters. Geraldo lay down on the sofa, and I was glad that 
he was with me. When I awoke this morning I looked at my watch; it was a quarter past four $-481 / 2$ hours after my wife had expired. I lay down again, but hardly slept, I was much excited. I rose before seven, and soon after Melchor and Rafael Velarde were already there to go with Garland and his sons to San Francisco, where they, Garland and his sons were the Chief mourners. Eliza, Guillermo's wife, was also with us; so was Doña Goya, as well as Isabel Coloma; Doña Eulalia, Dr. Ribeyro's wife, came at about nine. Eliza received her and some others ladies. Somewhat past ten whilst I was walking up and down the corredor a great many gentlemen came up stairs; they had returned from the pantheon; I hardly recognized them: Meceno Espantoso, Evaristo Gomez Sanchez, Corso, the brother of the Judge, Federico Marriott, Manuel Alvarez Calderon, Federico Palacios, etc. I merely begged [...] take a seat and then made my escape. Shortly after Garland [97] and his sons came. They told me that the concourse $[\ldots]$ had been extremely great, and that an altogether unusual number of coaches, amongst which twelve private ones had accompanied my dear Mariquita to the pantheon, where for the present she lay in the niche San Florentino, D, $\mathrm{N}^{\circ} 135$.

In the Church the four ribbons had been taken hold of by Dr. Muñoz and Dr. Vidaurre, Vocales of the Supreme Court, Anibal La Torre, Minister for Foreign Affairs, and General Freyre, Minister for War. It was certainly gratifying to see that my wife had been so much beloved; but, as she had expressed herself many a time - what matters that to the dead? I breakfasted with Doña Angela, Doña Goya, and Ricardo in my dining room, but Enriqueta wished me henceforth to take my meals with her and her family, and to dismiss our cook Achipe. About 3 or 4 in the afternoon, when I dictated to Bryson, I felt more quiet than I had done for the last sixty hours. Charles Pflücker and Carlos Bergmann sent me their condolence, through the medium of Garland's sons. In the forenoon I remodelled with Bryson some pages on my old diaries, which took up much of our time. What else I did I hardly remembered, probably I only walked about, thought, and did nothing. I dined with the Garlands, and through the intervention of Guillermo dismissed poor Achipe. I made him a present of $S / 20$ and promised him that the first of every month I would give him two Soles. He did not say a word, but I believe he was very sad. I arranged with Enriqueta, though very reluctantly on her part, to pay her S/10o monthly for my board, which she assured me was much more than what she spent extra for me and for Ayao. Bryson read to me from 7 to 8.30 Walter Scott's History of Scotland, but I was so sleepy, and my thoughts wandered so much, that many passages he had to read over again. I took tea in Enriqueta's bedroom. Some gentlemen came whom Garland received in my saloon. Past ten we retired to our respective dormitories. 
Tuesday, $23^{\text {rd }}$ of May 1876. Last night Enrique slept on the [98] [...] O'clock read to me in Spanish. I slept soundly, without dreaming, from 11 till 6.30. I rose at 7.30 walked the corred[_] signed some Cedulas for the Banco Hipotecario, which had been sent to my house for signature, conversed with Garland's sons, who all conducted themselves very properly, and about 10.30 sat down to breakfast with the Garlands. Both the milk woman and the baker I told not to return. I was quiet, but sad in the extreme; what had occurred seemed to me a mere dream. My wife's hard cold forehead I had now always before my eyes; I wished it were still within my reach. In the pantheon, from the door to the niche, the ribbons had been taken hold of by General Pezet, Manuel Francisco Benavides, Manuel Alvarez Calderon, and Juan Bazo.

The time till dinner passed away I hardly knew how. I dictated a letter to my cousin Frances Cresswell, making use of my wife's note paper with her monogram, and enclosed one of her visiting cards, in token of remembrance. Rafael Velarde and General La Puerta came, whom I received in my saloon. At Garland's, where so many sit down to the dinner table, we did not rise before 6.30. Little did I eat. To Bryson's reading I gave somewhat more attention than I had done on the previous day. When he was gone I went to my bedroom, where in the dark, a little light coming in through the glass door of Enriqueta's bedroom, I took my tea, and had with me Guillermo, Geraldo, Melchor Velarde, and Dr. Middendorf. Enrique, who slept on the sofa in my room, read to me till near twelve. I soon fell asleep, and did not awake till near eight on.

Wednesday, $24^{\text {th }}$ of May. The remodelling of my old diaries occupied some time, and interested me. I finished signing the Cedulas. In the state of my mind there was no change. The papers said that owing to Prado's arrival in England, and his having entered into negotiations relative to the guano question, La Société Genéràle had withdrawn from the contract which the same had signed with Riva Agüero ad referendum.

Bryson read to me from the "Eclectic", a very good article on the [f]rightful burdens which the Governments of the large continental [99] powers [_] Europe imposed on their subjects in order to keep up [...] immense military establishments. Russia's army, when placed on a war footing was to number two millions of men; France's, one million five hundred thousand; Germany's, one million three hundred thousand; and Austria's, one million.

At dinner, the laughter, and the jokes, especially of Juan, grated on my feelings, and I rose before the others did. When Bryson was gone I withdraw to my bedroom, where I took my tea, and Guillermo read to me the article on Perú written by Markham, and translated into Spanish for one of the daily papers.

In Enriqueta's bedroom, in her parlor, and in my drawing room, she, Eliza and Garland, respectively received a few visitors. 
Thursday, $25^{\text {th }}$ of May 1876. Ascension Day. Last night I went to bed at eleven. Juan lay down on the sofa but hardly had I fallen asleep, when I again awoke, and felt quite bewildered. I knew I was not in my own bedroom; I looked out for my wife's bed; I saw that the lamp which was burning was not that of my own bedroom; for a moment I feared I should turn crazy. Then to assure myself that my intellect was still in its right place I tried to multiply in my head, multiplied four figures, fortunately again fell asleep and did not awake again till 8 O'clock this morning.

I walked the corridors; Dr. Palacios came for a few minutes. I begged him not to neglect the suit against Leyva in which my wife had taken such a lively interest. Garland wrote for me rough drafts of my letters to the gerentes of the Banco de Lima, and Banco Hipotecario; also to Andrés Rey of the Water Company, in which I informed them that I threw up my Directorship in their respective establishments; I merely kept the Directorship in the Insurance Coy. "Lima", because I thought prudent to preserve at least one link with the outer world; moreover my co-directors were pleasant men, and the establishment flourished. I also withdrew my subscription to the German Club [100] [...] never frequented it I had been a member for seve[_] years. To the German Relief Association I continued to contribute.

Bryson wrote the above letters in clean, read to me in the Eclectic an article on French literature, and left at 2.30. Till dinner time I mostly walked the corridors. Alejandro read to me from the daily papers a speech, the most insolent imaginable, delivered by the Cojo Larrañaga in the Superior Court in defence of the part taken by him in Pierola's expedition in 1874. After dinner, of course with the Garlands, Doña Angela, and Eliza, Enrique read to me in my room from 7 to 8 a popular work on astronomy written by a certain Camilo Hamarion, translated from French into Spanish. He gives a short description of the universe, the immensity of which is such that the human mouth may well pronounce the number of leagues, and of years, but the mind cannot form an idea of them. We know that the stars are divided as to their magnitude, which does not mean according to their greater or smaller size, but according to their more or less brilliancy with which they appear to the human eye. Astronomers count about eighteen of the first magnitude; three times as many, say fiftyfour, of the second, again three times as many of the third, and so on until the sixth magnitude, always three times as many as the previous one; as far as here, about six thousand in number, the stars are visible to the sharp naked eye. By means of telescopes stars are discovered up to the thirteenth magnitude, and then they number as many as forty three millions. Of all the stars - I do not speak of the sun, and our solar system - the nearest to us is that named by Astronomers "Alpha", in the constellation Centaur, 211,00o times more distant 
from the earth than the sun, which according to Flamarion is $38,000,000$ leagues off, and thus the light which travels at the rate of 77,000 leagues per second reaches us from the said star Alpha, in three years and eight months. From a star of the seventh magnitude, the light reaches us in fifty years, from a star of the eight magnitude in seventy two years. When Enrique left off reading I withdrew to my dark bedroom [101] where I was joined by Rafael Velarde, and afterwards $[\ldots]$

Friday, $26^{\text {th }}$ of May 1876. Last night I slept without waking till seven. Geraldo slept on the sofa. I learned that the Pacific Steam Navigation Company had bought the steamers of the South American Company, established in Chile, for 2,300,00o Chilian dollars; one million in shares of the Pacific Company at their quotation in Liverpool. And the remainer, cash, to pay the debts of the South American Company. Garland read to me before breakfast articles from the Revista de Lima written about 186o. There is one of José Antonio Lavalle on Chile; he states that in 1831 when order was established, and Pinto elected President, the revenue of that country amounted to $11 / 2$ million dollars. Pinto was President till 1841, Bulnez till 51, Montt till 61, when the revenue had risen to 7 1/2 millions. I again enquired most particulary from Doña Angela how my dear Mariquita had fared last Friday. She said that she had told me more than once that Mariquita had breakfasted well upon a little beef, an egg, a little broth, a cup of tea, and some toasted bread with butter. At about 2, Enriqueta had brought her a cup of tea and two rosquetes; her dinner had been similar to her breakfast; and her supper at 10, a cup of broth, which she took entire that Doña Angela might not get angry as she said; and hardly half a cup of Malaga Wine, which she liked well, but which she complained that evening burned her throat a little, and this Doña Angela told her not to forget to mention to Middendorf on the following morning. Both Doña Angela and Enriqueta repeated to me that that night they considered my wife in a comparatively speaking good state of health, and that they had gone to bed, the same as I did, without the slightest apprehension. I may mention here that my wife when she was uneasy in her sleep sometimes called upon her mamá; never did she mention any other person. Of her mamá, or more properly speaking of her aunt Doña Berna who had been with her from her infancy, for her mother Catalina died in child bed she [_]d been passionately fond. [102] [...] Indians under Pumacagua entered Arequipa, [_]e, then a young woman fled with her entire family to Lima. About this time, or immediately after her return to Arequipa, her grandfather Agustin Velarde, whose favourite she had always been, married her to a young Biscayan, Alejandro Diez. Her father Col. Pablo Sierra took heed of the children by his first marriage after he had taken for his second wife Doña Josefa Nieto. Rosalia was the first child Mariquita bore her 
husband; she died young of the measles which had turned in owing to a cold she caught when an earthquake made her mother carry her out into the open air. The next child was Rosa (now Mrs. Schutte), the third Juan, born $1^{\text {st }}$ March 1819. Alejandro Diez died in Ica, when returning from a journey to Lima. He left her with a small, perhaps with no fortune. The entire family of the Velardes, formerly in affluent circumstances had been ruined by the payment of a large sum of money to the Spanish Government, to whom Don Agustin had given his guarantee for the good behaviour of one of his sons-in-law Arauzo, who, sub-delegato of one of the provinces of Arequipa, had gambled away the public money he had collected. Mariquita with her children and her aunt Doña Berna had then a bad time of it. She told me more than once that at the period of her life, she earned many a rial by the sale of artificial flowers made by herself. Better times were in store for her, when about the year 1822 or 23 the strict Colonial laws of Spain, which prohibited all intercourse between its colonies and foreign countries, were somewhat relaxed. Foreign produce and manufactures articles were admitted; foreigners were allowed to land, obliged to consign themselves to a Spanish merchant, and then came to Arequipa the few Englishmen, Germans and Frenchmen of whom I have spoken in the first volume of this my diary. All flocked to the humble dwelling of Mariquita, who, if not the handsomest was perhaps the most interesting of the young Arequipa beauties. Samuel B. Mardon, afterwards my principal, sent out by A. Gibbs \& Sons of London, and super cargo of the "Bristol"; Daniel Schutte [103] of Bremen, supercargo of the Alabama from [_]; Anton Von Lotten, native of Twistringen, a small Hanoverian town close to Bremen, supercargo of the "Chancy", also from Baltimore, were the most intimate. The last named offered her his hand; they were married in July 1823 and in their house I was introduced to my future wife on the second day of my arrival in Arequipa, by Mr. Mardon. In April 1824 the first Enriqueta was born, who died when eight months old. Mr. Von Lotten died in May 1825; Enriqueta, now Mrs. Garland, is a posthumous child. On the $10^{\text {th }}$ October 1831 the Canon O'Phelan blessed my union with Mariquita. For further particulars I refer to the first volume, though they are by no means so detailed as I could wish them to be.

Of course I did not go out into the street nor did I intend to do so for several weeks; remodelling my old diaries, which occupation diverted my thoughts more than anything else, walking the corredores, and thinking almost invariably on the same subject, whilst Bryson continued copying the corrected diaries, took up my time. Garland delivered to me the accounts of the expenses occasioned by my wife's burial etc., which, including a balance of nearly S/10o which I left on Enriqueta's hands that she might purchase stuffs for mourning, exhausted the $S / 1000$ for which I had given him a cheque on the $20^{\text {th }}$. I found 
one item called "mortaja" and as I had given strict orders that I did not wish my wife to be wrapped up in the ordinary gray cloak of the barefooted friars, as is so often done, I enquired from Enriqueta and Doña Goya what that meant, when they told me that they had placed over her body when in the coffin, a light brown dress of fine woollen stuff, which is the same as that worn by all those who are devotees of La Virgen del Carmen, and as my wife had always shown a great predilection to the Virgen under this denomination of course neither was, nor could be dissatisfied with what Enriqueta and [104] [...]

In the evening when Bryson was still reading to me, Middendorf came in to converse with me, and thus to divert my thoughts. I however soon took him over to Enriqueta's rooms where he took tea with us. Somewhat later Enriqueta related to Doña Angela what she had suffered from sea-sickness the various times she had passed the channel, and this narration of hers whiled away the time till near eleven when we separated. Enrique who slept on the sofa in my bedroom read to me till midnight. I immediately fell asleep, but had the most confused dreams, and awoke at two. I again fell asleep, again dreamt, and re-awoke at a quarter past four - seven days and half an hour had elapsed since on the $20^{\text {th }}$ May at 3.45 in the morning I heard that fatal fall, the last groans, and the last breath of my dear Mariquita. I dosed again, and did not rise till

Saturday, $27^{\text {th }}$ at 8 a.m. This day I passed exactly in the same way as the previous one. General Pedro Cisneros entered my office; of the other visitors I saw none except Rafael Velarde, who from 10 till 10.30 p.m. kept me company in my bedroom whither Enriqueta at the usual hour of nine was in the habit of sending me my tea. Geraldo passed the night on the sofa. Last Thursday evening took place the marriage of Oscar Heeren, at present Gerente of the Anglo Peruvian Bank, with Ignacia Barreda, one of the daughters of Don Felipe. Heeren had rented from the family Ferreyros the upper story of their house Calle de Zarate, the corner house of the the row of houses which is opposite ours, and which looks sideways to the Plaza de la Inquisicion. Carlos Ferreyros, formerly a naval officer, and commander of the "Chalaco", had gone as Prefect to Lambayeque. The highest exchange which this day was paid for 90 $\mathrm{d} /$ st. bills on London was $26 \mathrm{~d} 1 / 2$. Dreyfus and the Banco Nacional drew small amounts at $30 \mathrm{~d}$. Holders of silver bars asked S/15.10 the mark without finding purchasers; coined silver Soles were up to $44 \%$ prem.

Sunday, $28^{\text {th }}$ of May. I slept soundly till day break and rose at half past seven. By last night's steamer I did not write to Juan [105] but addressed a few words to Rosa with [...] which completed the $\mathrm{S} / 10,000$ presented to her. I likewise directed a few lines to my cousin Frances Cresswell of Winchmore Hill. When Bryson was gone Ricardo read to me a good deal both before and after dinner out of a German book called the Kaisersaal, which contains the history of the 
German Emperors from Charlemagne to Francis II. It is written in a popular manner, and adorned with pretty engravings. Fortunately Enriqueta had no visitors, and I took tea with her and Doña Angela in her bedroom; we talked a great deal about the last moments of my dear wife.

Enrique read to me in his astronomical work till midnight. According to the author the sun is one million four hundred thousand times more voluminous than the earth. The papers said that Mr. Charles Williams who in former years had a school here in Lima, and who was now employed by Pardo in the nitrate of soda business in Tarapacá had discovered a new guano depot of three million tons, of which he had given due notice to the government.

Monday, $29^{\text {th }}$ of May 1876. At twenty five minutes past seven, when I was still in bed, though wide awake, we experienced a very severe and long lasting shock of an earthquake. I did not rise; Enrique jumped up from his sofa. The day was spent like the previous ones. Visiting cards under black edged covers were brought in in great numbers. Enriqueta having again visitors with her I took tea in my bedroom. Guillermo Garland and Rafael Velarde were with me, each for a short time. Gerald slept on the sofa in my bedroom. He read to me some of the speeches delivered on Saturday last at a banquet given by Aurelio Garcia y Garcia, Minister of the Interior to nineteen individuals, editors of Lima and Callao papers. Tobar, a clergyman, Editor of La Sociedad, gave his toast for the immortal Pius IX.

Tuesday, $30^{\text {th }}$ of May. This forenoon I had to note down my wife's soiled linen which I delivered to the washerwoman [106] [...] sad job, and still more was I affected when I had to [_] some of my wife's presses in which she kept her dresses, and her linen. It was fortunate indeed that my mind was now and then taken up by occupations to which I had necessarily to attend. Henry Meiggs had made a proposal to the Government to prolong the Oroya railway as far as the Cerro de Pasco, and to work a new adit wherewith to drain all the mines of the Cerro, in remuneration for which he demanded that all mines in the Cerro which have either been abandoned or filled with water, as well as those to be discovered hereafter were adjudicated to him, and to the company which he might form. A few days back Alejandro brought me S/5100 (Noml.) Vales de la Nueva Consolidacion which he had received from Ruden; they were the proportion which corresponded to me on my S/12,00o (Noml.) Preference Bonds of the Pasco Mineral Railway Company, say seventeen trimestres at the rate of $2 \%$ each from $28^{\text {th }}$ February 1872 till $30^{\text {th }}$ June $1876=34 \%$ on S/12,000 $=$ $\mathrm{S} / 4080$ equal to $\mathrm{S} / 5100$ Internal Debt, at $80 \%$. I learned this morning from Garland, and it was afterwards confirmed to me both by Alejandro and by Dr. Palacios from whom Bryson had gone to enquire, that in my suit against Leyva, Dr. Ignacio Tavara acting as Fiscal, had given his vista in my favor. How my 
dear Mariquita would have rejoiced had we received this good news whilst she was still with us. During her long illness this suit was always uppermost in her mind; frequently she spoke of it and enquired of me how it was going on. Even only twelve hours before her end she had occupied herself with preparing some sweetmeats for the wife of the crabbed and always, to us, hostile Vocal of Dr. Mariano Cossio.

Wednesday, $3^{7^{s t}}$ of May 1876 . Last night, for the first time since the $20^{\text {th }} \mathrm{I}$ dreamt of my wife. I heard her call out "Le toca la ventana." I replied, I cannot say whether I actually pronounced the words, at all events I awoke; "nada, hijita, nada." The small clock which Enriqueta brought for her mother from Paris, and which now stood on my night table, struck two. Enrique also awoke; we spoke a few words and again fell asleep. Somewhat [107] after I again heard my wife call out to me; [...] I did not awake, and slept till daylight. At my request Sagastabeytia had the kindness to look in. He told me that the Banco de Lima had paid off the $S / 50,000$ it owed to the Banco de Londres, which sum it had again taken up on interest from La Marca. Manuel Mendoza's debt to the bank Felipe Barreda, his father-in-law, had cancelled. Also Basagoytia and Nicolas Hurtado had paid. Arancibia had gone to Iquique to receive the Salitrera "Esperanza", and thus the affairs of the bank were going on, not well, but fairly. Cucalon had been named President of the Directory in lieu of me. Nothing else occurred worth noticing; for several hours Bryson copied the old diaries; I walked the corridors, lost in thought. By the North Steamer I received letters from Juan, Rosa and Corina dated the last days of April. The first two silver bars for Rosa had arrived, and apparently come in very good time. Shattuck, Amalia, and the four children had left for Bremen and Hamburg in which latter place they were to embark for Boston on the $3^{\text {rd }}$ May. Rodewalde had received them with great politeness in Bremen; the unmarried sister and brother of the Schuttes were both alive; the sister, though deaf, very amiable; Frederic, the brother, was suffering from gout and his memory was fast failing him. Daniel and his wife in Hamburg had shewn them every attention.

When Bryson was gone we spent the evening by ourselves in Enriqueta's bedroom. Garland was of opinion that I should send another telegraphic dispatch to Juan. I did not agree with him. At 11 I went to my bedroom. Ricardo slept on the sofa.

Thursday, $7^{\text {st }}$ of June 1876. I dreamt last night, not of my wife, but that I was again a young fellow looking out for a situation in a counting-house. I awoke at 4, and my thoughts kept me awake till past 6 . What was I to do? Should I remain in Lima? Should I revisit Europe? I could come to no resolution. I saw by the Nacional that a great majority in the German Parliament had voted that the Government should purchase all the railways in the Empire. The 
S/5100 noml. of the Internal Debt. [108] [...] received by me from [_] Pasco Railway Company, I offered for redemption at $58 \%$ and had the good luck to be accepted. The boxes redeemed a very large amount at $571 / 2$; then I came with my $S / 5100$, and a small balance which still remained of the $S / 85,000$ cash destined for the monthly redemption, was absorbed by Alejandro who had proposed at $581 / 2 \%$. Garland went in the evening to his lawyer Fernando Palacios. I took tea with Enriqueta, Doña Angela, and Ricardo and went to bed at near eleven. Enrique slept on the sofa, but did not read to me.

Friday, $2^{\text {nd }}$ of June 1876 . I slept soundly till day light. The eldest son of Don Domingo Valle Riestra y Virginia la Torre, a lad of fourteen or fifteen, came to invite me and Garland to be present at the marriage ceremony of his sister Juana with Dr. Selaya, son of the public notary of the same name. All who knew them, the bride and the bridegroom, deplored that the former should make such a match. I of course did not go. Rosa in her letter dilated on the dreadful state in which Dr. Grau found himself. This gentleman had left Lima some time back in order to be cured of a cancer which had appeared in his face, and which had been operated upon more than once here in Lima. The medical men whom he had consulted in London and Paris had with one exception declared his case to be incurable, and he, being of the same opinion was in a lamentable state of desperation. Somewhat past one I left my house and ascended San Cristobal, in hopes that the exercise of the body would for some time at least overcome the anxiety of the mind, and in this I was not altogether disappointed. At any rate when I ascended, and still more when I descended when I had to pick my way carefully in order not to have a fall, my thoughts were diverted, but when I walked leisurely in the plain they again centred on the same subject. I reached the top from the basis without much difficulty in about twenty seven minutes, but the descent into the valley of Lurigancho, which was a very long one, took me about thirty seven minutes, [109] and thence to my house it was a walk of nearly $[\ldots]$ an hour. In the evening we were by ourselves, Enriqueta, Doña Angela and I; this I liked best. Eliza was occupied sewing in the adjoining room. Guillermo with his father and his brothers who were playing rocambor in the sitting room of the young men. Geraldo who slept on the sofa, read to me part of the Comercio. A certain Miguel Aranda had discovered a new guano deposit said to contain 1,200,000 Tons in the neighbourhood of Iquique.

Saturday, $3^{\text {rd }}$ of June 1876. Last night I again awoke at four, the fatal hour. At past 2 p.m. I like the previous day went over the Balta Bridge, and climbed up the Cerro which took me about twenty-five minutes, the descent nearly thirtyfive, for where the ascent is very steep I find it more easy to climb up than to descend. One with another I was absent from my house about two hours. In the evening when alone with Enriqueta I told her that I was decidedly averse 
to sell my wife's and my handsome furniture, as little as the many curiosities of Bohemian glass, Berlin porcelain, Chinese and Japanese articles etc., of all which my wife was so excessively fond, and I added that I thought best to propose to Rosa to come hither with her husband and Corina, who might occupy the suite of aparments hitherto inhabited by my wife and myself, whilst I would be satisfied with the two rooms where I had my office; the inner one might be made my dormitory. Both Enriqueta and Garland, who came in when we were speaking on the subject, had no objection to my plan. Enrique who slept on the sofa read to me out of his astronomical book till past midnight.

Sunday, $4^{\text {th }}$ of June. Whitsunday. I felt somwhat stiff in my thighs. Yesterday I had not shed a tear. Not so this morning when I opened a drawer in my wife's writing desk where Enriqueta thought that my wife had kept some bank notes. I found a mere trifle, letters, and many things, fans, gloves etc., the mere look of which made me very sad.

This morning for the first time this season the streets [110] [...] which had fallen during the night. Thermometer in my office at noon, $66^{\circ} \mathrm{F}$. Bryson was with me till 1.30. Then Ricardo read to me the German Kaisersaal, and after dinner an extremely interesting article on Vesuvius and its eruptions, the last, which had been unusually violent, and of which I had not heard anything until now, took place in 1872 . I should like to revisit this volcano, which in 1845 I twice ascended. Guillermo and Eliza took tea with us. The former spoke to me a great deal of a new invention made by one of the employees of Meiggs which consisted in smelting ore by means of Steam converted into flame, by the admixture of a little petroleum. Guillermo added that a flame fourteen metres long was produced, and that the expense in combustible was extremely little. Ricardo who slept on the sofa in my bedroom read to me a few short articles out of Chambers' Encyclopaedia lately published.

Monday, $5^{\text {th }}$ of June. Whitmonday. It again had rained during the night. Bryson was with me as usual till 1.30. We busied ourselves with indexing the remodelled diary of 1860 . Ricardo read the Kaisersaal before dinner, and after dinner we were in Enriqueta's bedroom were we took tea: Garland, Ricardo, Guillermo, Eliza, Doña Angela, and the little girls. Ricardo slept on the sofa.

Tuesday, $6^{\text {th }}$ of June. There was nothing new, and thus the day passed in the same manner as the former one, with the only difference that this being no holiday Bryson was with me till past four and read to me for full an hour in the evening. Ricardo again kept me company in my bedroom during the night. Papers said that the Sultan of Turkey Abdul-Azis had been deposed and a nephew of his been raised to the throne. It was rumoured that the cash-keeper of Gibbs of Arequipa, a German, had disappeared with S/30,00o. Not many 
months back the same thing happened to Gibbs of Lima; then the sum was $\mathrm{S} / 25,000$, and the culprit also a German Ulrich.

Antonio Martinez y Velarde was about this time very dangerously ill in Arequipa; it was even said that he had died, but this was not true. He was second cousin of my wife's [111] and came to Lima in November 1865 with Prado [...] he had followed since February of the same year when the latter raised the standard of rebellion in Arequipa. As long as Prado's administration lasted he had a situation in the Ministry for the Interior, and during that period he frequently came to our house. He was a good natural insignificant person. When Prado was turned out he lost his post and returned to Arequipa where he gained a livelihood by keeping a store in which he sold Chile produce consigned to him by his Brother Luis of Valparaiso. This Luis many years back began his mercantile career as clerk of Manuel Baltazar de la Fuente at the time owner of Salitreras in Iquique. Luis Martinez gradually got on, became himself owner of a Salitrera, and was fortunate to sell it exactly at the right moment, for how much I cannot say, but I should think that Luis possessed now at least three hundred thousand Chillian dollars. I well remembered their father who resided in Arequipa, a vulgar Spaniard, called Antonio Martinez, and their mother, Melchora Velarde; they lived and died poor.

Wednesday, $7^{\text {th }}$ of June 1876. At 1.30 I climbed up San Cristoval, as usual from the side where the paseo militar ends. I reached the summit without difficulty and descended towards the valley of Lurigancho, at least four fifths of the height, with the greatest ease, but I then lost the right path, and reached the bottom with much difficulty, and perhaps not without a little danger. Once I stood upon a rock without knowing whither to turn, so steep was the ascent above, the descent below me. I then crept along on all fours, and so got out of the scrape, but my fatigue was great; my breath was completely gone, and to recover it I had to rest for several moments on the sandy ground. I was absent from my house nearly two hours and a half. I took tea with Enriqueta. We were by ourselves, only Doña Angela, and the little girls.

Thursday, $8^{\text {th }}$ of June. I awoke this morning rather more tranquil than hitherto, and could think of my dear wife with some degree of composure, but this was completely [...] [112] [...] ng the many knick-knacks of which she had [...] extremely fond. As to my future movements I could come to no determination, and anxiously did I await Juan's arrival in order to consult with him. The remodelling of my diary was always an occupation in which I took great interest. Bryson got on well with the copying of the same. Cedulas del Banco Hipotecario were up to 75 , Territorial $1 \%$ lower. The Internal Debt was fast declining; it was quoted at $55 \%$. I had done well when I redeemed my 
S/5100 at $58 \%$. Silver Bars S/14.6o the mark fineness 999/1000 ${ }^{\text {ths }}$. Bills on London $90 \mathrm{~d} / \mathrm{st}$., $26 \mathrm{~d}$ 1/2. Only Dreyfus and the Banco Nacional drew at 3od. Within these last few days an act of dishonesty committed by an Italian who about four months back professed as Franciscan Monk, having until then belonged to the secular clergy, had come to light. Some time back a Lima lady placed for safety's sake into the hands of a nun a considerable sum of money; the nun when confessing to the Italian Franciscan Monk Pardini, told him that she had this money in deposit; he persuaded her to give it to him in order to place it in the London Bank. The nun did so without the consent of the lady, which latter within these last days, a house being offered her for purchase at a low price, demanded the money from the nun, the nun demanded it from the monk, who declared that he had deposited the money, but could not produce the deposit document; in short, the money was gone and the monk was arrested.

Friday, $9^{\text {th }}$ of June 1876 . One day passed like the other; I rose as late as eight. Ricardo read to me from 9 to 10 . I breakfasted with the Garlands and Doña Angela, then Bryson came, who remained till past four; to allow him time for copying I was in the habit of walking the corridors, I strolled as far as the gate of Barbones, and back, or ascended San Cristoval; occasionally Ricardo read to me before dinner, from which meal we did not rise till past six. Bryson was again with me from 7 to 8 . This evening he commenced reading to me a highly interesting work translated into English from the French by C. Joinville. I saw by the same [113] that the family Romanoff from which the present [...] descends, was originally settled in Lithuania were they were chief and hereditary high priests at the altars dedicated to the Sun. The sword of the Teutonic order drove them to Moscow where they embraced Christianity, and had their ups and downs like other noble families until in 1613 Michael Romanoff was elected Czar of all the Russias. When Bryson was gone I joined Enriqueta in her bedroom, where we took tea, and retired to rest at about eleven.

Saturday, $10^{\text {th }}$ of June 1876. Last night I awake at 3.30 exactly three weeks after the $20^{\text {th }}$ May. I remained awake but a short time. In Salonica a few months back the German and French Consuls were murdered by the Turkish mob, whose outrages the Turkish authorities were unable to suppress, and therefore the five great powers of Europe were sending their men of war to the said port.

Sunday, $11^{\text {th }}$ of June. When Bryson had left me at 1.30 Ricardo read to me till four; then he and I walked as far as the gate of the Maravillas and returned through the unpaved streets of the Cercado, and over the spot where once the Barbones gate stood. Of the walls which formerly encircled Lima, but a few remnats were still standing. Henry Meiggs, the North American, had been the purchaser and demolisher of them. After dinner Enriqueta had the kindness to entertain me by reading to me in Spanish out of a work historical and geographical, by Count Las Cases, originally written in French. Antonio, 
Ricardo, and their father came in afterwards. With Antonio I searched in vain for the genealogy of Henry IV of France, the first of the present family of the Bourbons. I know that he descends from Robert, Duke of Clairmont, fifth son of St. Luis, but the intervening links of the chain I could not discover. I went to bed at 10.30 much composed and

Monday, $12^{\text {th }}$ of June I continued in the same [_] of mind [114] [...] received to the effect that General Prado had made a contract with the firm of Raphael Raphael \& Sons of London for the sale of guano and the payment of the Peruvian Foreign Debt. Six cupons, viz.: those of $30^{\text {th }}$ June, and $31^{\text {st }}$ December $1876,30^{\text {th }}$ June and $31^{\text {st }}$ December $1877,30^{\text {th }}$ June and $31^{\text {st }}$ December 1878 , would not be paid, but be capitalized. This was the only condition which became known. It was added that the contract had been well received in London, badly in Paris. I received a letter from my nephew Johannes Limpricht dated Hamburg $4^{\text {th }}$ May, who informed me of the death of his nephew Paul Bobertag whom when my wife, the two Misses Schutte, and I paid a visit to my relations in Ratzeburg in 1855 , was a child just beginning to prattle. He had died on the $23^{\text {rd }}$ April in Meran in the Tyrol whither his medical adviser had ordered him, in expectation that the pure mountain air would benefit his diseased lungs, but far from it. From week to week, from day to day his debility increased, and this to such a degree that when his mother, my niece Elizabeth, hastened to him when informed of the dangerous state of his health, she found him so weak that he could hardly lift up his arm to his mouth, and in fact he expired in her arms whilst she was feeding him at breakfast. For the last few years I had regularly rendered Paul some trifling pecuniary assistance. This Johannes now wished me to transfer to Paul's younger brother Henry, which of course I willingly did. Henry, my godson, the youngest child of the family, was at the time as apprentice in the counting-house of George Knauer of Hamburg where his exemplary conduct gave the greatest satisfaction to his employer. From October 1877 to October 1878 he would have to serve the obligatory one year in the Prussian army.

In the evening Garland had a visit from Francisco Ramos, Enriqueta from his wife, a Chilian lady. This Ramos was our fellow passenger in 1863 from Europe and was one of the many children of the late Ramos, a Chilian, and owner of the valuable sugar estate in Cañete called Hualcara, which at present the heirs were unable to dispose of at a satisfactory price. The ladies told us that in [115] Balta's time her father-in-law might have sold [... S Soles; now it was valued in seven hundred thousand, but, as I already said, no purchaser could be found.

Tuesday, $13^{\text {th }}$ of June 1876. I had ceased weeping; I had ceased calling out for my wife as I had done more than once. My grief however though silent, was not the less, nor did I wish it to decrease for this would be ingratitude to my dear wife. Here follow a few details which, omitted hitherto, and of no real 
importance, are however of value to me, as they refer to my Mariquita. Ever since our return from Chorrillos in the beginnig of the year my wife seldom joined Doña Angela and myself at our breakfast in the dining room; she usually took this meal in her bed; not only the servant, but Doña Angela and I attended her, and we had frequently the satisfaction to observe that she enjoyed her beefsteak, and particularly her tea and buttered toast; between eleven and twelve she was in the habit of rising, and it depended upon the state of her health how long she remained up. Also her dinner she seldom took in the saloon, because the temperature there was rather cold. If unwell, it was served her in bed; if well enough she partook of it sitting on the green maroquin sofa, with one of the small Chinese tables before her. When she retired to bed at an early hour a circle formed by our relations and best friends was often formed; she always took a lively interest in the conversation which was going on, and frequently an active share in it. As long as her health and the warm season permitted she, Enriqueta, and I sometimes with Ricardo, sometimes with Garland or Limpricht, passed the evening hours in our corridor. When the weather got too cold she had her customary seat in an arm chair in the salita, where many a time when Bryson had remained with me longer than usual, I was received with the words "porque vienes tan tarde; he estado aqui como una alma en pena." Whilst by herself she pretended to have said her rosary, but I believe that more than once she must have dosed half an hour or so. All her life time she had been very fond of society and therefore more than once [116] [...] me of the long solitary evenings now spent by [_]en I did not fail to observe that as we had neither card playing nor grown up daughters, the two principal attractions, it was quite natural that we old folks should not have many visitors. In former years she herself had made and served the tea in the evening, but of late Enriqueta or I had taken this trouble off her hands. At 11.30 we retired to our bedroom; when undressing she frecuently made me observe the icy coldness of her left leg, whilst the right one preserved its natural warmth, a phenomenon which neither we nor the Doctor could account for. I had to lock the passage leading to our rooms from the corridor, to look into the kitchen to see that fire on the hearth was properly put out, to bar, and lock our own rooms, and to extinguish the gas, and thus it was generally eleven before I turned in. I found by chance in my writing desk, a copy of my letter to Mr. Charles Crawley dated Arequipa $4^{\text {th }}$ Octr. 1831, six days before my marriage, and I think it well to affix it in appendix, under $\mathrm{N}^{\circ} 3$. It will be seen that it was written by me in answer to a letter of his, which replied to a previous one of mine, in which I had informed him of my intention to marry.

Wednesday, $14^{\text {th }}$ of June. I extracted from the Nacional the following, probably solely published to introduce to the public the hitherto in Lima unknown firm of Raphael Raphael \& Sons. 


$\begin{array}{lccl}\text { N. M. Rothschild \& Sons } & 1863 & \text { Successors of } & \text { N. M. Rothschild } 1804 \\ \text { Antony Gibbs \& Sons } & 1803 & & \\ \text { J. S. Morgan \& Co. } & 1864 & \text { do. } & \text { George Peabody } 1838 \\ \text { Baring Bros. \& Co. } & 1805 & \text { do. } & \text { John Baring } 1763 \\ \text { J. H. Schroeder \& Co. } & 1815 & & \\ \text { Raphael Raphael \& Sons } & 1843 & \text { do. } & \text { Raphael Raphael } 1815 \\ \text { Fred Huth \& Co. } & 1816 & \text { do. } & \text { F. Huth } 1809\end{array}$

All these were classified in the London Commercial List A1 as regards General Standing, Mercantile, monetary, Trading credit and negotiability of acceptances. [117] Garland told me at dinner that it was [...] that the following parties were interested with Raphael Raphael \& Sons in the guano contract: Thomson Bonar \& Co., Lazky, Carlos Candamo, Jose Canevaro, Joaquin Osma (the eldest of the brothers who resided in Madrid) and Felipe Barreda of Lima. In the evening Ricardo read to me a very interesting article written in German, regarding the plan formed by the German Government to purchase all the railways in the Empire. This article said amongst other that in 1874 of the entire population of Great Britain and Ireland numbering thirty millions and odd, every person had on an average made 14.89 journeys by railway, in Germany, of the population of forty one millions and odd only 4.62 had been made by each person; also that in 1873 in England the expenses of the railway had absorbed annually $52 \%$ on the gross income, in Germany $64 \%$.

Thursday, $15^{\text {th }}$ of June 1876 . On the $15^{\text {th }}$ June 1685 the Spanish Government decreed the construction of a wall round Lima. To-day Corpus Christi, the Congress Extraordinary assembled. On the $13^{\text {th }}$ and $14^{\text {th }}$ the Deputies had had their preparatory meetings, the Senators, only one yesterday. In our street there was some bustle caused by soldiers, military music, carriages occupied by Deputies to inform the President that they were ready to receive him, by the President and his retinue walking to the Congress, his return, etc. I heard the noise, but did not go to the balconies to look out. When Bryson was gone Ricardo read to me, and from 4 till 5.30 he and I took a walk. The time from dinner till 10 I passed in Enriqueta's room, very dull and sad.

Friday, 16 $6^{\text {th }}$ of June 1876. Pardo's speech in the Congress was published in the papers; he said that the only object which he had had in convoking this Congress Extraordinary was to lay before them his project for raising the export duty on Nitrate. A copy of the same goes affixed in appendix under $\mathrm{N}^{\circ} 4$.

To-day in the Senate the Finance Minister J. Y. Elguera in a long and detailed message, probably written by Pardo and [118] [...] Minister, gave the reason why the export duty [_] ught to be raised to $S / 1.25$ or more properly speaking to 5od, viz.: S/1.2[_] at 4od, in conformity with the just spoken of project. 
The Opinion Nacional informed its readers that the Directors of the four associated Banks were occupied with discussing three knotty points, firstly, when and how they were to resume cash payment; secondly, whence they were to procure the silver for the coinage of small change, and thirdly, whether they were in a situation to make to the Government the new loan demanded from them. Whether there was any truth in his report I did not know because for the last four weeks I had not come in contact with anyone who could give me any particulars on the subject. At 1.30, the sun being out I went over the Balta Bridge and ascended San Cristoval which I did without difficulty, but on my descend had a great deal of trouble. I could not find the right path. I believe the reason was that the long shadows thrown by the setting sun bewildered my imperfect sight, and it seemed to me as if I had a steep descent before me which I did not like to venture at, and it was thus as late as 4.30 when I reached my house.

Saturday, $17^{\text {th }}$ of June. Four weeks had elapsed since the $20^{\text {th }}$ May. Till 1.30 I was generally occupied with Bryson, he reading me the old diaries, the style of which I tried to improve; so I did this day and whilst Bryson was copying, I, not inclined to go out, sat for some time moping in the corridors. From 4 till 5 I took a walk. At dinner Garland told me that he had been informed that the particulars of Prado's contract with Raphael of London, had been communicated to the Government in a telegraphic dispatch of about 200 words, and that Pardo had not approved it. Enriqueta read to me in the evening the letter from Juan of $15 / 16^{\text {th }}$ May. Lima letters of the middle of April had not yet been received. He wrote that the contract between Riva Agüero and the Société Generale of Paris was quite as favourable for the Peruvian Government as circumstances allowed, but that it was not carried into effect because it contained one clause which [119] said that London holders of Peruvian Bon [...] of it, and this they had not done. Juan added that Prado was surrounded in Paris by a group of persons of no high standing and inimical to the Société Générale, with which company Dreyfus was intimately connected. He specified: Luis Auregan, Duperont, once apothecary in the Calle de Mercaderes, Lima; Sescau; Bernardo Canevaro; Juan Martin Echenique; the members of the Anglo-Peruvian Bank; and Francisco Rivero, in former years Peruvian Minister in France. Prado had dined with Toribio Sanz; Grimaneza Cotes; Francisco Rivero; Carlos Candamo, and Augustus Dreyfus, at whose house Juan had been one of the guests. Arthur Heeren had given Prado a lunch in St. Germain in Laye. In the Nacional of this evening the Contract between the four associated banks and the Government relative to the Nitrate business was published, of which the principal conditions will be found further down. In the Senate they were quarrelling as to the question whether Ceferino Elguera had a right to preside as Vice President in 
the absence of Francisco de Paula Muñoz, hitherto President. A certain Torres from Cuzco or Puno, and Salazar, brother of him, who was oficial mayor in the Ministry for Foreign Affairs, pretended that as Muñoz had ceased to be Senator and President, having been named post master general, there could be no Vice President either, and consequently Elguera could not preside as such. I doubted they would carry the point, but at least many days would elapse before the question were decided. Lízardo Montero had demanded that all documents relative to the guano business should be presented to the Congress by the Minister for Finances, because the sales of Nitrate of Soda and of guano depended in a great measure the one upon the other.

Sunday, $18^{\text {th }}$ of June 1876. After Bryson was gone, Ricardo read to me from three till four in the uninteresting Kaisersaal. Dr. Muñoz called and wished to see me. I went to Enriqueta's salita where he was and I felt very [_] to him for his attenti[_] [120] [.... I walked as far as Maravillas gate, and after dinn[_] I was so sad I went to bed at as early an hour as 8, though it was 11.30 before I fell asleep. Enriqueta brought me my tea at nine, and sat down at my bedside. Ricardo read aloud from 10.30. There had been a rising in Cuzco on the $7^{\text {th }}$ inst., which was put down after seven hours fighting.

Monday, $19^{\text {th }}$ of June 1876. I occupied myself for some time with looking over the many keys left by my dear Mariquita, also with cleaning and arranging one or two drawers in her writing desk; this was a sad, but necessary task. I did not go out in the course of the day. Joinville's History of Russia which Bryson continued reading to me gives a detailed account of the murder of Paul, husband of Catherine I, and speaks in very high terms of the Emperor Alexander I, born in 1777. This evening at 8 p.m. died on the age of 67 Pedro Paz-Soldan, a very good friend of my wife's whom he had survived no more than one month, less 8 hours. Before he left Lima for his sugar estate in Cañete, where he had been struck by apoplexy he had one day been with my wife to bid her good by, when he was particulary kind, and friendly. This day the motion of Salazar and Torres as to the election of a new President instead of Francisco de Paula Muñoz in the Senate was gained by 19 against 17, and accordingly Ceferino Elguera ceased to preside as Vice President.

Tuesday, $20^{\text {th }}$ of June. I again occupied myself for two hours with looking over, and endeavouring to arrange my wife's keys. Again I did not go out. I received a note from Elizalde, Gerente of the Insurance Coy. Lima, citing me to a meeting of the Directory to be held tomorrow. I answered, begging to be excused. In the Senate Dr. Jose Aranivar was chosen President by 37 votes, Dr. Rios, A. Althaus, Secada and M. F. Benavides, had each one vote. On Saturday last a daring robbery was committed in broad day light in Callao. A clerk of the railway Company took from the office more than seven thousand Soles in 
billetes to pay the workmen and em- $[\ldots]$ week. The factory where they were [121] at work was but a short distance from the Station of Santa [...] his way he was attacked by three men well-mounted, who threatened him with revolvers, and thus forced him to deliver up the money.

Wednesday, $27^{\text {st }}$ of June 1876 . Nothing worth noticing. Once more I was busy with my wife's keys, took a short walk before dinner, and in the evening when Bryson was gone, took as usual tea with Enriqueta in her bedroom. The Canon Mora, an insignificant talkative man, was of some use in whiling away the heavy hours.

Thursday, $22^{\text {nd }}$ of June. The same as the previous day. At 3.30 I walked with Bryson out to the pantheon to see the tombstone placed to my dear wife's niche. We saw it done, and were back by 5.30. In the evening when Bryson had left I entered Enriqueta's bedroom, where I found so many lady visitors that I went at once to my room and to bed. Enriqueta herself brought me my usual two cups of tea, and at a later hour Ricardo finished reading to me the detailed description of the fearful eruption of Mount Vesuvius which took place on the $25^{\text {th }}$ or $26^{\text {th }}$ April 1872 . I was very quiet and composed, but angry with myself at my composure and tranquility.

The papers contained some details as to the rising attempted in Cuzco on the $9^{\text {th }}$ June. The revolutionists were headed by a certain Col. Salas, Manl. M. Galvez, the brothers Astete and others. They had chosen the very night of the day when the new prefect Francisco Luna had been installed. The previous Prefect Col.Ibarra rendered his assistance to Luna and was dangerously wounded by a musket ball which fractured his thigh. The revolutionists, who huzzaed for Pierola, fled after a fight of eight hours; some of them were made prisoners. The inhabitants of Cuzco took no share in the movement.

Friday, $23^{\text {rd }}$ of June. Garland told me at breakfast that he had learned that Pardo had asked the banks for a loan of eight million Soles and that they were likely to [...] his wi[_] [122] [...] this time frequently absent from breakfast as [_] had to go to the dentist to have her teeth plumbed. Alejandro had begun a suit against the Banco Anglo-Peruano; he had collected S/32,00o of their notes, and demanded payment in silver or gold. Verbally he let them know that he would be satisfied with a premium of $15 \%$, in my opinion a very low demand, but the gerentes, especially Oscar Heeren, offered him 7 1/2\% which he refused. They pretended that many months back they made a verbal agreement with Alejandro, to buy up for the bank its notes for a commission of $1 / 2 \%$. Alejandro did not deny that there had been such an agreement, but affirmed it was null and void, in the first place because they never furnished him with the funds wherewith to make the purchase, and secondly because contrary to their contract they had ordered other brokers to make purchases 
whilst the agreement, a mere verbal one, was that Alejandro should be the only purchaser. He had called the gerentes before the Juez de $1^{\text {a }}$ Instancia Quiroga to recognize the notes, which hitherto they had not done, and yesterday they presented themselves before the Consulado, demanding the delivery of the notes in payment of the premium paid by Alejandro, and the $1 / 2 \%$ commission.

This forenoon I occupied myself several hours with looking over and cleaning out my wife's writing desk; a large number of worthless articles I handed to Enriqueta that she might do with them what she liked. I kept for myself a small "porte-monnaie" which of late she had been in the habit of using and in which I found a few silver rials.

Before dinner I took a short walk, and in the evening was alone with Enriqueta till past eleven.

Saturday, $24^{\text {th }}$ of June. San Juan. Five weeks had elapsed. I awoke last night exactly at four, but immediately again fell asleep. This morning for the first time since the $19^{\text {th }}$ May, I walked to the Plaza Mayor, got shaved and had my hair cut at the French barber's. I also had a look at the house, belonging half to José Maria Sancho-Davila, half to Ignacio Osma, in front of the [Calle de] [_] enaderia, close to the prefectura, which they had just sold [123] for S/10o,ooo to Meiggs, representative of the Oroya rai[_], who was making some alterations to adapt it for a railway station. Of the house close to mine in Calle del Correo where the new Post Office was to be built, but little remained standing. On the $17^{\text {th }}$ May the privilege of the Candamo Railway to Callao expired, and today for the first time the passenger trains of the Oroya Railway ran between Lima and Callao, from 7 a.m. till midnight, fifteen trains both ways. The fare was the same as on the other line, viz. four rials first, two rials second class.

Dr. Middendorf who breakfast with us, Enriqueta in bed, with her usual migraine, gave me an account of the proceedings in last night's meeting of the shareholders of the Banco de Lima. I had given my power to John Gallagher. Manuel Cucalon presided, who after last acta had been approved and the names been called over, opened the meeting by reading a short message in which he said that the affairs of the bank had improved in the course of the last two months, that the Delegates of the Bank had exceeded their powers, and that the shareholders should now approve what they the Delegates had done. Rufino Echenique rose and observed that there was an evident contradiction between the two last sentences uttered by the President. Next Garcia Calderon spoke, and his speech, in Middendorf's opinion, had been a master piece; he explained in the most lucid manner all that the Delegates had done. On the other hand Derteano's discourse had been a complete failure; his passion had got the better of him, and he gave to understand that the Directory of the Banco de Lima was not fit for its post. This imputation Cucalon had to reply 
to which he did in proper terms. Luis Cisneros defended all the proceedings of the Delegates. Lembcke read a plain statement, in which he made manifest that even were the Banco de Lima inclined to withdraw from the association with the other three banks, this could at present not be done, because the Government [_] unable to return the money ad [...] [124] [...] three million Soles, and that the other three banks, even if th[_] were inclined to pay these three millions on account of the Government, were not in a position to do so. He also showed the advantages which accrued to the bank from the contract made with the Government, and gave it as his opinion that the Banco de Lima could not do otherwise but continue united with the other three. Gallagher made a motion so self evident that it hardly required being made, viz.: that the Delegates of the Banco de Lima should always submit to the majority of their colleagues, the other Delegates. Finally Juan Martin Cardenas, at whose request the meeting had been convened, rose at 11.30, when the Doctor left; he was of opinion that Gallagher's motion would be approved by a great majority. When Bryson was gone I took a walk, and when I had come as far as Balta's bridge I observed that within the last few days a wide convenient wooden staircase leading down to the bed of the river had been constructed. I descended and came to a solid wooden platform, upon which a small station house belonging to the Oroya railway stood. Where this plattform ended, I had to walk for a short distance over stones and pebbles as far as the next platform, similar to the previous one, which extended as far as the stone brige; from its upper extremity two wooden staircases led up to the new station house formerly Osmas and Sancho Davilas; from the lower end a gently rising inclined plane brought me to the street close to the bridge. To the right of the platform runs the Oroya railway which is defended by a low wall from the inwards of the river.

After dinner, from 7 till near 10, Garland and I kept Enriqueta company, who was in bed. It was a very sad evening.

Sunday, $25^{\text {th }}$ of June 1876 . Bryson was with me till past two. Ricardo read to me the Kaisersaal for about two hours. I walked as far as the Maravillas gate, and dined with Garland, Enriqueta, Enrique and Ricardo; the remainder of the family were dispersed here and there. The two little girls had been sent to Villacampa's huerta in the street of Malambo. Doña Angela, unwell [_] in bed. After dinner Ricardo concluded an interesting [125] article on Japan published in a German Review [_] the "German Look out". Enriqueta had a long visit from Doña Pancha Cardenas, step-daughter of the late Juan Ugarte, and wife of Gregorio Benavides. She was very talkative and thus the time passed more rapidly than usual till near 11 when she left. When in bed Ricardo again read to me from the same German Review, two well written short biographies of the diplomatist Henry Bulwer Lytton, born 1804 died 1871; and of the North 
American Stateman, Henry William Seward, President Lincoln's right hand, born 1801 died 1872 . In the course of the day I removed for safety's sake our silver plate, kept by my wife in her writing desk which stood in our bedroom, to another piece of furniture in my present dormitory. When thus occupied I tried to move the heavy sofa, which prevented my opening one of the doors of the writing desk; it was too heavy for me and I felt in the upper part of my right arm a hardly perceptible tick as if something got out of order. I immediately felt a pain in that part of the arm below the elbow and could not move it with ease. Enriqueta rubbed it with arnica.

Monday, $26^{\text {th }}$ of June 1876 . This morning Enriqueta was busy putting my pantry or "dispensa" to rights. She found there sperm candles, windsor soap, and a long lost case of sago which I received from China I suppose twenty years ago. I occupied myself with arranging the papers and other things in the drawer of my wife's writing desk. Rehder came and asked me for a loan of $\mathrm{S} / 4000$ and offered as security the certificate of a silver bar which he had bought. He told me that it was rumoured that the bills of the Banco Nacional had been protested for non-acceptance in London. Before dinner I took my usual walk, and in the evening when Bryson was gone, Enriqueta examined a number of letters which I had taken out of my wife's portfolios, of which she read aloud more than one. We tore those from Rosa and Schutte, written to my wife when we were travelling about in Europe. Enriqueta put aside a considerable number written by her [_] [126] [...] and Garland were last absent in Europe from 1872 to January 1873 and preserved as a relic every slip of paper with her mothers hand-writing, also a letter written to Mariquita by her brother Don Mariano. The Nacional of this evening informed its readers that in the Senate General La Fuente had spoken against the increase of the export duty on nitrate, and that Silva Santistevan had impugned the entire nitrate contract with the banks. The "Nacional" further gave some details received per cable of the guano contract concluded by Prado with Raphael Raphael \& Sons, Carlos Candamo, and Arthur Heeren. $£_{700,000}$ annually the Peruvian Government was allowed to dispose of, to begin from January of this year. The number of tons to be consigned, to be 1,900,000. All expenses not to exceed $£ 4.15 /$ per ton, as long as the freight did not surpass 6o/ and the loading expenses 10/. Other conditions were not clear. The Government might at once draw for £100,000, of which facility Pardo however did not avail himself.

Tuesday, $27^{\text {th }}$ of June 1876 . For a short time I was once more occupied in my wife's room with picking out keys. Rehder did not come for the money, and the rumour about the bills of the National Bank seemed to be without foundation. I presented Dr. Alvarez with 2 dozen wine. Heaven only knew when my lawsuit with Leyva would be decided in the Supreme Court. Silver bars had been 
sold at S/14 the mark, ley 993. Of the remainder of the day, nothing was to be said; I spent it in the same quiet and sad manner as was now my habit.

Wednesday, $28^{\text {th }}$ of June. I learned that on Saturday last the Directory and a few of the shareholders of the Banco de Lima such as Garcia Calderon, Derteano, Luciano Benjamin Cisneros, and Calderoni, had remained together till past one, and that the majority resolved that the Delegates had not exceeded their powers, that they were chosen to administer the guano and nitrate business, that what they had done was well done, and that the minority of the Delegates must submit to the majority. Thus we were now tied hand and foot and completely in the power of the just enumer-. [...]. The following were at this time the capitals of the [127] banks established in Perú

\begin{tabular}{lrc} 
Names & \multicolumn{1}{c}{ Capital } & Paid up \\
Banco Nacional & S/12,000,000 & $35 \%$ \\
Perú & $8,000,000$ & $50 \%$ \\
Lima & $5,000,000$ & $50 \%$ \\
La Providencia & $3,200,000$ & $50 \%$ \\
Garantizador & $1,094,000$ & $50 \%$ \\
Anglo Peruano & $£ 2,000,000$ & $50 \%$ \\
Banco de Londres, M. \& S/a & $£ 900,000$ & $50 \%$ \\
Banco de Arequipa & S/1,000,000 & $50 \%$ \\
Tacna & $1,000,000$ & $50 \%$ \\
Piura & 500,000 & $35 \%$ \\
Hipotecario & $3,000,000$ & $100 \%$ \\
Trujillo & $2,000,000$ & $50 \%$ \\
Territorial & $1,000,000$ & $100 \%$
\end{tabular}

Rehder came for the $\mathrm{S} / 4000$ now increased to $\mathrm{S} / 4500$. Felipe Barreda paid me a short visit. The project of the Executive to raise the export duty on Nitrate to $5^{0}$ cents a $\mathrm{ql}$ was approved in the Senate by a considerable majority more or less in the proportion of 2 to 1.

Thursday, $29^{\text {th }}$ of June 1876. San Pedro y San Pablo. In former years it had always been my habit to call upon the Pedros and Petronilas, Pablos and Paulas of my acquaintance. This year I contented myself with sending my card to Petita Puente, wife of Frederic Marriott. Bryson was with me till 1.30. Ricardo read till near four when I walked to the Barbones and Maravillas Gate and upon the newly laid platform in the bed of the river. At dinner we were merely Garland, Enriqueta, Juan, Ricardo and I. The other young men were absent in Chorrillos at a regatta of rowing boats. Corina in bed with a cold. 
Friday, $30^{\text {th }}$ of June. I saw by the Eclectic for May 1876 that in 1870 the population of the United States am[_] [128] [...], and that since 1830 it had increased $35 \%$ every ten years.

At 1 I started for an ascent of San Cristoval, which I accomplished as usual from that side where the Paseo Militar ends. On descending towards Lurigancho I lost my way when perhaps three-fourths down. I re-ascended, and then descended on the opposite side towards the Convent of Los Descalzos, where the road cannot be missed. After all I was absent not much above two hours and a half without feeling the least stiffness in my limbs.

After Bryson had gone in the evening I was generally alone with Enriqueta, when our conversation ran mostly on our beloved lost. My arm still pained a little; Enriqueta rubbed it both in the morning and evening with arnica. All the papers of this evening contained a wonderful new financial project proposed by Pardo to the four united banks; a copy of same goes affixed in appendix under $\mathrm{N}^{\circ} 5$.

Saturday, ${ }^{\text {st }}$ of July 1876 . I went to the Gas Company to receive $21 / 2 \%$ dividend on C. W. Schutte's 385 , my 69 , and Juan's 54 Shares of S/500 each. On taking the cheque to La Providencia I met Juan Martin Cardenas, with whom I had a long conversation. He was not at all pleased with the manner in which the Banco de Lima's affairs were managed, and he suspected that it was Lembcke's wish to be named Gerente of the Banco Central, if ever established, and that for this reason he was keeping on good terms with Derteano, Garcia Calderon and the like. Cardenas was further of opinion that Pardo's project would not be accepted by any of the banks, whilst I afterwards learned from Garland and Alejandro that in all probability the banks would accede to it, if Pardo were willing to agree to some modifications proposed by them. Past nine in the evening the letters per North Steamer were delivered, and I had an unusually large number: from Juan, Rosa, Corina and Schutte. Garland's telegraphic dispatch of $20^{\text {th }}$ May had reached them on the $23^{\text {rd }}$. Juan's letter above all was written in [...] style. What I regretted was that he could not [129] yet start for Perú, because the state of his health obliged him [_] go to Wildbad, there to use its waters. From my cousin Frances Cresswell, and my friend G. H. Sieveking - who of course could not yet know of my loss - I had also letters. Sieveking informed me that on the $14^{\text {th }}$ April had died Theodore Elmenhorst, I suppose my younger by two or three years; $63 / 4$ years were we two together clerks at $C$. H. Donner's, his and my desk stood close to each other. We were always on excellent terms, and after my mother's death his widowed mother, the sister of our principal C. H. Donner, always treated me with the greatest kidness. In later years when I visited Altona in 1854/5 and 1863, Theodore and his wife, did however not shew 
me the same attention as the greater part of my other friends. The night of his death his wife who lay alongside of him heard a low sigh; she took no notice of it, and when she awoke in the morning she found Theodore a corpse. Sieveking also wrote me of the death of Eliza, Semper's sister. She died unmarried; the last year of her life she had been rather weak in her mind, whilst in her younger days she like her brother had been distinguished by a very clear understanding.

Sunday, $2^{\text {nd }}$ of July 1876. A day beyond measure sad. When Bryson was gone I went out at half past two to the Gate of Barbones to that of Maravillas, to the pantheon where I remained more than half an hour, then to the Gate of Martinete and down into the bed of the river where Meigg's new platform afforded a nice promenade. At dinner we were merely Garland, Enriqueta, Enrique, Ricardo, and I. The two little girls had gone to see Maria La Croix, daughter of the widowed Isabel Aliaga. Antonio and Juan were unwell in bed; Geraldo with his brother in Chorrillos.

In the evening, whilst Enriqueta had a visit from a friend of hers I was by myself in the office until 8.30. Afterwards Enriqueta, Garland and I were by ourselves quietly, not to say silently. Only the bringing in of the tea things caused a momentary interruption. Our house was fearfully solitary at this period, all our rooms shut up and on Sunday forenoon no visitors [130] [...] not wonder at.

Monday, $3^{\text {rd }}$ ofJuly 1876 . From the Banco Hipotecario I collected a considerable amount of money, I having had the good luck that at the last drawing, five of my Cedulas had been redeemed, and were now paid me in full. La Empresa de Obras Publicas y Fomento paid me the monthly rent of S/540 which I at once handed to Enriqueta for I knew that my wife in her last will and testament had left the house Calle de Zarate to her daughter, though as yet we did not know whether her share of the inheritance would suffice to pay the total value of the same. I called in the locksmith, who amongst other things opened the lower press of my wife's writing desk, which we had not been able to open for a length of time. I began examining various articles which my wife had shut up there, but made very little progress. In the evening we had José Basagoytia, his wife, Juana Rosa and their two little girls, with us. Garland was not in.

Tuesday, $4^{\text {th }}$ of July. This morning I was more than usually sad. In the course of the day I finished examining and arranging the various articles in the writing desk of which I spoke yesterday. I found amongst other things two small cases locked which I believed contained the silver gilt teaspoons which my wife had promised to Enriqueta, and I therefore took them to her. In the evening we were alone. This day was the hundredth anniversary of the declaration of the Independence of the United States, in celebration of which Henry Meiggs gave a ball to which the entire family of the Garlands was invited, but none went. 
Present were about seven hundred persons, and Dr. Middendorf, who had also been there, was of oninion that the cost could not have fallen short of S/15,000.

Wednesday, $5^{\text {th }}$ of July. Nothing occurred worth noting down.

Thursday, $6^{\text {th }}$ of July. My arm, which I sprained on the $25^{\text {th }}$, continued to pain me a little whensoever I made the smallest effort. This morning Dr. Middendorf bandaged it. Lembcke came to tell me that Manuel Cucalon, the President of the Directory of the Banco de Lima, had named me to form one of the committee [_] should give its opinion on Pardo's project of $30^{\text {th }}$ June. I [131] declined to accept this nomination. Besides the rent from the Compañia de Obras Publicas, I likewise handed Enriqueta the S/216 rent received from Sattler. I dictated a very long letter to Juan, in which I gave him a detailed account of all that had occurred since my last letter per Steamer of $14^{\text {th }}$ May. This day the Chamber of Deputies approved by a majority of 56 to 33 the project of the Executive to raise the export duty on Nitrate of Soda to S/1.25 at $40 \mathrm{~d}$ say $5^{\circ}$ pence per quintal. In the discussion the opposition had in my opinion the better of the argument; particularly Luciano Benjamin Cisneros distinguished himself by an excellent speech, whilst on the Government's side Emilio Solar was the only real orator. Bao, sometime ago agent for the Pasco Railway Company, during the period when I was one of the Directors, and at present Deputy for the Cerro, made his maiden speech defending the project, but accordingly to the Nacional it turned out a miserable failure.

Friday, $7^{\text {th }}$ of July 1876 . Enriqueta had invited to dinner Teodoro Harmsen, who had come from Arequipa on business; he was the eldest son of the late Wm. Harmsen and Dolores Averasturi, a particular friend of my two daughters. We expected him at 5.30, but he came exactly one hour later, and consequently I could not be with Bryson the usual hour from 7 to 8. Dr. Middendorf, Guillermo and Eliza sat down with us, Doña Angela not. I was extremely quiet. After dinner we withdrew to Enriqueta's salita, and I was in bed by nine, whither Enriqueta was good enough to take me my two cups of tea. Ricardo read to me an extremely interesting article on the inauguration of the monument erected on the spot where, nine years after Christ, a German, called Arminius by Tacitus of the nation of the Cherusci, defeated and completely annihilated the Roman Legions, led by their General Varus. This monument owes its existence to a certain Von Balwen who from his early youth had formed the resolve to have a lasting structure erected to perpetuate the memory of the German hero whose victory preserved his nation from the Roman [...] [132] [...] to be overcome, many obstacles to be removed, but he pursued his plan with unswerving constancy, and had at last the satisfaction to see his exertions crowned with success. On the $9^{\text {th }}$ July 1838 the first stone was laid, and on the $18^{\text {th }}$ August 1875 the monument was inaugurated by the Emperor of Germany. 
Mr. Von Balwen was also present. It stands on a hill called Grotenburg, near Detmold, Westphalia.

Saturday, $8^{\text {th }}$ of July. I awoke in the middle of the night and hardly had I been awake one or two minutes when it struck four - exactly seven weeks had elapsed.

At 1 p.m., after a long interval, I went again to the meeting of the Directory of the Insurance Company Lima. They had removed from the dark rooms occupied by them in the house of Varela, Calle de Valladolid to light and nice apartments in Gil's house, Calle de Judios. We were: Carlos Elizalde, Gerente; Moscoso Melgar President; Michael Carrol, Vice; Robertson of the firm of Sawers Woodgate \& Co.; Valentin Gil; and I. We remained together till three, and though we treated on many subjects nothing of importance was done.

Sunday, $9^{\text {th }}$ of July. Bryson read to me a very pretty article in the Eclectic which treats on La Scala, the well known opera-house in Milan, or more properly speaking on the various composers who have written for this house: Mozart, when a boy of fourteen, Rossini, a youth full of fire and fun, and Bellini a native of Catania, the very reverse of Rossini, mild and bashful. Bellini died a young man on the $23^{\text {rd }}$ Septr. 1835 , and exactly a year later died in Manchester, the famous singer Signora Malibran.

Ricardo finished reading the Kaisersaal, and commenced a little novel in German which I had read many years ago, called the Bernstein-hexe (Amber witch) which gives a, I believe, true account of a suit carried on about 1630 , against a poor girl accused of witchcraft. We left off at about 4 when I walked out to the pantheon, and was back in time for dinner at six. After dinner we were by ourselves; Garland, who hardly ever opens his mouth, Enriqueta, Doña Angela and I. The little girls had [133] gone to Eliza, Guillermo's wife. It was, as the evenings [...] were at this time, very sad and quiet. Shortly after ten I went to my bedroom when Ricardo read to me for about half an hour an article in one of his German Magazines, "The Constitutional Denmark".

Pardo gave this day a dinner party in the port of Santa Catalina, to more than 300 persons, viz.: the officers of the army and National Guard, down to sergeants, and even one soldier of each battalion, the head officers of the fleet, some of the officers of the police, the present ministers and Pardo's ex-Ministers, the post-master general, and chiefs of many other ministerial departments and offices.

Monday, $10^{\text {th }}$ of July 1876 . We saw by the papers that to yesterday's banquet in Santa Catalina, Pardo had invited 675 persons. At 3 O'clock sat down about half the number, the soldiers, and sailors, at 5.30 the other half, consisting of the higher classes. At 8.30 these latter broke up, and accompanied Pardo on foot to his own house. Pardo delivered two speeches, first to the one, then to 
the other half, very adequate discourses no doubt his own composition. They were received with enthusiastic applause.

Enriqueta did not sit down to dinner, for dreadful toothache had driven her to bed. Some days ago a dentist, considered extremely clever in his profession, had examined and plumbed many of her teeth. Today an inflammation came on which caused her excruciating pains. In the evening I did not go to her bedroom, for she was unable to speak a word, but tea was brought to my office where Ricardo read to me till 9.30. We put aside the "amber witch" for he could not understand the Old German in which it is written and began reading Rahncke's History of the Popes, a very erudite work. When in bed he again read to me, now on the subject of railroads. The tunnel through Mont Cenis has cost forty million francs; the cost of that through the St. Gothard was estimated in 185,000,000. The Pacific Railway from New York to Sacramento is nearly 3300 English miles [_] [134] [...] 48 degress longitude; the fare is no more than 140 American, I suppose paper Dollars; the convenience of a bed at night, of comfortable chairs in the day time etc., cost $\$ 26$ in gold extra. The time which the train takes is 6 days 17 hours, and the line was concluded on the $10^{\text {th }}$ May 1869, when a golden nail was driven into a sleeper of cedar wood.

Tuesday, $17^{\text {th }}$ of July 1876. Enriqueta continued in bed with her toothache, and I spent the day in a manner similar to the previous one.

Wednesday, $12^{\text {th }}$ of July. Enriqueta was very poorly, suffering not only from toothache but also from her usual migraine and from fever and ague. In the evening she wept bitterly; she sorely missed her mother, who, if well enough, had always come to her and nursed her when she was indisposed. As regards myself, it is true that I had shed less tears than I had done three or four weeks back, but I thought of my dear Mariquita quite as much as ever. I saw her moving about in her bedroom dressed in her woollen gown of a whitish color, with dark blue, or black stripes, her head a little bent, the keys in her hands, and going from one of the presses to the other, and then I again saw her stretched out in the room, where we used to wash, with her beautiful white forehead. I recollected her in a thousand other ways, but there was no use in putting it to paper.

Thursday, $13^{\text {th }}$ of July. To my great surprise I received a circular from the Callao agency of the Pacific Steam Navigation Company, informing me that a dividend of $4 \%$ would be paid. I I saw by the statement a copy of which they sent me that this dividend arose from the gain made on underwriting account. The company had at present a fleet consisting of 29 vessels for the West Coast service, valued in $£_{799,901}$ and 19 for Liverpool and Callao service, valued in $£ 1,748,656$. To collect the dividend on my eleven shares, I went to Callao at 1 O'clock availing myself of the new Oroya line. I took my ticket in the house 
which was formerly Sancho-Davila's. I entered the train below on the platform in the bed of the river. The train steamed on, under one of the arches of the old stone bridge; then it stopped at another station still in the bed of the river, that of La Palma, so-called from a street [...] the same name, where not very long ago a wooden [135] bridge had been constructed across the river to the [...]. The line gradually leaves the bed of the river, and passes through the extensive Monserrate establishment which stands outside the town at the extremity of that street which passes the Church of Santo Domingo, and is now called Calle de Lima. Henceforward the line leaves the river's side, not that it runs more to the left than hitherto, but that the river flows more to the right. On both sides of the line extend for the greater part tracts of barren land, sometimes pasture ground, occasionally, but seldom cultivated fields. Exactly ten minutes after starting we met the train coming from Callao.

When I arrived in Callao I did not know where I was, so much had everything changed; the station is a fine wooden building, opposite an open place with trees and bushes, La Matriz, for the principal Church of Callao stands there. In the office of the Steam Company I was quickly dispatched, got my money exchange was calculated at $28 \mathrm{~d}$ - and was back in my office at 2.30 .

The opening of this new line caused, as might have been expected, a considerable falling off in the traffic on the old English line. Not only were the means of conveyance doubled between the capital and the port, but to a great part of the population of Lima the new stations in the bed of the river were more conveniently situated than the old station in San Juan de Dios, so that of passengers certainly more than one half availed themselves of the new line, whilst the conveyance of merchandize still continued for the greater part in the old Channel. About this time President Pardo, always anxious to further education, placed the extensive premises belonging to the Church of San Pedro, at the disposal of some nuns of the order of the Holy Heart of Jesus, whom he had called hither for the education of young girls. This order, spread all over the West of Europe, had a well known establishment in Paris. These nuns, called by Pardo were however of the English branch, and it was said that the teaching of the English language would be [_] [136] [...]. Many years back this locality had been ceded by the then Government to the members of the Congregation of San Felipe de Neri. Their number, small from the beginning, had gradually died out, and thus the Government had now a perfect right to dispose of the building as they thought proper.

Friday, $14^{\text {th }}$ of July 1876. Before breakfast Dr. Fernando Palacios was with me to treat on a business which some time previously he had proposed to me through Garland, which at first I was inclined to enter into, in the belief that it might facilitate my remitting funds to Europe at a favourable exchange, but 
which I was now determined to have nothing to do with. Palacios had pawned with Antonio Bazo seven Cape diamonds, the biggest of which weighed 22 1/2 carats, the smallest $55 / 8^{\text {ths }}$ all of a yellowish tinge, not of the fine white water of the Brazilian and East Indian diamonds. Bazo had lent him upon them, if I mistook not, $\mathrm{S} / 30,000$. Palacios said that they were valued some time back in S/65,00o silver. Alejandro took them to Rönacher, the Danish watchmaker, who valued them at 48 odd thousand Soles as will be seen by the valuation in appendix $\mathrm{N}^{\circ} 6$. But since then Alejandro had found out that these Cape diamonds are not valued like the Brazilian, or East Indian, instead of squaring the weight, and multiplying this square with the value of the carat. The true weight in carats is taken which is multiplied by the price. Thus for instance, a Cape diamond weighing 30 Carats at $S / 60$ the Carat, is worth $S / 1800$ and not as was done hitherto, $30 \times 30=900$ at the price of $S / 30$ or $S / 40$ which of course gives quite a different result. Now Palacios wanted me to give him 6o Cedulas of $\mathrm{S} / 1000$ each, to send the diamonds, and two more belonging to his mother, which he valued at $S / 20,000$ to a house in Europe there to have them sold; then calculating the netproceeds at the exchange of the day I should have to pay over to Palacios the amount of the surplus if there were any; in the same manner as he would have to make good to me any deficit there might be, he in the meanwhile securing me for this deficit by a mortgage upon his house Calle de Gallinacitos which was at present mortgaged [_] [137] the Banco Hipotecario, but which mortgage he intended [...] by the very Cedulas which I should deliver to him. I did not like the affair, but was sorry to have to refuse this favor to Palacios, he being my lawyer. In the course of the forenoon I paid a long visit to Juan Gallagher, who having hurt his foot when playing at cricket was lying on the sofa unable to move.

The "Nacional" of this evening contained a decree which raised the prices to be paid by Government to some of the Salitreras, the owners of which had hitherto not offered them to Government for sale, also limited the production of nitrate on account of the Government for one year, from $14^{\text {th }}$ July, to two million quintals, of which 1,150,00o were contracted for with Gibbs and Gildemeister. The last quotations for nitrate from England were 10/6 to 11/6 the cwt, very low figures.

Saturday, $15^{\text {th }}$ of July. As usual I awoke last night, and lay awake for many hours; it could not be otherwise, for today eight weeks had elapsed. Dr. Palacios was again with me at an early hour, and we had the same talk as yesterday but I remained inflexible.

In all probability my suit with Leyva would come on today, in the Supreme Court, and Dr. Palacios prepared himself for his pleading. This day there would be meetings in three banks viz.: At 12 p.m. an ordinary one in La Providencia, 
for which I had given my power to Alejandro; at 2 p.m. one in the Banco Hipotecario when the numbers would be drawn of the Cedulas to be redeemed at par on the $2^{\text {nd }}$ January next year; and the third at 8 in the evening in the Banco de Lima where six new Directors would be chosen in lieu of Oyague, myself, Bernales, Cisneros, Mariategui and Cardenas. I thought of giving my power to Gallagher, but as he was prevented from going by his lame foot, Mariategui and Barrios had asked me for the same, and probably I would give it to one of them. These two, and Cucalon, I was told, kept closely together on all questions and of late on more than one occasion Cucalon [_] [138] [...] many unpleasant truths. From 2 till just [_] I strolled about in the garden of the Exposition, and was extremely well pleased with every part of it. The walks and paths were well kept and clean, the trees particulary the cypresses, carefully trimmed and though as it was said, many animals had either died or been sold yet there were still a good many well worth attention. The lions were of an extraordinary size; I believe bigger than I had seen in any other menagerie; there were also tigers, a hyena, leopards, bears, savage mountain cats from the interior of Perú, two very tall camels, an elephant, rather small, a particulary beautiful bull, and many cows of all descriptions, a strong buffalo, and another animal of the same bovine species, which I was told was a bison, and very savage. There were various classes of sheep, a vicuña which spat at me, a very fine collection of eagles, condors, and other birds of prey, a great many pigeons, a garsa, a kind of stork from the interior and several other birds, more or less of the same genus, a few monkeys, very few parrots, a great many rabbits, geese, and ducks and many more which I either did not see or did not recollect. There were several artificial ponds, and besides the principal exhibition building one house in the Swiss style, another pavilion, a house for the restaurant, two or three hot houses etc. For a long time I walked about and actually lost myself, when I fortunately meet a young man whom I asked for the way out; he was very agreeable and showed me all around. We returned to town, and when on separating he told me that his name was Enrique Taboada, and that he was well acquainted with Guillermo Garland, it was clear to me that I was not a stranger to him.

Sunday, $16^{\text {th }}$ of July. This morning Dr. Middendorf again bandaged my arm; I had but little pain but no strength whatever in it, and I much feared that it would never be cured. There were advices from England that silver was down to $47 \mathrm{~d}$ per ounce troy. I learned from Garland that in the Banco de Lima of the six Directors who had gone out by lot, all had been re-elected except Oyague and myself, who had been replaced by [_] Cantuarias and Hy. Higginson.

Bryson remained till two, and the very moment I was leaving [139] my office, Dr. Manuel Antonio Puente Arnao, the [...] sentenced in my suit against Leyva, ascended the stairs, and thus I had necessarily to receive him, which I did in 
Enriqueta's salita. He expressed himself in very grateful terms towards Rafael Velarde, who had contributed a great deal by his influence with La Puerta, with Fuentes (El Murcielago) and Teodoro de la Rosa of the Superior Court, to

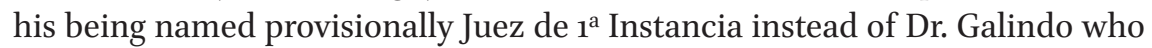
in the Superior Court supplied the place of Teodoro La Rosa, Deputy to the Congress. It was nearly 2.30 when I started for my ascent of San Cristoval. I went to its furthest point, where I climbed up and descended near the Alameda de los Descalzos. This day I met not less than fourteen or sixteen persons on the mountain, some ascending, some descending, some resting, whilst generally the mountain was quite solitary. I prolonged my walk to the Ancon station where I crossed the river over the wooden bridge, which is the furthest down; the old stone bridge is in the middle, higher up the iron one of Balta. It was a quarter past five when I got home. In the evening as Dolores Puente was with us for about an hour, the time did not hang so heavily as it generally did on other evenings. Ricardo accompanied her home.

Monday, $17^{\text {th }}$ of July 1876 . Here follow some particulars regarding the Suez Canal taken from a German work "The Supplementary Volume of 1875 to the Book of Inventions". In 1855 a railway was finished from Alexandria to Cairo and thence to Suez on the Red Sea. When the canal was concluded, to this railway a different direction was given; it runs since 1869 from Alexandria, without touching Cairo to a place called Benha, thence to Ismalia, and finally to Suez. Pasha Said of Egypt conceded $5{ }^{\text {th }}$ January 1856 to Ferdinand de Lesseps, formerly French Vice Consul in Alexandria, permission to form a Company founded on shares for cutting a canal from the Mediterranean through the Isthmus to Suez. The inauguration took place on the $22^{\text {nd }}$ April 1859 [140] [...] of time the Pasha forced 20,000 Fellahs, or Egyptian peasants to begin the work under the direction of for the greater part French engineers. The expense was immense, for everything required, except the provisions which came from the Interior of Egypt, was brought from Europe; sixteen hundred camels were employed daily to bring fresh water from the Nile, which was a daily expense of 8000 francs. To obviate this difficulty a canal was cut to bring fresh water from the Nile to the town Ismalia, built on the border of the lake Timsa. In the cutting of this canal, which were finished 1863, 15,00o labourers were at work for two years. In 1864 the Fellahs were dismissed and machinery moved by steam was made use of, and henceforward the work proceeded much more rapidly than hitherto. On the $16^{\text {th }}$ Novr. 1869 the Canal was opened with extraordinary festivities, the Pasha of Egypt acting as profuse host to all corners. Present were about 30,000 persons of all nations, amongst whom the Emperor of Austria, the Empress of the French, the Crown Prince of Prussia, Prince Amadeo of Italy, and a great many other high personages. A fleet of 42 vessels, merchant 
vessels, and men-of-war then passed through, and since that time the canal serves as a thoroughfare between the West and the East. As regards the profits to be made by the shareholders, they up to this day had by no means answered the expectations of Lesseps; its cost had been, according to the Gotha Court Almanac of $1875,471,769,980$ francs, whilst the above mentioned book gave following details of the cost.

200,000,000 francs

$100,000,000$ francs

$37,500,000$ francs

$100,000,000$ francs $437,500,000$ francs

\section{Original Shares}

paid by the Pasha of Egypt, who waived all interest, until the shareholders obtained a dividend of $10 \%$ annually (Of late he had sold his shares to the English Government.)

Debentures, to rank after the fcs 200,000,000 but before the 100,000,000. And lastly

What privileges this loan had was not stated

Lesseps had calculated that the gross [141] income would be sixty million francs; he then reduced [_] calculation to twenty five million, and the result was that that the net revenue was

$\begin{array}{ll}\text { in 1872 } & 2,071,000 \text { francs } \\ \text { in 1873 } & 7,400,000 \text { francs } \\ \text { in 1874 } & 8,590,000 \text { francs }\end{array}$

In 1870, 486 vessels measuring 453,911 tons passed through: in 1871765 vessels, 761,467 tons; in 1872, 1082 vessels, 1,439,169 tons; in 18731173 vessels, 2,085,073 and in 1874,1264 vessels of $2,423,672$ tons. On an average $3 / 4^{\text {th }}$ were English. The toll charged for passing the canal is ten francs each ton, and ten francs each passenger. At the nothern end of the Canal, in the Mediterranean, lies the place called Port Said a, in every respect, new town. The port itself is formed by two Moles, which like two arms stretch far into the sea; they measure in length each 2500 metres. On shore the distance from each other is 1400 metres; at their extremities it is reduced to 500. In their construction, 25,000 blocks of artificial stone, each weighing four hundred hundred weight were used. From this port the canal begins, which, cut through solid ground, passes through the Lakes Momsale and Bullah, at no great distance from each other, until it reaches the Crocodile Lake, also called that of Timsah, on the Western shore of which the new handsome, and flourishing town of Ismalia had sprung up. On the sourthern side of this lake the engineers met with greater difficulty than 
hitherto, because as far as the Small and Large Bitter Lakes - the latter of which so extensive that its flat shores cannot be distinguished from on board - the ground is calcareous rock. The Canal, which hitherto has run due South, now takes a turn to the South East, and being once more cut through firm ground of a similar nature to that on the other side of the crocodile lake, it terminates at the Port of Suez, the number of whose inhabitants had increased from 3000 to 13,000 . The length of the canal is 162 kilometres, depth on an average $71 / 2$ to 8 metres; width upon the surface varies from 58 to 100 metres, at bottom 22 .

Tuesday, $18^{\text {th }}$ of July 1876 . At this time it was my habit to walk alone in the town for an hour and a half or $[\ldots]$ in the [142] [...] Bryson time to copy the remodelled diaries, with which he made very good progress. Formely when I was Director of several companies, the meetings of these Directories called me frecuently away, and thus there was no necessity for my absenting myself purposely. Hardly was Bryson gone when at about 4.30 Alejandro came in with a great friend of his, one of the sons of the Vocal and present President of the Supreme Court, Dr. Antonio Arenas, Antonio Jr., who had taken a great interest in my suit against Leyva, and Alejandro having introduced him to me I begged him to request his father to let my suit come on as soon as possible with the only condition that the Vocal Oviedo, whom I knew to be in favor of Leyva, were not among the Judges.

In the evening after 8 I went first to Dr. Muñoz, who contrary to his custom, hardly allowed me to sit down, and dispatched me in about two minutes. It is true I interrupted him in an earnest conversation with another gentleman whom I did not distinguish, and who for aught I knew might have been Leyva himself. From his house I went to Rafael Velarde who was in bed with a severe pain in the waist, Sciatica - and lastly, to Dr. Alvarez, where he, his wife Doña Mariquita, and his daughter Doña Asuncion received me in their usual friendly manner. It was as late as half past nine when I came home. Dr. Middendorf was with Enriqueta, for little Corina was once more unwell, and when he was gone she read to me Juan's long letter from Paris, dated $14 / 16^{\text {th }}$ June. He spoke of Prado's contract with Raphael, Candamo and Heeren, with which he was by no means pleased for the Interest of the Bond holders had been entirely neglected. Not only had six cupons been capitalized, or in other words the stipulated interest for 3 years at 5 and $6 \%$ respectively was not paid, but even the promise now made to pay $3 \%$ interest on the $1^{\text {st }}$ January 1879 was very vague, for its fulfillment or non-fulfillment depended upon the amount of guano sold; in case it exceeded the $£ 700,000$ which the new Company had bound itself to hold at the disposal of the Peruvian Government, then this interest would be paid, otherwise not. No Surplus, no interest. All expenses, commission, freight, insurance, $[. .$.$] included, except 10/ the ton for loading to be debited with £ 4.15$ 
[143] but should the freight surpass $£_{3} .10 /$ per ton, then the ex [...] charged the Government. Interest $5 \%$ as long as the rate of discount of the Bank of England were below or equal to this figure; of above the Interest to be charged in proportion. Juan wrote that the Société Générale had offered the very same conditions besides $£ 450,000$ annually to the Bondholders, and as the English Committee of bondholders had approved Prado's contract, it was rumoured in Paris that the new Contractors at the bottom of whom was the notorious Lazky, had bribed both Prado, and the President of the Committee. This day Prado arrived in Callao at about 1 in the afternoon, and was received with a, in my opinion, ridiculous, nay stupid enthusiasm. He came up to Lima in an open coach by the high road, in order not to offend either of the two Railway Companies, both of which had placed their trains at his disposal gratis. In Lima his reception was as enthusiastic as in Callao. In his speech from the balcony of Pablo Vivero's house, where he had alighted as it was his habit, he said that by his contract he had saved to the nation seventy or eighty millions of Soles. In the evening fire-works were let off in the Plaza.

Wednesday, $19^{\text {th }}$ of July 1876 . This morning at 9, Dr. Palacios was again with me; he would not take my refusal, and begged and prayed that I should render him the service which to him was of vital importance, but I did not see how it was possible for me to comply with his wishes. We went together to Garland in the Banco Hipotecario, who said neither the one thing nor the other. By myself I went to Dr. Ribeyro's house, who was not in; I spoke with his wife Doña Eulalia who was wonderfully kind - for she owed me money - but whether she would really interest herself for me with her husband was another question. Within these last few days the Peruvian Man of War, the Chanchamayo, commanded by a certain Aguirre, had been lost in the neighbourhood of Sechura. The crew was saved.

Thursday, $20^{\text {th }}$ ofJuly. Again Dr. Palacios was with me at about 9 a.m. To get rid of him I said at last that Garland, to whom I would lend the Cedulas required, might perhaps render him the service; immediately he caught at this idea [144] [...] apartments, spoke to him, and to my utter surprise Garland acceded to his proposal. In the course of the forenoon I had a visit from Vicente Gonzales, my fellow passenger in the Vicar of Bray in 1843. In the Senate the session was of great interest, particularly to the Callao people, as it was to be decided whether Francisco de Paula Muñoz, lately made Post Master-General, a great friend of Manuel Pardo, and much liked by the Chalacos, or Dionisio Derteano of Dreyfus house, supported by Lizardo Montero's party, would be qualified as Senator for the Port. Muñoz carried the day by a majority of 23 against 11. All the daily papers contained the text of the contract for the consignment of $1,900,000$ tons of guano to a company to be formed in London under the name 
of the Peruvian Guano Coy. Limited, whose capital was to be at least £8oo,ooo. Those who signed the contract were: for the Peruvian Government, Mariano Ignacio Prado; for the future company, Raphael Raphael \& Sons, Carlos Gonzales Candamo, and Arthur Heeren; witnesses: Charles Eggert who, it was said, would be manager of the company, and a certain Felipe Santiago Franco. Charles Russell, President of one of the Committees of the English-Peruvian Bondholders, had given his consent to an additional agreement made by Prado with the bondholders, and in proof of this his consent had affixed his signature to the document. One of its articles said that the $6 \%$ Peruvian Bonds were to be converted into $5 \%$, and that even then the interest to be paid on them was to be no more than $3 \%$. See what I said on the subject on the $18^{\text {th }}$ of this month. Another article introduced a vital alteration in the manner how the bonds were to be redeemed; hitherto it had been done by lot, and at par, henceforth they were to he bought up at the current market rate by commissioners named for the purpose.

Friday, $27^{\text {st }}$ of July 1876 . In the morning we had a visit from Doña Juana Rosa, the wife of José Basagoytia, who also came at a later hour, it was near 11 O'clock when they left.

Saturday, $22^{\text {nd }}$. During the night I awoke, lit the candle, looked at my watch, it was five minutes to four - nine weeks had [_]. In the course of the forenoon I went to see Rafael [145] Velarde who still kept his bed with pains in the waist $[\ldots]$, his present indisposition came to him at a very inconvenient moment. He had been chosen Deputy to the Congress for the Province of Castilla in the Departament of Arequipa, his qualification would be discussed within these days, and as he himself could not be on the move to stir up his friends, he much feared that his dual would carry the day. Together with me, Jose Maria Peña went into his bedroom, and they had to say so much on this topic that I was nothing but a silent listener.

Sunday, $23^{\text {rd }}$ of July 1876 . Little Corina's birthday, who completed her sixth year; she was as happy and merry as she well could be; the first thing she did in the morning was to go to mass with the servant girl Virginia. The round table in Enriqueta's bedroom was covered with presents, mostly dolls none of great value. My present consisted of twenty silver Soles for her "Alcanzia".

I on the other hand was very low spirited, and dictated my letter to Juan. From 2 till 5.30 Bryson and I took a long walk; up San Cristoval from the Lurigancho side where it is steepest, and down on the other side as far as the Chacarilla. The weather was very unfavourable, extremely foggy. Within these last days, a fraud, committed by the Colonel of one of the battalions stationed in Lima, was discovered. On the $15^{\text {th }}$ of each month the soldiers used to pass revista, which means that they were counted, and for each man the Colonel or treasurer in 
his stead received the pay due to him. Since the declaration of Independence, perhaps even under the Spanish rule, it had been the custom for the Colonels of the various battalions to receive the pay for a greater number of men than his battalion really consisted of, either the same man passed twice, or a number of men were engaged for the Revista only, and then again discharged. Thus the fraudulent proceedings now discovered were not of a particularly heinous nature, but on this occasion the Inspector General, General Silva, whose duty it was to keep an eye upon the chiefs of the battalions, and upon their doings, had not only [_] at the Colonel's mis[_]ed, but even tak [...] [146] [...] The moment this came to the knowledge of [_] President Pardo, he turned him off, and named General Rivarola in his stead.

Monday, $24^{\text {th }}$ of July 1876. Last night I was awake since half past two, and for the first time since the $20^{\text {th }}$ May, succeeded in multiplying in my head seven numbers by seven numbers; during the last nine weeks I had frequently attempted such a multiplication, but had never succeeded in bringing it to a conclusion. The greater part of the forenoon was taken up with Consular occupations, a very rare occurrence. By last steamer I received a letter from a certain Jürgen Nielsen of Bogense in the Island of Funen, who made me a small remittance on London, and requested me to send home his brother-inlaw Andreas Holck, in the employ of the South American Steam Navigation Company, whom he supposed to be sick. Yesterday a certain Hans Peter Jürgensen, a Dane, Captain of the hulk belonging to the said company was with me on the same subject; this morning he came again, we walked together to the Hospital 2 de Mayo, and entered the ward where, the sick man lay; it was clean, airy and without the slightest disagreeable smell. Holck suffered from tremendous tumour in his right side, which he would not allow to be operated upon by the surgeons of the hospital. His thinness was extreme, and his only desire was to be sent home. Jürgensen and I walked thence the the house of Dr. Cervera, one of the medical men who had attended Holck; he was not in. We returned at eleven, and obtained from him a certificate to the effect that in his opinion Holck was strong enough to bear the passage home; now Jürgensen returned to the hospital, took Holck to the train, and thence to Callao. Bryson and I followed at 1. In the office of H. Moss \& Co. who acted as agents for the Hamburg Steam Navigation Coy., I paid Holck's passage, second class, with $\mathrm{S} / 250$. Whitout the medical certificate they would not have received him on board. About S/10o I paid for clothes and other things which Holck required, and for the balance having credited him the remittance at $30 \mathrm{~d}$ per Sol. I gave him an order upon Sieveking \& Co. of Altona, in Reichsmark, at $21 / 2$ Reichsmark per Sol. Bryson and I were back in my office at 3.30. Without 
Jürgensen's [147] assistance it would have been impossible for me to [...] affair in so short a time.

Lembcke came in, and read to me his written report on a proposal made by Manuel Pardo, to the four associated banks which opinion of Lembcke's differed completely from that given by the three other members of the committee named for the purpose by the Directory of the Banco de Lima. Heudebert, Pratolongo, and Pedro Bernales accepted the proposal with modifications. Lembcke rejected it in all its parts. Some time ago Lembcke had come to me by order of the Directory to request me to be one of this committee, which I had then declined. Pardo's project was vast and was founded in a great measure upon the result of the nitrate consignments, which he believed would leave enormous profits, and of which I had but a poor idea. For this reason I believed that the project could not be carried out. Part of the proposal which he made to the banks was the following: of the $£ 700,000$ which Raphael and others were ready to advance annually, he placed $£ 600,000$ into the hands of the four banks; that is to say, he authorized them to draw every month $£_{50}$,ooo which they were expected to sell for coined silver or gold at 4od. Accordingly the $£_{50,000}$ would yield 300,000 Soles. Of these 300,000 Soles, $S / 150,000$ in Silver or Gold were to be applied to the redemption and interest of the Internal Debt; $S / 100,000$ to be paid to the Banco Central, and S/50,00o to be handed to the Government. By means of these $\mathrm{S} / 50,000$ the revenue from the Custom Houses, and the surplus on the Nitrate Consignments, Pardo calculated that the Government could meet all other necessary expenses; to me this was quiet illusory, and Pardo himself was by far too clever not to know this as well as, if not better than I, consequently there must be other clauses in this project with which I was not conversant which were favourable to the Government, and probably prejudicial to the banks. I went to bed as soon as Bryson had left. I was angry myself that I had allowed the whole day to elapse without having given even a thought [148] [...] wife. Enriqueta brought me the tea at nine; she and [_] spoke whom we had lost, and fortunately I not having slept the previous night soon fell asleep, and slept soundly till 6.30 on

Tuesday, $25^{\text {th }}$. Middendorf prescribed for my arm baths of tepid water in which bran was boiled, and into which arnica and other ingredients were thrown. This morning I bathed it in this manner, but I did not promise myself any benefit from it. At noon I went to see General Prado, who called me as usually Amigo Witt, but was not so cordial as before his voyage to Europe. He did not embrace me, only shook hands. Manuel Francisco Benavides, who it was said, would be his Minister of the Interior was with him, and I therefore remained but a few minutes. In the office of the Banco de Lima Lembcke told 
me that in last night's meeting of the Directory, it had been decided not to give any definite answer to Pardo's project of which I have spoken above, and thus to put it off until the $2^{\text {nd }}$ of August when Prado would take the reins of Government. I also learned that the Banco del Perú was authorized to draw on account of the Government upon Raphael of London $£ 150,000$ of which amount the proportion corresponding to each of the four banks was placed at their disposal. Lembcke added that last night he had proposed to the Directory to remit these $£_{30,000}$ to the Bank's creditors in London but as this idea of his had been rejected by the majority, the bank had no need of the $£_{30,000}$ which it would have to pay for at $30 \mathrm{~d}$, and it was therefore decided not to receive them from the Banco del Perú. Exchange was 3od, and there was some appearance of its going down, that is to say that next steamer it might perhaps be at $3^{2}$ pence. At later hour the Delegates of the Banks had a meeting; they could not come to terms. What they resolved upon I did not learn, but the upshot was that the Banco del Perú did not draw the $£ 150,000$ on account of the Government and that Pardo had authorized Manuel Candamo to draw this sum. This day Ignasio Tavara, chosen Senator Suplente for Piura, was not qualified. He was no friend of Manuel Pardo which accounted for his want of success. Within these few days [149] died here in Lima Santa Maria, Minister [...], he had made an enormous fortune in an ilicit manner. Immediately after Pardo's accession he went to Chile where he made such extensive purchases of Cedulas del Banco Hipotecario that an immediate rise in their price was the consequence. Now at his death it was said that his family was left in actual poverty in such a manner had he squandered his money in Chile.

Wednesday, $26^{\text {th }}$ of July 1876. At about 9 in the evening Mariano Bustamante, son of the late Don Pedro José of Arequipa, came and sent word that he particularly wished to see me, and I could therefore not refuse to receive him; he was with me nearly an hour. He told me amongst other things that the deficit in the cash of W. Gibbs \& Co. of Arequipa, of which I have already spoken, amounted to 95,000 Soles, and that moreover some jewels worth from fifteen to 20,000 Soles which they had had in deposit for many years had also disappeared.

Bustamante was further of opinion that as soon as Prado were elected, a revolution would break out in Arequipa, and that if the Arequipeños were to be believed he would be upset in less than two months. Either Nicolas Pierola or Lizardo Montero was he whom the Arequipeños wanted to take Prado's place. Here in Lima Pardo was omnipotent in the Congress, whilst Prado had hardly any influence, and many were of opinion that neither La Puerta nor Helguera, but that Riva Agüero would be chosen Vice President of the Republic. 
Thursday, $27^{\text {th }}$ ofJuly. Since Monday last I had been shamefully oblivious of my dear wife, but this morning when I awoke, as to make up for this forgetfulness, my thoughts immediately reverted to her, and I may say whitout exaggeration that excepting the hours that I dictated to Bryson or listened to his reading I thought of her the whole day long. This day the business between Dr. Palacios and Garland, initiated a few days previously, was brought to a conclusion. I lent Garland sixty Cedulas of the Banco Hipotecario of one thousand Soles each, for which he signed me an obligatory note to return them to me within six months. [_] [150] [...] handed over to Dr. Palacios, who cancelled with them [_] various mortgages upon houses of his in favor of the Banco Hipotecario. As a security for this loan which Garland made him, he delivered to him the diamonds of which I have already spoken, and which Garland consigned to A. Gibbs \& Sons of London, in the firm expectation that their proceeds, would surpass the cost of the Cedulas, but as a further security in case the proceeds should fall short, Palacios gave him a mortgage - a second not the first - upon his house occupied by him in the street de los Gallinazitos. In taking these precautions Garland thought that he ran not the slightest risk in making the loan of the Cedulas. The Insurance upon the diamonds shipped per steamer via Panamá, I had also to advance, and the amount was included in the above pagaré.

In the Senate José Antonio Garcia y Garcia, a man well known for his infamous conduct at the time he was sent to the Unites States to contract for the monitores, over head and ears in debt to the South American Coy. of London, and in every respect without an idea of honesty, was chosen President. Pardo's ex-Minister Dr. Rosas, Vice-President in the Chamber of Deputies, Ignacio Osma, President, Chinarro, Vice.

Friday, $28^{\text {th }}$ of July 1876 . The fifty-fifth anniversary of the Independence of Perú. I awoke this morning extremely sad, and rose late. The despondency from which I suffered was owing mainly to my irrecoverable loss, but other causes also contributed. The conviction which I had that my sight was gradually deteriorating, and might, who knew, end some day in total blindness; the slight injury which I did the other day to my arm had taken away all its strength, which I much feared I should never recover; then again my indecision as to my further proceedings, the apprehension I entertained that some disputes might arise when the partition of the inheritance were made between my three stepchildren; there were also other minor causes, but all taken together kept me very low spirited, as may easily be conceived. The cheerfulness of my former years, I was certain, I should never regain. When Bryson was gone Ricardo read to me a few [151] pages in German, of Rahncke's History of the Popes, [...] I had 
a long call from Alejandro, who also was with me in the evening. Garland had been invited to rocambor by Carrol, of the firm of Bates Stokes \& Co.

At about 2 p.m. the Congress had been opened. Manuel Pardo read his message, a long document, and at 4 O'clock returned to the Palace, accompanied by many corporations.

Saturday, $29^{\text {th }}$ of July. Ten weeks. I awoke in the middle of last night, heard the clock strike the half hour, but immediately again fell asleep.

Last night a ball was given in the Club de la Union, which lasted till this morning, and which, according to the Nacional, had been splendid in the extreme. This day horse races were held, but were not particularly well attended owing in a great measure to the distribution of prizes which took place in the Exhibition Palace, and where the first gold medal was handed by the President Manuel Pardo to General Manuel Mendiburu, for having written two volumes of a work called Biografia Americana; it was however not the President of the Republic who had assigned the prizes, but for this purpose a special commission had been named of which Granda was the chairman, who delivered a speech, to which Pardo replied, before the distribution of prizes began. I was, as usual, quietly at home, occupied with Bryson and with Ricardo. At 4 I went out to the pantheon, but unable to read the number of the niche, could not find it out; I had forgotten the number of niches which I had to count from each end, in order to find the right one. In the evening Diego Masias called. Enriqueta did not receive him; Garland and I did, and he made me pass a pleasant hour giving me a very interesting, perhaps a little exaggerated account of the many things he had seen in the United States, especially in the Exhibition of Philadelphia. He and his wife Doña Jesus had returned about a fortnight ago from their visit to two of their sons who were at a college in New York. [152]

[...] was given this day in the palace, to the Diplomatic and Consular Corps. I was invited, but sent my excuse on the plea of indisposition. Finally this day the first stone of a monument to be erected at the expense of the Students of San Carlos to the memory of Dr. Unanue, was laid in the Plaza de Santa Ana; this Dr. Unanue, was a man who at the time of the War of the Independence distinguished himself by his patriotism, and his great knowledge; he was a medical man by profession, and for some time minister of San Martin. His children have not followed in the wake of their father; on the contrary, they were known to be rather of limited intellectual capacity. They are: José, a bachelor, very rich, owner of a valuable sugar estate in Cañete, and three daughters married respectively to Pedro Paz-Soldan, to Matalinares, once interpreter in the Ministry fo Foreign Affairs, and to a Frenchman Laraburre, one of whose sons married nearly two years back, Rosa, daughter of Cipriano Correa. 
Of late the census had been taken all over the Republic; the population of Lima turned out to be 100,081; that of Chorrillos 7000, Callao 35,000 Souls. In my opinion the last may be correct, whilst the first is, I should say, below, the second above the mark. The President's message, delivered in the Congress on the $28^{\text {th }}$, was printed in the Nacional $N^{o} 3410$ of $28^{\text {th }}$ July. It said amongst other things that the regular army of Peru numbered less than 3000 men, and that the soldiers were voluntarily recruited for three years, which term having expired if they liked they might return to their homes. This was a great improvement on former times, when men of the lower classes, wheresoever they were found, were forcibly taken up and carried off to the barracks. I myself had seen them in the Interior tied together, and in this manner marched off to their respective depots. Pardo further said in his message that for the annual expenses of the Government there would be henceforth an income of 18,500,00o Soles, annually, viz.

over: [153]

$\begin{array}{ll}4,000,000 & \text { from Guano } \\ 6,000,000 & \text { from Nitrate, and } \\ 8,500,000 & \text { from Custom Houses and other branches } \\ 18,500,000 & \end{array}$

This statement I believe to be incorrect in every point. Firstly, as nothing could be paid on the external debt till the first January 1879, the $£_{700,000}$ which Raphael advanced annually at $30 d$ amounted to $S / 5,600,000$, not to $S / 4,000,000$. Secondly, the Nitrate would never give a surplus of six million Soles. Thirdly, the income of Custom Houses \& Co. was overrated; and fourthly, as the service of the external debt was not included, $181 / 2$ millions per annum were more than the Government ought to spend.

Sunday, $30^{\text {th }}$ of July 1876. A very quiet day. When Bryson was gone I ascended San Cristoval; after dinner Ricardo read to me, and at a later hour Doña Pancha Cárdenas, wife of Gregorio Benavides, and her niece Rosaura were with us.

Monday, $37^{\text {st }}$ of July. In the forenoon I once more busied myself with arranging a few small drawers which my wife had left filled with many trifles. I called on Raphael Velarde who was getting better, and who expressed the hope that he would be qualified as Deputy for the Province of Castilla; he was positive that General La Puerta would be named first Vice President by the Congress. Afterwards, Bryson finished reading to me in the Eclectic an extremely interesting article on Michael Angelo Buonarotti, born in 1474, and began reading another, very amusing on the spelling of the English language. In the evening he finished Joinville's history of, in reality his panegyric, on Alexander I of Russia. This work, in three volumes, contained a great many 
important facts, but was written in the most slovenly manner, and is full of the most palpable mistakes, errors, and inaccuracies. The author is in my opinion a Russian, perhaps also Dr. Wylie, a Scotchman, who as is seen by the book, was always in attendance [154] [...]

This day the Congress chose the two fiscales of the Supreme Court, who were to replace the late Drs. Ureta, and José Gregorio Paz Soldan. The Government proposed for each two lists of three persons; at the head of the list, to replace Ureta, stood Eusebio Sanchez, ex Minister, and Teodoro de la Rosa, both Vocales of the Superior Court; at the head of the two lists for Paz-Soldan were placed the names of Anibal de la Torre, Minister for Foreign Affairs, and José Aranivar, lawyer, at present President of the Senate. The choice fell upon Dr. Teodoro de la Rosa who had 69 votes against 50 for Sanchez, and upon José Aranivar, with 86, against 33 for La Torre.

Tuesday, $7^{\text {st }}$ of August. By the steamer from Panamá, arrived amongst other personages, Frederic Elmore, secretary of Aurelio Garcia y Garcia on his embassy to Japan and China, and left by Garcia in his place when he returned to Perú; also Jose F. Canevaro who would probably be named second Vice President of the Republic; a great many people went down to receive him and to accompany him to Lima. In the evening fireworks were let off opposite his house.

In the Congress the commission named to examine the actas with regard to the election of General Mariano Ignacio Prado for President of the Rebpublic, gave following account of its labours. The 95 Provinces of which the Republic consists have 5276 Electors; of these 95 Provinces the commission considered that the actas of 1879 with 3606 electors were properly qualified, and of the 3606, 3418 had given their votes for Prado, and 136 for Lizardo Montero and consequently Prado was declared to have been duly elected. In the evening we had a visit from José Pablo Escobar, and his wife Emilia Lopez; she remained with Enriqueta in her bedroom whilst Garland and I received the husband, who told me amongst other things that the three banks Nacional, Lima and Providencia had directed a letter to the Minister of Finances protesting against the legality of Manuel Candamo's drafts by last steamer on Government's account on Raphael \& Sons of [155] London, because in conformity with the co $[\ldots]$ the four associated banks and the Government dated September last, of the first funds which the Government might have disposable, $\mathrm{S} / 3,500$, ooo were to be handed to the banks in drafts on England, and this had not been done. Escobar further told me that the $£ 150,000$ drawn by Candamo, was the balance of what the Government had to dispose of in the hands of Raphael, down to the $31^{\text {st }}$ August of the present year, because, as it will be remembered, the first money to be received from Raphael was to be made use of in paying the 
Government's debts to the Banco Anglo-Peruano, and the Societé Générale, and these two debts, together with the $£_{150,000}$ drawn, absorbed the first eight monthly instalments of the present year; consequently to Prado there remained only one third of $£_{700,000}$ of which he could dispose in Europe to the $31^{\text {st }}$ December.

When our visitors were gone Enriqueta read to me the letters received by steamer, of which I had an unusual number, from Juan, Rosa, Corina and Amalia, from Frances Cresswell of Winchmore Hill, and from my niece Elizabeth Bobertag, dated Drossen $25^{\text {th }}$ June, in which she merely dilated on the death of her son Paul. Juan wrote that Raphael had been notified by a public notary not to deliver any funds to the Peruvian Government. Rosa advised the death of the wife of Juan José Araoz, Carolina Sotomayor, who, after a violent attack of mental derangement had fallen into idiotcy and then expired. From a German paper which Ricardo read to me I learned the death of the Baroness Du Devant, born 1804, authoress of many French novels written by her under the pseudoname of George Sands. Also that of Josephine, mother of the present king of Sweden, Oscar II and his late brother John Charles XIV; she was the daughter of Eugene Beauharnais, Duke of Leuchtenberg, and widow of Oscar I of Sweden.

The papers also spoke of preparatory steps wh[_] [156] [...] Sangatte on the French side of the Channel in order to ascertain whether there was a possibility of cutting a tunnel below its waters from the French to the English Coast. The result of their labours was favourable to this project; nowhere on the line of the intended tunnel was the depth of the sea more than 54 metres, and to where the depth was greatest, in the middle of the channel the bottom of the sea gradually shelved downwards. Juan said in his letter that if the state of his health permitted, he would leave Europe for Lima by the steamer of the $2^{\text {nd }}$ November.

Wednesday, $2^{\text {nd }}$ of August 1876. This was the last day of Manuel Pardo's and the first of Mariano Ignacio Prado's Presidency. On the $2^{\text {nd }}$ August 1872 the balconies of my house were crowded with lookers on; my dear wife had prepared a good lunch for our guests, and everything in our house was cheerful; this day it was the very reverse. Enriqueta did not leave her bedroom; Eliza, Guillermo's wife was, I believe, in the balcony which looks towards the Calle de Aldavas, and in one of the balconies towards Zarate there were but a few gentlemen whom I did not even know, I believe they were: Minor Meiggs, and a North American for some time Minister in Bolivia, now in transit in Lima. I saw and conversed with Melchor, and Umlauf, a German, book-keeper of the Compañia de Obras Publicas y Fomento. The Government coaches with the members of the commissions named in the Congress to make known to Pardo and Prado that they were expected, passed our house several times; soldiers 
lined the streets. I think it was about 2.30 when Prado passed by on foot, dressed in black and accompanied by a considerable number of his friends and the members of his clubs, several of them carrying arms. At the corner of our street flowers were thrown to him by Rafael Velarde's wife from the balcony of Goyeneche's house; shortly after came Manuel Pardo, still President, accompanied by the Judges de $1^{\mathrm{a}}$ Instancia, the Vocales of the Superior and Supreme Courts by the members of el Tribunal [157] de Cuentas, and by some private gentlemen [...] upon him, flowers and garlands were showered from the balconies of Ayulo's house close by and from that of Manuel Espiritu La Torre at the corner of the Plaza de Bolivar. The following I took from the "Nacional". Prado took his seat amongst the Senators. When Pardo came he made a short speech, which contained nothing particular, and handed the scarf, the symbol of the Presidency to J. A. Garcia y Garcia, President of the Congress. Prado knelt down, and took his oath as President of the Republic, whereupon Garcia delivered to him the said scarf, and Prado read a short, but very sensible discourse. He said amongst other things that in the beginning of 1868 the debt of the Republic of Perú, external and internal, amounted to forty million Soles, and that if the system upon which the Government then acted, had been strictly adhered to, at the end of 1871 Peru would not have owed a cent. Now Perú owed two hundred million Soles, and the proceeds of guano merely sufficed to hacer el servicio of the external debt. Never, added he, can we cease to lament such a state of things, never can we cease to blame those who have caused it. He recommended to the members of the Congress two cardinal points to which they ought to direct their exclusive attention; firstly, the reconstruction of an equilibrium between the revenue and the expenses of the country (which I believed to be an impossibility) and secondly, the revision of the laws of elections. The President and the ex-President left the Congress jointly and on foot. Pardo giving the right to Prado; they were accompanied by a vast number of people, and followed by several battalions of soldiers. I did not see them, for just at the moment Eduard Knauer came and delivered to me a very kind letter from his mother, which he read to me; he remained with me a considerable while and told me amongst other things that Gänslie had entirely abandoned his wife Emily, Knauer's sister, who for a long time had sustained herself and her daughter Elena with giving lessons in [158] [...] ied some time back, when studying painting in Munich, a painter whose name I did not know, and now the whole party were going to take shelter under the maternal roof of the excellent Mrs. Knauer in Altona. Arthur Donner, the husband of Edward Knauer's eldest sister Maria, was also badly off as to his finances; for some time he had been the Director of a glass manufactory established in Ottensen by some of his friends solely for the purpose of securing him a livelihood; but he 
had been obliged to liquidate, and all interested had suffered a considerable loss. Kochen, the husband of the third sister, Julia, after having failed twice as merchant was now doing well as bill-broker. When Knauer was gone, nothing more was to be seen in our street and I quickly walked our corredor till it was dinner-time. In the palace Pardo bade farewell to Prado, whose intention it was to remain at once in his new abode. Pardo, when returning to his house was accompanied by an enormous multitude of people who so closely pressed upon him that he could hardly move. At the corner of Bodegones, some of his intimate friends had been desirous that he should go with them upstairs to the Club de la Union but such was the throng that he could not get through it; in this manner he was carried along through Bodegones, Coca, Nuñez to his house, which was completely invaded, and filled in a trice. The Diplomatic Body were waiting for him together with the students of San Carlos, and San Fernando, and many other persons; he had merely time to salute them, and to run up stairs, where from a window he addressed the multitude assembled below. Several of the lower classes embraced him, began to speechify, someone even cried out in a loud voice: "Viva Don Manuel Pardo, nuestro Presidente en el año 1880." I believe the enthusiasm shown this day was not less than that with which he was received four years back.

In the evening only Eliza and Guillermo were with us; they, Doña Angela, Enriqueta, Enrique - who had just returned from his mine - and the little girls played the insipid game [_] lottery. I went to my bedroom as early as ten. [159]

Thursday, $3^{\text {rd }}$ of August. In the forenoon [...] time to copy the remodelled diaries. I took a walk to Santa Sofia, thence to the Hospital del 2 de Mayo; afterwards I began dictating an answer to three letters received at different times from my niece Elizabeth Bobertag. The papers said that yesterday a deputation of Chinese likewise waited upon Manuel Pardo, who, when all were gone received a visit from the President Prado. Lizardo Montero published a kind of protest against the election of Prado; concluded however with saying that if the present Government conducted itself properly, he would favour it with his support; otherwise he would raise his voice against it in the Congress. Luciano Benjamin Cisneros was elected Deputy for Huanuco by an overwhelming majority.

Pardo's Minister: La Torre, for Foreign Affairs; J. Elguera finances; Aurelio Garcia y Garcia, Interior; Odriosola, Justice; and Nicolas Freyre, War, gave in their resignations, which were accepted, and the new Ministers were sworn in, viz.: Dr. Antonio Arenas for Justice and President of the Cabinet; M. F. Benavides, Interior; Dr. Jose Aranivar, Finances; J. A. Garcia y Garcia, Foreign Affairs; and General Pedro Bustamante, War. Of these I considered Antonio Arenas undoubtedly the most respectable. For a long series of years he had been 
one of the most eminent lawyers of Lima, and under Balta's administration had been made Vocal of the Corte Suprema. He had frequently sat in the Congress; I recollect him as Minister for Foreign Affairs; and he even came forth as candidate for the Presidency of the Republic towards the end of Balta's term. Dr. M. F. Benavides, a native of Arequipa, used to come regulary to Enriqueta's Thursday tertulia. I did not like him much, nor did I believe him to be a man of great capacity; nevertheless, of late he had always figured in the Senate and in his political opinions had [_] [16o] [...] as great [_] Pradista as Pardista. Dr. José Aranivar was undoubtedly an extremely clever lawyer, though he lost his suit defending the Sotomayor's agst. Dr. Palacios who defended me; but whether I owed my victory to the lawyer, or to my wife's and my influence I will not decide. Aranivar had hitherto been lawyer for the Banco de Lima; within the last few months he was Fiscal de la Corte Suprema; after all he was no honest man. In Balta's times he was minister for a few months, and he himself had boasted that the few months had sufficed for him to make a considerable fortune. Of J. A. Garcia y Garcia I have given my opinion. John Gallagher, who was with me this day, called him the greatest scoundrel. General Bustamante was an insignificant man; he was Prado's last Minister of War in 1867, and fell with him in January 1868.

Friday, $4^{\text {th }}$ of August 1876. I finished dictating the letter to my niece. In the Senate, Dr. Rosas, hitherto Vice-President, was elected President in lieu of J. A. Garcia y Garcia; in the Chamber of Deputies the commitee named to examine the different actas of the Colegios Electorales as to the election of first Vice-President stated that the following had been the result of their labours. La Puerta had had 1432; Elguera 1042 and Riva Agüero 939 votes. None having obtained the absolute majority required, the Senate had now to choose between la Puerta and Buenaventura Elguera. The audience, or barra, consisting mostly of Elgueristas raised their voices, complaining of partiality.

In the evening we had a visit from the Canon Mora, an insignificant and even vulgar man.

Saturday, $5^{\text {th }}$ of August. Eleven weeks. I awoke in the middle of last night, but could not say at what time, for I was again asleep before the clock struck the full hour. From various books I took the following particulars. In 1870, eight hundred and sixty two million letters passed through the post offices of Great Britain and Ireland; in 1873 the number increased to nine hundred and seven millions, in 1874 to $965,000,000$. In 1870 the gross revenue of the Post-Office came to $£ 4,900,000$, and in the same year nearly twenty million pound sterling were remitted through the [161] Post-Offices. In the German Empire, inclu [...] and Hungary for the year 1874 - Bavaria for 1873 - the letters forwarded by the Public came to 521,900,000, official letters 37,000,000, newspapers 47,700,000. 
The gross revenue ninety seven million Imperial marks. The Imperial German Post Office had one branch establishment, which as far as I knew, did not exist in any other country, it was the so called Field-post; the object of which was to keep up in war time a constant and postage free communication between the hundreds of thousands of whom the armies in the field consists, and their friends at home. In the war of $1870 / 71$ from July to the $31^{\text {st }}$ March $89,000,000$ letters were forwarded one way and another. This proves one fact to which the book from which I have taken these particulars, does not refer, viz.: that in Germany the knowledge of writing is universally diffused amongst the lower classes, whilst the same book affirms that according to a census lately taken in Great Britain and Ireland of the male population 1/3, of the female $1 / 2$ cannot write. The same book goes on saying that extensive as the Imperial Post Office in Berlin is, it is thrown into the shade by the London post Office in St. Martins le Grand, or, as I thought, in Aldgate Street. A graphic description is given of the turmoil which prevails in the vast halls of the office every Friday evening, mostly from 5.45 to 6 O'clock; when the clock in the neighbouring church strikes the last stroke of six, no more letters are received unless paying an extra postage. On every Friday night the correspondence for the East Indies is fowarded, and this accounts for the extraordinary bustle of that day; upon an average 76,000 letters are dispatched every week to the East Indies. The mail leaves the Post Office on Fridays at 8 p.m. and reaches Brindisi on Tuesdays at 4 a.m. The steamer is ready to receive it, and from twenty to twenty-four days after leaving London, the mail arrives at Bombay. The British Government pays to the P. \& O. Company an annual subvention of $£ 450,000$.

In the forenoon I extended my walk to the Carretera [162] [...] from the monument del 2 de Mayo where formerly the ga[_] stood, to Callao. The road is well kept, whilst the same cannot be said of the wide footpaths on both sides. They are confined partly by mud walls which enclose orchards, partly by pieces of pasture land, also here and there patches of barren uncultivated ground. Instead of the willows of former times, four rows of a tree called Astrapea are planted. These trees were introduced into Perú perhaps fifteen or twenty years ago, from Central America, and thrive well. They have a straight trunk, do not grow to a great height, and distinguish themselves by a dense, beautifully rounded cupola of very large leaves. This day Gibbs' house received a telegraphic dispatch announcing the death of Edward Stubbs, active partner of the London firm. He was the son of a merchant-tailor of Manchester, brought a letter of introduction to the Lima firm about the year 1838 or 1840 when John Hayne engaged him and sent him as clerk to Arequipa. After some years he quarelled with Went, left the house, for short time did business on his own account, was clerk of C. W. Schutte, made his peace with Went, re-entered Gibbs' house, and 
when Went took charge of the Lima establishment, was placed at the head of the Arequipa branch. When Went went home Stubbs was called to Lima, and during his administration Gibbs lost the guano consigment, I will not say through his fault. At a later period he removed to London where I believe he had of late been the principal manager. His wife was Manuela, daughter of José Rey de Castro, at present one of the Fiscal commissioners to examine the affairs and accounts of the English Guano Consignment Company, and of Thomson Bonar \& Co. In the Senate Dr. Forero was named Vice-President in lieu of Dr. Rosas, at present President.

Sunday, $6^{\text {th }}$ of August 1876. Little Corina was very unwell and had been so for two or three days; she threw up everything she took. At 2 O'clock Bryson and I started for a walk; we first went to the pantheon where I ascertained the exact position of the niche; we strolled about, looked at the various monuments, and continued our excursion. The powder magazine adjoins the pantheon; it is flanked at each end by a big round tower. [163] Where its enclosure ceases, a narrow lane leads do[_] river; a little further on a well filled acequia runs under-ground which I believe is one of the principal affluents which supply Lima with potable water. This we crossed, and began ascending a ridge of hills which runs far inland; to the left, or in the direction of the Sierra extends a large plain of well cultivated land; we continued upon the ridge, descending and ascending many a time. Sometimes we had to clamber over large blocks of rock lying in the way. Further on the ground was covered with a green carpet of small plants, and thus we proceeded till we reached the summit where a cross stands, at twenty minutes past four. The ridge, gradually lowering stretches still further, but for us it was high time to return lest darkness might overtake us. The descent took forty minutes. When below we found ourselves in a sandy cart road; this we followed for a short distance, then took a short cut over a large piece of barren ground, and reached the spot where formerly the Barbones gate stood at 5.30 ; thence twenty minutes walk brought me to my house. I was in time for dinner, but, notwithstanding the great exercise I had taken, I had no appetite, and ate as little as usual. I was very sad, formerly when I came home from such a walk I had to give an account where I had been to my wife, and had the pleasure of being scolded by her; now of course there was nothing of the sort. "Where have you been, why do you come so late, why do you expose yourself to the danger of being robbed, of being killed, or at the very least of having a bad fall?" Quietly and even gladly did I use to listen to such and similar expostulations, for I knew but too well that they emanated from my dear Mariquita's solicitude and affection for me.

Doña Juana Carbajal, who had been such a good friend of hers, came to see Enriqueta. I went to bed before nine. Ricardo read to me till ten; he still slept on the sofa in my bedroom. 
Monday, $7^{\text {th }}$ of August 1876 . I saw by the papers that Sagastabeytia had on account of ill-health received permission to withdraw temporarily from the Gerencia of the Banco de Lima, and that Manuel Cucalon had for this time taken his place. Ricardo [...] [164] [...] newsmonger, told me that Dr. Luis Benjamin Cisneros had thrown up his post as Delegate of the Banco de Lima, and that Focion Mariategui had been chosen in his stead. Finally, I learned from Valentin Gil, whom I met at the meeting of the Directory of the insurance Company Lima, where nothing of importance was transacted, that John Gallagher had been named instead of Manuel Cucalon, chairman of the Directory of the Banco de Lima. A better election could not have been made. Henry Higginson had been chosen Vice-President. In the Congress the first Vice-President of the Republic was chosen; there were 133 voters. General La Puerta obtained 72 votes; Buenaventura Elguera 55; four votes were in blank; two were faulty, "viciados", and consequently General La Puerta was proclaimed.

Tuesday, $8^{\text {th }}$ of August. In the Congress a Vocal Interino for the Supreme Court, in lieu of Antonio Arenas, as well as a Fiscal Interino to take the place of José Aranivar, both Arenas and Aranivar being at present members of the cabinet, were chosen; and the choice fell upon Dr. J. Eusebio Sanchez, Vocal of the Superior Court, and upon Dr. Chacaltana, member of the same Tribunal, the former for Vocal, the second for Fiscal. Anibal V. de la Torre, Minister for Foreign Affairs during Pardo's administration, was named by the Executive Vocal of the Superior Court "en propiedad".

Wednesday, $9^{\text {th }}$ of August. The friends of the late President Don Manuel Pardo gave him a lunch in the Exhibition Palace and according to all accounts it came off in a most satisfactory manner. Alejandro who had also subscribed his S/4o told his mother that more than five hundred gentlemen had sat down to four or five large tables. Of foreigners, Henry, Ruden, Böhl, Mac Andrew, Swayne, and Dr. Maclean were mentioned; of members of the Congress there had been about ninety, according to Nicolas Hurtado. Further, Manuel Costas, the late Vice-President, the ex-Ministers, some of the ministers of the present administration, Directors and gerentes of Banks, etc. Of course several toasts were given in honor of Pardo, and were received with great applause. Whilst this occurred in the Exhibition, my lawyer Fernando [165] Palacios commenced his pleading in the Supreme [...], the Vocales were: Dr. Vidaurre, who presided; Drs. Cossio, Oviedo, Cisneros, Ribeyro, Alvarez, and Muñoz. On the preceding day the interest due to me by the United States Guano Company on my loan, had been paid, and this day I went to the office to speak with Vicente Hurtado, the Gerente, about the repayment of the capital, amounting to $S / 41,000$. To my great surprise I learned from John Bryce, one of the Directors, that Hurtado had left the employ of the Company, and that he was not quite sound in his mind. I told Mr. Bryce that as the company could not pay me what they owed, 
they ought to give me some security, which request of mine he said he would lay before the Directory at their first meeting. The papers said that last night thirty nine Deputies had met in the house of Emilio del Solar, and testified their dissatisfaction with the present cabinet, because it was presided by Dr. Arenas, a known reactionist. We further saw by the papers that in the war which had broken out in Europe between Turkey and Servia, the Turks had generally had the advantage in the various encounters which had taken place.

Thursday, $10^{\text {th }}$ of August 1876. At 1.30 p.m. Rafael Velarde, accompanied me to the palace, where I intended to pay my visit of congratulation to the President Prado, but he being occupied with his Ministers, I could not see him, and merely left my card. In the Congress General La Puerta took his oath as Vice President. In the Supreme Court of Justice, my lawyer, also the lawyer of Leyva, concluded their pleadings. Palacios told me that some of the pamphlets which were printed some time back on my account, and which contained his pleading, had been distributed amongst the Vocales of the Tribunal; also that Dr. Oviedo, who had been worked upon by Doña Francisca Canseco, the widow of General Castilla whose natural son people said Leyva was, had taken the Autos to his house.

Friday, $11^{\text {th }}$ of August. Before 10 O'clock I was with Dr. Melchor Vidaurre, who received me very politely; he took me [166] [...], where I stated to him what I thought necessary, and on my requesting him to give his particular attention to the Vista-Fical he replied that he was perfectly well acquainted with all the documents relative to the case, and finally observed in rather an apologetic tone that I could not but be aware that he was not allowed to give his opinion, to which I of course assented. When I left he asked: "Y como está la Señora?" He immediately however recollected himself, and said "quiero decir la niña". I, who had been very miserable the whole morning, could not refrain my tears, when he requested me to re-enter and sit down, which however I declined. In the street I met Henry Higginson, at present Vice-President of the Directory of the Banco de Lima. He told me that in the first meeting at which he had been present, very high words had passed between Cucalon and Lembcke, but that now as co-gerentes they got on pretty fairly. On another occasion Cárdenas had insulted Castillo, who had since then given in his resignation. He, Higginson, was commissioned to examine the accounts and statements drawn out by Focion Mariategui relative to his late trip to La Salitrera "Esperanza", in which labour he had taken Guillermo to assist him. At about 1 I went to see Doña Irene, the wife of Dr. Muñoz; she was in her parlour conversing with two gentlemen one of whom was Dr. Acuña, to whom she introduced me; she herself began to speak of my lawsuit with Leyva, and when after some unimportant chat I, on taking leave, once more recommended the case to her, she replied, "no tenga 
Ud. cuidado". At home I had nothing particular to do. Bryson being occupied copying the remodelled diary, and it being a fine clear day, I went over Balta's Bridge, and ascended San Cristoval from the Piedra-Liza. When climbing up, I took great care in noting the path, nevertheless, when I had reached the top and attempted to descend the same way I had come, I could not find the right way and the descend appeared to me so very steep that I had again to climb up part which I had come down, and descended in the opposite direction towards the new Alameda. I was absent [...] house two hours and ten minutes. Hardly had Bryson [167] began reading to me from the Eclectic Magazine when [...] interrupted by the porter of the Supreme Court, who advised me by order of Dr. Palacios that the Vocales of this Tribunal had not agreed in their sentence of my suit: "que habia discordia"; that is to say that of the seven, four had voted the one way, three the other, and that Dr. Loayza had been named to decide the question. I ran to the office of Dr. Palacios, who was of opinion that as Dr. Aramburú, Leyva's lawyer, worked with Loayza in the same office; Loayza could not be a judge in what might be called his own case, and therefore if he did not excuse himself, he would recuse him. This day Enriqueta's dinner table was crowded to excess; we sat down: she, Garland, and I, her nine children, except Alejandro, Eliza, Guillermo's wife, and her sister, Maria Luisa Higginson. The last named remained to tea.

Saturday, $12^{\text {th }}$ of August. Twelve weeks. I awoke in the night, at what hour I could not say, also rose early, for Antonio had invited me to take a walk with him to what was formerly La Chacra de Santa Beatriz, on the Chorrillos road, and which during Balta's administration, had been bought from its owner, Dr. M. O. de Zevallos by the Government, for the purpose of establishing there a model farm. Very fine wide walks, or rather roads, are cut through the grounds, new trees were planted, old plantain trees still existed. There were maize fields and pasture lands; the old house was repaired, a new one as a college for the pupils was built and one with another, though yet much remained to be done, what had been done was well done. We were home in time for breakfast.

In the course of the forenoon Doña Eulalia, wife of the Vocal Ribeyro, sent for me. I immediately went, but all the news she gave me I already knew, viz.: That the Vocales had not agreed, and that there had been four against, and three for me; she would not even give me the names of those who had voted the one way or the other. [168]

Sunday, $13^{\text {th }}$ of August 1876 . Bryson went up with an excursion train the Oroya line, and I spent a long, tedious, and sad day, for having little fixed occupation I thought a great deal of my dear Mariquita. I walked about in the environs of the town, but did not climb up any mountain. Ricardo read to me a little, and I paid one visit which I could not avoid doing, viz.: as Danish Consul to the New 
Minister for Foreign Affairs, J. A. Garcia y Garcia; he was in his Ministry; his wife Rosalia Delgado was dressing, and I was received by his second daughter, quite a young girl, but I wondered how rationally she talked, without any affectation. In the evening I went with Enriqueta to Rafael Velarde, and consulted with him to whom to apply, and what steps to take in order to secure to us a favourable sentence from Dr. José Eusebio Sanchez, who, as Vocal of the Supreme Court, in which capacity he had taken his oath on Saturday, would decide my cause against Leyva, and not Dr. Loayza who was only called in as an adjunct, in case there had been no Vocal. This day a concert was given in the Palace of the Exhibition for the benefit as the invitation said, of the Statues to be erected by the the Students of San Carlos and San Fernando in honor of General San Martin, and Dr. Unanue.

Monday, $14^{\text {th }}$ of August. At somewhat past twelve I was at a meeting of the Directors of the Insurance Company "Lima". Robertson and Peña were wanting. We ascertained that upon a loan of $\mathrm{S} / 20,000$ made several years back to José Larco, S/750o had actually been lost. Whilst he was absent in Europe, his brother had obtained a loan of S/20,00o upon S/50,00o Shares in the Banco de Lima, $50 \%$ paid up. When José Larco returned from Europe he was dissatisfied with what his brother had done, and proved to the company by the power given him that he had no right to hypothecate the shares. In order not to have any judicial question, with Don José, we had agreed with him to purchase the $\mathrm{S} / 25,000$ paid up for the $\mathrm{S} / 20,000$ lent him if within a certain period he did not decide otherwise. The term having now elapsed he had written a letter to the Company [...] right he might have to the shares; consequently the [169] $\mathrm{S} / 25,000$ paid up capital were now the Company prope[_] as their quotation in the market was $50 \%$ they was worth $S / 12,500$ and their cost being $S / 20,000$, there was a loss to the company of $\mathrm{S} / 7500$. Carrol was of opinion that we should immediately proceed to their sale if $50 \%$ could be obtained, but Moscoso Melgar, Gil, Chavez, and I opined that it would be better to keep them. Next it was discussed whether it would be advisable to lend money on the security of the Salitrera Certificates. Carrol and I were at first opposed to it. It was however finally decided that the Gerente might lend as much as S/50,00o to a respectable borrower on such certificates valuing them at $75 \%$, at the very utmost 80 , at $10 \%$ annual discount.

With Chavez I went to the meeting of the shareholders in the Banco del Perú. The usual six-monthly informe was read, which said amongst other things that the net gains for the first six months were two hundred and odd thousand Soles consequently $41 / 2 \%$ upon the paid up capital of four million Soles might be distributed, and the balance carried to reserve fund. Next, the informe was read, drawn out by a commission. Carlos Elizalde, Rufino Echenique, and Luis 
Benjamin Cisneros who had been named in the meeting of February last to examine and to report on the debts due to the bank. The principal point on which they treated was the debt of about six hundred thousand Soles owing by the Eten Railway Company to the Bank. The commission proposed to accept the offer, made by the said Railway Coy., viz.: to take the railway on the bank's account. About $\mathrm{S} / 500,000$ privileged obligations or debentures, paying $8 \%$ interest, had been emitted of the Company. Of the Net proceeds of the railway, amounting to about $S / 100,000$ annually, the $S / 40,000$ interest due on these debentures should first be paid, the holders of them waiving the right they had of a gradual redemption of their obligations and somewhat more than $S / 40,000$ would be applied to pay $4 \%$ annual interest upon the more than $\mathrm{S} / 1,000,000$ the railway owed, including the $\mathrm{S} / 600,000$ to the bank. I went away, and left my power with Felipe Varela having little doubt [170] [...] majority would approve the plan, though there were a few, Camogli, Villemars, and perhaps four of five more who would prefer that the bank should endeavour to make effective certain obligations or bonds, which many of the shareholders in the Eten Railway, I amongst the number for S/30,000, had been foolish enough to guarantee as per escritura publica in favor of the railway company and which were deposited with the Banco del Perú as collateral security, of which in proper time I gave a detailed account. If this proposal of the commission passed, then these bonds would be annulled.

Tuesday, $15^{\text {th }}$ of August 1876. It being a holiday, La Asuncion, Bryson was with me in the morning, till nearly 2.30 , also in the evening from 7 to 8 , and thus the day was much more supportable to me than otherwise it would have been.

At about 3 I went to the house of the Vocal Dr. Jervacio Alvarez, to congratulate one of his married daughters Asuncion to one of whose children, Maria, my wife had stood god mother at her confirmation, and with whom I myself was on very friendly terms. I had sent her as a present a very handsome French fan, cost $\mathrm{S} / 23$, and a large dish with manjar-blanco, cost $\mathrm{S} / 4$. She, and her mother Da. Mariquita, a little insignificant Cuzco lady of very good family, received the visitors, who were besides myself, Dr. Puente Arnao, a Deputy and a Senator.

From Alvarez' house I walked as far as the Convent of los Descalzos, and thence to the Maravillas gate.

Wednesday, $16^{\text {th }}$ of August. Before breakfast I went to see the Vocal, Dr. José Eusebio Sanchez, who was to give his vote in my suit against Leyva, decisive if he voted against me still subject to another discord if he voted in my favor, for I had had three, Leyva four votes; my three were those of Dr. Muñoz, Ribeyro and Alvarez, upon whom I had counted, and who had not deceived me. Polite he was of course, listened to what I had to say, and merely told me that he 
had received the pamphlet which I had sent him and also a letter written by Enriqueta on the subject. This letter Enriqueta had ventured [171] [_] address him, because when last in Paris, Doña Jesus [...] in whose house he had been very intimate when a child, had given her a letter of introduction to him. We took also other steps to influence him, and one from which we promised ourselves a good effect was the request made by Garland to Felipe Varela, one of the lawyers of the Banco Hipotecario, to speak in our favor with his motherin-law Doña Rosa Mercedes Riglos de Orbegoso, who was a great friend of Sanchez.

In the Chamber of Deputies Rafael Velarde lost his deputation for the Province of Castilla; 38 voted for him, 54 for his rival, a certain Febres. Prado did nothing whatever for his adherents, whilst Pardo's party in the Chamber of Deputies, the so called Argolla (the ring) became more powerful from day to day. Every new election increased its number, and consequently its strength. Some meetings had been held in Lima and Callao to counteract the influence which this party, the Civilians, possessed, but they had led to no particular result.

Thursday, $17^{\text {th }}$ of August 1876. This morning Juan Garland left us. He had been employed some time ago in the London Bank, was dismissed, and had now obtained a situation as cash-keeper in the Company established for loading guano. His residence would be for the present on the Lobos Islands, whether in the inner or the outer he did not know. The inner was thirty miles distant from shore, and situated a trifle to the North of the latitude of Lambayeque; these islands were completely deserted; there was nothing but rock and guano. The salary of course was good, though I did not learn the exact amount; he had everything free, even washing. In the course of the forenoon some of the shareholders in the Banco Hipotecario assembled, but there not being a sufficient number, we had no regular meeting. When I entered, not only Gallagher as Gerente but all the Directors rose to shake hands with me. The object of the meeting was to approve the new statutes. As a preliminary step we discussed some articles. The lawyer M. M. Galvez, Rodrigo's son-in-law, presided but José V. Oyague with hi[_] [172] [...] importance and self conceit took the lead, and spoke as if he [_] the only one who understood what we were treating about. His opinions however did not pass unquestioned and uncontradicted. Gallagher, Dionisio Villate, Henry Nöel, Melchor Velarde contributed their share. I also said a few words. Nothing however was decided because, as already said, there was no sufficient number of shareholders present. In the Congress José F. Canevaro was proclaimed second vice President. The letters which I received by the North Steamer were from C. W. Schutte, very polite, from Corina, Juan, and Johannes Limpricht. The family Schutte was on the 
point of leaving for Kissingen. Schutte walked with the greatest difficulty; Juan said his legs were as weak as those of a man ninety years of age. Juan was about starting for Hombourg, thence to Gastein. Limpricht was enjoying the tonic mountain air of Badersee in upper Bavaria. Rosa had not yet received my letter, in which I encouraged her and her family to remove hither, which accounted for my not hearing from her.

Friday, $18^{\text {th }}$ of August 1876 . The rainy season of this year was uncommonly warm and dry; rain we had hardly any, and many a day the sun was out. Thermometer in my office at $2.30 \mathrm{p} . \mathrm{m} .70^{\circ} \mathrm{F}$. In the Congress Ignacio Tavara was defeated and his rival chosen as Deputy for Ayabaca, which province he, Tavara, had represented for several years. In the Supreme Court before the deciding Vocal J. E. Sanchez, my suit agaist Leyva came on. "La Relacion", very long, was read, whereupon my lawyer Palacios began his pleading, which in fact was only the reading of the pamphlet more than once referred to.

This day the members of the club "La Union" gave a dinner party to Manuel Pardo. Alejandro was one of them, and contributed his ten Soles. The "Nacional" said that Carlos Elias, President of the Club, had taken his seat in the centre of the table, Manuel Pardo to his right, to his left Aurelio Garcia y Garcia, ex-minister for the Interior; opposite to him the lawyer Ricardo Zevallos. The remainder had taken their seats indiscriminately, without [_] rule or precedence. [173]

Saturday, $19^{\text {th }}$ of August. This morning at 1.30 a.m. [...] awakened by a severe shock of an earthquake. I did not rise, but purposely kept awake, and when I looked at my watch I had so well guessed the time that it was exactly fifteen minutes to four; thirteen weeks after I had heard the sound of the fatal fall. I know some gentlemen, well educated, and of fair intellectual capacity, who believe in supernatural apparitions and who affirm that they have actually seen them. Garland is one of them; others believe in supernatural sounds. My incredulity, or scepticism, does not allow me to share in their belief but at this time I wished it were possible that the fervent desire of the survivor could call back an image or apparition of the deceased, to this, from what is called the other world. I confess that I really when I went to our apartments to open the windows regularly stopped for a few minutes at the foot of my wife's bedstead, and called upon her with the most endearing names, but of course everything was quiet, there was no answer, and I withdrew, not disappointed but miserable. This was the birthday of Maria Garland who completed her tenth year; she received many presents, principally dolls, nothing of great value. I gave her my twenty silver Soles for her "alcanzia". The two little daughters of Isabel Aliaga, widow of La Croix, named Maria and Isabel, and Sofia Rafael Velarde's daughter, kept her company, and dined with us. The lawyers concluded their pleading in 
the suit against Leyva, and the Vocal Dr. Sanchez asked for all documents to examine them in his own house.

Sunday, $20^{\text {th }}$ of August. At 7 O'clock, I, accompanied by Holcombe, clerk in the house of Sawers Woodgate \& Co. started for an ascent of San Cristoval, which we easily accomplished taking the slanting path which leads to a point of the mountain whence we had to pick our way, over large blocks of stones till we came to that kind of resting-place where the very steep ascent, which the other day I climbed up with Bryson, emerges. We returned by the road which leads close to the Chacarilla and [174] [...] back before 10.15, I actually tired. When Bryson was gone I for the first time after a lapse of more than three months, went to see Doña Dólores Puente, who was particularly agreeable, and with whom I remained a long while. A niece of hers, daughter of her brother Lorenzo, is married to Dr. Francisco Rosas, one of Pardo's ex-Ministers, and who, with Emilio Althaus was of late in Europe to negotiate a loan. To him Doña Dolores had addressed herself to speak in behalf of my suit to Dr. Sanchez, who was Minister at the same time with Rosas. I next called upon Dr. Bernardo Muñoz, whose Saint's day it was; he, without his wife, received in the saloon. There were several gentlemen, of whom I only knew Dr. Vidaurre, who a few days back had sentenced against me. The two Vocales and I conversed together in a friendly manner but I remained only a short time. At home Ricardo read to me out of Rahncke's Lives of Popes, and I went to bed very early, not knowing what to do with myself. In the meanwhile there had been some riots in the streets of Lima, caused in some measure by certainly imprudent declaration which the most fervent partizans of Pardo had made the other day against the present Ministry. There must however have been some occult instigators, but who they were, I had not learned as yet. One or two hundred individuals, for the greater part of the lower classes, had come up from Callao, joined the Lima meeting and from the steps of the cathedral had been harangued by several persons, the most notable of whom was Mariano Osma, the brother-in-law of Manuel Pardo, who, I knew, had for many years back paid to Diego Masias the monthly rent which his sister Francisca, Mariano Osma's wife, owed for the apartments which she and her family occupied in his house. The mob, now excited, cried "Viva Prado, muera la argolla", and the first thing they did was to break the windows of the Club House "La Union", where on Friday last the dinner had been given to Pardo; thence they directed their steps to this gentleman's house, no doubt with sinister intentions. Fortunatly however [_] they could break through the iron railing which defends the patio [175] the authorities appeared, accompanied by soldiers, who were [_] to fire upon the rioters, four or five of whom were killed. All this occurred between two and six in the afternoon. 
Monday, 27 $7^{\text {st }}$ of August 1879. I went out this morning, and noted about twenty celadores, policemen, posted upon the elevated space in front of the Cathedral, also a strong cavelry piquet riding through the streets.

I received a letter from Sieveking dated $13^{\text {th }}$ July in which he informed me of the sudden death of Henry, the youngest son of my niece Elizabeth Borbertag, at the age of, I suppose, more or less eighteen years. He had been for two or three years youngster in the house of George Knauer Junior of Hamburg, who had been extremly well satisfied with him. From the beginning of next year he was to have received a small salary and from October 1877 to 1878 to have entered the German army as volunteer. Sieveking added that he had overheated himself when rowing, had caught cold, had fallen ill of what is called in German "the galloping consumption", and died in a few days. What a blow for his mother! who had now lost her two youngest sons in the course of six months.

The day passed over quietly, groups of people assembled here and there, but were easily dispersed; no harm was done to them; nor did they do any harm. The banks however were closed, also a great many shops and stores. Piquets of soldiers marched, and rode through the streets. Some were stationed at the entrance of the Congress Hall to protect the Deputies. The five Ministers who had been cited to appear in the Senate replied that they could not come till the following day. In the Chamber of Deputies, Moreno y Maiz, German Tejeda, and Constantino Duarte moved the censure of Ministry for not having taken the proper steps to prevent the disorders of the previous day. The next motion was whether this motion of the censure should be discussed or not; the votation by ballot gave 60 , for, and 25 against the discussion. Luciano Benjamin Cisneros demanded the nominal votation when the result was different 47 for $3[\ldots][176][\ldots]$ done, the motion for the censure was passed to a commiss[_] called that of "infracciones", where it would perhaps remain dormant for some time. Hereupon the Deputies also cited the Ministry to appear before them, and received the answer that they would come as soon as they could leave the Senate. The Nacional said that a few members of the Congress known as ardent Pardistas, had been ill treated after leaving the hall.

Friday, $22^{\text {nd }}$ of August. To the account given of the disturbances which took place on Sunday I have to add that the meeting first assembled in the Convent of San Francisco, that thence they proceeded to the Plaza de Bolivar, and finally to the elevated open place in front of the cathedral. General La Fuente presided, but made room for more violent and passionate orators; one of them was a Sambo, carpenter Aguilar, who preached a social revolution similar to that in France of 1789 and 93, said that in Lima there was a woman similar to Catherine of Medicis of France, and advised the fellow workmen to arm 
themselves with daggers, and beginning with the Congress make a clean sweep everywhere. This day the banks were open.

I went to the Banco del Perú where I received $41 / 2 \%$ divident upon Schutte's, Juan's and my shares, which amount I immediately deposited in the Banco La Providencia. At about two the banks closed. More or less at about the same time strong cavalry piquets were placed at the corners of the streets which lead to the Plaza de Bolivar. This was done to prevent the mob from entering the Senate were the Ministry appeared at three, and notwithstanding this precaution, a passionate audience or bar, was present, which interrupted the proceeding with cries of "abajo la argolla", "abajo el civilismo", "abajo los Chinos de Pardo" whereupon they were all turned out, and the sitting continued secret. The Ministers remained till 6.30. The papers said that the answers which they gave had not been satisfactory. The intention to attack Pardo's house had previously been known, and no sufficient steps taken to prevent it. It was believed that at all events the Minister of the interior M. F. Benavides would have to resign. Twice I myself was stopped [177] by the cavalry piquet, and had some trouble to get [...] my own house; nevertheless I went to see Dr. Palacios, who told me that the Vocal Dr. Sanchez had not yet returned the autos.

Wednesday, $23^{\text {rd }}$ of August. This day passed in a manner very similar to the previous one. The troops and police were again on the move, and piquets stationed at the corners of several streets. In the Senate the motion of a vote of censure on the Ministers, Antonio Arenas and M. F. Benavides was made by M. M. Zalazar, M. M. Rivas, San Roman, Javier Osma, Pablo Seminario y Echeandia, and passed by a majority of 25 to 11. Lizardo Montero voted in the minority; he founded his vote, saying that in his opinion the entire cabinet should have been included in the censure. In the chamber of Deputies the five Ministers appeared and were interrogated (interpelados) by various members amongst whom Ramon Ribeyro was the most prominent. The answers given by Arenas and Benavides were not considered satisfactory. It was 6.30 before the session closed.

Thursday, $24^{\text {th }}$ of August 1876. On Sunday last when the mob attacked Manuel Pardo's house, he himself and Dr. José Aranivar, who was with him, escaped over the roofs to the house of Godoy, the Chilian Chargé, which was in the same block of houses in the street known as that of Castilla. Pardo's mother Doña Petita, née Soyer, and his wife Mariana, the second daughter of Felipe Barreda, with children and servants did not move. Antonio Bazo was with them. It was generally believed that the intention of the rioters had beed to kill Pardo, perhaps his family also. On the same evening an armourer's shop in the street of Castilla was broken open and ransacked. The Legation of the United States was likely to make a claim on the Government for the loss 
sustained by the owners of the shop, North American subjects. In the Chamber of Deputies the comission to which the examination of the budget for the two years 1877 to 1878 had been referred, approved that part of it which treated on the revenue $[178][\ldots]$ summed up in a more succint form than the original stands as follows:

Import and Export Duties together with some minor branches for the two years

Contribution for the two years

$15,366,600$

630,400

Post Office and Telegraphs for the two years

574,502

Railways for the two years

600,000

Various for the two years

614,000

Guano: $£ 100,000$ annually which remained in Europe to pay the Legations and other expenses $=£ 200$, ooo at $\mathrm{S} / 5$

$1,000,000$

$£ 600,000$ annually at $S / 6$

$7,200,000$

Sold for Cuba, Porto Rico, and China

300,000

Sales for United States

$1,753,708$

Proceeds of Nitrate of Soda, calculated the annual sale in $5,500,000$ quintals less amount required for the service of the certificates

$12,000,000$

Unforeseen

818,000

$40,857,210$

It must not be forgotten that the surplus of the proceeds of guano over and above the £7oo,ooo annually had to be applied to the cancelment of the Government's debt to Dreyfus, say 350,000 Tons annually at $\mathrm{S} / 32$

$\mathrm{S} / 22,400,000$

and that the guano shipped for Mauritius and other Islands was hypothecated to the four associated banks, viz. 40,000 tons at $\mathrm{S} / 35 \mathrm{~S} / 1400$ p.a

$\mathrm{S} / 2,800,000$

$\mathrm{S} / 25,200,000$

See for these particular "El Nacional" of $24^{\text {th }}$ August.

Friday, $25^{\text {th }}$ of August. In the office of the Banco Hipotecario a meeting of the shareholders was held, for the purpose of revising the new Statues. Besides the Directory and the Gerentes there were present: J. V. Oyague, Dionisio Villate, James Henry, Bohorquez, Noel, a certain Rubio, and I, very few to be sure, but according to statues when a meeting was convoked for the second time, any number of shareholders sufficed. No great alterations were made in the new [_]tutes and everything went off pleasantly and quietly. [179] Gallagher, Oyague, and Villate took the lead in [...]. We broke up at 5.30, and when I 
reached my house I felt truly unhappy. On former similar occasions Mariquita used to receive me with: "Donde has estado? Que has hecho, como te ha ido?" Now of course no one received me in this manner. The President Prado had not accepted the resignation of the Ministers and all five were at work this day in their respective offices. In the Chamber of Deputies the members who on Monday last moved the censure of the five Ministers, withdrew this motion to-day. To me it appeared that the Government had gained a victory over the opposition.

Saturday, $26^{\text {th }}$ of August. Last night something happened to me, which I had not experienced in the course of my whole life. In the middle of the night I rose, whilst I was asleep, and did not awake until my foot touched the ground; I could not recollect whether I dreamt anything which made me rise. I lit the candle, looked at my watch, which pointed at a quarter to three, not to four as I expected it would. I remained awake for about an hour.

The President admitted the resignation of Benavides and Arenas, and instead of them named General La Cotera Minister of the Interior, and Dr. Teodoro de la Rosa Minister of Justice, and President of the Council. In the Senate Dr. Francisco Garcia Calderon and Corales Melgar were qualified as Senators for Arequipa; Evaristo Gomez Sanchez lost his election. Dreyfus drew by this steamer about $£_{35,000}$ at $30 d$, and la Caja Fiscal $£_{57,000}$ on account of the Govermment. I was told that the last named sum was quickly sold to few persons. An advertisement had been published to the effect that such companies, who had not signed an escritura when forming the partnership, and which escritura was not registered in the Consulado, would not receive any bills from the Caja Fiscal. I wondered whether I would get any were I to present myself. From Dreyfus I took $£_{340}$ to remit to Schutte, therewith to cancel the amount received from the Banco del Perú. [180]

Sunday, $27^{\text {th }}$ of August 1876 . This forenoon Bryson finished reading to me an article in the Eclectic Magazine of July, taken from Frazer's Magazine, which gave the biography of Francois Bonnivar[_] the prisioner of Chillon - see Vol. II pages 856/7 and Vol. VI 157/8. This biography, no doubt, a true account, corrects the ideas which I, and probably many thousands besides myself, led away by Lord Byron's poem, have formed of Bonnivard, and of his character. He, born about 1497 in Leyssel, a small place situated in the Genevese territory, was by no means a reformer, nor did he suffer, for religion's sake; on the contrary, though no ordained clergyman, he, whilst residing in Geneva, enjoyed one or two Catholic benefices, amongst which the Priory of St. Pierre. In the differences between the authorities of Geneva, who defended their liberty, and the despotic Duke of Savoy he sided with the former, and drew upon himself the hatred of the Duke, who, whilst one day he was returning from Leyssel to Geneva, 
had him seized and conveyed to the Castle of Chillon, where for the first two years he was treated with lenity; the four last years of his imprisonment he was actually chained to the pillar which I saw when visiting the castle. It is true that the castle was taken by the united Bernese and Genevese, when he recovered his liberty. The two brothers of whom Byron speaks and who, according to him, died in prison, are a mere myth. When Bonnivard returned to Geneva, the Reformation had triumphed, the strictest Calvinistic principles prevailed in the town, and an annual pension was allowed him by the authorities for his sustenance; his way of life was so irregular that he was condemned by the ecclesiastical court to a forced attendance at sermons on Wednesdays and Sundays. After having recovered his liberty, he married four times, the last with a woman formerly a nun. He died in 1570 .

After Bryson was gone, I climbed up San Cristoval, and did so without fatiguing myself in the least. I returned by the way near the lime Kiln, and was home in little less than two hours. Before and after dinner Ricardo [181] read to me Rahncke's Popes.

Monday, $28^{\text {th }}$ of August 1876. A meeting of the shareholders of the Banco del Perú was convened for one O'clock. I went at this hour, and found the room completely filled; never before had there been such a numerous attendance of shareholders. A party with José Maria Peña at the head had demanded this meeting for the purpose of reconsidering the resolution taken in the meeting of the $14^{\text {th }}$ relative to the Eten Railway; with him sided Manuel Costas, José Maria Costas, Moscoso Melgar, who held the power of the Goyeneches, a certain Cipriani, and a considerable number of the smaller fry. Their spokesmen were Peña and Cipriani, and what they wanted was that the Banco del Perú should force the railway company to declare itself bankrupt, and then proceed against those who had guaranteed the bonds in favor of the Railway Company, deposited by this company as prenda pretoria with the bank. The plan of the other party, at the head of which stood Ruden, who however did not appear at the meeting, and instead of whom Calderoni presided, was to take the administration of the railway on account of the bank, and not to proceed against those who had guaranteed. The meeting was very stormy. Cipriani spoke very well. Peña less so. On the other hand Forero made a very long, but confused speech in defence of the plan recommended by the comission of which I spoke on the $14^{\text {th }}$, which was then sanctioned by all present except Camogli, and which the opposition party now wanted to upset. Felipe Varela on the same side spoke a few words much to the purpose. Agusto Althaus, Escobar, Calderoni and César Canevaro, all were against the reconsideration. At last Carlos Paz-Soldan proposed an aplazamiento, or postponement for ten days, and when Calderoni began to take the votes nominally this was again opposed by Cipriani, who pretended 
that it was sufficient to give the vote by standing up, or sitting down. Now the uproar became general, many left the room, and the aplazamiento was I may say voted by acclamation. I begged Calderoni to note that I [_] [182] [...]. When leaving the bank, the Government's coach passed with José Canevaro who had just taken his oath as second Vice-President of the Republic, and on my reachig my house I found Enriqueta weeping, I did not know why, nor did I ask her; perhaps a quarter of an hour later Garland told me that I had lost the law-suit against Leyva, which news Alejandro had already communicated to Enriqueta. I hurried to Dr. Palacios, who knew nothing of it. However the daily paper published the following: "Se votó la causa seguida por Don Enrique Witt con Don Segundo Leyva sobre derecho a los Aires de una finca; se declaró no haber nulidad en la sentencia de vista, que revocando la de primera instancia declara infundada la demanda interpuesta por el primero, y absuelve definitivamente a la parte demandada, con costas. Habiendo sido el voto de los Señores Alvarez, Ribeyro, y Muñoz, porque hay nulidad." Thus the suit was decidedly lost, and now Leyva might, if he liked, inconvenience me with building upon the disputed roof of his house. I rejoiced indeed that this sentence had not been given during my wife's life-time; upon her it would have made a deeper impression than it did upon me. The very last day she was with us she sent the sweet-meats to the wife of Dr. Cosio who, as Dr. Alvarez had told my lawyer Palacios, had been wavering for some time whether to vote with Ribeyro, Muñoz and Alvarez, or with Oviedo, Vidaurre and Cisneros. Had he leaned towards the former I should have gained, because I had the Vistafiscal in my favor, which, counted for a vote, would have given me five votes; the number required. Alejandro had heard somewhere, and told his mother, but I did not believe it, that Leyva had paid Cosio S/100o for his vote, through the intervention of Carolina Manrique de Lara, a woman who lived in the street leading to the Maravillas Gate, and who, some weeks previously when I passed her house, sent her son after me, requesting me to come in, which I refused to do, fearful she would ask me for money. Had I acceded to her request, perhaps the lawsuit would not have been lost, for now it seemed to me very likely that her object in asking me in had been to insinuate or perhaps [183] to tell me in clear terms, that a small present to her, [...] more considerable one to the Vocal's wife would have secured his vote.

At about 9 p.m. Garland received an invitation from José Canevaro to take a cup of tea with him. He went, and told me on

Tuesday, $29^{\text {th }}$ of August 1876, at breakfast, that there had been a large and gay party, that there had been dancing and card playing, all present in high spirits. Last night Enriqueta and I conversed on many things till a late hour. In the course of this day I went to Dr. Palacios who of course had nothing to say 
on the subject of the lost law-suit. In the evening whilst Bryson was reading to me I was called, because General Prado, the President, had come and asked for me. I found him dressed as a civilian with his two aides-de-camp in Enriqueta's parlour. He was very polite, called me over and over again his "amigo Witt", I him, "Vuestra Excelencia", but keep up a conversation he could not, and if I had not endeavoured to say a few words on some subject or other we should all have been mute.

Somewhat later Macandrew and wife came. Neither Garland nor Enriqueta would go out, and I had to receive them. Macandrew gave me a short account of the rudeness with which the Minister of Finances, José Aranivar had received him as representative of Graham Rowe \& Co., Böhl for Gibbs, and Maître for Gauterau \& Co., when presenting to him a petition on the subject of the decree spoken of on the $26^{\text {th }}$; he would not read the petition, threw it on the table, and said contemptuously that he did not know any such firms as Gibbs, Graham Rowe, or Gauterau, by which, as far as I could judge, he gave to understand that he did not consider them to exist, because they had not signed here in Lima an escritura of partnership.

Whilst I was in bed Ricardo read to me some interesting details relative to Sub-marine cables, from a German book published in 1873. The electric telegraph was invented between the years 1830 and 1840 by two German scientific men. Weber and Gau[_] [184] [...] successful experiment was made in 1840 on the railway from London to Blackwall. In 1843 the telegraphic wire was made use of in the neighbourhood of Aix-la-Chapelle, in 1844 Washington and Baltimore were united by this telegraph. In 1845 it was introduced into France, since when it has spread all the ober the Globe. Almost all electric telegraphs use more than one wire some as many as fifteen between two stations, and thus a calculation has been made, which however I believe cannot be an exact one, that the telegraphic wires which run over the earth in every direction, measure two million kilometres, that is to say fifty times the circumference of the earth round the equator. In 1873 seven cables were laid between England and France, six between England and Belgium and Holland; five between England and Ireland. Two run from England to Russia, one across the German Sea, Norway, Sweden, the Gulf of Bothnia, to Niestad in Finland, from both which places the wire communicates with the Russian Telegraphs, which go as far as the Shores of Kamtschatka. According to the same book there was in 1873 telegraphic communication by land and sea from San Francisco to the Eastward, as far as the said shore of Kamtschatka; there, from Kamtschatka across the Pacific to America was the gap.

Wednesday, $30^{\text {th }}$ of August. Santa Rosa. Sundays and holidays were always for me the saddest days. I did not call upon one single Rosa, but sent as many as 
eleven visiting cards, but the three Vocales who voted for me in my suit against Leyva, I had necessarily to see, and to thank, and therefore I could not avoid going out.

When dressing I was beyond measure low spirited; formerly when I was dressed I used to present myself before my wife and to ask her whether all was right. Some trifle or other she had always to arrange, pour eau de-cologne upon my handkerchief, asked me whom I intended to visit, begged me not to forget such or such a call, and dispatched me with the words "Ahora estás buen mozo." To-day my old braces broke; I [185] went over to Enriqueta to arrange new ones, and [...] she did so, both she and I wept. At last I had to go; it was near three. At Dr. Alvarez I found Doña Asuncion by herself; she was very agreeable, and I was by no means pleased when her brother Benjamin, late Peruvian Consul in Hamburg, with his French wife, their little boy, and another gentleman came in, which latter seemed annoyed that I did not recognize him. By and by he asked me how his recomendado had turned out, and then I recollected him to be Ulyses Delboy, who had recommended to me my secretary Mr. Rees, who had been with me as secretary and lector five or six years ago. This Mr. Delboy had of late been in Europe in the suite of General Prado; nevertheless I did not believe that he was an over respectable character. In the street I met Dr. Alvarez with whom I exchanged a few words, and who told me that Leyva's title deeds did by no means prove his right to the Aires. Next I went to the Ribeyros, one of whose daughters was Juana Rosa. The Doctor was not in; his wife and daughters were; also the son Don Ramon, the lawyer who at this time was acting a prominent part as one of the argolla.

With Dr. Muñoz I was but a few minutes; I also looked in at Rafael Velarde's, and finally presented my congratulations to Dr. Teodoro de la Rosa, the new Minister of Justice. At dinner we were only Enriqueta, who suffered from migraine, Doña Angela, Ricardo, Antonio and I. Garland and the two little girls were at José Basagoytia's who gave a dinner party, it being his wife's Saints day. His father had not yet been dead four months, and one of their most faithful servants a favorite of the deceased father was lying on her deathbed; and thus it was no doubt a very improper time for giving a party. Ricardo read to me from 7 o 8; Enriqueta was in bed with her migraine and I was glad when it struck ten, that I might go to bed.

Thursday, $37^{\text {st }}$ of August 1876. At 2 in the afternoon I went to the Exposition, and was back by 5 O'clock. I was much pleased with this beautiful spot, but my wife's image was conti[_] [186] [...], and I reproached myself for my remissness in not having taken her thither so frenquently as I should have done. As far as I remembered she and I were only twice there, and both times almost as exclusively in what is called the palace. It is true I myself had not the 
slightest idea that the park was so pretty as I now found it to be; also owing to my many meetings in the banks, I had then not so much leisure as I had at present; nevertheless I might and I ought to have found time to accompany her thither, which exercise would no doubt have done her much good. In the evening Garland had gone to Gallagher's to play rocambor, and thus Enriqueta read to me from the Comercio an interesting account of a journey made by a Frenchman from New York by an express train L'Eclair, or the lightning, to San Francisco, 3355 English Miles in 83 hours 50 minutes, including the difference in time. The reason for this quick journey was the necessity which some actors had to be in San Francisco on a certain day, whilst their engagement in New York did not expire till the $31^{\text {st }}$ May. They had two wagons, one of which was divided into two halves, one for the luggage and correspondence, the other waggon contained a kitchen and a dining-room, converted at night-time into a dormitory. They left New Jersey City opposite New York on the $1^{\text {st }}$ June at 1 O'clock in the morning, and arrived Halkland, opposite San Fransisco, on the $4^{\text {th }}$ June at 9.23 a.m, the difference in time between the two places being 3 hours 30 minutes, that is to say, when in San Fransisco it is noon, it is 3.30 in New York. The first place at which they stopped was Pittsburg, 439 miles distant from New York, where they changed the locomotive and the engine driver. The same was done at Chicago 467 miles further in, the next station was Omaha, then Ogden. From this place to Halkland the distance is 882 miles, which was done without stopping in less than twenty hours. On this last tract the Sierra Nevada is passed, which forms the Watershed between the rivers which flow to the Atlantic and to the Pacific. This chain of mountains countains the lately discovered rich silver mines. When Enriqueta had done reading and Doña Angelita had withdrawn [187] we once more conversed on the one subject which was always uppermost in our thoughts.

Friday, ${ }^{\text {st }}$ of September 1876 . Alejandro Garland had the good luck to redeem S/70oo Noml. of the Internal Debt at $99 \%$. He owed this out of the way high figure to the circumstance that the other redemptions at the real market price of from 63 to $65 \%$ did not absorb $S / 85$,0oo cash, which the Government employed regularly on the $1^{\text {st }}$ of every months for the redemption of the Internal Debt; and thus the surplus fell to Alejandro's share, who had calculated upon the possibility of such a thing happening.

Saturday, $2^{\text {nd }}$ of September. I awoke in the night as I had done every night from Friday to Saturday for the last fifteen weeks; upon looking at my watch it was a quarter to five, not a quarter to four. Little Corina was again unwell; she had an extremely weak stomach, and ate too much. At 12 I went to the office of the Insurance Company Lima, where as this month it was the turn of Peña, who hardly ever made his appearance, and of myself; I, together 
with the Gerente Carlos Elizalde and Valentin Gil, one of the two Directors who went out, examined all the documents which were in the portfolio and signed a receipt for them. These documents, together with the receipt, were deposited in the iron chest, which had two locks; the key of one of them the Gerente kept in his possession, the other, I, as long as I was "de turno". At 2.30 I went to the office of the Banco Hipotecario where, as is always the case at the first convocation, there were not a sufficient number of shareholders to form a quorum; we were: the Directors, Col. Joaquin Torrico, Noel, José V. Oyague, Dionisio Villate, and myself. The affairs of the bank formed of course the topic of our conversation, and the following instance of unpardonable mismanagement, of which I had had a remote idea, was laid before us by Gallagher. The Judge de $1^{\mathrm{a}}$ Instancia in Callao, Wenceslao Rospigliosi, owed S/66,0oo and paid regularly monthly $S / 250$ whilst [_]ought to [_] [188] [...]. The Gerentes dumied him, when he wrote in a new [...] a letter, in which he expressed himself more or less in the follow[_] terms: "Many years back I came to the office about another business. Riva Agüero and Garcia Calderon were there. In the course of the conversation I said that I wanted some money, but did not apply to the bank, knowing full well that the property which I could hypothecate being my wife's and not my own, the bank would, and could not lend me any money upon the same; those gentlemen answered 'that is a rule for other people, but not for such a gentleman as you', and accordingly I did not hesitate to ask for money, and received it, mortgaging my wife's immovable property. At a later period I arranged with Riva Agüero to pay monthly S/250, the utmost which I can pay, and which payment I have regularly made. Now, should the gerentes, notwithstanding this true and veritable statement, think proper to proceed judicially against me, then I shall be under the necessity of availing myself in defence of my wife's right, of all the means which the laws of the country place at my disposal." I had no idea what steps the Gerentes would take, for $\mathrm{S} / 250$ monthly or S/3000 yearly did not even cover the interest of $8 \%$ upon $S / 66,000$, say $S / 5280$ annually; thus the interest already in arrears increased day by day, and the capital was never paid.

Sunday, $3^{\text {rd }}$ of September. This morning at the usual early hour was celebrated the funeral of the eldest daughter of Charles Pflücker by his second wife, a, as it was said, nice and accomplished young girl who had died of consumption in Jauja. I did not attend; Garland did, and drove out to the pantheon. At a later hour José Canevaro, the lately elected second Vice President of the Republic called. As Enriqueta did as yet not receive anybody, and Garland had gone out, I had to take their place; he was beyond measure polite, and told me amongst other things that he had advised President Prado on no account to dispose in anticipation of the proceeds of the more or less $£_{5} 8$,ooo [189] which he had a 
right to draw monthly upon Raph [...] further advised him to pay above all the navy, the army, and the police; next, the civil employees of all description who were in active service, and the balance distribute proportionately amongst indefinidos, widows, and other pensioners; he added that he was not certain whether Prado would follow this his counsel. Of the Peruvian Bonds of the external debt, he said that he personally held as many as £10o,0oo nominal, which cost him more or less $60 \%$, and that he had been induced to make this large investment, because Pardo had frequently assured him that he would rather have his hand cut off than not pay the interest on this debt.

Afterwards I went out and called upon the wife of Melchor Velarde; Melchor himself, and some of his daughters, had gone to Jauja, there to remain some time, for the girls suffered more or less from weak lungs, and also to him that climate would do much good. Next upon Doña Dolores Puente; whilst I was with her Francisco Sagastabeytia came in; afterwards I took a walk, and when I came home learned that it was Garland's birthday, which I had entirely forgotten. On such an occasion Enriqueta put a somewhat better dinner than usual on the table. Doña Juana Carbajal came; also Rafael Velarde with family, and José Basagoytia. It was the first time since the $20^{\text {th }}$ May that Enriqueta received in the Salita. I was very low spirited, for I missed my dear wife. Enriqueta told me that she had felt the same as I. In the morning whilst taking his breakfast died José Maria Sancho Davila, struck by apoplexy; three or four times he had had similar attacks, and part of his body was paralytic, thus his death, though sudden, did not come unexpectedly. He belonged to the aristocracy of Lima, and had still the title of Marquez de Casa Davila, which of course was of no use to him in a Republic. His mother was a Mendoza, who after the death of Sancho Davila's father, married the landed proprietor Menendez, who in 1842 during Gamarra's absence in Bolivia and after his death in the battle of [190] $[\ldots]$ the Republic till he was upset by the revolution of J. C. Torrico. José Maria Sancho Dávila was one of the richest men of Lima, and beyond measure close. Not many years back he married Fortunata, one of the daughters of General Domingo Nieto, a very nice woman, by whom he had no children.

A few days ago died the notary J. A. Menendez. Many years back he had the office in the Calle del Correo, now occupied by Francisco Palacios. As notary he understood his business and no flaw could ever be found in a document drawn out by him. I myself employed him at that time; so did Candamo, Pio Tristan, and J. M. Goyeneche, which latter entered with him into extensive transactions. Menendez put out money on interest on Goyeneche's account, without charging commission; he rented the estate of Villa from Goyeneche; in one word, he was Goyeneche's factotum. I even recollect that once when my wife and I were at Toribio Sanz', these two gentlemen came in together 
to pay a visit, and Menendez even introduced Goyeneche, which we thought very strange. The result of this intimacy was that Goyeneche lost a large sum of money with his friend, who failed; and not satisfied with this, Menendez instituted a lawsuit against Goyeneche, I do not know for how much, and published article after article in the daily papers. In this manner he completely lost the good reputation he once enjoyed, and for some years before his death he was shunned by everybody.

Monday, $4^{\text {th }}$ of September. At 8 O'clock Mr. Mould, the architect in the Compañia de Obras Publicas y Fomento del Perú, walked out with me to the pantheon, where we met Enrique, Ricardo, and the administrador of the cemetery.Jointly we chose a spot six varas long, and six broad, where I intended to have a chapel constructed, containing inside an altar, and two sarcophagii, into one of which the coffin containing the mortal remains of my dear wife was to be deposited, as soon as the regulations of the [_] tery would allow me to remove it from the niche where it now [191] [_]ood. By the 12 train I went with my Chinaman [...] Chorrillos where I left him in the kitchen of the rancho for the purpose of rubbing all the iron parts of the hearth with tallow, and I in the meanwhile took one of my long walks first to the cross which stands on the extremity of the Moro Solar, which points towards Callao, descended to el Salto del Frayle, and then climbed up from the very beach to the highest point where another cross stands; thence the descent was easy, and I reached my rancho at 3. Ayao in his opinion had finished his job, opened all the doors, and I lay down for a few minutes to rest, thinking of her who had taken so much pleasure in fitting up the sala; however I had not much time to lose, and went to the kitchen to see what Ayao had done, and put him again to work. By about four he had concluded, and we then walked leisurely to the terminus whence I thought the train would not start till a quarter past four but it had left at 4 precisely, and I had thus to while away the time walking up and down the streets, and sitting in the waiting-room till a quarter past seven when the next train left. Antonio Bazo took his seat near me and with him I conversed till we separated at the corner of the Calle de Arzobispo, he having been cited to appear in the palace by the President Prado. I took a very cold dinner, my tea, and conversed with Enriqueta. Garland went to Sancho-Davila's house to accompany the corpse to the Church of Santo Domingo.

Tuesday, $5^{\text {th }}$ of September. In the meeting of the Directory of the Insurance Company "Lima", only Gil, Robertson, Carrol and I were present, Chavez and Moscoso Melgar having to attend a meeting of the Delegates of the four associated banks. The majority, to which I belonged resolved that henceforth no loans should be made upon the security of Nitrate Certificates unless the borrower were of first rate respectability, by which decision it was given 
to understand that the certificates by themselves were in our opinion an insufficient [...]. [192] [...] onal of the previous night appeared a resolution of the Minister of Finances, Aranivar, with the rubrica of the President, to the effect that an amount of about 5,000,00o Soles, which the Administration of Pardo was owing to civil employees, widows, indefinidos, etc. for monthly payments which had fallen in arrears as well as for other recognized claims besides what might be due to the guano contractors for loading the guano, which was done on Government's account - would not be paid by the present administration, until the Congress determined how these payments were to be made, but that the from the $1^{\text {st }}$ August onwards no payment whatever would be allowed to fall in arrears. In this day's Nacional appeared a proposal made by John G. Meiggs dated $23^{\text {rd }}$ June last, and the acceptance of the proposal by the Finance Minister Elguera, countersigned by Pardo $3^{\text {rd }}$ July, both relative to the Salitreras of Bolivia, which said Meiggs had partly bought, partly rented from the Government, for twenty years at \$120,000 (Bolivian) annually. Meiggs bound himself to produce for the next five years one million quintals annually, for which placed in the Bolivian Port ready for shipment, the banks were to pay him S/1.95 in Bills on England, $90 \mathrm{~d} / \mathrm{st}$. and at the exchange of 42d. This agreement would of course do away with the competition of the Bolivian Nitrate. Of the contract relative to the Peruvian Nitrate concluded by the banks, and the Government in June last, a translation made by me will be found in appendix under $\mathrm{N}^{\circ} 9$.

Wednesday, $6^{\text {th }}$ of September. Since June last Alejandro had instituted a claim both against the Banco Anglo-Peruano, and the Banco Garantizador, which two banks were not included in the decree of $1^{\text {st }}$ August 1875 which relieved the four associated banks of their obligation to pay their notes in coined silver or gold. He had collected and bought at different premiums 32,00o Soles in billetes of each for which he demanded payment in hard silver or in billetes autorizados, calculating the premium of the silver at the rate at which it stood in June last. Yesterday Alejandro had made a great step in advance. Oscar Heeren, Gerente of the Banco Anglo-Peruano, had to acknowledge the correctness of the notes presented to him by Alejandro, and the [_] Quiroga had ordered their payment as well as an embar- [193] [_] be laid upon S/100,00o which the Banco Anglo $[\ldots]$ deposited in the Banco Nacional.

Once more I wrote to Juan Aliaga y Puente requesting him to pay me what he owed, capital and interest.

Thursday, $7^{\text {th }}$ of September. Doña Angela Villena left us, though Enriqueta and I begged her to remain; she said that as at present she was of no service whatever, she did not like to trouble us with her presence, nor to cause us extra expence. The real motive was that Nicolas Pierola and his wife - her nephew 
and niece - who did nothing for her, on the contrary, had deprived her of the little property she had, had found fault with her, because she, their aunt, had gone to a stranger's house, there to render what they called, menial service. The wife of the ex-Vocal Jose Luis Gomez-Sanchez, sister of José Rey de Castro, had died; this poor woman had suffered dreadfully for a long series of years. About 1866 when the family resided in the first story of a house in the Calle de Padre Geronimo, she first felt some pain in one of her legs, which rapidly increased, so much so that she could not go up and down stairs, and this was the reason why they removed to the house where she expired, on the ground floor, near La Recoleta; her illness had been a gradually increasing paralysis. By and by she could not keep her head straight, and when I last saw her, her head had nearly touched her knees; she was completely bent, round like a ball. She could not walk, and at the same time she had such a disquietude in her body that she never sat more than a quarter of an hour in one spot. Two female assistants who were always in attendance, had to lift her up, to hold her whilst she was moving along, and again to make her sit down. She was sensible, but could hardly speak, and the saliva always ran out of her mouth. Her death was a blessing for herself, and all around her. Dr. Manuel Morales was once more chosen Provisional Fiscal of the Supreme Court, to act in lieu of Teodoro de la Rosa during the term of his being Minister. He had 68 votes, Dr. Leon 62. [194]

Friday, $8^{\text {th }}$ of September. Holiday. La Natividad de la Señora. I awoke early, could not sleep, rose, and not knowing what to do with myself ascended San Cristoval, but was much fatigued. I was back in exactly two hours.

Last night the Canon Mora, an intimate friend of the Sancho-Davila's, was with us, and related that he had been present at the opening of the will of the deceased, which provided that the rent of the greater part of his immovably property, estates, and houses, which the Cannon valued, probably too high in $\mathrm{S} / 4000$ monthly was to be his wife's during her life-time; after her death, he had otherwise disposed of the property; he had also left a considerable number of legacies. I had necessarily two visits to make, one to José Canevaro, and wife, who were not in, the other to Dr. Morales whom I congratulated on his having been named provisional Fiscal. I then walked out as far as the Convent of Los Descalzos, and when I returned home, Ricardo read to me a pamphlet sent round by the Banco del Perú, and which contained all the documents relative to the Eten Railway question.

The society instituted for athletic exercises, of which Mr. Henry was the President, and Antonio Garland an enthusiastic member, had this day a great meeting on the cricket-ground near Santa Sofia. Antonio had unfortunately sprained his foot four or five days ago, and thus to his great regret could take no share in the various feats of leaping and running. Garland, Enriqueta, the 
two little girls and I were by ourselves; it was a tedious, and at the same time very sad evening.

Saturday, $9^{\text {th }}$. Sixteen weeks had now elapsed. I of course awoke during the night first at 12.30, and again at a later hour, but I did not know exatly when. At 2.30 p.m. I went to the office of the Banco Hipotecario, and perhaps an hour later the Directors, the Gerentes, and four of the shareholders, J. V. Oyague, Dionisio O. de Villate, Nöel and I, were assembled, and this being the second convocation, any number of shareholders formed the quorum; consequently Gallagher read the remodelled Statutes, which with one or [_] insignificant modifications were now finally approved. The [195] steamer from Panamá, which corresponded with the [...] from St. Nazaire, arrived, without bringing the correspondence of the end of July. On board of her arrived the wife of Juan Bryce, one son, unmarried, and another son Luis with his wife Grimaneza, the eldest daughter of the late M. M. Cotes and Grimaneza Althaus. From this Grimaneza, mother, Enriqueta received a letter in which she was informed that C. W. Schutte had had the good fortune to dispose of his lately built house, or hotel, in Paris, exclusive of furniture, for 1,250,000 francs.

Sunday, $10^{\text {th }}$ of September. The European news went to the $22^{\text {nd }}$ August. The war between Turkey and Servia was still being carried on. It was rumoured that Mr. B. D'Israeli would be raised to the peerage, under the title of Lord Beaconsfield. The bank of England had fixed the rate of discount at $2 \%$ p.a. Several months ago Queen Victoria was proclaimed Empress of India, which new title had upon the whole not been well received by her Europeans subjects.

In the forenoon I went to Eliza Higginson, wife of Guillermo, to congratulate her on her birthday. She invited me to dinner, which I declined. Before and after dinner Ricardo read to me Rahncke's Popes, and I was in the evening quietly alone with Enriqueta; Garland and Enrique dined with Guillermo

From Monday, $11^{\text {th }}$ to Thursday, $14^{\text {th }}$ of September. Four very dull days. I made heavy recoveries $S / 31,500$ from Canevaro, a/c Banco Hipotecario, and S/80oo from J. M. Zuloaga, balance of the $S / 10,000$ lent Juan de Ugarte more than three years ago; thus I had now about S/70,00o in the Banco La Providencia, without knowing how to employ them, because having erelong to make a partition of my fortune, I durst not run the slightest risk with what I had. According to all appearances the present government did nothing at all, or at all events if the Minister of Finances Dr. José Aranivar, who within these last days had been very ill of colic, occupied himself with the Directors or the Delegates of the banks the result of their lucubrations did not come to light. The[_] [196] [...] El Tribunal de Alzadas, to which hitherto the appea[_] from the Consulado had been made; now they had to go to the Superior Court. It further resolved that in the Superior Court of Justice, litigants were not obliged to make use of the 
services of a procurador. The budget was also discussed, however the greater part of the time was taken up with quarrels about elections.

Though I was Director de Turno in the Insurance Company "Lima", this gave me but little extra occupation, and as I had made it a rule to give Bryson sufficient time to copy at least four pages in the remodelled diary, I had unfortunately many leisure hours. On Wednesday I whiled away two of them by ascending San Cristoval with great ease. On Thursday night Fannie (this is the Yankee way of spelling) Meiggs, daughter of Henry Meiggs, married Alexander Ravenscroft Robertson, the Grandson of William Parish Robertson, with whom I was pretty well acquainted, and whose name has occurred more than once in my diaries. The ceremony was perfomed in Meiggs' house by the English clergman, and such a number of gentlemen were present that one could hardly move in the apartments, extensive as they were. This at least was the account of Garland, Sr. who with some of his sons had been invited. Within these last days said Henry Meiggs had removed his office from J. V. Campo's house in the Calle de Mantas to the two stores 92 and 94 Calle de Zarate, let by me to the Compañia de Obras Públicas y Fomento, and had made some improvements in them.

Friday, $15^{\text {th }}$ of September 1876 . The Senate qualified the Senator for the Department of Lima, José de la Riva Agüero, absent in Paris as Peruvian Minister; and as Suplentes Fernando Sorria, Prefect of Lima under Pardo's Administration, and at present on an estate in the North, belonging to Flores Carranza which he administered as Interventor for the Banco Nacional, and J. F. Selaya, who lately married Juana Valle Riestra, and was provisional postmaster. All three were friends of Manuel Pardo to the back bone. [197]

Saturday, $16^{\text {th }}$ of September 1876 . A very confused dream [_] me at 2.30. I was much agitated, and when looking at my watch I found that seventeen weeks previously my dear wife had at this time in all probability been still fast asleep without the slightest foreboding that in about 80 minutes she would be called off, who can say whither? It was past four before I again fell asleep.

Enriqueta had yesterday and to-day been sitting nearly the whole forenoon in the Church of La Merced, where, completely wrapped up, she had been selling small images of the virgen which Doña Grimaneza Cotes had sent her for this purpose. The money was to be employed as Enriqueta thought proper, probably it would be distributed amongst poor people. When in bed Ricardo read to me a short article from a German Review which clearly showed that the Empress Eugenia had in reality been the cause of the War of 1870, and the consequent overthrow of the Napoleon Dynasty. In the first days of July of the said year, it became known in Paris that Marshall Prym had offered the crown of Spain to Prince Leopold of Hohenzollern. In the Chamber of Deputies a certain Cochery interrogated the Minister Gramont on the subject; on the $5^{\text {th }}$ July a council of Ministers, presided by the Emperor, met at St. Cloud, both 
before and after dinner when a reply to be given by Gramont, was drawn out in pacific and moderate terms, the Emperor showing no inclination to go to war. Whilst this Council deliberated, the Empress, who had been overexcited, ever since the news relative to the Spanish crown had arrived, was conferring with the Baron Jerome David. On the Emperor's returning from the Council to his wife, they had a conference, and it is highly probable that the Empress who exercised a great influence over her husband then induced him to change his mind. At all events in the morning of the $6^{\text {th }}$ when the Ministers again met, and Emil Olivier and the Duke de Gramont presented the rough draft of the answer agreed to on the previous evening, Napoleon took a much more active [198] [_] he had done before, introduced some alterations, and above all insisted upon concluding the reply more or less in the following terms: "France relies upon the wisdom of Germany, and the friendship of Spain, to avert the danger which may arise to Europe from a change in the equilibrium of political power between the different states, but should this not be done: then France knew her duty and would do what became her." If these were not the exact words, at least it was their meaning. Some of the Ministers opposed the threat contained in this sentence, but ceded to the Emperor's will, though full of apprehension. At 1 P.M. Gramont returned to Paris where in the Chamber of Deputies the last sentence, menacing and warlike, was received with the greatest enthusiasm and we all know the consequence.

Sunday, $17^{\text {th }}$ of September. Enriqueta's birthday. I presented her with S/400 as for some years past it had been my wife's and my habit. Enrique, Alejandro and Geraldo each gave her some trifle; Guillermo confessed he was too poor, he could not. Garland had ordered one or two black dresses from Paris, which arrived just in time. In the forenoon the project relative to the Central Bank, published in the Opinion Nacional of yesterday was read to me, but as it had not been approved by the Congress and therefore was not the law of the country, I thought it superfluous to give its details. As far as I could judge, its conditions were in every respect favourable to the Government, and infavourable to the banks, which took upon themselves the obligation to make several payments, and for the reimbursement had merely to look to the surplus which the sales of Nitrate of Soda were expected to leave. Bryson read to me an article from the Eclectic of August, by which I learned to my great surprise that towards the end of the twelfth, and beginnig of the thirteenth century, there existed in Germany really great poets, that the Dukes of Austria, residing in Vienna were their principal protectors, and that one of them was Walther Von der Vogelweide, on whom the article mainly treated. When Bryson was gone I felt no [_]lination to pay a single visit and therefore ascended San [199] San Cristoval. When on the saddle where one path [...] the other to Descalzos, I reascended on the other side, until I came to the rock formed in the shape of a shell, of which 
I have made mention once or twice, returned to the saddle, and as the sun was still pretty high on the horizon I once more climbed up to the top of San Cristoval where I rested for a few minutes. I was home a little past five, having accomplished all the foregoing in three hours. Till dinner time Ricardo read Rahncke's Popes. At dinner, Guillermo and his wife Eliza were with us. Absent were: Juan in the Lobos Islands, and Alejandro, ill of the quinsy in Chorrillos. Doña Juana Carbajal came, and brought her nosegay to Enriqueta. I can hardly say whether I was more tired, or more sad, at all events I went to bed at 8.30. When I was in bed Manuel Semenario and wife, Rafael Velarde, and family, and José Basagoytia, came, and remained till 10.30. Before Ricardo went to sleep he read to me for half an hour a rather uninteresting review, treating on the life of the famous German composer J. Sebastian Bach.

Monday, $18^{\text {th }}$ of September 1876 . Anniversary of the Independence of Chile, in which Republic, for the next Constitutional period of 5 years Anibal Pinto was elected President. For the last term of five years, the President has been Frederic Errázuriz, brother of Maximo my fellow passenger from Europe in 1863. In Santiago had died in his $87^{\text {th }}$ year, Manuel Blanco Encalada, well known as the deaf Admiral Blanco who in 1837 commanded the first Chilian Expedition against Perú and who then concluded with Santa Cruz the capitulation of Paucarpata. Yesterday here in Lima some Lima electors had a meeting in the convent of San Francisco, where they signed a document by means of which they protested against the Senate, for having annulled the Lima elections, and qualified Riva Agüero and others, as said on the $15^{\text {th }}$.

Tuesday, $19^{\text {th }}$ of September 1876. Alejandro was still unwell. [200] [...] not yet come in from Chorrillos. Enriqueta continued selling in the Merced the small images of the "Virgen de las Mercedes". At 1 O'clock the saloon in the Banco del Perú gradually filled with shareholders to treat on the Eten Railway question. The Directos were not all present. Calderoni presided. Amongst the shareholders I missed José Vicente Oyague, James Henry, Augusto Althaus, and José Canevaro. Those on Pena's side had found two excellent spokesmen in Carlos Paz-Soldan, and Francisco Garcia Calderon, whilst the majority was rather silent, relying upon its number; nevertheless, instead of coming to the decisive vote, whether the resolution of $14^{\text {th }}$ August should be confirmed, or annulled, they agreed to a trimming measure proposed by Garcia Calderon, viz.: to name a new commission which was to treat with the Garantizadores, and endeavour to come to a friendly understanding; a long dispute ensued as to who should be the members of the commission; at last, said Garcia Calderon, Forrero, and Heudebert, were fixed upon. I was the only one who voted against the naming of the commission.

By the steamer from the North, which arrived this day, came passengers: J. A. Lavalle, his eldest daughter Susana, and three children more; Dr. Mesones 
and family; also the widow of Genl. J. C. Torrico. At night Enriqueta read to me the letters received: those from Schutte, Rosa, and Corina were dated Kissingen $30^{\text {th }}, 29^{\text {th }}$ July and $12^{\text {th }}$ August respectively. They gave me their thanks for the proposal I had made to Rosa in the middle of June, to come over hither, and to occupy my wife's and my apartments, but said that they could not accept it, owing to the poor state of health of Schutte and Corina. Juan wrote from Homburg, and enclosed a cutting from the Times - see $\mathrm{N}^{\circ} 7$ in Appendix, which shows that some eminent English lawyers were of opinion that the Peruvian Bondholders had a right to fall upon the guano in the hands of Dreyfus, to pay themselves for the hitherto unpaid cupons. Dreyfus had always assured Juan that there was not the slightest danger of such a thing happening; nevertheless [201] this opinion made me very uneasy as regards the [...] Shares which Juan and I possessed in the Dreyfus contract. Juan's health was very delicate; from Homburg after the date of his letter he had removed to Salzburg, where he intended to remain for some time, in hopes that in the hotels of Gastein some apartment would become disposable, all having been occupied when he applied for one. From Elizth. Bobertag I heard under date of $28^{\text {th }}$ July, that her son Henry, though very weak, was gradually getting better, whilst her brother Johannes wrote me on the $13^{\text {th }}$ August that the poor fellow, who had just reached his $20^{\text {th }}$ year, had already expired, and been interred on the $10^{\text {th }}$ August in the sepulchre which the family of Limpricht possessed in the cemetery of Jacobi. There was nothing but sadness at present in our family; I at least was beyond measure low spirited.

This day I closed with the Compañia de Obras Publicas y Fomento del Perú, for the construction of a chapel in the Pantheon. It was to contain an altar and two Sarcophagii, one for my wife; the other for myself; its cost S/90oo, of which S/3000 were to be paid in cash, S/3000 in four months, and S/3000 at its conclusion, the date of which was not to pass the $19^{\text {th }}$ September 1877 .

Wednesday, $20^{\text {th }}$ of September 1876. When in bed Ricardo read to me in German, a very pretty little novel, in which in the course of the narrative a medicine was mentioned which Dr. Middendorf had prescribed to my wife, also that a little girl had knelt down in the middle of the bedroom praying for her sick mother, this placed before my mind so vividly, what had happened to me that I felt extremely sad, and on

Thursday, $27^{\text {st }}$ of Septrember 1876 I felt exactly the same as I had done on the previous night.

Alejandro came up from Chorrillos; he felt somewhat better, not yet quite well.

The papers said that the Sultan in Constantinople [202] [...] had been deposed, and Abd Ul Hamid raised to the throne. The war between the Turks and Servians continued to rage. 
Friday, $22^{\text {nd }}$ of September 1876 . The papers gave the news that in Iquique the notorious Bogardus, and Espinosa, ex Secretary of Nicolas Pierola, were arrested on shore. Their presence gave rise to the suspicion that some friend of theirs might have remained on board the steamer from which they had landed; accordingly, the steamer was searched by order of the local authorities, and Nicolas Pierola found. All three were placed on board the Peruvian Man-ofWar "Union". Little Corina was very unwell, so much so that her mother was prevented from going to the Church de la Merced, for the purpose of selling the small engravings of the Virgen. Eliza did it for her. She, Guillermo, and her sister Maria Luisa dined with us. In the evening José Pablo Escobar, with his wife and sister-in-law called. Garland was not at home, Enriqueta could not leave her sick child, thus Eliza and I had to receive them. Escobar told me that in all probability the Banco Central would be allowed to raise its circulation to twenty million Soles, which to me seemed a very large sum, though it might also be that otherwise the bank could not possibly make all the payments which the Government insisted should be made by the same.

Middendorf had come in the course of this day to see Corina but about 10.30 p.m. she was so ill, her pulsation having risen to 148 per minute, whilst the extremities of her little body felt cold, that Guillermo went out and brought with him his friend the young Dr. Bravo, whose opinion was that Corina suffered from bronchitis, and was much exposed to become asthmatic; he prescribed some medicine which Ricardo fetched, and it was near twelve before we went to bed.

Saturday, $23^{\text {rd }}$ of September. I awoke during the night; it was half past one. I fell asleep, again awoke when it was [203] exactly 3.45. Certainly very strange. [...] Enriqueta told me that she and Aurelia had hardly had a wink of sleep; about 2 a.m. Corina had been very ill; at a later hour she had vomited - now she was somewhat better. The violence of the fever had not abated, but her extremities had again a natural warmth, whilst her little belly felt uncommonly hot. She had always much phlegm. She continued very poorly the whole day long. Both Doctors came. Late in the evening Rafael Velarde called. The news of Pierola's arrest seemed to be without foundation.

Sunday, $24^{\text {th }}$ of September 1876. Dia de las Mercedes. This forenoon the collection in the Church de la Merced came to an end. Enriqueta and her friends who had assisted her had got together above S/200. In the same Church mass was said by the barefooted friar Masia, whom Don Manuel Pardo, when President of the Republic, had sent out of the country for his attempts to rouse the population of Arequipa against the then existing Government. Not only had he since then returned to Lima, but he had even been consecrated Bishop of Loja, a town in the Republic of Ecuador. 
Little inclined as I was to make any calls, I had necessarily to pay official visits: To Riofrio, Ecuatorian Chargé; to Comme. G. B. Viviani, Chargé for Italy, and his secretary Dre. A. Tescari, of whom fortunately none was at home, and I therefore merely left my card. On the other hand with Doña Dolores Puente I stayed full half an hour then walked out as far as the Convent of Los Descalzos, and was home for dinner, when our party was still smaller than it had been at breakfast, for Garland and the two little girls had gone to Villacampa's huerta.

At a later hour Ricardo read to me Rahncke's Popes; with Enriqueta and Doña Juana Carbajal I took tea, and at 9.30 retired to my bedroom. [204]

Monday, $25^{\text {th }}$ of September 1876. In the middle of last night, an earthquake awoke me; of late we had experienced several shocks, none particulary severe.

Dr. José Aranivar, Minister for Finance, was said to be sick, and did not go to the Palace; this again delayed the final arrangement between the four associated banks and the Government, as well as the establishment of the Banco Central. Exchange on London varied from 28 to 3 od the Sol, payable in bank notes. In the evening Doña Francisca Cardenas, wife of Gregorio Benavides, took tea with us; when she was gone, Enriqueta and I remained together till nearly 11.30, talking, projecting, and weeping. Ricardo read to me in bed till past midnight

Tuesday, $26^{\text {th }}$ and Wednesday, $27^{\text {th }}$ of September. Silver Soles were at $38 \%$ premium. Bar Silver, ley 993 S/14.6o per mark. The Banco Nacional had advertized that it drew on London $90 \mathrm{~d} / \mathrm{st}$. at $39 \mathrm{~d}$, receiving payment in bars, coined silver, or gold. I much doubted that anybody would take these drafts. On Tuesday, when walking to the Alameda I slipped upon a rind of banana, and fell on the ground, but believed that I had not suffered any injury. On Wednesday I felt a pretty severe pain in the fleshy part of the thigh, which prevented my walking with my habitual ease. The United States Guano Company paid me S/16,0oo, which I immediately took to La Providencia, where I had now to my credit more than $S / 80,000$, whithout knowing what to do with this large amount of money.

Dr. Aranivar again returned to his Ministry.

Thursday, $28^{\text {th }}$ of September. My thigh continued to pain me, and Enriqueta rubbed it with Rum, in which camphor and arnica were dissolved.

The bill for granting amnesty to political offenders, which had passed the Deputies, was thrown out in the Senate, by a majority of 36 to 8 . Consequently Guillermo Bogardus and Enrique Espinosa remained prisoners and [205] would be judged in conformity with existing laws. [...] there was a meeting of the shareholders in the Banco de Lima at which I did not attend, being prevented by the pain which I experienced in walking.

Friday, $29^{\text {th }}$ of September 1876 . Owing to the pain in my thigh, I did not stir from my house. The day was extremely tedious. I was told that the meeting of 
the previous night in the Banco de Lima had been very stormy, that Cardenas and Gallagher had quarrelled, and that the latter was about throwing up his post, both as President of the Directory and as Director. Were he to do so, it would be a great loss to the bank; he being one of the few, clever, energetic and honest members.

Saturday, $30^{\text {th }}$ of September. Last night, being that from Friday to Saturday, I was awake from 1 till past four. I saw by the papers that the Caja-Fiscal easily placed the drafts of $£_{58,000}$ upon London even with the until now unheard of condition that the takers of the bills had to pay for them the very moment they inscribed their names when they received a kind of receipt or certificate which was exchanged three or four weeks for the bill itself. Ricardo even assured me that not only all the bills to be delivered on the $28^{\text {th }}$ October were taken, but that the inscription had already commenced for November, and money been paid for bills which would be received on the $27^{\text {th }}$ of that month. In the street I met Evaristo Barrios, one of the Directors of the Banco de Lima, who gave me an account of the proceedings on Thursday night. Gallagher as President had asked the shareholders whether the authorization given to the Directory on a previous occasion extended to the project proposed by the Government to the four associated Banks. This was insured in the negative. Then Rufino Echenique, Gerente of the Banco Nacional, and as such, shareholder of the Banco de Lima, proposed that the shareholders should give the necessary authorization [206] [...] Directory. Now the debate commenced. Cardenas spoke only of his own project, Gallagher stopped him, because, he said, that was not under discussion; Cardenas spoke again and the two quarrelled. Felipe Salaverry, lalety arrived from Europe, son of the General shot in Arequipa in February 1836 by order of Santa Cruz, said some words offensive to John Gallagher; John's brother, Peter, took him up, and the two nearly came to blows. Castro Zaldivar spoke against the Authorization; so did a certain Camino, whose son had for a long time been clerk in the bank, but been dismissed, because the expenses had necessarily to be reduced, the meeting broke up, whithout having come to any decision.

Pedro Seminario, one of my tenants in the Calle del Correo, was in arrears with his payments. At his request the Mineral Company of Canza, in the neighbourhood of Ica, which had its office in my house Calle de Zarate, promised to pay S/40. The manager gave me an order for that amount upon the cashier of Henry Meiggs, Urquhart, who had his office in the large store, corner of Aldavas, which had of late been very prettily arranged, and in which a good deal of work had been done by order of Meiggs - whether paid for was another question. I presented the order for forty Soles and was answered it 
could not be paid for want of money. Meiggs' finances were no doubt in the most dreadful disorder.

Sunday, $7^{\text {st }}$ of October. Last night I awoke; a few minutes later my small clock struck four, the hour at which I was in the habit of awaking.

My Chinaman Ayao came with the news that the crystal globes which every night were placed upon the lamps on the staircase had disappeared. They were probably stolen on the previous evening between 9 and 10; the porter, paid by the Compania de Obras Publicas, was not keeping watch as he ought to have done. My occupation with Bryson kept me very agreeable employed till past two. I then went to the barbers, and took a very slow walk to the Convent de los [207] Descalzos. On my return, Ricardo was already wai[_] for me, and read Rahncke's Popes till dinner time, when as usual on Sundays, our party was very small. Ricardo fetched the letters from the Post Office; Garland and Enriqueta had none, I one from Gibbs, the other from Juan, dated Gastein, $26^{\text {th }}$ August with an enclosure to him from Corina, dated Kissigen $18^{\text {th }}$ August. Juan had received my long letter of July, and both he and his niece expressed themselves in a very affectionate manner; he would not receive the rent which I had remitted of the house Calle del Correo, because, as he said, he would first be convinced that when the partition were made between him and his two sisters, sufficient would remain to enable me to live in a decent manner; there was little doubt but that he would embark in Southampton on the $2^{\text {nd }}$ November.

Afterwards Peter Gallagher paid a visit; Garland and I received him. When he was gone Garland went to José Canevaro's habitual Sunday evening party, which I was afterwards told became every time more elegant. Enriqueta and I remained together till 10.30, and I must say that notwithstanding the impression made by the letters received from Juan, I spent this day pleasantly enough.

Monday, $2^{\text {nd }}$ of October. Last night I again awoke at five minutes past four. The temperature got warmer; the weather was pleasant, this year we had had hardly any cold or rain, but within the last week we had experienced a great number of slight earthquakes, many more than usual.

There was a meeting of the shareholders of the Lima Gas Company at which, as it was always the case, J. V. Oyague presided. It was resolved in the first place that as the capital of the company had been increased from one million five hundred thousand dollars, to two million Soles, a new escritura, including the new statues, should be drawn out, and for the difference of $\mathrm{S} / 500,000$ in conformity with the laws of the country $1 / 4 \%$ stamps $S / 1250$ be paid to the Government. The remuneration [208] [...] was again mooted, and for the next year $21 / 2 \%$ upon the net profits, which might perhaps amount to 
200,000 or 240,000 Soles were to be allowed to the seven Directors, so that each would receive from seven to eight hundred Soles annually; this proposal was made by Oyague, and objected to by nobody; I understood afterwards from Garland, that the present Directors, he, Ruden Mathison, and Carrol, were not satisfied. At 9 p.m. Garland went by invitiation to the palace to play rocambor; till nearly ten Guillermo and Eliza kept Enriqueta and me company; no one could imagine how I missed my dear Mariquita.

Tuesday, $3^{\text {rd }}$ of October 1876. For a wonder I slept the whole of last night, without awaking till day break; thermometer at $3 \mathrm{p} \cdot \mathrm{m} .70^{\circ} \mathrm{F}$.

Col. José Panizo had died. Many years back he and my wife were good friends; of late we hardly ever saw him. His widow was the daughter of that bad woman Doña Manuela Pando, of whom, and whose death I gave an account Vol. 5, pages 511, 512, and who bore him one son Federico. The Col. and his wife quarrelled soon after their marriage, owing I believe to the bad conduct of the latter. When Doña Manuela Pando died, Col. Panizo took possession of her valuable house as protector of the interests of his son; though this house was certainly the property of his wife; hereupon these two carrried on a law suit, and the most virulent articles written on both sides, frequently appeared in the papers. When the Col. was in his death-bed, the clergyman who assisted him, I believe the notorious Bishop Huertas of Puno, brought about a reconciliation between him and his wife, from whom he had been separated for a long series of years, and I was told that the son and his young wife, Manuela Orbegoso had now made up all differences with their mother, who would henceforth live with them in the splendid house where Doña Manuela Pando died, the last on the right hand side in the Calle de Piedra. My month for being Director de Turno of the Insurance Company Lima, having expired [209] I delivered the key of the iron chest to my successor [...] and was present whilst he received the documents which constituted the portfolio of the company. I then went to the Banco Territorial, and Banco Hipotecario, where I received three months interest on my Cedulas; from the latter a much smaller amount than formerly, for Garland could not pay me the $S / 2200$ interest at $2 \%$ on the $S / 60,000$ Cedulas lent by me to him, and by him to Dr. Palacios. In the office of Dreyfus, Scheel, who a fortnight back had held out hopes for a bill of $£$ 1ooo, now reduced it to $£ 500$.

Wednesday, $4^{\text {th }}$ of October 1876 . Having nothing whatever to do, I took a very slow walk, as far as the Exhibition, looked in at the watchmaker Rönacher's and was back before 3 O'clock. Eliza was with us in the evening.

Thursday, $5^{\text {th }}$ of October. No bills upon England were to be had, so that I could not remit to Schutte the amount received for him from the Gas Company. I went to the offices of Mathison, and Graham Rowe \& Co., Garland to that of 
Dreyfus; everywhere the answer was that they did not draw and were not likely to draw for some time. This want of bills augured a further deterioration of the exchange, and a corresponding rise in the prices of all articles imported from abroad; of this latter, an evident proof was given in the shops where every article one might ask for was considerable dearer than it had been but a short time previously.

At 8 p.m. I went to a meeting of the shareholders of the Banco de Lima, which was poorly attended. I took my seat exactly opposite the President Gallagher, and delivered to him the power which Dr. Middendorf had given me to represent him. The names were called over, the last acta approved, with a few observations, which being done Gallagher said the object of the meeting was to communicate to the shareholders the last project regarding the establishment of the central Bank which the Minister of Finances, Dr. Aranivar, had communicated to the four associated banks, and to know from [210] [...] ers whether they would authorize the Directory to treat with the Ministry about this project or not. Then Lembcke rose, and in a long very sensible speech informed us that he had had a long conversation with Aranivar, and that the question was now, not whether the Directory should be authorized, but whether the bank would take a share in the projected Central Bank. When he had spoken, I was the first to say in a few words that I was of the same opinion as he, excepting however that I did not entertain such brilliant expectations of the Nitrate business as he. Lembcke replied that for some reason or other the nitrate business might perhaps not turn out quite so advantageous as he had depicted it. Now Serdio delivered a long speech, somewhat confused, but in many parts very correct; he showed in what a miserable state the banks were, and was rather, but not decidedly, against the project - Salaverry spoke much against it; he founded himself upon articles of the commercial code, but what he said was not to the purpose. Castro Zaldivar followed in the same track. I went out for a short time, and then took my seat near Dionisio Villate. Lembcke had held out hopes that if the Banco de Lima took a share in the Central Bank, then we shareholders would be released from the obligation we were still under, to pay the remaining 50\% Capital not yet paid up; more than one said: "if this were certain, they would immediately agree to the proposal." Lembcke answered that it was probable, not certain. Rufino Echenique spoke in favor of the project, so did a certain Zavaleta, and when at about ten it was put to the vote, all were for the affirmative, with the exception of four or five, who were I believe, Salaverry, Camino, Dionisio Villate, and perhaps one or two more. Neither Oyague nor Cárdenas was present. Heudebert accompanied me to the door of my house; Enriqueta was in bed, Garland out. I was awake a very long time, pondering on the miserable state of this country, and its daily decline. 
My own fortune was dreadfully reduced. I did not give the particulars of the new project as it would still have to pass through many stages, and finally [211] have to be approved by the Congress, before [...] law of the country.

Friday, $6^{\text {th }}$ of October 1876 . The monthly meeting of the Directors of the Insurance Company "Lima" was held; everything went off quietly and smoothly. Before dinner I took a short walk, and on my return Garland handed me a letter, directed to me by the sub-secretary of the Pasco Railway Coy., inclosing a printed informe, drawn out and given in by Colonel Joaquin Torrico in which he not only made the Directors of this company - who were in the beginning: Manuel Pardo, Nicolas Rodrigo, José de la Riva Agüero, Francisco Sagastabeytia, and I - responsible for many omissions and commissions, but also threw out not a few insinuations offensive to their good name and characters. See for this document appendix $\mathrm{N}^{\circ} 8$.

At dinner, the first news communicated was that Pierola had landed, and was again in Torata, close to Moquegua; the advice had come by cable. In the evening, two battalions, some artillery, and cavalry were shipped off, probably for llo, under the command of the Minister for the Interior, Col. La Cotera; I had not slightest confidence in this officer, and much feared that it was a very serious affair.

I was extremely low spirited so much so that in bed I paid hardly any attention to Ricardo's reading.

Saturday, $7^{\text {th }}$ of October. Last night, being that from Friday to Saturday, I awoke of course. I was awake at one, two, three and four O'clock. I confess it was not only the recollection of what occurred twenty weeks previously but also that abominable informe of Col. Torrico, which prevented my sleeping. At 12 O'clock I went to take Manuel Pardo's opinion. He received me with his usual politeness, told me that he himself had as yet formed no opinion on the subject [212] [...] ed me for Monday next, when Felipe Varela, one of the Directors of the Pasco Railway Company, would also be present. "Calma, calma, es lo que se necesita", he said, "I am accustomed to such things, and they do not prevent my sleeping." As to Pierola's reappearance, he looked upon it as a very grave matter and when speaking about the establishment of the Banco Central he said that he would do everything in his power that the bill for the illimited issue of bank notes should not pass. In the course of the day news came that Pierola after having beaten the few men whom the Prefect of Moquegua had led against him, had made himself master of this town. In a nocturnal session of the Congress, full and extraordinary powers were given to the President Prado by 110 votes, against 12. In the minority voted Lizardo Montero, the son of Herencia Zevallos, Luciano B. Cisneros, who previously had delivered a long speech against the extraordinary powers, Emilio Luna, Juan Luna, Aparicio Oviedo, and Galvez, Rodrigo's son-in-law. 
When Bryson was gone, Guillermo wrote for me the month of March last in the clean cash. Eliza was with Enriqueta; Garland at Rafael Canevero's. As soon as I laid my head upon the pillow I was asleep.

Sunday, $8^{\text {th }}$ of October. After a sound night's rest I rose at 6.30, and ascended San Cristoval. Never before had I done it in such a thick fog; I was however fortunate enough not to lose my way, either going up or down. The big cross on the summit had been removed, and temporarily, a small one of reeds put in its place. On my return home I lay down in my bed for about an hour; not because I was much tired, but because I was very sad.

Necessarily I had to make some calls, which I did with great reluctance. I had to inform our friends that we were about removing for a short time to Chorrillos. I first went to Pancha Castañeda, wife of Melchor Velarde, who is always very agreeable, next, to Doña Gregoria, the widow of Manuel Velarde, with whom was the father of Baltazar Aranivar, who [213] had just arrived from Arequipa, and who said that he [_] feared that erelong the whole south would be up in arms, and this out of hatred to Pardo, not Prado. At Dr. Jervacio Alvarez' his daughter Asuncion was extremely friendly, and I could hardly refrain from weeping when I said good by, not that I was so sorry to leave her, but because I thought of my dear Mariquita, who was Doña Asuncion's comadre. Dr. J. A. Ribeyro was talkative and agreeable; Dolores Puente had gone out. Dr. Muñoz and his wife Irene were not at home either, and Rafael Velarde, who had just come from the Palace, seemed very low spirited. Ricardo read to me Rahncke's Popes till 8. Juana Carbajal kept Enriqueta company; Garland was at José Canevaro's playing rocambor, and I lay down at 8.30, not to sleep, but to think and to remember. Enriqueta sat near my bedside till 11.30.

The "Independencia". Peruvian man-of-war Steamer left this day for the South with troops on board, under the command of the war Minister Pedro Bustamante of whom I entertained as poor an opinion as of La Cotera. José Antonio Garcia y Garcia, Minister for Foreign Affairs had temporarily taken charge of the Ministry for the Interior instead of La Cotera.

Monday, $9^{\text {th }}$ of October 1876 . I slept soundly till day break.

We were preparing for our removal to Chorrillos. Every moment I missed my dear wife. At 12 O'clock I was in the house of Don Manuel Pardo; Dr. Felipe Varela was already there, not knowing why he had been summoned, which I explained to him. As soon as Don Manuel joined us Varela proposed, as I had advised him to do, that Pardo should ask for all the documents of the Pasco Railway Company in order to be able to answer Joaquin Torrico's abominable informe, and then keep these documents for an indefinite length of time. This, Pardo declined to do, and requested Varela, he being one of the Directors of the said [214] [_] ay Company, to speak with the other Directors, and to persuade them not to trouble us any further with similar notes as that lately 
received, and this Varela promised to do. At a later hour the shareholders of La Providencia, I of the number, otherwise there were but few, had a meeting, the object of which was to authorize the Directors to take a share with the other three associated banks in the Banco Central; but few spoke; I was one of these few and I moved that the authorization should be given to the Directory, recommending them however to introduce a limit to the circulation of notes. This was agreed to. In the evening Bryson assisted me in packing my trunk for Chorrillos.

Tuesday, $10^{\text {th }}$ of October. I rose early. We also took our breakfast at an earlier hour than usual, and, thanks to the indefatigable Enriqueta who arranged and did everything herself, we left for Chorrillos by the 12 O'clock train. This word "we" included Enriqueta, the two little girls, Bryson, and myself, the two Chinamen, Achú and Ayao, the three black women Aurelia, Rosalia and Virginia, and the old Chola woman Juana Távara, a natural daughter of one of the brothers of Don Santiago Tavara of Piura. We left our house to the care of the sons of Garland, who generally slept at home, and to that of a stout Cholo Serapio Becerra, with his wife Isabel, and their children, whom my wife and I had in our service towards the end of last or the beginning of the present year. Serapio accompanied us to Chorrillos to attend to our luggage, which consisted of a great many packages. The servants had an enormous deal to do, to sweep, to clean, and to arrange things. I could render no other assistance, but unpack my own trunk. I took for myself Mariquita's bedroom, whilst Bryson took mine. Garland, Enriqueta, and the servant women occupied the other apartments, where they were rather crowded. Bryson began reading to me the very interesting work Philip II by Prescott, to which I now listened for the third time. Garland came to dinner, which we [215] took at about six.

After dinner Bryson again read to me, now the life of Mary II by Miss Strickland, written with a partiality which surpasses all bounds; to the authoress, the stuarts are the virtuous and the good the unfortunate sufferers, whilst Mary and her sister Anne and above all the Dutch William, as she calls him, are the compound of everything vile and mean. Till about 10 O'clock José Maria Costas was with us; also Alejandro for a short time. A telegraphic dispatch from Arequipa brought the news that on the previous night, Monday, the conspirators in Arequipa had made a rush to posses themselves of the railway station, but had been defeated in their attempt. Part of the soldiers under La Cortera had landed in Mollendo; the remainder had gone on to llo. General Buendia was named Minister of War instead of Bustamante. When I had undressed, and lay down in the bedstead, and on the mattress which had been used by my Mariquita I felt so unhappy, as can hardly be described; nevertheless, so fatigued was I that I soon fell asleep, and did not awake until 
Wednesday, $11^{\text {th }}$ at 5.30 in the morning.

Bryson and I bathed at somewhat past seven. The water was very cold, and we remained in but a few minutes. We then took a walk over the hill to the Salto del Fraile and back by the Chorrillos burial-ground, on approaching which I observed that the echo noted in previous years was still unaltered. Garland and Enrique, who breakfasted with us, went to Lima by the 11 O'clock train. When they were gone, Bryson read, and wrote for me as usual till past four. The room which Enriqueta had assigned to us was that which adjoins the saloon, which had served for Juan's bedroom, and in which we were in the habit of taking breakfast and dinner, when it was too cold to do so in the corredor.

Besides Garland, Ricardo came by the train, and brought me various letters, one circular signed by Francisco Garcia Cald[_] [216] [...] he invited all interested in the Eten Railway, to meet to-morro[_] at 12 O'clock in his office in the house of Goyeneche, Calle de Zarate. I felt no inclination to attend; the other letters were from Paris, from Rosa, of $1^{\text {st }}$, Schutte and Juan of $6^{\text {th }}$ September; they had returned from their respective watering places, without however, as far as I could judge, having derived much benefit from the same. Juan wrote that he would leave Liverpool on the $7^{\text {th }}$ October in the "Liguria" through the Straits, a long sea voyage having been recommended to him by his physician, and that consequently we might expect him here about the $27^{\text {th }}$ November.

After dinner Bryson read to me an article from the Eclectic of October, which contained a new hypothesis regarding the solar system. This is to be considered as separate and quite isolated from all the others stars, and has been created by itself; there existed originally in space a chaotic mass of vapoury matter. To this the will of the creator gave a rotary motion, by means of which one planet was thrown off after the other, the first of which was the most distant, Neptune, then the one less distant, and so on until at last a mass containing heat and light remained which condensed, and formed the sun; an experiment had been made to prove the correctness of this hypothesis. Some oil was thrown into a liquid of alcohol and water; through the oil, which again by virtue of molecular attraction took the form of a globe, a metal wire was passed perpendiculary, so as to form the axis of the globe. To the wire a small disc was added, and by turning the axis, a rotary motion was given to the globe of oil the first consequence of which was that it flattened at the two poles, and bulged out at the middle. The rotary motion being continued; and increased, the oil took finally the shape of a ring and this ring threw out small globular particles, which preserved the rotary motion. So we had here in miniature the formation of the solar system, according to the theory of La Place. Doña Juana Novajas, with her niece Teresa Marzo, called upon Enriqueta. When they were 
gone, came Trinidad [...] General Pedro Cisneros with her daughter Maria [217] and finally Pepa Bazo, the wife of Anibal Gonzales [...] them together, and went to bed before ten.

Thursday, $12^{\text {th }}$ of October 1876 . After a very sound sleep I awoke at five, rose before seven, and whilst Bryson and Ricardo went to bathe ascended to the highest point of the Moro Solar, where the cross stands, and was back by nine. Till 10, our breakfast hour, Bryson read Prescott's Philip II. We took our meals in the corredor, where as yet it was rather cool, but we had no other room for that purpose. The rancho was certainly very small. The time till dinner passed as usual, Bryson reading and writing. At five we went to meet the passengers per train, I being desirous to see Alexander Ruden, who told me that but a few of the guarantees of the bonds of the Eten Railway had been with Garcia Calderon in the morning. That José Canevaro Jr. and Manuel Candamo had proposed to pay to the bank in settlement of all its claims on the Railway, two hundred thousand Soles they by this means becoming the owners of the bonds deposited in the bank. This proposal Garcia Calderon, Forrero, and Heudebert, members of the committee, would now have to submit to the shareholders. Ruden added that Canevaro and Candamo were willing to give to each of the guarantees his proportionate share in the two hundred thousand Soles to be paid by them. These were the outlines of the plan, and if it was really so, as Ruden explained to me, I was very ready to pay ten thousand Soles, by means of which payment I expected to get released of my guarantee for thirty thousand Soles, and to obtain a share in the railway. Time would shew how this turned out. At dinner we were quite by ourselves, and by the 9 train came Guillermo with Eliza. He returned to Lima; she would remain for a few days. Her bed Enriqueta had put up in the room where Bryson and I had been working, and we now removed to the saloon.

Friday, $13^{\text {th }}$ of October. I started before seven, [_] [218] [_], and was back by twenty minutes to nine, consequently this expedition took exactly the same time as the ascent of San Cristoval from the house in Lima, say two hours.

When I dressed for breakfast, I by chance looked in the looking glass which I but seldom do - and immediately the idea came to my mind how often this glass had reflected the image of my dear wife. In the Eclectic of October we read a highly interesting article, which, drawn from one of Cicero's speeches, gives an account of the dreadful state of depravity in which the Roman commonwealth was at the time of Sylla, not many years previous to the subversion of the Republic by Octavianus. I went to Lima by the 1 O'clock train, and had a good deal to do until about five, when I returned to Chorrillos. Amongst other things I paid to Dreyfus $\mathrm{S} / 4000$ for a draft of $£_{500}, 90 \mathrm{~d} / \mathrm{st}$., on 
their London firm at zod which I remitted to Gibbs. Bills of the same firm had been resold at $26 \mathrm{~d}$.

In the waiting room of the terminus I met Ruden who told me that he had seen Canevaro, and that if the shareholders admitted the offer, the affair would be arranged as yesterday explained. In Chorrillos I found part of the family, but she was missing who used to receive me with a kind "¿Cómo te ha ido, que has hecho?" or “¿porque no vienes a darme un abrazo?” The time was spent as always and I went to bed early, Enriqueta keeping me company till half past nine.

Saturday, $14^{\text {th }}$ of October. Last night I awoke, as I regularly did in the nights from Friday to Saturday, but only for a second.

Instead of ascending to the cross I walked along the railway as far as the Barranco Terminus, and back, which took a little more than an hour.

On the $13^{\text {th }}$ La Cotera had entered Moquegua, without having met with any resistance. Pierola was supposed to [...] ted to Torata. In the course of the day [219] I had a visit from Antonio Lavalle, he spo [...] the highest terms of Geraldo whilst he had been in his employ, as second secretary of the Peruvian Legation in Berlin and St. Petersburg, and expressed a regret that he, Geraldo, had abandoned the Diplomatic career.

Virginia La Torre, with one of her daughters, and Josefa Bazo, came to see Enriqueta in the evening. I went to my bedroom at 9.30, suffering a little from toothache, and in very low spirits.

Sunday, $15^{\text {th }}$ of October 1876. It had rained much during the night; the streets and fields were wet; nevertheless Bryson and I walked along the high cliff which runs along the sea shore, as far as the Barranco, where we descended to the beach, ascended again to the station, and walked back along the railway. This walk took us about two hours. Enrique and Antonio were with us at breakfast. Bryson and I were occupied till about two, when I went out to see José Maria Costas, Alexander Ruden, and General Pezet. The first and the last I did not find at home; in the corredor at Ruden's, where his friends were always in the habit of meeting, both in the forenoon, and especially at night-time, whilst his wife, Doña Pepa Puch, was never visible, I remained some time in pleasant conversation. Enriqueta had some visitors: young Pezet; General Pedro Cisneros, and Böhl; these three at least I saw; perhaps more had come in, but I feared that except Enriqueta and myself none ever gave a single thought to our dear Mariquita, to whom, and to whose care, everything in the rancho, at all events the nice and comfortable arrangement was owing. Guillermo, Ricardo, and Antonio, dined with us. Bryson went to Lima, and Ricardo read to me for an hour Rahncke's Popes. We had a visit from Julia Cavenecia, the widow of 
Federico Bergmann, and remained together till 10.30, when Guillermo returned to town. Telegraphic dispatched down to the $10^{\text {th }}$ October were said to have [_] [220] [...] in Lima, which brought the news that war had been declared according to some by Russia to Turkey; according to others England had taken a part with Turkey; and still others merely said the aspect of things looked menacing.

Monday, $16^{\text {th }}$ of October 1876 . By the 11 train Enriqueta and I went to Lima; she had to receive the washed linen, whilst I had to collect some trifles, to ask Scheel for drafts, which he promised, though not the exact amount I wanted and principally to speak to Jose Canevaro about the Eten Railway. After some conversation I agreed with him that if his proposal were accepted by the Banco del Perú, I would pay him S/80oo he would release me from all responsability as to my guarantee of $\mathrm{S} / 30,000$ and I, on the other hand would cede to him all my rights and claims on the railway. In short, I lost the original amount of $S / 15,000$, long ago written off to the debit of Profit and Loss; and incurred another loss of $\mathrm{S} / 8000$, by means of which payment I got released from the stupid obligation which I and many others had taken upon us, para hacer el servicio of bonds, to the amount of $S / 1,000,000$ deposited as security with the Banco del Perú. The servicio was either an unusual interest of $5 \%$ and $5 \%$ annual redemption, or $6 \%$ interest and $4 \%$ redemption; I did not exactly remember which of the two. Perhaps others of the guarantees might in course of time obtain better terms from Canevaro, but I thought I had done right freeing myself of all further annoyances. I was back in Chorrillos in time for dinner, which Dr. Middendorf took with us. Bryson read to me a very tedious part of Miss Stricklands life of Queen Anne, and I went to bed before nine. This day more troops had been embarked for the South, on board the "Huascar" and "Pilcomayo".

Tuesday, $17^{\text {th }}$ of October 1876 . The forenoon passed away pleasantly and quickly. I remodelled the old diaries, Bryson copied them. He was progressing fast, and copied at present in clean the first months of 1862. I took a short, by no [_] pleasant walk through the [...] ields which lie on the [221] right side of the railway going to town. The roads were sandy, and now and then ditches impeded further progress.

Wednesday, $18^{\text {th }}$ of October 1876 . Before breakfast I ascended once more to the cross, this day taking the path near the cemetery which saved a considerable distance, and thus I was back in an hour and forty minutes; nevertheless I felt rather tired. From an article in the Eclectic I took the following interesting statistics regarding Russia. The population numbered hardly ninety million

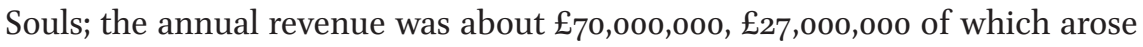
from excise on spirituos liquors. The army cost annually £23,000,00o and for the construction of railways $£_{70,000,000}$ had been borrowed from other 
nations, especially England, hardly one twentieth of which bonds were in the hands of Russian subjects. The only news from the South was that the small steamer which plied the lake of Titicaca, had been taken by a certain Enrique Bustamante, who acted in concert with Pierola. This Bustamante is no son of the late Dr. Pedro José of Arequipa. On board of her was Aurelio Garcia y Garcia on a pleasure trip to Bolivia; he was taken prisoner, but effected his escape. A few small craft on the lake fell also into Bustamante's hands. Don Aurelio had been named by Prado, Comandante General of the military forces in the Department of Puno. In the evening Garland played rocambor at General Aparicio's. Enriqueta, Eliza and I were by ourselves, and retired to rest at about 10 .

Thursday, $19^{\text {th }}$ of October. I went to town by the 1 train, and someway or other was occupied the whole time from 1.30 when the train arrived, till 5 O'clock when I returned. In the evening we were by ourselves. As yet I could not possibly overcome my sadness, when I recollected that we were now enjoying ourselves, or at least that we were residing in the rancho without my dear Mariquita who always one way or other was busy arranging [...] [222] [...]and now no one thought of her except Enriqueta and I.

Friday, $20^{\text {th }}$ of October 1876 . At 1 O'clock I started for a walk. Below on the high road to Villa, the heat was oppressive whilst on the ridge of the hills the fresh breeze from the sea made the temperature very agreeable. As the straight ascent to the cross was somewhat steep, I made twice the attempt by taking a path turning off to the right, to reach it from behind; the second time I succeeded, but the first time I placed myself for a moment, in a really perilous situation, which I shall endeavour to describe. The path ran alongside the mountain, which to the left rose somewhat higher, and consisted of broken ground, whilst to the right it descended in an inclined plane, covered with an unbroken crust of hard earth, down to the bottom of the many ravines which branch off from the ridge, both seawards and landwards. This path, extremely narrow, consisted of deep sand, through which for some distance I walked along without the slightest risk. Then I came to a spot where a strip of flat rock several yards wide, extended from the very top to the bottom; upon this stone those who passed over it had made no impression; in reality there was no path whatever. I ventured a few steps on, but then my heart failed, for I had not slightest secure footing, and I turned back, but where I stood I had hardly room to turn, and it was with the greatest difficulty, taking hold with my hands of the higher ground, which I had now to my right, that I reached the safe sandy path. I recollected the fall which in December 1844 I had near Chamounix, on my way to the Mer de Glace, on a somewhat similar spot. In the evening Guillermo, and a young Enrique Gibson, son of the late James Gibson 
of Islay were with Enriqueta. I, fatigued, went to bed at 8.30, as soon as Bryson had done reading

Saturday, $27^{\text {st }}$ of October. Last night I awoke [_] 1 O'clock, I fell asleep, again awoke, and after some [223] time heard my clock strike four; it could not have [_] otherwise, for it was the night from Friday to Saturday. Eliza went to Lima with her husband. In the middle of the day whilst I left Bryson writing, I took my usual walk, this time a very pleasant one to the Barranco. The ground was dry and the sky clouded. In the Barranco I passed from the one side to the other, where the church stands, over the bridge which spans the descent to the beach, then perambulated this village in every direction, and was astonished to find so many well constructed houses. I returned along the railway. The whole excursion took me nearly two hours and a half.

Sunday, $22^{\text {nd }}$ of October 1876 . This morning nearly the whole family of the Garland's was at breakfast. Eliza had returned, and only Enrique, Alejandro, and Juan were wanting. Telegraphic dispatches were received from the South, which stated that Pierola's inconsiderable forces had been defeated by la Cotera's troops, and that Pierola had fled, nobody knew whither.

Formerly when silver of the fineness of $925 / 1000^{\text {ths }}$ was worth in England about 60 pence per ounce troy, 48 pence the silver Sol, or the ancient Spanish silver dollar, was considered to be par between England and Perú, or $\mathrm{S} / 5$ were calculated to be equal to a sovereign. Now that the value of silver in England had declined to 53 or even $52 \mathrm{~d}$, par had changed in the same proportion say to $421 / 2$ or $411 / 2$, and to make a pound sterling $S / 5.60$ or $S / 5.80$ were required. At about two Bryson went to Lima, and I dressed to pay a few visits, which I did most reluctantly, for I could not possibly overcome my sadness, which pursued me wheresoever I went. Doña Paula Benavides, the old lady and good friend of Mariquita's, was very friendly; with her I found Amancio Castillo, with two of his daughters; one of them, with whom I conversed a few words seemed to be an agreeable young lady. Next, when I looked in at Doña Trinidad's, General Cisneros' wife, I most unfortunately was received by her mother Doña Eusebia, a very old lady who [_] [224] [...] would complete her $93^{\text {rd }}$ year. She knew nothing [_] my loss, and thus enquired very affectionately for my wife, which question I had great difficulty to answer; then Trinidad came in and took me to the adjoining room. My third call was upon General Pezet, where I found an old acquaintance, Col. Arancibia, whom, now white haired and white bearded, I did not recognize. In 1856 after our return from Europe, I used to meet him every afternoon at Fleminex's since when he had been absent from Lima, generally in Brussels more or less sixteen years. The high exchange had driven him home. Gregorio Benavides and Dr. Middendorf dined with us. They and Garland played rocambor, whilst we others had a visit from Böhl, but to me it was always the same. I could not at all enter into a lively conservation. 
Monday, $23^{\text {rd }}$ of October. I went to Lima at eleven, and collected some money, which I took to La Providencia. To my great annoyance a bill of the expenses incurred in my suit against Leyva, lost by me, was presented to me, provided with the Visto Bueno of Dr. Palacios. It amounted to S/117.70 the payment of which could not be avoided. From the present Gerente of the United States Guano Coy., Mr. Parker - the previous one, Vicente Hurtado, had gone to Europe I learned that the price of guano, containing $10 \%$ or more of ammoniac, was in the United States $\$ 60$ currency, that is to say paper money, not gold per ton. From the Lobos Islands two cargoes had gone to the United States, which had not paid freight. They had contained $50 \%$ Stones, and the guano only $2 \%$ ammoniac. The Guañape Islands contained very fair guano; that from the Lobos was decidedly the worst; that from the Pabellon de Pica on the main land, considerably better, though all inferior to that formerly exported from the Chincha Islands. Manure, made from the refuse of fish, was sold in the United States to the extent of 50,000 tons annually. I returned by the 3.45 train. At dinner we were quite by ourselves, and in the evening we had a visit from Maria, and Juana, daughters of General Cisneros. [225]

Tuesday, $24^{\text {th }}$ of October 1876 . Whilst Bryson [...] the remodelled diary, I did not go out but sat in the corredor, dizing, calculating and thinking. Garland did not come to dinner, but arrived past 10 O'clock, he having dined with Rafael Velarde, whose Saints day it was.

Wednesday, $25^{\text {th }}$ of October. Before breakfast I ascended to the cross, which took me till I was back in my rancho fully an hour and a half. Alejandro came in and told me that he had settled his lawsuit against the Banco Anglo Peruano. The Banco Nacional owed to the Banco Anglo Peruano, and the former bought the billetes from Alejandro, paying him a premium of $18 \%$. They had cost him one with another $8 \%$, but from the $10 \%$ gain, had to be deducted law expenses and interest.

The "Nacional" contained the project relative to the Central Bank signed by José Aranivar, Minister for Finances, and the 8 Delegates, viz.: F. Garcia Calderon, and M. Moscoso Melgar of La Providencia; Dionisio Derteano, and Guillermo Scheel for the Nacional; M. G. Chavez and J. Calderoni for Perú; and Focion Mariategui, and Pedro Bernales for Lima. This project would now be laid before the Congress, and if approved of, would be law of the country, when I intended to give the particulars in this my diary. Just before dinner Bryson and I walked a short distance along the beach, and returned the same way to the bathing place. We, or more properly speaking, Bryson, for I could not distinguish well, observed the different layers, or strata, of which the high cliff is formed; on the top lay one of earth; below this, one of round stones, which clearly denoted the action of the sea; below this another of earth, again one of pebbles, and at last another of earth, which extended to the pebbly beach upon 
which we were walking. Now this proved evidently that the sea must gradually have retired. At first it reached so high up as where the highest strata of stones was discernable; centuries back it once more retired and left the second layer of pebbles [_] [226] [...] whether it will not again retire, and many genera[_] later the present beach will form part of the cliff.

Thursday, $26^{\text {th }}$ of October 1876 . I went to town by the 11 O'clock train, for the purpose of getting a few bills from Dreyfus who drew at $28 \mathrm{~d}$, but they were not yet signed. Other bills had been sold at $25 \mathrm{~d} 1 / 4$ the highest exchange hitherto paid. Coined silver was at a premium of $55 \%$; Silver bars ley 993 at S/ 16 the mark. I looked in at the Insurance Company Lima, where I had not been for a long time. The insurances effected had been few, but loans were always being made. Whilst I was there, one of $\mathrm{S} / 35,000$ for four months at $12 \%$ annual discount to Rufino Echenique, with sufficient guarantee. Don Carlos Elizalde, the Gerente, related to me that the meeting of the previous day of the shareholders of the Banco del Perú, had been a stormy one, similar to the last. The minority, which called itself the opposition, and of which, as previously said José Maria Peña was the head, disapproved of the offer made by José Canevaro of $S / 200,000$ in payment of the banks claim on the Eten Railway Company, and after a violent discussion it had been resolved that the committee named for the purpose, viz.: F. Garcia Calderon, Dr. Forrero and Heudebert should endeavour to obtain one half of the original debt due to the bank by the railway, exclusive of interest. Fabre, the French carpenter, presented in his name, and in that of forty shareholders, a protest against the Directory, which, they demanded should resign, and another be named. It was put to the vote, and negatived by a vast majority. In the minority voted, the two Costas, Cipriano Correa, the hatter Cipriani, one of the principal speechifiers on the side of the opposition, Carlos Paz-Soldan, Figari, and others. In the majority voted against all expectation Jose Maria Peña.

Friday, $27^{\text {th }}$ of October. I went to Lima by the 1 O'clock train, obtained the bills from Dreyfus, and closed my letter to C. W. Schutte, and A. Gibbs \& Sons. Within these days Dr. Eusebio Sanchez had been named Vocal de la Corte [_] in lieu of Dr. Blas Alzamora, who had resigned his [227] post on account of old age. The Tribunal de [_] which hitherto had been the court of Justice to which the appeal lay open from El Tribunal del Consulado, had been abolished, and henceforward the Superior Court of Justice was the $2^{\mathrm{a}}$ Instancia. In the evening we had a visit from a clergyman, Gregorio de la Rosa, Capellan de los Desamparados, who seemed to be a very intelligent and agreeable man.

Saturday, $28^{\text {th }}$ of October. I awoke in the course of the night but did not know the hour, nor was I awake long. 
In the course of the forenoon Enriqueta called me to look over with her various papers and other things which she had found in a small working table used by my wife. There was nothing of the slightest importance, but I was glad to find a letter which she had written me in May 1842, a few days after my departure for the Northern Provinces of Perú. See Appendix $\mathrm{N}^{\circ} 10$. It will be seen by the same that she personally attended to the repairs of the house Calle del Corréo, which I had just bought from the family Maldonado. The individuals Pastrano, Gorochano, and Forcelledo were persons belonging to this family who caused us much annoyance after the purchase had actually been made. The compadre Don Carlos is Mr. Charles Pflücker who acted for me during my absence, and rendered my wife every service which she stood in need of. Corina, then about five years old, is the present widow of Ferdinand Cordes. Doña Carmen (Bustamante) an Arequipa lady who resided at the time with us.

Sunday, $29^{\text {th }}$ of October. At a little past six in the morning Bryson, Ricardo, and I started for a walk to the hacienda, or sugar plantation called Villa, owned by the family of Goyeneche, and situated perhaps a league from Chorrillos, more or less to the S.E. We walked along the sandy road, keeping to the right near the foot of the ridge of hills, stopped now and then looked at the $[\ldots][228][\ldots]$ up a skull or a piece of ancient texture. The [_] was overcast, and thus we did not suffer from heat; I was desirous to reach the beach, but though we trudged along bravely, it got too late, and turning off to the left, always over an arid, sandy plain, we came to the cultivated fields of the estate. Again we had to walk along a sandy lane before we came to the houses of the plantation. On entering the large building two individuals presented themselves to shew us where the sugar cane was ground and the sugar boiled. The machinery seemed to me very plain, and could not have cost much money. The principal wheel was put in motion by water power; this large wheel moved a smaller one, and this again three iron cylinders, two below one above. The whole day long Chinamen, of whom there were 160 on the estate, placed the cane between the cylinders. The juice is pressed out, and runs into a subterranean canal to another part of the building. On the other side of the cylinder the sugar cane reappears, dry, without a drop of juice; it is called "gabazo", and serves for fuel. The juice is boiled, partly by means of fuel placed below, partly by steam introduced into the Pailas. These Pailas, of which there are six or seven, are circular receptacles made of copper, wide above, and narrowing towards the bottom. How long the sugar remains in these pailas I did not enquire. The scum which gathers on the surface, and which contains all the impurities, is skimmed off, and poured into another small receptacle close by, whence it finds its way underground to the 
distilling apparatus, where that kind of rum is made of it which is used all over the country for burning. When the sugar is sufficiently boiled in "the pailas" it is poured into moulds of zinc, with a hole at the bottom where the treacle filters out. This filtering has the technical term of "purgar". In these moulds the sugar remains a considerable while, in the warm season perhaps three weeks, in the wet season, a longer period. When sufficiently [_] it is taken out and now appears in the shape of large [229] loaves not refined. There is also some [...] the centrifugal, put in motion by steam. How it works we did not see, because it being Sunday all labourers were at rest. We were told however that in about a quarter of an hour the sugar is produced in the shape of powder, of which we saw heaps lying on the ground, some a lighter, some of a darker color. We thanked the persons who had shewn us round and then made the best of our way home along the sandy road we had come. We were in time for breakfast. I somewhat tired. Bryson wrote and read as usual in the forenoon, and went to Lima. I paid two or three visits. José Maria Costas was not in; neither was Böhl; in his rancho the same which he had formerly occupied jointly with Macandrew, I found a German who was now his co-tenant. He knew me, and I remainded a short time with him, though I had no idea who he was. At Ruden's I met Calderoni, Vice-President of the Directory of the Banco del Perú, who had the fame of knowing something about finances. In one of the daily papers he had proposed a plan by means of which in his opinion the present miserable financial state of the country could be mended, and the exchange on England again be lowered to 38 or 4 od per Sol. Lembcke had published an article in opposition to Calderoni's, but as I did not believe that the ideas of either the one or the other would ever be carried into effect I thought it unnecessary to give the particulars. At 5.30 I went for a few minutes to Josefa Bazo whose birthday it was. Her husband Anibal Gonzales was there, whom I had not seen since his return from England. He looked old, and had become grayhaired. In the evening we had a short visit from Juanita, a genteel daughter of Don Domingo Valle Riestra, and her vulgar looking husband José, son of the [notary] public Sel[_]. [230]

Monday, $30^{\text {th }}$ of October 1876. Enriqueta and the [_] little girls took their first bath. By the 1 train I went to Lima, where I had hardly sufficient to do to keep myself occupied till near five. Gustavus Rehder told me that as at present they effected no sales on credit they could give me no pagarées to discount as they had done hitherto and that he expected to be able to pay me all they owed by the end of February next. Eliza and her sister Maria Luisa dined with us. Guillermo came afterwards and they returned to town by the last train. My spirits were unusually depressed - I always thought of my dear wife. 
This day arrived from Chile Magdalena, President Prado's wife. In the evening we saw from our rancho the fireworks which were let off in Lima in celebration of her arrival.

Tuesday, $3^{7^{s t}}$ of October 1876. I remained in Chorrillos and spent a quiet day. In the forenoon whilst Bryson was writing I ascended to the cross. The sun was out which made me very sleepy, and thus I went to bed early. In the Eclectic for August 1875 we found an article taken from Blackwood's Magazine, which says that the English Government had fitted out an expedition to the North Pole. No expenses had been spared, and everything had been arranged upon the most approved plan. The steamers - how many in number was not said - were to be commanded by Captain Nares. They were to take their way up Baffins Bay, through Smith's Sound, and Kennedy's Channel, as far North as possible by water, and then to continue their journey by sledges, some drawn by dogs, others by men. Though it was not stated I was of opinion that these sledges were so constructed - in the same manner as Parry's were in the Expedition of 1827 - that they could be converted into boats [_] used as such. Parry reached to the North of [231] Spitzbergen $81^{\circ} 5^{\prime}$ North Latitude, since when [...] tall in the US Gunboat "Polaris", reached $82^{\circ} 16^{\prime}$ ' the highest latitude as yet attained. The lowest temperature, or in other words the greatest cold which had ever been noted by observation has been that experienced by Neveroff on the $21^{\text {st }}$ January 183 [_] in Jakutsk in Siberia, when the quicksilver marked $76^{\circ}$ below zero of Fahrenheit.

Wednesday, ${ }^{\text {st }}$ of November 1876 . Being a holiday I started on my customary errand, that of making calls. At Felipe Varela's the door was shut; so was that of Jose Maria Costa's house, and I merely was about twenty minutes with Julia Cavenecia, no doubt a very good woman but of no shining intellect. Enriqueta looked over the papers found the other day in my wife's working table. There was amongst others, a letter written by Luis Orbegoso, President of Perú in the years 1834 and 35, directed to Mrs. Schutte which I keep for the sake of the signature. See appendix $\mathrm{N}^{\circ} 11$. Also another document worth preserving, viz.: copy of a protest drawn up by Felipe Santiago Salaverry, a short time before his being shot by order of Santa Cruz, $\mathrm{N}^{\circ} 12$.

We were by ourselves at dinner, and at a later hour Bryson read to me Queen Anne's life by Miss Strickland, generally dull, and too detailed, this evening more than usually interesting. Queen Anne was in my opinion a poor miserable woman, of weak intellect, with no will of her own, vulgarly bred, badly educated, and little instructed. Towards the end of her life she was fat to unwieldiness, at the same time a voracious eater. She died on the $1^{\text {st }}$ August 1714 . 
Thursday, $2^{\text {nd }}$ of November 1876 . We saw by the papers that on the previous day Meiggs had run express trains from his various Lima stations to the entrance of the pantheon, and it was computed that nearly 20,000 persons had availed themselves of the same. Last steamer brought us the news of the death of Dr. Grau, who after protracted and dreadful suffering had died [_] [232] [_] which had shewn itself here in Lima on his face, and of $[\ldots]$ he had been in hopes to get cured in Europe. Juan's letter was of $30^{\text {th }}$ Septr. On the $7^{\text {th }}$ October he intended to embark in Bordeaux. He had sold all his $5 \%$ Anglo Peruvian Bonds, £10,000, at $141 / 4 \%$. £16,00o at $143 / 16$, which sale must have left him a heavy loss. The Turks continued their cruel war against the Servians, and Montenegrinos; hitherto the great European Powers contended themselves with exchanging diplomatic notes. In the forenoon I did not leave the house, and took my bath at 4.30. It was not too cold, and I enjoyed it. Before dinner I asked Garland what advices he had received from Gibbs regarding Dr. Palacios' diamonds consigned to them. His answer was that Gibbs had begun their letter with expatiating on the bad state of trade in general, and the consequent difficulty of selling diamonds. They then said that a partner of one of the first jewellers in London had come to their office and examined the diamonds which, as I had expected, he declared to be in all probability Cape diamonds, that their yellowish color made them of very difficult sale in England, and that such precious stones found only takers in Constantinople, for which market, under present political circumstances, there was not the slightest demand. He valued, the hundred and twenty odd carats which they weighed at $£_{15}$ the carat, thus the entire lot about eighteen hundred and odd pounds. Gibbs had then called in a first rate Dutch Jeweller who was by chance in London; he valued them at $£_{20}$ and offered $£ 10$. Rönacher here in Lima had valued seven of them at $S / 48,000$ silver. Palacios said that they had been valued previously at 65,000 , and two more at $S / 20,000$. Accordingly the Lima valuation of $S / 85,000$ Silver was reduced in London to 1800 or at the utmost $£ 2400$ Stg. which at the most favourable exchange of the day would only yield eighteen or twenty four thousand Soles paper. Palacios now spoke of selling his house, which as he held it in enfiteusis only for 42 years longer, could not fetch the amts [_] which he had mortgaged it, viz. S/31,00o to Antonio Bazo [233] and I did not know how much to Garland. [...] had escaped, but how Garland would now return to me the sixty Cedulas of one thousand Soles each, was more than I could say. In the evening we finished Queen Anne's life. The dead body of her father James II stood overground more than one hundred years; he died at St. Germain en Laye in 1701, and was buried in the same place in 1813 by order of George IV.

Friday, $3^{\text {rd }}$ of November 1876. In the forenoon I took a pleasant walk to the Barranco along the Alameda which was now being made, descended to the beach and returned along the cliff. I again bathed at 4.30. 
Ricardo brought from Lima a written notification made to me by a notary at the request of Fabre, and other shareholders of the Banco del Perú on the subject of the suit which they had instituted against the gerentes of the bank referring to the guarantee often spoken of, and given by me and others.

Enrique brought dispatches from the Danish Govt. with a small casket containing a cross, and the white and red ribbon belonging to it. What cross it was I could not say until the letters written in Danish were read to me by Rönacher. Coined silver was at $54 \%$ premium; silver bars, ley $993, \mathrm{~S} / 15.80$ to $\mathrm{S} / 16$ the mark.

Saturday, $4^{\text {th }}$ of November 1876. I awoke last night, as I always did in the night from Friday to Saturday, but did not know the hour, and immediately fell asleep again. La Cotera with the troops under his command, who had returned from the South, made yesterday their entrance into Lima. It was now known for a certainty that La Cotera on his march from Los Angeles to Yacango, exposed his troops to the greatest danger, that the rearguard was actually beaten by the enemy, and that the whole division might easily have been defeated, had [234] [...] possessed the silghtest notion of strategy. The two Ministers, Aranivar of Finances and J. A. Garcia y Garcia for Foreign Affairs, had within these last few days an angry dispute in the presence of several witnesses. Aranivar counselled Garcia to obtain another commission for the purchase of Monitores in the United States, whereupon Garcia retorted, referring to the round sum of money which Aranivar had received when Minister of Balta, from parties interested in the dirty affair of the English Guano Company, and Thompson Bonar \& Co.

In order that Bryson might have time to copy the remodelled diary - in doing which he made fast progress - I absented myself every day more or less two hours. This forenoon I crossed and recrossed the ridge of hills, without ascending to the cross. No pleasure was to be derived from these exertions, for there was nothing but sand, and everlasting sand; the only vestige of vegetation found in certain spots is a unusually sapless plant which has no root, and draws its nourishment solely from the atmosphere, and which goes by the vulgar name of "piña sin marona", for its leaves bear some resemblance to these of the true pine apple. I have not seen it bear any fruit. Its flower was large, but dry, and whitout any sap. Though I derived no pleasure I was confirmed in my opinion that notwithstanding my advanced age, much exercise did not easily fatigue me, and did no harm to my constitution.

In the evening Garland played rocambor at Varela's whilst I conversed with Enriqueta till half past ten.

Sunday, $5^{\text {th }}$ of November. I took my bath at 8 O'clock. At two, when Bryson and I had finished our occupations I went out, and called first upon Ruden whom I found by himself, and with whom I had a long talk. He told me amongst other things that a notification similar to that received by me had been made 
to himself and to [235] the various persons who had guaranteed the $[\ldots]$ the so often spoken of bonds, amounting to one million Soles, deposited with the Banco del Perú, and that they had resolved to present each a separate escrito, so that the carpenter Fabre and his thirty eight associates would be under the necessity of carrying on a number of lawsuits which would naturally cause them a very heavy expense, and by proceeding in this manner hopes were entertained that they, who were the minority of the shareholders of the Banco del Perú, would at last give in, and yield to the majority which was desirous to come to a friendly understanding not only with the guarantees, but also with the original debtor, the Eten Railway Company.

From Ruden's I went to the handsome house of the late José Maria Varela, inherited, and at present occupied by a second son Felipe, the lawyer, and his wife Rosa Orbegoso; they were not in, having gone to Lima to witness the extraordinary performances of the famous rope-dancer Blondin, who exhibited himself in the park of the Exposition Palace. I was received by one of Don Felipe's sisters, widow of Llerena; with her was a young man, unknown to me, but who, I learned afterwards, was a Chilian Irrarzabal, son of the Chargé who committed suicide in Chorrillos many years back. He was married to one of the daughters of the Chilian Ramos, owner of a sugar estate in Cañete, whose children were now quarrelling about the division of the property left by their parents. At George Elster's all was shut up. With Doña Paula Benavides I remained some time, and finished with a call upon our neighbour Federico Panizo and his wife Manuela Orbegoso. He talked exclusively about a law-suit he was carrying on with a natural son of his father, who claimed part of the property. When I, a few pages back spoke of this Panizo, I believed that he was on good terms with his mother, but this was not the case. Without [_] [236] [_] she had turned him out of her house, together with [_] entire family, and he now resided in Chorrillos until he could find a home in Lima to his liking. Fortunately he had a property of his own left to him by his father, a very valuable farm, not far from Callao called Maranga, from which he derived a very handsome annual income. In our rancho we had a visit from Anibal Gonzales and another from Federico Pezet, and his English wife. Guillermo and Eliza dined with us.

Monday, $6^{\text {th }}$ of November. With Enriqueta and the little ones I went to Lima at 9 and the whole day till $5 \mathrm{I}$ had so much to do, and so much to run about that I actually forgot to be present at a meeting of the Directory of the Insurance Company Lima, which had been one of the objects of my going to town.

Rönacher read to me the dispatches from the Danish Government who admitted my resignation of my Consulship which I had sent in several months back - and which I then omitted to mention in my diary, and who now made me commander of the second degree, of the order of Dannebrog, 
of which they sent me the cross and ribbon. My former cross of Knight of the Dannebrog I was requested to return to the Chapter in Copenhagen. Twice, or even three times I went to the counting house of Dreyfus in search of Scheel, from whom I wanted to get Bills on London; to the house of Felipe Varela, with whom I wished to speak about the Eten Railway; to the office of the Minister for Foreign Affairs, to whom, or the oficial mayor I had to say that I had thrown up my post as Danish consul; but all was in vain, for Scheel, the only one whom I found in, could not even promise me the bills on London of which I stood in need. With Becker I had a long conversation about the mortgage which his firm had to give me as a security for the credit which I had opened in their favor, with Köpcke, and with Grönewald of Hamburg [237] From Carlos Paz-Soldan I collected another divid $[. .$.$] the telegraph bond received long ago in payment$ from Escudero and Roca. Finally I went to Dr. Palacios', who dictated an escrito in answer to the notification of Fabre and others. He declined the jurisdiction of the Juez de $1^{\text {a }}$ Instancia; this being an affair to be settled by the Consulado; also declined La personeria, because Fabre and others had to submit to the majority according to statutes of the bank; in short he did not contestar but exceptuar; in other words he merely threw difficulties in the way, exactly as I wished him to do. On my arrival in Chorrillos I was much fatigued and ate hardly anything. Enriqueta suffered from migraine. Bryson began reading to me Tristram Shandy by Sterne, which did not please me so much as it had done on previous perusals. Afterwards I had a visit from Felipe Varela with whom I conversed about the Eten railway. The "Nacional" of this night contained a copy of a contract concluded between the Government and Oliphant \& Co. of Hong-Kong, whose partner H. Seymour Geary was at present in Lima, for the immigration by steamer, of free labourers from China to Perú. Their steamers would make twenty eight round voyagues during the five years that the contract lasted. By each steamer five hundred labourers would be shipped. The Peruvian Government paid them a subvention £16o,ooo Stg. in various instalments as specified in the contract. I have already mentioned that the $£_{50,000}$ which the Government drew at the end of each month upon Raphael Raphael \& Co. were always brought up long before the bills were issued; the takers made large profits by these rather hazardous transactions; they bought them at $30 \mathrm{~d}$ and sold them at 26 , and 25 . In order to put an end to this abuse, José Aranivar, the Minister of Finance, issued a decree, a copy of which I affix in appendix under $\mathrm{N}^{\circ} 13$.

Tuesday, $7^{\text {th }}$ of November 1876. I remained in Chorrillos, did not walk out in the forenoon and bathed at $1[-] \cdot 30$. [238]

Wednesday, $8^{\text {th }}$ of November 1876 I went to Lima at 12 and when there directly to the office of the Insurance Coy. Lima. Carrol had resigned his post as Director, for within a few days he would embark for Montevideo, there to take charge of 
the house of Bates Stokes \& Co. Isaacson, married to a Miss Wilson, daughter of that Capt. Wilson of whose queer marriage with the daughter of John Warde and Joaquina Chocano I have given an account in my diary, succeeded Carrol as head of the firm. José Maria Peña left this day for the South, accompanied by Julius Pflücker, one of the clever sons of Don Carlos, and by Manuel Ortiz de Villate, a practical miner of the Cerro de Pasco, with the object of examinig some silver mines which he possessed in the province of Huancane. They would take the steamer to Mollendo, the train to Arequipa, thence to Puno, again the steamer upon the Lake of Titicaca, and finally they would have to go one or two days on mule back. Consequently we were only the five Directors required to form a quorum: Moscoso Melgar, President; Robertson, Gil, Chavez and I; and Elizalde, Gerente. Nothing of particular interest was laid before us; instead of Carrol we elected Henry, Director; and fixed a day for an extraordinary meeting of the shareholders for the purpose of altering an article in the statutes which had hitherto shackled the Directors in the distribution of the annual dividend. The question was also mooted whether we would form amongst ourselves a small knot of private underwriters in the same manner as the South American Insurance Company had done, for the purpose of taking the surplus of risks which the company, in comformity with its statutes, could not take in their totality. From Scheel I took a bill of his own on Albers and Gildemeister of

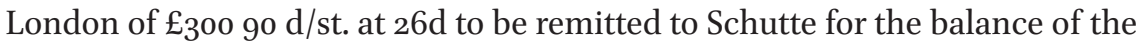
gas dividend received by me for him. I also made a proposal to the Caja Fiscal to [_] of the Government's drafts of the $27^{\text {th }}$ [239] December and $27^{\text {th }}$ January, $£_{743}$ each [...] Alejandro promised to attend to this petition of mine. Finally in the Ministry for Foreign Affairs I saw Salasar, the Oficial Mayor, to whom I mentioned that I had given in my resignation, and that my government had admitted it. I returned to Chorrillos at 3.15 and bathed at 4.30. In the evening we had a visit from young Luis Bryce, and his wife Grimaneza, daughter of Mr. Cotes of Paris. Alejandro brought me a fresh notification by the notary Perez Egaña, who was in the juzgado of Olivares, the object of which was to make known to me, and all guarantees of the bonds spoken of, that Alejandro Ruden had cancelled his guarantee. I begged Alejandro to speak to Felipe Varela about it and on

Thursday, $9^{\text {th }}$ of November 1876 in the morning he brought me Varela's answer, that as those who had guaranteed, had not done so de mancomun et insolidum, but each by himself for a certain amount, Ruden was quite justified in cancelling his guarantee in the manner he thought proper. In the forenoon under a broiling sun I walked to the Barranco, and back, which, added to the very cold bath at 4.30, was probably the cause of my extraordinary drowsiness 
which drove me to bed before nine, and made me sleep the whole night, without awaking till

Friday, $10^{\text {th }}$ when I rose in very low spirits. In the forenoon whilst I left Bryson writing I merely walked up and down the malecon for about an hour.

As private individual, not as Consul, I wrote to the Ministers for Foreign Affairs, both in Copenhagen and in Lima; to the former I gave an account of the general state of the country; to the latter I made known that I had resigned my post of Danish Consul General in Perú. In the evening we had Doña Virginia, wife of Domingo Valle Riestra with us. I accompanied her home, and entered her house, where I found her hus [...] [240] [_] of para[_]. Of the few words which he attempted to [_] to me I could not understand a syllabe, so totally lamed was his tongue.

Saturday, $17^{\text {th }}$ of November. I passed a bad, and sleepless night. The Nacional said that war between Russia and Turkey had actually broken out. I went up to the cross; my bath I took at the usual hour. Josefa Bazo dined with us. Alejandro told me in the evening that he had resold £10,00o bought from Mathison at $25 \mathrm{~d} 1 / 2$ part at 25 , part at $251 / 4$, and a small balance at $251 / 2$ pence.

Sunday, $12^{\text {th }}$ of November. I awoke last night just before four; a slight pain in the waist prevented my bathing. When Bryson was gone Ricardo read to me for about an hour Rahncke's Popes, and at about two I went out. I first called upon Ruden, where I met José Calderoni, Dr. Carranzas, one of the editors of the Comercio, José Maria Costas, and a certain Toribio Calmet, unknown to me. The contract between the Government and Oliphant was the main topic of conversation; there was a general outcry against it; for it was almost impossible to draw it out in a manner more favourable to Oliphant; more unfavourable to the Government. There could not be any doubt but that Garcia y Garcia would receive a handsome remuneration from Oliphant if the contract passed the Chambers, and was really carried out. I left my companions because I saw the rocambor table laid out, and was perhaps half an hour with Virginia La Torre, and her daughter Juana, both very nice ladies. At Elster's I only found him, for his wife Mercedes Soyer, who shortly expected her confinement, did not like to show herself. As the astma from which he suffered did not allow him to live in Lima, he had rented Lanfranco's house in Chorrillos for three years, and fitted it up, and furnished it with great elegance. When I returned to my rancho [...] Enriqueta expected from Lima had [241] arrived. Garland, Gregorio Benavides, and José Basagoytia sat at the rocambor table in the corredor. In the parlour were: Enriqueta with the wife of Federico Palacios, with Juana Rosa Basagoytia and her two grown up children Enrique and Filomena. Federico Palacios had gone out with Geraldo to take a stroll. Malinowski and Dr. Middendorf called, 
and both were requested to stay to dinner. At this meal I sat next to Federico Palacios, and did my best to keep up a conversation with him, which was rather a difficult job, though he was an agreeable and well instructed man.

Coffee having been served by Enriqueta - who in fact did everything. Garland, Benavides, Basagoytia and the Doctor again sat down to rocambor, and I had once more to converse with Palacios. I was really glad when at 10.15 all said good bye to return to Lima by train.

Monday, $13^{\text {th }}$ of November. Once more I awoke at 4. I also heard a cry of Witt, of course imaginary, but the pain I felt in my waist was not imaginary. I therefore arose, early, and stiff and painful as I felt walked many times up and down the malecon which certainly did me good, for at a later hour I felt hardly any pain. At 12 I went to Lima where I had all kinds of things to do. From Scheel I got the draft of $£_{300}$ previously bought. From Alejandro I purchased ten shares in the Banco Hipotecario at 55\% and lent him S/16,0oo for 3 months at $1 \%$ monthly discount upon the security of forty shares. When I reached the terminus at 5 O'clock, the train had just started, and the time till the 6 train I whiled away in the store of Knauer \& Pfaff, conversing with both. In Chorrillos I ate a poor dinner, Bryson read to me Prescott's life of Philip II. I took my usual cups of tea, and conversed with Enriqueta till ten. Garland [...] [242] [_] arising no doubt from having caught cold by bathing, seemed to be gone, but on

Tuesday, $14^{\text {th }}$ at 5 a.m. I awoke again suffering from it. In bed I could not find any position which would relieve my pain, and thus, half-dressed, and well covered up I lay down upon a sofa in the drawing room, and slept till half past seven.

The whole day long the pain in various parts of my body continued, and though I made an effort to cross over the hill to the Salto del Fraile, never before, I think, had the ascent of such a trifling height been so difficult to me. I ate hardly anything at dinner.

Wednesday, $15^{\text {th }}$ of November. At 3 a.m. I awoke with such a violent pain in my left knee that it was impossible for me to remain in bed. I again lay down on the sofa in the drawing-room where, well wrapped up I found myself more at ease. A few minutes past half past four when I was wide awake, we experienced a pretty severe earthquake of unusual duration. I really feared that the roof would come in, nevertheless I did not stir. Towards 8 O'clock I got up, but the pain had now settled in the left knee and could hardly be tolerated. I managed to dictate a few words, and without taking breakfast I went to bed. Enriqueta brought me a bowl of hot milk with a little cognac, which made me perspire profusely, but the pain increased instead of decreasing. She applied other palliatives but all in vain. Of course I ate nothing. I was assisted to the sofa in 
my bedroom where I lay down and thence to another sofa in the saloon. Here I passed a sleepless night till

Thursday, $16^{\text {th }}$ of November. Enriqueta on the other sofa slept as little as I, though in reality she could render me but little assistance. At seven O'clock a telegram was sent to Middendorf. He was with me at 10. After having looked at my knee, and listened to the account of what I had suffered, he declared that there was water in the knee [...] to an inflammation in its [243] articulation, and this, no doubt was the consequence of [_] having taken cold in the bath, probably on Saturday last. He prescribed a blister and an opening medicine. The former was applied to my knee, the latter I took. I passed a most miserable day, in bed of course. The only nourishment I took was a glass of lemonade. Eight or ten times the medicine called me up, but each time I required some assistance to reach the chamber. It was readily rendered me by Enriqueta, by Bryson, or by the servant girls, nevertheless whensoever I felt a little at ease, I managed to correct my old diary; we were now in January 1863.

Towards evening the blister was taken off, when a quantity of liquid matter like water, ran out, which was exactly what Middendorf had had in view when prescribing the blister. After Enriqueta had dressed the sore, all the Garlands, also Eliza and Josefa Bazo, came in to see how I was. From them I learned that on the previous evening, a consultation of several physicians had been held in the rancho of Don Domingo Valleriestra and that little hopes were entertained of his recovery. Also that Dr. Tomás Davila had died on his estate near Moquegua. With this Davila I had become acquainted in Arequipa in 1859. Shortly after he with his family settled over to Lima where he filled the post of Juez de $1^{\text {a }}$ Instancia, and occasionally that of provisional Vocal of the Superior Court. When the visitors were gone I was awake for more than three hours, but such a mass of confused thoughts crowded my head that I could not form a single clear idea. It was past midnight when I fell asleep

Friday, $17^{\text {th }}$ of November 1876. I awoke at about 5 , when day broke through my window. The pain in my knee seemed to be gone, and I now only felt the burning of the sore.

To Enrique, whose birthday it was, I gave my usual present of S/100. [244] [_] Dr. Middendorf came he thought that I was much b[_] for the principal pain was gone; also the fever from which I had been suffering yesterday; but my debility was extreme, and all over the body I felt some trifling pain owing no doubt to the many hours which I had necessarily to lie in the same position. At one I took some sustantial broth with an egg, and half a glass of wine with water. I remained in bed the whole day, took again some broth, and was upon the whole pretty well. Alejandro, who came in in the evening, told me that the 
evening before he had been with Pardo and several others in Ruden's corredor, that the present Ministers, principally Aranivar, and Garcia y Garcia were continually quarrelling, and that the majority in the Congress upon weighty matters, was generally opposed to the wishes of the Executive. He added, but this I could hardly believe, that already now a considerable party of politicians thought of re-electing Pardo for the next constitutional period. Bryson read to me from the Eclectic of November two highly interesting letters written by Mrs. Wordsworth, and her son Charles who were wrecked on board the Strathmore in July 1875 upon one of the rocks called the Twelve Apostles comprised in the Crozet Group; they struck at a quarter past three, in a cold, wintry and foggy night. About one half of the people on board, including the captain, were drowned, whilst the other half amongst whom Mrs. Wordsworth, the only lady, were saved in a life boat and a quarter-boat, and landed upon a small ledge of rock from which another steep rock rose to some height; the men managed to climb, whilst the lady was hoisted up. Before the vesseI went to pieces they fetched from on board some provisions, and trifles of little importance, also a pretty large quantity of wood. Upon this rock grew nothing whatever but some rank weeds, not even grass. The sole inhabitants were small white doves or crows, to which the party gave the name of thieves on account of the cleverness with which they robbed and picked the eggs of the birds of passage which visit [_] rock at certain periods of the year, albatross, penguins, [245] Stink pots - a class of carrion bird - and Mollyhawks. [_] this inhospitable spot the party remained seven months, feeding all the while, as soon as the provisions from onboard were consumed, upon these birds and their eggs. When they became apprehensive that their fuel might soon get consumed they dried the oily skin of the penguins which would do for fuel. The sheds under which they lay were nothing but protruding pieces of rock against which rested walls made of sods which they had to tear up with their hands, not having a spade with them. A few of the party, amongst whom an old quartermaster, and a child, died in the course of these seven months. When the signals which the party made with waving blankets, were observed by a North American Whaler, the "Young Phoenix", this vessel came to and took them all on board. They were transhipped to other vessels, and the mother and son landed at Rangoon. This night I persuaded Enriqueta to sleep in her own bed, whilst Bryson lay down on the sofa in my bedroom. The opening medicine continued to inconvenience me; and the whole night, it was that from Friday, to

Saturday, $18^{\text {th }}$ of November I did not sleep a wink till five in the morning. I felt much better, but could not walk as yet, and only limped about a little, being sustained on the painful side. Dr Middendorf would not allow me to get up till Monday. 
Antonio came from Lima; he had badly injured his eye and arm by a fall with a velocipede. The advices from Europe received by yesterday's steamer spoke a great deal about the Turkish affairs. England had sent great naval reinforcements to the Mediterranean. In the Lima Congress a motion had been made by a certain Flores to suppress the convents of Santo Domingo, the Merced, and San Agustin, which had at once been admitted to discussion by the Chamber of Deputies. The Pol[_] [246] [_] under Capt. Nares, which I mentioned page 230, had returned to England and Captain Nares given his opinion that the Polar sea is not navigable.

Sunday, $19^{\text {th }}$ of November 1876. Last night from 11 to 1 O'clock p.m. I suffered much from the pain in the knee; I was almost despairing, and did not know what to do with myself. Bryson assisted me in turning round, and at last, contrary to my expectations, my sleepiness overcame the pain and I slept soundly till this morning at somewhat past five. I felt pretty well and until 1.30 Bryson and I were indexing my diary of 1855 . He then went to Lima whilst the remainder of the day I spent as well as I could, always in bed. Ricardo read to me a good deal from Rahncke's Popes. Poor Enriqueta suffered from her usual migraine. Garland was out the whole forenoon playing rocambor. Middendorf came to dinner and on my telling him what I had suffered on the previous evening, he prescribed a few drops of landanum to be pored on bread softened in tepid water, and this to be placed upon the painful knee. We shut up at about 9, and I slept till 11, when I awoke with pains similar to those of last night. I felt as uneasy as I then had done; I had to call Aurelia, the negro servant who had lain down on the sofa in my room, and after an hours turning, tossing and complaining, at 12 I again fell asleep, and slept soundly till

Monday, $20^{\text {th }}$ at 5 a.m. Middendorf was with us at an early hour, and bandaged my painful leg as tightly as possible, leaving however the joint of the knee quite free. He also ordered eight quinine pills to be taken gradually before 6 p.m. by means of which he expected to overcome the pains and uneasiness which seemed to make their appearance every evening at a fixed hour. Little Corina had suffered from her chest the previous night, and Enriqueta, ill as she was, had hardly been able to sleep an hour or so. From [_] particulars given in a Boston paper of Capt. Nare's Artic [247] expedition, I inferred that the difficulties to reach the $[. .$.$] are really insurmountable, and that therefore$ both Governments and private individuals would henceforth abstain from directing their artic expeditions in this direction. I took my pills, remained in bed, dictated to Bryson, listened to his reading, and so the day passed, not pleasantly to be sure, but it passed. Bryson began reading to me Cromwell's Letters by Thomas Carlyle; but the prose written by the latter, which serves as a background to the letters themselves, is written in such a decided Carlylean 
style that in my present weak state I found it impossible to understand everything. At one or two O'clock in the morning I had the same difficulty as in other nights to find a position in which I could remain for any length of time. I slept for five or ten minutes, then awoke, lighted my candle, put it out again, arranged my bedclothes, and so on till about 4 O'clock, when I called Bryson, who assisted me to sit down in one of the arm chairs from the parlor, but also here I did not hold out half an hour, till at last day broke, when I fell asleep, and

Tuesday, $27^{\text {st }}$ in the forenoon I felt the same as I had done on the previous day. This was my wife's saint's day. Last year it had fallen on a Sunday, and we celebrated it with a little evening party, when we had dancing, and all, my poor wife included, seemed to enjoy themselves. How differently was this day spent by me this year. Transito Llosa with her niece Justa Masias came from Lima to see Enriqueta, remembering the anniversary this day was. I saw by the Nacional that Col. La Cotera had again taken charge of the Ministry for the Interior, and that he had passed a note to the Municipality in which he requested this corporation to remove the shops on the ground-floor of the Palace, which go by the name of the Rivera, as it was the Government's intention to give to the Palace a new, and handsome facade, a pretty idea indeed when they had hardly sufficient funds to meet the daily necessary expenses. [248] [...] aros and my requests for bills had been denied by [_] commitee established for this object, merely by writing a big "no" upon our Patentes, which were returned to us.

Eulogio Delgado and George Elster had made a proposal for the loading of guano vessels. A certain Gama had presented another, in which he bettered the conditions of Delgado and Elster, and demanded that the Carguio be put up to public auction in conformity with the laws of the country.

Dr. Middendorf did not come, and the tight bandage which he had put round my leg inconvenced me so much that at 7 O'clock Enriqueta took it off, and in order to calm the pain, which as yet had not decreased, put upon the knee a little moist bread with a few drops of laudanum, and this had the desired effect; at all events I passed the night without being under the necessity of calling any one to my assistance.

Wednesday, $2^{\text {nd }}$ of November. Enriqueta was very sad because she feared that little Corina was suffering from incipient asthma; and I was equally downhearted, because I feared that Middendorf did not know how to cure me. Thus, both she and I, occupied with our own ideas did perhaps not think of our dear Mariquita quite as often as we ought to have done; all the other Garlands, I was pretty sure, hardly ever bestowed a single thought upon her. Middendorf came, and ordered a new ointment consisting of laudanum, camphor, belladonna and another ingredient; he also prescribed an infusion of bark of which I had to take one spoonful every three hours; for an hour I sat in an arm chair; 
the remaineder of the day I spent in bed, sometimes listening to Bryson's reading, sometimes correcting the old diary, for the greater part thinking and doing nothing. My daily nourishment consisted of two large cupsful of very strong broth in which one egg was beat up, two cups of tea, hardly any bread, and half a glass of wine of the country with the same quantity of water.

Thursday, $23^{\text {rd }}$ of November. Last night I slept fairly [249] but not without pain in the knee. Enriqueta went up to Lima with two servant girls and the little ones, to arrange Juan's bedroom.

Antonio with his wounded hand and black eye now stayed with us in Chorrillos. It seemed to me as if my leg was getting a little better. I could stretch it out much further than I had been able for the last week, nearly as straight as the sound one. The pains were trifling, but strenght it had not as yet. The day passed like the previous ones. The Government sent me a note accusing receipt of mine in which I informed them that my Government had admitted my renunciation of the Consulate. The Comercio of this day had published in its leading article a few lines very flattering to me as Consul, which I affix in appendix under $\mathrm{N}^{\circ} 14$.

Friday, $24^{\text {th }}$ of November 1876. Last night passed exactly like the previous one. Middendorf again bandaged the knee, and strictly prohibited my bending it. I had to keep it stretched out as straight as ever I could. I dictated a letter to Mr. Schutte, and corrected a great many pages in my diary of 1863 written by Mejer. Alejandro sold for me all my shares in the Banco Nacional 80 of S/10oo paid up $35 \%, \mathrm{~S} / 28,000$ at $50 \%=\mathrm{S} / 14,000$, to Dionisio Derteano. I paid him a commission of $\mathrm{S} / 70$. I considered this to be a good sale. Not many days back Juan Gallagher sold his shares at $65 \%$ discount. This day the Congress resolved by a vast majority to prolong its sittings for "cincuenta dias utiles". This was again a victory gained by the Pardistas over the Government. The latter wanted to have the sitting closed and then to convoke a Congress Extraordinary in which case the Congress would only have been allowed to discuss those subjects laid before them by the Executive, whilst in the ordinary Congress they were at liberty to discuss whatever they thought proper.

Saturday, $25^{\text {th }}$ of November 1876 . Last night that $[250]$ [...] Friday to Saturday, I spent so so. In the middle of the night I was awake for at least an hour, and then when I again fell asleep I had all the while till daybreak the consciousness of the pain. I could not as yet walk three steps without assistance. In the course of the day I managed to limp as far as the sofa in the parlor, where I again lay down, well wrapped up. Rehder came to pay me part of what he owed, and to ask for a prolongation of the term to pay the balance, till the $10^{\text {th }}$ January, which I agreed to. He brought me several sheets of what he called gutta-percha paper, which, he told me, ought to be wrapped round any part of the body which 
suffers from cold or rheumatism as it produces an extraordinary warmth which no cold can withstand. He added that at present no other remedy was used in Europe against rheumatism. I intended to consult with Middendorf about it. Conversing with him on various topics, he told me amongst other things that Mr. Sand, a Swiss, many years established in Lima and to whom occasionally I had lent money, was at present in a lunatic assylum in St. Gallen, whilst his wife, a Montero, from whom he had been living separate for a number of years, resided generally in Spa, in Belgium. Towards seven I again went to bed, and Bryson read me Philip II till nearly 8.30.

Sunday, $26^{\text {th }}$ of November. The two hours from midnight till 2 a.m. I spent in the most miserable manner, without being able to sleep, tossing about in the bed, changing my position every five minutes, lighting the candle, and putting it out again, till at last at somewhat past two I fell asleep, and did not awake till daybreak. Afterwards I again slept an hour or so. Bryson and Antonio, who had been up very early, saw a steamer come in, which from her size they judged to be the "Liguria" and at 11 a.m. Juan Bazo sent word to say he had come up from Callao with Juan, who had gone from the Station to our house in Lima. Garland went to town.

I [_] so much better that my pains only came on at [251] Intervals, but walk I could not a step with my left leg, [_] in the left upper arm rheumatic pains began to make themselves felt, in the same place where I had suffered many years back. About 12.30 Juan entered and came to my bed. He embraced me tenderly and for two or three minutes my tears prevented my uttering a single word. Fortunately the pain from which I was suffering led us to speak about the remedies to be employed. Juan also complained much of severe rheumatism all over his body; and thus erelong we could converse on various topics. He had had a very good voyage but considered the passage through the Straits always dangerous. Towards the Atlantic side the shores are sandy whilst the other half, after passing Punta Arenas is somewhat more picturesque; on both sides are mountains both in the fore, and in the background. When the "Liguria" passed there was no wind, the sea was smooth, and the night was lighted up by a brilliant moon. Nevertheless, the whole night through the Captain did not move from the bridge across the deck, because every moment the course had to be altered. In the daytime I again moved to the saloon. José Maria Costas came to see Juan, who went out to see Ruden; to dinner came Dr. Dorado and a young daughter of his. Ricardo read to me at intervals and thus the day till seven, or thereabouts passed pretty quickly.

This night José Canevaro gave a grand ball to celebrate the arrival from Chile of Doña Magdalena, the President Prado's wife. He had invited all of us, but I believe only Alejandro and his wife, together with Geraldo went. 
Monday, $27^{\text {th }}$ of November 1876 . I again passed a miserable night till near four; from that hour till past six I slept. Before breakfast I once more conferred with Juan, and after having explained to him the reasons which had induced Mariquita to make the last alteration in her will, to his prejudice and to Enriqueta's advant[_] I had [252] [_] hope he would make no objection to the same. He went to [_] by the 11 O'clock train after Bryson had brought the key to my rooms, which he Juan, now occupied. The greater part of the day I lay on the sofa without however correcting any part of the old diary. Bryson had brought from my library Walter Scott's Woodstock, or the Cavalier, which he began reading to me, and which was interesting as far as we had proceeded.

Tuesday, $28^{\text {th }}$ of November. I slept well last night till four O'clock, then I awoke, and had as usually one or two unquiet hours. After six I again slept for some time; and it was as late as 8.30 before I was fairly awake, and able to remove to the saloon. Middendorf came by the 10 train, examined my leg, found that some water had again accumulated above the knee, and prescribed another blister. He was certain that he would finally cure me, but was quite as certain that some weeks would still elapse before my complete recovery. For the present he would not allow me to leave my bed on any account. Nearly the whole forenoon Juan was in my bedroom reading to me a very long document drawn out by Schutte proving the total groundlessness of the heavy claims which Garland made against him. At my request he also read over carefully the Profit and Loss account, and the Balance Sheet of my books on the $28^{\text {th }}$ February last. By today's steamer Dr. Fernando Palacios left for London; what the object of his sudden departure was, I knew not. Once in London he would no doubt try to dispose of the precious diamonds stones, consigned to Gibbs \& Sons by Garland on his account. José Basagoytia also embarked and I should not wonder if his voyague had some connection with that of the Doctor's, who told Garland that he would be back within four months. In bed the whole day. I dictated to Bryson, listened to his reading, and spent the day as well as I could. At Canevaro's ball, given last Sunday, Manuel Pardo had not been, neither La Puerta, first Vice-President, but to my utter surprise I heard that Simon Soyer had ventured to shew his face [253] and that being the brother of Canevaro's wife, had [_] himself quite at home, and taken a glass of wine with the President Prado.

Wednesday, $29^{\text {th }}$ of November 1876 . The blister remained on my knee the whole night, without much troubling me, but the pain in the knee itself continued; I slept fairly, though I heard it strike three, four, five, and finally six O'clock. Dr. Middendorf came, took off the blister; a considerable quantity of water, the Doctor said about an ounce and a half, was extracted. The sore was dressed and 
I was again in bed, without being able to move. The Doctor insisted upon my taking more nourishment, also a little wine.

Thursday, $30^{\text {th }}$ of November. This morning Enriqueta dressed the knee. Juan was with me part of the forenoon, and at somewhat past two Bryson came in to correct the old diary under my dictation. It was rumoured that the present Executive intended to withdraw from Europe the Legations hitherto kept at the Courts of Berlin, Paris and London. One day passed like the other; nothing was to be said of them.

Friday, ${ }^{\text {st }}$ of December. Last night I slept better than any other night since my falling ill. I was awake only for one hour from three till four. Dr. Middendorf came, and said that he was quite satisfied with the manner in which I was progressing. I opined rather differently. John Gallagher, who yesterday dined with the family, had rented from the widow of José Maria Sancho Davila an estate called Pariache, a short distance from Lima, on the Oroya Line, which he intended to convert into a sugar plantation. The sugar cane would be ground at the neighbouring estate of Santa Clara, belonging to Francis Bryce, so that Gallagher would not have to incur the heavy cost of machinery. The great rise in the price of sugar in Europe had no doubt induced [254] [_] to invest his capital in this manner. Near sev[_] in evening Middendorf again appeared to my great surprise, and told me that this very night, or at the latest tomorrow morning he and Mrs. Blume would leave for Payta in a special steamer, a telegraphic dispatch having been received that Mr. F. Blume, the St. Thomas man, engineer and contractor of the Payta-Piura Railway, had been shot through one of his lungs, and one of his hands. The Doctor said that he would be back on Tuesday - which I doubted - and he requested me not to leave the bed until his return.

Saturday, $2^{\text {nd }}$ of December. The pain on my knee was nearly gone, but this day I did not feel so well as in the previous one. In the evening from 9.30 to 10.30 Josefa Bazo kept me company. She expatiated on the happy hours she had spent in London, whilst her husband was manager of the South American Company, but which had come to an end when his affairs took that unfortunate turn which obliged them to abandon their comfortable home, and to return to Perú. I listened with great attention to her narration, and thus the time passed more swiftly than it usually did.

Sunday, $3^{\text {rd }}$ of December. The papers brought all kinds of news. The election of Mr. Tilden, President of the United States, was not yet quite certain; he, a democrat, that is to say of that party which during the civil war went by the name of confederates, had 184 votes, whilst Mr. Hayes, the other candidate, a Republican, who had on his side the Northern States, had 166 and as three states had not yet voted there was still a possibility of the latter gaining the majority 
by one vote. From Russia the advices were very warlike. The Czar, as soon as he became acquainted by telegraph of the contents of a speech delivered by Lord Beaconsfield (D' Israeli) in the Mansion House, had given orders that a large proportion of his army should be put in the war footing. As yet however war had not been declared against Turkey and hopes were still entertained [255] that at a conference which was shortly to be [_] of the Ambassadors of the Great European Powers in Constantinople, the intricate Eastern question might be solved in an amicable manner. Cardinal Antonelli, for a great number of years Minister for Foreign Affairs at the Court of His Holiness, had died. Also the Duchess of Aosta, wife of Amadeo ex King of Spain, had gone to her long home.

Here in Lima the Finance Minister Dr. Aranivar had published a new decree as to the manner in which the $£ 50,000$ Stg., which the Government had to draw on the $27^{\text {th }}$ February next upon the Peruvian Guano Coy. Ld. were to be sold to the Public. On the $31^{\text {st }}$ January sealed tenders were to be given in by such as wanted bills to a body called La Junta de Almonedas, at the exchange which the taker of the bill was willing to pay, not worse for the drawer than 30 pence the Sol. The most favourable offers would be accepted, and if the decree was to be literally understood the bills were only to be drawn for $£ 800$ each, not more or less. Ricardo read to me a few pages in Rahncke's Popes, from which it was evident that about the year 1629, when Ferdinand II, Emperor of Germany, was in the zenith of his power, it was not only Richlieu, but even the Pope Urban VIII who called in the heretic King of Sweden Gustavus Adolphus to put a stop to the continual encroachments of the German Emperor, a truly Orthodox Catholic power.

Monday, $4^{\text {th }}$ of December 1876 . Once more I passed a bad night. I hardly slept from 1 to 4 and only an hour or so after daybreak. Though the swelling of my knee had gone down considerably, and the pain I had could well be borne, this morning when Enriqueta and Juan compared the two knees there could be no doubt that the left one was not yet in its normal state, whilst in the right one every bone could be clearly distinguished. [256]

Tuesday, $5^{\text {th }}$ of December 1876. Last night I was not much more than one hour awake. Also towards morning I slept a good deal, thus I had every reason to be satisfied. The Lima papers were full of what they called the heroic and patriotic exploit of Leoncio Prado, 24 years of age, a natural son of the President who held a military post in the revolutinary army of Cuba. A steamer Montezuma, under Spanish colors, the property of a certain Herrera, Colonel of Spanish volunteers in Cuba was in the habit of plying from St. Thomas to Porto Rico, Puerto Plata in Santo Domingo, and thence to Havana with passengers and Merchandize. In Puerto Plata eleven individuals embarked, pretending to be 
of various nationalities. They were in reality ten Cubanos, their Chief, said Leoncio Prado, a Peruvian. Their object was to make themselves masters of the Montezuma. Hardly were they a few hours out of port, and the Captain, first mate, and passengers had sat down to dinner, when Prado went up to the Captain and in the name of the Republican Government of Cuba, intimated to him that he was his prisoner of war, and had to give up instantaneously the command of the vessel. Very naturally the Captain resisted, and threw a bottle at Prado's head: it missed him, but a second, better aimed, felled Prado to the ground. Meanwhile the other conspirators had entered; a scuffle ensued, the Spaniards without arms, defended themselves with whatsoever came in their way, but the captain being shot dead they were soon overpowered, the Cuban flag hoisted, Prado gave to each of his confederated a sabre which he had brought with him in his trunk, and the crew submitted to the will of the victors. Killed were: The Captain, a cabin boy, a stoker, a sailor, and one passenger. In Port au Prince in Haiti all who wished to go on shore were landed, whilst eighteen remained on board, and swore fidelity to the Cuban Government.

At 10.30 in the evening Enriqueta, Juan giving [257] her his advice, cut the blister which Juan had [_] with from Lima, into two, and applied it to two parts of the knee, where it was evident that some water had collected below the skin.

Wednesday, $6^{\text {th }}$ of December 1876. Though I had passed the previous night better than any since my illness yet I again began to despair of my ultimate cure, for the two blisters had not drawn. Telegrams from Payta said that F. Blume was out of danger. I learned quite by chance that last Sunday the 3 inst., José Canevaro to celebrate his birth, or Saint's day, had given another ball not much inferior to that in honor of the arrival of the President's wife.

Thursday, $7^{\text {th }}$ of December. Last night was once more a miserable one. Though Enriqueta had taken off the blister, and dressed the wound, it inconvenienced me a great deal.

The "Nacional" published the Census taken this year all over the Republic of Perú. It gave a population of 2,707,035; Ancahs being the most populous department with 137,130 males and 146,961 females; Moquegua, the least populous with 14,504 and 14,282 . In all probability the Census was not quite correct, for in Perú it is generally the custom not to state the exact number, people being afraid that the Government has some sinister object in making these enquiries. Moreover, in the highest regions of the Andes it is next to impossible to obtain an exact account of the indians who live there; and I should therefore be inclined to state the real population at about three million souls. Late in the evening Enriqueta again dressed the wound caused by the blister. It gave me much pain; however, when Juan and Enriqueta left my bedroom at eleven - till which hour they generally kept me company, I slept 
till 1.30, and though I was awake for two hours; I felt so little pain that after a long interval I attempted to [...] [258] [_] multiplication in my head, in which I succeeded pre[_] well.

Friday, $8^{\text {th }}$ of December 1876. La Concepcion. Holiday. I felt better, but was not yet able to make use of the infirm left leg. Juan read to me a Vista-Fiscal directed by German Tejeda to the Supreme Court, by which I saw that the amount taken by Dr. Fernando Casós, revolver in hand, from the Treasury or Caja Fiscal, at the very last moment when in July 1872 the Dictatorial power of Tomás Gutierrez came to the ground was $S / 164,580$ in billetes, of which he delivered the smaller to the Intendencia, putting into his pocket the bigger one $S / 96,800$. To me it appeared that of this there was not the slightest doubt. Part of them he might perhaps have given to his accomplice Manuel Eugenio Velarde, who was probably at this time in Lima, but concealed. Acciones of the Banco Hipotecario had been sold at $70 \%$; Cedulas of the same bank were up to 9o. Though the affairs of this bank had wonderfully improved since it was managed by Garland and Gallagher yet in my opinion its future prospects did not as yet warrant such an extraordinary and sudden rise.

Josefa Bazo with her children, had left Chorrillos, and removed to the Chacra Manzanilla, the property of her brother Antonio where her husband Anibal Gonzales worked as Administrador. I was sorry she was gone, for she was an excellent woman and an intimate friend of Enriqueta's. Day and night passed like previous ones.

Saturday, $9^{\text {th }}$ of December 1876. Fifty-second anniversary of the battle of Ayacucho. I was certainly gradually getting better, though if I placed my infirm leg on the ground, without exactly resting upon it, it still gave me considerable pain. In the afternoon I sat down for a moment on the sofa, but felt so extremely weak that I had necessarily to take a little port wine. We had a sharp, but short shock of an earthquake at 1 a.m. of

Sunday, $10^{\text {th }}$ of December. Middendorf had not yet arrived. [259] Bryson went to Lima after having been with me [_] entire forenoon. I sat down on the sofa for an hour, Ricardo read to me some pages of Rahncke's Popes, but upon the whole it was to me a very long day, and so was the night when I slept but poorly.

Monday, $17^{\text {th }}$ of December 1876 . We now learned that the Steamer Girafa with Dr. Middendorf and Mrs. Blume only entered the Port of Payta when the steamer left, which arrived on Saturday night. Both Enriqueta and Juan, who carefully examined my knee every twenty four hours, assured me that it was materially getting better, that the swelling gradually diminished, and that the different bones of the knee, hitherto round like a cushion, became visible. They dissuaded me from calling in another medical adviser, because they feared that his treatment might interfere with that of Middendorf which in their opinion 
had its due, though slow effect. I was again up for about an hour lying on the sofa; otherwise day and night like the previous one.

Tuesday, $12^{\text {th }}$ of December. The Nacional gave an account of a dreadful crime committed by the curate of the Parish of San Lazaro, Dr. José Maria Dianderas. He was the confessor of a certain Juana Rosa Gonzales; he became too intimate with her, and to conceal the consequence of their intimacy he proposed to her to take some pills to bring about a miscarriage. The first time she threw away the pills, but on Sunday last he made her take others in his presence, which caused her death, after a few hours. The medical men called in, gave it as their opinion that she was poisoned, and a post-mortem examination was ordered by the police. Meanwhile the Doctor was kept in confinement. In the forenoon I lay for more than two hours on the sofa, and got shaved which I had not been for more than four weeks. No alteration whatever in the manner in which the remainder of the day was spent. I corrected with Bryson the old diaries. He continued r[_]ing to me Woodstock by Scott. After [26o] [_], which like breakfast I of course took in bed, Enriqu[_] and Juan kept me company for at least an hour, then Bryson read to me the description of the Battle of Lepanto, which forms an interesting chapter in Prescott's Philip II. Alejandro was with me for some time. I took sago and milk and slept very fairly from eleven till nearly five.

Wednesday, $13^{\text {th }}$ of December 1876 . Enriqueta and Juan once more examined my knee, which, compared to the sound one was still considerably swollen, and we agreed to send for Dr. Espinosa. Juan had taken upon himself a very disagreeable and difficult commission, that of mediator between his two brothers in law, Schutte in Paris and Garland in Lima. Both made claims, the one upon the other: the former founded his upon contracts, accounts, and irrefutable figures, the latter, his upon equity. I doubted that Juan's exertions would lead to any satisfactory result.

After having washed, which for the last four weeks I had always done in bed, I managed to get up and to lie down on the sofa, where Juan read to me for more than an hour in a, as far as I could hitherto judge, interesting book, written in German, translated into French by Baron Hübner, the same to whom when

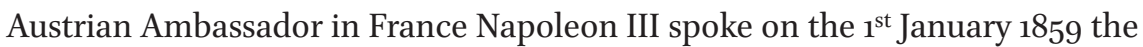
few ominous words, which were the prelude to the Franco-Italian-Austrian War of the same year. It was an account of his voyage from Queenstown, across the Atlantic, through the United States, to Japan and China. To-day we had come as far as Washington. The exchange on London was by this steamer $27 \mathrm{~d}$ though a few bills might perhaps have been sold at $263 / 4$. This was a trifling improvement. Dr. Espinosa came to examine my knee a little before six O'clock. His opinion was that the original infirmity, that is to say the water in the knee, 
was cured, and that I only required time to recover the natural strength. He prescribed an ointment and recommended me not to remain in bed but to rise [261] and lie down on the sofa with the leg extended, and [_] I did. After Bryson had read to me Prescott's Philip from 8.30 to nearly 11 I went to bed, and spent a very bad night. I hardly slept three hours.

Thursday, $14^{\text {th }}$ of December 1876 . On Sunday last a fight between a lion and a bull took place in the bull ring with the permission of Manuel Candamo, Alcalde of the Municipality or Consejo Provincial of Lima. The lion proved victorious but it was generally believed that if he had not been so intent upon the destruction of his enemy he might have broken through the cage, in which both animals were kept. When this opinion came to the knowledge of La Cotera, Minister of the Interior, he instructed one of his head clerks, Carlos Lisson, to address an official note to Candamo, in which he was requested to take in future better precautions on similar occasions. Candamo's reply was published in the Nacional. It was in my humble opinion written in a very improper and even insolent manner. He said that the Minister of the Interior had no right to interfere in the proceedings of the Municipality, which was an independent, and self-governed corporation, for which reason he begged the minister not again to address himself to the Municipality in such terms as those of the note to which he now replied.

The bill for suppressing the three convents Santo Domingo, San Agustin, and La Merced, was gradually progressing in the Chamber of Deputies.

Rafael Velarde with family, and his brother Francisco, resident in Arequipa, came to pay us a visit and remained for lunch and dinner. Shortly after they had returned to Lima we had a call from Pedro Beltran and Carlos Elias whom Enriqueta and Garland had to receive, though the former suffered from migraine the latter from bellyache. As regards myself I was up the whole day lying on the sofa in my bedroom, or in the parlor, dictated to Bryson, and listened alternately to his, Juan's, and Ricardo's reading. [262]

Friday, $15^{\text {th }}$ of December. Last night I passed uncommonly well.

The Nacional contained the answer given by the Minister for the Interior to Manuel Candamo's note, which had been approved of by the members of the Municipality. In the answer, signed by Carlos Lisson, Candamo's note was returned to him. He was reprimanded for the terms used by him, informed that in pursuance of the $6^{\text {th }}$ article of the law relative to Municipalities the Government had a right to watch the proceedings of this body, and concluded with saying that this reply closed the correspondence on the subject. The Editorial article of the Nacional quoted this $6^{\text {th }}$ Article, which literally says that the Consejo Provincional is subject to the superintendence of the Consejo Departamental, and this Consejo Departamental to the Ministry of 
the Interior. Consequently Lisson was not quite correct in his assertion. After having breakfasted and washed in bed, I again lay down in the parlor, and Juan read to me Hubner's work till 1.30. We had now come as far as the Salt Lake City, the Mormons, Brigham Young, polygamy and the tabernacle. Hubner's opinion was that the importance of the Mormons was declining. I began to walk, or rather to limp a little, sustained on the right by Bryson, on the left by my stick. Afterwards I removed to the bedroom, and sitting upon the sofa I remodelled the diary of 1863 and listened to Bryson's reading Woodstock. At a later hour I returned to the parlor, where I spent the remainder of the day lying on the sofa. Bryson finished reading to me Prescott's Philip II, which work, as everybody knows, he did not live to conclude. Alejandro told me that the affair of the Eten Railway had been settled, and that Canevaro had offered to the Committee named by the shareholders of the Banco del Perú to treat with him, and consisting of Garcia Calderon, Forrero, and Heudebert, the sum of threehundred thousand Soles, payable in five years with an interest of $6 \%$ p.a. and that this offer had been accepted. [263]

Saturday, $16^{\text {th }}$ of December 1876 . Last [...] pretty fairly, though not so soundly as the previous one, but awoke in the morning with a slight belly-ache, which did not fail to inconvenience me, the more so as the whole family had gone to Lima, Garland, Enriqueta, and the little ones at 7, Juan at 9, and I was at a loss what remedy to take. My breakfast consisted of a little broth and a cup of tea; afterwards by Aurelia's advice I took two Seidlitz powders which had their due effect. I rose at two, dictated my diary, and felt very weak and miserable.

I saw by the Nacional that a meeting of the shareholders of the Banco del Perú was convened for the $28^{\text {th }}$, to whose approbation Canevaro's offer would probably be submitted.

During the time of Balta's administration Enriqueta had endeavoured to make an emphiteutic purchase for 150 years of a large area covered with miserable buildings belonging to, and adjoining the Convents of San Francisco of which she held a lease for 10 years, not yet expired. At that time she obtained the consent of the whole community as well as of the Archbishop, but when the expediente was sent to the Government for the approval of the purchase, Balta personally ordered that it should not be dispatched, because he wanted the area for his soldiers, but could not yet take possession of it on account of Enriqueta's lease. During the four years of Pardo's Presidency nobody knew what had become of the Expediente. Some said it had been stolen, others it had been lost, at all events it did not make its appearance. Not many months back when Dr. Arenas was Minister of Justice, Alejandro, through his intimacy with Arenas' son Antonio, had another search made, and the expediente was not only found, but even handed o[_] to Alejandro who was allowed to keep it 
for several days. Now a new escrito was presented by Enriqueta in which she renounced [264] [...] she might have as present tenant, and demanded the public sale of the area in question. To this Dr. Teodoro de la Rosa, Minister of Justice, acceded ordering at the same time that the sale should be advertized in a daily paper for twenty days consecutively. Enriqueta chose La Sociedad as this paper had the least circulation in Lima. However the Monks of San Francisco read the advertizement, and presented an escrito demanding the postponement of the public sale. This was denied them by the judge M. A. Puente Arnao in whose Juzgado the sale was to be held this day at twelve exactly. However, when the family returned from Lima they told me that at the very last moment the sale had been suspended in consequence of a new escrito given in by the friars.

Garland at my request had been with José Canevaro who, if the offer of S/300,000 for the Eten Railway were approved of by the shareholders of the Banco del Perú, had ageed to release me of all the responsibility which I had taken upon myself when guaranteeing the Servicio of the S/30,00o often spoken of, if I paid him $\mathrm{S} / 8000$ cash, and ceded to him all my rights on the railway. It was the same amount which I had offered him many weeks ago, when he had offered for the railway only S/200,00o. Juan thought I ought to have waited, and acted in concert with all the others guarantees, such as Varela, Ruden, Escobar, Irrigoyen, Delgado, Garcia y Garcia Unanue etc., but I myself wanted to get this heavy weight off my mind, and even should the other parties obtain hereafter better terms from Canevaro, I did not repent of what I had done. Candamo and Derteano were said to be interested with Canevaro in the purchase. In the course of the day I limped about a good deal, sustained by Bryson or Aurelia, and by my stick in the other hand. Enriqueta and Juan were certain that the swelling of my knee was gradually going down.

Sunday, $17^{\text {th }}$ of December. Last night I was awake [...] hour and a half. This day I felt much better. [265] Juan told me that Derteano on his own account [_] ordered 100 Chinese from San Francisco for his estate, and if they answered his purpose, he would regularly repeat the order. He had also bought from a German, a tract of land close to his estate, with 50,00o mulberry trees with the intention of rearing silk-worms.

I again limped about a little, and though Ricardo read a few pages of Rahncke's Popes, the day was upon the whole, a very tedious one. Juan usually dined one day with the Garlands and one day with Ruden. In the evening he went regularly to the latter, with whom he remained from 8.30 till 10.30, and was sure of meeting there many visitors, such as Felipe Varela, José Maria Costas, Dr. Espinosa, DuBois, a German, partner of Graham Rowe \& Co.; Böhl and others. As soon as he came home I was in the habit of going to bed, when 
he and Enriqueta examined my knee every night. Both were always as kind to me as if they were my real children.

Monday, $18^{\text {th }}$ of December 1876 . Last night I slept uncommonly well, being awake only for a few minutes. Enriqueta went to Lima by the 7 O'clock train. At about 8 Garland received a telegram from Guillermo, informing him that at 1 a.m. Eliza had been brought to bed of a little boy. Within these last few days Dr. Jorge Loayza, a lawyer of great repute, widower, I suppose about fifty years of age, had married Doña Ramona widow of Castañeda. To-day, the birthday of the President, a lunch was given to him and his lady in the quinta of Juan Rivera, by Pablo Vivero; Manuel Maria Valle; Carlos Pividal; Augusto Althaus; Ulises Delbois; Focion Mariategui; and Carlos Paz-Soldan; the most respectable of whom was no doubt Carlos Pividal.

Juan again read to me from Hubner's work. The opinion which I formed of Brigham Young the prophet [266] [_], and the creditor of nearly all the Mormons, was [_] he was a hypocrite, a rogue, and at the same time a clever, energetic and voluptuous man. He was born in 1801 in the State of Vermont, and was by trade a carpenter. He succeeded the first prophet of the Mormons, Jose Smith assassinated by his enemies, persuaded the Mormons to abandon Illinois, where they had resided hitherto, and to settle over to the Salt Lake. This migration went by the name of the Exodus. During the journey they suffered incredible hardships, and many died on the road. Young pretended, and his followers believed, or as I thought feigned to believe, that he was inspired by God. "Labour, and Faith" was the creed which he insisted upon; poligamy, he not only permitted, but ordained, on condition that the man were able to sustain the wives he took; but according to Hubner, the wives who upon the whole had a dejected and melancholy appearance - frequently maintained their husban[_]. After Young the Prophet ranked the bishops and elders, all North Americans, whilst the lower classes of the Mormons were mostly from England, the refuse of the large towns from Wales, whence the greater part of the women, and a sprinkling from the Scandinavian Kingdoms. Young's missionaries generally addressed themselves to the most ignorant and the most destitute, they gave a short account of the creed, but dilated on the advantages and pleasures which awaited them in the New Jerusalem. Young's bankers - for he was said to possess millions of dollars - advanced the passage money, paid the expenses from New York to the Salt Lake, and on his arrival the immigrant received a piece of land and utensils for working the soil, but for all this outlay he became Brigham Young's debtor. The prophet himself had sixteen wives, and in 1871 forty eight children. Those who rank next to him must have a corresponding number, whilst the lower classes contended themselves with two wives. The Pacific Railway, which passes close to New Jerusalem, and Silver mines discovered in the neighbouring [_] which bring many immigrants to the 
vicinity, began [267] in 1871 to affect the seclusion, in which until [...] Brigham Young had been able to keep his 200,00o subjects from the surrounding world. My opinion was that at the death of Brigham Young, this un-natural system of Government would fall to pieces. At no great distance from the Salt Lake lies a small town called Corinne, in 1871 with 2000 inhabitants, the sworn enemies of the Mormons; according to Hubner this town was likely to progress in course of time. Dr. Middendorf arrived by the ${ }_{5}$ O'clock train. After dinner he examined my knee, and - as I had expected - declared himself satisfied, for how could a Doctor do otherwise? He recommended me to continue the ointment prescribed by Dr. Espinosa, and bandaged my knee tightly, by which means he thought of giving more stability to the leg. When in bed the bandage was to be taken off, and again to be put on in the morning.

Tuesday, $19^{\text {th }}$ of December 1876. For the first time since my illness I slept without awaking from 11 to 5.30. I received several letters; from C. W. Schutte, and A. Gibbs \& Sons on business, nothing particular; friendly communications from my cousin Frances Creswell, from Henry Sieveking, and from Johannes Limpricht, all three as kind as I had any right to expect. Frances completed this year 57; she was exactly the same age as my son Juan. Limpricht wrote that the 680 Soles of which I had made him a present, four or five months ago, he had at once placed in his books to the credit of his nephew, Johannes Bobertag, the clergyman, to whom he had lent 3000 marks at the time of his marriage. Elizabeth and her daughter Emma were at the time, that is to say about the middle of November, in Moers, with her married daughter Maria. This morning I took my breakfast in the parlor, and managed to walk a few steps with the help of my stick only. The worst was that I was extremely weak. Juan read to me Hubner's work. We had [_] [268] [...] sit from Becker, who brought me Limpricht's letter, [_] was a very good fellow, but tremendous talker. I still hobbled about a little, and after dinner Bryson continued reading Woodstock. When Enriqueta took off the bandage at near 11, she was sure that the knee was a little more swollen than it had been in the morning.

Wednesday, $20^{\text {th }}$ of December 1876. I slept well, but felt extremely weak this morning. Juan went up to Lima by the 11 O'clock train, thus I had no reading from him. For a short time I sat down in the corredor. Mariano La Fuente had died in Lima. He was the same who about a year back had a dreadful operation perfomed on his tongue where a cancer was then cut out. I believe the cancer reappeared, and brought about his death. He and his brother Ramon, still alive, are the sons of the late Basilio La Fuente of Arequipa, brother of our good friend Mariano Blas who also went to his account, perhaps a year ago.

The Government thought of sending a military commission to Europe in order to make themselves acquainted with the latest improvement in the science of war. It was said to be Prado's own idea, and was lauded in the 
"Nacional". To me it appeared to be a new proof of the absolute want of common sense in the Executive. They owed millions and millions of Soles, could not pay their debts, and incurred this new, completely unnecessary expense.

Thursday, $27^{\text {st }}$ of December. The last few nights I slept without awaking till half past five in the morning. I got on a little better with my walking, or rather limping, but the knee continued swollen. The day before yesterday Enrique had been out with Mr. Mould, the Architect, and three others, belonging to the Compañia de Obras Publicas y Fomento, to the Pantheon, where they measured the 36 square Varas which some time back I had bought from the Beneficencia, and probably this day a beginning had already been made with laying the foundation of the Chapel [269] there to be built on my account. It was [_] over Lima that Dionisio Derteano had promised to several ladies to give a magnificent ball in honor of the President's wife. This lady had however requested him to distribute the sum which he had intended to lay out in the festivity amongst the poor of Lima. Accordingly, he handed in to Doña Magdalena Ugarteche de Prado the sum of ten thousand Soles, in the distribution of which she had associated herself with Isabel Soyer, wife of José Vicente Oyague, with Doña Amalia wife of Pablo Vivero, and with the wife of Don Pedro Telmo Larrañaga, which last named I did not consider to be exactly fit for the purpose.

Juan read me this morning, again from Hubner's work; it was the description of an extremely interesting excursion from San Francisco to the big trees of Mariposa, and the valley of Yosemite. These enormous trees are the renowned Wellingtonia, which grow to the height of far above 300 feet, and the diameter of the one or the other is thirty feet. One was lying on the ground quite hollow, forming a tunnel, through the length of which Baron Hübner mounted on a small pony, rode, without being obliged to stoop.

By the 5 train came Dr. Middendorf, and after dinner he examined my knee. He now prescribed tepid baths, by means of which he expected to render the sinews of the knee which had become rather stiff, more flexible. Juan found it impossible to come to any arrangement with Garland about his debt to Schutte in Paris. Bryson finished Woodstock: the last scene in my opinion is the best of the whole work. Charles II after his restoration returns to London, accompanied by the most brilliant Cortege, and under the loudest acclamations of the people. On Black Heath sits a small circle, apart from the Multitude consisting of Sir Henry Lee, his [270] [_] Alice, her husband Col. Markham Everard, their children; the wild Cavalier Wildrake, the keeper Joceline Joliffe, with his wife Phoebe Mayflower, all these the principal personages in the novel. The king jumps from his horse and addresses a few words to every one of this group, 
mostly to the old graybearded man Sir Henry Lee, who, overpowered by an excess of joy and loyalty, expires as soon as the king had remounted his horse.

Friday, $22^{\text {nd }}$ of December. The Philadelphia Exhibition had been visited in the course of the six months from $10^{\text {th }}$ May to $10^{\text {th }}$ November, by nine million persons of whom more than eight million paid entrance money.

Sugar continued to rise in Europe and such as had speculated in this produce here in Lima would undoubtedly make large profits. Graham Rowe \& Co. were the principal speculators. All the owners of sugar estates were in high spirits, and the Banco Hipotecario was much benefitted by the sudden improvement in the situation of the Hacendados, the banks principal debtors.

Saturday, $23^{\text {rd }}$ of December. This day I did not feel so well as the day before. I even walked with somewhat more difficulty, if walking it could be called, for at the utmost I moved twice around the sitting room, sometimes assisted by the one or the other, and by my stick in the right hand, sometimes leaning solely upon the latter. The mortal remains of General J. C. Torrico who died in Paris on the $25^{\text {th }}$ March 1875 were brought to Callao some months ago and deposited there on board a pontoon. Yesterday there were conveyed per train, accompanied by a small cortege to the Chapel in the Pantheon, and this day they were solemnly deposited in a vault constructed for the purpose.

I saw by the papers that some gentlemen resident in Callao - amongst whom the only names known to me were Carlos Weiss, the German, and Champeaux, the Frenchman [271] who on account of La Sociéte of Paris attended to the [_] Dársena business - intended to establish a bank in Callao with a Capital of one million Soles, say 1000 Shares of 1000 Soles each. They expected to succeed, because all the branch establishments of the Lima Banks had been closed. I thought they would find but few subscribers.

Of the statements which by order of Government the various banks established in Lima had to publish every fortnight, that which about this time appeared of the Banco de Lima was certainly the worst. On the $15^{\text {th }}$ inst. this establishment held in coined silver $S / 180,404.16$, in coined gold $S / 309$; with Vales á la vista, notes of other banks etc. the cash came up to $S / 412,763.90$, whilst the billetes in circulation amounted to $S / 2,921,722$. The seventy five shares of this bank, which not long ago were sold by John, Peter, and Alice Gallagher at $40 \%$ had been resold to Valentin Gil at 50 . Shares of the Banco Hipotecario had been sold at $71 \%$, Cedulas at 90 ; bar silver fineness 997 at S/16 per mark; coined silver, premium 51\%. Exchange on London fluctuated between $271 / 2$ and $27 \mathrm{~d}$ At 2.30 I took the tepid bath prescribed by Dr. Middendorf. I remained in the water a little more than twenty minutes, then went to bed, and slept about half an hour. For some hours I felt rather weak, but towards bed-time came round 
again. Perhaps once a week Manuel Pardo came from Lima in the evening to spend an hour or so with Ruden and the customary visitors; this night he had been there.

Sunday, $24^{\text {th }}$ of December 1876. As usual I was awake before six, and was beyond measure low spirited; it was a cold, foggy morning. I could manage to walk by myself leaning only upon my stick. Little Corina had a bad cold, and coughed much. I saw by an article in the Eclectic that the Buddhists number nearly 500,000,000; Christians of all denominations 350,000,000 Brah[_] [272] [...] 120,000,000; Mohamedans 130,000,000 and Pag[_] 200,000,000. Jews were not mentioned, probably because the number was too insignificant. I saw by another article that the novel Jane Eyre, which at the time of its publication caused such a stir in the literary world, and which Mr. Coleman read to me about twenty year's ago here in Chorrillos in the rancho of General Sierra, was written by Charlotte Brontë, a young one might say untutored girl, brought up in a small place called Haworth in the moors of Yorkshire, without her mother, for she lost her when young, and with a father, who was an unfeeling selfish man.

I indexed part of my remodelled diary; Bryson read to me from the Eclectic the account given by a lady of her visit to Ragusa and to Cetinge, the Capital of Nicholas I, Prince of the Montenegrinos, then Ricardo read a few pages in Rahncke's Popes, we had a pretty long visit from Böhl and so six O'clock came on. Dr. Middendorf and Cudlip dined with the family, whilst I took my light dinner by myself in the parlour. The hours till bed time, 11 O'clock passed very heavily. Enriqueta suffered severely from migraine.

A general outcry, and with great justice, had been raised against Prado's nomination of a young son of Pablo Vivero, to be Vista in the Callao Custom House.

Monday, $25^{\text {th }}$ of December 1876 . When I awoke, after a good night's rest I found that Enriqueta had made me a very pretty Christmas present, viz.: a photograph of my wife taken in Paris in 1863, in a small black frame which she had hung up close to the head of my bed. I could now walk by myself, with the aid of my stick, but the knee was swollen a little, and pained when I leaned upon it. Juan read me from Hubner's work the description of Yokohama, which was quite a new town, built by English settlers, or rather merchants who had flocked thither at the time when the first treaty between Great Britain and Japan [273] and Japan was concluded. It takes its name fr [...] small Japanese village close by. Of European manufactures goods English cottons took by far the first place, Hubner did not say whether grey and white, or printed. I suppose they are the grey and white, calicoes and domestics. He also described a journey right through the country to the foot of an extinct volcano, Fujiyama, 14,000 
feet high, which he did not ascend, but preferred extending the excursion to a holy town with its temple, no great distance off, called Yoshida. Afterwards Bryson read to me, and we indexed part of the remodelled diary, which kept us occupied till dinner. This meal I as usual took by myself in the parlour, whilst Guillermo, Jorge Valle, and Gregorio Benavides joined the family in the corredor. Garland, Benavides, and Valle played rocambor. Bryson read to me from the Eclectic a certain Mrs. Barkers letters from Maritzburg in Natal, South Africa. She complained bitterly of the weather and dreadful thunderstorms, of the shockingly bad roads and of the want of many comforts of life to which she had been accustomed, even in New Zealand.

Tuesday, $26^{\text {th }}$ of December 1876. I was certainly getting better, slowly, but gradually. By the last steamer arrived Mejer, the notorious Chevalier d'industrie, once my secretary and lector, the some who introduced to me the Frenchman Duval, who cost me so dear; also George Petrie, some years ago the all powerful agent in Callao of the Pacific Steam Navigation Company; he had now come out in the employ of the Anglo Peruvian Guano Coy. Ld. to which Raphael \& Co. had given their name, and in which were interested: Carlos Candamo, Arthur Heeren, Lescau, José Canevaro and others. Petrie related that Federicó Barreda not many years back believed to be worth ten million American Dollars, had been so completely ruined, principally by unfortunate railway speculations [274] [...] his old age had been obliged to accept a situation as clerk in a New York counting house. Juan read again to me from Hubner's work. His excursions in Japan were extremely interesting. I took my tepid bath, which did me a great deal of good, lay down for half an hour, but did not sleep. Though the time hung heavily on hand, nevertheless I got over it, and was anxiously looking forward for the time when I might again walk about freely and without difficulty. From an article in the Eclectic I was confirmed in the opinion hitherto entertained by me that Sir Joshua Reynolds did not rise to be a first rate painter. He was one of the first in the second rank, and painted mostly portraits.

Wednesday, $27^{\text {th }}$ of December. This being again a working day, all went to town. The little ones were getting better of their cough. I now rose before breakfast, and to-day for the first time was again dressed; no more merely wrapped and covered up. I sat the whole morning in the corredor, and Enriqueta read to me part of a General history of England which I wrote for her in Spanish forty years back. Afterwards, I occupied myself with Bryson. I was told that in the previous day horse races had been held, the net proceeds of which were dedicated to the contruction of the new Chorrillos Church, which Doña Petronila, Manuel Pardo's mother, had taken under her particular protection, but which as yet was far from being concluded. In the evening Enriqueta had a visit from her good friend Isabel Coloma de Canseco, who, a decided anti-Pardista, told 
me in the course of conversation that Manuel Pardo and Manuel Francisco Benavides were the candidates for the Directorship of the Beneficiencia, and that the latter had the protection of the Government.

Thursday, $28^{\text {th }}$ of December. The daily papers informed their readers, that the day before yesterday a great lunch was given to General La Cotera in the Exhibition Palace, by Dr. Saavedra, Pablo Vivero, and others. José Canevaro, $2^{\text {nd }}$ Vice-President, [_] all the Ministers, also Scheel and Von der Heide, the [275] President's brother-in-law had been present. [...] his great exploits, the victory of Yacango, were extolled to the very skies. It was a decidedly Pradista meeting. Of Pardo's friends I did not notice a single one. Juan read to me Hubner's work. We had then a visit from Col. Vargas, and only at 2.30 I found time to dictate to Bryson. An hour later I took my tepid bath. With my walking I got on nicely, but began to feel rheumatic pains in my left arm. After dinner Bryson began reading to me one of Lever's novels called Davenport Dann; as far as he had read it I liked it very well. From 9 to 10, at which hour I went to bed, I spent a miserable time. I had the severe rheumatic pain already spoken of, and did not know what to do with myself. Julia Cavenecia, Federico Bergmann's widow, was with Enriqueta.

Friday, $29^{\text {th }}$ of December. At 6 O'clock I was awake but remained in bed till 10.30, when the Doctor came who examined my knee, which, though much better was still considerably bigger than the sound, the right one. For my rheumatic pain he prescribed external frictions as well as a medicine to be taken four times a day. From Hubner's work Juan read me the account given by him of the audience which the Mikado of Japan granted him in a pavilion, not in his imperial palace. Baron Hübner was accompanied by Mr. Adams, Chief of the English Legation, and by an English interpreter belonging to this Legation. At the extremity of the room, about twenty four feet long and 18 wide, without a single piece of furniture, the floor covered with a straw mat, sat the Mikado, immovable upon a tabouret, plainly dressed in a silk tunic. On one side stood his two first Ministers, on the other the two principal agents in the revolution of 1868 which had crushed the old aristocracy, and w[_] now introducing European reforms. The Mikado, who called and believed himself to be a son of God, sat quite immovable, and when he spoke murmured indistinctly. His [276] [_] were repeated by one of his Ministers, and translated by the interpreter. The purport of his words was that he had been informed that Baron Hübner had filled various Diplomatic posts in Europe, and that he should be glad if he, the Baron would communicate to the Ministers anything which might contribute to the well-being of his the Mikado's empire. To this short speech Hübner made an appropriate reply, which was again translated. Neither on entering nor on withdrawing did the Mikado vouchsafe to salute them; he was a man of about twenty, and had a rather insignificant face, somewhat lighted up when he 
spoke. After leaving the pavilion Hübner and his companions were conducted to another by the Ministers, where refreshments were offered them. With these Ministers, as well as with the leaders of the revolution he dined more than once. Of the remainder of the day I had nothing to say. Bryson continued reading Davenport Dunn.

Saturday, $30^{\text {th }}$ of December. I slept soundly from eleven to five O'clock, and again from five to six, from six to seven, from seven to eight, and from eight to half past nine; this last sleep was with me rather unusual.

Juan went to town at 9 O'clock; his object was to collect from the Gas Company his, Schutte's, and my dividend of $21 / 2 \%$ on our respective shares. I could walk well enought if once I was on my legs, but the getting up was rather difficult and always gave me a slight pain in the knee.

Maria's and Corina's cough had decidedly changed into whooping-cough; they expectorated a great deal, and during the night allowed Enriqueta hardly any rest. In the meeting of the members of La Beneficiencia, Manuel Pardo had been elected first Director by a majority of 35 to 23 which last number M. F. Benavides had. Second director had been chosen J. Ignacio Elguera, Pardo's Minister for Finance by 55 votes. In the meeting of the shareholders of the Gas Company, Guillermo had been [277] named to examine the acccounts of last year, by one thousand and odd votes; Ruden, who voted in his favor represented more than eight hundred. Calisto Pfeiffer had about six hundred votes, mostly those of José Vicente Oyague. The remuneration was to be S/30o, which would not come amiss to him. Dreyfus had declared no dividend for the year 1875. Juan had spoken to Scheel on the subject, who said that he could not declare a dividend for the present as long as they had not come to an arrangement with the Peruvian Government regarding the heavy claims - I believe thirteen million Soles - the latter made upon them. This made a great difference in Juans and my yearly income, for in former years we had received regularly towards the end of December somewhat about $9 \%$ on our joint $\mathrm{S} / 100,000$ for which we were interested in Dreyfus contract. In Ecuador a revolution had been brought about by General Veintemilla, chief of the so called liberal party, who had defeated Govenment's troops and accordingly overturned the authority of President Borrero, who had followed in the footsteps of Gabriel Garcia Moreno, who was assassinated a few months back.

Sunday, $33^{\text {st }}$ of December. I was told that on the previous evening in the meeting of the members of the Municipality, or Consejo Provincial of Lima, Aurelio Garcia y Garcia, Pardo's late Minister for the Interior had been elected Alcalde.

We did not make great progress in the indexing of the remodelled diary being interrupted by a long visit from Anibal de la Torre. Hardly was he gone when my tepid bath was ready. This and my repose in bed, again took up an 
hour. We had then a visit from Macandrew, and upon the whole I felt pretty well the whole day. I could walk with comparative ease and my arm did not pain me much. After dinner Juan [278] [...] with Ruden. Garland went out to play rocambor. Enrique and Alejandro went to a ball given in Lima in the Club de la Union, and thus Geraldo, who had nowhere to go to, kept Enriqueta and me company. Don Electro Corso paid us a visit, and the evening hours passed more rapidly than they usually did. Geraldo told me that when in Japan, all the members of the Peruvian Legation, he of the number, had had an audience from the Mikado. They had been the first of all Foreign Legations, who had driven in a coach to the very door of the palace. They, like Baron Hübner, were received in a large saloon without furniture, boarded prettily, and not covered with a mat. The Mikado sat at the one extremity, and on both sides stood the high functionaries; the Minister for Foreign Affairs and several inferior employes, dressed in dress coats in European fashion, the Mikado and the remainder in Japanese tunics. Garcia delivered his credential in a golden box to an employé who handed it to the Minister for Foreign Affairs; the Mikado made a short speech in Japanese to which Garcia replied in Spanish; the translation of both speeches in English had been previously communicated to both parties. Every member of the Legation was presented to the Mikado who nodded to each of them. After taking leave they had retired backwards, their face twined towards the Mikado, and there being at the end of the saloon a low step which they had not noted, one or two of them were on the point of falling.

Past eleven O'clock I was in bed. [279]

1877

Monday, ${ }^{\text {st }}$ of January. One thousand eight hundred and seventy six was gone. What a year had it been to me!

I did not feel so well as yesterday. I walked with less ease. The whoopingcough of the little girls was very bad; last night they did not allow Enriqueta a wink of sleep, and Corina's nose bled frequently. Whilst we were indexing the remodelled diary Dr. José Maria Pezet came in. After him General Pezet, and before they were gone, Federico Palacios and his wife Mercedes Villacampa, whom, together with the latter's father, Enriqueta had invited to dinner. Of course I had to be with them, at least until dinner time. Alfred Böhl called, and was requested to remain. From 6.30 till 11 when I went to bed the time passed very heavily. I was by myself did not feel well, had no inclination to join the others, and at the same time politeness impeded my being read to either by Ricardo or Bryson. 
In the course of the day Middendorf had been with me; my knee was not yet in its normal state.

Tuesday, $2^{\text {nd }}$. Last night I slept from 11 till 7 this morning, which was something quite uncommon since my indisposition. I had little pain in the arm, but did not walk as readily as I did on Saturday.

Hubner's promenade round the Globe; Walter Scott's biography of Swift, and Lever's novel Davenport Dunn are books, each interesting in its way, and they helped to while away many an hour. The last advices from Europe were not of a warlike nature. In a speech delivered by Von Bismark in the Reichstag, he had informed his audience that the three Emperors continued to $[\ldots][280]$ $[\ldots]$ and friendly terms.

In the United States it was not yet finally settled who of the two candidates for the Presidency, Hayes, the candidate for the Northerns, or Tilden, the candidate for the Southernes, would have the majority, two or three votes at the utmost. In Mexico things looked black. A certain General Iglesias had declared war against the President Lerdo de Tejada, and the third party adhered to Porfiro Diaz, President of the Supreme Court of Justice, who in Mexico answers the same purpose as a Vice President in other Republics. In Bolivia the President Frias, who took the helm after the death of Adolfo Balivian, had been ousted by a military revolution headed by Genl. Daza.

Wednesday, $3^{\text {rd }}$ of January 1877 . This morning I myself carefully examined my knee and I found that the flesh was somewhat swollen just above it. I walked with comparative ease.

We determined to return to Lima, mainly by the advice of Dr. Middendorf, who recommended a change of Climate for the cure of the two little girls' whooping-cough. Enriqueta was very busy making the necessary arrangements for our departure and with paying a few farewell visits. At 4 O'clock a.m. died here in Chorrillos Admiral Domingo Valle Riestra, at the age of 68. In the evening we had a visit from our neighbour Federico Panizo and his wife Manuela Orbegoso.

Thursday, $4^{\text {th }}$. I felt pretty well, and could walk with less difficulty than on previous days. Dr. Middendorf, who came just when we had done breakfast, carefully examined my knee and again bandaged it; it was undoubtedly much better than it had been, but still looked round and swollen compared to the sound one. Juan read me a long time from Hubner's work, from which I took a few particulars. The Mikado has for centuries back been the spiritual chief and been looked upon as the Son of [...]. [281] He resided in Kiyota. The Shogun, the temporal chief, or, as [_] name denotes, the general-in-chief though of great power and influence all over the country, was not the Mikados equal, 
but his inferior. In 1854 a North American squadron commanded by Admiral Perry, forced the Japanese Govt. to open the country to foreigners, and by a treaty concluded in 1854 or 55 with the Shogun, erroneously believed to be absolute temporal chief, two ports were opened to the North Americans. In 1858 the English and French after their fortunate campaign against China the former represented by Lord Elgin, the latter by Baron Gros, insisted upon the Japanese Government granting to them what they had granted to the North Americans, and new treaties were concluded, which opened five ports to the said powers. In later years Prussia, Belgium, Russia, and Austria, obtained the same. From 1858 to 68 the Japanese nation was in a state of ferment, and in 1868 a revolution broke out, the details of which it is difficult to understand. The Daimios are feudatory princes, who, each the head of a powerful clan, though acknowledging the Mikado as their Suzerain rule, or at all events ruled with a nearly absolute power over extensive provinces of the Empire. Four of them, who were the most influential, guided by their counsellors, probably more clever men than they themselves, formed common cause with the Mikado, and overturned the authority of the Shogun, who, after some unsuccessful resistance, and more than one battle, abandoned Yeddo, to which town the Mikado removed, and made it his capital. The four Daimios, whose watchword was destitution of the Shogun and expulsion of the barbarians (the foreigners), laid at the feet of the Mikado the absolute feudatory power they had exercised each over his expective provinces but were reinstalled by the Mikado as Immperial Governors of the same Provinces. The lesser Daimios followed their example, and to judge from Hübner these latter were obliged to fulfil what they had offered, whilst the four powerful ones remained exactly the same as they had been before with the [282] exception that they allowed their feudatory followers - Sumara[_] to form the Imperial army to be uniformed and drilled in the European fashion. The expulsion of the foreigners was no more thought of; on the contrary the Mikado ratified the treaties concluded by the Shogun, and continued to introduce in a, in my opinion reckless manner, European innovations. Nevertheless, I must confess that since Hubner was there more than five years had elapsed and as yet no reaction had taken place in favor of the old institutions; even the religion of the country, Buddhaism, was attacked by the reformers and many convents had been suppressed. At the same time, if Hübner may be believed, the hatred against Christianism continued unaltered and unchangable. The finances were in a dilapidated condition, and only paper money besides some copper coin was in circulation.

In Lima, in the elections of the new members of the Municipality, the adherents of Prado preponderated. 
Bryson and I occupied ourselves with remodelling my old diary. We had come now as far as our stay in Vichy in May 1863, which was written in Lima by Mejer, and strange to say, his flowery, sometimes incorrect, sometimes very pretty English, gave me more trouble to correct to my liking than my own, no doubt in many instances inferior dictation.

In the evening Enriqueta had visits from Federico Palacios and his wife Mercedes, whose little girl Maria quite as spoiled as our own Maria, had kept Enriqueta's children company since last Monday; from Trinidad Cisneros; from Dolores Puch, widow of General Deustua, and from Alejandro's wife. I was in my bedroom, listening to Bryson's reading Davenport Dunn.

Friday, $5^{\text {th }}$ of January 1877 . Enriqueta with the servants was up very early in the morning. We breakfasted at 9.30 and before 12 O'clock all was properly arranged and put away; the rooms were shut up, and our luggage, not less than twenty packages conveyed to the terminus. I was [283] to have been carried in a chair by cargadores, but as they did not come in time I walked onfoot, and sustained by Col. Juan N. Vargas, Enriqueta's compadre, on the left and by my stick on the right side. I reached the terminus just in time, a little tired to be sure, but without much pain in my knee. From the Lima terminus to our house we drove. Nearly the whole day was taken up with receiving the luggage. I however made a beginning with installing myself in the small room which was my dear Mariquita's budoir, and which looks into the garden. At ten in the evening Garland and Juan accompanied the corpse of Admiral Valle Riestra from the railway terminus to the Church of La Merced. Bryson read to me Davenport Dunn, and Rafael Velarde and family paid us a visit.

The object of Palacios' and Basagoytia's voyage to Europe was a complete mystery. Rafael gave various versions of the same, I was sure none the correct one. He further told us that La Puerta had been raised to the first Vice Presidency by the influence of Pardo. He was also of opinion that Buenaventura Elguera would be chosen President of the Consejo Departamental, of which, he, Rafael, was a member.

Saturday, $6^{\text {th }}$ of January 1877 . Twelfth day. I had to remain in bed till a much later hour than I should have liked, because Middendorf, who wanted to examine my knee did not come till nine O'clock. The knee was nothing worse for yesterday's exercise; on the contrary, it got better day by day but very slowly. This forenoon Bryson was already writing in my new office. Juan and Garland were in the Merced at the funeral of Valle Riestra, and accompanied his mortal remains to the pantheon. The former was not satisfied with the manner in which they were laying the foundation of the chapel; the mortar, he said, had too much sand and too little lime. [284] [_] the forenoon Bryson began 
removing the books from my library for we had determined to take this piece of furniture out of my former office, now occupied by Juan, and to place it again in our dormitory, whither I intended to remove as soon as my leg was well. Mariquita's bed was to remain where it stood. When Bryson was gone I had a long day before me. Ricardo began reading to me out of a German monthly publication called the Rundschau, but as its style was very heavy, and Ricardo himself did not understand everything he read, I could not take the slightest interest in it, and I begged him to leave off.

In the evening Bryson continued with Davenport Dunn; when I went to Enriqueta's room I had the pleasure of meeting there Doña Dolores Puente. Corina was very unwell; besides the whooping-cough she suffered from fever.

Sunday, $7^{\text {th }}$ of January. Bryson continued carrying over my books from the library, and was with me till 2 O'clock. Not one visitor came in to interrupt the monotony of the day, very different from former times when somebody or other alway called upon my wife. Ricardo read a little from Rahncke's Popes, which at all events was intelligible and interesting.

Garland dined with José F. Canevaro, the second Vice President. Juan went at 8 p.m. to pay a visit to Ford, of Dreyfus house, lately returned from Europe.

Monday, $8^{\text {th }}$ of January. Little Corina was nearly quite well. Bryson finished carrying over the books. Some pieces of furniture were replaced in the small room occupied by Doña Angela Villena when with us, and which adjoins my present office. I continued limping about, and though in my opinion the tepid bath did me but little good, Middendorf insisted upon my continuing with the same. Ford confirmed last night to Juan what we had already heard before, that [_] London the firm of Dreyfus had been sued by the English [285] holders of Peruvian Bonds, for the payment of several cou[_] as well as for the payment of such bonds as were to be redeemed annually. The suit was carried before the Court of Chancery where the verdict was given against the bondholders. In France Dreyfus had been sued before the Tribunal de la Seine, and the lawyer who pleaded for him was M. Grévy, present President of the Chamber of Deputies. In the course of the day we were busy arranging the room adjoining my office. The long suite of rooms, formerly occupied by Mariquita and myself, looked to me quite desolate though not a piece of furniture had been taken away. This evening was married in the house of Enrique Canaval, his sister-inlaw Amalia Bolivar, to Felipe Barreda y Osma, eldest son of Don Felipe. The two daughters of Bolivar, viz.: Amalia and Enriqueta, Canaval's wife, are cousins of Manuel Pardo, their mother being Doña Rosaria, sister of the late Dr. Felipe Pardo. Bolivar, one of the gerentes of the Banco La Providencia, lived separate from his wife since many years. 
Tuesday, $9^{\text {th }}$ of January 1877. Every morning before I got up Enriqueta bandaged my infirm knee, and before I went to sleep at night she again removed the bandage.

I of course breakfasted and dined with the Garlands and Juan, and after Bryson was gone in the evening, spent the few hours till bed time with Enriqueta, sometimes together with her brother. Garland was frequently out playing at rocambor. I really should not have known what to do with myself had Enriqueta and Juan not been with me.

About a fortnight or three weeks back Juan Garland, who had for about four months filled the situation of cashkeeper in the Empresa del Carguio de Guano in the Lobos islands, with an excellent salary, returned to his paternal home without a rial in his pocket. What he had done with his money, why he had come, whether turned off, or by his own accord, and what he intended to do of all this I knew nothing. [286] [...] O'clock I took my tepid bath in the bath on Garland's side of the house, which, exactly like our own is very inconvenient. It is so long that when stretched out I cannot touch the two ends with my head and feet, and at the same time so high that with my weak leg I have the greatest difficulty in getting out.

Through Alejandro I obtained a bill for C. W. Schutte, of 14,00o francs, 90 $\mathrm{d} / \mathrm{st}$., at 2 francs goct as near as possible equal to 28 pence per Sol, drawn by Dorca Ayulo \& Co. of Lima on their Paris firm.

Wednesday, $10^{\text {th }}$ of January. I did not feel quite so well as on the previous day. I walked with less ease and had a most disagreeable itching all over the body. At 9 p.m. when Enriqueta and I were sitting by ourselves in her salita, Enrique and Carlos Cox came in. Enrique the elder came to take leave, it being his intention to embark on the $14^{\text {th }}$ via Panamá for Hamburg, whence he had received a telegraphic dispatch from one of his sisters married there, to a certain Kalenberg, who had suddenly fallen dangerously ill. These two Coxes are sons of William Cox, many years partner of Thomas Hoyle of Trujillo. They are men of property, seen in the very best society, and are doing business partly as brokers partly as discounters, dealers in public securities on their own account. They were, I should think, not quite so active as Alejandro, but the money they possessed gave them an advantage over him.

Thursday, $11^{\text {th }}$ of January. Dr. Middendorf came when I was still in bed; he examined my knee, which was certainly a little more swollen than it had been; he ordered, above all, rest, next to this, some liquid to be put upon it every three hours, and against the itching of my body another somewhat oily liquid, which made me remain in bed till near two O'clock for I wished it to dry, before putting on my inner clothes. In the meanwhile Bryson, with the assistance of 
some cargadores removed my library from Juan's room, and put it up in my wife's and my bedroom. I heard from Alejandro [287] that many bills were offered for sale at $273 / 4$ - purchaser[_] stood out for 28 pence.

Friday, $12^{\text {th }}$ of January 1877 . I again rose late, for the same reason as yesterday. By the advice of Doña Josefa Bazo, who had come to spend the day with Enriqueta, the latter rubbed my whole body with pure common brandy of the country, which did me much good. The swelling of my knee was again going down. News had been received from Guayaquil, that the house of Luzzaraga, of late managed by Thomas Carlos Wright, the eldest son of the late General, had stopped payment. In the Congress the Government had suffered two defeats. It had been resolved that the telegraphs were to be managed by the Government itself, not to be let to the best bidder, which latter was the plan of the Government, and secondly, the contract concluded by J. A. Garcia y Garcia, Minister for Foreign Affairs, during the short time that he was Minister for the Interior, with Oliphant \& Co. for the importation of free Chinese labourers, had been disapproved. The contract between the Government and Henry Meiggs for the prolongation of the Oroya Railway to the Cerro de Pasco and for the working of the entire mineral district, not owned and worked by other miners, had been signed and this approval already been telegraphed to John Meiggs, who was at present in England, solely for the purpose of raising the funds required for such an enormous undertaking.

Saturday, $13^{\text {th }}$ of January. The itching over the whole body, of which I was complaining arose from a very slight cutaneous eruption, which, I expected would soon disappear. I continued limping about, without making much progress. The little girls were getting better of the whooping-cough, but Corina was always ailing; sometimes she suffered from fever, on other occasions from diarrhœa, and to her mother she caused many an anxious hour. Enriqueta and I really led a sad life.

This evening we had a long and agreeable visit [288] [_] Alfred Böhl. I saw from the Patria that the debt of the Empire of Brazil external, internal and floating, amounted to $\left(£_{72,000,000)}\right)$ Seventy two millions pounds Sterling, and that the annual revenue, as well as the expenses, came up to between twelve and thirteen million pound Sterling.

Sunday, $14^{\text {th }}$ of January 1877 . The following was my present way of living, for a certainty not a very interesting one; I rose late, for though I was invariably awake by daylight at somewhat past five, I again fell asleep an hour or two later. Enriqueta came in, bandaged my leg, and rubbed my body with brandy; we breakfasted at ten; only Juan and Enriqueta made the meals somewhat agreeable. Bryson came a little past 10.30; he read the Nacional, I dictated my daily diary, and then in order to leave him time to write four or five pages in the 
remodelled diary, I did not know what to do with myself, lay down on the sofa, walked about a little, arranged my papers, went to Enriqueta and so on; for about an hour we corrected the old diary which was to me the most agreeable occupation. For the last half hour Bryson read to me; we were now finishing Scott's biography of Dean Swift. If Juan did not go to Chorrillos, he read me Hubner's work till dinner-time. It was on the $21^{\text {st }}$ June 1870 when the French Consul, the French Sisters of Charity, French Missionaries, three Russians, and two or three other Europeans were massacred in Tientzing by the Chinese mob. We sat at dinner from six till near seven. Bryson read till 8.30, still in Davenport Dunn by Lever. The last hours of the day till near eleven I was with Enriqueta, frequently by ourselves, she had always a cup of tea for me and in bed dressed my knee.

This day, when Bryson had gone at 2 O'clock, Ricardo read to me for more than an hour, Rahncke's Popes. Since the time of Urban VIII, who sat on the throne whilst the thirty years war raged in Germany the power of the [289] Popes had been gradually declining, and it was [...] lowest ebb, at the beginnig of the French revolution, when Rome was taken, and Pius VI carried off as prisoner to France, where he died in 1799 . It was on the $21^{\text {st }}$ July 1773 that Pope Clement XIV, whose name had been Ganganelli, dissolved the order of the Jesuits. Afterwards I had an agreeable visit from Vicente Gonzales, and his sonin-law, the North American Du Bois. Juan had gone to Chorrillos, and in the evening Enriqueta and I were by ourselves till about nine, when Rafael Velarde, wife, and Zoila, came in and remained till eleven.

Monday, $15^{\text {th }}$ of January 1877 . Bryson collected for me $4 \%$ dividend on my shares in the Banco La Providencia and when he came back he accompanied me to the office of the Insurance Company Lima, Calle de Judios, where a meeting of the Shareholders was to take place at 2 p.m. I was there long before the hour fixed upon, when the gerente Carlos Elizalde read to me the Actas of the meetings of the Directory, at which I had not been present; also the yearly informe drawn out by him, and signed by all the Directors. Moscoso Melgar, who was the next to come, told me that the Delegates of the four associated banks had chartered tonnage for about ten or eleven thousand tons of guano to Mauritius, Barbadoes, and another island in the West Indies, whose name he did not remember. In Mauritius, the Guano went consigned to the correspondent of Dreyfus - in Barbadoes to Emilio Mora. It was nearly 3 O'clock before we sat down and after all there were but eleven or twelve; of the Directors, Moscoso Melgar, Chavez, Carlos Prevost - chosen in lieu of Carroll - Jose Maria Peña, and I. The informe was approved without any observation. We declared a dividend of $18 \%, 6 \%$ paid in June last, and $12 \%$ now to be paid. The Reserve fund, which did not yet come up to $S / 200,000$ 
was about S/10oo less than it was in the $31^{\text {st }}$ December $1875[290][\ldots]$ debited with somewhat more than S/14,0oo, the [_] debt of Mazzini, and only credited with $S / 13,000$ at the end of the year. Three Directors went out by rote, viz.: Moscoso Melgar, José Maria Peña, and I; re-elected were: I, with 42 votes out of 49; Moscoso Melgar with 37; and John Mathison with 32; Peña had only 20. Valdivieso, the head clerk in the Company's office, accompanied me home. Going upstairs was easy to me; in the descent lay the difficulty.

In the evening Mr. George T. Pinto was with us for nearly an hour. I was very glad of it, because it whiled away the time. In the course of last week shares of the Banco del Perú, perhaps 6o, had been bought by Escobar at 40\% discount.

Tuesday, $16^{\text {th }}$ of January. Whilst Bryson was copying the remodelled diary, Juan read to me for some time Hübner's promenade. He was now in China, and confirmed in every respect what is but too well known, viz.: the cruelty of the Chinese laws; torture and executions are resorted to on the slightest occasion. Little Corina was again very unwell; this evening she had such a violent fever that at 11 p.m. Middendorf was sent for. She was a great favorite, not only with the whole family, but also with the servants. Enriqueta again spoke of changing climate: La Chosica on the Oroya Road, Magdalena, and Chorrillos were spoken of. I thought that if the family actually left Lima, the preference would always be given to Chorrillos. Enriqueta was thankful for everything I did for them, but Garland, I believe was unacquainted with the word "thanks".

Wednesday, $17^{\text {th }}$ of January. Juan Martin Larrañaga, a native of Spain, had died at an advanced age here in Lima. I did not recollect whether I had mentioned in the course of my long diary that about the year $183^{1}$ or $3^{2}$ he was the chief of that iniquitous band of ruffians, who in Arequipa planned the attack on, and the murder of severaI muleteers who had to take down to the port of Islay a large amount of specie. In those years the road from Arequipa [291] [_] the Coast was considered so safe that the largest amou [...] always went without military escort. The muleteers, and two or three young men from the houses were looked upon as sufficient. Knowing this, the plan had been formed; amongst the set was however a young Lavalle, who though a spend thrift, and good for nothing fellow, had been willing to attack, and rob, but when murder was spoken of he drew back, and denounced the plan to the Arequipa authorities, which was accordingly frustrated. Enriqueta, at my request, began looking over, and arranging the contents of the two large presses, which stood in the little azotea. My dear wife had like me the habit of never throwing away anything, and thus Enriqueta found a great many useless things, and bits of stuff, which she took away to divide amongst her poor acquaintances.

We were by ourselves in the evening. Only Middendorf came at a late hour. Juan had gone to Chorrillos. 
Thursday, $18^{\text {th }}$ of January 1877 . It became known that Henry Meiggs had at the last moment refused to sign the contract of which I spoke on the $12^{\text {th }}$, not that he drew back from what he had agreed to, but because the Government continued to add new conditions, which had not formed part of the original agreement.

We saw by the papers that the Minister of Finances Dr. Aranivar had refused to ratify the valuation made by appraisers (peritos) of the plant, which means the fixtures and movables belonging to the Company which had hitherto carried on the loading of guano vessels, and which in virtue of a contract between the Company and the Government had to be taken by the latter at a fair valuation; but this valuation the peritos had run up to the enormous sum of three million three hundred thousand Soles, and Aranivar very properly refused to acknowledge the same as correct. When I was still in bed Middendorf came and examined my knee, which was gradually recovering its proper, and natural shape, but strength I had not, and walking continued to be difficult and [292] [...] ful. Enriqueta cleared out two chests of drawers in Mariquita's boudoir, a very trying job for the poor woman. By the North Steamer I received a letter from C. W. Schutte extremely polite; another from Sieveking, handing account current. His son-in-law Behn, a man sixty years of age, he told me, had lost his entire fortune, and was again looking out for a situation in a counting house. Six children of his left him by his late wife Theresa, Sieveking's daughter, he would very likely be obliged to take care of, because their father had now no means to sustain them. By the same North Steamer arrived from Europe Pedro Galvez, hitherto Peruvian Minister in Paris; also the notorious Andrés Alvarez Calderon, and Mercedes Castañeda de Villamil, who for many many years had resided in Versailles. She was the sister of Melchor Velarde's wife; some said that her husband Emeterio Villamil, who had abandoned her, was still alive, others, that he was dead. From Valparaiso had come Amalia Riglos, widow of Dr. Francisco Moreyra.

Friday, $19^{\text {th }}$ of January 1877 . This day passed over as quietly as all the days had done since our return from Chorrillos. I began removing part of my clothes from the rooms which Juan now occupied to my new office. In the Evening Enriqueta and I were quite by ourselves for Garland, suffering from bellyache, had retired to bed and it was past ten when Juan came home from his visits.

At about 11 there was an alarm of fire in the printing office of El Nacional, Calle de Melchor-Malo, but in half an hour the noise subsided.

Saturday, $20^{\text {th }}$ of January. Juan finished reading to me Hubner's work. In my opinion the lives of all foreigners who live in the interior of China, even those of the diplomatic agents, run great risk, at all events I should not like to take up my residence there on any account. In the [_] the foreigners are safer because 
they are always under the [293] [_]otection of the men-of-war of different nations. [_] is quickly gaining in commercial importance, and not only Canton, but even Hong Kong will soon be left far behind by this new thriving port. Hübner says that in one year the amount of business done between the United Kingdom and China - I suppose export and import jointly - came up to forty two million pounds sterling. Last night's Nacional made known that the Consejo Departamental did not admit my claim for a reduction in the patente of last year, and I had to pay the thousand Soles yearly - which was a downright robbery. The United States Guano Company wrote me that they could not pay the twenty five thousand Soles which they owed me, and which were long overdue; they proposed to pay on the $22^{\text {nd }}$ together with the interest then due S/100o cash, and to give three pagarées of 8000 Soles each, with interest, and at six months. The Comercio said that in the suit of the bondholders against Dreyfus, the Tribunal de la Seine had decided that Dreyfus should "dar cuenta"; what was meant by this expression I could not say, whilst the "Patria", the organ of Dreyfus in Lima, affirmed that the bondholders had been non-suited. Juan went out to Chorrillos.

Sunday, $27^{\text {st }}$ of January 1877 . Bryson was with me till two O'clock. Garland dined with Villacampa and Federico Palacios, and as soon as he came home he went to bed. Enriqueta and I had with us, first Francisco Velarde, no bright genius, afterwards Francisca Cardenas de Benavides.

Monday, $22^{\text {nd }}$ of January. Juan, who came in from Chorrillos had spoken with Ford, Dreyfus' partner; the sentence of the French Tribunal de primera Instancia had been, firstly that the bondholders had no right to embargo the guano in Dreyfus hands; and secondly that within three months Dreyfus should present to the Tribunal a statement of their accounts [294] [...] vian Government. In Brooklyn, the theatre had been destroyed by fire, and many lives been lost.

In London the Peruvian Consul, Manuel de la Quintana, had stopped payment; he was a natural son of Mrs. Elias' father and when in Lima was known as Manongo Bolon, a nickname given him on account of his stoutness; he was always servicable and good natured, but having married an English lady, lived by far beyond his income, and was by no means exact in pecuniary matters; thus for instance, not very long ago the Archbishop of Lima requested him to buy a carriage for him, and at the same time remitted the money. The coach was ordered, sent out to Lima, received by the Archbishop, but was not paid for by Quintana, and the Archbishop being applied to by the London coachmaker, had to pay for it the second time.

Tuesday, $23^{\text {rd }}$ of January. All I could say was that I was by no means the same man I had been twelve months back. My sight was worse than at that time; as yet I could not walk - or at least not venture down stairs - and for the moment 
I suffered from a cold, my bowels were out of order and I felt a continual itching all over the body: these last three ailments I trusted I should soon get rid of; but, what was the worst of all, my good and elastic spirits of which I formerly boasted, were gone.

Wednesday, $24^{\text {th }}$ of January. Ricardo finished reading to me Rahncke's Popes. On the $7^{\text {th }}$ August 1814 Pius VII re-established the order of Jesuits. In 1829 when the Duke of Wellington was Prime Minister, the Bill for the Catholic Emancipation passed both houses. In the evening Enriqueta and I had visits from Mrs. Pinto, and her two daughters, Leonor and Rosa, very nice people; whilst they were with us, Manuel Costas called with his two daughters. I really wondered that he came, because the whole period of his Vice Presidency we had hardly taken any notice of him: he was a very old, and I may say good friend of ours, not so clever as his brother José Maria, but very good natured. [295]

Thursday, $25^{\text {th }}$ of January 1877 . Having passed a [_] bad night I fell asleep in the early hours of the morning, so that I was still in bed when Dr. Middendorf called. He and I looked at my left knee; it was much better, but not yet like the right one; for the first time for the last ten weeks I again ventured to put on the boot on my left foot.

In the course of the forenoon Mr. Linich, in former years partner in the Lima branch of Huth's house, now in the same capacity in Valparaiso, and on his way to Europe via Panamá, called upon Juan. I also saw him, and amongst other things he told us that in the commercial community of Tacna silver was exclusively the circulating medium; the Lima Bank notes nobody took, nobody paid.

The Banco Anglo Peruano, of which establishment at the time of its foundation such great expectations were entertained, was liquidating. Jameson, the head manager, had come hither from Iquique, and Oscar Heeren and Rafael Canevaro, the gerentes, had lost their situation.

Juan began reading to me another French book called Cinq Mars, written by Le Comte Alfred de Vigny. Cinq Mars was the young Frenchman who, for some time the favourite of Louis XIII fell a victim to the King's moral debility, and to Richlieu's unrelenting despotism. He was the second son of the Marquis D'Effiat, and his christian name was Henry.

Garland had gone to Chorrillos to dine with Gallagher and when Bryson had done reading to me at 8.15 p.m. I found with Enriqueta and Juan two sisters, Moreyra, the one wife of General Freyre; the other wife of Hulsenbeck. There was also Pedro Mascaro, just arrived from Paris, brother of Felipa and of Rosa, the unfortunate wife of Andres Alvarez Calderon.

Friday, $26^{\text {th }}$ of January. Exchange on London fluctuated between 28 and $281 / 2$ pence. Rehder told me that Scheel had offered him $£ 2000$ at $30 d$ the bills to be given on the 27 March, whilst the money was to be paid cash down. He 
had not accepted the proposal. From Alejandro I learned that for [296] [...] about £21,00o had passed through his hands, whi[_] he had bought at $28 \mathrm{~d}$ and resold, partly at $273 / 4$, partly receiving a brokerage of $1 / 4 \%$.

In the evening Bryson finished reading to me the long novel Davenport Dunn by Lever, which, though very amusing, does however not stand on a level with Walter Scott's or Bulwer's master pieces.

Saturday, $27^{\text {th }}$ of January 1877 . I passed a shockingly bad night, coughing incessantly; at four Enriqueta entered my bedroom; she had been there twice before, when I had not observed her, and gave me a teaspoonful of syrup against the cough. I then fell asleep, and did not awake till half past ten when Bryson sent for the key. In the daytime I was much better. In the evening we began reading Washigton Irving's Live of Mahomet. Mahomet was born in Mecca in April 569; he belonged to the distinguished tribe of the Koreish, from whom descended Haschem, and Abd Schem; the former had under his charge the Caaba, a structure revered by the Arabs being an imitation of the tabernacle in Paradise, adored by the Angels. It was built, as Arabian tradition says, by Ishmael, assisted by his father Abraham, and in the walls of the Caaba, a stone of wonderful holiness is immured. This stone, the accepted tradition says, was originally Adam's guardian Angel in Paradise, which angel, when Adam and Eve were expelled, was punished for his want of watchfulness by being changed into stone. Haschem's son was Abd-al-Motalleb, who had many sons and daughters, amongst whom five sons Abu Taleb, Abu Lahab, Abbas, Hamza, and the youngest Abdallah, who, a very handsome man, married Amina, and became the father of Mahomet. Abdallah dying young, Abu Taleb took his nephew under his care.

Sunday, $28^{\text {th }}$ of January. Bryson commenced reading the New Testament to me. According to the Evangelist Matthew fourteen generations passed between [297] Abraham and David; fourteen between [...] the carrying away of the Jews into Babylon; and fourteen from the Babylonian captivity unto Christ. When Bryson left me at two, Guillermo came, who was occupied till past five posting the cash book into my ledger. Juan was in Chorrillos. Francisco Velarde dined with us, and in the evening, when Garland and Enriqueta had gone to visit their daughter-in-law Eliza, Ricardo read to me from a German Review an article treating on the notorious assassination of the French Plenipotentiaries close to Rastadt in 1799. According to the writer, who gives very weighty reasons for his opinion, Thugut, at the time Prime Minister in Vienna, gave orders to Archduke Charles, who commanded the Austrian Army, to possess himself of the archives of the French Embassy. Archduke Charles transmitted the order to Subalterns, who again ordered the officers commanding a regiment of hussars, known as Secklers, to attack the French Ambassadors on the high road, and to 
take their papers from them: this in itself was an unheard of breach of national law, and the hussars, rough, and cruel, exceeded their orders - first murdered and then robbed. The officers were placed before a tribunal, at first with great apparatus, but by and by the affair was drawn out to an uncommon length, and finally the whole buried in oblivion: the officers underwent no chastisement. This, in my opinion is quite as wicked an affair as Napoleon's murder of the Duc D'Enghien, which took place in the same year. [...]

Monday, $29^{\text {th }}$ of January 1877 . I still coughed during the night, and again Enriqueta came, about 4 a.m. to give me a teaspoonful of syrup. My knee was getting better, but was not yet so strong as the sound one. This morning died Henry Swayne, at a very advanced age, and after an illness of only two days. He used to go to his estates in Cañete once, and even twice a week, and was to the very last a strong, hale, and active man. I hardly knew him by sight. [...] [298] [_] than forty years back he and William Reid were establish[_] in Lima as import merchants; they failed, and, as it was said, had not paid all their debts up to this day. One of their debtors was a certain Narciso Colina, owner of an estate in Cañete. This estate came into their hands, Swayne bought others, and was at the time of his death one of the largest propietors of sugar estates in that valley. To the Banco Hipotecario he owed S/340,000 and had always paid with the greatest regularity. His wife was a daughter of the old Vocal Francisco Javier Mariategui, and his death would certainly cause a notable void in his family. Now Charles Pflücker, my junior by a few years, and I were the only foreigners left in Lima from the time of the Independence. In England there were still John F. Johnson; on the Continent Daniel and Christopher Schutte. The whole forenoon Enriqueta was occupied with arranging the various presses which my wife had left filled with her dresses and quantities of different stuffs of little value. It was an ungrateful task, and Enriqueta did it because there was a necessity for her doing so. According to the late Baron Bunson, Prussian Chargé in Rome, afterwards in London, the three prevailing failings or Vices of the French, English, and German nation are respectively: licentiousness, selfishness, and self conceit. In the evening Bryson continued reading to me the life of Mahomet, and whilst he was so occupied, Dolores Puente, who was with Enriqueta, sent for me, and of course I had to go.

Tuesday, $30^{\text {th }}$ of January. About one in the morning I had once more a severe attack of coughing. Enriqueta as usual came and gave me some syrup. I then slept till about 8 , when on awaking I found Dr. Middendorf standing at my bedside: he was of opinion that I had again caught cold. This day I did not feel well. Again the whole forenoon Enriqueta was occupied, not with the presses, but with many trunks which my wife had left filled with all kinds of things. Frequently she called me to shew me contents and both to her and to me it was 
a sad occupation. In the [299] evening when Bryson was gone I immediately $[\ldots]$ bed for I did not feel well; it was late before I fell asleep. I coughed but little and

Wednesday, $37^{\text {st }}$ of January I awoke rather better. Again Enriqueta was busy with the many things of wearing apparel left by her mother. Juan went to Chorrillos. Nothing worth mentioning occurred. The North steamer brought me a very polite letter from $\mathrm{C}$. W. Schutte, and from Gibbs their account current to the end of the year. On the $1^{\text {st January I had in their hands } £ 2,106.15 .5 . ~ I ~ s p o k e ~}$ to Garland about the payment of the $2 \%$ interest on the $\mathrm{S} / 60$,ooo Cedulas lent him in August 1876, and which interest was due since the $2^{\text {nd }}$ inst. He answered that he would again speak about the payment to the notary Palacios, his brother, the lawyer, and real debtor being absent, to which I replied that I had read his pagaré, in which it was clearly said that I had to look to him for the payment, and that no mention was made of Palacios. No doubt he heard what I said but, as it is his custom, he said nothing.

Thursday, $7^{\text {st }}$ of February. Though I slept soundly the whole night I awoke this morning rather unwell, and at a later hour suffered from headache. Advice from Europe said nohing certain regarding the Turkish question. The conferences in Constantinople continued without having as yet led to any result. In New York had died the rich Vanderbilt, who, the papers said, had left a fortune of between ninety and one hundred million dollars. Ricardo read me from a German Review that on the $11^{\text {th }}$ October last year Joshua Waddington had died. He, born in York 1792, had since the first years of the Independence of Chile, been well known in Valparaiso, not as a political character, but as merchant, and builder. Once a rich man, the fortune now left by him could, in Juan's opinion, not exceed S/200,000. For a series of [300] [...] in Valparaiso, and that of Templeman Bergmann \& Co. of Lima, both branch establishments of the firm of Brownell of Buenos Ayres, had formed one joint concern. Afterwards they separated, and then Templeman Bergmann \& Co. changed into Templeman \& Bergmann. The Finance Minister José Aranivar published a decree of importance. Considering that the Congres would close its sittings, without coming to a decision relative to the Banco Central, it was indispensable that some measures should be taken to decrease the circulation of the notes of the four associated Banks, and consequently, in the course of one year from the $31^{\text {st }}$ January, the four banks jointly, each in proportion to the amount of its notes, were ordered to withdraw from circulation one million Soles and deliver them to the Government. Secondly, they had to coin every month in the Lima Mint S/50,000 in one and two rial pieces, for which sum in silver, the Government was to give them S/50,000 of their notes; and these S/50,000 monthly would be annulled in the same manner as the one million annually. 
Also the Government ordered the coinage of $S / 5^{0,000}$ in small coin and the joint $S / 100,000$ were to be put in circulation all over the Republic: my opinion was that the standard of the small change ought to be very low, otherwise it would again be exported. The steamer "Montezuma" which, as said some pages back, had been taken by some Cubano insurgents headed by President Prado's natural son, and whose name was afterwards charged into that of "Cespedes" was no more in existence. Near the port of Trujillo on the Coast of Honduras she was chased by two powerful Spanish Steamers, and seeing the impossibility of saving the vessel, the crew set fire to her and escaped on shore. Juan continued reading to me the novel Cinq-Mars, which gives a horrible, but I believe not exaggerated account of the character of Cardinal Richelieu, and of those persons who [301] formed his most intimate circle: of them, one Capu [...] Joseph - who went by the name of "his grey eminence" - surpassed all the rest in astuteness and wickedness.

Friday, $2^{\text {nd }}$ of February 1877. Candlemas. In yesterday's meeting of the shareholders of the Banco Hipotecario, for which I had given my power to Evaristo Barrios, Mr. Henry made the following motion, which passed without any dissenting voice. The $S / 14,109.60$ which remained to the credit of Profit and Loss, after $\mathrm{S} / 300,000$ had been distributed amongst the shareholders, were to be divided in the following manner: $S / 6000$ to be paid as remuneration to the Gerentes, each one half; $S / 2500$ to the Drirectors; $S / 2000$ to the clerks; and the small remainder of $S / 3000$ more or less, to be carried to Reserve fund. Advices were received by telegraph from Europe that the Conferences in Constantinople had been broken off, and that all foreign Ambassadors had left this capital.

My leg got stronger from day to day, and my cough was not so troublesome, nevertheless I was not altogether well, now and then I suffered from a slight headache, a thing which I had hardly ever known before. The whole day long, from 10.30 when I rose from breakfast table, till 8.30 in the evening, when Bryson ceased reading to me, I was, with the exception of one hour for dinner, continually in the inner rooms, first with Bryson, then with Guillermo who wrote up my books. I went to bed before nine, but Juan and Enrique kept me company till half past ten. Thirty seven weeks had now elapsed since the $20^{\text {th }}$ May 1876, but not one single Friday night had I lain down without remembering that it was in the night from Friday to Saturday that my dear wife was taken from me.

Saturday, $3^{\text {rd }}$ of February. Last night I was awake from 2 till 3 a.m. In the course of this day I was many hours totally unoccupied for Bryson had necessarily to copy many pages of the remodelled diary and Juan had gone to Chorrillos [302] $[\ldots]$ however a visit from Evaristo Barrios, who gave me some information 
about the Banco de Lima. A partner of Huth's house in Valparaiso, who passed through Lima a few days ago, brought with him full power to proceed against the Bank for his own firm, as well as for the International Bank of London, both creditors of the bank to a considerable amount. After several disagreeable and even stormy conferences it had been agreed upon that of the Nitrate Certificates, property of the bank, arising from their claim on the Salitrera Esperanza, a sufficient number should be placed into the hands of Graham Rowe \& Co., to cover Huth, and the International Bank, for the amount of their claims. The Banco de Lima further took upon itself the obligation to remit every

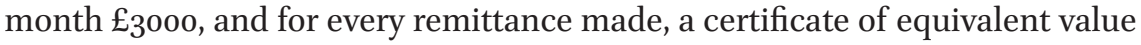
should be returned to the bank. A dividend of $9 \%$ would be paid, because, without valuing the bad debts of the bank, last year a profit of S/270,00o had been made, of which S/225,00o would be divided, and the balance carried to reserve fund.

Sunday, $4^{\text {th }}$ of February 1877. I coughed a good deal in the night and I had now come to the conviction that it was a slight attack of whooping cough from which I suffered. My knee again began to pain me, and I was by no means so well as I could have wished. I saw by the papers that the contract between Henry Meiggs, and the Peruvian Government respecting the conclusion of the various railways, which had been begun, the draining of the Cerro de Pasco Mines by means of a new adit and the working of all those mines on Meiggs account, which had no owner, or were not worked at present, had at last been concluded. I did not understand the terms. In one place it was said that the Government had to raise a loan, and provide the money required; in another, that Meiggs was to find the funds, and it was well known that about a year back John Meiggs went for this purpose to England. The [303] Finance Minister made known that sealed [...] be given in by such persons as required Bills for the 22 [_] March, the money to be paid on the $9^{\text {th }}$ inst. The sum the Government had disposable was £25,00o; the exchange, the Minister said, would be 30 pence, and then he added that offers might be made. This was Aranivar's usual confused manner of expressing himself.

In Chorrillos, Mariano Olazabal had suddenly died struck by apoplexy; he was a very active man, a relation and particular friend of the Paz-Soldans. When Bryson was gone, Ricardo read to me several hours in the forenoon from a German Review an interesting article on the late war in the United States. Of the seventeen Presidents who had ruled the destinies of this vast country from Washington inclusive, to Lincoln exclusive, eleven had been natives of the Southern States. Sherman, the famous General of the Federals, was a native of Ohio; Lee, the equally famous General of the Confederates, was born in Virginia. His wife was a daughter of George Washington, the great 
Washington's adopted son. In the evening were celebarated in the house of our neighbour Enrique Ayulo, the nuptials of his eldest daughter Rosa, an agreeable young lady, with Carlos Ferreyros, in former years commander of the 'Chalaco', at present Prefect of Lambayeque. The Canon Bandini performed the ceremony, to witness which a great many persons had been invited. Of the number were: Alejandro, married to a cousin of the bride; also Geraldo, but neither Mr. and Mrs. Garland, nor myself: they, because since Alejandro's marriage an estrangement had arisen between them and the Ayulos; I, because I had completely left off going into company.

Monday, $5^{\text {th }}$ of February. I again coughed a great deal during the night. Nothing worth mentioning occurred in the course of the day. Juan continued reading to me before dinner the novel called Cinq Mars, whilst [304] [...] to me when we had a moment's leisure in the forenoon, Walter Scott's Life of Swift, and in the evening Irving's Life of Mahomet.

Tuesday, $6^{\text {th }}$ of February 1877. Last night the Congress Extraordinary closed its sittings. In one of its last sessions a motion made by the friends of Doña Virginia La Torre, to obtain as her pension or montepio the entire pay which her late husband Admiral Domingo Valle Riestra had received, was negatived: she would therefore only receive the lawful pension, a mere pittance, insufficient for her and her family's maintenance. By another law given by the Congress, a new Department was formed, that of Tarapacá, which hitherto part of that of Tacna included the nitrate districts, the ports of Iquique, Mejillones, and Pisagua, and extended Southwards as far as the river Loa.

At somewhat past one, I, after the lapse of a month ventured downstairs without assistance, and went to the office of the Insurance Company "Lima". We were only four - not the requisite number - viz.: Mathison, lalety elected Director, Robertson, Gil, and I; nevertheless we proceeded to business Robertson taking the chair, there being neither President nor Vice. The only thing of importance on which we treated was the plan to which I have already alluded on a former occasion, of forming a group of private underwriters in the same manner as it had been done in the South American Insurance Company. We came to no decision, but for my part, after mature reflection, I resolved not to take any share, even should my colleagues be inclined to form such a company.

Wednesday, ${ }^{\text {th }}$ of February. Middendorf was already with me before I rose. He examined my knee and declared that it was exactly like the sound one; he also said that in course of time it would recover its pristine strength.

Having felt very weak the whole day long, I went [305] to bed at as early an hour as 9. Ricardo however [_] to me from 10 to 11 an article in German, regarding a certain Robert Von Mohl, born in August 1799 in Tübingen, a 
University in the Kingdom of Wirtemberg, and who died in November 1875. I had never heard of him before, but in this article he was represented as a man of extraordinary learning, especially in everything relative to international law, to Governments, to Constitutions, etc. Secondly, as a true German patriot of the liberal school who from his youth had at heart the unity of the Fatherland; thirdly, in his moral character of spotless purity; it is not said whether he was married. In the course of his life he wrote a great many works, upon the whole much esteemed; he had been professor in Tübingen and Heidelberg; he had been member of the Chamber of Deputies in Wirtemberg and Baden; and even Minister of Justice during the short regency of the Archduke John in 1848 and 1849. All who knew, loved and respected him.

Thursday, $8^{\text {th }}$ of February 1877 . I again spent a bad night for the cough allowed me no rest. I rose very late, and did not feel any stronger than I had done on the previous day. Alejandro brought the news that his suit against the Banco Garantizador, from which establishment he demanded for thirty thousand Soles in their notes, payment in coined silver had been voted, but not decided, in the Supreme Court. Four of the judges had voted in his favor, probably Sanchez, Vidaurre, Oviedo, and Leon. They opined "que no habia nulidad", in other words they confirmed the sentence of the inferior courts. The other three Ribeyro, Cosio, and Muñoz had given it as their opinion "que habia nulidad", that is to say they annulled the inferior sentences. All seven disapproved Morales' Vista-fiscal to the effect that the appeal was improcedente; it was procedente they said, and accordingly they had sentenced. Now an juez derrimente had to be named. In the evening whilst Ricardo read to me, Garland and Enriqueta went to see the Vocal [306] [_]ez and his family, who were always particulary polite towar[_] us. It was nearly 11.30 before we retired to rest.

Friday, $9^{\text {th }}$ of February. Last night I coughed little, and slept well. Nothing worth mentioning occurred in the course of the day. We, that is to say, Enriqueta, Juan and I stayed up till 11 O'clock.

Within these days died Rosa Robinet, widow of Peter Conroy who, in the course of her life had experienced many vicissitudes. When unmarried and residing under the paternal roof, little mention was made of her in the Lima society, for her father - an Englishman from the East Indies - had just the means to maintain his family, his wife, Rosa Garcia, and Several children, of whom Rosa was the eldest daughter. When she became the wife of Peter Conroy, a great change took place in her circumstances. He was a man fond of ostentation, and erelong husband and wife vied with each other to make their house the most frequented in Lima, and certainly they succeeded in what they had so much at heart. On Sunday forenoons no lady had more 
visitors than Doña Rosa, agreeable, well educated and good-looking - though not handsome, still less beautiful. Their dinner parties were first rate. In their saloons when a dance was given the first society of Lima was seen, and all guest returned home, pleased and satisfied. This lasted for a few years until the house of Naylors of Liverpool, and its various branch establishments stopped payment, which was in a great measure owing to Conroy's mismanagement and extravagance. Not long after the failure he was struck by apoplexy, then followed his death and thus poor Rosa gradually descended from the pinnacle of human enjoyment to the straights of poverty. During the last years of her life she lived upon the donations of those who had known her when in affluence; at first they came in voluntarily and readily, then more reluctantly, and finally in many instance ceased altogether. Her father and mother had preceded her to the grave. She left no children.

Saturday, $10^{\text {th }}$ of February 1877. I slept the whole of last [307] night without awaking. The $\mathrm{S} / 1200$, interest at $2 \%$, due [...] on the $\mathrm{S} / 60,000$ Cedulas del Banco Hipotecario, lent by me to Garland, had not yet been paid. Garland, to whom I spoke on the subject answered that the notary Francisco Palacios from whom he had to receive the amount had not paid, and as to his own reponsability he made me observe that there was a clause in the pagaré which said that for any delay, interest would be charged by me. I saw by the paper 'El Nacional' that the first steamer which crossed the Atlantic was the "Savannah" under American colors, from Savannah to Liverpool, where she arrived on the $20^{\text {th }}$ June 1819 .

The old Frenchman Chalons, who called himself an architect, and whom my wife employed once or twice, had lately died.

Juan continued reading to me the French novel Cinq-Mars. We had come to the discovery of his conspiracy against Richelieu, to his arrest, and to his execution in Lyons. If the novel can be believed, so many of his friends had assembled, ready and able to overpower the troops round the scaffolding, that he might have been saved, if he had but willed it; but he was determined to die, and was accordingly beheaded, at the early age of 22 . Juan went out to Chorrillos, where he intended to remain during the three Carnival days.

Sunday, $11^{\text {th }}$ of February 1877. Carnival. I slept well and coughed little, but my knee did not get stronger; and in the first hours after breakfast, I always felt an extraordinary debility: the worst was that I had never any appetite, and therefore ate very little. This forenoon I was so weak that I had necessarily to eat a biscuit and take a little port wine. When Bryson was gone, Guillermo was with me writing up my books till the $3^{\text {st }}$ January. Our whole family had been invited to spend the day with Federico Palacios. Only Garland, the two little girls and Juan - who returned this morning from the Lobos islands - went and 
came home about ten. Guillermo and Geraldo were with us till 8 after which hour Enriqueta, Ricardo [308] [...] were by ourselves.

Monday, $12^{\text {th }}$ of February 1877 . I felt a little stronger than on the previous days. A strange change had come over me. It seemed as if since the $20^{\text {th }}$ May of last year not nine months but nine years had passed over my head; I did not like to go into company; I could not walk well owing to the weakness of my knee; and sometimes, this day for instance I was very low spirited. Guillermo was with me writing till past three, when he had done all he could do for the present; then Ricardo read to me some interesting, but heavily written observations on the last Franco-German War. The French Marshals, particulary Bazaine, had acted without any fixed plan, and without any energy.

Eliza, Guillermo's wife, dined with us. A few nights ago there was a fire in a shop close to J. V. Oyague's house in the Calle de Boza; the owner was insured in the South American Insurance Coy. Lima; and it was generally supposed that he himself had set fire to the few articles he had in the shop. This morning there was another fire in a pulperia, Calle de la Palma, and in the afternoon a third, in a coal depot in the Calle de San Jacinto, belonging to Rivarola \& Co., of which firm Guillermo was a partner; fortunately the fire was soon extinguished, but the loss would always come to a few hundred Soles.

Tuesday, $13^{\text {th }}$ of February. My cough was getting better, but my general debility, as well as the weakness of the knee continued. I limped down the staircase as well as I could manage, opened the iron chest, and Bryson and Ricardo carried up all the contents, of which Bryson wrote a new list. In a few days it was my intention to have the chest brought up; meanwhile I stowed away the contents in my rooms. When Bryson had left me, Ricardo read to me from a German Review an article on the oriental question, but I paid little attention to the reading, sleep overpowering me every ten minutes. I could hardly eat anything at dinner, and after Bryson had read to me, I felt so extremely weak that I Immediately went to bed. [309]

Wednesday, $14^{\text {th }}$ of February 1877. This day my [_] was worse than ever. Middendorf was called, and he prescribed some bitter drops to give me appetite. It had been my intention to be present at the meetings of the shareholders of the Banco del Perú in the forenoon and the Banco de Lima in the evening, but I found it quite impossible to go out. Juan, who had come in from Chorrillos, represented me in the former, Evaristo Barrios in the latter.

In Chorrillos the three Carnival days had been very gay. Ricardo Zevallos gave a ball on the $1^{\text {st }}$, Felipe Varela on the $2^{\text {nd }}$, and José Canevaro on the $3^{\text {rd }}$ evening. William Scheel gave likewise a well attended ball in his house in Miraflores on Sunday evening. On Monday early in the morning died Dr. Blas José Alzamora, pensioned vocal of the Supreme Court, at a very advanced age. At 20 he had 
begun his career, as legist, when the Spaniards were still ruling the country; already at 22 he exercised his profession under the patriot Government, and very strange to say, though he had been more than once Deputy to the Congress, frequently provisional vocal of the Supreme Court, and quite as often fiscal of the same tribunal; he only obtained his seat in the same as Vocal in propiedad, two or three years before his death. I was pretty well acquainted with him, and believed him to be one of the cleverest men in his profession.

This day after dinner I felt what I might call uncommonly well. We had a visit from the Italian clergyman Dr. Valeri, and it was 10.30 when I went to bed.

Thursday, $15^{\text {th }}$. I slept so so, and was extremely weak. Juan told me that in yesterday's meeting of the shareholders of the Banco del Perú, the informe had been read, which declared a dividend of $41 / 2 \%$ to the shareholders, and these $41 / 2 \%$ added to the $41 / 2$ paid in the course of last year, made a total of $9 \%$ for 1876. The terms of the Gerentes having expired, new ones were to be named, and the choice fell upon the previous ones J. P. Escobar, and Cesar Canevaro, whose salary was increased [310] [...] each p.a. besides $5 \%$ each upon the net profits after deducting $9 \%$ for the shareholders. Also some Directors went out by vote, and in the usual manner, the names being written upon folded up pieces of paper, and then thrown into an urn, new ones were elected, but as Juan had left before they were called over, he did not know who had been chosen. The affair of the Eten Railway was not yet settled. With Bryson I spent the forenoon in the usual manner; he copied some pages in the remodelled diary; we corrected that of September 1863, made out an account-current for C. W. Schutte, and found still time to read an article in the Eclectic on Charlotte Bronte, the authoress of Jane Eyre. In the evening Enriqueta had a visit from Dolores Puente, who wanted to see me, and I of course remained a few minutes with this excellent lady. Juan, with a bad cold, did not go out, and he, Enriqueta, and I, who was unusually well, remained together till half past ten.

Friday, $16^{\text {th }}$ of February. By the advice of Dr. Middendorf, who was of opinion that fresh air, and a little exercise would do me good, I drove out to the Exposition park accompanied by Enriqueta and the little girls; here we alighted, and walked about a considerable while. I however derived but little pleasure from this promenade, for the slightest inequality in the ground caused me a momentary pain in the infirm knee, besides which, my weak sight suffered from the occasional glare of the sun, which we could not avoid as it was impossible to keep always in the shade. We were home before breakfast time.

I learned that the informe which was read on the $14^{\text {th }}$ in the meeting of the shareholders of the Banco de Lima, by the gerente, was a very poor one; it said that, without valuing the outstanding debst, which operation would naturally bring a large sum to the debit of Profit and Loss, the gains made in the course 
of 1876 enabled the Directory to declare a dividend of $9 \%$, to be paid when the state of the cash would permit. In the same meeting Manuel Cucalon, hitherto provisional [311] gerente, was named "en propiedad". Lembcke [...] as his collegue. It was also voted that henceforth the directory could not ask a fresh quota, without being authorized to do so by the majority of the shareholders. This, in my opinion meant to say that no further quota would ever be asked for, but whether such a resolution could release the shareholders from their responsibility for the second $50 \%$ not yet paid up was quite another question, and I was convinced that if the bank were in such a bad condition as not to be able to pay the billetes which had been issued, each shareholder in proportion to the amount of shares he held, was responsible for the deficit.

Saturday, $17^{\text {th }}$ of February 1877 . Last night I was awake from before 3 till past 4 , the very time when thirty-nine weeks back I experienced my irreparable loss. I was again awake before seven, and after Enriqueta had bandaged my weak leg, I arose. Long before eight the same four as yesterday morning drove down the alamedas de Acho then round that of Los Descalzos, walked about a little in the garden, and were back in an hour's time. I much enjoyed the drive, but when the Cerro San-Cristoval came in view I could not but apprehend that the weakness in my leg would not allow me ever to ascent it again.

In the course of the forenoon I ventured down-stairs, went to a barber to get shaved, which for many weeks past had been done in my own house, and looked in at Carlos Elizalde's in the office of the Insurance Coy. 'Lima', with whom I remained about a quarter of an hour. Many rumours were afloat as to the intention of Henry Meiggs to issue on his own account bank notes to the extent of three or four hundred thousand Soles, to be signed by the Compañia de Obras Publicas y Fomento del Perú. The general opinion was decidedly opposed to this new emission of paper money.

Juan as usual went out to Chorrillos to remain there till Monday morning. For the greater part of the evening [312] [_] a and I were by ourselves.

Sunday, $18^{\text {th }}$ of February. I felt this morning pretty well. Ricardo read to me some German newspapers, by which I saw that on the $23^{\text {rd }}$ December the new Constitution for Turkey had been published. It was a wonderfully liberal one. Turkey was to be a Constitutional Monarchy with a Senate and a lower Chamber, the Senators to be named by the Sultan, and to receive a salary of two thousand three hundred francs monthly; the Deputies to be chosen by the people one for every fifty thousand. They were to sit from November to February, inclusive, and to receive the same pay as the Senators. The Ministers, to be responsible; the Sultan to be the Chief of the Empire and the Caliph of all faithful; Islaamism to be the religion of the state; all other religions to be 
tolerated; the press to be free; the Municipal institutions to be as independent as possible from the central power.

On New Year's day 1877 Queen Victoria was proclaimed Empress of India on a small plain close to Delhi, with extraordinary pomp. The Viceroy Lord Lytton, the Presidents from Bombay and Madras, and many Indian Chiefs for instance he from Cashmere - tributaries to the Anglo India Government, military forces and a large concourse of people were present at the ceremony.

I dictated to Bryson a long letter to my cousin Frances Cresswell, which took up all my time till two O'clock. Hereupon I begged Enriqueta to come to my apartments to look over a quantity of glass and Chinaware which my wife had kept in the sideboard, and in other pieces of furniture, and which my daughter now rearranged. I had a long call from my tenant S. Sattler, Cousin and partner of Gildemeister; he told me that he was fast losing his sight; he had given up writing and reading, and about the end of April or beginning of May he would go to Europe with his family, in hopes that the oculists theres would be able to cure him. On the two export articles of sugar and nitrate he gave me many details, which were new to me. A Fanegada - or about 42,00o square varas - of well [313] [_] planted with sugar cane, gives a crop of from four [...] o seven hundred quintals annually, which difference in the quantity arises from the circumstance that the first crop, or cutting gives most, the second less, and the third least. Of all the Nitrate consigned by the Government to Gibbs in London not a pound had as yet been sold. Gildemeister \& Co. were under the obligation of producing yearly 650,000 quintals, Gibbs 500,000, and other producers of minor importance Sattler thought might produce jointly in the year somewhat more than 1,000,00o quintals. The total, which surpassed by far 2,000,000 quintals annually, Gibbs had to pay for on account of Government at $S / 1.70$ at an exchange of from 40 to 44 pence, I did not remember which. Then they had to pay the freights, the landing and storing expenses, and finally the interest of $8 \%$ p.a. upon the certificates given by the Government to those who had sold their nitrate establishments, the one with the other, a very heavy outlay to be incurred by them. Sattler was moreover of opinion that the free producers could not continue to export to advantage with the present export duty of $S / 1.25$ at $40 d$, equal to $4 / 2$ per ql and thus, Gibbs becoming in course of time the only holders, would have it in their power to raise the price to fourteen of fifteen shillings cwt.

After dinner Ricardo read to me from German Reviews interesting articles relative to Turkey. All was new to me. On the $9^{\text {th }}$ and $10^{\text {th }}$ May of last year the Sophtas and Ulemas presented themselves before the Sultan Abdul Azis and demanded the dismission of the Grand Vizier, whom they knew to be a mere creature in the hands of the Russian Ambassador Ignatief, as well as of another 
high functionary. This demonstration was so well backed that the Sultan had to give way, and by and by an entirely new Ministry was named, all whose members were determined to raise Turkey from its debasement and from its dependence on Russia. Ignatief, not feeling himself secure in his official mansion in Pera, removed to his country house. One German review translated Sophtas in[_] [314] [...] mas into learned men. Another called them the representatives and interpreters of Islam, as regards religion, law, and justice. They further demanded a liberal constitution in imitation of that of England; which not being granted they retired in high dudgeon. The Russian influence was for the time at an end in Constantinople, and it was evident that the new Ministry leaned for support on England. The stubborn Abdul-Aziz was dethroned in the night from the $29^{\text {th }}$ to $30^{\text {th }}$ May. He, born in 1830 , had succeeded Abdul Meschid in 1861. All his life time he had been a slave to one all absorbing passion, that of insatiable acquisitiveness, joined to an ungovernable desire for hoarding. During his rule the treasury was empty, the people poor; he was the only rich man in the Empire. After his dethronement his nephew Murad, who all his lifetime had been opposed to the political views of his uncle, was raised to the throne under the name of Murad V. A few days later the death of Abdul Aziz became known; it was said that he had commited suicide - and on the $31^{\text {st }}$ August Murad V was forced to descend from his elevated station under pretence of mental derangement, and his brother Abdul Hamid raised to the throne in his stead. This last named one of the German Reviews represented as a true Turk of the old school a decided enemy to all foreigners and all reform; but if this were true how did it hamonize with the liberal constitution proclaimed on the $23^{\text {rd }}$ December 1876, of which I have spoken above. The insurrection in Herzegovina, Bosnia, and Montenegro began in 1875 and extended to Bulgaria. The Servians rose in 1876 . At a later hour Enriqueta read to me a short diary, or rather mere notes written by my wife on our travels from 1854 to 1856 .

Monday, $19^{\text {th }}$ of February 1877. Last night I was again awake more than an hour, and this day I was very low spirited.

Juan came in from Chorrillos, and Enrique started for his mine in the Cordillera. In the forenoon [315] whilst Enriqueta was occupied in the same manner as she [...] $\mathrm{n}$ the previous day, she called me and made me observe how neatly every article, both glass and China had been wrapped up, and how carefully it was stowed away. My dear Mariquita had done this assisted by the black girl Rosalia, and without my knowing anything about it. Now, my daughter and I were quite at a loss to guess the motive which could have induced my wife to take this, apparently, unnecessary trouble. Perhaps she might have apprehended that her end was not far distant, and therefore thought it her duty to leave everything in the very best order. Garland and Enriqueta went 
out in the evening to pay a visit to the Basagoytias. Whilst they were absent J. P. Escobar came to see us. Juan and I had a long talk with him. As far as I could judge, the affairs of the Chilete Mine looked rather gloomy. Escobar said that if of the enormous mass of metal which had been extracted, ten tons daily could be separed by the machinery, then in the course of the present year the advance made by José Canevaro might be paid off, and this done, the shareholders would have some prospect of a fair dividend; but, was it possible to separate such a quantity, of a sufficient value to make it worth shipping? A. Gibbs \& Sons of London continued to be the consignees.

Tuesday, $20^{\text {th }}$ of February 1877 . Having slept well, I was this morning better in health than yesterday, not in spirits. At 9 p.m. came Rafael's wife and two daughters, with his brother Francisco. They, Enriqueta, Juan, Garland, and I remained together till past ten sitting in my corredor outside the room, which we call the salita, and where last year during my wife's illness so many acquaintances used to meet. Though Juan was very agreeable and kept up the conversation I could not help thinking every moment of her whom I had lost.

Wednesday, 27 $7^{\text {st }}$ of February. This morning at about 8 a.m. Enriqueta and I took a short walk, but though we walked very slowly I soon got tired, and we had to return home. Middendorf looked in and in my opinion he could [316] [_] not do anything more for me; he however prescribed a tepid [_]. This afternoon I was again very weak.

Juan, Enriqueta, and I agreed upon the following: Firstly, to send to Rafael and Melchor Velarde each S/500, which sums my wife had wished to be presented to them to defray the expenses of their mourning.

Secondly, to pay the expenses of Juan's voyage, from, and back to Europe.

Thirdly, to pay for the painting of the two houses Calle de Zarate and Calle del Correo, all which expenses to be entered in my books before the $28^{\text {th }}$ February, when they were to be closed and the division of my wife's half of our joint property made between my three children.

The papers said that Pedro Galvez, hitherto Peruvian Minister in England, and José Antonio La Valle, employed in the same capacity in Germany, had resigned; and that Riva Agüero, hitherto Minister in Belgium and France, was only to act in this capacity in the latter country.

At 4 p.m. I took the tepid bath, which I thought did me some good. In the evening Enriqueta went out to see her friend Isabel Coloma, whilst Ricardo read to me in German an article on the Samoa Islands situated 35 degrees east of New Holland and $14^{\circ}$ South Latitude. Here, to my great astonishment, a Hamburg firm, name not given, had a very large establishment, solely employed in collecting from these and the neighbouring islands, the dried pulp of the Cocoa nut, called Coppra, which they carried to Hamburg there to be used in 
the making of soap and oil. The business was so extensive that many vessels were employed in the same. The principal settlement was in the Port called Appia. They had planted new Cocoa-palms, but as these take nine years before giving fruit they had in the meanwhile sewn Cotton, and the inhabitants of the Islands being too indolent to work, they had been obliged to introduce coolies from other islands, contracted for five years. The writer, who visited Appia on board of a German man-of-war, described both men and woman - more or less [_] the color of Cinnamon - as the most beautiful and [317] most happy people in the world, happy, as he said, because they did nothing but amuse and enjoy themselves. This however cannot be taken literally, because, as they do not go stark-naked the making of their vestments, slight as they may be, always require some labour. Their character is mild and docile, which accounts for the progress which the missionaries - whether Catholic or Protestant is not said - make with introducing Christianity amongst them. The writer makes no mention of horned cattle, sheep, nor horses from which I infer that they are not known in these islands; fowls there are, and to them the inhabitants attend, not for their own use, but for sale to the Europeans. Even the snakes which are found here are not venomous.

Thursday, $22^{\text {nd }}$ of February 1877. After Enriqueta had bandaged my leg, and she and the little ones were taking their cold bath in the Pozo of the house the clowdy sky induced me to take a short walk - eight cuadras was the utmost I could manage and they took me half an hour. Two new Delegados Fiscales had been appointed by the Government for the purpose of investigating the accounts of Thomson Bonar \& Co. and the old English Guano Company. They were, José F. Selaya, who would take with him his wife Juana Valle Riestra; and Juan Martin Cárdenas, both persons not particulary fit for the object in view. As Inspector-Fiscal to supercede Mariano Lino de la Barrera, Carlos Pividal was named; before embarking he was to be united in holy-wedlock to Victoria Soyer, widow of one of the Ramos, and sister of José Canevaro's wife. The whole day long I was pretty well. In the evening Garland, Enriqueta, Juan and I remained together till near 11 O'clock.

Friday, $23^{\text {rd }}$ of February. At 8 a.m. I again went out and managed to walk ten cuadras. For a considerable while I remained with Evaristo Barrios in his store, and listened to the account he gave me of the affairs of the Banco de Lima. Though I breakfasted very little I felt this day better than I had done for a long time past. Dr. Middendorf took his leave having been called to Tacna by the wife of Mr. Campbell who [_] [318] [_] account, was losing his memory, and began to be deficien[_] in his mental faculties. Lembcke, whom I had not seen for very long time past, paid me a visit. He read to me the informe of the Banco 
de Lima for last year, which had been laid before the shareholders in a late general meeting. The profits made arose exclusively from the business done with the Government; otherwise, the bank had not discounted more than 65,000 Soles during the whole year. The proposals made by Julian Guimet, one of the principal debtors of the bank, Lembcke assured me were utterly unacceptable, which I regretted because Guimet's son-in-law, the judge Manuel A. Puente Arnao, had written me a letter requesting me to do my best to have these proposals admitted.

Saturday, $24^{\text {th }}$ of February. I again walked this morning ten cuadras, but this short distance took me nearly one hour. The following statistical memoranda I took from various papers. The amount of gold extracted in Australia and California from the mines and washings in the course of twenty years, counted from the first discoveries in 1848 , amounted as a German Review said to $15,000,000,000$ francs. In 1875 all the mines on the Globe produced about $£_{25,000,000}$ in gold, and $£_{17,000,000}$ in Silver. the richest silver mine, in the State of Nevada, United States, called Comstock-lode, discovered hardly two years previously, produced in March 1876 nearly $£_{75^{0}, 000}$ Stg. in Silver mixed with gold.

The indemnifications paid by Railway Companies in England, probably Scotland and Ireland included, from $1^{\text {st }}$ January 1870 to $31^{\text {st }}$ December 1875 , to sufferers by railway accidents came to three million pounds Sterling.

For the first year of 1876 the shareholders of the Lima, Callao and Chorrillos Railway Compy. received a dividend of $21 / 2 \%$.

Mr. Rollin Thorne, long time resident in Lima, and whom the papers called a respectable man, had died in Brooklyn at an advanced age. Many years ago he had been Auctioneer in Lima, afterwards he had for some time the monopoly for [319] [_]ntroducing ice from the United States. In Septr. 1854 [_] was my wife's and my fellow passenger from Colon to New York. I was never intimate with him.

This day I had two agreeable visits. The one from Charles Pflucker, just returned with his family from Ancon; he told me that the business of his sons prospered so well, both in the silver mines of Tuctu and Castro Vireyna, and in the sugar plantation of Falcalá, that his eldest son Carlos Maria, who was the head of the four brothers, sometimes did not know what to do with the money he had at his disposal. The other, from Pedro Galvez who was very friendly; from him I learned that though a Government's decree lately published, had annulled all Peruvian Legations in the Exterior, viz.: in Rome, Turin, Berlin, Paris, Brussels, London, and Washington, yet there was some chance of one or the other being still reestablished, and it was for this reason that he was 
still here in Lima and had frequent conferences with Prado. I went out in the forenoon as far as the Banco de Lima, received S/4500, $9 \%$ on my S/50,000 shares, and left them to my credit in a/current.

Sunday, $26^{\text {th }}$ of February 1877 . The papers contained two decrees which were worth noting. The one, signed by Aranivar, said that "the internal credit being the key stone of the Governmental Structure" all considerations must give way to the necessity of redeeming los Vales Consolidados, and paying interest on the same. Consequently, as this could only be done by means of the revenue of the Custom Houses, it was ordered that the Bonos del Tesoro including those given to Meiggs; which would fall due on the $3^{1^{\text {st }}}$ May, should be received in payment by the Custom House at par, but in the proportion of $13 \%$ to $87 \%$ in coined silver or authorized notes. The same decree shewed that the revenue of all the Custom Houses was calculated at 7,683,000 Soles p.a. and that the expenses for collecting this sum, including the salaries of all the employees, came to 1,334,00o Soles. In order properly to understand the injustice of this decree, it must be borne in mind that these so-called Treasure Bonds issued [_] [320] [_] Minister of Finances say that at maturity they are to [_] paid at par and that in the Custom House they would be received as cash in payment of duties for their entire nominal Value.

The other decree referred to a contract made between the Government and Mariano Bedoya \& Co. - one of the partners of which firm was a Von der Heide, brother of Charles, married to a sister of the President's wife. They bound themselves to irrigate with the waters of the river Tambo, 8000 Topos of hitherto uncultivated land between the Port of Mollendo and the said river, which irrigation being completed to the satisfaction of the Government they were to receive $\mathrm{S} / 400,000$ whereupon Bedoya \& Co. might sell of the irrigated ground as much as they could, and with the proceeds of these sales, and with their own funds if necessary, construct a railway from Mollendo to Islay, which being satisfactorily done, they were again to receive from the Government $S / 1,600,000$, and the railway would then become the property of the Government. If this payment could not be made at the stipulated period then Bedoya \& Co. were to be credited interest at 6\% until they received the money. There was another article which I did not clearly unerstand and which said that the Government was to have one fourth in Bedoya's profits. The Comercio attacked this contract as illegal and very properly so. It was against law to make such a contract without the intention of Government being made publicly known, and sealed tenders asked for, when the proposal most advantageous to the Government would be accepted. And again, no such amount as the two million Soles being included in the expenses sanctioned in the budget, which, being approved by the Congress had become the law of the country, the Executive had no right to dispose of this sum. 
I did not stir from the house the whole day long, but as Bryson was with me till two, and Ricardo read to me a great deal, the time passed away not too heavily. Ricardo's reading made manifest to me that I was living here in a [321] great measure ignorant of what was going on in the world. For instance I knew nothing of the following: On the $5^{\text {th }}$ December 1875 the steamer Deutschland belonging to the Northern Lloyd Steam Company, left Bremer-Hafen, bound for New-York. There was a heavy snow-fall, the wind blew from the East, and no observation could be taken. The captain, though a clever, and careful man, shaped his course too much to the North, and on the $6^{\text {th }}$ at $5.30 \mathrm{a} . \mathrm{m}$. the vessel struck upon a sand bank called the Kentish Knock, 17 miles from Harwich. She stuck fast and could not be got off; two boats were lowered, one with four men which immediately upset, the other with three, which with one man alive reached Sheerness on the following day. To lower any more boats would have been downright madness, so violently did the waves break over the vessel. Signals of distress were hoisted; when night came on, rockets were thrown out. As the tide rose, both crew and passengers had to climb up the rigging and hold on the whole night through as well as they could. Many were overcome by sleep, or their strength failed them, they fell off, and perished in the waves. On the morning of the $7^{\text {th }}$ when the tide had receded they descended to the quarterdeck, and at about 11 the tug-steamer "Liverpool" arrived from Harwich and took off the survivors. Forty four of the passengers and twenty of the crew had found a watery grave. This shipwreck caused great sensation both in England and Germany. Strict enquiries were set on foot. No blame was attached to the Captain, but much fault was found with the Harwich authorities, who had not a single life-boat in the port.

On the $11^{\text {th }}$ December in the same Bremer-Hafen the "Moselle", a steamer belonging to the Northern Lloyd, was on the point of leaving for New York. On the $2^{\text {nd }}$ day, when the vessel was crowded with people, all of a sudden a dreadful explosion took place. Between one and two hundred people were mutilated, wounded, and killed. The [322] [_] herself suffered considerably. At first nobody had a[_] idea what had been the cause of this disaster; gradually however the truth came out. In the afternoon groans were heard to issue from one of the cabins of the vessel; the door was forced open, and an individual found who had shot himself, but was still alive. He survived two or three days, and gave some details of the execrable deed which he had planned. He was a native of Brooklyn, W.S. His name was William King Thomas, or William King Alexander, and for several years he had been living with his family near Dresden in a rather extravagant manner. Now, with a shattered fortune he had hit upon the following scheme to replenish his empty purse. His intention had been to proceed to Southampton, there to purchase some goods of little value, to embark them on board the "Moselle", and to insure them for a very large 
amount. Then he intended to remain on shore and let the vessel proceed on her voyage but when in the open sea, by means of a truly infernal machine put on board by him, an explosion was to have taken place which would have entirely destroyed the vessel. After the lapse of some months when the vessel not being heard of, was supposed to have foundered at sea, he would have applied for the amount ensured, and have received it without any difficulty. This was his plan. This machine employed consisted of a box, for the greater part filled with Dynamite; the remaining void was occupied by a watch, the ticking of which was imperceptible, which was worked in such a manner that it would go for a certain number of days; when it stopped, a hammer, lifted up until then, would fall upon the dynamit and cause the explosion. This watch had been made by a certain J. J. Fuchs, one of the most skilful watchmakers of Germany, King pretending that he required it for a silk manufactory. Its workmanship was the most complete, and delicate imaginable, and perhaps this was exactly the cause why King's plan miscarried. When it was wound up [_] it was moved about, or for some other reason which [323] [_] annot be known, the machinery got out of order, [...] stopped long before the time calculated upon, and the explosion ensued, when the "Moselle" was still in harbour.

Garland, who had slept in Gallagher's house in Chorrillos and came in by the first train, related that on the road a German had commited suicide; he had taken his seat in one on the first-class carriages, and when the train was going at full speed between Barranco and Miraflores, had thrown himself into the narrow open place between the two waggons and been immediately crushed to death. This night's "Nacional" said that his name was Rudolph Nebers, that many years back he had been clerk of Campo \& Estrada, and had afterwards entered the service of Andrés Alvarez Calderon, where he had been cash keeper and been highly esteemed. At a later time he got enamoured of the daughter of a German resident in Lima, asked for her hand and was refused. Since then he had given himself up to drinking, and though he always did his duty, this vice grew upon him from day to day, till at last his mind became unsettled, and to this the fatal deed must be attributed.

Tuesday, $27^{\text {th }}$ of February 1877 . With the exception of my knee, which was still very weak, my health was improving from day to day, not so my spirits.

I said, perhaps a month ago, that the Congress had insisted upon the telegraphic lines in the Republic being worked on acct. of the Government. To circumvent this law, the Minister of the Interior La Cotera had given a decree, provided with the President's rubrica, or flourish, which made Carlos Paz-Soldan Administrador of the telegraphic lines for eight years, with the condition that all expenses were to be borne by him, and that any deficit or any gain was to be on his account. 
Wednesday, $28^{\text {th }}$ of February. For some time past the Minister for the Interior, and the Municipality of Lima, or Consejo Provincial, had been constantly quarrelling. At last things came to a point. La Mesa Calificadora of the [324] [_], of which Aurelio Garcia y Garcia was the Alcalde, had black balled, and consequently excluded six individuals all decided Pradistas - amongst whom Gregorio Benavides - who by the Electors of Lima had been chosen members of the Consejo. The six individuals complained to the Minister of the Interior who applied for an informe to the Consejo. The Alcalde in his answer merely said that those six had been rejected by votation, and now the Minister decreed that there being no motive for their rejection, the Consejo should admit them as members.

The other great news of the day was that La Compañia de Obras Publicas y Fomento del Perú was about issuing $\mathrm{S} / 1,030,000$ in billetes, as a security for which issue they had deposited in the Consulado $S / 1,500,000$ Noml. Bonos del Tesoro, and promised to exchange their notes at any time in the current Lima money. This being Guillermo's birthday he and his wife, Alejandro, in fact all Garland's children - except Antonio - Francisco, Zoila and Sofia Velarde dined with us. It was half past six when we sat down, and nearly eight when we rose, thus I could not attend to Bryson's reading. About this time I was far from deriving any pleasure from such dinner parties. When all were gone Diego Masias came in, and though I knew full well that all he said was not to be believed, I liked to converse with him, for he was always full of news.

By this steamer the Exchange on London had risen to $26 \mathrm{~d}$. Juan had been fortunate enough to get from Ford of Dreyfus' Brothers $£_{320}$ at $28 \mathrm{~d}$. He had also made a tender to the Government for $£ 700$ to be received on the $28^{\text {th }}$ April, but to be paid for immediately at $29 \mathrm{~d} 1 / 4$. Things here looked very black indeed. All the daily papers were in arms against Government and very justly so on account of the late decrees.

Thursday, $7^{\text {st }}$ of March 1877 . It seemed to me that my knee was getting worse - otherwise I was in fair health.

I saw by a German Review, which Ricardo read to me, that it was calculated that about the year 1500, the amount of silver and gold extant all over the Globe [325] came to $£_{30,000,000}$ Stg. In 1848 it had risen to nearly $£_{2,000,000,000}$ and in 1875 to $£_{3,000,000,000}$. Yesterday J. F. Selaya, of whom I spoke on the $22^{\text {nd }}$ February, embarked for Europe with his wife, and Margarita Valle Riestra, one of his sisters-in-law. J. M. Cardenas did not go. To celebrate the birthday of my son Juan, Enriqueta had invited to dinner the same persons as had been with us on the previous day. We rose at 8 , when Bryson read to me the conclusion of Charlotte Brontë's biography in the Eclectic. In Enriqueta's parlor I met Rafael with his wife; he, though a partizan of General Prado, to whose election he had 
contributed, blamed, as everybody else did, the steps which the executive was taking.

This evening, a Drama, called the "Passion and Death of our Saviour", was represented in the Theatre, which I looked upon as real sacrilege. The Archbishop had tried in vain to have the perfomance suspended.

Friday, $2^{\text {nd }}$ of March 1877 . I continued in the same state of health, and the same low spirit; I began to doubt I should ever recover either the one or the other. Juan's tender for $£_{700}$ at $29 \mathrm{~d}$ 1/4 had been admitted; by far the greater number had made their offers at $29 \mathrm{~d} 3 / 4$, which were likewise accepted.

Vales Consolidados had been redeemed yesterday at from $683 / 4$ to $721 / 4$, at which last rate Alejandro had offered S/100,00o, but only got rid of 4000 and odd.

This day the meeting was held in the Exchange Room in the house of the Consulado of the holders of Bonos del Tesoro, for the purpose of making a representation to the Government, requesting the revocation of the decree relative to these Bonds. See $26^{\text {th }}$ Feby. Col. Joaquin Torrico was named President; Climaco Basombrio of the Banco Nacional Secretary; and a certain Tejerina Treasurer; each member present had to suscribe $S / 25$, to defray the expenses it might be necessary to incur. Another representation, drawn out by Alfred Böhl, and signed by the greater part of the Foreign Import houses, by J. V. Oyague, by Alexander Ruden, and others, with William Gibbs \& Co. at the head and which treated on the recent [326] [_] on of notes of the Compañia de Fomento, was to be presented to [_] Government. The Minister of Finance had again given a decree; this, on the subject of the loading of the Guano VesseIs, which henceforth was to be carried on, not on account of the old company, but on account of the Government itself; and the Delegates of the four associated banks were ordered to pay monthly $\mathrm{S} / 50,000$ to defray the expenses.

As usual when by ourselves, Juan, Enriqueta, and I were in the Salita till near 11 O'clock.

Saturday, $3^{\text {rd }}$ of March. At mid-day I went into the street, and looked in at the South American Insurance Company, where I conferred with Ruden on the probable value of the preference obligations of the Pasco Railway Company, of which the Insurance Company, I, and a few more, were the holders; to judge from the account he gave me, I believed them to be worth very little. Thence I went to Scheel, with whom I wished to speak about the obligation which in the opinion of the holders of the Peruvian Bonds in Paris, Dreyfus Brothers were under, to pay the Cupones on these Bonds, but did not find him in. In the Comercio it was stated that Dreyfus had bound themselves to make this payment, and that they had abandoned the right they previously had to be first paid for their advances before paying the cupons. 
At a later hour Dr. Jervacio Alvarez called, which visit I probably owed to a loan of S/40o made by me to his daughter Doña Asuncion.

When going to dinner I found to my great surprise that Enriqueta was in bed; she was really very ill, suffering pains all over the body, and with a violent fever. Middendorf being absent from Lima, Dr. Bravo was sent for, who could not come, being himself unwell; then a certain Dr. Loza was called in. He said that her illness was a very severe cold with accompanying fever. When Bryson was gone I went to see how she was, but for the greater part of the time till I withdrew to my bedroom I sat on my side of the corredor, moping, thinking and calculating.

Sunday, $4^{\text {th }}$ of March 1877 . Enriqueta was nothing better. [327] She remained in bed and slept a great deal; her two [...] whom she wanted to send to Eliza would not leave her.

The Nacional of last night published a very strong note drawn up by Pedro Saenz, Administrador de la Compania del Carguio de Guano, in reply to the Government's decree; he said that he was quite ready to deliver up the deposits, but not the plant (los Capitales) to which the Government had no right, until they had paid for it, and in case they took possession of it by force he threatened to lay a complaint before the Supreme Court for "Despojo", and claim indemnification for "daños y perjuicios", as well as interest at the rate of $11 / 2 \%$ monthly.

A telegram from Constantinople of the $2^{\text {nd }}$ inst., said to have been received here on the $3^{\text {rd }}$, stated that Turkey had made peace with Servia and Montenegro. In the United States Mr. Hayes and Mr. Wheeler, the Republican or Northern Candidates, had been elected respectively President, and Vice-President for the constitutional period of four years, to begin in the present month of March.

Our Old Chinese cook Achipe, to whom I was in the habit of giving S/2 monthly, came to tell us that next week he intended to return to his native country.

Before Bryson was gone, Guillermo came at about one, and with the exception of hardly an hour for dinner, he worked the whole day till 11 O'clock at my books. I was with him all the time, as occasionally he had to ask me one question or another. A pretty way of spending a Sunday! When my dear wife was still with me I had in reality nothing to complain of, but then I did not appreciate my felicity.

Monday, $5^{\text {th }}$ of March 1877 . I awoke this morning with a headache, and with a bad cold in the head. I did not feel well at all.

Guillermo was with me at 7.30 a.m. and long before breakfast time he delivered me the balance sheet, neatly drawn out. The gross profits came to the enormous sum of $S / 78,000$ without having received a rial on the $S / 60,000$ 
Shares in Dreyfus Contract. I however calculated that this sum would be [328] [_] ed by the many extraordinary expenses I had had last ye[_] and by the depreciation of the value of my property, without taking in[_] consideration that the sol which I now had was nothing like the dollar of former years. Exchange on London might be quoted at 27 pence, whilst certificates for bills given by the Government could be had at 29 to $291 / 2$ pence. Enriqueta was still in bed, but much better. In the forenoon I reposed on a sofa for nearly two hours; in the evening when Bryson was gone I immediately went to bed, slept till ten, when Aurelia, the Servant woman, awakened me to cure my weak knee, and to give me an excellent slight purge, consisting of very diminutive cakes made of Tamarinds which Juan had brought with him from Paris; and I again slept uninterruptedly till

Tuesday, $6^{\text {th }}$ of March, when I awoke better than yesterday, but beyond measure weak.

Yesterday I had been cited to the Insurane Company Lima, but could not attend. Enriqueta was this day somewhat better.

On the $28^{\text {th }}$ February I stated that the Minister for the Interior had ordered the Consejo Provincial to admit the six members whom they had rejected; the Municipality now determined to present a petition to the Minister requesting him to reconsider the said decree because it was against the law of the country, which says that if the Minister of the Interior thinks he has a right to interfere he must address himself to the Consejo Departamental which is the immediate superior of the Consejo Provincial. The Minister - clearly for the purpose of annoying both Consejos - named two commissions, which were to examine all their accounts and papers.

In reply to the petition of Gibbs and others, the Minister of Finances, Aranivar, had resolved, firstly that all those who signed as companies were to present testified copies of the articles of partnership, but that in the meanwhile the representation was to be communicated to Meiggs, whose long reply was published in the papers. The principal points upon which he [329] founded himself were:

Firstly. That the Compañia de Obras Publicas y Fomento required the small assistance which these notes would render them to carry on their vast mining enterprize in the Cerro de Pasco. Secondly. That the capital of the said Company was more than sufficient to answer for such a small issue as $\mathrm{S} / 1,030,000$. Thirdly. That "la industria es libre" and fourthly that nobody was obliged to take the notes.

I was occupied with Bryson in drawing out a list of the different items of which my property consisted, and which had to be valued before a partition could be made. Enriqueta continued unwell, and in bed. I thought of retiring 
to my bedroom immediately after Bryson had gone, but was prevented by Garland, with whom I had a long conversation. Afterwards Ricardo read to us various articles from the daily papers. Aurelio Garcia y Garcia had addressed a note to the Prefect in which he complained of the highly improper interruption to which the Consejo Provincial had been exposed in its last meeting, owing to the noise and tumult caused by "la barra", or the audience, consisting of people of the lower classes, no doubt paid by the Minister of the Interior: they had even attempted to stop the members of the Consejo when returning to their homes. There was again a new decree of the said Minister, which ordered the formation of a commission with Mariano Felipe Paz Soldan as President, to fix the exact boundaries of all the Departments, Provinces and other divisions of Peru - "para hacer una nueva demarcacion". Manuel Pardo could not bear the Paz-Soldans - now they were in the ascendant. I was told that Dreyfus' Lima firm had presented themselves to the Government, claiming the plant made use of by the Guano loading Company, it being mortgaged to them. What a confusion there would now be, and how many lay days would have to be paid! All finally to be borne by the nation. From the Eclectic of February 1877 Bryson read to me an article on the Artic Expeditions, which said that attempts had been made to reach the North Pole, by going firstly to the East of Nov[_] Zembla, secondly [330] [_] en Nova Zembla and Spitzbergen; thirdly between Spitzbergen and Greenland; and fourthly, up Baffin's Bay, in which latter direction Captain Nares, who left England in 1875, followed in the footsteps of the American Capt. Hall. From Baffin's Bay, Nares two steamers, the "Alert" and "Discovery", ran up Smiths Sound, Kennedy's Channel, and Robeson's Channel, in which latter they wintered from 1875 to 1876 in Latitude $82^{\circ} 31$ '. For one hundred and forty days they did not see the Sun, and the cold was more bitter than ever experienced; it went down to $104^{\circ} \mathrm{F}$. below the freezing point. When the sun reappeared, they recommenced their struggles, and in 1876 with better success than in the previous year. An expedition was sent to the Westward to explore Grant Land where the most Northern Cape they reached was $83^{\circ} 7$. Another went Eastward, to explore Greenland; and a party under Markham went straight North and reached $83^{\circ} 20^{\prime} 26^{\prime \prime}$ North Latitude. Further they could not proceed.

Wednesday, $7^{\text {th }}$ of March 1877 . Enriqueta still in bed, and hardly any better. I suffered from cough, and the weak knee; otherwise I felt pretty strong to-day. From 8 to 10 Juan, Garland and I were occupied valuing my property. I believe both were satisfied; at least they ought to have been, for if there should be in future any loss it was most likely to fall upon that property which I kept for my own share. One expression of Garland, Juan and I had certainly not expected. When we came to value his and Guillermo's pagaré for 18,360 Soles he said: 
"I think we must value it in nothing." when I said "How, your own signature you value in nothing?" Juan of course took the same view as I, and then Garland altered his mind. Juan went to Chorrillos. In the evening when Bryson was gone, I found Rafael Velarde sitting near Enriqueta's bed. Even he disapproved the many decrees lalety given by the Ministers of Finance and of the Interior. As soon as he was gone, at about ten, I went to bed.

Thursday, $8^{\text {th }}$ of March. By daybreak I was invariably awake. Garland was of opinion that we had valued too low my S/60,0oo Shares in Dreyfus Contract which we had put down [331] at 50\%, because, as I said, they were either worth nothing, or $100\left[{ }_{-}\right]$thus it was correct to take the medium value, say $50 \%$. Garland therefore instructed his son to go in search of Meliton Porras and to offer him the said S/60,000.

In the course of the forenoon I was present at the meeting of Directors of the Insurance Company "Lima". None was wanting. We were: Moscoso Melgar, President; Chavez, Vice; Valentin Gil; John Mathison; Enrique Prevost; Robertson; I, and the Gerente Carlos Elizalde. A good many question were laid before us; but hardly a single one of importance, so that we disposed of them, quickly and unanimously. Only when Elizalde asked whether he was authorized to receive in payment the newly issued notes of the Compañia de Fomento, there was some divergency in our opinions. Robertson, Meiggs' son-in-law, thought that they might be admitted on certain occasions, as for instance if Pedro Bernales were to offer payment of his pagaré in Meiggs' notes, it would be highly imprudent to refuse them, Bernales being, as it was well known, in very bad circumstances. Notwithstanding this observation, which was by no means an improper one, the majority decided that these new notes should not be admited.

In the evening Bryson began reading to me Prescottt's History of the Conquest of Perú, which book is so well written and so interesting that though it had been read to me more than once, I with pleasure listened to it again.

Enriqueta in the course of the day lay down on the sofa for several hours, and went to bed as soon as the sun was down. Afterwards Juan, Garland, and I remained with her till half past ten.

Friday, $9^{\text {th }}$ of March 1877 . The state of Enriqueta's health hardly improved. I was much troubled with my cough, which had of late again become worse.

The firm of Dreyfus, of Lima, made known in the daily papers that the shareholders in their contract with the Government, might apply at their office $5 \%$ interest for last year. [332] [_] gave our joint $S / 100,000$ to Juan, who would make the collection. Within the last week or so, died here in Lima a very peculiar person known all over the town by the name of Manungo Muñon; his real name was Manuel Muñoz, but he having an impediment in his speech, 
could not pronounce his own name, and thus this nickname was given him. He was a huckster of the very lowest description; I myself had never seen him sell anything but matches, but as he hoarded every centavo which he gained, he might well have left the three or four thousand Soles, of which the papers spoke. I could not bear him and always treated him with asperity: neither did my wife ever allow him, to take any of those liberties which he was accustomed to take in other houses. He was as silly as he was forward. Doña Catalina Mendoza, the widow of General Guarda, had given him an apartment in her house, gratis; he used to breakfast and dine wheresoever these meal hours chanced to overtake him. His clothes were those presented him by his friends; and in washing it was not likely he spent much.

Alejandro told us that Porras would not buy any more of the Shares of Dreyfus Contract, and we were now at a loss how to value my S/6o,ooo.

I went to bed as soon as Bryson was gone, and though I was awakened more than once by my abominable cough, yet I slept better than I had expected.

Saturday, $10^{\text {th }}$ of March. Once more I felt very weak, and was hardly able to do anything. Bryson, under my direction, drew out a new document which showed how the Cuerpo de Bienes to be divided between myself and my three step-children, consisted of the amount of my debits in the balance sheet, less the amount of the valuation. When Garland came home he told me that he had sold through the broker Puente, formely manager of Juan de Ugarte's house, my $S / 60,000$ Shares in Dreyfus Contract, at par, the interest on the same, just due, to be received by the seller. I was rather taken by surprise, for I did not think [333] that I had given him such an unlimited authority to sell. However, the sale was made and I considered it a good one though, if it had not been for the partition of my property, and the consequent necessary valuation, it would never have entered my head to dispose of these shares. Dr. Sosa, Enriqueta's physician, prescribed to me bitter drops to be taken before breakfast and dinner in order to give me appetite, and a syrup of lettuce to assuage my cough.

I sat near Enriqueta's bedside till 10 O'clock, my usual bed time.

Sunday, $11^{\text {th }}$ of March 1877 . I continued to feel very weak. Enriqueta was this morning again at breakfast.

Yesterday La Compañia de Fomento y Obras Publicas paid their rent of S/540 due the $1^{\text {st }}$ in their notes, new from the fabric. I had not expected that they would have had this barefacedness; I received them in order not to quarrel, but they would soon wander to "La Providencia".

For about two hours Bryson and I occupied ourselves remodelling the diary of 1864, which, written by Mejer, required sometimes a multitude of corrections; on other occasions it ran on in an easy and smooth style. When Bryson was gone I had to put away my clean linen, amongst which some napkins and 
sheets, articles which my dear wife always kept under lock and key; now that I had to put them away, her image came before my eyes more vividly than ever, and the whole day long I was very sad. Till dinner time I sat by myself in the armchair in the corredor, dozing, thinking, and calculating. I had a short visit from Mr. Macandrew who was of opinion that Meiggs, and his issue of Notes enjoyed the secret protection of the Minister of Finance, Aranivar. Lembcke, to whom I had given up my Chorrillos Rancho, for an indefinite time, without charging him any rent, also looked in. From about 8 till near 10, Ricardo read to me an article in German on the relations between Hungary and Austria. [334]

Monday, $12^{\text {th }}$ of March. I felt exactly the same as yesterday, both physically and morally. Juan as usual came in from Chorrillos. The S/6o,ooo Dreyfus Shares were delivered, and the $S / 60,000$ in billetes received for them taken by Garland on my account to the Banco de Lima. The broker did not refuse Meiggs' notes, with which I paid him his commission of 300 Soles. I had now concluded the exact calculation of my property to be divided between myself and my three step-children. It came to $\mathrm{S} / 923,000$, a much larger amount than I had ever thought it could have risen to, and this was owing to the circumstances that a great many of the items of which my property consisted, were now valued much higher than I had done hitherto. The papers contained a decree published by order of the Minister of the Interior which said that the former decree of $22^{\text {nd }}$ February, relative to the Municipality, would not be reconsidered, and that the Alcalde, Aurelio Garcia y Garcia, considering himself to be impeded; and the Vice-Alcalde Felipe Barreda y Osma being absent, the Prefect had without loss of time to convene an extraordinary meeting of the Municipality, and to take the oaths of the six members hitherto blackballed, which being done the members who might be present were to choose a momentary President out of their number, and then to proceed without delay to fill up the different posts.

This decree was in every respect unconstitutional. The only thing Aurelio Garcia y Garcia had been able to do, was to protest against it.

Died in Chorrillos between 10 and 11 p.m. in the house of Don Manuel Pardo, his uncle, that is to say his father's brother, Don José "el sordo", who for many years past had been residing in Chile, where he had married a daughter of Juan de Dios Correa, and the well known Señora Toro. Frequently he had been Peruvian Minister in Santiago, in which capacity he died. He had come to Lima, accompanied by his daughter, whose health he expected would be benefited by the change of climate.

Tuesday, $13^{\text {th }}$ of March 1877. The great part of the [_] I was busy with Juan dividing the property between [335] him, his sister Rosa, and myself. Enriqueta's share was easily paid her. She received the two houses Calle de 
Zarate and Aldavas, the value of which came nearly up to the amount due to her, the small balance which then remained in her favor was deducted from the pagaré for $S / 18,000$, signed by her husband and Guillermo. At 1 O'clock, in pursuance of the Prefect's citation, twenty five members of the Municipality, all Pradistas, not one adherent of Pardo, met in the locality of the Cabildo. The Prefect Andraca took the oath of all such as had not yet been sworn in. Then a momentary President was chosen. The choise fell upon Col. Secada, which being done, the Prefect left the hall and the elections commenced. Dr. Pedro Saavedra was chosen Alcalde; Col. Secada Vice; Focion Mariategui and Teran Sindicos. The other posts were likewise filled up. Rockets were left off, the populace shouted, the bands struck up and the Municipality was installed. At 9 p.m. Rafael Velarde and family came, and kept us company till nearly eleven. Garland was unwell in bed. I was in a fair state of health, but my knee did not get stronger, and in a cheerful humour I certainly was not.

Wednesday, $14^{\text {th }}$ of March 1877. The funeral of José Pardo took place in the church of Santo Domingo, whence Alejandro and Juan drove out in the cortége. Bryson copied in clean the documents relative to the partition of my property. In the evening Dr. Middendorf, who had returned from Tacna, looked in.

Thursday, $15^{\text {th }}$ of March. I remained in bed till Dr. Middendorf came, who compared my two knees; the left one was still somewhat larger than the other, but the difference was so small that only he who knew it could notice it; weak however it was as yet. He told me that there was no further use in bandaging it and that he would try whether electricity would do it any good. In reality, he did not know what to do, or what to prescribe, and then had recourse to his last remedy [_] [336] [_]ge of climate. A considerable number of the members of Municipality, that is to say all the old ones, friends of Manuel Pardo, had protested against the late proceedings. The Minister of the Interior had published a decree in which he ordered the public sale of the Salitrera Barrenechea in Iquique; the previous government, that of Pardo, had lent the same $S / 130,000$ in the expectation that by means of this assistance, the salitrera would overcome all its difficulties, and be able to produce 300,000 quintals annually. The term stipulated for returning the loan had expired, and therefore the Government was perfectly right in ordering the sale, thereby to cover itself for the S/130,00o. Manuel Pardo himself, Malinowski, and many friends of the former were interested in the Salitrera, and as the establishment had not prospered, notwithstanding the loan the loss arising from the sale would no doubt be very great.

The clergyman Dianderas, who some months back was accused of having caused the death of a certain woman Gonzales, with whom he had been on 
intimate terms, and who therefore was put under arrest, had been placed in liberty, there being, in the opinion of the criminal Chamber of the Superior Court no proofs of his guilt.

In the forenoon I went out for about an hour, looked in at Carlos Elizalde's in the Insurance Company "Lima", went to Garland in the Banco Hipotecario to shew him the partition document drawn out by Juan and myself, got shaved, and returned home. In the evening we were by ourselves till near 11 O'clock.

Friday, $16^{\text {th }}$ of March. My cough was decreasing, but my general weakness, and that of the knee continued the same as heretofore. La Compañia de Obras Publicas y Fomento had made known in the papers that by the steamer of the $27^{\text {th }}$ it would draw on London at $28 \mathrm{~d}$ against its own bank notes, and at the current exchange of the day against notes of the other banks. What the current exchange would be was [...] uncertain. In the forenoon of this day Juan [337] and Enriqueta divided my dear wife's jewerly. A few mon[_] before her death she had declared that she intended the diamond cross which I had presented to her about three years ago, and which cost $\mathrm{S} / 2500$, for Corina. Then Enriqueta had asked her whether she would not leave anything to Maria, and to her she assigned the medallion, not of so much value as the cross but also a pretty jewel. There now remained of some value a pair of earrings which many, many years ago I bought from Garland at an extremely low price; these Enriqueta kept; and a small brooch in the form of a knot which I had got made in Paris in 1856, Juan took for his sister Rosa. This brooch was an exact imitation of one which my wife had seen in June 1855 amongst the Imperial jewels, shewn to us in the Burg in Vienna. She had then taken a particular fancy to it, and cut a model in paper, unperceived by the person who shewed us round. The other pieces, of less value, they distributed I knew not how. One pair of earrings, which by my order, Juan bought in Paris some time ago, and which were of superior quality had within the last four of five weeks been mislaid or lost. I myself never had had them in my hands and Enriqueta herself could not form any idea of how they had disappeared. The remainder of the day I passed in the usual manner. I did not go out, and at near 11 O'clock we retired to our respective bedrooms.

Saturday, $17^{\text {th }}$ of March 1877 . Last night, being that from Friday to Saturday, I awoke at about three, and I suppose an hour elapsed before I again fell asleep. Middendorf came at about nine, and applied an electrified brush to my knee and leg. It was by no means a pleasant sensation, and made me make grimaces against my will.

The Mininster of Finance made known that being in want of funds, he was ready to receive tenders for bills to be drawn on the $27^{\text {th }}$ May for $£ 14,400$, the 
balance which remained disposable of the monthly $£_{50,000}$. For a short time I went out and looked in at the Banco La Providencia where I [338] [_]ned from Bolivar, the gerente, that the bank allowed the follow[_] interest on money placed there in deposit, viz.: for 1 year, $7 \%$; for 9 months $6 \%$; for 6 months, 5 ; for 3 months $4 \%$ and in account current $4 \%$ per annum. I made these enquiries as I thought it might perhaps answer Rosa's purpose to leave the money which she received as part of her inheritance here in Lima, gaining interest, instead of having it remitted at the present unfavourable exchange. Juan went to Chorrillos and Garland, Enriqueta, and I remained on my side of the corredor till half past ten.

Sunday, $18^{\text {th }}$ of March. I slept the whole night through, without even feeling a shock of an earthquake which occurred at about 2.30 a.m. The Nacional stated that in that part of the desert of Atacama which belonged to Chile, valuable deposits of nitrate of Soda had been discovered; it also mentioned as a rumour afloat here in Lima that if the Minister of Finances, Aranivar, could not obtain from the associated banks a loan of one and a half million Soles which he required, he would take the sum in notes from the Compañia de Obras Publicas y Fomento del Perú, and order the Treasury, and other public offices to receive them in payment as legal tender. My knee continued as weak as ever. Guillermo closed, and balanced my books till $28^{\text {th }}$ February last. When he was gone, I, by myself, walked as far as the Plaza de Santa Ana, where I sat down twice; going and returning took me three quarters of an hour; in former times I would have done it in the third part of the time. When again at home Ricardo began reading to me in German a particulary interesting article which gives an account of the unsuccessful attempt made in $183^{2}$ by the Duchess of Berry to rouse the Legitimists in France against the then existing Government of Louis Philippe; she was a Neapolitan princess, Maria Caroline, sister of Maria Christin[_] Queen of Spain, and of Ferdinand II, King of Naples, which latter was again the nephew of Marie Amálie, spouse of Louis Philippe. She was moreover the widow of the assassinated Duke of Berry, son of Charles X of France and mother of Henry V. [339] better known as the [_] de Chambord.

Garland, Enriqueta, and the two little girls drove out to the garden of Villacampa. After dinner we sat on my side of the corredor till near nine, when Ricardo again read to me till half past ten.

Monday, $19^{\text {th }}$ of March 1877. San José. Dr. Middendorf once more applied electricity to my knee, which, I was quite certain, did me no good. I was as weak and sad as ever. When Bryson was gone I sat down on my side of the corredor doing nothing. After sunset I took a very short walk. Garland was in Chorrillos. Though it was holiday, Bryson came in the evening, and concluded reading 
to me the first volume of Prescott's History of Perú, which, written in a very flowery style gives, in my opinion, not quite a correct description of the Sierra and Cordillera, over which I myself have travelled many a time.

Tuesday, $20^{\text {th }}$ of March. My knee pained a little, and Enriqueta at my request again bandaged it. Before breakfast I had a very disagreeable and violent scene with Garland, who decidedly refused making any payment to Schutte. As it was unfortunately always the case with me on such occasions, I could not keep my temper, flew into a passion, and made use of expressions which I afterwards regretted. At last I said that I would remit to Schutte on Garland's account the rent which I should have to pay for the apartments occupied by me in the house Calle de Zarate. Garland and Enriqueta both opposed this proposal, but I was of opinion that finally it would be accepted by them. At breakfast I could only take liquids, for my excitement had not yet subsided. Juan came in from Chorillos, and when I told him what had occurred with Garland, he was of the same opinion as I that Garland was too obstinate in his refusal to make any payment to Mr. Schutte of Paris. (I may say in anticipation, August $25^{\text {th }} 1879$, that up to this day, no payment whatever has been made by Garland to his brother-in-law on account of his debt). [340] [...] steamer which came in yesterday brought me a letter from [_] and a long one from C.W. Schutte; the latter enclosed cuttings from The Times relative to the Turkish question. The conferences in Constantinople had been broken off, and the ambassadors of the great powers had left without having been able to obtain a single concession from the Sublime Porte in favor of its Christian subjects; they had insisted upon interfering in the local government of the various parts of the Turkish Empire, which the Divan very naturally had rejected. The cuttings will be found in appendix, $\mathrm{N}^{\circ} 15$.

At a later hour I took a short walk as far as the barber's shop in Mercaderes. In the evening Enriqueta, Juan, and I sat and conversed on my side of the corredor till past eleven.

Wednesday, 27 $7^{\text {st }}$ of March. I was awake by 6 O'clock but had to wait in bed till past nine for Dr. Middendorf who then came, and applied the Electric brush to my leg. He said that my knee was as sound and healthy as the right one, but that there was a weakness in the muscles, and these, it was his object to strengthen by electricity.

In Europe had died the ex-Dictator of Buenos Ayres, Rosas, who had resided for many years in the vicinity of Southampton. This year's budget of the German Empire showed a deficit of twenty five million Imperial marks, equal to $£ 1,250,000$. In Arequipa the principal merchants had had a meeting and come to the resolution not to admit the new bank notes of the Compania de Obras Publicas y Fomento. This Company, which had its office in the ground 
floor of my, now Enriqueta's house, Calle de Zarate, had affixed a placard to the wall stating that they required labourers, probably for the working of the Oroya Railway. This morning Carlos Pividal, a son of Pividal of Tacna, late Deputy in the Congress, and who by the present Government had been named Delegado Fiscal, or something of the kind, in England, with a large salary, was married in Chorrillos in the house of José Canevaro, to Victoria Soyer. Immediately after the ceremony they went per train to Callao, and [341] [_]mbarked for Europe.

H. Seymour Geary, partner of Oliphant \& Co. of Hong Kong, had made to the Government a new proposal for the importation of free Chinese labourers. The contract was at last for five years, during which time Oliphant \& Co. bound themselves that their steamers should make twenty-eight round voyagues and bring each voyage, at first it was said 1000, afterwards 500 Chinese. The Government paid them an annual subvention of 160,000 Soles in silver, or, if the Government preferred, in Nitrate of Soda at the current price of the day when the shipment was made. The Government likewise bound themselves to ship guano by the return vessel, at $£_{3}$ per ton. In case Oliphant \& Co. should find at the end of the first year that they lost by the contract, then they might discontinue the voyagues. If, whilst the contract was in force, they should not have made the voyages which they were bound to make, they should pay to the Government a fine of $S / 5000$ all fortuitous cases expected.

Juan, Enriqueta, and I signed the escritura of the partition of my wife's property left by her to her children.

At 3 p.m. I felt better and stronger then I had done for a long time past.

Garland was unwell and went to bed early whilst we three others remained as usual on my side of the corredor till nearly half past eleven. Juan fixed upon the $14^{\text {th }}$ April as the day of his departure; and I was extremely sorry that he would leave us so soon.

Thursday, $22^{\text {nd }}$ of March 1877 . I rose at seven, and took a short walk before breakfast. Ricardo finished reading to me the article on the Duchess of Berry. The only foreign Court at which she had found some assistance was that of Carlo Alberto, King of Sardinia. About the middle of 1832 she landed secretly on the South Coast of France. The Rising of the Legitimists in Marseilles was quickly put down, whereupon under many disguises she reached [342] [...] where some of the descendants of 1793 took up arms, but they also were easily suppressed by the established authorities. The Duchess then fled to Nantes where she resided in the strictest concealment for several months; and Louis Philippe's Government had entirely lost sight of her when a German Jew from Cologne called Deutz, who had been a favourite of the Duchess, and whom she had created a Baron, made a offer to Thiers then Minister for the Interior, to deliver her up, on his receiving half a million francs. Thiers agreed to it. Then 
Deutz apparently repented, and proposed to betray instead of the Duchess, General Beaumont, one of her adherents. Thiers gave the noble answer that he would not purchase an individual whom, if once in his power, he would be under the necessity of having shot. Then Deutz conducted the police officers to the house where the Duchess was supposed to be. Nowhere was she to be found, and already the police despaired of discovering her, when by a mere chance some Gens d'armes to warm themselves lighted a fire in the chimney place. Contiguous to the same was a closet, so small that the police had completely overlooked it. Here the Duchess, with four of her friends had been concealed for sixteen hours; now the heat drove them out, and they gave themselves up. The Duchess was converged as prisoner to the castle of Blaye on the Gironde, near Bordeaux where after the lapse of some months it became evident that she was with child. She strenuously denied it, but at last confessed that in April of the previous year she had been secretly married in Italy to Hector Luchesi Palli, of the princely family of Campo-Franco, Chamberlain to the king of the two Sicilies. In the night from $9^{\text {th }}$ to $10^{\text {th }}$ May 1833 she was brought to bed of a girl and on the $8^{\text {th }}$ June she was set at liberty, and sailed for Palermo. Of her adherents and partizans not a single one I believe lost his life on the scaffold.

In the course of the forenoon I delivered up to Juan the shares in joint stock companies, pagarées, and other documents which belonged to him and his sister Rosa. We [343] discovered that in the statement of my fortune [...] an error against me of 1780 Soles, there being in reality two Cedulas of the banco Hipotecario less than I had put down and two Cedulas of S/100o each, at $89 \%$ were equal to 1780 Soles. Garland and Juan of course agreed immediately to bear their respective part of this sum.

Before dinner I took a short walk. This being the birthday of the Emperor of Germany William I, who completed his $80^{\text {th }}$ year, Dr. Lührsen gave a dinner party to about twelve of his friends in Miraflores. In the German Clubrooms the subscribers celebrated the day by dramatical performances and a supper.

Friday, $23^{\text {rd }}$ of March 1877. Dia de los Dolores. Dr. Middendorf once more applied the brush to my leg. To Dolores Puente I sent a small present, with my wife's visiting card consisting of a very pretty box for keeping gloves, and a valuable piece of wearing apparel.

I saw by the Nacional that the famous singer Adelina Patti and her husband, the Marquis de Caux, were on bad terms. Their last quarrel occurred in a box in the Opera house in St. Petersburg. It seemed that both parties demanded a divorce, and that a certain Nicolini was mixed up in the affair - why or wherefore was not stated. Before dinner I managed to walk as far as the Church of Carmen Alto, a good many cuadras off in the direction of the Barbones Gate.

In the evening we were by ourselves on my side of the corredor. 
By one of the late steamers Ulyses Delboy left for Europe to join his worthy colleague J. F. Selaya as Delegado Fiscal. Exchange on London 25 1/2 pence per Sol.

Saturday, $24^{\text {th }}$ of March. I saw by the Nacional that the two Consejos, Provincial and Departamental, the former Pradista the latter Pardista, had not yet made up their disputes. Fifteen members of the Consejo Provincial, or Municipality of Lima had addressed a petition to the Departamental requesting the same [344] [_] the late elections in the Provincial, and on the other ha[_] the Provincial, with Pedro Saavedra, the Pradista at their head as Alcalde, protested against the sale which the Departamental - called by Saavedra "El Titulado" - intended to make of some ground in the bed of the river Rimac, which ground Saavedra asserted, belonged to the jurisdiction of the Provincial, not Departamental. I managed to walk as far as the watchmaker Rönacker, eight and a half blocks from our house; on my return I looked in at the Bank of London Mexico \& South America, where I asked the manager J'Ansen whether he was inclined to open with their London firm a credit for C. W. Schutte of Paris, to the amount of $£ 1500$ under my guarantee. This I did in compliance with a wish expressed by Mr. Schutte in his last letter.

Mr. J'Ansen's answer was that their instructions were only to open credits in London if the amount was deposited before hand. This I did not believe to be true, but it put a stop to any further conversation. J'Ansen however gave it as his advice that Mr. Schutte might enter into direct correspondence with their London firm 144 Leadenhall Street. Though Juan had gone to Chorrillos, Enriqueta and I, accompanied by Ricardo were up till 11 O'clock.

Sunday, $25^{\text {th }}$ of March. Once more Dr. Middendorf applied electricity to my leg. Aranivar, the Minister of Finance, asked for sealed tenders to be delivered on the $27^{\text {th }}$ March, for Government Bills to be drawn on Rafael for $£_{30,000}$ on the $27^{\text {th }}$ June, three months hence! The lowest exchange of the last Government's drafts for the $27^{\text {th }}$ May had been 291/4. In the forenoon I dictated to Bryson a letter to C. W. Schutte, and we then began making in rough the journal entries which arose from the partition made of my wife's gananciales. When Bryson was gone, Ricardo began reading to me, but we were soon interrupted by a visit from Mr. Heinecken, chief of D. Schutte's former establishments in Hamburg and Valparaiso, who came to look for Juan. In the winter from 1875 to 1876 he had been suffering from rheumatism and when in the autumn of 1876 symptoms of the [345] [_]me disease again shewed themselves, and his medical [_] counselled him to go to the South of Europe, he preferred going to Chile, where in the baths of Chillan, in the mountains at the foot of a volcano, he had been completely cured. He was with me for two hours, and his conversation was full of interest. When he was gone, accompanied by Ricardo I 
took a walk of nearly an hour without getting particulary tired, nor feeling any bad effects from the same. In the evening when Enriqueta and Garland paid a visit to Rafael Velarde and family Ricardo again read to me a long article on the oriental question, by which I saw that in 1875 the Christian population in Bosnia and Herzegovina had risen against their Turkish oppressors and that as late as the $30^{\text {th }}$ June 1876 Servia and Montenegro had declared war to Turkey. On both sides atrocious cruelties had been committed, and already at the end of October an armistice with Turkey was negotiated through the intervention of the great powers.

Monday, $26^{\text {th }}$ of March 1877 . My knee occasionally pained me, nevertheless I was again able to take a walk of nearly an hour duration.

The Minister of the Interior La Cotera had asked for sealed tenders to be given in within a short time by such as were inclined to make a contract with the Government for the introdruction of free Chinese labourers; the last proposal of Oliphant \& Co. with a few modifications made by the government was to serve as the basis. We regularly sat up till nearly 11 O'clock at night on my side of the corredor.

Tuesday, $27^{\text {th }}$ of March 1877 . My knee occasionally pained me. Middendorf came for the fifth time with his brush. He thought that it had had a good effect upon my whole system. I did not observe anything of the kind.

On Saturday last the "Copiano" belonging to the Chilian Steam Company, had run aground about five leagues to the North of Pacasmayo. The Government dispatched the "Huascar" to render assistance - and she would probably be [346] [_]. Also the Rimac belonging to the same company had gone thither for the same purpose.

Telegrams from London of the $26^{\text {th }}$ inst. quoted the price of Silver at $53 \mathrm{~d} 1 / 2$ the ounce troy. Peruvian Bonds $5 \%$ at $14 \% 6 \%$ at $18 \%$. Nitrate of Soda $12 / 6$ the cwl. Alpaca Wool 2/ very low. In the course of the day I managed to walk as far as the Alameda de los Descalzos.

Wednesday, $28^{\text {th }}$ of March. This day I got as far as the Pantheon. The walk tired me a little, but did no injury to my knee. The niche of my dear Mariquita I could not find, because I was unable to distinguish the letters cut into the marble slab, but I found the spot where the Chapel was to be built: hitherto only the foundation was laid.

Thursday, $29^{\text {th }}$. Holy Thursday. Dr. Middendorf applied the the Electric machine for the last time to my leg. He repeated that the electricity had done me a great of good. It might be so, but I hardly believed it. On Holy Thursday of last year Mariquita for the last time had expressed a wish to go into the street to visit different churches - para andar estaciones - but had been dissuaded by Enriqueta, who represented to her that she might be hurt in the crowd. As 
I was now remodelling my diary of 1864 I saw that at that time my lawsuits and Consular affaires gave me much to do. Last year my time was in a great measure occupied by the meetings of the different directories of which I was then a member. I recollect my wife told me more than once "Ya no vives sino en los Bancos, nunca estás conmigo." At present on the contrary I was unoccupied for many an hour; for I had necessarily to leave Bryson two hours, if not more, that he migt be able to copy from four to five pages of the corrected old diaries, for only by this means was there a possibility, though hardly a probability of bringing up my diaries to the day when I shall be carried off from this world.

Bryson and I occupied ourselves with the entries to be [347] made in my journal, above referred to. The remainder of the day passed in a very lazy manner. I went out for a very short time, and in the evening Ricardo read to me somewhat more than an hour an article written by the son of the famous German composer, Charles Maria Weber, who gives an amusing account of the enmity of Weber, the leader of the German, and of Rossini, the leader of the Italian school of music, in their youngers days; and how in their riper years they became acquainted with and respected each other. Another article treated on the authors who have written the Roman History under the Emperors, by which I saw in the present century nothing of importance has been written on the subject, and that Gibbon continues to stand unrivalled, though nearly a century before him a Frenchman, Sebastian le Nain de Tilemont, had been an indefatigable collector of facts, and in some manner smoothed the way for the author of "The Decline and Fall of the Roman Empire".

Friday, $30^{\text {th }}$ of March. Holy or Good Friday. Before breakfast I took a short walk, and observed that I had necessarily to take short steps, long ones immediately caused a pain in the knee. The entries in the journal begun on the previous day, Bryson and I brought to a close. Guillermo would now at an early day have to copy them in the clean journal and post them into the ledger. My fortune in my books stood now at $\mathrm{S} / 463,458.30$ besides $\mathrm{S} / 28,833$ undivided property of rather doubtful recovery, and of which, if collected, I had to pay the half to my children.

When Bryson was gone, Ricardo read a little to me, and in the evening Bryson finished Prescott's Conquest of Perú. The last chapters of his work treat on the mission from Spain of Pedro de la Gasca, a clergyman who arrived in Lima without a single soldier, and yet succeeded in putting down the dangerous rebellion of the Pizarros. This extraordinary result he owed to his moderation, patience and generally excellent character. When for the last time in the neighbourhood of Cuzco, the two armies, that of Gonzalo Pizarro and that of Gasca, collected by him $\sin \left[\_\right]$[348] [...] opposed to each in hostile array, the former [_] abandoned by all his soldiers, and he had to surrender without [_] 
blow being struck. His first lieutenant, Francisco Carbajal, 84 years of age, was also taken, and both, together with several of their staunchest adherents, were publicly executed by order of Gasca.

Saturday, $3^{\text {st }}$ of March. I went to the Church of San Pedro, where many years ago I had been delighted at the misa de Gloria. This day it did not please me at all, and I came home quite disappointed. Juan went out to Chorrillos; he said that it would be the last time. Forty thousand Soles which I had paid to him on his and Rosa's account he had invested in documents called Certificados de Salitre, some of one thousand, others of ten thousand Soles each, bearing $8 \%$ annual interest, payable every three months, in bills in London at 44 pence. These certificates had been given by the government to the owners of Salitreras, who had sold their establishments to the same. Ricardo read to me an article which gave an amusing account of the difficulties which Clement XI had to preserve the requisite impartiality, when in the beginning of the $18^{\text {th }}$ century, Philip Duke of Berry and Charles, Archduke of Austria fought for the crown of Spain; the former being the grandson of His most Christian majesty, the King of France; the latter the son and brother of the most Apostolic King of Hungary.

Sunday, ${ }^{\text {st }}$ of April. Easter Sunday. The bandage was taken off my weak leg, and an arnica plaster put on the knee, which still continued weak.

The Minister of Finance had published a new decree referring to the sale of guano in Europe, by which I saw that guano of good quality sold at $£ 12.10 /$ contains 7 to $8 \%$ Azote, and up to $20 \%$ Fosforic Acid. The unit, or each $1 \%$ of Azote, is worth 20 to 21/, each unit of Fosforic Acid is worth 5/6 up to 8/ if completely soluble. Azote, also called Nitrogen is the gas which the atmosphere contains in the [349] proportion of $78 \%$, the remaining $22 \%$ being made up by oxygen $21 \%$, Carbonic Gas $1 \%$ and an atom of hydrogen. On Thursday last died at 9 a.m. in the house of his sister Augusta, Miceno Espantoso's wife, Carlos Bergmann, unmarried about the same age as my son Juan; for the last years of his life he drank hard, and no doubt this contributed to his death. Now, of the once so numerous family of the Bergmanns only Augusta remained. For the first time, after nearly six months I went out to pay a few visits, and walking very slowly, so that I took at least double the time than formerly. I reached the house of Dr. Alvarez, where his daughter Asuncion was in the greatest affection, her second son who had lately arrived from Germany having thrown up blood. The Doctors had ordered his immediate removal to San Juan de Matucanas and she had the other day been with Enriqueta, begging her to procure a free passage for her and part of her family by the Oroya Railway. Fortunately a Mr. Charles Watson, connected with Meiggs, was likely to rent the house Calle de Aldavas which Sattler would leave towards the end of the month, and thus Garland had an opportunity to speak with him and ask him for the favor. From Alvarez' 
I walked to Dolores Puente from whom I learned that Charles Bergmann had died comparatively poor. In his will he had left to the children of his brother Frederic and his sister Augusta in equal parts, all he might ever receive from the Society of the Muelle Darsena of Callao. A few jewels, S/400o in money, and shares in the Trujillo Bank he left to a woman with whom he had been living for a number of years. Of my call on the family of Rafael I have nothing to say whilst I could not pass unnoticed the great politeness with which I was received by Dr. Muñoz. In the evening the letters by the North steamer were delivered. Schutte's of $6^{\text {th }}$ February, via the straits, contained copies of a disagreeable correspondence, between him and Dr. Fernando Palacios. The latter had asked him for a loan of $£ 2000$ which he [350] [_] pay on my accounts to Gibbs in London. Schutte refused the loan, and entered into some explanations which he had better not had done, and this led to an insolent rejoinder from Palacios.

Palacios and Basagoytia had both arrived from Europe via Panamá, without as far as I understood, having succeeded in doing anything to their advantage, either in London or Paris. What the object of their voyage had been remained a secret.

Monday, $2^{\text {nd }}$ of April 1877 . Hardly was Bryson gone when I had a visit from Dr. Muñoz, who was quite as polite as on the previous day. I then ventured out, and called upon Mr. Henry with whom I remained full an hour and from whom I learned many news. The steamer "Copiapó" which had struck somewhere in the vicinity of Pacasmayo, as above said, had been got off, without much damage, and safely arrived in Callao. Nitrate had risen in London to 12/10 the cwt, at which price Gibbs were selling considerably of the large stock they held. A telegram had brought advice that silver was up to $54 \mathrm{~d} 1 / 2$ the ounce Troy. Statistic returns, which referred to the population of London, Westminster, Southwark, and the other parts of the Metropolis which lie within the bills of mortality, give the proportion of deaths to births in the year 1876 , on an average as 15 births to 9 deaths per hour. From Henry's, I went to Macandrews, where I found none at home, the entire family having removed to Chorrillos. When I reached our house I found Alejandro's Coupé at the door: with him, Maria, Corina, and Sofia Velarde. I drove to the model farm, close to the exposition park. Here we alighted and walked about a little. The temperature was very pleasant, the warmth being tempered by a slight breeze.

Bryson read to me in the evening a very affecting, short novel written by Bulwer, called Mortimer, or the Memoirs of a gentleman, and the greater part of which at a later period he incorporated in his Pelham.

Tuesday, $3^{\text {rd }}$ of April 1877. Before breakfast I ventured as far [351] as a Smith who lived opposite Oyague in the $\mathrm{Ca}[\ldots]$ and returned without feeling any pain in my knee. Garland was far from well; he experienced a difficulty in 
breathing and felt a pain in the region of the heart. Nevertheless he went to the bank, this being the first day for paying interest on the Cedulas, of which, alas! I had now not a single one, except the sixty which Garland owed me. Enriqueta sent for the Doctor, who immediately wrote his prescriptions. I received a letter from Johannes Limpricht dated Hamburg $26^{\text {th }}$ February, in which he told me that his sister Elizabeth, who, it was true, had never been very strong, was now suffering from incipient consumption, which, no doubt was owing to her grief for the loss of her two youngest sons, who had been taken from her within six months. Her medical adviser had prohibited her returning to Ratzeburg, where the winds were two sharp for her weak lungs; and had ordered her to Montreaux near Vevay, on the Geneva Lake, whither she intended to proceed, accompanied by her unmarried daughter Emma.

Wednesday, $4^{\text {th }}$ of April 1877. A great deal of my time was taken up this forenoon with going to the banks and other establishments where I had to arrange the transfer of those shares which in the partition had fallen to the lot of Juan and Rosa. I did so without feeling any pain in my knee. I also looked in at José Basagoytia's, who, as it seemed to me was not so much pleased with what he had seen in Paris and London, as I had expected he would have been; he complained of the length of time he had been at sea viz.: a fortnight from St. Thomas to Southampton and vice-versa. He even went so far as to say that if anyone offered him S/50,000 to go and return from Europe, he was very doubtful whether he would accept such an offer. He further assured me that John Meiggs had not been able to form any company for the working of the Cerro de Pasco Mines, and that the utmost he could dispose of was £10,0oo to $£ 12,000$ whilst on the other hand Garland told me that he knew from a trust[_] [352] [...] this person had seen on the hands of the Minister Aranivar, a letter of credit from a London firm, in favor of Henry Meiggs for £250,0oo. I doubted the veracity of this information.

Thursday, $5^{\text {th }}$ of April. Garland was considerably better. The Gas Company declared a dividend on the $31^{\text {st }}$ March, of $31 / 2 \%$ which, added to the dividends already received, made a total of $11 \%$ for the year 1876 . In the course of said year 107,000,000 Spanish cubic feet of gas had been produced, of which 88,000,000 were consumed, and the rest lost. By an article read to me by Ricardo I saw that the London severage flows into the Thames fourteen miles below London Bridge.

In Chile great expectation were entertained: firstly, from the Nitrate of Soda Deposits said to have been discovered in Chilian territory; and secondly, from a Company whose object was to extract gold from the desmontes of copper mines. Though the temperature was getting cooler, as yet it was not so cold as 
to prevent our sitting in the open air on my side the corredor, till nearly eleven O'clock.

Friday, $6^{\text {th }}$ of April. Garland spent a very bad night, and though he went to the bank as he was in the habit of doing, there to attend to his duty as Gerente, I much feared that his life stood in imminent danger, for the pains in the head, and the region of the heart were very bad symptoms. The Calllao Bank had opened on the $4^{\text {th }}$ inst. Its nominal capital was half a million Soles.

I learned from a German article read to me by Ricardo, "Holiday spent in England" that Northumberland House on the South side of Trafalgar Square, which I visited on the $16^{\text {th }}$ August 1851 had been sold by the present Duke of Northumberland to the Westminster town authorities for £500,ooo. Probably at the present moment it was already demolished, and a commencement made with a new street which was to join Trafalgar Square with the Thames Embankment. At two O'clock I went to the meeting of the Shareholders of the Lima Gas Company. After I had received a cheque for not [353] [_] than S/8977.50, being the above dividend of [...] Rosa's, Juan's, and my shares, I joined the sharesholders who were already assembled, viz.: George Petrie, John Bryce, Alexander Ruden, Mathison, Isaacson, and Juan. To some of us Petrie presented a paper, on which he had drawn up a motion to the effect that henceforth no shareholder in the Gas Company, who in his own person, or as attorney for another firm had mercantile connections with the said company, could be elected Director. This was evidently a blow armed at Isaacson, partner of Bates Stokes \& Co. of Lima, the Liverpool firm of which house had ever since the establishment of the Gas Company been their correspondents; and secondly, at Albarracin, partner of Albarracin and Freundt, the Company's agents in Callao. This proposition was signed by Petrie, Ruden, Bryce, Juan, and myself, for I considered the principle laid down in the same to be correct and just. We had to wait till 4 O'clock before Manuel Ortiz de Villate and José Vicente Oyague came, which latter excused himself with saying that he had been in conference with the Minister of Finances. He as usually presided. The informe, or annual report, was approved, then, before we proceeded to the election of the new Directors, for all the old ones went out on this day, the above motion was discussed and decidedly opposed by Oyague, who, though he acknowledged the correctness of the principle, was of opinion that the services of such valuable and proper persons could not be dispensed with, and that therefore they ought not to be excluded. Finally, he thought that a postponement of the question would be advisable. Dr. Galvez, who had entered in the meanwhile, proposed one modification, Villate another, and after a very long debate, during which Oyague spoke most, and was occasionally opposed 
by a few words from Ruden, Petrie, and myself, we at last proceeded to vote. The postponement was unanimously negatived, and the motion, as it stood, approved of by all, even by Albarracin who had also made his appearance, whith the exception of Isaacson and Oyague who withheld their votes. Then the [354] [_] of [_]tors was proceeded, and by an overwhelming majority the following were chosen: Oyague, Ruden, Mathison, John Bryce, Alfred Böhl, Dr. Galvez and Manl. Ortiz de Villate, Suplentes, M. G. Chavez, and Carlos Prevost. Oyague proclaimed the nomination of these gentlemen, said there was no time to chose an auditor, or examiner of accounts for the end of this year, and rising, said in a choleric tone that he gave up his Directorship, because he observed that his opinion was not attended to; he wound up with the words "porque Uds. saben mejor que yo." No one answered, and we all left, rejoicing that we had got rid of him. I was told afterwards that Villate had accosted him in the street, had told him that he was not accustomed to be treated in such a manner and that an altercation between the two had been the consequence.

Saturday, $7^{\text {th }}$ of April 1877. Garland continued very unwell, but did not omit to go to the bank. In the course of the forenoon I managed to walk as far as the Convent of los Descalzos. The Pacific Steam Navigation Company made known that from the $15^{\text {th }}$ of this month onwards, all freights and passage money to the Ports North of Lima had to be paid in silver, or if in paper, with a premium of $50 \%$.

Sunday, $8^{\text {th }}$ of April. This morning, I again walked as far as I had done yesterday; nevertheless strength in my knee I had not. I have said that Juan, in the name of Rosa, and Enriqueta, had divided my wife's jewels. They now proceeded, also with my consent, to distribute Mariquitas body linen, dresses, shawls, etc. Of the shawls, Juan took three with him for Rosa, and her two daughters. Shifts, and so on Enriqueta distributed between poor relations, and the servants girls, whilst of the silk, and other dresses she kept one or two for herself and gave the others as far as I understood, to Eliza, Guillermo's wife, and to Rafael Velarde's wife and daughter.

Amongst my own things I found a completely new livery for a coachman which had been made when we were [355] last in Paris. I presented it to Alejandro who [_] received it, as it would do for his coachman. I myself remained with all the furniture, the silver plate, the plated china, and glassware, table and bed linen, and towels. In our apartments nothing had been changed except my bedstead, which had been removed to the room adjoining Enriqueta's dormitory, and which I expected, would shortly be carried back to its former place. Bryson again commenced reading to me in the bible, viz.: the Gospel written by St. Mark. When he was gone I sat down in my corredor, for the heat was great, and I was not inclined to pay visits. Ricardo read to me 
a little. When the sun was going down I took a walk in the direction of the Barbones Gate. Juan dined in Chorrillos with Heudebert, and in the evening when Garland and Enriqueta went to Rafael Velarde's, whose eldest son José was dangerously ill, I again listened to Ricardo's reading. He concluded the biography of Thomas Cromwell which contained more or less the same details as one finds in Encyclopaedias, and in Miss Strickland's Lives of English Queens. New to me was that his son Gregory, who had been knighted by Henry VIII, had married Elizabeth Seymour, sister of Queen Jane, to whose influence it was no doubt owing that though the father Thomas was accused of high treason by act of attainder, condemned by the house of Lords, and executed, his fortune was not confiscated; also that Oliver Cromwell was no direct descendant of Thomas, but of a nephew of his who had taken the name of Cromwell in gratitude for having been favoured with some of the spoils of the convents and monasteries abolished by his uncle. He read likewise a short article on a French authoress, the Countess d'Agoult, née Flavigny, who wrote under the pseudoname of Daniel Stern, and who died at an advanced age in 1875 or 1876. Though educated in an establishment of Le Sacré Coeur her morals were not immaculate; under the title of Nelinda she wrote the biography of herself; she wrote an account of the Paris disorders of June and July 1848 much [356] [_], in favor of the mutineers - also a dissertation on the [_] merits of Dante and Goethe.

Monday, $9^{\text {th }}$ of April 1877 . Since the beginning of last month Enriqueta had of course collected the various rents of the two houses, stores, and shops, Calles de Zarate and Aldavas. La Compañia de Obras Publicas y Fomento paid their S/540 in their own billetes which Enriqueta sold to Haynes \& Co. at a premium of $3 \%$, an evident proof that this house took Meiggs' bills upon his brother at $28 \mathrm{~d}$. My iron chest was brought upstairs, and though at the imminent risk of our marble staircase, it safely reached its destination, my new office, where I now had it quite at hand, whilst where it had stood hitherto, in a small apartment which opens into the patio, the frequent running down and coming up again to fetch the one document and put away another had been very inconvenient to me.

Tuesday, $10^{\text {th }}$ of April. The heat still continued. The greater part of the forenoon was taken up by my looking in at the Insurance Company "Lima" where a few Directors were assembled, and the monthly routine business gone through with; and with calling upon Melchor Velarde, and the wife of Rafael Velarde. The eldest son of the latter had been at death's door owing to convulsions, and Melchor with by far the greater part of his family, had just returned from Jauja, where they had resided for seven months, in hopes that their weak lungs, a complaint from which the whole family, the mother excepted, was suffering, 
would be benefitted by the pure, and somewhat rarified air of that elevated plain; the health of the girls, they said, had much improved, whilst the father, Melchor, was quite as thin as when he went up, perhaps even thinner.

Wednesday, $11^{\text {th }}$ of April. Thermometer in my office at 12 O'clock $82^{\circ}$ F. My knee always pained a little, and as to my state of mind certainly I could not boast of great cheerfulness. The papers contained a short correspondence between a certain Mr. William Clarke, who had been sent hither by a considerable number of the English holders of Peruvian Bonds, in order to treat with the Government on the subject of the overdue interest, and not [357] [_]eemed bonds. He had asked the President for an audience, which being denied him, he had levied a protest against the last loan made by Rafael \& Co., and demanded payment of the said overdue interest and redemption, amounting to no less a sum than £2,300,0oo. Though the protest was well drawn out and founded, he, as well might have been expected, did not obtain the object he had come for.

In the course of the forenoon Juan and I occupied ourselves much against my inclination with drawing out an answer to a letter addressed to us by Garland, in which he asked for our opinion relative to the claims which he thought he had a right to make against C. W. Schutte of Paris; our answer was copied in my press letter-book. I called upon Pedro Galvez and J. Antonio Lavalle, who were both going to Europe by the steamer of the $14^{\text {th }}$. The former was in, the later not. In our corredor we were together till nearly midnight.

Thursday, $12^{\text {th }}$ of April 1877. I saw by the papers that on Holy Friday the Archbishop of Quito had died. It was supposed that poison had been mixed up with the wine which he drank when taking the communion on the said day.

Garland gave me his thanks for our answer to his letter. Juan thought that they were ironical; but Enriqueta assured me that her husband was satisfied.

Juan dined for the last time with Ruden in Chorrillos, Enriqueta and I waited for him in our corredor, and we then remained together till midnight.

Friday, $13^{\text {th }}$ of April 1877. The "Nacional" made known that in the meeting of the members of El Consejo Departamental it had been resolved by a majority of 8 to 3 not to recognize the legitimacy of the Consejo Provincial with Pedro Saavedra as Alcalde. The minority consisted of J. M. Cardenas, Dr. M. L. Galvez, and a certain Basallo.

This being the last day of Juan's residence in Lima, Enriqueta had invited the three Velardes, Melchor, Francisco, and Rafael to dine with us. Rafael did not come under th[_] [358] [...] several of his family were sick. After Me[_] and Francisco were gone I withdraw to my apartments with Guillermo where he was occupied till past ten writing up my clean journal.

Rumours were afloat that on Sunday next a popular meeting would take place in the Plaza Mayor, its object being, as it was said, to protest against the 
circulation of paper money. Juan, Enriqueta and I remained in the corredor till 11. Garland, always unwell, retired earlier.

Saturday, $14^{\text {th }}$ of April 1877. Before seven I was dressed and went to Juan's room, who was occupied with sending off his trunks. Shortly after, little Corina came to see him, and whilst I left her with him, and took a turn in the corredor, he, whilst my back was turned, quickly and quietly slipped out, so as to avoid saying good by. Enriqueta and Maria had not seen him either. Garland took leave of him in the terminus; some of the sons accompanied him to Callao. I was very sleepy, and dosed in my arm chair till it was breakfast time. Last night, Friday to Saturday, I awoke, lit my candle, looked at my watch, and strange to say it was a quarter to four.

A question relative to the payment of redeemed Cedulas had arisen in the Banco Hipotecario, which would probably have to be decided by the Tribunals. The case was this. An individual is owner of a Cedula, which has, I will say, been drawn in the beginning of January 1875 . The statutes say that it will be paid on

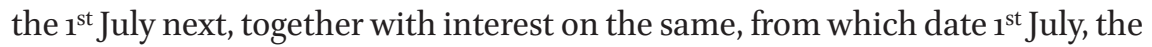
Cedula ceases to gain interest. Both the owner of the Cedula, and the clerks of the establishment overlook that the Cedula has been drawn, consequently the latter pay, and the former receives the interest, till the beginning of 1877 . He then claims the $S / 1000$ value of the Cedula. The Gerentes are ready to pay the $S / 1000$ but deduct the interest improperly paid since the $1^{\text {st }}$ July 1875 . The individual refuses to allow this deduction. He says "if you have paid me the [359] interest, it is paid by your own clerks, and I cannot [_] responsible for their error, and they ought to have advised me that the Cedula was drawn, and the money was ready." "No", answer the Gerentes, "the numbers drawn have been made known in the papers, you should have demanded payment on the $1^{\text {st }}$ July, and the money improperly received by you must be returned." The Statutes say expressly "la Cedula redimida cesa de ganar intereses."

Enriqueta and I, not having Juan with us did not remain together till midnight as on the previous evenings.

Sunday, $15^{\text {th }}$ of April 1877. For some time past an epidemic had prevailed here in Lima, which was generally believed to be yellow fever in a mild form, but which hitherto had fortunately not proved fatal in a single instance. The persons who fell ill suffered from fever, headache, and pains all over the body. Sudorifics, opening medicines, and quinine, were the remdies employed; gererally eight or nine days was the term the illness lasted. To-day Geraldo caught this fever. His mother sent to Dr. Middendorf, who replied that he could not come, being prostrated by the same disease. On Sunday forenoons Bryson frequently read to me a chapter or two from the New Testament; but I confess that I did it, because I looked upon it as a kind of duty, not that the listening 
to it afforded me any pleasure. Afterwards, whilst I was sitting in the corredor, Ricardo read to me in German a journey to Italy in 1805 , by a certain Benkowitz very amusing. From a German monthly Review called the "Rundschau" an article on the political parties in the United States very tedious, which we did not continue: thirdly, from the same Review, interesting letters written in 1856 by a military person who as first aide-de-camp accompanied the then Crown-Prince of Prussia Frederic William, to the coronation of Alexander II in Moscow, they were addressed to a lady in Copenhagen; someway or other they, translated into Danish had found their way into a Copenhagen newspaper, and from [360] [_] paper they were now retranslated into German; the author[_] believed, but not known to be, the renowed Count, then Baron Moltke, Chiefof-the-Staff in the last Franco-German war.

The expected popular meeting was not held; on the contrary when I went out to get shaved, the streets appeared to me emptier than usual.

Telegrams had been received by Graham Rowe \& Co., and Dreyfus, which said that the outbreak of war between Russia and Turkey was unavoidable.

After dinner I was very sleepy, and about 9 O'clock when I heard Zoila with her uncle Franciso Velarde come in, I went to my room and to bed. Garland and his son Enrique had gone at 8 O'clock to the Altos in the Banco La Providencia where Charles Cudlip from Pataz, secretary to Malinowsky, was married to a French lady from L'Union, or from Mauritius, widow of Francisco Calderon, who, born in Guayaquil, brother of Doña Baltazara, widow of Rocafuerte, had in his youth been captain of a merchant vessel, and in later years one of the Directors of the Banco La Providencia. The widow owned some property perhaps the reason why Cudlip had chosen her for his partner.

Monday, $76^{\text {th }}$ of April. Geraldo continued in bed, but felt somewhat better than yesterday. My knee was always weak, and the time hung sometimes very heavily upon my hands. Formerly the long walks assisted me in whiling away the hours, but now not only my sight, also my walking powers were impaired.

Tuesday, $17^{\text {th }}$ of April. Last night's Nacional contained two decrees of the Finance Minister Aranivar, both dated $13^{\text {th }}$ of this month, in which he declared that the certified copies taken by the Peruvian Consul in Valparaiso of the manifests of the steamers of the Pacific Steam Navigation Company, and the so-called South American Company, clearly proved that in Peruvian Ports coined silver had been shipped for Valparaiso and other ports, and that such exportation being contrary to [_] laws of the country, the two said Companies had to [361] [_]ay a fine equal to the value embarked, say about S/[_]. If the "Comercio" was to be believed, José V. Oyague who for many years past had supplied the markets of Cuba and Porto Rico with guano, had made a new contract for the said two islands with Dr. Aranivar. The contract was to last till 
the $1^{\text {st }}$ January 1881 , the number of tons shipped to be 16,000 at $S / 48$ paper: for 4000 tons he had to pay cash down; for 4000 to give an acceptance at 4 months; and the remaining 8000 he would pay for when shipped. Moreover - for the guano arising from former contracts, which had not yet been embarked, he bound himself to pay the price of $S / 31$ hitherto agreed upon at the exchange of $421 / 2$ pence. I felt very weak the whole day, owing perhaps to my not having slept well the previous night, perhaps also to the great heat. At 3 p.m. the thermometer indicated in my office $85^{\circ} \mathrm{F}$.

Wednesday, $18^{\text {th }}$ of April 1877. I slept well, felt better than yesterday, but to keep up my system had to take a little portwine in the forenoon.

The plaster on my knee had drawn some moisture, which I though to be a good thing, though the Doctor said it was quite indifferent. Geraldo, still unwell, took some quinine. The papers published a letter, written by Mr. West, manager of the Pacific Steam Navigation Company, in which he stated that the various amounts of Soles, landed in Valparaiso, were not actually Peruvian Silver Soles, but other foreign coins, and even bars, the value of which was expressed by the sign of sol. He added that if the Minister of Finance had referred to the Custom Houses of the Peruvian Ports, he would have found that upon these various shipments of treasure export duty had been already paid, a proof that they did not consist of Peruvian Coin, the exportation of which was prohibited. The only tender given in for the importation of free Chinese had been that of Oliphant \& Co., represented by Mr. Geary. By the steamer I received very agreeable letters, written by Sieveking, Limpricht, and my cousin Nelly Kramer, about the middle [_] [362] March. Sieveking continued to recommend the reading of [_] bible, not only the new, also the old testament. Both he and the other correspondents expressed their regret at my having postponed my voyage to Europe till next year. Semper, strong in health, in mind, and body, had celebrated on the $14^{\text {th }}$ March his $82^{\text {nd }}$ birthday; he spoke of making a journey to Italy. Behn, 60 years of age, widower of Sieveking's daughter Teresa by whom he had six children, and who lost all the fortune he once possessed, had taken for his third wife a girl 18 years of age. My old, excellent friend Albert Schmidt born in March 1799 had died in the latter half of last year. His brother Gustavus, a widower, two years younger than he, had given up his practice as physician in Hamburg. Mrs. Emily Knaur, Nelly wrote, had become so stout that she could hardly move. Her intellect however had not suffered by her obesity. Magdalen, the eldest dgtr. of Maria Siemssen, was, Limpricht informed me, not pretty, but well educated. Siemssen, who with his family had of late entirely resided in Eppendorf, wanted to sell his country-seat, and to judge from Limpricht's letter it was not at all unlikely that he had taken this resolution owing to the heavy losses, which he, as well as other German firms in China, had of late 
sustained. Even Mr. Pustau who had established the first German house in Hong-Kong and was always believed to be a rich man, had now, in his advanced age, returned to China, after selling his house in Altona. My niece Elizabeth Bobertag had not yet removed to Montreaux.

I opened Schutte's letter to Juan in order to see whether it contained any enclosures for Enriqueta, and I found some cuttings from papers, one of which goes affixed in appendix under $\mathrm{N}^{\circ} 16$. It showed that the Vice-Chancellor in London had given his sentence decidedly in favor of Dreyfus and J. H. Schröder \& Co., and against the holders of bonds, who had demanded that the unsold guano in the hands of Dreyfus should be held at their disposal. Ricardo also fell ill of the epidemic. [363]

Thursday, $19^{\text {th }}$ of April 1877. Geraldo was well enough [...] to Alejandro's office, where the two brothers worked together with Ricardo and Antonio as their clerks, neither of whom of much use to them.

When I went out I looked in at the Insurance Company Lima, where I learned from Carlos Elizalde that Pedro Bernales had been arrested, without anyone being allowed access to him and with a sentry at sight. His crime was, they said, that he had been selling promissory notes of Nicolas Pierola.

Thermometer at half past two, $82^{\circ} \mathrm{F}$. In the evening we finished Bulwer's novel Pelham, which pleased me much. Pelham's own character, though perhaps a little overdrawn, is in my opinion, not unnatural, but this I can hardly say of the other hero Reginald Glanville. I can well conceive his hatred of the villain Tyrel, but not his pursuing him all his life time with an unrelenting thirst for revenge; moreover, if he, Reginald, was not actually the murderer, it was at least his intention to kill Tyrel, and was only forestalled in the deed by the two actual perpetrators.

Friday, $20^{\text {th }}$ of April. The heat continued, and there was hardly a house in Lima or Chorrillos, in which some one did not lie sick of the fever. Several medical men believed it to be the certain forerunner of the yellow fever for next year; and it was affirmed that two or three persons had already died in Lima of the real disease. The "Nacional" contained all kinds of news. The arrest of Pedro Bernales was confirmed. Oliphant's contract for the importation of Chinese free labourers, with certain modifications, had been accepted by the Government. On board a steamer of the English Company, which had arrived from one of the Southern ports, the Government had received the advice that thirty-two boxes, containing Peruvian coined silver money had been embarked for transhipment to Panamá. Pepe Izcue, oficial mayor of the Finance Ministry, was sent on board to examine these boxes, but the Captain would not allow [_] [364] [...] opened. 
The "Comercio" published a telegram received here at somewhat past twelve, which had left London the day before at 6 in the morning; it made known that Russia had declared war to Turkey.

In the forenoon I went to the Insurance Company Lima, where Elizalde, who was also Vice President of the Directory of the Banco del Perú, told me he was much inclined to accept the new proposals made by the Minister of Finances to the four associated banks. Of these proposals, if accepted, I purposed to give an account in due time. Alejandro, also ill of the epidemic, did not come to town, and I had therefore myself to go to the Juez de Paz Bresani, who received me with great politeness, and who told me that Seminario, the tenant of 16 Correo, had been with him, and begged for the term of a fortnight during which time he would pay what he owed, and then leave the shop. I made no objection to his request. In the evening, Enriqueta with a bad headache, went to bed earlier than usual. I walked our corredor in the beautiful moonlight till eleven.

Ricardo continued in bed; Geraldo though not quite well, had this day gone to the office.

Saturday, $27^{\text {st }}$ of April. Last night - Friday to Saturday - I again awoke at the usual hour - a little past three. Of the S/240o due by Dr. Palacios, and by Garland to me, for twice $2 \%$ interest on the $S / 60,000$ Cedulas due $1^{\text {st }}$ January and $1^{\text {st }}$ April, Palacios had paid S/920, which Garland delivered to me. I bought 5 Cedulas of $\mathrm{S} / 1000$ each, at $89 \%$.

It was rumoured all over town, and no doubt it was true, that Pedro Bernales had cheated a great many people. He had given them promissory notes, to deliver within three of four months, bills on London, at a very favourable exchange, say even $32 \mathrm{~d}$, they paying him the money for the same, cash down. The three or four months elapsed, and he could give [365] no bills, neither return the money received. Bar silver [_] at $\mathrm{S} / 16.40$ the mark; coined silver $5^{8}$ to $64 \%$ prem.; bills on London $90 \mathrm{~d} / \mathrm{st}$. 25 to $25 \mathrm{~d} 1 / 4$.

Sunday, $22^{\text {nd }}$ of April 1877. The weather had changed all of a sudden. It rained this morning; at noon the sky was overcast. Thermometer in my office $79^{\circ} \mathrm{F}$.

The Nacional made known that the thirty two-boxes on board the "Eten", see page 363 , had been examined, and found to contain not coined Peruvian Silver, but plata piña, and one thousand dollars Bolivian money.

After Bryson was gone Guillermo posted the entries arising from the partition of my property, closed the accounts, and copied the balance sheet. Whilst at dinner we received invitations to attend at the funeral of Anselmo Centeno, who had died one or two days previously, and who, by Enriqueta's calculation must have reached the age of 110. My wife, if alive, would have been at present nearly eighty years of age. Her mother died when Mariquita 
was born; thus at the very least she would have been 96; my wife's aunt Doña Berna, who brought her up from her childhood, was several years older than her mother, consequently, she would have been if alive, 100 to 101, and she had always spoken of Centeno as having been an elderly man when she was still a girl.

Monday, $23^{\text {rd }}$ of April. The rainy weather had acctually set in. Thermometer in my office at 11 a.m. $78^{\circ}$ F. Ricardo was much better; Alejandro, in Chorrillos, was getting on.

It was certain that Bernales had taken in a great many people. Mr. Ford, of Dreyfus house, who was about embarking for Europe with his family, had told Dr. Middendorf, and he told Enriqueta, that the two gerentes of the National Bank owed to the same: Climaco Basombrio, S/300,00o, Rufino Echenique $\mathrm{S} / 160,000$. What might Derteano be owing? At dinner, Garland added the following figures: Derteano's debt to the bank was $S / 1,000,000$ (one million Soles), Scheel's S/60o,0oo. [366] In the forenoon I took a walk to the Exhibition garden, which was very pleasant; the temperature was mild, the sun not out, and the vegetation all around, the most luxuriant imaginable. Unfortunately I lost myself, could not find the gate, and thus had to walk much longer than I intended, and ought to have done, considering the state of my knee; in town I picked up a coach which put me down at my house. Lembcke came, and read me a long article, written by him, and inserted in the Patria of last Saturday, in which he defended the banks against the aspersions thrown upon them. It was well written and well founded. In the evening for the first time we did not sit in the corredor, but in Enriqueta's salita, where I was with her till past eleven.

Tuesday, $24^{\text {th }}$ of April. The system pursued by Bernales to give promissory notes for bills on England, deliverable after the lapse of two or more months, for which the money was paid cash down, had been carried on by the Minister of Finances and by Rufino Echenique for a long time; today Rehder \& Co. placed into my hands as security, one of these notes of Echenique for £1ooo due on the $27^{\text {th }}$ June. Bills on England were hardly to be got; from Scheel I obtained the promise of $£ 200$ drawn by the firm at 26 pence, which I thought of remitting to Gibbs. I looked in at Sattlers, the tenants of Enriqueta's house, Calle de Aldavas, to bid good by to him and to his lady, for on Saturday next they intended to embark for Europe, via Panamá, probably not to return. He suffered from great weakness in his sight, and was in hopes that the renowned European oculists, if they could not completely cure him, might at all events be able to procure him some relief.

Wednesday, $25^{\text {th }}$ of April. The temperature being warm, I took a tepid bath before breakfast. Dr. Middendorf came, and examined my weak knee, which no doubt was somewhat bigger than the left one; this, however, might be 
its natural [_]ation. The Minister of the Interior and the Concejo [367] [_] epartamental, whose President was Dr. Ramon Ribeyro were again quarelling; this time, I thought, the Minister was in the right. Since December last the new members elected for the Concejo should have been qualified; under various pretences this had not been done; the Minister passed a note calling upon the Concejo to qualify the elected, so that their number might be complete. Ribeyro answered that he and his colleagues knew very well what was their duty, and that there was no necessity of their being told what to do. The Minister replied that it was incumbent upon the Government to interfere, whensoever it was discovered that an inferior body did not do its duty. So the affair stood. Last Sunday, Maria, the youngest daughter of Julius Pflücker married M. G. Cuadros, son of the old Vocal of Arequipa, who when in advanced age had taken for his wife a comparatively speaking young woman of Piura. In the evening various visitors came in: J. P. Escobar, and lady, the curate Aguila, and Sattler with his wife; the three former we did not receive, Enriqueta and Garland having gone to Rafael Velarde's, where about half the family was sick of the fever. The two last named remained with us till 1o O'clock, sitting on my side of the corredor.

Thursday, $26^{\text {th }}$ of April 1877. The daily papers contained the declaration of Pedro Bernales' bankruptcy, decreed by the Consulado, and dated as far back as the 13 March. Rufino Echenique's affairs did not stand much better and about the middle of this day it became known that he also had suspended payment; his liabilities came to £96,ooo Stg. Early in the morning I had refused drafts of Grace on Baring at $25 \mathrm{~d}$. As soon as Echenique's stoppage came to my knowledge I changed my mind, and took from Basagoytia £6oo - on Dreyfus at $243 / 4$ which I intended to remit through Juan to Rosa, leaving it at their option whether they would keep them, or remit them on my account to Gibbs.

Friday, $27^{\text {th }}$ of April. Last nights Patria contained an advertisement which cited the shareholders of the Banco Nacional [368] [...] meeting on the $5^{\text {th }}$ May, the object of the meeting being to dissipate rumours which were afloat as to the bank's solvency, and these rumours, the advertisement went on saying, had their origen in the groundless fear that the bank could be affected by the pecuniary difficulties in which the ex-gerente Echenique found himself. Yesterday the bank had paid cheques to the amount of $S / 1,700,000$. This day the rush continued, and somewhat before half past three, the usual hour for closing, they had no more notes, and for the moment suspended payment. Now the bank offered their drafts on Dreyfus at $25 \mathrm{~d} 1 / 2$ for which I believed they would find but few takers. The "Nacional" made known that the Government had let to Adrian Bielich the Railway to Chancay for ten years. For the present he had to pay S/50,00o annually, in four three-monthly instalments. As soon as the Mole in Ancon were concluded the rent would be raised to S/10o, ooo p.a. 
Alejandro bought for this steamer, with the greatest secrecy, to the amount of $£ 20,000$ in good bills on London at 25d and bar-silver at 17 Soles p. mark, for the Compañia de Obras Publicas, which proved that though this company might have an open credit in London, they had to make remittances hence to cover their drafts at maturity.

I went to Rehder's to look a little into their books, for I had lent them 7000 Soles, as security for which they had given me, as said above, Echenique's promissory note for $£ 1000$ which note I now returned to them, as it was of no

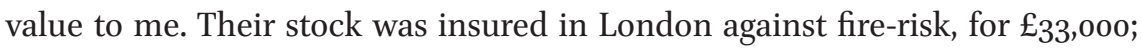
and they sold monthly on an average for cash about 16,00o Soles, upon which, as one of the brothers told me, they made a gain of from 25 to $30 \%$, reduced to 10 or $15 \%$ after deducting all expenses, their own living included. In the evening we had the Basagoytia's with us till 11 O'clock. Oscar Heeren, lately married to Teresa Barreda, had been taken in by Echenique for £40oo; Carlos Wheelock for $£_{3000}$. In the papers of this evening appeared an article signed by Climaco Basombrio, Gerente of the Banco Nacional in which he affirmed upon his honour that he owed [369] nothing to the bank, and that Rufino Echenique's debt only amou[_] to $S / 135,000$, and was guaranteed.

In the forenoon when I went to Dreyfus' offices for the bills bought from Basagoytia Scheel and the clerks seemed to me to be in uncommon flurry. The heat, which had decreased a little in the beginning of the week was this day nearly as great as it had been a fortnight ago. At 3 p.m. Thermometer in my office $811 / 2^{\circ} \mathrm{F}$. In the night from Thursday to Friday last, the Railway station of Santa Rosa in Callao, belonging to the English line, was burned to the ground, its cost was said to have been thirty thousand Soles. An English engineer, Mr. Wilmot, lost his life in the conflagration.

Saturday, $28^{\text {th }}$ of April 1877. On going out this forenoon I found the doors of the Banco Nacional open; many people were grouped outside, also several carriages standing in the street.

The Comercio of this morning said that yesterday the bank had paid cheques to the amount of $\mathrm{S} / 800,000$, and that to day it had resumed payment.

I took a tepid bath, but my knee felt uncommonly weak; both Maria and Corina had fallen ill, no doubt of the epidemic. From Juan I had a very nice letter dated $16^{\text {th }}$ inst. when the steamer was on the point of entering Payta; besides J. A. Lavalle, and Pedro Galvez he had as fellow-passenger the lame William Robinet, sent as Peruvian Consul to Mauritius, which no doubt he owed to J. A. Garcia y Garcia, a relation of his. The Banco Nacional continued paying the whole day. The papers of the evening contained a decree of the finance Minister, naming a commission consisting of José Feliz Garcia, and Mariano Tur, Government Employe's, Alfred Böhl of Gibbs, and Joseph Macandrew, 
chief of Graham Rowe \& Co., who were without loss of time to examine the state of the affairs of the bank. The decree further said that the thirteen million Soles, issued in notes by the four associated banks were guaranteed by the Government's debt to the banks [370] [_] amounted to seventeen million Soles; further, that the [?] of the fours banks continued to be received in all public offices.

Sunday, $29^{\text {th }}$ of April 1877. Part of last night I was very unwell; I suffered from belly ache, incessant diarrhea, and a slight attack of vomiting. This morning I felt very weak, without inclination to eat anything; I attributed it to a mere indigestion. Dr. Middendorf, who by chance came in, thought it was the effect of the epidemia. I dictated a long letter to Sieveking, and when Bryson was gone, though I had made up my mind to pay some indispensable visits, felt too weak to go out and for some time lay down on a sofa. Then Ricardo read Benkovitz's journey. After dinner we had with us for a short time Doña Juana Carbajal and Francisco Velarde, who, though far from interesting, interrupted for a short time our usual monotony. At 9 I took my cup of tea; at ten, when already in bed an infusion of hot water upon dry rose leaves, an excellent remedy against diarrhea. I slept the whole night; and

Monday, $30^{\text {th }}$ awoke in perfect good health. Thermometer at 11 O'clock $80^{\circ} \mathrm{F}$.

Benkovitz's book, written in 1805 contains excursions made in the vicinity of Naples in 1802; the style is extremely familiar and popular, more so than at the present day would be permitted to a good author; his description are very minute and exact, and to me particulary interesting as they go over the same ground which I visited in 1844. Bryson had read to me a splendid article on Edmund Kean, published in the Eclectic of April. The year of his birth, as well as his father was not known; his mother was a low strolling actress Nancy Carey who tramped the country; education, Kean hardly had any but his innate talent for acting carried him through all the vicissitudes of a strolling childhood and youth, until in January 1814 he was admitted to the boards of Drury Lane, then under the management of Mr. Arnold. His first performance of Shylock established his fame as the first tragedian of the time; afterwards he represented with the same success [371] Richard III, Othello, Iago, and Macbeth; Sir [_] Overreach - I do not know from which play - and Sanga in Young's revenge. Riches were now showered upon him: "his son Charles played in the midst of bank-notes and guineas"; he was sought after, and admitted into the highest classes of society, but his moral character did not keep pace with his talent as an actor; he was fond of low society; he had a love intrigue with the wife of an Alderman, Cox; he was hissed from the stage, took refuge in the United States, and when in 1827 he returned to London was received with the same applause as before, but his constitution was broken; to keep up his 
system he had recourse to strong brandy and water; it was even said that more than once he was tipsy when going upon the stage, and on the $25^{\text {th }}$ March 1833 , when he performed Othello, he literally broke down; he spoke these words "Othello's occupation's gone", gasped for breath, fell upon his son's shoulders saying to him, "speak to them for me" and the curtain fell. This was the last time he appeared on the stage; he died on the $15^{\text {th }}$ May 1833. In the evening Bryson read to me the history of Dr. Oliver Goldsmith by Irving; it is written in a light and amusing style; many anecdotes are related of him and of his friend and protector Dr. Samuel Johnson, which if referring to other persons would hardly have been worth preserving. Goldsmith, an Irishman by birth, was the best natured creature imaginable, mild, benign, charitable in the extreme; at the same time inconsiderate, improvident and extravagant so that his whole life long he was in pecuniary difficulties; he preferred his boon companions to the more refined society; he was however one of the members of the at that time renowned Liberty Club of which Johnson was President; also member of the Royal Society, presided by Sir Joshua Reynolds. In the course of the forenoon I went to the office of Dr. Felipe Varela whom I wished to consult about the Eten question. Ruden was with him. The Superior [372] [_] had decided that all those against whom Fabre in the [_] of various shareholders in the Banco del Perú carried on a [_] for the purpose of annulling a meeting in the bank in which it had been decided that the bank was to take the railway on its own account, had to name a procurador to represent them all; and on the other hand the same Superior Court in the suit carried on by the bank against Fabre, had decided "que él no tenia personeria," that is to say that he had no right to represent the opposition members. Varela's answer was: "let us first be notified, and then we may determine what to do."

Bryson finished reading to me another article on Sir George Nares' Artic Expedition. There was no doubt that it had been a complete failure, for only the heroism of the sailors and officers in supporting unheard of fatigues was praised. After a night of 141 days the sun reappeared on the $1^{\text {st }}$ May 1876 ; sledge expeditions were got ready, and towards the end of the month one started for the North, one for the East; and another for the West. All three broke down owing to the scurry; it was not ascertained whether Greenland is an island, or whether it stretches across the Pole to the opposite hemisphere. It is well known that at the Poles the Earth's centripetal power, or power of attraction, is greater than at the equator; the exact proportion wa[_] t[_] have been ascertained by means of the pendulum, but it was not done, because the clock to which the pendulum was affixed would not work. A new field of coal was however discovered in these high latitudes. 
Tuesday, $7^{\text {st }}$ of May 1877. I awoke before four, thought of the Eten affair, and kept awake till near five, when I heard the bell of a fire engine which passed by. I dressed and rose. All in the house were up. We could see the flames and the smoke from our corredor. I went into the street, and ascertained that the Interior of Dinegri's store in the Calle de Judios was on fire. I returned, was extremly sleepy, Ricardo read [373] a little, and by Dr. Middendorf's advice I took another [_] bath, for my knee felt very weak. Already at eleven a loose sheet was published referring to the conflagration; it stated that the store of Dinegri was nearly burned out, that the altos or first story upon the same, had suffered, and that the contents of two other stores in Bodegones, the one owned by Ferro, many years back the Café Nacional, afterwards Francia's, and another, owned by an ironmonger, had been destroyed; the different companies of firemen, as well as the Salvadores, had behaved well as they always did. At a later hour I went out, and learned that the so-called Callejon de Balega had been completely destroyed, and other stores in Bodegones partially suffered from fire and water. A large new store of Davis Brothers, close to Dinegri's, had escaped without damage. The South American Insurance Company lost $\mathrm{S} / 70,000$, the body of private underwriters, consisting mainly, not exclusively of the Directors of the said Insurance Company $S / 50,000$, in which sum of $S / 120,000$ Dinegri's store was insured. How the fire broke out was not known. My shares in the South American Insurance Company I took when making the partition in March at $220 \%$; now they would not be worth so much. Whilst the fire was raging the Prefect took the very proper precaution to place soldiers at the Banco del Perú, and the Banco Nacional to protect them in case of need against the rabble. The rush upon the Banco Nacional had ceased; in all probability very few would now continue to keep their accounts with this bank. The commission continued to investigate its affairs. Garland went in the evening by invitation to play rocambor at Basagoytia's; strange indeed, for this was the anniversary of old Basagoytia's death.

Wednesday, $2^{\text {nd }}$ of May 1877 . A new project of the finance minister, the object of which was to mend the present monetary situation of the country [374] [_] been laid before the four associated banks, about a week [_] ten days back. It depended exclusively upon the willingness or unwillingness of the banks to take upon themselves the consignment of guano to Mauritius and other islands, and to advance to the Government six million Soles, half in coined silver or gold, half in notes. Each of the banks had named one of its members to form a commission for discussing this proposal: L. B. Cisneros for El Nacional, J. P. Escobar for Perú, and G. Heudebert for Lima had agreed to the proposal, with some slight modifications. Aurelio Dinegri for La Providencia had differed 
from his colleagues. I considered it superfluous to enter into any further details until the contract between the banks and the Government were signed.

When Bryson was gone Ricardo read to me from two till past four, Moltke's letters, written from Russia in 1856 already spoken of above. I then took a walk. In the evening Bryson began reading to me a well written History of Poland in Gardner's Encyclopaedia. Both Maria and Corina were in bed with the epidemic; also Enriqueta fell ill with a violent fever, and excruciating headache.

At 2 a.m. died suddenly Gaspar Puente, a man not far from seventy, belonging to the aristocratic family of the Puentes.

Benita, sister of General Echenique, for many years widow of Col. Mateo Arospide, from Arequipa, had also gone to her last account; she expired on Tuesday morning more or less at the same time that the fire broke out in Denegri's store. Though this was the anniversary of the victory of 1866 the day passed over as quietly as usual; only the fort of Santa Catalina fired a salute at daybreak, at noon, and at sunset. In Callao on the contrary it was celebrated with great rejoicings.

Thursday, $3^{\text {rd }}$ of May. I was awake at an early hour and very uneasy about Enriqueta. At 11 a.m. the fever, [375] not the headache had left her. Dr. Middendorf prescribed q[_] his favourite medicine.

In the forenoon I was about an hour with Zuloaga, who had his apartments in the Altos called de Valega, close to where the fire had raged the other night. He was in bed, and complaining of a severe contusion caused by a blow which he had given himself when hurrying down stairs and making his escape to the house of Graña. A Chinese coverlid, and some clothes to the value of five hundred Soles, had been stolen from him.

Friday, $4^{\text {th }}$ of May 1877. Enriqueta got up after breakfast. Maria and Corina had also recovered their health. The commission named for investigating the affairs of the Banco Nacional, finished their labours on Tuesday. I understood that Macandrew had done everything; Böhl had not been able to render him any assistance having fallen ill of the epidemic. The declaration of war by Russia against Turkey was confirmed.

The Nacional stated that in the House of Commons, the Chancellor of the Exchequer had made known that in 1876 the revenue of Great Britain and Ireland had surpassed the expenses by $£ 443,000$. The Budget for 1877 shewed a revenue of $£ 78,700,000$, an expense of $£ 80,900,000$, consequently a deficit of $£ 2,200,000$; nevertheless no new taxes or duties would be imposed, nor the old ones raised.

From a German Review Ricardo read to me that in 1875 the population of France had only increased 105,900 Souls. At two I went to the Judge of the Peace Bresani, told him that Pedro Seminario had not paid anything, and 
requested him to cite the debtor for Monday next. In the Insurance Coy. Lima only Mathison, Gil, Robertson and I, with the gerente met, Chavez, Moscoso Melgar, and Prevost being sick, probably of the epidemic. Though we formed no quorum we came to various resolutions. The Gerente Elizalde proposed to make a present to the five fire brigades, established in Lima, say the Peruvian, English, French, and Italian, and that of the [376] [_]ores, S/200 each, thereby to render them some assistan[_] in paying for the repairs of their implements, which had necessarily suffered in the last fire. I coincided with him, the three others opposed us, considering it a bad precedent. The following insurances against fire were proposed and accepted: S/6o,0oo on Valentin Gil's house and stores, Calle de Judios; S/35,00o on the same gentleman's house in Bodegones; $\mathrm{S} / 10,000$ on wine and liquors in a store in the house of the Pflücker's, opposite mine Calle de Zarate; and S/200o on furniture in the house of Melchor Velarde, Faltriguera del Diablo, these two last, property of a certain Benedetti, represented as an honourable man, all for 1 year at $1 \%$. The insurance of the Wine and liquor was by no means to my liking, but the majority found no fault with it. When Mathison and I left the office together, he told me that Ruden and Villate, two of the Directors of the Gas Company, had taken upon themselves to request J. V. Oyague to resume his post as Director, which he had done accordingly.

Saturday, $5^{\text {th }}$ of May. As was often the case with me in the nights from Friday to Saturday, last night I was again awake for many hours. At noon the sky was overcast and the thermometer marked in my office $79^{\circ} \mathrm{F}$. Telegrams of the $1^{\text {st }}$ May received on the $3^{\text {rd }}$ stated that Prince Bismark had resigned his post as Chancellor of the Empire of Germany. The Emperor had not admitted the resignation, but given him permission to retire for one year from activelife. It was said that he thought of visiting England. The English Government intended to remain neutral in the war between Russia and Turkey. The statement presented to the Peruvian Government by the commissioners, relative to the affairs of the Banco Nacional, was published in the papers. On the $28^{\text {th }}$ April the Bank owed, partly payable at sight, partly payable at different periods, $\mathrm{S} / 2,310,000$. The assets not including the documents of the portfolio amounted nominally to $S / 3,100,000$, which included the debt of Dreyfus Brothers \& Co. [377] which could be realized at any moment, the Bank being authorized to draw on Dreyfus on London or Paris for £1oo,ooo. From this sum the commissioners deducted the depreciation on these credits amounting to $S / 394,000$, which reduced the assets to $S / 2,925,000$, sufficient to cover the bank's debts of $S / 2,310,000$. On the documents in the portfolio, the commissioners made the following observations. The ex-gerente Echenique owed S/134,0oo said to be guaranteed by his maternal inheritance, not yet received: various persons de mancomun et 
insolidum under the heading of B. y Quiroz - probably meant for Basombrio, present gerente - S/194,20o said to be duly guaranteed. Derteano and Scheel owed, mancomunados $\mathrm{S} / 127,000$, Scheel by himself $\mathrm{S} / 339,000$ arising from his having taken upon himself the settlement of the bankruptcy of Castilla and Kast, said to be guaranteed by various estates in the North of Perú. Derteano had to his credit in the bank S/50,000 - Scheel S/110,00o. The commissioners did not venture to give their opinion on the following amounts due to the bank: S/800,00o by Flores Brothers \& Co., owner of an estate in the North; $\mathrm{S} / 1,090,000$ - owing by the branch establishment in Iquique, and $\mathrm{S} / 740,000$ cost of nitrate bought. Since the establishment of the bank in 1872 notes had been issued to the amount of 6,949,00o Soles; to be destroyed, as worthless $\mathrm{S} / 1,272,000$; deducting the one from the other, remained $S / 5,677,000$. They had on hand $S / 250,000$ - consequently in circulation $5,424,000$, about $S / 300,000$ more than the authorized circulation of 5,122,000, but as they affirmed that $\mathrm{S} / 200,000$ were in the chest of the branch establishment of Iquique, no more than $S / 100,000$ unauthorized notes were actually in circulation and these they expected they could easily withdraw by means of their drafts on Dreyfus in London. This statement showed that the public had nothing to fear, but that the loss, if any, would fall upon the shareholders. In the Consulado the creditors of Bernales were cited to a meeting; in the Banco [378] [_]cional, the shareholders; meanwhile, I not being interested either in the one or the other, took a pleasant walk to the Alameda de los Descalzos.

Sunday, $6^{\text {th }}$ of May 1877 . Again a hot, sunny day, thermometer at noon in my office $80^{\circ} \mathrm{F}$.

The Nacional of last night contained a succinct account of what had occurred in the Banco Nacional, for cutting, see appendix $\mathrm{N}^{\circ} 17$. In its leading article it made the following very proper observations: "Why did the commission not ask for the 'testimonio' of the escritura said to guarantee the debt of R. P. Echenique; the statutes prohibit any loan being made to the gerentes; consequently the Directory have infringed these statutes when making loans to Basombrio and Echenique; the Directory have deceived the Government and the public by publishing false statements; for some time past they had issued more notes than they were authorized to do, and their statement showed that they were always within the limit; and lastly, why did they not make it known when they deprived Echenique of his post as gerente; if they had done so in proper time, Echenique would probably not have been able to deceive the public to the exent he did, acting as one might say, under the shade or protection of the bank."

I dictated a long letter to Juan, and then went out to pay a few visits, which I had not done for a long time past. They were the following: to Dr. Jervacio Alvarez, where for a pretty long time I conversed with him, his wife Doña 
Mariquita, and his daughter Asuncion, which latter was always particularly friendly towards me; her brother Benjamin, with his French wife, and a little child, had embarked on the $21^{\text {st }}$ to fill his post as Peruvian Consul in Liverpool. Secondly, to Doña Dolores Puente; thirdly to Rafael Velarde; and fourthly to Dr. Muñoz, who together with his wife had gone to the bull fight. The remainder of the day I was quietly at home. [379] Ricardo read to me in German a criticism on an [_] novel, Daniel Deronda, written by a lady who called herself George Elliott.

The temperature was still so mild that we could sit in the corredor till past half past ten.

Monday, $7^{\text {th }}$ of May 1877 . A cloudy day, thermometer at noon $79^{\circ} \mathrm{F}$.

The great news of the morning was that last night at about 8, the "Huascar", the best ship in the Peruvian navy had left her moorings in Callao Bay, and had probably gone to the south to aid Nicolas Pierola in his renewed attempt to bring about a revolution. Alzamora, her captain and the second in command, had been on shore whilst on board of her were the Cojo Larrañaga and José Maria Echenique, both known as expert conspirators. The Comercio informed us that two brothers Carrasco, one second in command on board the "Apurimac", the other officer on board the "Huascar" were the two other leaders and that they had availed themselves of the absence of their superior to carry their plan into execution. At two I went to the Juez de Paz Bresani, who told me that Seminario had given in an escrito to the Juez de Revision who is the Judge superior to the Jueces de Paz, complaining that the bit of paper in which he was cited to appear had been fixed on the outside of the door of his office, thus greatly injuring his credit. The Juez de Revision had enquired of the Juez de Paz how the affair stood, and meanwhile had ordered him to stop all futher proceedings. In the evening Bryson continued reading the Polish History in Lardner's Encyclopaedia and Ricardo from a German Review, a good and succinct account of the civil war in the United States from which it was evident that the Southerners were merely overwhelmed by numbers, not beaten by superior tactics on the part of the Northerners.

Tuesday, $8^{\text {th }}$ of May. The papers said that vari[_] [380] [_]ior officers in the fleet who on Sunday evening had been on shore instead of on board as was their duty, had been arrested; also that the "Atahualpa", the unwieldy monitor, the "Independencia" and the "Union", would be sent in pursuit of the "Huascar", under the command of Captain More, son-in-law of General Miguel Medina, and son of that Scotchman John More, with whom, then clerk of the firm of Price, I made my long journey through the Interior of Perú from November 1827 to February 1828. This Capt. More was the same whom President Pardo had placed before a court-martial for dereliction of duty, and who was then acquitted. 
Garland said at breakfast that the nitrate certificates had declined owing to the conspiracy on board the "Huascar", and that they did not find purchasers at $90 \%$.

Yesterday the four associated banks proffered their pecuniary assistance to the Government, which was thankfully declined. The National Guard was called into active service. Number 10 commanded by Cesar Canevaro, to which Alejandro belonged formerly was the first which would go into barracks.

This day my customary walk took me through a part of the town, hitherto unknown to me. Just before the Church of San Lázaro, I turned to the left, then to the right, through a street little frequented, with low houses on both sides, which brought me to an open place El Limoncillo, traversed by the open acequia which comes from the Tocuyo manufactory. Both before me and to the left further progress being blocked up, I took a street to my right, which emerges on this side of the new Alameda.

Wednesday, $9^{\text {th }}$ of May. The sun was out; thermometer at noon $79^{\circ} \mathrm{F}$. Last nights papers gave all kinds of news. On Monday the Directors of the four associated banks had met, when the long spoken of project of the Finances, the object of which according to him was to remedy all the pecuniary evils of the Republic, was discussed. The written opinion on the same, signed by Heudebert, Luciano Benjamin [381] Cisneros, and J. P. Escobar, was taken into consideration and the first article, that the four associated banks should take on their own account four millions of the internal debt deposited with them by the Government, was negatived, and consequently the whole project fell to the ground. They then agreed to offer the Government pecuniary assistance. Prado referred them to Aranivar, who asked half a million Soles in silver to be repaid in monthly drafts on London $£ 12,500$ each the first in September next, at 42 pence per Sol. Infantry, cavalry, and artillery about one thousand men, under the command of the Minister of War Bustamante, were about being sent to the South in a steamer of the P.S.N Company. The "Nacional" affirmed that on board of the "Huascar" was Juan Martin Echenique, the second son of the General José Rufino, and that a nephew of the General was concealed in Lima. José Maria Lastre, brother-in-law of Emilio Solar, whom Pedro Bernales had taken in for a large sum, had instituted a criminal suit against the swindler. From Dreyfus I bought $£_{500}$ at $26 \mathrm{~d}$ which I remitted on my own account to Gibbs; on my asking for another $£_{500}$, which I intended for Juan and Rosa, the answer was that they could not draw any more.

Thursday, $10^{\text {th }}$ of May. Ascension Day. Before breakfast I took a tepid bath, probably the last for the present.

In appendix under $\mathrm{N}^{\circ} 18$ goes affixed a copy of the manifest published and signed by the revolutionists on board the "Huascar". All the faults, with which 
they taxed the Government had certainly been committed. I received a letter from Doña Mercedes Villamil dated La Paz $26^{\text {th }}$ April, in which she condoled with me on my loss and informed me of the death of her husband José de la Peña which had taken place on the $15^{\text {th }}$ December last. Ford of Dreyfus house and his family embarked this day for Europe through the straits. Advices were received from Mollendo, Callao, Chorrillos, and Ancon, all to the same effect. On the previous evening at 8.30 an earthquake was experienced in Mollendo at the same [382] [_] in Arequipa, whilst in Callao it was not felt until this morning at 3.30, which had been followed in the just mentioned ports by the sea retiring for a considerable distance, after which it had returned, not in a mighty wave, as at the time of the earthquake of 1868 , but with an undercurrent which gradually lifted up the waters. In Callao the entire Muelle Dársena, and even the esplanade as far as the Oroya railway station were overflown, some ranchos carried away, damage done to merchandize lying on the cars, and the Muelle Darsena itself considerably injured; the loss was estimated at from half a million to a million Soles. Mr. Champeaux, the agent for the Muelle Darsena, with three companions, had been carried away by the waters, and with difficulty escaped drowning. In Chorrillos all the inmates of Cucalon's hotel, amongst them Enrique, were called up at about four; the sea was dry as far as the extremity of the mole. When it returned it nearly reached up to the top of the staircase which leads to the bathing place; the mole was not overflown. In Mollendo the water rose from six to seven feet; at Mejia to the South of this port, the railway was carried away to the extent of three hundred feet.

I made four calls, the first upon Henry and his lady of whom I only saw the latter, who was very busy preparing for their departure for Europe on Sunday next. James Hayne from Valparaiso came in, so did Alfred Böhl. I next went to J. P. Escobar, whose wife was in bed with a bad headache; with him I had a long talk; he was confident that the fraudulent issue of notes by the Banco Nacional came at least to a million Soles. He also told me that the first article of Aranivar's financial project - see $9^{\text {th }}$ - had not been decidedly negatived, but its discussion by the banks postponed, and this because "La Providencia" was opposed to it, and El Banco de Lima declined to proceed any further until an escritura, or public document, was drawn out, establishing the basis upon which the association of the four banks was founded; and to this demand the other banks had [383] acceded, El Perú, and Nacional very reluctantly. My [_] call was upon Margarita Aliaga, wife of Daponte, Brazilian Chargé in Santiago de Chile, who was on a visit to her sister Isabel, widow of Lacroix; and the fourth to the Canon Bandini. Bryson came in the evening, and read me the history of Poland, which made the time pass quickly and pleasantly. 
Friday, $11^{\text {th }}$ of May 1877. I was still in bed when my dear daughter Enriqueta, with her two little girls entered my bedroom, all three bringing me presents; neither did Ricardo forget me, from him I received a German biography of Prince Bismark. He continued reading to me an account in German of the civil war in the United States, from which I learned that on the $2^{\text {nd }}$ May 1863 General Lee gained a victory over the Federals under Hooker, at Chancellor's Ville close to Richmond. General Stonewall Jackson was killed by his own soldiers; when returning from a reconnaissance they mistook him for the enemy, repeatedly fired upon him, and within a few days he died of the wounds received.

After the victory, Lee with General Stuart under him, who had taken Jackson's place, invaded Pennsylvania, and near Gettysburg was repulsed on the $2^{\text {nd }}$ July, by the Federals, under General Mead who had superseded Hooker. This was the turning point of the war; the fources of the Confederates were exhausted. Lee retired across the Rappahannock, and since that time was obliged to abandon the offensive. Vicksburg on the Mississippi fell about this time into the hands of the Northerners.

On the $1^{\text {st }}$ March 1865 I gave an account of the manner I then spent my time. I will now do the same. I still slept in the room close to Garland's and Enriqueta's bedroom, that which is erroneously called his study. Before rising Enriqueta was always with me to bandage my weak leg. I got up at about eight, sometimes Ricardo read to me, sometimes I sat alone on the convenient armchair presented me by Juan. At 10 I breakfasted with the Garlands. Guillermo and Alejandro were never with us. Geraldo, [384] Enrique, and Antonio, generally, not always. Bryson came at eleven; the first we did was to read the Nacional, to write my present diary, and to correct the old ones. We had come now as far as February 1865, and made quick progress. For two or three hours I had to leave him time to copy four or more pages in the remodelled diary. I looked in at the Compañia de Seguros "Lima", did what I might have to do in the street, and took a walk, not so far, nor so quickly, as a year ago, for my leg had not recovered its strength; climbing I had given up for the present. From 3.30 till 4 Bryson usually read to me some article in the Eclectic; then Ricardo took his place, or I rested in the armchair in the corredor; we sat down to dinner at near 6. Bryson returned at seven, and remained with me till past eight. What still remained of the day I used to pass in the armchair; generally Enriqueta accompanied me, sometimes Garland, sometimes Ricardo, or when the two former went out the latter read to me. Towards eleven, I retired to my bedroom. Enriqueta never failed to come in to bid me good night; without her I should not know what to do. On Sundays I seldom went out in the forenoon; formerly I liked to pay visits; now it was a bore. I then made them, because if 
I did not go out nobody would come to see my wife; and I knew that she was fond of receiving her friends, and these in reality seldom failed to call upon her.

This day at dinner the whole family of the Garlands was assembled, also Eliza. We had turkey, which Enriqueta always placed on the table on the occasion of a birthday in the family. At a later hour Enrique Higginson, the father, came. In the course of the day cards had been sent me. In the afternoon of this day the expedition for the South, which it had taken a long time to get ready, left Callao. The general in chief was Bustamante, whose place as War Minister was occupied by General Buendia. The merchant steamers "Limeña" and "Girafa" conveyed the troops, about 1000 men. The "Limeña" belonging to the Pacific Steam Navigation Coy. took the monitor [385] [_]tahualpa" in tow. This latter, under the command of Miró Quesada carried two five-hundred pounders; the "Independencia", Capt. More, was armed with 14 guns of 70 and two 150-pounders; and the "Union", Capt. Portal, carried twelve seventypounders. The hostile "Huascar" provided with a moveable turret like the "Atahualpa" was furnished with two 300- and two 40-pounders.

Saturday, $12^{\text {th }}$ of May 1877 . The only thing I had to note was that the squadron had been seen behind the island of San Lorenzo, where it stopped for nearly twenty-four hours because the tow-line which held the Atahualpa to the Limeña had broken. In the afternoon they pursued their voyage.

Sunday, $13^{\text {th }}$ of May. To Bryson I dictated my testament in rough. When he was gone, and I had been shaved, I walked to the park of the exposition, which pleased me beyond measure. The sun was not out and I walked about for a long time. I spoke here a few words with Enrique Carrera, who told me that for the next day Peter Gallagher, the secretary of the Directory of the Pasco Railway Company, had called a meeting of Directors. I much feared that Col. Torrico would again be troubling us. A little further on I met Valentin Gil, from whom I learned that very bad news had been received from the South, regarding the damage done by the sea in the night from the $9^{\text {th }}$ to the $10^{\text {th }}$ inst. The more to the South, the greater had been the agitation of the waters. In Pisco the mole had suffered some damage. From Mollendo, nothing new. In IIo the sea overflowed the beach, and carried off several huts. The damage done to Arica had been more considerable; here the British Consulate, the offices of the P.S.N. Coy. and the Telegraph Coy., were destroyed. The water entered the Custom House and damaged a great deal of merchandize; it inundated part of the town as far as the Church, and the North American vessel "Watery", thrown on shore at the time of the earthquake of 13 August 1868, was carried two miles further nothward. The submarine cable had changed its position and been laid bare. [386] In Iquique, the commercial part of the town, including the [_] had been 
destroyed, so had been the salitrera la nueva Carolina. Fresh water there was none, for the condensers were gone. A German vessel laden with nitrate was wrecked; another vessel went on shore; a third stuck fast, and a cistern with water was lost; also the railway was injured. The village of Pabellon de Pica lay in ruins; five vessels were totally lost, twenty-seven considerably damaged. Also Cobija, it was said, had been destroyed. The smelting works between this place and Tocopilla were swept away by the sea; the mine of Peña Blanca annihilated; and many lives lost. Antofagasta did not fare better than Cobija, where the water rose thirty-five feet, whilst in Mejillones de Bolivia it reached the height of 65; also Mejillones del Perú and Pisagua suffered great damage.

The Huascar had been seen in Islay and Mollendo, steering for Iquique. The English steamers Santa Rosa and John Elder had both been boarded; the former by Juan Martin Echenique and Larrañaga; the latter by the two Carrascos, but neither the Captain of the one nor the other had given up the official dispatches which were demanded from them. The Peruvian Government had bought the Limeña from the Pacific Steam Navigation Coy. for S/150,000 in Silver. This afternoon the entire squadron was still outside San Lorenzo, for the "Atahualpa" could not get on.

Monday, $14^{\text {th }}$ of May 1877. At noon, with a cloudy sky, in my office thermometer nearly $80^{\circ} \mathrm{F}$. The whole day long the sea to the south of Callao, named the Mar Brava, was much agitated, and rose to an unusual height. Many Chalacos emigrated to Bellavista and Lima. In the evening, at one or two minutes past nine we had a severe shock of an earthquake; there was no noise, but much motion; the glass drops of Enriqueta's chandelier not only shook but actually struck against each other.

Tuesday, $15^{\text {th }}$ of May. The temperature was getting cooler, thermometer at noon hardly $78^{\circ} \mathrm{F}$. The damage done to the town of Arica in the night from the $9^{\text {th }}$ to the $10^{\text {th }}$ had been still [387] [...] han said on the $13^{\text {th }}$. In Valparaiso in the night of the $1^{\text {st }}$ May, a violent storm raged, which blew off the zinc roofs of many houses, broke and rooted up trees, and did other injury; the shipping however suffered but little. Then came a deluge of rain and the water rushing from the hills inundated more than one house. The steamer "Girafa" in the Government's service returned to Callao, and brought the advice that the squadron, including the "Atahualpa", was steaming southward at the rate of from seven to eight miles per hour. The Minister of Justice Dr. Teodoro de la Rosa was about leaving for the Southern departments on board the Chilian steamer Copiapó; he took with him S/100,000 in silver, and provisions wherewith to render assistance to such as had suffered by the last inundation of the sea. Whilst here in Lima the necessaries of life were getting dearer from day to day, and in some departments the inhabitants were nearly starving, the 
harvest in the province of Cajabamba, in the department of Cajamarca, had been so abundant that the arroba of wheat could be bought for two rials, that of maize for 1 to $11 / 2$, of potatoes, good quality for 1 rial; a sheep for 4 rials, an ox for eight dollars. Only beasts of burden were dear, and for want of good roads the surplus was actually thrown away.

It was calculated that during the whole of last night the trains took nearly 4500 people from Callao to Lima. In the course of the day I met Felipe Varela, from whom I learned that, as I had supposed, the Directors of the Pasco Railway Company had been called together on the $14^{\text {th }}$ at the urgent and repeated request of Col. Joaquin Torrico, but that after all for want of the sufficient number, they had not been able to transact any business. I made an attempt to climb up an insignificant height on the basis of San Cristoval, but had to desist, my left leg being nothing better than a dead weight, which I had to drag after me. Bryson read to me in the evening Bulwer's splendid novel, the last days of Pompeii.

Wednesday, $16^{\text {th }}$ of May 1877 . Thermometer at noon $77^{\circ} \mathrm{F}$. The British merchants resident in Lima [388] [_]ted a petion to their chargé, requesting him to take the necessary measures for protecting the British interest, especially in Iquique. A manifest signed by Nicolas Piérola, dated Valparaiso $15^{\text {th }}$ April, published in the daily papers, was now declared to be a spurious document drawn out in Lima.

I went to the Juez de revision Dr. Arnao, who had his office in one of the rooms of the justice hall; he sent for Pedro Seminario who immediately appeared, but made some ridiculous excuses for not having paid his rent. I told him I would pardon everything he owed if he would leave immediately; he answered that it was impossible to do this, having such a large archive to remove. I then allowed him five days; he begged for ten and these were at last conceded to him.

Thursday, $17^{\text {th }}$ of May 1877 . Sky cloudy; thermometer at noon $76^{\circ} \mathrm{F}$. Last night's papers contained further details of the disasters which had occurred in the South of the Republic, as well as on the Coast of Bolivia in the night from the $9^{\text {th }}$ to the $10^{\text {th }}$ inst. In the latter Republic the ports of Antofagasta, Tocopilla and Cobija had been destroyed. In Cobija the entire family of the representatives of the firm of Artold had found their death in the waves. The loss sustained by Gibbs interested in the Salitrera of Antofagasta, had in all probability been very considerable, also in Iquique they, as well as the firm of Gildemeister, could not have escaped without great loss. Chanabaya, which seems to be situated at the foot of Pabellon de Pica, was first visited by a conflagration, caused by the lamps fed with oil and kerosene being upset by the earthquake at about 8.30 p.m. on the $9^{\text {th }}$; whilst the inhabitants were busy extinguishing the flames, the 
big wave came, and swept away the entire population. The Church had been seen drifting on the sea like a vessel. The number of lives lost was not given; hundreds emigrated by sea and by land; those who remained were starving for want of provisions and water, till they were relived by the steamers which came both from the north and South. As far as advices went, Chile had not suffered. In the forenoon I walked to Santa Sofia, where as far as I could [389] judge a little progress had been made since my last visit.

At a later hour I was present in the Consulado at the meeting of the creditors of Lopez Hurtado \& Co., who failed in the beginnig of 1874 . The object was to classify the various debts. Present were: Böhl of Gibbs; Meliton Porras; Dr. Saldaña, representing some creditor of other; Dr. Sandoval, with his lawyer Dr. Palacios, I, and a few more. Lecca, Prior of the Consulado, at the same time Sindico of the estate, for the previous sindico Charles Wheelock had not given satisfaction to the creditors, read his statement, by which it appeared that my claim for rent, and another for salary were the only privileged ones, and would be paid in their totality; the remainder, common Creditors, amongst whom Sandoval for 45,700 would only receive $71 / 2 \%$. Böhl for Gibbs insisted that their claim for goo Soles should also have a preference, because the goods sold by them to Hurtado had been on hand at the time of the stoppage. After a short discussion the claim was admitted, with a discount of $30 \%$; this extrapayment to Gibbs reduced the $71 / 2 \%$ dividend to $7 \%$. In the meeting of the year 1874 the creditors, and particulary the then Sindico Wheelock had insisted that Dr. Sandoval was not a creditor but partner of Lopez Hurtado, and that consequently he was responsible to the creditors. Sandoval, who took Palacios for his lawyer, instituted a suit against the estate, and gained the point, for the tribunals declared that he was a creditor, not a partner of Lopez Hurtado \& Co. Lecca stated the debt due to me as $\mathrm{S} / 480$; I rectified him, saying it was no more than $\mathrm{S} / 288$.

Friday, $18^{\text {th }}$ of May 1877. I saw by the papers that the Prefect of Arequipa had directed a circular letter to the principal foreign houses established there: Gibbs, Fletcher, Stafford and Suwers Woodgate \& Co., in which he requested them to dispatch their goods from the Mollendo Custom-House, no doubt with the object to place them out of the reach of the "Huascar", but he had not offered them a reduction on the duties. The Minister for Foreign affairs, J. A. Garcia y Garcia had been named during the absence of [390] [_] oro de la Rosa, Minister of Justice and President of the Council. Yesterday the creditors of Rufino Echenique, whose debts amounted to $S / 1,400,000$ had a private meeting in his house. Rufino was not present. Dr. Ricardo Ortiz de Zevallos, acting for him, offered to the creditors, in cancelment of all their claims, $20 \%$, half payable in one, half in two months, which proposal was not accepted and the meeting adjourned till the next day. In course of the day I did not go out. Guillermo, 
who to save expenses intended living perhaps for a year with his wife and babe in Higginson's house in Chorrillos, had with my permission taken his furniture to the room in my apartments formely occupied by my wife's servant woman. In the evening I listened with pleasure to Bulwer's Last Days of Pompeii; however my thoughts strayed more than once, for I recollected that by the day, not by the date in 1876 , this was the last time that my Mariquita saw the light of day.

Enriqueta suffered from headache; she and Garland retired to rest at an early hour. Ricardo read to me till past ten. Dolores Puente and José Basagoytia had been with the Garlands whilst I was with Bryson.

Saturday, $19^{\text {th }}$ of May. I awoke before five, rose as soon as Aurelia had bandaged my leg, and at seven walked to the pantheon, whence I returned a little before breakfast-time. The papers gave the following news. The Government's troops had landed in Mollendo without having been troubled by the "Huascar"; three companies were to proceed to Iquique.

The dearness of provisions increased fast here in Lima. Very small loaves which the poorer classes used to purchase for one cent, now cost two. Commissions had been named to collect subscriptions for the sufferers in the South; Krüger came to me in the name of Scheel, one of the commissioners, and I subscribed S/10o. Telegraphic dispatches from Europe said that owing to the catastrophe in the South, communicated by telegram, nitrate had risen in London to $14 / 6$.

On the $26^{\text {th }}$ April the Russians were said to have been beaten [391] by the Turks and to have lost 800 men. The Turkes had [_] bombarded some forts in the Crimea; on the other hand the Russians had taken a town in Armenia called Bayazid. In the course of the forenoon I was notified by a notary of the Superior Court that this tribunal had decided that in the suit instituted by the carpenter Fabre, in the name of various shareholders in the Banco del Perú, for the cancelment of the resolution taken in the bank a long time back, Thomas Lachambre \& Co., Alex Ruden, J. P. Escobar; Denegri hijos \& Co., and I, had to name a procurador on joint account, in conformity with an article in the Codigo de Enjuiciamientos. I went to Escobar, who was with Althaus; Ruden; and Candamo, talking largely about the political state of the country. At last I obtained a hearing, and as Escobar could not leave, for the Directory was in the point of assembling, I went in his name to Dr. Ramon Ribeyro, the bank's lawyer. He agreed with me that we should not appeal to the Supreme Court, but as to what was to be done, he said he could only decide after we had been notified that the autos had been returned to the Juez de $1^{\text {a }}$ Instancia, and after he had examined them.

It had become too cold to be in the corredor at night; till bed time I was with Enriqueta, Garland, the little ones, and Ricardo in their salita. 
Sunday, $20^{\text {th }}$ of May 1877. I slept uninterruptedly till a late hour in the morning, 7.30, when Enriqueta came to bandage my leg. It was getting cool; the sky was cloudy thermometer at noon $74^{\circ} \mathrm{F}$.

The apparatus for loading guano in the Pabellon de Pica having been destroyed by the late inundation, Government decreed that the vessels chartered for guano should load at the Lobos Island where some guano still remained.

A few days back advice was received here that the "Huascar" had boarded one of the merchant steamers and taken out her two officers, Espinosa and Varela, in the service of the established government. This was an atttack made [392] [_] the territory of Great Britain, and it was as yet uncertain what steps the English Admiral De Horsey on board the Shah, a splendid frigate of 7000 tons register, which had left Callao, would take. From Europe we learned that about the 23 or $24^{\text {th }}$ April, the Russian army commanded by the Grand Duke Nicholas had passed the Pruth and entered Roumania as friends, and as such, everything consumed was to be duly paid for. They had reached the Capital, Bucharest. Also in Asia they had passed the frontier and made themselves master of three towns belonging to the Turks, situated in a straight line from N.W. to S.E.; the first Batun, a port on the Black Sea, the next Kars; the third Bayazid; the town bombarded by the Turks in the Crimea was Kaffa, or Theodosia. The English Govt. had dispatched 40,00o men to Malta. Count Otto Von Moltke, the renowned chief-of-the-staff in the Franco German war, had delivered a speech in the German parliament, in which he shewed the necessity of a large loan, wherewith to pay the expenses attendant upon an increased military establishment, for, as he said, the Empire could not remain indifferent when the neighbouring Republic of France was making such extensive armaments.

At about 1 I had an unexpected, but agreeable visit from Johannes Peter Sieveking, the second son of my friend Henry Sieveking of Altona, whom I had last seen in 1856 in Gottingen, where he was then studying chemistry under my nephew Henry Limpricht. He afterwards dedicated himself to other sciences connected with mining, and when he had concluded his studies he embarked for Chile, where he soon found a situation with Echevaria the notorious gambler, and owner of rich silver mines in the vicinity of Copiapó. After having worked here for several years he removed to Valparaiso, where he found sufficient and remunerative occupation. He married a Chilian daughter of a Scotchman, Mr. Livingstone, and after the lapse of time, why I cannot say, settled over to his native place, Altona where he took a house for himself, engaged a German governess [393] for his children, and lived in a manner which proved that his finances were in a fair, if not flourishing condition. At that time his father 
frequently wrote me of the amiable Virginia, and her lovely children. The cold, nothern winter at last affected the southern constitution of Virginia, and after a residence of three years the entire family returned to Valparaiso whence he had now come to Lima in the expectation of doing here some good for himself, and in this he was likely to succeed having been applied to by Mr. Thorndyke, formerly of Meiggs' establishment, who owned some mines about Puno, and who stood in need of a person versed in the science of smelting ore, and to this branch, Sieveking told me, he had always given his particular attention. He had been at sea at the time of the earthquake; the motion of the steamer had been violent in the extreme. Antofagasta, I learned from him, is separated from Tocopilla, which lies close to it to the North, by a mound which stretches out to the sea, called el Moro Moreno; this in some measure protected Antofagasta, and particulary Gibbs' property. He confirmed what we had heard before, that Tocopilla, Mejillones de Bolivia, Cobija and Chanavaya were completely swept away. In Iquique Gildemeister had comparatively speaking suffered but little, Gibbs' much. Ricardo read to me, before and after dinner, the life of Prince Bismarck. It begins with giving a short account of the decline of the German Empire, from the time of the Hohenstauffen when its authority was at its zenith, till August 1806 when Francis II laid down the imperial dignity, and declared the Empire to be dissolved. The author then gives a short sketch of the rise of the Hohenzollern, which being done, he begins with the ancestors of Bismarck, and from this point onwards I dictated an extract from this work, on separate sheets, which will be found amongst my papers. At dinner and in the evening we were by ourselves.

Monday, $27^{\text {st }}$ of May 1877. Bryson was with me till near three. Guillermo wrote up the Cash journal for [394] March and April, then Ricardo read to me till dinner time. We sat down at six, together with Johannes Sieveking, whom Enriqueta had permitted me to invite. He spoke Spanish perfectly, had travelled a good deal, had seen much of the world, and was thus enabled to keep up a pleasant conversation.

Tuesday, $22^{\text {nd }}$ of May 1877. Last night at about 4.30 I dreamt that a low voice called me by my name "Witt", and I awoke immediately. At noon, thermometer with a clouded sky $73^{\circ} \mathrm{F}$.

Every day the papers gave more details of the damage done along the coast of Perú and Bolivia, by the late catastrophe. Also in Copiapo in Chile, the earthquake had been felt. In all probability there had been the eruption of a submarine volcano in the latitude of Tocopilla; and Carrazal a little to the North of Coquimbo seemed to have been the most Southern place where its effects were felt. In Pisagua the "Huascar" took by force 150 tons coal out of an English vessel, the "Edmondson" for the value of which they gave a promissory 
note, by whom signed was not said. They had also sent a written message to the gerente of the associated banks in Iquique, ordering him to keep the export duty on nitrate, at the disposal of His Excellency the Supreme Chief Nicolas de Pierola, and making him personally responsible if he made the payment to any other person. In the course of the day the United States Guano Company paid me one of their pagarées of $S / 8000$, with Interest, and from the Water Company I received the dividends due $30^{\text {th }}$ June and $30^{\text {th }}$ September of $21 / 4 \%$ each.

Wednesday, $23^{\text {rd }}$ of May. The cloudy, rainy weather had set in, thermometer at noon $73^{\circ} \mathrm{F}$. Nicolás de Pierola had embarked in Valparaiso to meet the "Huascar" in Antofagasta. Johannes Sieveking came to bid me good by; to-morrow together with Thorndyke, he would embark for Mollendo, thence to proceed to Puno.

Thursday, $24^{\text {th }}$ of May. Thermometer at noon $73^{\circ}$ F. At 1 a.m. died Dr. Don Pedro Carbajal, native of Arequipa. [395] In 1865, when Vocal of the Superior Court of Tacna he took a part in Prado's revolution, and to remunerate his services Prado when in power raised him to the Superior Court of Lima, at which time I, being involved in several lawsuits, Rafael Velarde introduced me to him and his large family, consisting of his wife, a good natured woman of low birth, many grown up daughters, and two sons, a Doctor of Medicine and a young lad. They then came frequently to our house to take tea. One single time he had an opportunity of sentencing in my favor. In 1868 when Prado was upset he lost his situation; for a short time he was Administrador of the Islay Custom-house, but upon the whole he was completely in the background, and it was a riddle to us how he managed to maintain his family. His wife, who was extremely fond of my Mariquita, who did not dislike her either, used to complain bitterly of her husband, of her daughters and of her poverty; of late she had come occcasionally to see Enriqueta. In the course of the forenoon the notary Iparraguirre came to our house to certify the wills of Enriqueta and myself; which we delivered to him in the presence of the following witnesses: Rafael Velarde; John P. Gallagher; Anibal Gonzales; Jorge Valle y Osma; Carlos Cox; Ferdinand Umlauff, book keeper of the Compañia de Obras Publicas; and Urquhart, a Chilian, cash-keeper of Henry Meiggs. In the evening Ricardo read to me in my inner rooms till 10.30, I being under the erroneous belief that Enriqueta was not at home.

Friday, $25^{\text {th }}$ of May 1877. The Comercio published a list of the Patentes for the present year, in which I was put down with one thousand Soles annually. It was my intention to present, without loss of time, a petition to the Consejo Departamental asking for a reduction of this exorbitant sum. 
The funeral of Dr. Carbajal took place this morning, at which I was not present.

The papers said that Nicolas Pierola had embarked on board "the Huascar" in Antofagasta. [396]

Saturday, $26^{\text {th }}$ of May. The papers contained two decress of [_] Finance Minister; the one in which it was said that Canevaro [_] were willing to advance $S / 80,000$ for repairing the apparatus for loading guano in the Pabellon de Pica; the other, that Wm. Gibbs \& Co. had to pay to the consolidated banks, and these to the Government, £20,000 at the exchange of ten Soles per $£$ in order to fill the empty treasury. Rey of the Water Company told me that the population of Lima consumed daily seven million gallons of water. The English papers spoke of an extraordinary feat accomplished by an Irishman O'Leary, who had for a heavy bet walked in the agricultural hall of London, 517 English Statute miles in 6 days and nights. In the course of the forenoon I went to Böhl of Gibbs, and asked him for a bill on London, one of the many which I supposed the house would have to draw, in order to pay the above amount to the Government. His answer was that he could not, because even if the matter were arranged, the Delegates of the Bank would draw, not Gibbs. Then I went to the office of the Delegates in Goyeneche's house where the secretary, Luis Císneros, told met that the Delegates had resolved not to give the above $£ 20,000$ to the Government. In the office of the Juez de Revision Arnao, I met Pedro Seminario, and an acta, or protocol, was signed by us, together with the judge, which said that if Seminario did not leave the shop by Friday next, he would be thrown out by force, "seria lanzado." Mr. John Gildemeister had received a telegraphic dispatch, probably by way of Europe, dated Jamaica, to the effect that Mr. S. Sattler who on the $28^{\text {th }}$ April together with his family left Lima for Europe, and who in Panamá had fallen ill of the fever, had died on board between Colon and Jamaica; the family was likely to proceed to Europe.

Sunday, $27^{\text {th }}$ of May 1877 . Thermometer at noon $73^{\circ} \mathrm{F}$. Exchange on London 23 to $23 \mathrm{~d}$ 1/2. I made no remittances by this steamer; bar silver $S / 18.40$ the mark, premium on coined silver Soles $74 \%$. When Bryson was gone, I went out to pay four visits; the first to the family of Dr. Jervacio [397] Alvarez, who himself was silent, and apparently in [bad] humour; his daughter Asuncion was not in, and I left little pleased; on the other hand, at Dr. Ribeyro's the daughters and the mother Doña Eulalia, whom my wife used to call mona sin rabo, were very agreeable. Dolores Puente and the family of Rafael Velarde were not in; the former had gone to see her darling Federico Marriott, who was indisposed; the Velarde's had gone to the bull-ring. The remainder of the day passed very tediously, though Ricardo read to me a good deal. 
Monday, $28^{\text {th }}$ of May 1877. Towards morning, about 6, it seemed to me as if I were called by my name, to which I gave my answer, "quien es?" in so loud a voice as to awaken Enriqueta in the adjoining bedroom. In a few minutes I was again asleep.

It was a clear day, the sun out at noon, thermometer $73^{\circ} \mathrm{F}$.

Tuesday, $29^{\text {th }}$ of May. My dear Enriqueta was very unwell for which there were several causes: her habitual migraine; the running away of her Chinese Cook Achú; and the loss of her suit in the Superior Court, against the friars of San Francisco, of which I have given some details pages 263/4 of this Volume. The Government gave permission for the public sale of the premises referred to, which permission Enriqueta had not been able to obtain under the administration of either Balta or Pardo. For a number of days the sale was advertized in a daily paper; thus it came to the knowledge of the friars, who had presented themselves before a judge de $1^{\text {a }}$ Instancia, and demanded the cancelment of the agreement made several years back between them and my daughter because the greater number of the friars who then had acceded to the sale had died, and those now alive would not consider themselves bound by what their predecessors had done, who were no more in existence. The Superior Court had sentenced in their favour and Enriqueta now intended to appeal to the Supreme Tribunal. [398] [_] greater part of the forenoon I was at a meeting of the shareholders of La Providencia, where the Directory submitted to us a project of the Minister of Finance, two principal points of which were: firstly; that the four associated banks should cancel four million Soles, part of the eighteen millions which the Government owed them, by keeping on their own account S/5,333,333, part of the eight million soles, Noml. Internal debt, which they held in deposit as a partial guarantee for the eighteen millions. These S/5,333,333 calculated at $75 \%$, are equal to the four millions; and the difference between the eight millions in their possession, and the $S / 5,333,333$ should be returned to the Government. Secondly; that the contract for 200,000 tons of guano to be exported on account of the banks to the island of Mauritius and the West Indian islands except Cuba and Porto Rico, should be transferred to the firm of Schmole Calderoni \& Co., they paying to the banks in the course of three years in monthly instalments, three million Soles paper, and three million Soles coined Silver. The entire project was unanimously rejected, and we broke up at four.

Andraca, the excellent Prefect of Lima, had resigned, and his post had been given to Capt. Enrique Lara, a by no means respectable character, who was implicated in the attempt to assassinate General Castilla in November 1856 see Volume V. Page 756. The papers made known that the "Huascar" had fired some cannon balls upon the defenceless town of Pisagua, and that part of the 
crew had made an attempt to land, but had been repulsed by the soldiers there in garrison; further, that on the $28^{\text {th }}$ a naval combat had taken place between the Huascar on the one, and the "Independencia", "Union" and "Picolmayo" on the other hand, and that the former had availed herself of the darkness of the night to make her escape. The losses on both sides were insignificant [399] if any at all. A few days back returned from [...] the "Copiapo", with Dr. Teodoro de la Rosa, who had fulfilled his mission. Within the last week or so the two rival companies, the Pacific Steam Navigation Coy. and the Sud Americana, established in Valparaiso, had at last come to an understanding. The P.S.N.C. took upon itself the entire management of both companies, no doubt allowing to the South American the profits which might correspond to the same.

To my great surprise Pedro Seminario, upon my making him a small reduction upon the rent due by him, paid me $\mathrm{S} / 100$ by which means his rent was settled up to the $18^{\text {th }}$ March last. I allowed him now to remain in his shop, and he promised to pay henceforth with due regularly.

Wednesday, $30^{\text {th }}$ of May 1877. In the course of the forenoon I went out, and made unsuccessful attempts to obtain either bills or bars. About 8.30 in the evening, just when Bryson was gone, there was an unusual movement in the streets. When Ricardo, and at a later hour Juan came home we learned that a telegram had been received and published - see appendix $N^{\circ} 19$. The 'Huascar' had been summoned by the "Shah" and "Amethyst" in the name of Queen Victoria, to surrender; the 'Huascar', refused to do so and shots were exchanged. She then got off, and and steamed for Iquique where Juan Martin Echenique, and two others went on shore in a boat with a white flag, and proposed to Captain More who commanded the Peruvian squadron, to join the "Huascar" and to fight the English. This, More refused to do, and summoned the commander of the "Huascar" to surrender. When this news became known amongst the Lima populace groups formed in the Plaza, round the palace, cries were heard of "Abajo con los Ingleses, abajo con el Gobierno"; and Minister La Cotera who ventured out was hissed. Cavalry and infantry were called out - they entered the plaza and the [400] [_] from a window of the palace harangued the multitu[_] which quietly dispersed. I went to bed at the usual hour 11.

Thursday, $37^{\text {st }}$ of May 1877. Alejandro and Geraldo, who came in from Chorrillos brought the news that the "Huascar" had been given up to the "Independencia".

Becker told me yesterday that a telegram had been received, announcing that Bamberger Castendyk \& Co. in Bremen had suspended payment. Their branch here had for ten years been my tenants of Stores 24 and 26 Correo. To the account of last night disturbances I had to add that the Deputy for Tacna, 
Dr. Oviedo, addressed the populace from the balcony of the Club Nacional, that a commission was named to interrogate the President on what had occurred and that the chiefs of this commission, a certain Alarco, well known as an unquiet spirit, and a natural son of General Castilla, nothing better than Alarco, were arrested, as soon as they crossed the threshold of the palace; after a short detention they were again placed in liberty. In Callao the disorders were similar to those in Lima "Viva el Perú, mueran los Ingleses." The "Huascar" had actually surrendered in the night of the $30^{\text {th }}$ to Capt. More of the "Independencia". This advice was communicated to the government by a telegram from the prefect of Tarapacá Bruno Bueno, dated Iquique $3^{1^{\text {st }}}$ May, 8.35 a.m. In the evening the conditions became known. Pierola had given himself up without asking for any guarantee, whilst to the other rebels, More had conceded that their political conduct since $6^{\text {th }}$ May should not be enquired into and that they might either remain in Lima, or leave the country as they thought proper. Meanwhile they were detained as prisoners on board the "Limeña". The whole day long the agitation continued, both in Callao and Lima; the students of San Carlos attempted to form a meeting, to protest against I do not know what. Oviedo from Tacna was at their head. Col. La Torre commanding a picket of cavalry, had some words with him. His horse became immanageable; he felt off, was laughed at; he [401] ordered his men to fire, and a ball grazed the chin of [...] La Puente, and passed through his shirt-collar; this occurred in the Calle de Bodegones. It being a holiday, Corpus, Bryson left at two; Ricardo read to me; in the evening Bryson finished Bulwer's Last Days of Pompeii and began Motley's Rise of the Dutch Commonwealth.

Tuesday, $7^{\text {st }}$ of June 1877. The town was quiet. The students of San Carlos held a numerous meeting in their own apartments and signed two protests; the one, against the intervention of the English men-of-war in the political dissentions of Perú; the other against Col. La Torre, who on the previous day had ordered his soldiers to fire on them. A commission was named to deliver these protests to the President. Whilst they were together some individual called out "Viva Pierola", and was immediately turned out. The popular meeting in Callao, which was held in the house of the Municipality was of a more serious nature. It lasted till 11 O'clock at night, and the most virulent speeches were delivered; the cries of "mueran los Ingleses, abajo el Gobierno, Viva Pierola, Viva el Huascar", resounded, and were not checked. Two of the principal orators, Dr. Fonseca, and a certain Garrido were however afterwards arrested by order of the Prefect Juan Bazo and sent up to Lima. In Lima it was said that Ricardo Espiel, one of the most enthusiastic of Pardos adherents had also been arrested. All the Ministers, say Teodoro de la Rosa, for Justice and President of the Council; J. A. Garcia y Garcia, for Foreign Affairs; General La Cotera for the Interior; Dr. José 
Aranivar for Finances; and General Buendia, provisionally for War, had given in their resignation which had been accepted by Prado.

From C. W. Schutte I received a voluminous correspondence dated $13^{\text {th }}$ to $30^{\text {th }}$ April, of which the principal items were; firstly, the confirmation of the Court of appeal in London, consisting of the Master of the Rolls, and two Judges, of the sentence given by the Court of Chancery in the case of the holder of Peruvian Bonds, against the firms of Dreyfus [402] [_], and the Peruvian Guano Company. Secondly, that already in April, it was known in Paris that Pierola was planning a new revolution and that his agents were trying to raise funds, which they could not obtain anywhere.

Saturday, $2^{\text {nd }}$ of June 1877 . Yesterday Alejandro communicated to me in the greatest secrecy that he had learned from Richard Dartnell, brother-in-law of Mathison, that this latter had received a telegram from his correspondents in Liverpool, to the effect that the Peruvian Guano Coy. Ld., had stopped payment. Accordingly, Alejandro immediately sold his certificates for bills, which he held of the Government. This forenoon the news spread all over the town, but towards evening it was already disbelieved, firstly, because other houses had received no advice to the same effect; and secondly because Gibbs had a telegram dated $31^{\text {st }}$ May, which said nothing on the subject. Both in Lima and Callao, the day passed quietly.

Sunday, $3^{\text {rd }}$ of June. Thermometer at noon in my office $731 / 2^{\circ} \mathrm{F}$. My knee, it would seem, was getting a little better, but in good spirits I was not. The Nacional made known that the resignation of the War Minister Buendia had not been admitted. The latest advices from Europe said that the Russians had not yet taken Kars; also that a Roumanian force, 9000 strong, had garrisoned Kalifat, situated in Wallachia, opposite the Turkish fortness of Widdin, on the right side of the Danube. A Turkish man-of-war which was bombarding Ibrail on the left side of the Danube, had been set fire to by a Russian bomb, had exploded, and sunk, all on board going down with her. The Leipzic Gazette stated that the Turkish armies consisted of: 250,000 men on the banks of the Danube; 50,000 against Montenegro, and 60,000 in Armenia. When Bryson was gone I made up my mind to pay a few visits. The first, to Dr. Morales, who, as well as his daughter Antonia were very friendly; he disapproved most energetically all the outbreaks of ill-feeling against the English. José Basagoytia, upon whom I next called, could not [403] [_]nceal that he looked upon the occurrences of the day in [...] different light; Prado, he called the worst of tyrants. With Doña Goya, Manuel Velarde's widow, and her daughter Adela, I did not remain long. Rafael Velarde, who was the last to whom I went, declared emphatically that if he were called upon to fill any Ministry he would not accept it unless under certain conditions to be laid down by him. At dinner we had with us 
young Urquhart, who had taken Maria and Corina with him to the circus; he remained till 10.30, and though this was rather a long time to be together, his conversation was so agreeable that we were not displeased at his staying.

From the "Nacional" of this day two cuttings will be found in appendix under Nos. 20 and 21, which I did not believe to be entirely trustworthy, for the particulars were given by two adherents of Pierola who had come prisoners on board the merchant steamer from the South: Lieut. Duffó and Mr. Billinghurst, the son of an Englishman of the same name who resided in Iquique many years back.

Monday, $4^{\text {th }}$ of June 1877 . Thermometer at noon $731 / 2^{\circ} \mathrm{F}$. As I had suspected yesterday, the news contained in the cuttings found little belief in Lima, a proof of which was that the town remained as quiet as in normal times. In Callao on the other hand the disorders which took place last night had been of a most serious nature. More than once the populace was dispersed by the troops, but at last they came to blows; the soldiers and gens d'armes found themselves under the necessity of firing, and two or three of the people were killed, and several wounded. A certain Domingo Coloma, cousin of Isabel Coloma, Enriqueta's friend, who had $\mathrm{pl}[\mathrm{ac}] \mathrm{ed}$ himself at the head of the rioters, and several others were arrested. I went out several times in the day in search of bars or bills to remit to Juan by next steamer, but was unsuccessful. Exchange was 22 1/2 to 22 pence per Sol; bars 19.20 the mark, not to be had. In the evening Ricardo read to me from the Comercio [404] [_] interesting details given by this papers correspondent in Paris, of the Turco-Russian War. The Russian army which was to act against European Turkey numbered as follows: 200,000 on the Danube; 80,000 reserve; and 100,000 guarding the Southern Coast of Russia, laved by the Black Sea. This army had been reviewed by the Emperor Alexander; it was commanded by his brother, the Grand Duke Nicholas. On the $24^{\text {th }}$ April it passed the Pruth, and entered Roumania as friends; probably it would pass the Danube near its mouth, but if they passed it on this spot, they would have to march through the territory called the Dobratschka, a swampy country notorious for its killing fevers. The Turks opposed to their enemies on the Danube, 120,000 men, but the entrance into their country was defended by the following fortresses on the banks of this river: Widdin, Nicopolis; Rustschuk, and Silistria; 50,000 were stationed against the Montenegrinos as already said. In Asia, another brother Grand Duke Michael had under his orders nearly 150,000 men; the number of Turks opposed to him was hardly 80,000. The only reserve of the Turks of which mention was made, was 22,000 men in Europe; but on the Black Sea their fleet, amongst which sixteen ironclads and two Monitors under the command of an Englishman Hobart Pasha, exceeded by far the Russian. In the Turkish army served amongst other English, 
Col. Lemox and Col. Baker, the latter notorious for his improper conduct towards an English lady with whom he was alone in a railway carriage.

Tuesday, $5^{\text {th }}$ of June 1877 . The tidal wave which in the night from the $9^{\text {th }}$ to $10^{\text {th }}$ May did so much injury on the coast of Perú and Bolivia was felt on the $10^{\text {th }}$ at Acapulco on the Mexican Coast.

This morning many rumours were afloat, some with some without foundation. The upshot was more or less the following. Some of Pardo's most intimate friends were at the head of a military movement, in all probability to favor [405] his views. What they actually were, did not come to [_] nor did he himself take any part in it. At an early hour Antonio Bazo with his battalion of "Cabos y Sargentos", who had all been drilled by him, marched upon the port of Santa Catalina; but Prado who had received timely advice, was there before him, and before Bazo took any step whatever the President ordered his arrest, and so this attempt failed. In Callao the rising had taken place last night. The ringleaders were: Aurelio Garcia y Garcia, who styled himself chief of the troops stationed in Callao; Juan Bazo, Prefect, by Garcia's authority Chief of the batteries; Col. Smith of the Cavalry regiment 2 de Mayo; Carlos Lagomarsino, who commanded the National Guard called Columna de la Constitucion; and Francisco de Paula Boza, who had under his orders the civic guard of the Customhouse. Saavedra, the second chief of the cavalry, was opposed to the movement; the artillery took no share in it; neither did the policemen, nor the battalion Callao, commanded by Col. Cáceres; and this want of Union accounted for the immediate surrender of the revolitionists as soon as summoned by Prado, nephew of the President at the head of the battalion Ayacucho which he had brought with him. Bazo was sent prisoner to San Francisco de Paula in Lima. Garcia was likewise arrested. Pardo remained all the while quietly in his house in Chorrillos. Here in Lima the streets were nearly deserted; only soldiers were on the move. There was a trifling disturbance near the theatre, another near La Merced, but both times the people were quickly dispersed. Policemen were stationed in the steeples of the various churches; in the evening even carriages were not allowed to pass. All shops, the banks, the tribunals were closed, many houses had only their street-door half open. Guillermo, Alejandro, and Geraldo returned to Chorrillos at an early hour for no business was doing. Garland did not go to the Banco Hipotecario even [406] [_]que and Antonio were at home in the evening and played rocambor with their father. Only Bryson was with me as usua[_]. Little Corina fell ill in the evening, and made her mother pass a very bad night.

Wednesday, $6^{\text {th }}$ of June 1877. The following well known persons had been arrested: Dr. Quimper; Jesus Elias; and Francisco, the third brother of the Bazos. The Vocal, José Eusebio Sanchez had been looked for in his house, but not 
found; probably many other persons had been taken up. Shops were opened, and business was resumed. I went out and was a short time with Elizalde in the Insurance Company Lima. A drizzling rain fell, and the streets were slippery and muddy, owing to the pavement having been taken up, and the so-called Oroya earth used instead of stones.

Thursday, $7^{\text {th }}$ of June. Thermometer at noon $72^{\circ} \mathrm{F}$. The weather more agreeable than yesterday. Jesus Elias had been placed at liberty. The house of José Eusebio Sanchez had certainly been forcibly entered, but by mistake; the police officers were not in search of him, but of arms said to be deposited in the neighbouring houses. Where Pardo was this day, only his intimate friends knew. Some pupils of San Carlos it was said had also been arrested. Yesterday about noon the "Shah" was in sight of Callao. Mr. Noel West of the P.S.N. Coy. on board the Guayaquil went to meet the Admiral De Horsey, and after a short interview the man-of-war continued her course nothward. The first note, dated Callao $16^{\text {th }}$ May, and directed by De Horsey to those on board the "Huascar" was published in the papers. In my opinion it was very well worded. It took no notice of the decree of the Minister for Foreign Affairs, Garcia y Garcia, in which the Peruvian Government declared itself to be irresponsable for the acts of the "Huascar"; it did not refer to the representation made by some merchants to the English Chargé Mr. Graham, in which he was requested to take measures for the protection of English interests. The note merely said that the Pacific Steam Navigation Coy's steamers "Santa Rosa", [407] and "John Elder" had been stopped, the former on the [_] and the latter on the $11^{\text {th }}$ May, by the revolutionary steamer "Huascar"; that in both cases the steamer had been boarded, detained, and the delivery of the mails demanded, which delivery had been negatived by both captains. The Admiral continued to say that notwithstanding his desire to maintain the strictest neutrality between the contending parties, such acts of boarding, detention, or any other intervention with English interests, would oblige him to take the "Huascar" and deliver her up to the Peruvian Government. (The Spanish translation did not clearly express whether this threat applied to what had already been done by the "Huascar", or what she might do hereafter.) The forcible detention of Englishmen on board the "Huascar" would oblige the Admiral to take the same step as already indicated. On the $22^{\text {nd }}$, Astete, on board the "Huascar" replied from Cobija, that the statements of the captains of the "Santa Rosa" and "John Elder" were incorrect, and that the "Huascar", if attacked, would know how to defend herself. We further saw by the papers that the Government of Prado had requested the Chilian Government to capture the "Huascar" and deliver her up, to which the answer was that the Chilian Government would not do so 
until the "Huascar" was declared a pirate, and that whosoever took a pirate had a right to keep the prize for himself. No Ministry up to this moment.

In the office of the Insurance Company "Lima", the Directory met, but nothing of particular interest was transacted; the company was in a flourishing condition. If the following details given by Moscoso Melgar were correct which I believed they were, the treachery of Antonio Bazo had been of the blackest dye. On Monday the $4^{\text {th }}$ he was in the palace to a later hour, and promised to be there next morning with his battalion of cabos, in order to protect the President's wife and family as the President would most likely be under the necessity of absenting himself from the [408] [_] for the greater part of the day. On Tuesday morning [...] sent for him three times. To me it appeared that Bazo had been vacillating, which had been the cause of his losing the precious hours. At last he put himself in motion with his battalion quartered in San Francisco, not towards the palace, but in the direction of Santa Catalina. Of this, Prado received notice, with a small escort he hastened to the said port and reached it before the entire battalion had entered. He taxed Bazo with his treachery, and ordered him to give up his sword which he did, mute and confused. At this moment he was seized with convulsions, to which he was frequently subject, and these only saved him from being put in irons. The "Comercio" of this evening contained the names of the Ministers which formed the new cabinet: General Buendia, President of the Council, Minister for the Interior, and provisional Minister for War; Manuel Morales, for Justice; Dr. Cirilio Rospigliosi, of late transferred from the Superior Court of Tacna, to the same in Lima, Foreign Affairs; and for Finances José Felix Garcia, who was Canevaro's competitor for the second Vice-Presidency, and had for a long time been Director de Contabilidad y Credito.

Friday, $8^{\text {th }}$ of June 1877. Dr. Quimper was this day set at liberty.

At dinner Garland's sons brought the news that Cajamarca, where Vidal Garcia y Garcia, brother of Aurelio and of José Antonio, ex-Minister, was prefect, as well as Chachapoyas, had declared for Pardo. This news however required confirmation. From Motley's Rise of the Dutch Commonwealth I learned that the Queen of the wretched Henry III of France, of whom, I mean the lady, no mention is made in history, was Louise, daughter of Count de Vaudemont, and of the sister of the renowned Lamoral, Count of Egmont, Prince of Gavres.

Saturday, $9^{\text {th }}$ of June. Little Vicente, son of Anibal Gonzales and Pepa Bazo, who sometimes breakfasted with us, told us that yesterday morning at nine three officers and eight soldiers had come [409] to the Chacra of Manzanilla, Antonio Bazo's property, [_] Pepa resided, and searched for arms; they opened everything but found nothing except one or two rifles, and a few old carabiners 
required for the defence of the farm. These they carried off. His uncle Lorenzo had not been arrested, for though searched for he had not been found. A considerable number of the minor offenders in the last disorders had been released. In the morning the funeral of the father of Nicholás Piérola's wife was solemnized in San Francisco; he was a man completely unknown and unnoticed; only remarkable in as far as he was the son of the Emperor Itúrbide of Mexico. A few decided Pierolistas, Antonio Arenas, Jorge Loayza, Evaristo Gomez Sanchez, Pedro Calderon, the Canon Tobar, and some more were in attendance. In the evening the family Basagoytia was with us.

Sunday, $10^{\text {th }}$ of June 1877 . I paid a few visits. To the family of Dr. Gervacio Alvarez, to Doña Josefa, widow of Prada, to enquire for the health of her sonin-law Domingo Mendoza, who lay ill of an inflammation of the liver; to Dr. Morales, to congratulate him on his nomination to the Ministry. I was rather suprised to find here only Juan José Moreyra, and when I left Dr. Palacios entered. Next, to Anibal La Torre, where all had gone out; to Rafael Velarde and Dr. Muñoz. Meanwhile, Enriqueta had been to see Pepa Bazo in the farm of Manzanilla; on the previous day she, Pepa, had called upon her brothers in San Francisco de Paula, but had not been admitted; both had iron fetters to their legs. Two or three small boxes with ammunition deposited in the farm by one of the Torrico's had also been found, and carried off to Santa Catalina. In the evening Garland and Enriqueta went to see Josefa Prada. Ricardo was unwell, and could not read, and I spent a few solitary very sad hours.

Monday, $17^{\text {th }}$ of June. This morning at $8 \mathrm{I}$ went out to the pantheon but to my great regret could not possibly find $[410][\ldots]$ where the Chapel was being built. I was nearly two [_] on my legs without resting. On level ground I walked well, but as soon as I had to ascend I felt the great weakness of my knee. Ricardo occasionally read to me the biography of Prince Von Bismark.

Tuesday, $12^{\text {th }}$ of June. Thermometer at noon $72^{\circ} \mathrm{F}$. The papers contained the translation of a letter addressed by Mr. Graham provisional British Charge d'Affaires date $9^{\text {th }}$ inst., to the Peruvian Minister for Foreign Affairs, in which he said that the British Admiral had requested him to state that owing to hostile acts committed by the "Huascar" against British vessels and property, he, the Admiral, had found himself under the necessity of interfering, but that he always preserved the strictest neutrality between the two contending parties. I remitted this day to Rosa and Juan £250 at 22 1/2 pence, and £250 at 23d per Sol. A similar bill of £250 I remitted to Gibbs on my own account. Bills had been sold at $201 / 2$ pence; Bars $S / 19.20$ p. mark, Silver Soles 82 1/2\% premium.

Wednesday, $13^{\text {th }}$. All was quiet. The various political prisoners were now ordered to be placed before the criminal judge. From the South a considerable number of persons had arrived, arrested by the there authorities. Within the 
last few days had died Manuel Salcedo, owner of the estate Talambo, frequently mentioned at the time of the outbreak of the differences between Perú and Spain in 1864. For some months he was one of the Directors of the Lima bank, perhaps the most tiresome and limited of all who had sat round that table. Afterwards he was one of the Sindicos of the Concurso of Zaracondegui.

This being the day of San Antonio I paid a congratulatory visit to Doña Antonia, the widow of M. M. Basagoytia who died on the $1^{\text {st }}$ May of last year, the second to Antonio Bandini, Canon of the Cathedral. The Basagoytia's gave a large dinner-party to which Enriqueta and Garland [411] had been invited, but only the latter went.

In the appendix under $\mathrm{N}^{\circ} 22$ a cutting from El Nacional, relative to the value of a Silver Sol, is affixed.

Thursday, $14^{\text {th }}$ of June 1877. In the forenoon I paid a visit to Josefa Bazo who resided at her brother Antonio's chacra Manzanilla. She assured me that Antonio had never dreamt of a revolution, and that he had only made himself guilty of insubordination in not having taken his battalion on the morning of the $5^{\text {th }}$ June to the palace as he had been ordered, but to Santa Catalina. The house which stands upon a slight eminence had been newly built, and the various rooms to which I was shewn were of a proper size, neat, clean and decently furnished.

Enriqueta with the two little girls and Garland dined at the Basagoytia's. When Bryson was gone Ricardo read me Von Bismark's biography till 1o O'clock.

Friday, $15^{\text {th }}$ ofJune. There had been a revolutionary rising in Abancay, headed by Benjamin Herencia Zevallos, son of him who was shot, jointly with Domingo Gamio when on their way to the frontiers of Brazil; and Calixto Araos, but it was believed to be of so little importance, that no troops had been sent to quell it.

In order to leave Bryson time to copy, I walked to the Alameda de los Descalzos, and was absent nearly two hours.

Saturday, $16^{\text {th }}$. Before breakfast I went out to the pantheon, found the spot where the Chapel was being built, and was glad to see that the work progressed rapidly.

The naval combat between the "Huascar" and the "Shah" and "Amethyst" took place on the $29^{\text {th }}$ May at about five in the afternoon, close to the Peruvian Coast, in the Bay of Pacocha or Ilo. It lasted three hours and a half, and though many projectiles struck the "Huascar" no great damage was done to her. Whether the English Vessels suffered any injury was not known. In the papers advertizements were published which said that a subscription had been set on foot [412] [_] a gold medal [_] presented to Pierola and his companions as an acknowledgement of their noble defence of the Peruvian flag. 
Sunday, $17^{\text {th }}$ ofJune. Temperature mild, thermometer at noon $71^{\circ} \mathrm{F}$. Enriqueta's Chinese cook had run away about a fortnight ago, since when Aurelia had been cooking till to-day, when a new cook, a sambo, made his debut. It was eleven O'clock before breakfast was ready and full quarter of an hour had we still to wait till the water was brought in for tea. In the beginning of the week Garland, at Dr. Palacios' request telegraphed to Gibbs of London through the medium of their Lima house, to dispose of Palacios' diamonds if they netted £180o. The reply, which reached Lima in twenty four hours was that the diamonds would not net more than £10oo. They had been valued here in Lima in 48,245 Silver Soles. See appendix $\mathrm{N}^{\circ} 6$.

Don Manuel Pardo went to Callao in the night from the $15^{\text {th }}$ to $16^{\text {th }}$ in an extra train, accompanied by the French Chargé, and embarked on board the "Santa Rosa", which left yesterday, probably for Valparaiso.

Dinner turned out very indifferent and in the evening the cook was turned off, and we had again to fall back upon Aurelia. From 8 to 9 Ricardo read Von Bismark's biography.

Monday, $18^{\text {th }}$ of June. We received our letters by the north steamer; Juan's was dated London $16^{\text {th }}$ May; he dissuaded me from undertaking the voyage to Europe, ordered me to sell his shares in the banks, and to buy Gas and Water shares, which at the time were not easily to be had. Corina Schutte advised me that she was engaged to Gustavus Adolphus Schön of Hamburg, a widower with four children, of whom the eldest, a girl, seventeen years old, had just married; the next were twins of 13 , and the last, a girl, eleven years old. He was one of the sons of the late Mr. Schön, partner of my relation Charles Willink, with whom they had quarrelled after the death of their father. [413] Gustavus Adolphus' inheritance had been [_]siderable, like [_] his brothers and sisters, and he was believed to be still a rich man at the present time. Corina wrote that it was not yet decided, whether after their marriage she and Mr. Schön would remain in Paris or remove to Hamburg.

Becker brought me a letter from Johannes Bobertag junior, the eldest son of my niece Elizabeth, married to Martha Behn, and clergyman in Drossen, Silesia; he wrote that his lungs were affected, that his physician had advised him to take mineral baths and that consequently he had resolved to abandon his curacy for a short time and to visit a watering place. The journey required money, which he had not, and he now asked me for from $£ 80$ to £10o, which latter sum, I determined to send him, though my finances were certainly not in a very flourishing condition. At 3.30 I went to a meeting of the shareholders of the Chilete Company, who met in a room adjoining that of the Insurance Company Lima, in Valentin Gil's house. J. P. Escobar presided; co-directors were: Derteano and Malinowsky. The company was in a very bad state. I was 
convinced that there had been gross mismanagement at the mine, moreover Escobar and Malinowsky, though they had not openly quarrelled, had always differed in their opinions. Now only $S / 10,000$ were asked for in order to pay the most indispensable expenses until the return of two persons sent to Chilete to give their ultimate opinion on the probability or improbability of an ultimate good result. The Company consisting of 500 Shares, twenty soles per share would suffice; even this trifle some would not disburse. At last Oscar Heeren and Jameson came forward with the proposal to advance against a proper mortgage £10oo in a bill on London, to be returned in a similar bill with $1 \%$ interest, on the day to be fixed between them and the Directory. This proposal was readily accepted.

Tuesday, $19^{\text {th }}$ of June 1877. Last night's papers contained many important news. The affair of the "Huascar" had given rise in the Santiago Chamber of Deputies to a very [414] [...] ered by the member for "Los Andes", in which he made manifest in the clearest manner, founding himself principally on the French maritime laws, that the "Huascar" was nothing but a pirate, and that as such she should have been treated by the Chilians. One of the Ministers replied, but did not invalidate the Deputy's argument. On the $17^{\text {th }}$ May the Ministry of Jules Simon, known for its Republican principles tendered its resignation to the President of the French Republic, Marshal Mac Mahon, who on the previous day had directed a note to Jules Simon, blaming him for not having defended his Mac Mahon's Government in a proper manner in the Chamber of Deputies. The new Ministry, with the Duke of Broglie at the head, was ultraconservative, if not ultra-montane. A great many prefects were immediately removed. This sudden change in French politics had given dissatisfaction in London and Berlin. Von Bismark was immediately recalled to his post and the German troops in Alsace and Lorraine were reinforced. In London there had been great excitement; the populace clamoured for a war against Russia and the queen had thought prudent to counsel Maria, daughter of Alexander II, married to Alfred, Duke of Edinburgh to leave the country for the present and to retire to St. Petersburg. In the meanwhile Great Britain continued her armaments on a large scale.

Batun on the frontiers of Armenia, it was now said had not been taken by the Russian, neither had [Kars]. Roumania was at war with Turkey, and Greece was also arming, though she would probably be prevented from taking part in the war against Turkey by the presence of an English army in the Pyreus. An English merchant vessel had been blown up on the Danube by coming in contact with a Russian torpedo; all on board were lost.

Wednesday, $20^{\text {th }}$ of June 1877. A fine Sunny day. At a little past eight I went out to the pantheon to see how the work of the chapel was progressing and was 
back in time for breakfast. At last [415] Enriqueta had a new cook, a Chinaman, who was $[\ldots]$ out well. At noon thermometer $72^{\circ} \mathrm{F}$.

The workmen in the Muelle Darsena had struck. They asked higher wages, founding their demand upon the depreciation of the paper currency.

The new Prefect of Puno, Quinoñes, had arrested on his own accord Manuel Costas, Vice President in Pardo's time, but as soon as this came to the knowledge of Prado, he ordered that Costas should be released at once.

The North American historian Motley, whose writings Bryson read to me in the evening, had died. The Leipzic Gazette read to me by Ricardo gave an account of the opening of the Turkish Parliament on the $19^{\text {th }}$ March. It was done in the approved constitutional style. The Sultan's message, a lengthy document was read in the presence of the deputies, the Senators, the high dignataries of the Empire; the foreign ambassadors, other distinguished personages, and the reporters of newspapers. The Senate consisted of 32, the lower Chamber of 106 members, of whom the greater part were Turks; there were also Greeks, Slaves, Armenians a few Christians; amongst the Mussalmans were Arabs, inhabitants of Asia Minor, and the Coast of Barbary, one with another a motley crowd of races and creeds. The Deputies met in a hall on the first story of a building once destined for a university. In the second story the Senate assembled. The ground floor was occupied by the Tribunal of Commerce. The sittings were of course public; however no more than eighty tickets for admittance to the lower Chamber had been issued. The writer of the article said that the Deputies took the thing very seriously, that signs of an opposition to the Government showed themselves, and that the most distinguished member was Yussuf Effendi from Scutari. What was wanting was perseverance, for after having been together hardly two hours and a half, the President got tired, yawned and said "tomorrow is another day, then we shall meet again" so that there was little probability that they would get through the many laws which the Sultan [416] [_] laid before them for discussion and approbation. The execu[_] and the lower house had the right of initiative; the Senate rejected, or approved.

In the course of the forenoon I went to the cuartel of San Francisco de Paula, to see Antonio Bazo, but was told by the officer that I could not be admitted. From the brothers Cox I bought on account of Juan four shares in the Gas Company at $96 \%$.

Thursday, $27^{\text {st }}$ of June 1877. Having received a note from the gerentes of the Banco Hipotecario in which they asked me to be present at 12 O'clock at a meeting of the Directors, I went at the appointed hour. Present were: the two gerentes, Garland and Gallagher; the Directory, consisting of the President Lorente, Dr. M. M. Galvez, George Elster; Jose Jimenez; and Evaristo Barrios, further, the Bank's principal lawyer, Ramon Ribeyro; and shareholders, José 
Vicente Oyague, Dionisio O. de Villate, and I. The case laid before us was the following: In 1873 the then Directory resolved, in order to increase the sale of Cedulas, that all such Cedulas as were sold in Paris, or were transmitted thither from Lima, should have their cupons paid in francs, and that the redeemed Cedulas should also be paid in the same coin. Advertizements to this effect were inserted in the Paris and Lima newspapers. Cedulas to the amount of somewhat more than $\mathrm{S} / 600,000$ were transferred to Paris. At the time when this agreement was made, which, in the first general meeting of shareholders was communicated to them by the then gerente, Garcia Calderon, and tacitly approved, because no observation was made; I say, at that time exchange on Paris was fs 4.65 the Sol. Ever since then, exchange had risen gradually, and at the present moment was a little above two francs per Sol, and consequently the loss to the bank was not only enormous, but ruinous. As soon as Garland and Gallagher were named gerentes they made known that payments in the manner originally agreed upon were to cease. With holders of about $\mathrm{S} / 300,000$ they had settled amicably in a man-[_] [417] [m] ore or less disadvantageous to the bank, but for some time [_] Enrique Barreda for himself, and as attorney for Osma of Madrid, had presented about S/300,000 in Cedulas and demanded the exact fulfilment of the original agreement. The Gerentes refused, and he instituted a suit against them, which was still being carried on. Meanwhile from both sides proposals were made for an amicable settlement. The last made by Barreda was the following. For all the cupons due, and not yet paid, he claimed payment at the rate of fcs 4.65 , to which in my opinion he was perfectly entitled, to be paid within sixty days. All the Cedulas he held the bank was to pay at $110 \%$ in the course of a year and in bills on London or Paris, at the present rate of exchange, making good to him for the delay in payment interest at the rate of $9 \%$ p.a. After a few words from Gallagher, Dr. Ribeyro stated the arguments on both sides, and seemed in favor of a friendly settlement. I then spoke and decidedly advocated this way of proceeding, for I was convinced I said that the Supreme court would sentence against the bank which would then lose perhaps S/500,00o, whilst now it would get off with a loss of 160 or 170,000 Soles. The first who opposed me was Lorente; the next, Dr. Galvez who affirmed that justice was decidedly on the side of the bank, which, in his opinion could not lose the suit. Dr. Ribeyro wavered, but was not so certain as Galvez, of a favourable issue. Oyague in a set speech in which he did not fail to say that he, at the request of Manuel Pardo, had founded the bank, would not listen to such a "transacion". This was, he said, no settlement, but the ruin of the bank. Villate opined in the same manner, but more openly, and frankly. Lorente and Galvez spoke more than once; energetically, and in the full conviction of what they said. I did my best to stem the torrent which 
ran against me but fruitlessly. Jimenez, Elster, and Barrios did not open their mouth, and finally at about two it was unanimously decided, my vote excepted, that the gerentes should continue to prosecute the suit against Barreda and others similarly situa[_]. [418]

Friday, $22^{\text {nd }}$ of June 1877. Last night's Nacional contained the correspondence between Alonzo, Chilian minister for foreign affairs and Segarra, Peruvian Chargé. The latter requested the Chilian government to lay hold of the "Huascar" and to deliver her up to Perú, whilst Señor Alonzo affirmed that all Chile could do was to deny to the "Huascar" every assistance except provisions and water. Segarra called the "Huascar" a pirate; Alonzo said that this word was not applicable to her. We also read in the "Nacional" a long defence of Antonio Bazo, who gave his version of what had occurred on the morning of the $5^{\text {th }}$ June, very different from that given by Moscoso Melgar on the $7^{\text {th }}$ inst. According to him he had made himself guilty of insubordination in marching the cabos y sargentos to Santa Catalina instead of to the palace as he had been ordered in the morning, not on the previous night; but no one could prove against him the attempt, still less the design to bring about a revolution. In the Patria of the same evening an article was published, signed by three superior officers, decidedly contradicting a great part of Antonio Bazos' statement. I bought for Juan thirteen shares in the gas company at par and $1 / 4 \%$ brokerage to Alejandro. The seller was Magill, of Sawers Woodgate \& Co. At about 4 O'clock a numerous meeting of merchants was held in the Exchange Rooms in the Consulado, the object of which was to stop if possible the further rise of the exchange on Europe. Garland was by no means well; last night he had one of his usual attacks, with pains in the region of the heart, and difficulty in breathing.

Saturday, $23^{\text {rd }}$ of June 1877. I started at about 1.30 and went to the Banco de Lima, where I asked Lembcke what had been the result of yesterday's meeting in the Exchange Rooms. The meeting had been numerously attended, Oyague presiding; the discussion had been animated and rational. The principal spokesmen had been: he, Lembcke, who had insisted upon the exchange being fixed at 24d. Emilio [419] Althaus, who had opined that this meeting could not lead to [_] favourable result; Böhl and others, that a trial ought at least to be made, as no harm could come from it; Calderoni who spoke against Meiggs' emission of notes; Meiggs, who tried to defend himself; Candamo who gave it as his opinion that if the drawers bound themselves not to draw at an exchange worse than 20 pence, the importing houses should also fix their prices in proportion to this exchange; Derteano, who in a great measure threw the fault of the rise in exchange upon the Government, and added that the Government should be requested to enter into the views of those now assembled. Finally, 
it was determined that the exchange on London should not be worse than 20 pence per Sol for the next three months. In this days meeting the exchange for this steamer was fixed at $201 / 2$ pence on London, and at 2.13 1/2fcs on Paris. From the bank I walked to San Francisco de Paula, on the other side of the bridge, where an officer told me that Antonio Bazo had been removed to the military hospital of St. Bartholomew; thither I went and here I learned that he was in the hospital del 2 de Mayo, and in this latter place I found him in a pretty comfortable, clean room, not particularly unwell, and accompanied by some of his relations. He told me that he was there upon his word of honour not to escape, and that he expected to be placed in liberty in less than three weeks.

Sunday, $24^{\text {th }}$ ofJune 1877. Some time back I spoke of a monk, Pardini, who had been accused of keeping for himself a quantity of money placed with him in deposit by a nun. He was condemned in the first and second instance, but had been absolved in the Supreme Court by a majority of five judges, viz.: Ribeyro; Muñoz; Alvarez; Manuel Cisneros; and Vidaurre, who sentenced that there was no proof of the deposit, and that the nun might sue him in the ordinary course, for the restitution of the money. Cosio opined that Pardini should return the money to the nun and Oviedo, Sanchez, and Leon confirmed the sentence of the inferior courts. Last night Garland had a blister put upon his breast - and this morning he felt better. [420] [...] went out to pay a few visits, the only one to my liking was that to Juan M. Zuloaga, with whom I met Genl. La Puerta. Zuloaga was of the same opinion as that which I had expressed the other day at the meeting held at the Banco Hipotecario, and told me as a certain fact that when Pardo embarked a few days back for Chile, he was accompanied on board by the French Chargé, his secretary, and José Canevaro, which latter continued on the most intimate terms with him, whilst at the same time he and his wife Luisa Soyer had much influence with Prado. On the $15^{\text {th }}$ inst. when Antonio Bazo marched with his battalion to Santa Catalina, Prado, when he heard of it, could not make up his mind to go there in person, and it was Saavedra who literally forced him to mount the horse. Doña Dolores Puente, though I was in her house at 3.30, had already gone out. Rafael Velarde suffered from toothache. At Dr. Juan Antonio Ribeyro's they were always very friendly towards me, and so was Doña Eulalia today. At Doña Juana Guise's the visitors formed a large circle, without my being able to distinguish anyone, and I was by no means pleased.

Without thinking that it was Dia de San-Juan, when it is the custom to go out to Amancaes, I walked to the Alameda de los Descalzos, which as well as the street leading thither was crowded with people; there were many open and closed carriages as well as gentlemen on horseback. One with another it was a very animated and pretty scene. In the evening we were by ourselves, 
I beyond measure low spirited. Dr. Middendorf came for a short time, and said that though Garland was somewhat better, it was by no means unlikely that he would have to apply another blister.

Monday, $25^{\text {th }}$ of June 1877. At 1 O'clock I went by the Oroya train to Callao, where I collected in the office of the Pacific Steam Navigation Company, last year's dividend of $4 \%$ on my eleven shares of $£_{50}$ each, which was paid at the exchange of 21d, and returned by the two O'clock train pleased with this little [excu]rsion. [421]

Tuesday, $26^{\text {th }}$ of June 1877. The papers made known that [_] Government had disapproved the guarantee given by Capt. More of La Independencia to the rebels on board the "Huascar", whereupon More had thrown up his post.

Mr. Charles Williams, formerly Director of a college, latterly employed in Iquique by Pardo's government, had made a contract with the present administration, in which he bound himself to construct in the Port of Iquique, a dock, Muelle Darsena, to connect the small island at a short distance from the coast, by means of an iron bridge with the mainland, and to build upon the island, a custom house, to cost two hundred thousand Soles; all to be done out of his own funds or those of the Company which he expected to be able to form in Europe. The custom-house was to revert to the government in ten, the dock and mole in fifty years, meanwhile Williams, or the Company collected on their account every description of dues, excepting, I should suppose, import and export duties.

The Gas Company made known to the consumers of gas that from the $1^{\text {st }}$ August next they would have to pay for every thousand cubic feet of gas, nine Soles, instead of nine dollars as hitherto. They founded the necessity of this increase in the price upon the depreciation of the billetes, and not on the rise of exchange on Europe, as in my opinion they ought to have said. The wages of their employées had been raised in the same proportion; so had been the wages of the labourers of the dock in Callao who had refused to work, as mentioned on the $20^{\text {th }}$ inst.

Wednesday, $27^{\text {th }}$ of June 1877 . This morning before breakfast I walked to the botanic garden, and was admitted by the director though a ticket was generally required. It resembled in a great measure the park of the Exhibition, but was not kept in such good order. Of course here were more flowers and fine plants, but the paths were uneven, and more than one thing I found out of repair. The papers published the following: On the $20^{\text {th }}$ inst. when the steamer Santa Rosa was in the port of $\mathrm{Pi}\left[\_\right]$[422] [_] [ready] to depart, lieutenant-colonel Bernal, who called himself a Comisario, went on board at past 10 p.m. accompanied by six soldiers, and requested the captain to deliver up to him his passenger Manuel Pardo. The captain refused to do so, sent for the Captain of the Port, 
and with much difficulty, and after the exchange of many high, and improper words, Bernal, who was very tipsy, returned on shore without having obtained his object. We now learned for the first time that the Government had placed four individuals, "guardianes", on board to prevent Pardo's landing in any Peruvian port. In Arica many respectable visitors had gone off to salute Pardo; the same had been done by Prefect Bruno Bueno in Iquique as well as by the commanders of the Peruvian men-of-war anchored there.

Thursday, $28^{\text {th }}$ of June 1877 . Last night's Nacional published a violent article against the Gas Company's attempt to raise the price of the Gas. In the twelve months from $24^{\text {th }}$ June 1876 to $24^{\text {th }}$ June $1877,1,379$, ooo passengers had availed themselves of the Oroya Railway between Callao and Lima, and 49,000 between Lima and the Sierra. These numbers were properly taken from the tickets sold, and there were certainly some passengers on the line who went without tickets.

Thermometer at noon $72^{\circ} \mathrm{F}$. Hitherto we had had but little rain. At 2 O'clock I went to a meeting of the shareholders of the Chilete Mining undertaking. Present were Escobar, President; with the two Directors, Malinowsky and Derteano; M. G. Chavez; Emilio Althaus; Le Maitre from the firm of Thomas Lachambre \& Co.; Tenaud; Rafael Canevaro; José Vicente Oyague, Cudlip and I. Heeren and Jameson had withdrawn their offer to lend £10oo; consequently the Coy. was in the same difficulties as on the $18^{\text {th }}$ inst. $S / 10,000$ were required, and could not be brought together. The only ones who subscribed were: Oyague for S/200o; Derteano S/200o; Malinowsky S/100o; Chavez, Cudlip and I, each $\mathrm{S} / 500$. The conditions were: firstly, if $\mathrm{S} / 10,0\left[{ }_{-}\right]$could not be brought together [423] we were not bound to give anything; secondly, the [_] to be returned in six months with interest at $1 \%$ and in bills on England at 30 pence; thirdly, our loan of $S / 10,000$ had the preference to all former ones in conformity with the ordenanzas de Mineria; and lastly, should another loan be necessary, then we were to be paid out of it.

Friday, $29^{\text {th }}$ of June 1877. San Pedro y San Pablo. Before breakfast I walked out to the pantheon, where, though a holiday, the workmen were busy at the Chapel. The arch of the window above the altar, consisting of one piece, had been placed, and the overseer told me that this arch, together with the side pieces of the window, and its mouldings, all of artificial stone weighed one ton.

After Bryson was gone I went out to pay a few visits to Doña Dolores Puente, with whom I was a considerable while, Doña Petronila, Pardo's mother, was in bed with a cold. At MelchorVelarde's I was received by two of his daughters Elvira and Christina, agreeable and good girls; at Petita Puente's, Frederic Mariott's wife, there was a numerous circle, amongst whom I distinguished J. J. Moreyra, Escardó, young Prevost, and the ex-Minister Dr. Rosas, who sat close to me, and 
with whom I exchanged a few words. Marriott, suffering from erysipelas could not move from his chair, and when General Buendia, the present Minister, entered, and took his seat near him, the conversation between the two turned immediately on the raised gas price, which was strongly animadverted upon by the Minister. The general opinion ran so strongly against this increase in the price, that in my opinion at least the company would be obliged to be satisfied with the old rate of $\$ 9$ per thousand cubic feet, but whether there would now be a possibility of paying dividend, owing to the enhanced cost of coal, was doubtful.

Saturday, $30^{\text {th }}$ of June. Bryson and I were so much occupied the whole forenoon that he found no time to copy the four or five pages in the remodelled diary, as he usually did. At 4 O'clock I went with Garland to José Canevaro's [424] [...] ge with him the conditions on which I was to be released from the guarantee given by me several years back para hacer el servicio on 30,000 Soles, part of the one million Soles Bonds which the Eten Railway Company had deposited with the Banco del Perú as a security for the loan made by the bank to the Company. These conditions we quickly settled, the more so as we had previously conferred on the subject. They were the following: I paid Canevaro $\mathrm{S} / 8000$, ceded him all the rights I had to the railway, as well as the fifteen shares of one thousand Soles each I had in the same and he released me from the above guarantee. We only differed as yet with regard to the document which was to be drawn out in order to give due validity to this arrangement. In the evening Enriqueta was in bed with migraine. Garland went out, and I spent not only a dull, but a sad evening till I went to bed.

Sunday, $1^{\text {st }}$ of July. At 5 a.m. I was awakened by a smart shock of an earthquake. Juan, the servant whom my wife and I had had for many years, this day entered Enriqueta's service.

The papers contained a proposal made by Henry Meiggs to the Government, the upshot of which was that he or the Government was to issue fifteen million Soles in paper money, with which the Bonos Meiggs already emitted and to be emitted, in payment of the construction of the railways were to be paid, and then, as he very properly observed, the interest payable on these bonds would be saved. If this plan were carried through we should have in circulation not less than thirty million Soles in paper money, a pretty lookout indeed. These newly issued fifteen million Soles should be redeemed gradually by means of $131 / 2 \%$ of the monthly revenue of the Callao Custom house. Whether they were to be redeemed in silver or gold, and whence these precious metals were to come, was not said.

At 2.30 Bryson and I started for a walk to Amancaes. [425] We came as far as where the Chapel stands, and where [_] the side of the hill on a piece of rock 
scooped out by nature the image of the virgen is painted; it was no pleasant walk for we had to wade through the powdered earth, but I had the satisfaction that I neither got tired, nor felt any pain in the weak knee. We were back by 5.30 when Ricardo read to me till dinner time; at, and after this meal we had Doña Juana Carbajal with us.

In the Commercial Rooms established by a Frenchman Lemale, in the large house opposite Gibbs, originally built by Pedro Terry, and now Candamo's property, a meeting of the smaller traders and shopkeepers was held, in opposition, as the papers said, to that held the other day in the Exchange Rooms by the Alto Comercio. About four hundred persons were present. Juan Revoredo presided. One of the principal speakers - and who certainly spoke well - was Cipriani, the Italian, whom I knew by sight since the meetings in the Banco del Perú, where he had annoyed the Directory more than once. The resolutions taken were the following: firstly, that from the next day onward all shops should be closed at 6 p.m.; secondly, that all those assembled and those in the same condition as they should withdraw their money from the banks; thirdly, that a commission should be named which was to ask the President for an audience, and when admitted inform him that if by the beginning of next year the Government did not give them Bills on England at 4od, they would cease to sell for bank notes.

Monday, $2^{\text {nd }}$ of July 1877. I was busy running about the whole morning. I looked in at Canevaros, where I told one of the brothers Don Rafael that I did not see any reason why they had any objection to give me an escritura publica instead of a simple document, which his brother José had been willing to give me - See what I said on the subject on the $30^{\text {th }}$ June. I next went to José Vicente Oyague from whom I learned to my great pleasure that there was every [426] [_]bility that the difference which had arisen between the Gas Company and the consumers would be amicably arranged. The price of the gas would not be raised, and the government promised to furnish the Gas Company with a certain number of bills on England, if I mistake not, $£_{3500}$ monthly, at 28 pence, by which means the coal from which the gas is made would stand in cheap enough to allow the company to furnish the gas at the same rate as hitherto. This arrangement, Oyague told me, he had made with the Minister.

Tuesday, $3^{\text {rd }}$ of July. I received letters from Juan, Sieveking, and a circular note from Charles Semper, who advised me of the death of his wife Luisa Reincke on the $28^{\text {th }}$ April. Sieveking wrote that on the $10^{\text {th }}$ May he had been dangerously ill, almost at death's door, owing to inflammation of the lungs, but that he felt better on the $30^{\text {th }}$ May, the date of his letter. Emily Rode, the only unmarried sister of that family, had also departed this life, I suppose more or less at the age of seventy. Juan informed me that the new English guano company, say 
Raphael and others, were pushed for money, and that he should not at all be surprised if erelong they were to telegraph to the Peruvian Government that they could not continue to accept their drafts. He was also of opinion that they were very desirous to transfer the contract to some other party; he further informed me that the bondholders were certain that they would gain the suit against Dreyfus, whilst Dreyfus was quite as sure that he would gain it; and finally, the diamond necklace which I had bought for $\mathrm{S} / 12,000$ and which when making the partition was valued at S/10,00o, consisted of Cape of Good Hope stones, for which the highest offer he had received was 18,00o francs, which he had refused. To Enriqueta he wrote detailedly about the differences between Garland and Schutte; he also mentioned the engagement of Corina to Mr. Gustavus Adolphus Schön of Hamburg. Last night [427] [...] both in Lima and Callao were all closed at six [_], so they were this evening, and they would continue to be so for the present.

Wednesday, $4^{\text {th }}$ of July 1877 . I attended one of the usual monthly meetings of the Directory of the Insurance Company Lima, where the customary routine business was transacted. The affairs of this company stood very well. Only upon Pedro Bernales' debt we would suffer a heavy loss; he owed S/24,00o and as security we held fifty shares in the Banco de Lima paid up capital $S / 25,000$ worth 40 to $45 \%$. There was no doubt that of late the exchange had improved a little, the last sales having been made at $211 / 2$ and 22 pence per sol.

The agreement between the Gas Company and the Government had not been carried out, the latter offering to give to the Company every month $£_{2000}$ at the current exchange of the day, which was of course not accepted, and consequently the three Gas Companies in Lima, Callao and Chorrillos did not recede, and intended to charge to the private consumers from the $1^{\text {st }}$ August onwards, $25 \%$ more than hitherto. The papers published many telegrams from Europe, one with another of little interest. As far as it was known, the Russian armies had made little progress in Asia-Minor, and in Europe they had not yet crossed the Danube. The Turkish fleet had arrived at Alexandria where 40,00o soldiers, the contingent of the Khedive were to be embarked under the command of his son Hassan.

Thursday, $5^{\text {th }}$ of July. This morning I went out to the pantheon where I noted that since my last visit no progress had been made in the construction of the chapel.

Thermometer in my office at 11 O'clock $71^{\circ} \mathrm{F}$.

In La Paz, the Peruvian Chargé, Miguel San Roman, son of the President of Perú, who died in the beginning of 1863 , had been insulted by the President of Bolivia, Daza, and had arrived in Puno. His secretary La Jara, had come to Lima. The cause of this mis-understanding was the following: On the $18^{\text {th }}$ [428] June 
last, [_]canor Herrera, Director de Contabilidad, took refuge in the Peruvian Legation. The Bolivian Government, on the plea that Herrera was no political but civil offender, demanded that he should be given up; meanwhile he had left the Legation and fled. Daza hereupon ordered the Legation to be surrounded by soldiers, and made use of highly offensive words towards San Roman. The Buenos Ayrean Chargé interfered, but San Roman thought proper to leave La Paz as already said.

From last night's Nacional I copied the following:

“En que se parece el reloj de la Catedral al Gobierno?

En que anda un dia, para dejar de andar un mes.

¿Y en que mas?

En que nadie sabe quien debe darles cuerda.

¿Y en que mas?

En que parecen existir para mera vista."

I need hardly say that the preceding words in Spanish are a very bitter satire upon the Government.

Friday, $6^{\text {th }}$ of July. Thermometer at noon $711 / 2^{\circ} \mathrm{F}$.

Bills on London had been sold at $211 / 2$ and $22 \mathrm{~d}$. Coined soles were at $80 \%$ prem.

Saturday, $7^{\text {th }}$ of July. Last night's "Nacional" gave a different version of the occurrence in La Paz. It said that Daza had not made use of insulting language to Míguel San Roman, or in his presence, but that he had done so in his most intimate circle. Also that San Roman had left La Paz a fortnight after he had fallen out with the President availing himself of leave of absence, conceded him by J. A. Garcia y Garcia, Minister for foreign affairs. The Minister for the Interior Buendia published a decree which gave liberty to all political offenders, with the exception of those against whom a final sentence had already been pronounced. (aquellos sobre quienes pesaba sentencia ejecutoriada.) I heard that this Buendia had at last married the woman or lady with whom he had been living for many years and who had become [429] the mother of several now grown up children. At [_] three O'clock a sufficient number of shareholders of the Gas Company were assembled to form an extraordinary meeting. Oyague was called to the chair. He gave a very long, but otherwise clear and fair account of what the Directory had done, viz.: that they had raised the price of gas, as much as $25 \%$ to all consumers, private individuals, the Municipality, and the Government; that the two latter had refused paying this increase; that he, Oyague, and Mathison had had an interview with the Minister of the Interior Buendia, and with the Alcalde of the Municipality Pedro Saavedra, from whom 
they obtained the verbal promise of which I spoke on Monday last, but that at the next interview the Minister had retracted. Dr. Loayza, a shareholder in the name of his wife, Ramona Castañeda gave it as his opinion that, having duly examined the contracts between the Gas Company and the private consumers, the former had certainly a right to raise the price if it thought proper to do so. As regards the government and Municipality the opinion of the shareholders was divided. It however seemed to me that the majority was inclined to persevere in the course which had once been adopted. I myself told Oyague secretly that I thought it more prudent to give way if necessary. Candamo went so far as to say that it might be advisable to give up the privilege which the Gas Company enjoyed. To this Oyague replied, and clearly proved that this was the worst which could be done. Manuel Ortiz de Villate took a part in the discussion; Böhl, Petrie and Dionisio Villate said a few words; silent auditors were: Ruden, Mathison, Williams, Prevost, Isaacson, Albarracin, I, and perhaps two or three more whom I could not distinguish. The result was firstly, what the Directory had done was approved; secondly, that the letters written to the Government, and to the Municipality after having been slightly altered were ordered to be sent, and thirdly, that the Directory was authorized to proceed in the [_] [430] [_] they thought proper, advising the shareholders in due time, of what they had done. A petition to the Government appeared in the daily papers signed by Dr. F. Palacios, José Basagoytia, Mariano Felipe, and Carlos Paz-Soldan, and several others who asked for permission to establish a new gas company. This however could not be granted for the old gas Company held a privilege for 75 years, of which twenty odd had elapsed. In the evening Garland having gone out, Enriqueta and I remained together till near midnight.

Sunday, $8^{\text {th }}$ of July. This morning Dr. Middendorf came to me, and told me in a very polite manner that having made his calculation he found that he had been a loser by the amount which I had last sent him for his fees, that he would send me a detailed account, and that he hoped I would not be offended by what he said. Certainly I was not offended, but surprised I was, for I had sent him $\mathrm{S} / 300$. After having dictated a long letter to Juan I went out to make a few calls. To Dr. Dorado, where nobody was at home, he and his family having removed to Chorrillos; next, to Doña Asuncion, daughter of Dr. Jervacio Alvarez, always very agreeable. To Doña Dolores Puente, where I met Francisco Sagastabeytia, who had come to town, after a short absence in Matucana. To Rafael Velarde and family; and lastly to Dr. Muñoz and lady who had gone out. After dinner Ricardo again read to me in Bismarck's biography.

Monday, $9^{\text {th }}$ of July 1877 . At 3.30 I drove out with Garland, Enriqueta, and the two little girls to the chacra of Manzanilla, where we expected to find both Antonio and Juan Bazo; only the former was there and at my request he 
showed Garland and me all over his extensive premises which he had been rebuilding of late, and which were not yet quite finished. They stood partly upon a solid hill partly upon an old Indian huaca, and from the same we had an extensive view over the lower lying grounds. We [431] were back for dinner. In the evening, by the steamer, cor[_]ponding to the French, one from St. Nazaire, I received a letter from Mr. Schutte, treating again on his differences with Garland, to which it was my intention not to reply. Juan's to Enriqueta was on the same subject, and not written in such a kind manner as in my opinion his letters to his sister should be. In the meeting of the members of the "Alto Comercio", 22d was fixed upon as the exchange of the day.

Wednesday, $11^{\text {th }}$ of July 1877 . The papers stated that on the $25^{\text {th }}$ and $26^{\text {th }}$ June in Quito and the environs subterranean noises and sounds similar to the discharge of artillery had been heard, a shower of ashes had fallen, and great damage had been done to villages and cultivated fields by the overflowing of several small rivers in the neighbourhood, all which, it was believed, had been caused by an eruption of the volcano "Cotopaxi". The "Independencia", commanded by Moore arrived in Callao. The other vessels of the Peruvian fleet, commanded by Portal, remained in Iquique with the exception of the "Huascar", which had gone to Arica. The interview which was to have taken place the night before last between the President and the Minister of Finances on the one, and the managers and directors of the banks on the other hand, was countermanded at the very last moment, the President having preferred to go to the theatre. Lucas Oyague, a natural son of José Vicente, was named gerente of the National Bank in lieu of Rufino Echenique. Of late had died here in Lima, José Martiarena, a well known gambler, otherwise an honorable man; Selaya, the notary public of most repute, and father of that Selaya who married Juanita Valle-Riestra; and Juan Cubillas, tenant of one of my shops Calle del Correo, also Notary public. In the evening José Basagoytia and wife were with us.

Thursday, $12^{\text {th }}$ of July. I awoke this morning at 3 a.m. and hardly got again a wink of sleep. At somewhat past eight I walked out to the pantheon where to my surprise I saw a lot of Chinamen come out who had accompanied to his [_] [432] [_]ing place one of their countrymen who had been converted [_] the catholic faith. In my chapel the two sarcophagi had been placed; they were of large dimensions, and the lids were so heavy that they could not be moved without pulleys.

Telegraphic dispatches from London of $25^{\text {th }}$ June, received per steamer from Valparaiso, stated that the Russians had passed the Danube near Galatz; also that the French Senate by a majority of 21 had ordered the dissolution of the Chamber of Deputies; this was a natural consequence of the change of Ministry of which I have already spoken. 
The forenoon passed in an incredibly quick manner. Bryson and I corrected my old diaries; I dictated letters to Europe, went out, enquired for news, and so the time went.

In the Banco de Lima the clerk refused to accept some of Meiggs' notes which I had sent in, and only took them by order of the gerente Cucalon as a particular favor done to me. I then looked in at Rehders and requested him not to send me in future any of Meiggs notes, and from him I learned that in a meeting of the committee of the "bajo comercio", it had been resolved on the motion of Lord, formerly barber and hairdresser, now seller of perfumery, that a petition should be presented to the Government, in which it was requested to order the four banks "El Nacional", "Perú", "Lima", and "La Providencia" to complete $60 \%$ of their nominal capital. If this were not done, they the petitioners and they who acted in concert with him, would not receive the notes of the four banks for more than half [their] value, unless provided with the Government's stamp. As to the notes of the Garantizador and the Compañia de Obras Publicas they would not receive them after the ${ }^{\text {st }}$ August. Further, that last night the Gerentes and Directors of the four associates banks had had a meeting with the President and the Minister of Finances, and that the President had laid before those assembled two plans; the principal purport of both was that the Government ceased to pay the banks the $6 \%$ annual interest on the seventeen and a half millions of Soles which it [433] owed to them. I considered it unnecessary to give mo[_] particulars until one of these plans digested by the respective Directories, and accepted by the Executive became the law of the country.

Friday, $13^{\text {th }}$ of July 1877 . This morning when dressing an uneasy feeling come over me. I had to go inside, a perspiration broke out all over the body, and I continued unwell the whole day.

Whilst the family was at dinner, I lay on my bed, and took nothing but two cups of tea. In the evening however Bryson read to me the usual time. My bowels were very loose, but on

Saturday, $14^{\text {th }}$ ofJuly I rose quite well. I sold forty shares of the Banco del Perú, belonging to Juan, by his express order, at $55 \%$ less $1 / 4 \%$ brokerage upon the net amount to Alejandro, a fair price in my opinion. Ruden had told Alejandro that he would sell him [_] at $551 / 2 \%$.

In the evening Enrique was present at the marriage of the daughter of George Petrie, in former years agent of the Pacific Steam Navigation Company in Callao, now in the employ of the Guano loading Company, with Mr. Noel West, who occupied Petrie's place in the Pacific Company. The marriage took place in the apartments of Mr. John Mathison, who, like Petrie is married to a daughter of the late Mr. Richard Dartnell of Callao. About this time it became 
known in Lima that José de la Riva-Agüero had received from the King of the Belgians the grand cross of the order of Leopold.

Sunday, $15^{\text {th }}$ of July. Thermometer at noon $71^{\circ} \mathrm{F}$. Bryson and I made good progress in indexing my diary of 1863 . At 2 I went to a general meeting of the shareholders of the Banco La Providencia, of whom fifteen or thereabouts were present. Albarracin presided, Garcia Calderon was not there, neither Moscoso Melgar, the Gerente, who for some time past had been residing in Matucanas with his family. The other gerente, Joaquin Bolivar, read the report, which declared a dividend of $8 \%$, which with $4 \%$ already paid made $12 \%$ for the year. I was the first to speak and observed that the [434] [_]ve [_] of sixteen or twenty thousand soles was by far too small, to which Albarracin replied that this was also the opinion of the Directory, and that therefore they proposed to the shareholders that two articles in the statutes should be reformed which said that $12 \%$ dividend must be paid to the shareholders annually. All present, except Moses, the Jew, a German, or North American tailor, at once understood that if the gains did not allow the paying of such a percentage, the payments could not possibly be made; but Moses insisted that the Statutes should be adhered to, and could not be reformed without the consent of two-thirds of the shareholders present. Then the motion was discussed, Pratolongo and the lawyer Pastor Sevilla being the principal speakers, and the proposal made by the Directory passed, if not unanimously, at least by an overwhelming majority. I proposed that before the dividend were paid, a large proportion of the gains should be carried to reserve fund; Cudlip, who sat next to me, was of the same opinion, but Pastor Sevilla and Focion Mariategui, who sat behind me, begged me to withdraw my motion which I did. Next, Albarracin read to the shareholders two proposals made by the Government to the four associated banks, the kernel of both of which was the cessation of the receipt of the $6 \%$ interest on the seventeen millions five hundred thousand Soles due by the Government to the banks. All the details I was not able to keep in my memory, but the first of the two projects said that the Govmt. would issue fifteen million Soles in paper money, hand this government paper to the banks, which were to withdraw from circulation their own notes, and of course would have no further responsibility. In this manner fifteen millions of the seventeen and a half would be paid, and the remaining two and a half millions, the Government would find means to cancel by and by. Albarracin added that three of the four banks had acceded to this main point, [_] not, and I learned from Mariategui that this one was the Banco [435] de Lima, whose Directors however had not been unanimous. Pratolongo was decidedly against the Government issuing paper money, because, as he said, if we open the doors we shall erelong be overwhelmed by unconvertible government notes. Others, such as Dionisio 
Villate and Cudlip were in favor. So was I, though I did not give my opinion, because, as they said, government could issue paper money when it thought proper, and by this combination we freed ourselves of all further responsibility. Pastor Sevilla called both projects malos, malisimos, perversos, and thought that another plan might be presented to the Government. Then Albarracin proposed that a commission of three shareholders should be named to study the question, and give their report. This was agreed to, and before we proceeded further I quickly broke in "que se nombren por Cedulas", which was conceded by the Directory. Majority of votes had Pastor Sevilla; Pratolongo; and Dionisio O. de Villate for which latter I had done what lay in my power, but he refused, and then came in Cudlip, who had the greatest number after Villate. Next it was proposed to give a gratification to the gerentes and clerks, which though animadverted upon by Pratolongo, was conceded. Finally, four directors who went out by rotation were re-elected, viz.: Menchaca, Aurelio Denegri; Bartolo Figari; and Nicolas Hurtado. It was 4 O'clock when we broke up. I called upon the family of Anibal de la Torre, and upon that of Rafael Velarde, none of whom was at home; next, upon Doña Baltazara, called Balta, Calderon, widow of Don Vicente Rocafuerte, an Ecuatorian, once President of the Republic of Ecuador, and one of the few public men in these Republics, who left behind him an unsullied reputation. The widow of her brother Francisco Calderon having of late married Charles Cudlip; she had come here merely for the purpose of looking after the interests of her brother's children. She was an elderly, not to say old lady, but very agreeable, and had taken up her quarters in the miserable altill[os] of the house which was at present Oyague's, and the ground floor of which was occupied by Felix Dibos and family. After having been some time with Doña [436] [_] I looked in below, and spent nearly an hour very pleasantly first with Doña Ernestina alone, and afterwards with her, her husband, and father Julius Pflucker.

Ricardo read to me from 7.30 to 9 the biography of Von Bismarck; then Rafael Velarde and family came, and at a later hour Juan Bazo, which latter, when the others were gone gave us an account of his unsuccessful attempt of the $5^{\text {th }}$ June in Callao. He said it failed, because it was not seconded in Lima as it should have been, and as it had been previously arranged. Here in Lima, had died at the age of 101 Doña Isabel Loyola de Caravedo, mother of General Baltazár Caravedo: her husband was shot by the spaniards in the beginning of the War of the Independence.

Monday, $16^{\text {th }}$ of July. On the $30^{\text {th }}$ June I spoke of the verbal agreement made between José Canevaro and others, and myself, by which I was released from my obligation "para hacer el servicio" of S/30,00o Bonds, placed into the hands of the Banco del Perú. Since then we had arranged that an escritura should be 
drawn out; the minuta dictated by me was signed; I paid the S/80oo but this day I learned from the notary public Manuel Iparraguirre, that Manuel Candamo who had signed the minuta per procuration of Carlos G. Candamo had no such power actually drawn out by a notary in Lima. I went to José Canevaro, who to obviate the difficulty proposed, that Manuel Candamo should sign in his own name, which I agreed to, with the condition that José Canevaro é hijos made themselves responsible if Manuel Candamo should not fulfil the conditions of the escritura. The third who signed was Dionisio Derteano.

Tuesday, $17^{\text {th }}$ of July. Geraldo related at breakfast that yesterday the Banco La Providencia had presented to the Compañia de Obras Publicas S/10,00o of their own notes, and asked that they should be exchanged for an equal quantity of notes of the four associated banks, which the [437] Company had refused to do. In the course of the forenoon Henry Meiggs with his lawyer Garcia Calderon had had a long conference with the President Prado, and in the meanwhile the office of the company was besieged by people of all classes who presented their notes, which the Company, having received assistance from one of the banks - which, I did not learn - was able to do. In the forenoon Enriqueta and I put away the innumerable knic-knacs of which my wife was so fond, and which filled her salita and sala.

Wednesday, $18^{\text {th }}$ of July. Hitherto we had no rain this year. Thermometer at noon $72^{\circ}$ F. The Eten, one of the Steamers belonging to the Pacific Steam Navigation Company was wrecked a few hours after having left the port of Valparaiso on Saturday last the $14^{\text {th }}$ inst. The details had not yet reached us. The run upon the Compañia de Fomento continued.

At 4 O'clock the shareholders in the Gas Company assembled in the usual locality, that is to say the saloon of Frederic Marriott. José Vicente Oyague, who presided, made known that after many conferences with the Minister Buendia, the Directory had obtained the promise, which was to be confirmed by a decree, that from October onwards, earlier if possible, the Government would let the Company have of their own drafts on Europe $£_{3500}$ monthly at 27 pence per Sol, and that owing to this assistance the Company would for the present suspend the effects of the previous advertizement. The rough drafts of the petition to be presented to the Government, in reply to which the decree was to be given, and the terms of the advertizement in the papers, were read, and somewhat modified, especially by the lawyer Loayza who was a valuable acquisition. Next, an examiner of accounts for the end of the year, or auditor as he is called, was named, and the choice fell upon Guillermo Garland. Lastly, a protest drawn out by Isaacson, against the resolution taken on the $6^{\text {th }}$ April was read. Loayza [_] [438] [...] commission should be named to examine the protest, and to inform about it. As members for this commission, Oyague chose 
Loayza, Dionisio Villate, and myself, but as Marriott observed that I had been one of the signers of the motion against which Isaacson protested, Prevost was named in my place. In the evening letters from Europe were delivered. Juan ordered me to sell all his shares in the Banks, and if I could not purchase gas and water shares, to remit the proceeds. The Lima papers contained an advertizement, signed Henry Meiggs, in which he said that for the present the Compañia de fomente suspended the exchange of their notes for notes of the associated banks until the Government paid what it owed him, and that in the meanwhile he had deposited in the Consulado, besides the 1,500,00o Soles, noml., Government Bonds, 500,000 Soles more of the same Bonds, so that, as he said, the 900,000 Soles, notes in circulation, were sufficiently guaranteed.

Telegrams from Europe stated that the Turks had retaken Bayesid in Asia Minor, that the siege of Kars by the Russians continued; that the Turks had made themselves masters of Cetinje, capital of Montenegro; that the fortress of Rustchuk was nearly destroyed by the furious bombardment of the Russians, and that the Turks had somewhat damaged the fortress of Giurjevo, situated in Walachia, opposite Rustchuk.

Thursday, $19^{\text {th }}$ of July. Once more many people presented themselves with their notes of the Compañia de Fomento, but instead of receiving in exchange notes of the associated banks, a loose sheet was handed them on which Meiggs' advertizement in the daily papers was reprinted, to the effect that he could not pay, until the Government paid him. The Banco Garantizador had to suffer a similar run; seventy thousand Soles, the papers said, were quickly and readily exchanged. The crew of the "Huascar", or, as they were called "los vencedores del 29 de Mayo", except Pierola, who had gone from Iquique to Valparaiso, arrived in Callao on board the [439] steamer "Lima", which steamer was the first which had entered the Dock, and landed her passengers there. The "Vencedores" were received by many of their friends with fine speeches, and crowned with garlands, took the English train for Lima, where they arrived at about three. Here they met with a similar reception, and in a kind of procession marched from the San Juan de Dios Railway Station, to the Plaza Mayor, thence through Arzobispo, San José, and passing our house to the Plaza de Bolivar, and finally to the dwelling of Mrs. Pierola. Here and there flowers were thrown upon them from the balconies and the only persons of note who walked at the head arm in arm with Astete, and Carrazco, the chief of the rebellion, were Evaristo Gomez Sanchez, and Pedro José Calderon. There was a band of music, a sufficient number of the lower classes of the population of Lima, ridiculous placards were carried on poles, and rockets were let off. Also a hymn was sung at the house of a canon, Medina, speeches were held in Pierola's house, and at 5 O'clock all went home. The "Eten", which was wrecked upon the rocks near a 
place called Vilos, was a screw steamer of 1853 tons: twenty four of the crew, the first and second mate, one of the engineers, and forty-three of the passengers, were known to have saved themselves.

Friday, $20^{\text {th }}$ of July 1877 . Before breakfast I went out to the pantheon, and was glad to see that they were making fair progress in the construction of the Chapel. They were now occupied with the altar. The side window frames of artificial stone, were also there, but had not yet been placed.

Thermometer at noon $72^{\circ} \mathrm{F}$. In the course of the day a printed paper was pasted by the clerks of the Compañia de Fomento, on our street door. It was the copy of a presentation signed by a number of artizans and labourers, and directed to the Supreme Government, requesting the same to authorize the notes of the said company.

In the meeting of the members del "Alto Comercio" held in the Exchange Rooms, and presided by José V. Oyague [440] [...] on London was fixed at 22 1/2 pence, and in Paris [_]. Becker brought me a letter from my nephew Johannes Limpricht, dated Hamburg $13^{\text {th }}$ June, in which he wrote that his partnership with Becker left him at present hardly any gain, if not an actual loss, that therefore it had to be dissolved and he would accordingly be here within a month or so. He also begged me to allow him a room in our house, to which Enriqueta immediately agreed.

Saturday, $27^{\text {st }}$ of July. A very disagreeable day. A thick fog, or drizzling rain fell the entire morning. At noon Thermometer $70^{\circ} \mathrm{F}$. The Compañia de Fomento was [no] more troubled, for people knew that they could not get anything. The run upon the Banco Garantizador diminished considerably.

Sunday, $22^{\text {nd }}$ of July. The sky was cloudy, but no rain fell. Thermometer at noon $70^{\circ} \mathrm{F}$. The papers said that the Eten struck on a rock at about 5.30 a.m. on Sunday last, and that of the crew twenty-three, of the passengers nine were saved. Some had scrambled up to the rocks along the shore, whence, as no assistance could be rendered them, they after some days threw themselves into the sea and thus put an end to their misery.

At about 2.30 p.m. I went out to pay some indispensable visits. The first to Enrique Cox, who had returned from Europe by last steamer, and who received me, together with his sister, the widow of a German, called Minx. Cox had been absent six months, one month going, one month coming, four months in Europe, where he had visited Hamburg, Berlin, Paris, and London, all which four towns, he said, were continually increasing in size and magnificence. From him I went to the house of Mr. Macandrew, who was not in, but his wife, and his mother-in-law were, with whom some visitors. The mother-in-law was Doña Manuela Cosio, widow of Henry Read, who was first married to her elder sister [Antuca]; she had been residing for many years in [441] London, 
where Mariquita and I paid her a visit [_] in a house in Torrington Square. She recognized me as soon as I entered. Thence I went to Doña Dolores Puente with whom I remained a long time. Dr. Muñoz and wife were not at home, and at Dr. Ribeyro's his wife, Doña Eulalia referred to the $S / 1200$ which my wife had lent her in 1874, to which I replied that I would send her the pagaré for this amount duly cancelled. I then walked to the Alameda de los Déscalzos and after dinner from 7.30 to 9 p.m. Ricardo read to me Bismarck's biography.

Monday, $23^{\text {rd }}$ of July 1877 . Little Corina's birthday. During the night Enriqueta had arranged upon a table in the bedroom the various presents for her, amongst which a large doll, which for some time she had been expecting with the greatest anxiety. I gave her twenty silver Soles. The little thing was this day, as happy as she could possibly be. The same I could not say of myself. At dinner the whole family of the Garlands was assembled, with the exception of Alejandro and Juan, which latter, one or two days ago, had gone with a friend of his to an hacienda in the neighbourhood of Chancay. Francisco Velarde, with Zoila and Sofia, Rafael's children, Eliza and Rosaura, the niece of Gregorio Benavides's wife, were the other guests. The young folks were in extremely good spirits, and talked, and laughed. I took no share in their mirth, and rose before coffee was placed on the table to listen to Bryson's reading. When he was gone I walked the corredor till I observed that several visitors who had been with Enriqueta had left. I then entered the salita and still found with her, Francisco, Zoila, and Sofia Velarde, Rosaura, and her aunt Mrs. Gregorio Benavides, who remained till eleven.

The escritura, relative to the Eten affair, was drawn out, signed, and the testimonio handed to me.

Lima, $24^{\text {th }}$ of July 1877. Last Sunday was the Saints day of Doña Magdalena, the President's wife, to whom we merely sent our cards. The papers said [that] there had been $[442][\ldots]$ of visitors the whole day long in the palace, that a dinner had been given to her intimate friends, that they had danced till an early hour on Monday morning, that fireworks and an innumerable quantity of rockets had been let off, and that one of the rockets at about midnight had set fire to the arch which stands on the bridge, but that it had been quickly extinguished. The papers also published the advertizement of the Gas Company, which, drawn out in the terms agreed upon in the last general meeting, stated that for the present the price remained unaltered. The same papers contained two Vistas-fiscales on the subject of the accounts between the government and the firm of Dreyfus; the one, that of Chacaltana, said that in conformity with the original contract of $17^{\text {th }}$ August 1869 , and that of $15^{\text {th }}$ April 1874, the government was entitled to its share in the excess obtained by Dreyfus over and above $£_{12.10}$ / the English ton, this being the figure fixed 
upon for the sale of the first rate Chincha guano, but that it had no right to the excess on the price paid Dreyfus, for inferior guano taken by him at the rate fixed by the Peruvian Fiscal Agent in Europe. Aranivar on the other hand asserted and endeavoured to prove in a very long document, that Dreyfus had to make good to the Government every advantage he had derived since the commencement of the first contract for the purchase of two million tons, from the sale of any quantity disposed of not only at a rate superior to the £12.10/ but to every other price fixed by the Fiscal Agent for the inferior guano. Should the Supreme Court coincide with Aranivar, then instead of Government owing to Dreyfus, the Government would be Dreyfus' creditor for a very large sum. The Comercio said that the Government had asked the opinion of the Fiscal Teodoro de la Rosa, and that it would then determine what was to be done; thus it would seem as if the Government intended to decide the question without bringing it before the Supreme Court. At 2 O'clock I went to the Banco [443] La Providencia, where some of the Shareholders met. [...] or opinions, given by Pratolongo and Pastor Sevilla, and that of Cudlip, widely differing from the former, were read. Then Aurelio Garcia, who presided, asked the opinion of the shareholders as to whether the projects of the government should be discussed, or not; a very small minority, I of the number, voted that they should. Thus Pratolongo and Sevilla's informe had the preference, and came first under discussion. The first article said: El Gobierno "no emitirá billetes." I said we had no right to give our opinion in such a positive manner, but had the majority against me. I also made use of the following few words: „Regalar al Gobierno los intereses, la unica entrada que tienen los Bancos, y al mismo tiempo quedarnos con la responsabilidad del $50 \%$, es un contra sentido", but not a single one chimed in with me. I left at 3.30 before any resolution had been taken. Through Alejandro I bought $£ 80090 \mathrm{~d} /$ st., for Rosa, and $£ 500$ for Juan, John Mathison on John Hegan \& Co. of London at 22 1/2 pence per Sol. At the same rate, and perhaps a trifle dearer the gerentes of the Banco Hipotecario had bought £12,00o which they handed to Enrique Barreda, and by means of this payment Garland assured me that they settled his claim much more advantageously than they had expected they would.

Garland and Enriqueta went out in the evening, and Ricardo read to me from the Leipzic Gazette, that in the first days of May the Emperor of Germany had paid a visit to Strasburg where he had met with a rather cool reception. In the open country round the town the people seemed to be more friendly inclined to him and in Haggenau, a frontier town with an entirely German population, he had been received with enthusiasm.

Wednesday, $25^{\text {th }}$ of July 1877 . Before breakfast I took a walk as far as the Exposition, thence to the left, to Santa Sofia, to the Hospital del 2 de Mayo, and 
back by Cocharcas. At 1.30 I was in the Banco del Perú, but it was nearly 2.30 before a sufficient number of shareholders [...] sembled [444] [...] proceeding to business. Emilio Althaus presided. The acta of the last meeting - at which I had not been present - was read, and approved. Then Althaus communicated to us the contents of the two projects which the President had proposed to the Directors and Gerentes of the four banks at their last conference in the Palace. The essence of both was that the Government would no more pay the $6 \%$ interest on the eighteen million Soles, it owed to the banks. To rid itself of this heavy annual payment, it proposed all kinds of things, one of which was to issue paper money for the same amount as that which in authorized bank notes was at present in circulation, say about fifteen million Soles, by which means the banks would get rid of their responsibility for the capital not yet paid up, say 50\% Perú, Lima, and La Providencia; $65 \%$ Nacional; but on the other hand, the door once being opened to the issue of government paper-money, nobody could foresee where it would stop, and therefore after a long discussion the project was unanimously rejected. No other resolution was taken and at 5 O'clock Althaus adjourned the session till the next day at 2 O'clock. The principal speakers were Cudlip and Cipriani, both of whom expressed themselves extremely well. So did Focion Mariategui who was opposed to the cession of the interest, at all events in its totality. What Pastor Sevilla said was not much to my liking. José Maria Peña said a few words against the issue of Government paper money. Luis Benjamin Cisneros delivered a long, pompous speech which led to nothing. All present of a certain age, such as Oyague, Lembcke, Bryce, myself, did not open our mouths. Althaus made a very good President; he spoke distinctly and slowly, so that every word he said could be understood. When I came home I found Alejandro who told me that Manl. Cisneros had given his vote in his case against the Banco Garantizador, and that there was still "discordia". Now Gervacio Alvarez was called in, and Garland and Enriqueta [445] went to see him. I was pretty sure that his vote [_] be in Alejandro's favor.

Thursday, $26^{\text {th }}$ of July 1877 . Before breakfast I went out to the pantheon. The artificial stone window frames were placed and the beginning was now to be made with the roof. As I had to write my letters to Juan and Schutte I did not go to the Banco del Perú, and gave my power to Foción Mariategui. At 8 p.m. I went to the Banco de Lima where thirteen shareholders and eight or nine Directors were present to discuss the Government's projects, as had been done in the Banco del Perú. Heudebert presided. J. M. Cárdenas delivered a thundering speech, knocked on the table with his fist, and worked himself up into an actual passion: he denounced the Delegates - in which I think he was right - spoke against the various Directories, disapproved of the new project 
which in the forenoon's session had been approved in the Banco del Perú, and of which Mariategui gave the outlines. The project of the Directory of the Banco de Lima differed but little from that of the Banco del Perú, but of course neither the one nor the other was to Cardenas' liking, and finally, he defended the issue of paper money, by the Government, in which he was seconded by José Basagoytia under certain conditions. Besides Cardenas, the principal speakers were: Aurelio Denegri, Foción Mariategui, Lembcke and J. P. Escobar who attended as representative of the shares in the Banco de Lima held by that of Perú. Luis B. Cisneros kept silent. Amancio Castillo, Dr. Pró, and I said a few words. The projects of the Government were rejected by all, except Cardenas and Basagoytia; and the two projects of "Perú", and "Lima" were submitted to a commission to inform on them. Lembcke alone was against the naming of the commission, for which after a slight discussion the following were chosen: Jose V. Oyague, who was not present; Casimiro Vera Tudela, son of the well known Minister of the same name, who died some [_] [446] [_] at an advanced age, and myself. It was 10.45 when I came home.

Friday, $27^{\text {th }}$ of July 1877 . Early in the morning I walked as far as the Descalzos. Ricardo read to me Bismarck's biography. In the course of the forenoon I called upon Carlos Elizalde, J. P. Escobar, Lembcke and José Vicente Oyague, and conversed with all four on the subject of the two projects for I wanted to learn their opinions. It was a fine day: at 4 the sun was still out and thermometer $70^{\circ}$ F. In the evening fireworks were let off in the Plaza Mayor; in the Club de la Union the young folks danced till five in the morning of

Saturday, $28^{\text {th }}$ of July. Anniversary of the Independence. About this time in the Exhibition Palace, a, as it was generally said, very fair collection of pictures was exhibited to the public; also a considerably quantity of Indian antiquities, other curiosities and a collection of plants and flowers. The greater part of the pictures were owned by private individuals, amongst whom Dr. Manuel Ortiz Zevallos, and Don José Davila Condemarin, resident in Lima. Of these pictures, some were by European masters, the remainder by modern Peruvian artists.

The last account of the shipwreck of the "Eten" said that she struck on Sunday the $15^{\text {th }}$ inst. at 1 a.m. and that of one hundred and fifty human beings on board, only thirty eight were saved.

The Peruvian fleet, which some time back left Callao in pursuit of the then rebellious "Huascar", had returned, viz.: the "Independencia", "Limeña", and "Atahualpa" - the last named towed by the "Limeña". The "Huascar" had remained in Mollendo, the "Pilcomayo" in Iquique. By the two train I went to Chorrillos, mainly for the purpose of calling upon José Maria Costas who was very ill, and low-spirited. The cancer in the tongue, which had been operated upon more than a year ago, had again shown itself, now in the shape of a big 
tumour on one side of his face. He himself [447] knew that there was no help for him. I also paid a visit [_] family of Lembcke, whose wife, Doña Isabel, was of course very grateful for the service I had rendered them in placing my rancho at their disposal rentfree. Next, to Doña Trinidad, the wife of General Pedro Cisneros, always very kind; thirdly, to Mr. Ruden, with whom I had a long chat, and finally to Mrs. Higginson, and her daughter Eliza. I was back for dinner.

Sunday, $29^{\text {th }}$ of July 1877 . When taking a walk in the morning, accompanied by Ricardo, I came to the market place constructed several years back by the Constructora in the former "Paseo de Aguas". The Municipality had now let this building to the contractor for the Lima tramways, or, as it is called here the ferro-carril urbano. The first rails had been laid. At the usual hour I called upon the family of Dr. Alvarez; only the Doctor's wife, Doña Mariquita, a good natured, but very ignorant old lady, was at home. At Dr. Lührsen's, the German Chargé, who occupied the first story of José Vicente Oyague's house, I heard some ladies talk in the balcony, but as none made her appearance I merely left my card; with Doña Manuela Portillo I remained a long time; at Rafael Velarde's and Doña Dolores Puente's, nobody was in. I therefore was back by 4 O'clock when I found with Enriqueta her friend Isabel Coloma, with one of her daughters; Francisca Cardenas de Benavides; with her niece Rosaura; and Asuncion Santillana, with her little girl Maria, my wife's god-daughter. There were moreover two little girls, Maria, and Isabel, daughters of Isabel Aliaga, widow of Lacroix. All were anxiously expecting la procesión civica which passed by at 5.30 on its way to Bolivar's statue. A band of music opened the procession; then came various knots of civilians dressed in black, each preceded by a standard-bearer; los vencedores, I believe both of Junin and Ayacucho, and the 2 de Mayo; representatives of the North American Colony; do. of the Cubanos; the firemen, Peruvians, English, French and Italian; the pupils of San Carlos; the boys of the different Municipal schools, and many more. I should suppose nearly one thousand in number [448] [...] military uniforms were wanting, they made no great show. At about three, the President had distributed prizes in the Municipal schools; thence they had walked to the monument 2 de Mayo, at the Callao Gate, and, as already said, to the Inquisition Square.

Our dinner table was crowded to excess, for of Garland's family only Guillermo and Alejandro were wanting; their places were taken by Doña Asuncion, Doña Isabel, and all the little girls. After dinner Ricardo read to me Bismarck's biography.

Monday, $30^{\text {th }}$ of July 1877. In Amancaes valley a review of the troops was held, also a match came off between amateur riflemen of the various nationalities. The banks were still closed, so were some shops; others were open. To allow 
Bryson time to make some progress in the copying of the remodelled dairy, I walked as far as the Chorrillos gate, thence to Santa Sofia, to the hospital 2 de Mayo, and once there I thought I might as well pay a visit to Doña Josefa Bazo, in the chacra of her brother Antonio. With her, was the widow of General Torrico. At dinner we had Enrique Gibson of Arequipa, rather deaf, son of James Gibson, who for many years was Gibbs' agent in Islay. With this Enrique, Alejandro did an extensive business on joint account, in bills and hard coin; in six months they had gained nearly ten thousand Soles jointly. Alejandro was also with us; besides, Federico Palacios, a very agreeable man, at present chacarero, in former years naval officer, together with his little girl Maria. It was ten when they left, and I went to bed.

Tuesday, $37^{\text {st }}$ of July. In yesterday's shooting match the English were the victors.

At 2 O'clock Casimiro Vera Tudela, and I were by appointment in the office of José Vicente Oyague, but as the projects of the Banco del Perú, and of the Banco de Lima had not been sent us by Heudebert, as he ought to have done, [449] we could not come to any decision, and agreed to meet ag[ain] on Thursday at the same hour, for, the next day Oyague was invited by Pedro Telmo Larrañaga to a lunch which he gave the President in Ancon. He however read to us the rough draft of a project, which as far as I recollected was for the greater part in accordance with that of the Banco del Perú. The principal points were: firstly, if better could not be done, the banks would reduce the interest on the eighteen million Soles due to them by the Government, to $4 \%$ annually; secondly, every month from August onwards the banks should destroy S/100,00o of their billetes; thirdly, the banks returned to the Government, the consignment of guano to Mauritius etc., on condition that the Government paid them annually in hard coin one million Soles. If the Government did not do this within four months, the consignment would revert to the banks, and the government prolong the term allowed them for the sale of the two hundred thousand tons of guano. Fourthly, by the $1^{\text {st }}$ January 1881 the banks should resume cash payment. Fifthly, these articles only remained in force as long as the government did not authorize any further issue of bank notes over and above that at present authorized. Garland, Enriqueta, and the little ones went to dine at the Chacra of Villacampa, father-in-law of Federico Palacios.

Wednesday, ${ }^{\text {st }}$ of August 1877. I went to the study of Dr. Fernando Palacios and asked him, whether he felt inclined to take charge of my claim against Juan Aliaga y Puente for S/7200 due since the $31^{\text {st }}$ July 1873 , and interest on the same at $9 \%$ p.a. He replied that he had no objections, whereupon I proposed to him as remuneration $20 \%$ of what might be recovered, say $10 \%$ in ready money, and $10 \%$ to be credited him upon his pagaré, with which he was 
satisfied. The first escrito was dictated, signed and taken by me to the office of Manuel Jesus Escobar. The "Nacional" informed its readers that just before the last civic holidays, the Banco Nacional had advanced to the Government $\mathrm{S} / 700,000$ (where they got the notes from was a secret to me) on condition that the Government would give them in return no doubt at a favourable [_] [450] on London to be drawn in October and November next. Moreover, the Bank had given to the Government a considerable amount of Bonos Meiggs at par, for which they had received in exchange Deuda Internas at $75 \%$. This, if true, was a most nefarious transaction.

Thursday, $2^{\text {nd }}$ of August. The Judge Quiroga sentenced that Juan Aliaga y Puente should pay the amount claimed by me, say S/7200 and S/2592 interest, within the third day, under pain of embargo. This was notified to me, but when the notary went to Aliaga's house his wife replied that her husband was absent in Chancay, for the benefit of his health, and that she could not say when he would be back.

At 2 O'clock Tudela and I met again at Oyague's, when we approved of the informe drawn out by him. In the evening Rafael Velarde and family were with us.

Friday, $3^{\text {rd }}$ of August. The informe yesterday spoken of was brought to me for my signature, when I added that in my opinion it would be advisable to postpone the resumption of cash-payments till the $1^{\text {st }}$ January 1882 instead of 1881. Last night's Nacional contained the details of the Eten's shipwreck given by a survivor. He said that the "Eten" left Valparaiso on the $14^{\text {th }}$ at 7 p.m. that from the very beginning they had had bad weather, that a violent thunderstorm came on, that the needle, owing to the electricity in the atmosphere, jumped about, that they lost their course, and the captain did not know where they were. The steamer struck on Sunday morning at 5.30, when it was still quite dark. The vessel immediately filled, and he only owed his life to his great expertness in swimming, of about 250 human beings on board, 35 reached the shore, and arrived in Valparaiso on the $21^{\text {st. }}$. The "Amethyst" and the "Chacabuco" attempted to render assistance to a few who had saved themselves upon the rocks, but such was the fierceness of the breakers that they found it impossible to approach with their boats, and those on the rocks died, perhaps of cold, perhaps of hunger, perhaps washed away by [the sea]. We learned by telegraphic dispatches from Europe that the [451] Russians had raised the siege of Kars. On the [?] St. John in New Brunswick was almost totally destroyed by fire; eighteen thousand human beings were said to have become houseless by this disaster; the loss was estimated at from seven to eight million American Dollars, of which about the half was insured by English companies. I presented 
an escrito asking for an order to the Juez de Paz of Chancay there to notify the sentence given by Quiroga to Juan Aliaga y Puente. Just before dinner I went to see Francisco Javier Correa, who was well acquainted in Chancay, and who told me that he had just returned from that place, but that he doubted that Aliaga was there; he promised to write and to let me know.

Saturday, $4^{\text {th }}$ of August 1877. Last night's Nacional said that the Government had sent for the Directors of the four associated Banks, and proposed to them to withdraw from circulation Meiggs lately issued 1,030,000 Soles, and that the Government would then authorize them to issue $S / 1,000,000$ of their own. As security, the Treasury Bonds for two million Soles Noml., deposited by Meiggs in the Consulado, would be placed into their hands. If they would not accept this proposal, the Government would be under the necessity of authorizing Meiggs' notes. The Directors replied that they would not increase their circulation. The details of the contract between the Banco Nacional and the Government were very different from those given on the $1^{\text {st }}$. Of the internal debt which the bank held hitherto as security, the government sold to them two million Soles at $75 \%$. In payment of these $S / 1,500,000$ the bank delivered to the Government treasuring bonds 1,039,800 Noml., interest upon them since $31^{\text {st }}$ May $S / 114,378$, and paid in authorized notes 345,822 Soles, total S/1,500,000. Moreover, the bank advanced to the Government at $1 \%$ monthly interest 355,000 Soles, against which the Government delivered certificates for Bills to be drawn in October and November, each month £22,00o (Exchange as near as [_]ble [_] d). [452] [_] Bank was to sell these bills at the best rate obtainable, and hand over to the Government the gain on exchange. Before breakfast I walked as far as the pantheon, where only one man was at work at the chapel, and I found it more or less as it had been a week ago. At 2 I went to the Exposition Palace to have a look at the various things exhibited there; though my weak sight prevented my distinguishing everything, I could not but be pleased with the whole arrangement. In the first hall when entering from the park, the portraits of several generals and civilians, the greater part of whom had been Presidents of Perú, were hung against the walls. The walls of the other large saloons were for the greater part covered in the same manner with oil paintings. Then there were many pieces of that description of antique furniture, inlaid with mother of pearl, which at present was much valued in Europe. Further, in glass cases, a considerable number of huacas. Also many plants and flowers, which, similar to those to be found in the park and the botanic garden contributed to give a cheerful appearance to the entire exhibition. I had still time to promenade in the park, went to the office of the notary Escobar, where I learned that the judge Quiroga had ordered that a judicial dispatch should be sent to the Juez 
de Derecho of Chancay, and was home in time for dinner. On level ground I could take as much exercise as I liked, without my knee paining, but stair cases continued to trouble me.

Sunday, $5^{\text {th }}$ of August. Thermometer at noon $68^{\circ} \mathrm{F}$. Last night's "Nacional" contained a well founded article written by lawyer Alejandro Arenas, in answer to some questions put to him by Enrique Barreda, which was a refutation of the pamphlet written by Dr. Forrero, and lately published by the Gerentes of the Banco Hipotecario, in which he defended the Bank's refusal to pay the interest on the Cedulas transferred to Paris at the fixed exchange at 4 francs $65 \mathrm{c}$, as well as the redeemed Cedulas at the same exchange. Arenas had the better of the argumentation. The same paper contained an article [453] of M. J. Espinosa, employed by the Editors of El Comercio, wr[_] against the Cronista of the "Patria", Benito Neto, in which this latter was treated as the greatest villain, and coward under the sun, the firm of Dreyfus called La Canalla Dorada, and Dionisio D. (Derteano) spoken of "como petardista en años pasados, ahora millonario". With Bryson I indexed the diary of 1863, viz.: the period when I, my wife, and Enriqueta were in Vichy. At somewhat past two I went out, and called firstly upon the Juez de Primera Instancia Dr. Antonio Puente Arnao, the same who sentenced in my favor in my suit against Leyva; secondly, upon Dr. Muñoz and wife; and thirdly, upon Doña Dolores Puente. At all three places I was much better pleased than is generally the case at these ceremonial visits. With Doña Dolores I found a gentleman from Cali, called Velazco, who narrated to us how on the $24^{\text {th }}$ December of last year, he, belonging to the conservative party, had been illtreated, his house and stores sacked and plundered by the democrats now in the ascendant in Nueva Granada. How he had fled to Buenaventura, without a change of clothes how a handkerchief, boots, and articles of dress had been presented to him by his friends, how he had fled to Quito, and finally, how he had found his way to Lima. At Theodore Harmsen's, of Arequipa, who was here in Lima on a visit with his wife; and at Doña Josefa's, widow of Dr. Prada, I found no one at home.

In the evening Ricardo read to me Bismark's biography and at a later hour we had a visit from Carlos Lopez of Payta, brother-in-law of J. P. Escobar.

Monday, $6^{\text {th }}$ of August 1877. Early in the morning I received a note from Juan Aliaga y Puente, dated $5^{\text {th }}$, in which he said, "que existia una condición moral de que yo (Witt) no hiciese efectivo la deuda, hasta que él estuviese en posesion de sus bienes mayorazgales." This was totally false, for I never heard, nor dreamt of such a condition, and I saw no reason why I should put a stop to my judicial proceedings against him. By the advice of Dr. Palacios I went to the [_] and [_] [454] [_] not to forward the despacho to Chancay, and notify Aliaga here in Lima. The notorious highwayman, robber, and assassin Chacaliasa 
was arrested in Callao, brought up to Lima, and taken to the penitentiary. The committee of El Alto Comercio presided by José Vicente Oyague, which met this day in the Exchange Rooms, fixed the exchange on London at 23d, and on Paris 2 fcs 40 cs for notes of the four associated banks.

Tuesday, $7^{\text {th }}$ of August. Before breakfast I went to the pantheon where I found the work of the chapel at a stand still, which Mr. Mould, the architect, told me was owing to the difficulty which Meiggs found in passing his notes. At the notary's, Manuel J. Escobar, Mauricio Saravia - who for a long time past had been his clerk, and who did at present all the active work - told me that this forenoon he had notified Juan Aliaga y Puente by esquela, that is to say he left with him a note containing the copy of the judge's sentence.

Wednesday, $8^{\text {th }}$ of August. Thermometer at noon $68^{\circ} \mathrm{F}$. I went to the Compañia de Fomento, and not finding Minor Meiggs the gerente, I spoke to Umlauff, the book-keeper who assured me that the work of the Chapel was improperly interrupted, and should again be taken up. Mr. Henry Meiggs was lying ill; his or rather the Compañia de Fomento's large notes were passed with the greatest difficulty; only the smallest of ten or twenty cents were readily received. At dinner, we had besides the whole family Garland, except Alejandro and Antonio, Teodoro, the eldest son of the late William Harmsen of Arequipa, and his sister-in-law Juana Moron, both of Arequipa, here on a visit; together with Dr. Middendorf and Zoila Velarde. I had to rise at 8, in order to be present at a meeting of the shareholders of the Banco de Lima; Gustavo Heudebert was in the chair. After the last acta had been approved, the informe signed by Oyague, Tudela, and myself, was read and discussed. The first clause, that Government paper should not be received, was unanimously approved. Next came the paragraph [455] which said that the Banks should destroy monthly S/100,00o in notes, which was also approved. The third, that the Banks should resume cash payments, by the $1^{\text {st }}$ January 1881 gave rise to violent debates. Aurelio Denegri was decidedly opposed to our binding ourselves in this manner, to the resumption of cash payments either on the $1^{\text {st }}$ January 81 or, as I had said, on the $1^{\text {st }}$ January 1882 . I moved the clause "a condicion que el Gobierno cumpla con las obligaciones que toma sobre si en el presente arreglo." Heudebert put the question whether the cash payment should be resumed without the clause proposed by me; it was rejected though amongst others Lembcke and Oyague voted in favor of it. Next, Heudebert put the question to resume cash payments on the $\mathrm{s}^{\mathrm{st}}$ January 1881 , on condition that the Government fulfilled what it had promised, which was unanimously approved, Denegri excepted. Then came that article, which recommended our returning to the Government the guano contract for Mauritius and other islands, on condition that we received annually one million of Soles in hard cash. In this 
discussion I took not the slightest part. Focion Mariategui explained clearly that this our cession to the Government was to our advantage; he was opposed by Savaleta, Aurelio Denegri, Manuel Cucalon, and various others. Lembcke spoke on Mariategui's side, and finally the motion was lost, Oyague, Antonio, Cucalon, the father, Lembcke, Mariategui, I and a few more, having voted in the minority. In this manner the Banco de Lima did not agree with the project of the Banco del Perú, and I much feared that it would be extremely difficult to come to any understanding with the government. It was now getting late, the attendance was much thinned, when the last article was approved, viz.: that the internal debt, which we held as security from the Government, should be returned to the Government, if it could be done without any loss to the Bank. [456] [_] Barrios accompanied me to the street door of our house, and it struck midnight when I began to undress.

Thursday, $9^{\text {th }}$ of August 1877. A horrible crime had been committed. A younger brother of José Pablo Escobar, Hortencio, married in Valparaiso, arrived in Callao, accompanied by a brother of José Pablo's wife, Emilia Lopez, called Enrique, a young man, eighteen years of age, and student in the naval college; they took the train for Lima. On their arrival they went straight to a room in the Banco del Perú, which was occupied by Francisco, one of Enrique's brothers. Here Enrique and Hortencio had some high words; their origin nobody knew. Enrique drew a revolver, shot Hortencio through the arm, and before Francisco could interfere he fired again; now the ball lodged in Hortencio's head, who fell; Enrique fled. These were the details given at the first moment; on enquiring I was told that the wounded man, if not already dead, was not likely to survive.

Friday, $10^{\text {th }}$ of August 1877. Though the exchange had been fixed on London at 23 pence, no first rate bills could be had at this rate. On Juan's and my account I took from Guillermo Scheel $£_{500}$ at 23d; through Alejandro, another for $£_{300}$ Gibbs on Gibbs, on Juan's sole account, at 22 1/2 pence.

Saturday, $11^{\text {th }}$ of August. This morning at the usual hour the funeral of Hortencio Escobar took place in the Church of San Francisco. I did not attend. Garland and some of his sons did, and told me on their return that but few persons had been present.

In the course of the day the rumour become prevalent that a telegraphic dispatch had been received; I knew not by whom that Henry Meiggs' drafts on John Meiggs of London had been protested for non-payment.

I presented an escrito to Dr. Quiroga, Juez de $1^{\text {a }}$ Instancia who sentenced that an embargo should be put [457] on Juan Aliaga's y Puente's property. In the evening José [_] with his wife Juana Rosa, his son Enrique, and daughter Filomena came to see Enriqueta and Garland. He said that he was doing everything in his power to induce the Government to authorize the notes 
issued by Meiggs to the amount of six million Soles. I told him very clearly that I was much astonished that he could exert himself for such an object.

Sunday, $12^{\text {th }}$ of August 1877 . Bryson and I finished my letters to Gibbs and Juan and at half past two I went firstly to the North American Minister, Mr. Gibbs, with whom I remained a considerable while. I learned from him that beef, not live cattle, was at present exported from the United States to England, where it arrived in good condition, and sold well. On the deck of the steamer a large shed was built, passages running through it; a current of fresh air was kept up by means of fans, and round the sheds ice was placed. An ox or cow was cut up in four quarters, each quarter sewn up in domestics, and hung up in the shed. From him I went to Doña Manuela Mendoza, a good natured, but wonderfully limited old lady. At Doña Francisca Cardenas', wife of Gregorio Benavides, and Francisca Benavides wife of M. F. Paz-Soldan. I left my card, and finally stayed a considerable while with Dr. J. A. Ribeyro and his wife Doña Eulalia, with whom I found one of the Monteros who gave us a long and interesting account of the manner in which Dr. Alarco had cured his right leg, which had been completely smashed by a piece of rock falling upon it. Dr. Ribeyro told us that the two elder brothers Lopez had been arrested on the previous evening, because they were suspected to have taken quite as active a part in the murder of Escobar, as their younger brother Enrique, who had fled; further, that Hortencio had been called to Lima by a telegraphic dispatch purpoting to have been signed by his brother José Pablo, who affirmed that he had sent no such message.

Monday, $13^{\text {th }}$ of August. Before breakfast I walked to the pantheon, where I found but a few men working at my chapel. They had just placed an arch over the entrance consisting [_] [458] [_]n pieces of artificial stone, alternately gray and black. There seemed to be no doubt that John Meiggs of London had prot[_] the bills drawn on him by his brother Henry of Lima for non-payment. A great many people were the whole day long changing the large notes of $\mathrm{La}$ Compañia for small ones, which continued to be taken by every one; the larger ones could not be passed, even at a discount. Enriqueta had about one hundred Soles left of the rent paid her on the $1^{\text {st }}$ inst. by the Compañia de Fomento. The Nacional of this evening said that the Carguio del guano had been knocked down in public sale to Andres Alvarez Calderon, at 77 1/2 pence the English ton. Further that el bajo Comercio had got up a resolution signed by a considerable number of them, to the effect that after eight days they would not receive any notes whatever, and this because the firm of Gibbs, after Mr. Böhl had on the $6^{\text {th }}$ inst. affixed his name to the quotation of 23 pence on England, had refused drawing at this rate, and sold his bills for coined silver.

Telegraphic dispatches said that the Russians, as well as the Montenegrinos, had been beaten by the Turks, the former in Bulgaria. 
Tuesday, $14^{\text {th }}$ of August 1877. From about 11 O'clock the patio of our house gradually filled with people of all descriptions, anxious to exchange the large notes of the Compañía de Fomento for smaller ones of the same establishment, and as their wishes were not complied with, they became unruly, and even broke the panes of the glass doors. At 1 O'clock General Buendia, Minister for the Interior, accompanied by the prefect, Intendente, and a few officers, appeared; he alighted, harangued the multitude, begged them to behave quietly, and assured them that Meiggs' notes were as good as those of the other banks, that they would be authorized, and be stamped by the government. The Patio was then cleared out, and some policemen placed outside, who only allowed one or two persons to enter at a time. At a later hour two porters of the Supreme Court, came to [459] advise Enriqueta that she had gained the law suit carried [_] by her against the friars of San Francisco. Only on Saturday last Ignacio Tavara had given his favourable vista, and it was very strange that the vocales had come so quickly to a decision. For her had voted Ribeyro, Muñoz, Alvarez, Sanchez and Leon; against her, Cossio, and Manuel Cisneros. Page 263 of this volume I gave the details of the case at the time the Juez de $1^{\text {a }}$ Instancia had decreed that the locality in question should be brought to the hammer. The friars appealed to the Superior Court, where Dr. Anibal de la Torre voted for, Simon Paredes, Rospigliosi, and Figueredo against the sale. Now the Supreme Court had confirmed the sentence of $1^{\mathrm{a}}$ Instancia, and the locality was to be brought to the hammer.

In last nights papers appeared an article signed by Alfred Böhl, in which he tried to clear himself of the imputation cast upon him that he had sold his drafts, or rather those of William Gibbs \& Co. on London, at a higher exchange than that last quoted in the exchange rooms, he said that as some of the firms correspondents in the Interior drew their bills payable in silver coin, he had necessarily to procure such coin wherewith to pay their drafts, and this he could not obtain by any other means than by stipulating when selling the drafts on England that they should be paid in Silver Soles, but that he had always taken great care when making this condition to fix exactly the exchange last quoted with the deduction of the premium paid on hard silver.

Yesterday embarked for Europe Felix Dibos with his wife, Ernestina, and their eldest child Anita; the other children, they left with Mr. Julius Pflucker, Ernestina's father. Dr. Simon Paredes also went, in the capacity of Delegado Fiscal.

Wednesday, $15^{\text {th }}$ of August 1877. Bryson, feeling indisposed, left at twelve, when I, not knowing how to while away the time otherwise, started for a long walk. First, down the two streets of Junin and Lima, as far as where further progress is stopped by the Oroya railway establishment. There I [46o] [_] to the left, and following the prolongation of the Calle de Mantas, came into the open 
country. When I had reached the camal, or slaughtering house, I again turned to the left, and continuing the walk outside the town passed the monument del 2 de Mayo, crossed the Callao Railway, re-entered Lima, and through a part of the town, perfectly unknown to me, along a street lined with small houses on both sides, emerged in the open place before the penitentiary. Thence, through the so-called Boulevard of Meiggs, to Santa Sofia, to the hospital 2 de Mayo, and home through where once the Barbones Gate stood. The entire excursion took two hours. On my whole walk I found but few vestiges of the walls which formerly encircled Lima. All the gates, except that of Maravillas are levelled with the ground. Henry Meiggs bought the walls, and some ground on each side of the same. The walls he demolished, and outside he planted several rows of Estrapeas, which should have been continued all round that part of the town which lies on the left bank of the Rimac, but want of funds put a stop to the work.

When I had came home I dressed to pay two or three visits; firstly, to Transito Masias, whose Saints day it was, in honor of which, a ball was to be given in the evening. Next, I called on Rafael Velarde and family, then upon Asuncion Santillana, who always received me as a particular friend, and well might she do so, for a few days previously I had returned to her, duly cancelled, her pagaré for four hundred Soles which I had lent her, and which of course she had been unable to repay. Her answer goes affixed in appendix under $\mathrm{N}^{\circ} 23$. Finally, upon J. P. Escobar, whose wife was very unwell; he and I conversed on many topics. As it was not yet dinner time, though I had been on my legs for several hours, I still walked as far as the convent of the barefooted friars, and in the evening many a time up and down the corredor, for Enriqueta was in bed suffering from migraine, and Ricardo [461] who might have read to me had gone out. Rafael [Velarde] and family called, but as Enriqueta was not there to receive them they remained but a few minutes, long enough however for Don Rafael to tell me that his compadre, the President Prado, had at last fulfilled his promise and named him "Superintendente" of the Callao custom-house, a post expressly created for him, for after the last change during Pardos administration, all the administradores enjoyed the same authority, whilst now the title given to Rafael raised him to the rank above his colleagues. In the course of the day horse races were held, which require no further notice except that they were all gained by mares. The ground formerly owned by Henry Meiggs had been presented by him, properly fitted up, to the jockey club, who on the other hand had ceded to him the former raceground which was more convenient to Meiggs for agricultural purposes.

Thursday, $16^{\text {th }}$ of August 1877 . Meiggs' large notes continued to be exchanged for smaller ones, though not to such an extent as on the previous days.

I bought a Nitrate Certificate for $\mathrm{S} / 10,000$ at $95 \%$. 
Friday, $17^{\text {th }}$ of August. The temperature this year was exactly like that of the previous, mild, and dry. Thermometer at noon $68^{\circ} \mathrm{F}$. On our street door a placard was fixed by the clerks of the Compañia de Fomento, which said that the small bills of Meiggs were exhausted, and that there was not the slightest doubt that erelong the government would authorize all his notes. As Juan Aliaga y Puente had assigned a small house of his $\mathrm{N}^{\circ} 11$ and 13 Calle de Polvos Azules, as that upon which the embargo was to be laid in order to satisfy my claim against him, and its value did not suffice, I intended to present an escrito demanding la mejora del embargo. Bryson being ill of fever and ague did not come in the evening, and Ricardo read to me. [462]

Saturday, $18^{\text {th }}$ of August 1877 . Last night's Comercio contained a highly important decree of the Government. It cancelled the loan of eighteen million Soles made by the four associated banks in September 1875 in the following manner. The Government took upon itself the responsibility of the fifteen millions authorized issue and paid the difference of three million Soles with Bonos de la Deuda Interna at $80 \%$; consequently the Government ceased paying the $6 \%$ annual interest, and on the other hand the shareholders in the banks were free of their responsibility for the not paid up capital. Secondly, the banks, if willing, continued in the administration of the sales of nitrate and of the guano consignment to Mauritius \& Co., this latter however only on condition that they procured for the partial cancelment of notes, one million Soles annually in hard cash. Thirdly, Government authorizes the issue of Meiggs notes for 5,333,333 Soles, of which 1,030,000 were already issued. The new issue was to be employed exclusively in the construction of the railway. Fourthly, both Meiggs' and the banks issue of notes was to be redeemed in the following manner:

A by $S / 1,000,000$ Cash to be received from the Mauritius Contract.

$B$ by the Interest hitherto paid to the banks by the Government, and now to be applied for this purpose.

C by a monthly payment of $S / 80,000$ to be made to Meiggs by the administration of the Sales of nitrate, and

D by the bills £12,000 monthly from September onwards which the Government bound itself to deliver to the four banks in payment of the last loan of $\mathrm{S} / 500,000$ silver.

Before breakfast I went out to the pantheon, where they were now making pretty fair progress with my chapel. Before 4 O'clock Bryson had a violent shivering fit, and went home. Ricardo in lieu of him read to me in the evening from past nine to near eleven O'clock.

Sunday, $19^{\text {th }}$ of August 1877. To Bryson who was again [463] with me I dictated an answer to Sieveking's last [...] which he gave me an account of his 
dangerous illness, from which he had however this time fortunately escaped. Schutte, according to last advices, was so ill that he could not bear the journey from Paris to Kissingen, and had therefore gone with his wife to Trouville, a bathing place on the Channel. Corina had gone to Spa, Juan to Wildbad. This forenoon I paid more visits than I had done for a long time past. With Dr. Morales, the wife of Dr. Fernando Palacios, Dolores Puente, Mrs. Prevost, and Mrs. Hülsenbeck, I left my card; the family Basagoytia, Goya Velarde, and her daughter Adela, the wife of Dr. Teodoro de La Rosa, and Doña Josefa TorreTagle, with her daughter Elena, I found at home, and remained with each of them a short time. We dined late, for it was Maria's birthday, whom I presented with the usual twenty Silver Soles. At dinner we sat down; the whole family of the Garlands, except Guillermo and Alejandro, Zoila, and Sofia Velarde, Maria and Isabel La Croix, the curate of Los Desamparádos, La Rosa and Urquhart, a Chilian, clerk of Meiggs. At nine Garland went to the Palace to play rocambor; somewhat later came Rafael Velarde, and his wife, who remained till near eleven. I found little pleasure in these and similar social meetings.

Monday, $20^{\text {th }}$ of August 1877. I went to the notary Escobar who had his office in the Justice Hall and who told me that the embargo upon Juan Aliaga's house 11 and 13 Polvos Azules had been laid in due form. In the course of the day I went out to the farm Manzanilla to enquire for the health of Antonio Bazo who was lying dangerously ill of disease of the heart. I found him up, and much better than I had expected; he conversed with me for a long while on different subjects, and apparently without any difficulty in breathing. Enriqueta and Garland who drove out one or two hours later, were of opinion that his life was in imminent danger. [464] [?] Committee of El Bajo Comercio, which last night had been together from 8 to 11, without having come to a decision as regards the late Governments decree, merely resolved that one commission should be sent to the four associated banks, another, to the committee del alto Comercio, in order to introduce some uniformity in the proceedings of el alto and el bajo Comercio.

This day the committee del alto Comercio met, fixed no exchange, and called for tomorrow a meeting of merchants of all descriptions, for the purpose of putting a stop if possible to the circulation of Meiggs' notes. Those who signed this call were: Gustavo Heudebert, Emilio Heyneman, Gmo. Gibbs \& Co., Graham Rowe \& Co., Ernesto Puccio, H. R. J. Jameson, Gautreau \& Co., Calderoni Schmole \& Co., Roca Pratolongo, Dorca Ayulo \& Co.; Duncan Fox \& Co; F. S. Isaac \& Co.; Ph. Ott \& Co., M. G. Chavez \& Co.; Pedro Dinegri \& Co.; and John Mathison. José Vicente Oyague's name was wanting. The Government published another decree which said that of the bank notes in circulation, only the fifteen millions of the four associated banks, and the $5_{1 / 3}$ million, 
Meiggs', were authorized by the Government; consequently these of the Banco Garantizador were not, and might be refused by whomsoever was not willing to receive them.

Tuesday, $2{ }^{s t}$ of August. At about 2 a.m. a considerable number of merchants of all classes assembled in the exchange rooms. José Vicente Oyague presided. The resolutions come to, in my opinion, of very little import were the following: Firstly, a deputation was to be sent to the President, begging him to reconsider his last decree of $17^{\text {th }}$ inst., so that the circulation of bank notes be not increased, because, as Oyague very properly observed, fifteen million Soles were required to carry out the public works commenced by Meiggs, and that consequently the present emission of five million Soles had necessarily to be succeeded by new ones. Secondly, it was resolved not tot admit Meiggs' notes, and [465] thirdly, to admit those of the Garantizador till the [_] of the year; but, by the time the acta was to be signed, nearly all had left the room. Mr. Henry Meiggs was lying dangerously ill; to-day the last sacrament was administered, and he was not expected to live.

Juan Garland had the good luck to obtain through the influence of Umlauf, book-keeper in the Compañia de Fomento, a situation in that establishment with a salary of $S / 150$ monthly, very handsome indeed. Many London papers, also those of Montevideo and Buenos Ayres, treated on the affair of the "Huascar", and looked upon the conduct observed by Admiral de Horsey in very different lights, some approving, some disapproving the same.

Wednesday, $22^{\text {nd }}$ of August 1877 . The Nacional was wrong when saying that the Billetes of the Banco Garantizador would be admitted until the end of the year as per resolution taken on Tuesday; on the contrary, the motion to this effect was thrown out and yet on my enquiring in the Banco de Lima and La Providencia I was told that they received the notes of the Banco Garantizador, and rejected those of Meiggs. Telegrams received from Europe agreed in the advice that towards the end of July the Russians had suffered a severe defeat near Plevna in Bulgaria.

Thursday, $23^{\text {rd }}$ of August. Both Henry Meiggs and Antonio Bazo were said to be a little better. The weather we had was extraordinary; no cold, no rain, the sun out the whole day, and at night an unclouded moon. Thermometer at noon $71^{\circ} \mathrm{F}$. I received this day through the medium of the firm of Bauer \& Kruger the ring with my dear Mariquita's hair which Juan got made for me in Paris; it fitted the third finger of my left hand on which I wear it. The papers made known that last night the following individuals had been arrested, some in the house of Aliaga, some in that of General La Fuente: P. J. Calderon, [466] [_] Echenique, Manuel Argote (many years back partner of Henry Higginson), Col. Alvisuri, son of the general; a certain Bentin, a miner, with whom Enrique was at law; 
Manuel Ugarte, ex-employé in the Ministry of finances; a certain Salmon, nephew of the late Don Pedro; and a Larrañaga, brother of Pedro Telmo, and of the "Cojo", who was under arrest. They were taken to San Francisco de Paula. Evaristo Gomez Sanchez was not found in his home where the police went in search of him; probably he had received timely advice.

Friday, $24^{\text {th }}$ of August. The following had come forward to represent the capital, Lima, in the next Congress to meet on the $28^{\text {th }}$ July 1878 : Juan Ignacio Helguera, Pardo's ex-Minister, for Senator; José Unanue, Manuel Candamo, Ignacio Osma, Ramon Ribeyro, for Deputies, which five belonged to the so-called Civilista, or Manuel Pardo's party. The Committee to direct the elections was presided by Manuel Costas, late vice-president.

Saturday, $25^{\text {th }}$. In the course of the forenoon I went to the Banco de Lima to gather some news; only the gerente Manuel Cucalon was there, who told me that Lembcke as Swedish and Norwegian Consul General had been invited by the diplomatic body to a lunch given by them in the exhibition park, to the president, to his ministers, to the second vice president, some of the first employes in the administration, and to the Consuls, all with their respective wives. La Puerta, the first-vice-president, whose saints day it was, had declined going. Cucalon further told me that the deputation from the four associated banks; Lembcke from Banco de Lima, chosen spokesman; Derteano from El Nacional; Cesar Canevaro from Perú; and Aurelio Denegri from La Providencia, had asked the president for an interview which he had not yet granted them; he had put it off to yesterday and from yesterday to Monday next. [467]

Sunday, $26^{\text {th }}$ of August 1877. Henry Meiggs physicians [_] of opinion that he was out of danger.

The bajo comercio had resolved that they would receive the notes of the Compañia de Fomento. I heard at breakfast that at yesterday's banquet in the Exposition palace, Godoy, Minister for Chile, and Senior of the Diplomatic Corps, who could not drink three or four glasses of wine, without feeling the effect, had had some high words with Azambuja, the Brazilian Minister; also that the President had been intoxicated. In Callao a serious accident occurred yesterday. To solemnize some religious festivity or other several "camaretas" had been let off; these "camaretas" are made of iron, about eighteen inches long, and twelve in circumference; they are more or less in the shape of a cannon. They are filled with gunpowder, well rammed in; they are then lighted by means of a fuze and explode with a report like that of a real cannon. Yesterday one of these "camaretas" burst as if it were a granade, and the pieces of iron were scattered in various directions; two of the many who stood round were killed on the spot, five or six more or less dangerously wounded. I finished dictating the letters to Sieveking, Juan, and Schutte, and then went out, firstly, 
to the family of Davila with whom I had not been for the last eighteen months; in the meanwhile the father Don Tomás had died in Moquegua in November last; the eldest daughter Delfina and the son Tomás, who received me, were of course in deep mourning, and so was a young Salcedo whom I found with them who had lately lost his father, Dr. Manuel, owner of the estate Malambo. I then went to Dolores Puente, to Col. Juan N. Vargas, and to Leonor Pinto, the eldest daughter of the Minister for one of the Central American Republics, who having been the previous day with her father and mother at the lunch in the Exposition Palace, gave me an account of what had occurred there. Asambuja had been annoyed that he had been requested to lead to the dinner table the wife of Pratolongo, Consul General for I do [468] [...] which small Republic. When dinner was near[ly] over he had gone up to Godoy, whose partner was the President's wife, and said to him rather jokingly, but no doubt meant in earnest: "voy a dar una lección al Señor Decano", which Godoy replied "yo le daré una lección de patia duras." I did not learn who interfered, and how they were separated. Garland was very unwell; he complained of oppression in the region of the heart, and breathed with difficulty; he also suffered from fever and ague. Dr. Middendorf came twice; a medicine called "digital", and a blister he prescribed against the former, quinine against the latter.

Monday, $27^{\text {th }}$ of August. Garland did not go to the bank and Dr. Middendorf came several times. Exchange on London which four or five days back was 19 and $191 / 4$ pence had improved to 20 and $201 / 4$ pence, per sol, at which I bought for Juan and myself together, £6oo.

Tuesday, $28^{\text {th }}$. Thermometer in my office at 11 a.m. $72^{\circ}$ F. Garland, still unwell, remained at home. I, in order to leave Bryson time to copy the remodelled diary, walked first, as far as the penitentiary, thence to Santa Sofia fifteen minutes, to the hospital Dos de Mayo, again fifteen minutes; and to the Chacra Manzanilla five. Here I remained half an hour with Doña Josefa Bazo, whose brother Antonio had felt so well as to venture to drive to the Exposition Park. From the farm to Dr. Palacios study it took me about 35 minutes, and here the Doctor dictated an escrito to the Juez de $1^{\mathrm{a}}$ Instancia Quiroga, in which he demanded the public sale of Juan Aliaga y Puente's house 11 and ${ }_{13}$ Calle de Polvos Azules.

Wednesday, $29^{\text {th }}$. Garland was considerably better. In consequence of the explosion of the Camareta on Saturday last in Callao, not less than six human being had lost their lives.

On the $21^{\text {st }}$ of this month, as already said, [469] a great number of merchants had met in the Exchange rooms; then it had been resolved to present a petition to the Government relative to the decree of the $17^{\text {th }}$. John Gildemeister, John Mathison, and Pedro Elguero, were named for this purpose, and in the petition 
presented by them, published in last night's papers, they said in the most polite and respectful terms; firstly, that as the budget, or estimate of the expenses to be incurred in the completion of the different works commenced by the Compañia de Fomento came to fifteen million Soles, they feared that after the present issue of five and a third millions, other emissions would become indispensable, and they therefore begged that the Government would find other means, and not the issue of paper wherewith to satisfy Meiggs' wants. Secondly, they requested the government not to release the four associated banks of their responsibility for the fifteen million Soles issued by them; and thirdly, that if their request should be denied them, the government would be pleased to name a committee of highly respectable persons who might be entrusted with the redemption and cancelment of bank notes in the manner proposed on the $17^{\text {th }}$. At about 1.30 I made a trial to climb up the lower range of San Cristoval; I ascended from the Descalzos side, descended into the little plain called el medio mundo up again, again down, and up for the third time. I took the greatest care not to make a false step, more than once assisted my left knee with my left hand, and upon the whole found greater difficulty in descending than ascending. All together I succeeded better than I had expected. My last descent was on this side of the baths of Altazar.

Thursday, $30^{\text {th }}$ of August 1877. Santa Rosa. I called upon a few of the many Rosas of my acquaintance: upon Rosa Lopez Aldana, married to Francia, upon Juana Rosa, wife of José Basagoytia, and upon Juana Rosa Moreyra, spouse of General Freyre; with these three I only found two or three visitors, whilst at Rosa V[?]'s [470] [_]ed [_] Cipriano Correa, it was like a bee-hive, so gentlemen went out and in; and finally at Dr. Ribeyros, whe[_] they always received me with apparent cordiality, and where there was one daughter, Juana Rosa, there was not one visitor except myself. I also went to see Rafael Quiroz who had lately returned hither from Paris, with his newly married wife Luisa, daughter of Vega, of the firm of Vega \& Ibañez. He, a very agreeable young man, is one of the many children of the late Francisco Quiroz and Rafaela Correa. His father left to him, as well as to all his sisters and brother, a fair fortune, the greater proportion of which he had lost, partly when he was partner of Lauezzari here on the coast, and partly in Paris, in Peruvian bonds. The evening of this day there was a ball at José Basagoytias to which all of us were invited, but only Guillermo with Eliza, Enrique and Antonio went. Smaller dances were given by Cipriano Correa; by Lembcke, one of whose daughters is called Rosa; and by Felipe Varela, husband of Rosa Orbegoso. Garland was somewhat better, Enriqueta again suffered from migraine.

Friday, $3{ }^{\text {st }}$ of August. Both Garland and Enriqueta were unwell, the latter in bed. In June of the present year died Luis III, Grand duke of Hesse Darmstadt 
at the age of 71, after a reign of twenty nine years. His wife, who had died before him, was the daughter of Luis I of Bavaria; his sister Maria is married to Alexander II of Russia. Having no children he was succeeded by his nephew Luis, husband of Princess Alice, daughter of Queen Victoria.

Saturday, $7^{\text {st }}$ of September. In the course of the forenoon I went out to the pantheon to have a look at my chapel and found to my regret that the work was not getting on so quickly as Mr. Mould had led me to expect. By this day's north steamer arrived from Europe, J. A. Lavalle, and José de la Riva Agüero.

Sunday, $2^{\text {nd }}$ of September. From Juan I received no letter. [471] C. W. Schutte wrote me; also Sieveking who begged me [_] allow him to render my niece Elizabeth Bobertag, who, owing to the bad state of her health, had to remain in the South of Europe, the pecuniary assistance she might stand in need of, out of my funds in his hands, which I of course acceded to. Enrique Garland received his diploma as Danish Consul General in Perú. When making my round of visits I called amongst other upon Mrs. Pfeiffer who lived with her son Calixto and his natural daughter in the Calle de Plateros de San Agustin, in the altos of Figari. She had been absent for a long time in England, where she had resided sometime with the one, sometime with the other of her two married daughters, Emily, Mrs. Rowe, and Caroline, Mrs. Hayne. I could not distinguish her features, but certainly she had altered much; her age was about the same as mine; she was neatly dressed, as she used to be. It seemed to me as if her memory was failing, the same as it was the case with my dear Mariquita.

Monday, $3^{\text {rd }}$ of September 1877 . I saw by he papers that the Prussian General Steinmitz who distinguished himself in the wars of 1866 and 1870 had died.

The Russians were being beaten in every encounter. At Plevna a little to the South of Nicopolis, on the Danube, they had been defeated with considerable loss.

This was Garland's birthday. Enriqueta had laid out the dinner table very neatly, and adorned it with flowers round which the entire family, Alejandro excepted, and in his place Dr. Middendorf, took their seats.

Tuesday, $4^{\text {th }}$ of September. Very quick progress was being made with the tramway, which, beginning at the market place in the Paseo de Aguas, had already reached the bridge where I saw this morning that the sleepers were being laid. This day the sentence of Dr. Quiroga was notified to me, in which he ordered the public sale, remate, of Juan Aliaga y Puente's house 11/13 Calle de Polvos Azules, in order that out of the proceeds I be paid for the principal of 7200 Soles, which I [472] [_], together with interest and costs

Wednesday, $5^{\text {th }}$ of September. The papers said that the crown lawyers of Queen Victoria had given it as their opinion that Admiral de Horsey had done his duty when he requested the "Huascar" to surrender, and attacked her when Pierola 
refused to give her up. Near 4 O'clock Ricardo brought the news that Alejandro had gained in the Supreme Court the suit which he had carried on against the Banco Garantizador. Accordingly, in conformity with the sentence of the Juez de $1^{a}$ Instancia, confirmed by the Corte Superior, and reconfirmed by the Corte Suprema, the bank had now to pay him in silver or gold the 32,00o Soles in billetes which he had presented to them for payment more than a year back. The bank had appealed to the Supreme Court demanding the cancelment of the sentence of the inferior courts, or, as it is said here "habian interpuesto el recurso de nulidad"; and here the judges had been so divided in their opinions that all nine had been called in to sentence. In favor of the nulidad, that is to say against Alejandro, voted Drs. Ribeyro, Muñoz, Oviedo, and Leon; and in his favor, Cosio, Alvarez, Manuel Cisneros, Sanchez, and Vidaurre. In the evening, Asunción, the daughter of Alvarez, with her little daughter Maria came to ee Enriqueta.

Thursday, $6^{\text {th }}$. It became known that a certain Dr. J. M. Puente, once Minister, I do not remember during whose administration, had been arrested. The cause of this arrest was the following: through his influence with those in power Meiggs had obtained the decree authorizing the issue of notes to the amount of 5,333,333 Soles, as above stated, and in remuneration for this service Minor Meiggs, the Gerente of the Compañia de Fomento, handed him five vales of one hundred thousand Soles each, signed by him - Minor Meiggs. Two of the vales, it was said, had been paid, three not, and it was added [473] that Watson, who during Henry Meiggs illness was the [_]pal manager, had prohibited their payment. Puente had bought, at least so the report went, the house of Francis Bryce formerly Torrico's, and before it was Torrico's, mine for a short time, for one hundred and odd thousand soles; this attracted Prado's attention, and he ordered Puente's arrest. The "Bajo Comercio", whose meetings Juan Revoredo continued to preside, was about forming an establishment something like a bank by the name of "Caja mercantil", consisting of 2000 shares of S/500 each.

Friday, $7^{\text {th }}$ of September 1877. At noon thermometer in my office $73^{\circ} \mathrm{F}$. In the Insurance Company "Lima" a meeting of Directors was convoked. When I went at past one, Elizalde, the gerente, told me that as nothing of any importance was to be discussed and as the various Directors were much occupied with their own affairs, he had laid before each, separately, just as he came in what he thought necessary to communicate. Chavez had been there before me; Prevost went out when I entered, and whilst I was there Gil came in. We all agreed that the various pagarées due this month might be prolonged the security held being sufficient with the exception of J. M. Latorre's from whom a partial payment of c/2000 was to be demanded, because the security, shares in La Providencia, had declined in value. 
In the evening Garland and some of his sons were present at the marriage of Ferdinand Umlauff, book-keeper in the Compañia de Fomento, with a sister of Daniel Igarza, the auctioneer. Enriqueta and I were by ourselves, for even Ricardo had gone out. We had a short visit from Dr. Middendorf who of late called frequently for both Enriqueta and Garland were far from well.

Saturday, $8^{\text {th }}$ of September. Natividad de Nuestra Señora. A fine summer morning, thermometer at noon $72^{\circ} \mathrm{F}$. I paid a few visits, of which the most agreeable was that to Doña Virginia La Torre, widow of Domingo Valle Riestra, who in my opinion [474] [_] one of the most agreeable ladies in Lima; with Doña Juana Guise, and her daughter Mercedes, widow of John Dartnell I found their good friend Dr. Melchor Vidaurre; with them I also remained about half an hour.

The athletic sports came off on the new raceground, Antonio who had expected to do great things was rather unwell, having suffered from fever and ague; he therefore only gained the second prize in the race of 220 yards with eight leaps of $31 / 2$ feet. Garland, who had taken his two little girls to see these sports was robbed of his pocket book with $\mathrm{S} / 250$, which he carried in the inside pocket of his coat, at the moment when he entered the train at the station of Los Desamparados. In the evening Rafael Velarde and family came to see us. From him, who had visited La Puente in his prison, we learned that it had been Watson and Dr. Garcia Calderon who had raised the outcry when they discovered that the vale for $\mathrm{S} / 500,000$ had been given to him, and that they had denounced him to the President. Further, that Puente had returned to the Compañia de Fometo not only the three vales of one hundred thousand Soles each, but also one hundred thousand in notes; the other hundred thousand soles he had already spent before he had been taken up. His purchase of Bryce's house would probably now be annulled.

Sunday, $9^{\text {th }}$ of September. By the 2 O'clock train I went to Chorrillos;José Sevilla took a seat near me in the train and the only thing he did was to talk about the gas company which establishment he said would erelong be bankrupt. I answered that if he had such a bad opinion of the company he should present himself in the meeting of shareholders, and speak on the subject; but this, he said, he would not do until he was sure of a majority viz.: 2001 votes. I could not bear him. In Chorrillos I went first to the house of Dr. José Maria Perez where they were busy painting and [_] and where I merely exchanged a few words [475] with Lino de la Barrera, the doctor's brother-[in-law]. [_] General Pezet's nobody was visible. At Elster's I did not see his wife Mercedes Soyer; neither did Luisa Soyer, the wife of José Canevaro, make her appearance. He, Don José, the second vice-president, with whom was Modesto Basadre, was polite and pleasant as always. I was also well pleased at Vicente Gonzales', where his 
daughter, married to the American Du Bois received me, whilst on the other hand Doña Petronila, the mother of Pardo, who was with José Antonio Lavalle in John Gallagher's rancho, was much less cordial than she used to be two or three years ago. Lavalle himself I did not see. After dinner Ricardo read to me; at a later hour I was with Enriqueta. Garland was very unwell.

Monday, $10^{\text {th }}$ of September 1877 . Near nine in the evening Enriqueta's Chinese Cook, who had ran away about three months back, quite unexpectedly made his appearance; he said he would again begin to cook, but our opinion was that he intended to take out of his room the few things which he had left there and then to re-escape as clandestinely as he had endeavoured to enter. Garland was not in, but fortunately, Juan, a son of Gregorio Benavides was with Enriqueta, who took him at once to the police office, where he was locked up, and where he would now remain until we could dispose of him.

Tuesday, $17^{\text {th }}$ of September. The papers said that on the $25^{\text {th }}$ or $26^{\text {th }}$ August died Mr. Adolphe Thiers, once Louis Philippe's Minister, author of Le Consulat et L'Empire, and of late President of the French Republic, from the fall of the second empire till the election of Mac Mahon. He was born in Marseilles in April 1793. For many months back I had been uninterruptedly Director de Turno of the Insurance Company "Lima", and I liked to be so, for it gave me some trifling occupation, and the gerente Carlos Elizalde preferred my filling this post to any other Director, because I lived close by, and could easily be called when he required my presence. Enriqueta was very unwell, and remained in [bed]. [476] [Ricar]do read to me in my rooms till near half past ten.

Wednesday, $12^{\text {th }}$ of September 1877 . Thermometer at noon $73^{\circ}$ F. The Firm Dreyfus drew by this steamer $£_{50,000}$ at $21 \mathrm{~d}_{1 / 2}$. I only knew of it at the last moment; what these bills were drawn for I had not been able to ascertain. On the $3^{\text {rd }}$ October the elections for the new deputies and Senators to replace the one third which had gone out in conformity with the constitution, would begin and as it was always the case on these occasions the two political parties in which the country was divided, that of the government, and that which called itself the Civilistas, the friends of Manuel Pardo, were exerting themselves to the utmost to gain the preponderance, and this of course could not be done without their coming in hostile contact more than once. In the same manner the Concejos Departamental and Provincial, both of Lima and Callao were in a continual state of excitement, for there also the members were not unanimous, there were Gobiernistas and Civilistas.

Thursday, $13^{\text {th }}$ of September. The Banco Garantizador having been condemned by the Supreme Court to pay to Alejandro in coined silver or gold the thirty thousand Soles in bank notes issued by them, declared their readiness to pay, but on condition that Alejandro presented a guarantee for the result of the 
causa ordinaria which they were about instituting against him. He might have opposed this demand, but then the delivery of the money would again have been delayed, and he therefore preferred to give this guarantee. He applied to his father, but as Mr. Garland Sr. did not possess any immovable property, Enriqueta would have to come forward, but this I would not allow on any account, as I did not wish that the possession of her house were in any way endangered, and I therefore offered my guarantee which was accepted, and this morning I signed the escritura before the notary Francisco Palacios.

In my suit against Juan Aliaga y Puente the Judge Quiroga ordered yesterday that the house 11 and 13 Calle de Polvos Azules, embargoed by me, should be valued before bringing it to the hammer. I named for my appraiser [477] Don Tomás Davila, son of the judge, lately deceased, but when the notification was made to Aliaga, the answer given was that he was in his chacra, and no one in the house would receive the esquela. This was the answer given to me by my notary Mauricio Sarrabia, whereupon Dr. Palacios went out and on his return told me that he had found another notary who would do the job. In the evening when Bryson was gone I went to Enriqueta's salita, where Garland, Juan Bazo and Dr. Middendorf were playing rocambor. A few minutes later Rafael Velarde's wife and her two daughters came, but I, low spirited as I was, went to bed before nine O'clock.

Friday, $14^{\text {th }}$ of September 1877 . The papers narrated that by order of Pedro Saavedra, soldiers had been placed at the door of the house of Ignacio Osma, a decided civilista, because he had not delivered up the parroquial books of the Parish 'El Sagrario', which he should have in his possession as Presidente de la mesa, at the time of the elections of 1875 . Osma had previously declared that Saavedra, secretary of the mesa in 1875 , and president in 1876 , had to account for them, and now at the request of this very Saavedra, at present Alcalde de la Municipalidad, Lara, the Prefect, had ordered the soldiers to Osma's house. Osma had presented himself before the Juez del Crimen Morote, instituting a suit against Saavedra and the Sindico, Teran, which demand Morote had admitted, and at the same time ordered the removal of the guard. My guarantee was not accepted by the Banco Garantizador, whereupon I presented the testimonio, or certified copy, which proved that I was owner of the rancho in Chorrillos, and accordingly Dr. Quiroga sentenced that my solvency was proved, that he admitted my guarantee and that the bank was to pay instantaneously. A notary succeeded in notifying Juan Aliaga y Puente by leaving an esquela in his house.

Sunday, $16^{\text {th }}$. Before breakfast I walked as far as the hospital del 2 de Mayo thence round the town to Santa Sofia [478] [_] [building] of which progressed very slowly, to the exhibition, and thence home, where I arrived somewhat 
tired; it took me an hour and a half. I saw by the Nacional that the prefect, Captain Lara, refused to withdraw the policemen from Ignacio Osma's house, because, as he said, he only obeyed the orders of the Municipality, of which Saavedra was Alcalde, and Terán Sindico. The visits I paid in the forenoon were to Dr. Lührsen, the German Chargé, who was not in; to Dr. Domingo Mendoza, with whom I stayed a considerable while, to Rafael Velarde, with whom there were always many visitors, today General La Puerta, his nephew, an officer Herrera; San Roman from Puno, and two or three more; to Dolores Puente, and Ramon La Fuente, both not at home, and finally to Doña Manuela Irriarte, wife of Demetrio Olavegoya; and her daughter Irene, lately returned from England, the latter, a very nice and good woman, had been shamefully abandoned by her husband Felipe Salaverry. The remainder of the day I was quietly at home. Garland went in the evening to the Palace.

Monday, $17^{\text {th }}$ of September. A fine warm day; thermometer at noon $72^{\circ} \mathrm{F}$. This was Enriqueta's birthday, and I told her that I could not as I had done in previous years present her with the usual S/40o but that instead of the same she might take the green mats which I had ordered from China several years ago to serve as curtains in the corredor, and which had not yet been used. All the children breakfasted with her. Alejandro told me that he had not yet got the money from the Garantizador, for on the one hand this establishment had not accepted the guarantee of my rancho in Chorrillos, because as they pretended, it was badly situated, and hardly worth S/10,00o and secondly, they had recused Quiroga, and Dr. Velez was now the judge. I went out to collect from Peter Gallagher, who represented the Directory of the Pasco Mineral Railway Company, the first and last dividend [479] which this unfortunate Company paid, say [...] [on the] original shares together with the addition of $14 \%$ which were added at the time that Juan M. Echenique took the enterprize on his account. Thus I received this percentage on my $\mathrm{S} / 22,800$, and on Juan's $\mathrm{S} / 11,400$. When I came home I found my nephew Johannes Limpricht who had arrived from Europe. Enriqueta gave up to him the two rooms occupied by my son Juan when here. Limpricht had become very stout. He told me that he had lost considerably in the course of the last two years in the Cigar business with Becker, with whom he had now to come to some understanding or other. Shortly after came General La Puerta, the vice-president, with his nephew Herrera, to congratulate Enriqueta, and hardly was he gone when Mrs. Lührsen came to invite us to a ball to be given by her on Friday next. Of course Enriqueta and I declined. At dinner we had the whole family, except Alejandro, but with Zoila and Sofia Velarde, Urquhart and Limpricht. I had again no letter from Juan. Schutte wrote that he had abandoned the idea of sending his attorney 
to Lima. He ordered me to buy Nitrate Certificates at par, shares in Dreyfus Contract at $10 \%$ premium, and if I could buy them at this rate - which I could not - to sell his Shares in the Banco del Perú at 50\%.

Also in Antwerp the Superior Court had decided against the bondholders, and there was now no chance of their embargoing the guano or the proceeds of the guano in Dreyfus' hands, in order to pay themselves for the overdue interest on the bonds. He further wrote that it was generally believed in the Peruvian Circle in Paris that Raphael \& Co. of London, and those who acted with them would not continue to accept the Peruvian Government's drafts as readily as they had done hitherto, for the sales of guano which they effected, bore no proportion to the heavy advances already made by them.

The Nacional made known that Brigham Young [480] and Capt. Semmes had died; the former, the well known Chief of the Mormons, the latter, the renowned commander of [_] privateer "Alabama", which during the civil war did such infinite damage to the trade of the Federals.

Tuesday, $18^{\text {th }}$ of September. Through Dreyfus house I received a letter from Juan written on the $8^{\text {th }}$ July from a small place called Axenstein, near the lake of the four Cantons in Switzerland where he was undergoing a water cure in a mitigated form.

Johannes Limpricht who had readily accepted the offer of the two rooms, declined, though with many thanks Garland and Enriqueta's proposal to take his meals with us. I sold this day through Alejandro for my son Juan forty shares in the Banco del Perú to Rafael Canevaro at 50\%, and bought for him a Nitrate certificate of $S / 10,000$ at par. Also for Schutte one of $S / 10,000$ at par and another of the same amount - to be delivered after the $1^{\text {st }}$ October at $97 \%$.

Wednesday, $19^{\text {th }}$. The papers said that the Guard had been removed from Ignacio Osma's house, but that an order for his arrest had been given by the Prefect at the request of the Sindico of the Concejo Municipal.

In the evening Ricardo began reading to me a German Book sent me by Sieveking of Altona, called Priscilla and Sabina containing letters purporting to be written by the former, a Young Roman lady, to her friend, in which she gives an account of her journey, and stay in Jerusalem about the years 29 to 33 A.D. Its object is to represent in a popular form the sufferings of our Lord. The two first letters bring the travellers as far as the island of Creta - the present Candia - and so far they are very amusing. I learned from the same that the common German expression Creti and Pleti, equivalent to the English Tagrag and bobtail, is derived from the name given to the body-guard of King David, called in the bible Creti and Pleti or Cretense and Philistines. 
Friday, $27^{\text {st }}$. Limpricht who came in the evening to Enriqueta's [481] salita before retiring to his own rooms, brought the news [_] [t]he English Government had proposed to that of Perú to take the Emperor of Brazil as arbiter in the Shah-Huascar question. Thermometer at noon $73^{\circ} \mathrm{F}$.

Saturday, $22^{\text {nd }}$ of September 1877 . Of our family only Garland, Enrique and Antonio had been at the ball given last night by Dr. Lührsen. The two latter came home at about five in the morning. It had been raining the whole night. Thermometer at noon $72^{\circ} \mathrm{F}$.

In the evening Bryson being prevented from coming by a fit of fever and ague, Ricardo continued reading to me the German novel Priscilla and Sabina. It gives a pretty description of the coast of Asia Minor and Lebanon, otherwise it is written rather heavily.

Sunday, $23^{\text {rd }}$ of September. I started at 2.30 for my usual round, Manuela, the wife of Dr. W. Rospigliosi, Juez de $1^{\text {a }}$ Instancia of Callao, was not in; neither was Irene, Dr. Muñoz's wife. With Doña Dolores Puente I was a long time, first Frederic Marriott came in, then Gregorio Escardó, Consul for Buenos Ayres, a very agreeable man. At Dr. Jervacio Alvarez' I only found his wife, whilst at Dr. Ribeyro's there was such a party, José V. Oyague, Dr. Corso of the Superior Court, and other gentlemen whom I did not recognize, the Doctor himself, and all his daughters, and the conversation so continuous that I was obliged to stay much longer than I had intended.

Limpricht dined with us; with him I afterwards walked the corredors for more than an hour.

Monday, $24^{\text {th }}$ of September. Dia de las Mercedes. Last year I noted down how I spent the day; this day I will do the same. At 8 I walked with Limpricht to the pantheon where several workmen were busy at the chapel; by ten we were back when we breakfasted, and shortly after his meal Bryson came to whom I dictated my letter to Juan, then had the index of the remodelled diary read to me. At two I started for an ascent of San Cristoval to the summit of which [482] I had not been for nearly a year. It was hot, for the sun sho[ne] from an unclouded sky. I walked as far as the beginning of the valley of Lurigancho; here the ascent is longest, consequently less steep, and thus, though very slowly, I reached the top without feeling any particular inconvenience in my weak leg. I rested for a few minutes upon the big stone and then walked down with the greatest care towards the saddle, more or less in a straight line with the Descalzos. When on level ground I again sat down for a little, and it was as late as five when I came home and lay down on my bed till dinner time. After dinner Ricardo read to me Priscilla, and towards 9 O'clock Rafael Velarde, wife, and daughter came. Before 11 I was in bed and asleep. 
To the Mercedes of my acquaintance I merely sent my cards. Garland dined at Doña Mercedes Villacampa; he was again rather unwell. From Dr. Fernando Palacios he received, and handed to me, in bran new notes of Meiggs, $S / 1200$

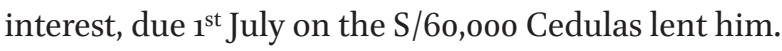

Tuesday, $25^{\text {th }}$ of September. In the course of the forenoon Manuel Mendoza and Pedro Elguera came, and tried to persuade me to affix my name to a petition signed by more than twenty shareholders of the Banco de Lima, in which they asked for a meeting on the $28^{\text {th }}$, and the immediate liquidation of the bank. I declined signing, because I considered the immediate liquidation not only prejudicial to our interest, but impracticable.

At 4.30 I went to see Alexander Blacker of Payta who was on a visit to Lima, and stayed with his brother-in-law Henry Higginson. On Sunday last there had been a fight in Chorrillos between the two political parties, "el partida Nacional", or that of the Government, and "el partido Civilista", on occasion of the election of the members for the Municipality; several persons had been wounded, the greater part by stones.

Wednesday, $26^{\text {th }}$ of September. Blacker breakfasted with us. Pedro Elguera again came to see me, and I acquainted [483] him with several particulars relative to the Banco [de Lima] which were new to him, but did not sign the petition yesterday spoken of.

I remitted to Juan $£ 200$ which at the very last moment I obtained from Alejandro at 21d; to Gibbs, on my own account £700, viz. £200 purchased with silver soles at 40 pence, and $£_{500}$ from the Caja Fiscal, for which, through the medium of Becker, I had paid 22d about a fortnight back; the bill was drawn by Dreyfus, on their firm, Paris, payable in London.

Friday, $28^{\text {th }}$ of September 1877 . In Chile a great swindling transaction had come to light. A few months back appeared in Santiago a man whose name was Paraff, and whose nationality I did not learn, who affirmed that all copper ore contained gold, let the quantity be ever so small, and that he knew how to extract it. Experiments were made, which turned out satisfactory, but it had now been discovered that the ingredient which he mixed up with the molten ore contained gold, and thus very naturally gold came to light, not that said to be contained in the copper ore, but the very same which had been thrown in. According to the papers more than a million of Chile dollars had been laid out in forming a joint-stock company, and in putting up various establishments. What proportion of this sum had come into Paraff's pockets was not stated.

At 8 p.m. I went to the Banco de Lima, where a meeting of the shareholders had been convened. That party which was intent upon the immediate liquidation of the bank was but poorly represented; the principal mover of this plan, Amancio Castillo, had even directed a letter to Heudebert, president 
of the Directory, in which he requested the postponement of the meeting, because, as he said, owing to the impending elections, the town was not in its normal quiet state. No notice had been taken of this letter, and at 8.30, when at the utmost twenty odd members were assembled, Heudebert opened the meeting. The acta of the last was read and approved; then Heudebert [484] proposed the election of nine new Directors in lieu of those who we[_] out. Now the discussions commenced. Cardenas, who as usua[_] spoke in violent terms, moved that this election should be put off until it were decided whether the bank should liquidate or not and this motion passed by a considerable majority, I voting in the minority. Pedro Elguera proposed that a commission of three members should be named to examine the state of the bank and to give their report whether it would be advisable to liquidate, and if so, when and how. For members of this committee were chosen Aurélio Denegri; M. G. Chavez, and José Vicente Oyague. We broke up at 10 O'clock.

Saturday, $29^{\text {th }}$ of September. Thermometer at noon $75^{\circ} \mathrm{F}$. The dispute between Ignacio Osma and the Municipality continued. The former had presented himself before the judge Morote, complaining of unjust imprisonment. The judge had ordered P.J. Saavedra, Alcalde, and Federico Terán, Sindico, to appear before him in order to give their declarations, which they had refused to do.

Sunday, $30^{\text {th }}$ of September. At 2 in the morning died Henry Meiggs. This day the Danish flag was again hoisted and the escutcheon fixed over our street-door. Yesterday Enrique paid all his official visits to the members of the diplomatic and consular bodies.

At breakfast we had besides the numerous family, Alejandro and Enrique excepted, Dr. Middendorf, Johannes Limpricht, and Dr. Gregorio de la Rosa, curate of los Desamparados, and "promotor-fiscal", who stands in the same relation to the Archbishop as the "fiscal" does to the Government, or rather the Supreme Court, for the archbishop cannot resolve any question laid before him unless the promotor has previously given his "informe", or written opinion. In the course of the forenoon the clubs which called themselves the partido nacional, in reality the Government's party, paraded the streets in considerable numbers, all on foot, except a few leaders who were on horseback. They [485] carried flags, and when I saw part of them coming [_] the Plaza de Bolivar passing our house, they conducted themselves very quietly; there was no shouting whatever. At about 1 O'clock the first burning of bank notes took place in the plaza Mayor; medals in copper and silver had been coined, and were thrown amongst the populace to celebrate this great event. I made a few calls; upon the family of Don Diego Masias, not at home; upon Isabel Coloma; and upon Rafael Velarde and family. José V. Oyague and wife were again out. At Mrs. Lührsen's I found a few visitors and remained but a short time; with Doña 
Fidelia, the wife of Anibal La Torre, I stayed somewhat longer. At 4.45 I had done, and walked as far as the corner of los Descalzos. At dinner we were but few, and this meal over Ricardo read to me from seven to nine the biography of the German author Henry Heine, and Priscilla and Sabina, which contains very interesting descriptions of Jerusalem, which town, if the author is to be believed, must at the beginning of the Christian era have been very different from what it is now.

Monday, $7^{\text {st }}$ of October 1877 . This morning I went out to the pantheon and found nobody at work, no doubt on account of the death of Henry Meiggs. The inner roof of the chapel is covered with cedar, but to my taste of by far too light a color. It looked like pine.

The papers said that at yesterday's burning of the billetes, the minister of finance and various chiefs of financial departments were present; also the cashkeepers of the respective banks, and that the President and his aides de camp looked on from the palace. The billetes burned were the following: S/100,000 of Meiggs; 78,00o of Perú, S/50,00o of La Providencia; S/48,00o of Lima; and S/22,00o of the Banco Nacional. These amounts destroyed did not correspond to the quantities issued by each bank respectively, and I learned from Lembcke that they had been fixed upon in order that the quantities issued by each bank might be [_]duced to a round [_] [486] [_] the Government had assumed the responsibility for all, it was of no importance which were burned.

Tuesday, $2^{\text {nd }}$ of October. Last night's papers gave the biography of Henry Meiggs of which the following is an abstract. He was born in July 1811 in the city of Catskill, County Greene, state of New York, where his father was a contractor for public works. When he grew up he dedicated himself to similar also to mercantile pursuits, both in New York and in the town of Wilhelmsburg. When the gold riches were discovered in California he settled over to San Francisco where he speculated largely and successfully until the year, which is not given in the biography, when disaster befel him, when he failed, and had to leave the country. His failure was of such a nature that for many years he was not allowed to return to the United States, but when doing well on the west coast of South America, he paid the San Francisco debts, and the interdict was annulled. At that unfortunate period the German firm of Godeffroy \& Sillem in San Francisco had to suspend payment owing to Meiggs' bankruptcy. In 1861 he appeared in Chile when the Railway between Valparaiso and Santiago was being constructed; but little progress had been made, and its conclusion was almost despaired of; then Meiggs took the work in hand, and concluded the road in two years and a half, six months less than the term allowed for its completion. The biography says that three fourths of the road made by Meiggs cost less than the one fourth finished before his coming. About this time J. M. 
Polar was Peruvian Minister in Santiago; he made Meiggs' acquaintance, and saw what this man was able to accomplish; accordingly, when in 1868 Polar was made secretary-general by Pedro Diez de Canseco, he called him to Perú, and a contract was concluded with him for the railway from Mejia, a port to the south of Mollendo, to Arequipa for twelve million Soles, distance 107 miles. Two or three years previously the concession for this railway had been granted to an Englishman, Pickering, and Patrick Gibson [487] of Islay, who entered into negotiations on the subject with [_] International Bank of London, which however led to no result. Meiggs availed himself of the surveys then made and paid for the same to Edward Harmssen of Arequipa, successor of his uncle William, who had been interested with Pickering and Gibson, the sum of one hundred thousand Soles. It was said at the time that Meiggs had to pay of the twelve millions, estimated cost of the railway, more or less one million Soles in bribes, to persons high in power such as: the President himself, members of his family, to the Ministers, Polar, Gomez Sanchez, Muñoz; even to our friend Don Diego Masias S/100,00o for the influence which he had with the president; these particulars of course the biography did not give. The beginning being made, and the men in power having tasted the sweets of such contracts, concessions after concessions were granted to him during the administration of Balta, viz.:

\begin{tabular}{|c|c|c|c|c|}
\hline December 1869 & $\begin{array}{l}\text { From Arequipa to } \\
\text { Puno }\end{array}$ & 217 miles & $\mathrm{S} / 25,280,000$ & Concluded \\
\hline December 1870 & $\begin{array}{l}\text { From Ilo to } \\
\text { Moquegua }\end{array}$ & 63 miles & $\mathrm{S} / 5,280,000$ & Concluded \\
\hline July 1871 & $\begin{array}{l}\text { From Pacasmayo } \\
\text { to Magdalena }\end{array}$ & & $S / 2,100,000$ & Concluded \\
\hline December 1871 & $\begin{array}{l}\text { From Juliaca to } \\
\text { Cuzco }\end{array}$ & 212 miles & $\mathrm{S} / 25,000,000$ & $\begin{array}{l}66 \text { miles } \\
\text { concluded }\end{array}$ \\
\hline October 1871 & $\begin{array}{l}\text { From Chimbote } \\
\text { to Huaraz }\end{array}$ & 172 miles & $\mathrm{S} / 21,804,000$ & $\begin{array}{l}87 \text { miles } \\
\text { concluded }\end{array}$ \\
\hline December 1869 & $\begin{array}{l}\text { From Callao to } \\
\text { Oroya }\end{array}$ & $\begin{array}{l}\text { neither di } \\
\text { not concl }\end{array}$ & ce nor cost & ven and \\
\hline
\end{tabular}

To these enormous undertakings is still to be added the contract concluded in this year with the Government, for prolonging the Oroya line as far as the Cerro de Pasco, for making a new socabon, or adit, in the Cerro on a level much lower than the present socabon and for working on his own account the ground between the two socabones. There is no doubt that Mr. Henry Meiggs had been a wonderfully enterprising, energetic, and very charitable man, but 
whether his integrity had been without blemish was a question I would not decide. Garland went at 10 p.m. to Meiggs apartments [in] [488] [_] [ho]use of [Antonio] Salinas, in front of the Concepcion, to accompany the corpse to the Church of La Merced. When he came home he told us that never before here in Lima had he seen such a concourse of people fill the streets; he estimated them at fifteen thousand.

Wednesday, $3^{\text {rd }}$ of October. This day the funeral of H. Meiggs was solemnized in the Merced. The number of people present, and those who accompanied the corpse to the pantheon was immense. The Banco de Lima had even shut up; La Providencia and El Perú, not. Within these few days died in Jauja, José R. Mendibil, port-agent of Callao, of whom I only knew that he was the uncle of Alejandro's wife, and that many years back he made a fortune - spent since then - by lucrative smuggling transactions: further, Villafañe, who though Chargé for Guatemala and Nicaragua was in Meiggs' employ. Urquhart dined with us; also Dr. Gregorio de la Rosa, to whom Enriqueta seemed to have taken a great liking. In the evening we received our correspondence by the North steamer. I had a letter from Sieveking, and another from C. W. Schutte, both dated the end of August. Juan did not write. From Sieveking I learned that he had paid on my account, one thousand Imperial Marks to Elizabeth Bobertag, who wrote to her brother Johannes that the physicians had ordered her to spend the winter in the South of Europe. Sieveking further said that his physicians had advised him to lead as quiet a life as possible, and avoid all excitement, for his heart had a tendency to become larger than it should be in its normal state. Schutte wrote that his daughter Corina was for the time with her uncle Daniel in Hamburg, where she was much admired by all her numerous acquaintance.

Thursday, $4^{\text {th }}$ of October. From Dreyfus' firm a letter from Juan, dated Axenstein $27^{\text {th }}$ August, was sent me. It was a long epistle and many pages were filled with [489] the details of the dispute between his brothers-in-law. [_] concluding, he said that this would be the last time he would write me on the subject, and I for my part had certainly no inclination to trouble myself about it.

The papers said that the Lords of the Admiralty, and Lord Derby had approved the conduct observed by DeHorsey against the "Huascar", about the end of May last.

Saturday, $6^{\text {th }}$ of October 1877 . Before breakfast I went out to the pantheon where they had not yet begun to roof my chapel with the black slate which had arrived from England a few weeks ago. In the large chapel in the cemetery two small rooms to the left on entering were thrown open; the first was transformed 
into "une Chapelle ardente": in the centre stood a large coffin covered with black, that of Henry Meiggs; at each corner of the same, a funeral lamp, consisting of burning spirits of wine; two persons in black were at the time strewing flowers. In the second small room stood an altar, and a clergyman was saying mass. When reaching my house I found the street door locked, and outside and inside, hundreds of poor people, mostly women, who expected to receive, and actually did receive, some alms, one or two rials each, from the executor of Meiggs, whose testament had yesterday been opened. There was a continual talking and buzzing; they swarmed up our stairs, and with difficulty could we keep them from our corredors. Thermometer in my office at noon, nearly $76^{\circ}$ F. In the evening Enriqueta and Garland paid a visit to the President and his lady. Ricardo read to me for some time the German book sent me by Sieveking, which contains much information, but is dreadfully heavy.

Sunday, $7^{\text {th }}$ of October. At 7 a.m. I started with Antonio for an ascent of San Cristoval, which I accomplished, slowly, but without any fatigue. The sun was not out. We were back by 9.30, when I lay down, and slept a little. I dictated to Bryson my usual letters to Juan, and to Schutte, and paid but a few visits for it was as late [_] [490] [...] away. Whilst I was with Doña Dolores Puente, the Columbian gentlemen, of whom I have spoken several weeks ago, entered to say farewell, as he was in the point of returning to the town of Cali. At Dr. Alvarez' the ladies received me with their usual amiability. Doña Antuca, the eldest daughter of the present Minister, Manuel Morales, was also very agreeable, but appeared to me to be extremely sad. My fourth call was upon the Basagoytia's. At dinner Urquhart was with us, and in the evening Federico Palacios looked in, so that the time passed pleasantly enough. To Urquhart, Enriqueta wished to shew a book with beautiful engravings of the virgens, painted by Raphael, of which, several years back, Dr. José Gregorio Paz-Soldan had made a present to my wife. I fetched it and to our sorrow we found it to be completely worm eaten.

Monday, $8^{\text {th }}$ of October. Thermometer at noon $75^{\circ} \mathrm{F}$. In the course of the forenoon I did not take my usual walk, but occupied myself with examining a considerable number of books in my library, of which fortunately, not a single one was worm-eaten. Dr. Lührsen, the German Chargé, called to see me, and to return Enrique's consular visit. The architect Tomas Davila brought his estimate of Juan Aliaga y Puente's house 11 and 13 Polvos Azules, which he valued at $\mathrm{S} / 7826$.

Enriqueta was once more in bed with her migraine and thus the few hours from 8.30 p.m. till near 11 when I went to bed, I passed in a most tedious manner. Enriqueta was asleep. Garland had gone out; Limpricht was not in 
his room; and what Ricardo read me from a German Review was as tiresome as well could be. In the church of Guadalupe the French, resident in Lima, celebrated this day the exequies of the late A. Thiers.

Tuesday, $9^{\text {th }}$ of October. This morning at 2 O'clock the shock of an earthquake was felt, which however did not awaken me. [491] In the forenoon a meeting of the Directors of the Insurance Company Lima had been cited; when I went, I found Chavez and Gil, and as nothing of importance was to be transacted we gave our opinion on what Elizalde laid before us, who afterwards procured those of the other Directors. In the suit against Juan Aliaga Dr. Palacios had forgotten to present an escrito de rebeldia, which he ought to have done, previous to Davila's estimate. I presented it to-day, and he was certain that this oversight would by no means affect the due progress of my claim.

Wednesday, $10^{\text {th }}$ of October 1877 . Yesterday the archbishop gave a dinner party to the Papal Delegate, Moncenni, lately arrived. A delegate ranks next after a nuncio. The Panamá Star and Herald of $2^{\text {nd }}$ October said that the railway from the capital of Mexico to Vera Cruz had cost 37,702,00o Mexican Dollars, that last year's gross revenue, came up to $\$ 2,000,000$, and the working expenses for the same period to a trifle more than $\$ 1,800,000$. In the course of the forenoon I walked to the Penitentiary, and outside the town to the Hospital del 2 de Mayo; thence to the Chacra Manzanilla where I remained but a few minutes, for Antonio Bazo, of whose illness I have spoken more than once, had become worse from day to day, so much so that his sister Pepa and his brother Juan had continually to attend to him and had no time to spare for an idle visitor, as I was. Don Antonio had always to sit in an arm-chair, for a postrate position was impossible to him, owing to the difficulty of breathing, and from the arm chair he could hardly rise.

The judge Quiroga decreed that the rebeldia should be notified to Juan Aliaga y Puente. Mercedes Villacampa, wife of Federico Palacios, dined with us; in the evening her husband came. He was a decided friend of Manuel Pardo, belonged accordingly to the civilistas, and was secretary of the club of San Lazaro, of which Col. Manuel Velarde was the chief. He assured me that in the Municipality they had hither[to] [492] [...] single carta de ciudadania to such as they suspec[_] to belong to the Civilistas; they were even stopped on the stairs and not allowed to enter the apartments.

Thursday, $17^{\text {th }}$ of October. The papers said that one of the objects of the papal delegate's visit to Lima was the suppression of some of the convents.

The German Book, Priscilla, read to me by Ricardo is crammed with Jewish learning, very erudite, not interesting. I learned from the same that five Roman Miglia were equal to one geographical, or German mile, and that 8 Stadia made one miglie. The Coliseum was commenced under Vespasian, and concluded 
under his son Titus. Pliny has said somewhere that in the Circus Maximus of which I speak in my remodelled diary $\mathrm{N}^{\circ} 3$ pages $4 / 233$ there was room for 250,000 people, which I look upon as a most ridiculous exaggeration.

Part of Henry Meiggs' testament was published in the papers; he had named a commission for the purpose of carrying out the contracts concluded between him and the Peruvian Government. This commission consisted of Charles Watson, President; with a salary of S/2000 monthly; Meiggs' two sons, Enrique and Minor; his son in law Alexander Robertson; Jacob Backus; and W. H. Cilley; these five with a salary of S/500 monthly; Dr. Francisco Garcia Calderon was to continue their lawyer.

Friday, $12^{\text {th }}$ of October. Before breakfast I walked to the pantheon; they had not yet begun roofing, but the inside ceiling made of cedar wood was very prettily worked. This day was fixed upon for the public sale of the premises belonging to the Convent of San Francisco, of which Enriqueta had had the lease for a number of years. The sale was for 150 years, and the friars of the convent had opposed themselves to it, but been cast in the Supreme Court. The sale was to be effected before the Juez de $1^{\text {a }}$ Instancia, M. A. Puente Arnao, and in conformity with Enriqueta's [493] request immediately after breakfast I went $[\ldots]$ Dr. Puente Arnao under pretence of asking his advice; but in reality for the purpose of inclining him favourably to Enriqueta. He received us both very politely.

At 12 the sale commenced, and the judge fixed ten minutes to two for the term when it was to close. Alejandro went for his mother; besides him there were but few bidders, one of whom, the broker Martinez. The conditions which served as a basis were $S / 1400$ Landeño, which means the sum to be paid immediately to the convent, and S/40 canon, or monthly rent; the latter was driven up to $S / 68$, the former to $S / 2800$, by Martinez to $S / 2900$ at about half a minute before the hour fixed upon by the judge, say 1.50; by Alejandro to $S / 3000$; to $S / 3100$; Martinez at the same time $S / 3100$, but the notary Garcia declared that it was Alejandro who had been the last bidder, and that Martinez's bid had come too late. Bryson had again a slight attack of fever and ague which prevented him from coming in the evening. After dinner I sat a long time in the corredor, multiplying in my head, but without coming to a result. At past 8 Enriqueta joined me; then came Limpricht, and the hours till bed time passed away pretty quickly. Garland was in the palace playing rocambor. My to-day's remittance to Juan of $£ 350$ cost at 21 pence $S / 4000$; a year back I got for S/4000 $£_{500}$. Exchange by this steamer fluctuated between 20 and 200 3/4.

Saturday, $13^{\text {th }}$ of October 1877 . The tertian fever obliged Bryson to leave at 3 O'clock. I went to the exhibition park where I walked about in every direction, and lost my way, as I had done more than once before. When I at last reached 
a gate, I had to take a cab in order to reach my house in time for dinner. In the evening Ricardo read to me Priscilla and Sabina, but only for a short time for he did not admire it.

At as early an hour as 10 I went to bed.

Sunday, $14^{\text {th }}$. In the forenoon Bryson indexed the diary of 1867 . There was this day a great gathering $[\ldots][494][\ldots]$, they were to unite in various parts of the town and then to march in a long procession to the Plaza de Acho. Guillermo, Alejandro, Geraldo and Antonio took part in it; once or twice they had their scuffle with the Nacionales, and a good many shots were exchanged, but few were wounded. I intended to give an exact account as soon as I found it published in the papers. I went to see the family of Rafael Velarde, and of Dr. Ribeyro; various others upon whom I called had gone out. At dinner we had Urquhart and Limpricht; with the later I walked the corredor till nine, went to the salita, and separated at eleven.

Monday, $15^{\text {th }}$ of October. Garland was very unwell in the evening and went to bed at an early hour.

Tuesday, $16^{\text {th }}$. The "Comercio" and "Nacional" of yesterday both decidedly in the interest of the Civilistas, said that the number assembled on Sunday last came up to between seven and eight thousand. The junta directiva, consisting of Manuel Costas, President; J. J. Helguera, ex-minister; José Unanue; Ramon Ribeyro; Manuel Candamo; and a great many other civilistas, had assembled at about 12.30 in the first house on the left side, at the corner of the Plazuela of Santo Domingo; they were first insulted, then attacked by a small number of Nacionales, who fired into the saloon, where they were, the pupils of San Carlos or San Fernando rushed out with revolvers, and drove back the Nacionales. They then marched to the Plazuela before the theatre where the clubs of the different parishes were assembled; at about two they put themselves in motion; at the head, the junta directiva, Manuel Costas, wearing for a wonder a black hat, the very first; next, a number of gentlemen belonging to no club; the pupils of San Carlos, those of San Fernando, the club of topographers, 11 Clubs of El Sagrario, 10 of Santa Ana, 4 of San Marcelo, 5 of San Sebastian and 13 of San Lázaro. The route they took was through the streets of Lescano, Espaderos, Mercaderes, [495] Mantas, Pozuelo de Santo Domingo, and Corre[?], when a $[\ldots]$ corner of the Plaza they were again attacked by Nacionales, shots were again exchanged; even from the balcony of the Municipality revolvers were fired and stones thrown. After a short fight they pursued their march along the Calle de Palacio, and over the bridge, when some Nacionales endeavoured to stop them, but were kept back by mounted soldiers. The clubs of Santa Ana, when entering the Calle de Palacio, were broken through by Nacionales and soldiers. When all had reached the Plaza de Acho, speeches were delivered by Manuel Costas, José de la Riva Agüero; Carranza, editor of the Comercio; 
Ricardo Espiel, and others. An individual belonging to no party whatever coming out of the Church of Santo Domingo was wounded in the belly, and was likely to die. A coachman, French by birth, had been wounded in the head. Besides these, eleven of the civilistas had been hurt, none dangerously, one of the Nacionales was said to have been killed, several wounded.

The judge Quiroga had decreed that the architect Tomás Davila's valuation of Juan Aliaga y Puente's house 11 and 13 Polvos Azules was to be made known to the parties interested who within two days after the notification had to make their observations, if they thought proper to make any. I was notified at about 5 p.m. in Escobar's office whither I went nearly every day to see how the suit was going on.

Wednesday, $17^{\text {th }}$ of October 1877 . At noon, sun not out, thermometer $76^{\circ} \mathrm{F}$. Juan Aliaga was notified this day. One of the men wounded on Sunday last died, and the Nacionales had his funeral solemnized in the Merced, with the object of making something like a party demonstration. It was also apprehended that on their return from the pantheon outrages would be committed; however, nothing of the sort occurred and the town remained quiet; moreover; the deceased belonged to no political party: he had been struck when coming out of the Church of Santo Domingo, as above said.

Thursday, $18^{\text {th }}$ of October. Juan wrote from Paris that [496] [_] [residence] in the baths of Germany had done him no good and that he felt extremely weak. The advices from the theatre of war were very difficult to be understood. The following however was certain: that the Turks were strongly fortified near Plevna, to the South of Nicopolis, and that the repeated assaults of the Russians had been beaten back with great slaughter; secondly, that the Russians were in possession of the Shipka Pass in the Balkan, from which the Turks could not expel them. The Leipzic Gazette spoke of the extraordinary aggrandizment of the British territory in South Africa. It was stated that it now extended from $35^{\circ}$, the latitude of Cape Town, to $22^{\circ}$ South latitude, which includes Natal, the orange Republic, and the Transvaal territory. Here in Lima we had the arrival of Charles Eggert, formerly partner of Gibbs, at present in the employ of the London Peruvian Guano Company Ld., with an annual salary of, it was said £500o. It was supposed that he had come hither to make proposals to the Government, both for the Nitrate and the guano business. At about 10 p.m. a group of 80 more or less, drunken Nacionales, preceded by some musicians, came along the Aldavas street, stopped before the house of Cox, before ours, and Ayulo's, and proceeded to the Plaza de la Inquisicion, vociferating continually, "abajo la argolla, muera la argolla canalla".

This day the Papal Delegate, who bore also the title of Envoy Extraordinary, was formally received by the President. 
Friday, $19^{\text {th }}$ of October. In the course of the forenoon I walked out to the pantheon, where they got on very slowly with the construction of my chapel. I also went to Gibbs' house, where Böhl told me that the whole day long Eggert was occupied in Canevaro's office; I therefore, returned at about 9 p.m., when I found Eggert, Böhl, Polis, head of Isaac's house, and Dr. Middendorf playing at billiards. Eggert was very friendly. I conversed with the one and the other, took tea, and was home by 10 O'clock. [497]

Saturday, $20^{\text {th }}$ of October 1877. A very hot day. When [_] went to the office of the notary Escobar, an escrito of Juan Aliaga y Puente, in which he manifested his disatisfaction with the valuation of his finca made by Davila, together with Judge Quiroga's decree "traslado" was notified to me, and this I took to Dr. Palacios, who without loss of time dictated an escrito in which he said that I would be satisfied with any valuation which Aliaga might put upon the house 11/13 Polvos Azules, and on my enquiring what was the object of his expressing himself in this manner, he answered: "If Aliaga puts a low valuation the house will be sold, and you at least be partially paid; if he puts a high valuation then perhaps the house will not be sold because the law requires that the public sale fetches at least $2 / 3^{\text {rds }}$ of the valuation, in which case we demand an amplification of his guarantee, and have a right to fall upon his valuable house Calle de Palacio." The Prefect made known that on the following day no one would be admitted to the mesas, or scaffolding in the different public places of Lima where the electors have to give in their votes, before 10 a.m. and thus we would not have the usual scuffle in the first hours of the day.

Sunday, $27^{\text {st }}$. The day fixed upon for the commencement of the elections of the electors who had to choose the new Senators and Deputies for the Congress of $28^{\text {th }}$ July 1878 , not of all, but of the third of the members who had gone out by rotation. Already at 6 a.m. I was awakened by the shouting of some Nacionales who passed our house. At 12, the greatest tranquility prevailed in the town; all the street doors were shut and hardly any one was to be seen in the streets. Bryson remained till near 2, from which hour till 4, Ricardo read to me. Urquhart dined with us. Alejandro, Guillermo and Geraldo, had not come in from Chorrillos; I did not go out the whole day. The Patria published a loose sheet which made known that the Nacionales had it everywh[_] [498] [_]way, that the mesas in the five parishes of Lima had been taken possession of by their leaders, and that the Civilistas did not show themselves amywhere. In the Sagrario for instance General La Cotera was President and the Alcalde José Pedro Saavedra one of the "escrutadores".

Monday, $22^{\text {nd }}$ of October. When I went out at somewhat past twelve, the tribunals were open, and I flattered myself that the day would pass over 
quietly; however, hardly had two hours elapsed when a great number of shops were closed, and when many street doors stood only half open. The civilistas, who had tried to form "dualidades", that is to say, separate mesas, where they intended to elect their own friends, were prevented from doing so, both in the Plazuela de Santa Teresa and that of the theatre; everywhere they were assaulted, and overcome by the Nacionales, who, protected and assisted both by the military and the police forces, had the upper hand. The tribunals shut up at 1 O'clock. Before dinner I took a walk through the town, where I found everything quiet, but as already said, not many shops and street doors open.

Tuesday, $23^{\text {rd }}$ of October. The Nacional of last night, though it could not conceal the fact that the civilistas had been overpowered and persecuted over since the night from Saturday to Sunday last, affirmed that yesterday in the parishes of San Lazaro and San Marcelo, they had succeeded in establishing a separate mesa and in electing the electors of their party. If this paper was to be believed in the smaller towns in the province of Lima the Civilistas had generally got the better of the Nacionales.

The day passed over more or less like the previous one; here and there there were scuffles and fights between both parties, in which, except in the parish of San Lazaro, where the tabladillo was placed in the open place before entering the Alameda de los Descalzos, and where Federico Palacios was the prime leader, the civilistas were always defeated. Nevertheless, the elections continued on both sides; there would [499] be in every parish a dualidad, and the Congress would [_] to decide who were truly and legally elected. The tribunals were open, but my escrito given in last Saturday was not dispatched by Dr. Quiroga. At 2.15 I was in the office of the Chilete Mining Company, but had to wait till three, before a sufficient number of shareholders were together. Present were: Malinowski, President; Derteano, and Rafael Canevaro, which three formed the Directory; José Vicente Oyague, Ruden, and I; opposite to us, Cudlip, J. P. Escobar, and M. G. Chavez, perhaps two or three more whom I did not know.

Malinowski read his informe, which was based upon that of the Polish engineer Babinski, dated $2^{\text {nd }}$ October, who gave it as his opinion that with a new outlay of thirty thousand Soles the company would be placed in such a condition as to be able to produce daily ten tons of ore, worth per ton $£_{21}$ consequently the year of 300 days would give $£ 63,000$ annually equal to, at $44 \mathrm{~d}$ per silver sol, S/343,636 from which deducting expense $2 / 3^{\text {rds }}, S / 222,090$ would leave to the shareholders annually $S / 114,545$, which, if all this were true would no doubt be a splendid result upon an original capital of $S / 500,000$ of which $\mathrm{S} / 340,000$ were actually paid in for the remaining 160,000 Soles, or $S / 60$ shares 
had been conceded to the owners of the mine. Now Malinowski said that as the last loan of 10,00o Soles had first to be paid off, in conformity with the then made agreement, and in order to be prepared for all extra expenses, he thought it prudent to raise the sum to 60,000 Soles, which sum, being properly invested, he was confident that all previous debts, especially a heavy one to Canevaro and Candamo would quickly be paid off and the shareholders receive erelong a handsome dividend. How was this money to be raised? After some discussion Oyague's proposal was approved, viz.: to issue bonds, the amount of each to be determined by the directory in Soles of the present paper currency, with $1 \%$ monthly interest and to be repaid at the exchange of $48 \mathrm{~d}$ out of the first net [_] [500] [_], after the last $S / 10,000$ and all previous debts we[re] paid off. The general opinion was that on such favourable terms the amount wanted would be brought together amongst the shareholders.

Several years back a Chilian called Tomás Solar Reyes, son-in-law of Dr. Carbajal, was the owner of some copper mines which went by the name of Canzas, four leagues to the east of Ica; when the money failed him to continue the work he applied to Henry Meiggs who furnished the funds and in course of time Solar was bought out, and Meiggs remained sole owner. Shortly after he admitted a certain Solari in the business, who was to administer the mines; however after his death when they fell into the hands of his son Minor, he Minor, could not agree with Solari, paid him a sum of money, cancelled the contract made by his father, and standing now in need of some other person to work the mines, made an agreement with Guillermo Garland to the effect that he ceded to Guillermo $25 \%$ of the mine, and Guillermo took upon himself the administration of the same. He was now about starting for his new post.

Wednesday, $24^{\text {th }}$ of October 1877 . Thermometer at noon $77^{\circ} \mathrm{F}$, a great heat for the present season of the year. Judge Quiroga decreed, not as I had expected, "traslado a Juan Aliaga y Puente", but "traslado al perito", who - the architect Tomás Davila, Junior - was now to give in his reply. This being San Rafael, the Saint's day of Rafael Velarde, Garland, Enriqueta, and the two little girls dined with him. I went in the evening to congratulate him and found a great many people, mostly employés of the Callao Custom house, whom I did not know, also Melchor Velarde, wife and three daughters. Before 10 O'clock we walked home.

Thursday, $25^{\text {th }}$. This morning it had rained a good deal, the sky was cloudy, and the temperature cooler. Thermometer at noon $75^{\circ} \mathrm{F}$. [501] I saw by the Nacional that a Japanese vessel with [...] of rice had arrived in London after a voyage of 141 days from Yokohama round the Cape of Good Hope.

The same paper gave the following news, to which I gave little credence. A submarine tunnel was about to be constructed from Algeziras in Andalusia 
to the opposite African Coast; its length was to be nine English miles, and the lowest part it had to reach below the level of the water 3300 feet, its cost $£ 4,000,000$, its incline $1 \%$. In the first place, where was the money to come from? In the second the American Encyclopædia says that at Gibraltar, where the straits are narrowest, the width is 15 miles, and in the third, 9 English miles are equal to a trifle more than 47,000 feet; consequently, to reach a depth of 3300 feet the incline is more than $12 \%$, because this greatest depth is to be reached half way.

The elections both of the Nacionales and Civilistas went on pretty quietly. I was told that the latter had no scaffolding, but only a table with a few chairs, which they placed, sometimes in the one, sometimes in the other open place, and with which they decamped at the approach of danger.

Friday, $26^{\text {th }}$ of October. Again a cloudy morning. Thermometer at noon $74^{\circ} \mathrm{F}$. I walked out to the pantheon where they had not yet made a beginning with the roofing of the chapel. In the evening Enriqueta and I had a very agreeable visit form Charles Eggert and Alfred Böhl, who took tea with us, and remained till past ten. Garland had gone to the Pintos, who had just lost a grown up son from consumption.

Saturday, $27^{\text {th }}$ of October. Once more a cloudy morning, Thermometer at noon $76^{\circ} \mathrm{F}$. The papers made known that in the present month of October the Russians had gained a great victory over the Turks in Asia; that the elections in France for the Chambers had ended, and that the result had been the complete victory of the Republicans 315 of their political creed, and 199 Monarchists having [_] [502] [_]en; and thirdly, that the firm of Alex. Cross \& Co, of Valpa[_] had stopped payment; drafts of theirs to the amount of $£ 99,000$ had been returned from London under protest, I should think for nonpayment, though this was not said.

By this steamer the exchange on London had fluctuated considerably; at first, first-rate bills such as Gibbs' and Graham Rowe \& Co.'s were sold at $22 \mathrm{~d} 1 / 2$. Then the Banco Nacional made known that they sold Government bills at 21. Bills drawn by the delegates of the banks were also in the market to a considerable amount and thus the exchange closed at $22 \mathrm{~d}$.

Within this last week and even in the previous one sales both in shops and stores had been insignificant owing to the disturbances caused by the elections, and thus the amount of cash in the hands of the usual takers of bills was less than on other occasions, which might also have contributed to the fall in exchange. Coined silver was at about 90\% premium; bar silver 20 to S/20.20 per mark. Bills on Valparaiso 100\%, on United States 125\%.

Sunday, $28^{\text {th }}$ of October. By this day's steamer George Elster and Peter Gallagher embarked for San Francisco, their object being to engage Chinese labourers 
for the working of sugar estates on the coast, the owners of which began to feel the want of labourers, for the contracts of the Chinese gradually expired, the free Chinese would not, or did not work as they did when forced, and the importation of Chinese had ceased for some years. The negro population was fast decreasing, and indians could not stand the climate of the coast.

This was the last day of the elections, and it was feared that it would not pass over quietly; the police however took the necessary measures, strong cavalry piquests rode through the streets, and everything remained tranquil. Horse races were held at the new race ground at which the President was present. I made a few calls. Limpricht [503] came about 9 p.m., Garland and the little girls had gone to the palace, and at the usual hour, about eleven, I retired to rest.

Monday, $29^{\text {th }}$ of October 1877 . It became known that yesterday morning whilst Elster and Peter Gallagher, with a few friends who accompanied them to Callao amongst whom John Gallagher, Rufino Echenique, Enrique Carrera, clerk in the Banco Hipotecario - were taking their breakfast at a certain Contreras' who lived in the altos of Higginson's house, they were fallen upon by a gang of ruffians who called themselves "Nacionales", cargadores of the Custom house, they were fired at, escaped to the roof, taken prisoners and carried to the arsenal; after a short detention they were placed at liberty, but not gratis. In Contreras' house many valuables were stolen. John Gallagher saw the president on the race ground, and laid his complaint before him, who seemed to be but little affected by the narration. This day the Civilistas concluded their elections in the locality of San Carlos, with closed doors. The tabladilla in the Plaza de Armas was still occupied by the individuals who formed the mesa. Strong patrols of cavalry rode through the streets of the town in every direction. On my going at about 5 O'clock from the justice hall to Dr. Palacios' office I passed the house of Don Buenaventura Elguera whence military music resounded, and where at the street door, as it had been the case for several days back, ten or twelve men of the lower classes were lounging. At about 9 in the evening we heard a noise in the street, and saw a small band of the Nacionales who came through the street of Aldavas, and went to the printing office of La Opinion Nacional, a paper in Pardo's interest, situated in the Calle de San José. Finding the street door locked they threw stones at it and marched off.

Tuesday, $30^{\text {th }}$ of October. This morning I saw some policemen guarding this printing office. At breakfast it was [504] [_] that last night's gang before coming to our street ha[_] forcibly entered the printing-office of El Nacional and done great mischief; they had tried the same at the office of El Comercio but were received with a discharge of revolvers which killed one, and wounded four or five of them. When passing the Club de la Union, at the corner of the Plaza, 
considered to be a meeting place for the Civilistas, they threw stones at the windows and against the street door. The Comercio and El Nacional were papers entirely devoted to Pardo's party. La Patria was the organ of Dreyfus, La Sociedad of Pierola. Government was represented by the official paper El Peruano.

Wednesday, $33^{\text {st }}$ of October. The individuals who on Saturday last were so illtreated in Callao, had instituted a criminal suit against Emilio Charun, the leader of the gang, for an attempt at homicide. The escrito was signed by Juan P. Gallagher, Rufino P. Echenique, Florentino B. de Tristan, grandson of Don Pio, last viceroy of Perú, Javier, son of Thomas Conroy of Callao, Enrique Carrera, Juan Vallarino, and Manuel Alvarez Calderon, brother-in law of Manuel Candamo.

Of late the Government had issued a decree promising a remuneration of $S / 10,000$ for the best drama on the subject of the Peruvian Independence, written by a Peruvian, and to be presented on the $28^{\text {th }}$ July next.

The exportation of coined silver was prohibited, and strange to say, I myself had signed the policy of insurance for S/10,00o in coined silver, shipped by order of the Government on board the steamer via Panamá to St. Nazaire, which money went to Juan Mariano Goyeneche y Gamio, of Paris, for the purpose of paying the expenses which would be incurred at the Exhibition of next year for Peruvian produce, and objects of Peruvian industry. This day S/300,00o in paper money, were again burned in the Plaza Mayor.

Thursday, ${ }^{\text {st }}$ of November. All Saints. A great part of the [505] forenoon Bryson and I were occupied with revising my old diary; we were now as far as July 1868. When he was gone Limpricht and I played two games at chess, which I had not done for about ten years, and I felt that I was out of practice. I lost the first, and gained the second game. Whilst we were playing, Pratolongo, Chargé for one of the small Central American Republics came to return Enrique's official visit; at his request I introduced him to Enriqueta, upon whom called afterwards M. F. Benavides and General La Puerta. I had a visit from Dr. Dorado. From 5 to 6 I took a walk to the Alameda. In the evening we had with us Rafael Velarde and family, and Urquhart. More than 15,00o tickets were given out this day on the Oroya Railway for visitors of the pantheon.

Friday, $2^{\text {nd }}$ of November 1877. All Souls. I went out before breakfast to the pantheon; my chapel, which I had feared, might have been somewhat damaged by yesterday's crowd had fortunately not been touched. The overseer told me to my surprise that he had again received orders to stop any further work. He, a dark sambo, poorly dressed, asked me whether I should like to see the mausoleum of his own family; he was, he said, a son of the late Santiago Lanfranco. I descended to the small vault, very airy. Here were entombed 
Don Santiago, and his father and mother-in-law Pio Tristan, and Joaquina Flores Tristan. Before the niche of my dear Mariquita hung a garland of fine flowers which Enriqueta had yesterday sent thither by Virginia. A great many niches were adorned in the same manner. Notwithstanding the early hour the cemetery was filled with people of all descriptions, and for some distance the broad footpath leading from Maravillas Gate to the entrance was lined with tables where sambos and sambas were selling cold provisions, chicha, brandy, and similar eatables and drinkables. By the North steamer I received letters from Juan and Schutte both long but without [506] anything of particular interest.

In Valparaiso another stoppage had occurred, that of the bank of David Thomas son-in-law of Thomas McLaughlan who belonged to the knot of foreigners who came to the intermediate ports shortly after the declaration of Peruvian independence.

Saturday, $3^{\text {rd }}$ of November. I learned this morning that last night there had again been a row in the streets. In the portales, Larco, and a certain firm of Thoel \& Co., Germans who did business in thread, ribbons, etc., had kept their shops open after six in opposition to the agreement entered upon by the retail dealers to shut up at this hour; to which however Thoel had not affixed his signature. A number of clerks of the other shops and stores assembled, were joined by some of the Lima rabble, hooted, whistled, and threw stones. Thoel denounced to the police office a considerable number whom he had recognized, and these were this day cited before the Intendente. The Nacional said that on the $10^{\text {th }}$ September, in the town of Santo Domingo Island of Haiti the discovery of a box containing the mortal remains of Columbus was solemnly authenticated and celebrated, whilst according to the North American Encyclopædia he died on the $20^{\text {th }}$ May 1506 in Valladolid, at the age of 70 and in conformity with his will his body was carried to the town of Santo Domingo, but in 1795 when Hispaniola was ceded to the French, transferred to the Cathedral of Havana. Where the truth lies I cannot say.

Sunday, $4^{\text {th }}$. Last nights Nacional published the copy of a contract between the Government and some individuals, "La Compania Fluvial Peruana", which contract was to last for fifteen years. The government paid a subvention of $£ 2000$ and sold to the company four steamers already existing on the river, at the prices hereafter to be fixed, and the company bound itself to establish three lines of Steamers, the one as far as Pará on the Amazonas. [507] When Manuel Pardo was last in Arequipa, he, then Presi[_] of the Republic, gave the verbal promise that to the reconstruction of the portales round the Arequipa Plaza, destroyed by the earthquake of 1868 , the Government would contribute one third. The cost of the rebuilding was valued in 156,00o Soles and the 
Government in Lima had now ordered that the Arequipa treasury was to pay the one third promised by Pardo. Where was all this money to come from?

The Nacional further said that the celebration of the last jubilee ordered by the Pope had brought into the chest of the Holy Father the enormous sum of sixteen million francs. In former times the Nuncio of the Pope had always had precedence of the Diplomatic agents of other nations. Now that the Pope had ceased to be a temporal prince and the Peruvian government had admitted the Pontifical Delegate lately arrived, as if he were the envoy of a temporal power, many, if not all, of the diplomats resident in Lima, had enquired of their respective governments, whether they were as heretofore to consider the Delegate as the Senior of the diplomatic body.

As we were likely to remove to Chorrillos erelong I thought proper to give a short account of the manner in which of late I had been in the habit of spending my time; seldom did I rise before eight; sometimes I took a walk, regularly once a week to the pantheon; sometimes Ricardo read to me the German book sent by Sieveking. In my last letter to him I compared my listening to the reading of the same to wading through a heavy sandy road, lined with stately edifices, without a single pretty cheerful view. We breakfasted at somewhat past ten. Bryson came at eleven; the revising of the old diaries was a pleasant occupation which took up an hour and a half; then I had to absent myself for 2 or $21 / 2$ hours to allow Bryson leisure to copy. This was a heavy time for me. I looked in at the insurance company Lima, walked to the Alameda, or, if the temperature was too hot, remained at home without knowing what to do with myself. From 4 to 4.30 we now read the first volume of my diary of [508] [...] which, though often flat and insipid contained how[_] many a paragraph, and more than one description worth preserving. From 4.30 to 5.30 I went to the notary and the lawyer, whensoever my presence was required there. We dined at about 5.30. From 7 to 8.30 Bryson was again with me. For a long time we had been reading Motley's United Netherlands which, though interesting, is almost too detailed. We had now come to his description of the Expedition of the so-called Invincible Armada, of which we were making an abstract to be copied in clean hereafter.

The time before going to bed at 11.30 was generally very tedious, and I then missed my dear wife more than ever. Enriqueta was an excellent creature, but of course we had not always new topics to speak about, and Garland, as is well known, was beyond measure taciturn, nor am I myself a great converser. Limpricht who now and then breakfasted with us occasionally looked in at about 10 O'clock and I was always glad when he did so. On Sundays and holidays Bryson left off at about 2 p.m; on Sundays he did not return in the evening; when he was not with me Ricardo frequently read to me; from 2.30 to 5 on 
these days I kept up my old habit of making visits, because it was necessary to preserve my acquaintances.

The shareholders of the Banco de Lima were convoked to a meeting at 1 O'clock. I went half an hour later and was one of the last comers, they had already commenced calling over the names. I took my seat opposite the President of the Directory, Heudebert. To my right I had Dr. Pró, to my left, a person unknown to me. More than two thirds of the shares were represented. Aurelio Denegri read in a loud and distinct voice the report drawn out by him and M. G. Chavez, which made manifest that of the bank liquidated, which they recommended, there was every probability of the liquidation producing $68 \%$, leaving thus a loss of $32 \%$ on the original amount invested. Cardenas as usual was the first to [509] speak, and after a great deal of useless talk the liquidation was voted by all except Derteano and Felipe Salaverry. Next, when was the liquidation to begin. The majority fixed upon the $2^{\text {nd }}$ January of next year; the minority, with which I voted, was of opinion that the liquidation should be deferred till a later date. Then the question was discussed, who should be the liquidators. I proposed that three remunerated liquidators should be chosen from the whole body of shareholders. Pratolongo seconded me, making however the alteration "without remuneration". Others declared that it was against the statutes, which said that in case of liquidation the Directory must liquidate. Cardenas took my view of the question, and after a long discussion a considerable majority voted against my motion. In fact it was quite indifferent to me whether it passed or not. Aurelio Denegri proposed a postponement, which though opposed by Cardenas was agreed to, and we were cited to meet again on the $18^{\text {th }}$ November. Limpricht who dined with us told me for a certain fact that the negotiations carried on in Europe between Raphael and Dreyfus had been broken off, and that Dreyfus would not take the guano consignment. Raphael and their friends, he said, found that they could not continue to accept and pay the Peruvian Government's drafts, as they had done hitherto, for their sales were, and would be, inconsiderable as long as Dreyfus sold a better quality of guano than that which they received. It was rumoured that Pierola had once more landed in the south of the Republic.

Monday, $5^{\text {th }}$ of November 1877 . Nothing worth noticing. Bryson had again the fever, and did not come in the evening; instead of him Ricardo read to me the heavy letters of Priscilla.

Tuesday, $6^{\text {th }}$ of November. Weather very warm. Thermometer at noon $77^{\circ} \mathrm{F}$. At 1.30 Chavez, Vice President, Robertson, Gil, Mathison, and I were assembled in the office of the Insurance Company Lima, together with the Gerente Carlos Elizalde. We rejected a proposal to insure $S / 70,000$ on a [510] [_] deposit in Callao, and after a pretty long discussion at the earnest request of Elizalde, authorized him to invest $S / 50,000$ in the purchase of nitrate certificates which 
were up to par, or even $1 \%$ premium. Elizalde apprehended that as the Banco de Lima was about liquidating, the S/90,00o which that establishment owed the company would be returned erelong, and that in this case he would have some difficulty in placing the money on good security.

Wednesday, $7^{\text {th }}$ of November. I went out to the pantheon where they had begun roofing the chapel with the black slate come from England. The inside of the building was so airy and roomy that one might actually live in it; the altar was rather small. The Nacional said that last night more than one shop had been open in the portales after 6 O'clock. In the evening Enriqueta went out to pay some visits. Garland went to the palace, and I sat by myself in the corredor till nearly ten when Limpricht joined me and afterwards read to me in German an article on Emilio Castelar whom the writer represented as the most upright and disinterested of men. After having been for some time minister of state in Spain, he descended from his post as poor as when he was appointed, and to secure his livelihood resumed his literary labours; he was an accomplished orator, and to his beautiful and flowery speeches, friends and foes listened with undivided attention, but when searching for the kernel enveloped in this mass of words, if any was found, it was insignificant and of little value. His writings, of which I had seen years back specimens in the Nacional, were of the same description; pompous; inflated, and of little real meaning. Amongst the Spanish politicians he belonged to the party of the men of progress, whilst at the same time he was an uncompromising adherent, and defender of the dogmas of the Catholic faith. How progress and such belief can go together I did not understand.

Thursday, $8^{\text {th }}$ of November. A few days back H.B.M's [511] corvette "Osprey" entered the port of Callao, and did not f[_] a salute though the President of the Republic was being rowed about in the bay; this was noted by some of the daily papers, whereupon Mr. Graham, the British Chargé, presented himself to the Minister for Foreign affairs, and explained to him that the captain of the corvette had not known of the President's presence, and that even if he had known, the corvette did not carry sufficient guns to fire a salute.

The Nacional said that in the course of the five days from $31^{\text {st }}$ October to $4^{\text {th }}$ Novr. incl., the 30,500 tickets had been sold on the Oroya railway to and from the pantheon; also that in Rome some admirers of Columbus had made an attempt to have him canonized, which the Pope had refused to do. Rumours were again afloat here in Lima of Nicolas de Pierola's reappearance in the South; according to some he had landed in Arica, according to others in Pacocha.

Friday, $9^{\text {th }}$ of November 1877. Troops were said to have been embarked in Callao last night for the South. Carlos, one of Pierola's brothers had been arrested. 
Saturday, $10^{\text {th }}$. Thermometer at noon $77^{\circ} \mathrm{F}$. This day Alejandro returned to me the $\mathrm{S} / 32,000$ which I had lent him nearly 18 months ago when he commenced the suit against the Banco Garantizador. He had now decidedly gained, but I was not quite sure whether the whole amount was already in his possession. Nearly half of it they had managed to scrape together in rials and two rial pieces. The premium was about $93 \%$ and Alejandro would thus make a large profit, though his expenses in carrying on the lawsuit had also been great. The bank now threatened him with a causa ordinaria, for the result of which I had given my guarantee. I bought from Alejandro 1 Nitrate Certificate of $S / 10,000$ at $991 / 2 \%$, whilst Elizalde for the Insurance Company Lima had paid $1001 / 2 \%$; also $£ 500$ on London. The Tacna Bank on Joseph Hegan \& Co., at 21d 1/4, whilst bills of Prevost \& Co. could be had at 21 1/2, and of Scheel at 22d [?] [512] [_] credit of the last named was fast declining.

Sunday, $11^{\text {th }}$ of November. I had necessarily some visits to make and thus as soon as Bryson was gone I started on this errand; and wheresoever I went I was received with more than usual politeness; at least this I could say of my calls on Dr. Morales, the Minister of Justice; General La Puerta, first Vice-President; and Doña Irene, wife of the vocal Bernardo Muñoz. This latter I met at Dr. Jervacio Alvarez', in whose house Doña Mariquita and her daughter Asuncion always treated me as a friend of the family. With Dolores Puente I found Francisco Sagastabeytia who had taken up his abode in Chosica on the Oroya line and only came to town now and then. Rafael Velarde and family, as well as the Ribeyros, were not at home. I had still time to walk as far as the convent de los Descalzos before dinner, at which Limpricht sat down with us.

Monday, $12^{\text {th }}$ of November. I heard from Garland that on Friday last there had been a tremendous row at a meeting of the Directory of the Gas Compy., owing to JoséSevilla, who was not a Director, having insisted upon being present.JoséV. Oyague, President of the Directory, who always avoided noisy meetings, and who no doubt had heard of Sevilla's coming, had very prudently stayed away. The steamer from Islay brought the news that José Maria Costas had died in Arequipa of the cancer in the tongue, from which he had been suffering here in Lima. He was a very good friend of all our family, and I myself liked him very much; though rather eccentric he had certainly a much clearer understanding than his younger brother Manuel, first Vice President under Pardo. José Maria died a bachelor.

Tuesday, $13^{\text {th }}$ of November. Garland told me that Sevilla had not been present at the meeting of the Directors of the Gas Coy., as said above; it was however certain that the Directors had had high words, and had spoken so [513] loudly that the clerks below could hear them. 
At 3 O'clock the shareholders of the Chilete Company again met, more or less the same as on the $23^{\text {rd }}$ October. Rafael Canevaro was not present; Emilio Althaus was. The firm of Canevaro, to whom the Company was largely indebted, proposed to make further advances, but on such onerous terms that they were rejected, whereupon we fell back upon the project of 23 October with the only difference that instead of sixty, seventy thousand Soles should be raised, and that before applying to the shareholders Canevaro should be asked whether he were inclined to make this loan himself on the favourable conditions stated on the $23^{\text {rd }}$ October.

Wednesday, $14^{\text {th }}$ of November 1877 . According to last accounts Peruvian Sugar had declined in Liverpool five shillings the cut, equal, at the exchange of 20 pence to more or less three paper Soles the quintal. Nitrate of Soda fluctuated from $14 / 6$ to $15 / 3$ for cargoes to arrive on the continent. Discount on London $5 \%$. Silver $55 \mathrm{~d}$ the ounce troy fineness $925^{\text {ths. }}$. The Turks were still masters of Plevna, but their situation was a critical one, they being completely surrounded by the Russians forces.

Thursday, $15^{\text {th }}$ of November. Thermometer at noon $77^{\circ} \mathrm{F}$; a 3.30 up to nearly 8o. Birthday of Mrs. Knauer of Altona, who completed her $77^{\text {th }}$ year. It was now a year since I fell ill in Chorrillos with water in the left knee, and up to this moment I had not recovered full strength; now and then I felt a little pain and with difficulty did I ascend and descend staircases. This day the electoral colleges for the province of Lima assembled; it was feared that disturbances would take place, but the day passed over quietly. The "Nacionales" met in the Municipality the "Civilistas" in the house of José de la Riva Agüero.

Friday, $16^{\text {th }}$. Thermometer at noon $79^{\circ} \mathrm{F}$. The Civilistas concluded their election. The following were chosen: J. J. Elguera, Pardo's Minister of Finance, Senator for Lima; José Unanue, Ignacio Osma, Manuel Cand[_] [514] [...] beyro, Deputies for Lima.

Saturday, $17^{\text {th }}$ of November. Thermometer at noon $79^{\circ}$ F. This being Enrique's birthday who completed his $28^{\text {th }}$ year. Enriqueta, as it was her custom on similar occasions, gave us a somewhat nicer dinner than usual. She had invited Limpricht, and Urquhart; Guillermo, with his parent's consent, his Godfather José Sevilla, and it was a pretty numerous party that sat down. Antonio had just returned from Matucanas, where he had been for nearly three weeks for the benefit of his health. Alejandro and Juan were not present, the latter, it appeared to me, led a very irregular life, and we saw him but seldom. Sevilla was beyond measure silent. Enriqueta called him stupid "demente". I rose when they were taking their fruit, and went to my rooms to listen to Bryson's reading. Ricardo related that also the Nacionales had this day concluded their 
elections, and that the following had been chosen: Senator, Ramon Montero; Deputies, Buenaventura Elguera, Dr. Ulloa, and Dr. Alejandro Arenas.

Sunday, $18^{\text {th }}$ of November. I dictated a letter to my cousin Frances Cresswell, and instead of going out after Bryson had left, played two games of chess with Limpricht, in the corredor from 2.30 to 5 . I gained the first and gave up the second game, though I might still have carried it on, having two castles for Limpricht's queen. We were few at dinner, and in the evening Ricardo read to me Priscilla's letters, with which we were drawing to a close.

Monday, $19^{\text {th }}$ of November. Thermometer at noon $81^{\circ}$ F. Government had issued a decree, which ordered the Banco Garantizador, and all other not authorized banks, to withdraw their billetes from circulation within four months from $1^{\text {st }}$ Decr. Alejandro had at last received from the Garantizador the 32,000 Soles in silver, for which he had been fighting for the last eighteen months; he sold them at $93 \%$ premium, and had now instituted his [515] demand for S/2500 in coined silver for interest; on [the] other hand the bank had commenced against him the "causa ordinaria". Many weeks back I spoke of the claim which the Government made on the firm of Dreyfus for the amount of the gain improperly made upon guano of inferior quality. The Comercio said that Dreyfus had offered to pay in settlement of the government's demands, half of the amount claimed; further, that the government had ordered their attorneys in Europe to embargo all the guano which still existed in Dreyfus' hands.

At 1 O'clock I went to Doña Eulalia, wife of the vocal José Antonio Ribeyro, who had requested me to go to her house. I much feared that she would ask me for money; fortunately she merely begged me to interest myself with Rafael Velarde, Director of the Callao custom house, for one of her relations who was employed there. Dr. Fernando Palacios who had been absent for about a week, dictated an escrito demanding the immediate approval by Juan Aliaga y Puente of the valuation put by any appraiser, on the house embargoed by me, whereupon Dr. Quiroga gave his sentence that Aliaga was within two days to present the witnesses whom he had promised to bring forward in order to prove the incorrectness of Davila's estimate, and who had not shewn their faces in Quiroga's office. Dr. Palacios told me that the Nacionales had chosen him Senator for the Province of Ica; the Civilistas had given their votes to Manuel Velarde Alvarez, nephew of Don Jervacio Alvarez, whilst Rafael Canevaro had also some votes. In the Department of Junin Manuel Pardo had been elected Senator for Cerro de Pasco and for Jauja. The news from Europe were upon the whole less favourable to the Turks than they had hitherto been, both in Asia and Europe the Russians were gradually progressing. 
Tuesday, $20^{\text {th }}$ of November 1877. At a little past 8 p.m. I went to the office of the Banco de Lima where a considerable number of shareholders were already assembled. I took my [516] [_]mary seat which had apparently been left open for me, opposite the President of the Directory, Heudebert. To my left I had Dr. Pró, next to him Dionisio Villate; the chair to my right was unoccupied. The acta of the last meeting was approved, with trifling modifications, whereupon the question was put by Heudebert whether that article of the Statutes which left the liquidation of the bank to the Directory should be altered or not. I took no share whatever in the discussion. Cardenas spoke as usual, but on what side I could not make out. In favor of the reform of the article, or in other words, to take the liquidation out of the hands of the Directory, spoke: Aurelio Denegri; Amancio Castillo; Felipe Salaverry; and perhaps one or two more; against it, that is to say that the Directory was to liquidate: Dionisio Villate, with great vehemence, Dr. Pró and Cipriano Correa, this last, contrary to my expectation, with great judgment and in very proper terms; Diego Lopez Aliaga, one of the Directors also said a few words, in a quiet manner, and much to the purpose; José V. Oyague, M. G. Chavez, Manuel Villate kept quiet, and, like myself, voted in the majority 448 against 205 that the article should not be altered: consequently the liquidation remained in the hands of the Directory. Lembcke and Cucalon, the two gerentes, announced that on the $31^{\text {st }}$ December they would give up their posts, of which declaration hardly any notice was taken. Dionisio Derteano made a, in my opinion, stupid motion viz.: that the Directory should be authorized to buy shares of the bank if any were offered for sale; it was opposed mainly by Cipriano Correa; and Derteano withdrew it. The only thing which remained to be done, was to choose nine new Directors, instead of those who had served their time. I begged Lopez Aliaga to write on a piece of paper the names of those who had gone out, and having deposited this paper in the urn, I left. I was home before 10.30 and walked the corredor till 11.30; it was a beautiful moonlight night.

Wednesday, $27^{\text {st }}$ of November 1877. My wife's birthday. [517]

I saw by the papers that Raphael \& Co., Carlos Candamo, and Arthur Heeren had made over their guano contract with the Peruvian Government, which was concluded by Prado, in May or June 1876 to another company, but which this company was, was not said; also, that there was very little chance that the

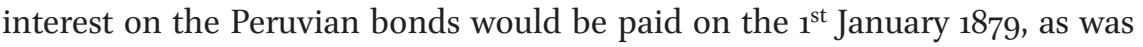
conditionally promised in Prado's Message. In Tacna the elections had given rise to considerable disorders; of the civilistas, a young man, said to belong to one of the best families, was killed, whilst in the Government's side the Sub-Prefect lost his life. In the evening Limpricht occasionally, not regularly, 
accompanied Enriqueta and me for an hour or so before retiring to rest, which we did more or less at eleven O'clock. Ricardo was also generally with us, whilst Garland, if he did not go to the palace, or somewhere else to play rocambor, always withdrew at an early hour.

Thursday, $22^{\text {nd }}$ of November 1877. In a meeting of the Directors of the Insurance Company Lima, at which Moscoso Melgar, President, and Prevost, absent in the United States, did not attend, the gerente Elizalde was authorized to settle in the best manner he could, the debt due to the Company by the insolvent Pedro Bernales; the company held shares in the Banco de Lima which he had given as security, but they did not suffice to cover his debt.

In the evening Limpricht and Urquhart kept Enriqueta and myself company, sitting in the corredor.

Friday, $23^{\text {rd }}$ of November. Thermometer at $2.3080^{\circ} \mathrm{F}$. The Comercio contained a telegram received from Valparaiso which made known that the Turks had given up to the Russians the fortress of Kars, by capitulation, which must have occurred about the middle of November.

I saw from the Nacional that the Anglo Peruvian Guano Company, Ld., with which Prado made the contract when he was in Europe, consisted originally of 160 Shares [518] [_] $£$ [_]ooo; of these 160 Shares Raphael held 40, a certain Cazenova 40, Lazky 20; Carlos Candamo 9, Arthur Heeren 9, Charles Eggert 5, Bernardo Canevaro 4, Lescau \& Co. 8, and so on. At the end of Septr. 1877 $£_{3750}$ per share or $75 \%$, had been called for, of which only $£ 496$, ooo had been paid in; and the amount paid to the Peruvian Government came to £1,250,000. Raphael \& Co., Candamo, and Heeren whose names had hitherto appeared as the principal contractors as yet kept their shares, and were responsible for the amount but for nothing more.

Saturday, $24^{\text {th }}$ of November. I received a letter from the gerentes of the Banco de Lima, informing me that as some of the gentlemen who had been chosen Directors in the late general meeting had refused to accept the nomination these were JoséV. Oyague, and Dionisio Villate - I had been chosen provisionally by the Directory, to which I replied that I could not accept the honor they had done me as I was about leaving for Chorrillos; the real cause was that I did not like to be made use of as a "suplefalta".

Sunday, $25^{\text {th }}$. In the forenoon I paid three agreeable and long visits: to Doña Manuela Portillo; Doña Dolores Puente, and Doña Manuela Cosio, the mother of Mrs. Macandrew, who, with her husband had gone out. Mrs. Dr. Muñoz was not in, and with the Alvarez I remained but a few moments. I invited Don Jervacio to come out to Chorrillos and dine with us, whensoever it might be convenient and he promised to do so. After dinner I felt so sleepy, and a heart 
burn I had was so intolerable that after Ricardo had read to me a little I went to bed at 9.30 and was immediately asleep.

Monday, $26^{\text {th }}$ of November. Temperature a little cooler, at noon $78^{\circ} \mathrm{F}$. At 4.30 we felt an earthquake of uncommon duration; I should not wonder if it lasted a minute; it seemed as if the glass doors would not cease vibrating, otherwise it was not accompanied by any noise; neither was the [519] shaking of the earth, of any particular violence. Dr. [Quiroga] sentenced that Juan Aliaga y Puente's house 11 and 13 Polvos Azules was to be disposed of by public sale on the $29^{\text {th }}$ Decr., he presenting the title deeds.

Tuesday, $27^{\text {th }}$ of November 1877 . This morning at about 6.45 Dr. Middendorf was with me to ascend San Cristoval; he was a slow walker, and thus it took us a long time before we reached that spot in the valley of Lurigancho where I knew that the ascent was easiest. We had reached about one third of the height, when I felt so completely knocked up that I had to sit down and rest for a considerable while. The Doctor attributed it to my having exerted myself too much in the beginning; I feared that it was the consequence of an actual diminution of my strength. The Doctor insisted on our returning, I on our proceeding, and we reached the summit without any further difficulty. I was home at 10, slept half an hour took my broth, and two cups of tea, and was then as well as usual. The whole day long the sky was overcast. Thermometer at noon $77^{\circ}$.

Wednesday, $28^{\text {th }}$. In the meeting of the shareholders of the Chilete Coy., on the 22 Novr., at which I did not attend, a new loan of $S / 70,000$ to be returned out of the first net proceeds at the exchange of 48 pence was quickly made up. José F. Canevaro took S/30,00o; Jose V. Oyague, Arthur Heeren, Dionisio Derteano, and Ernesto Malinowski, each $S / 10,000$. Out of these $S / 70,000$ the last $S / 10,000$, in which I had taken $\mathrm{S} / 500$ were first to be paid, and from Oyague I received for my $S / 500 \mathrm{~S} / 703.41$, the difference arising from interest at $1 \%$, and a gain on the exchange between $30 \mathrm{~d}$ at which the 500 Soles were to be returned, and $22 \mathrm{~d}$ the present quotation. Juan Aliaga y Puente had appealed to the Superior Court from Dr. Quiroga's sentence, see above. Quiroga had further sentenced that the woman who occupied the ground floor of the house 11/13 Polvos Azules, and who had refused to pay the rent to Alej. Garland, the Depositario had to do so with[_] [520] three days, or soldiers would be placed at her door. Thermometer at $380^{\circ} \mathrm{F}$.

Thursday, $29^{\text {th }}$ of November. Through the medium of the broker Guillermo Salcedo. I lent Calixto Pfeiffer S/20,00o for six months, at $11 \%$ discount, he giving me in security 50 shares of the Banco Hipotecario of $S / 1000$ each. When Bryson was gone at 8.30 I sat down by myself in the corredor. Enriqueta was in 
bed suffering from migraine, Garland had gone out; Ricardo played the piano; at past 10 I was joined by Limpricht, and we conversed together for more than an hour.

Friday, $30^{\text {th }}$ of November. The Nacional of last night made known that the Banco Anglo Peruano had ceased to exist, and that its debts and assets had been taken over by a new bank, El Banco Mercantil, established in London, with a capital of $£ 120,000, £ 112,000$ paid up, with a branch establishment sucursal in Iquique and agency in Lima, the former to be managed by Jameson, formerly of Gibbs, the latter by Oscar Heeren. In the plaza, again S/300,00o in billetes were burned. This was the third time.

Saturday, ${ }^{\text {st }}$ of December. At as early an hour as $7.15 \mathrm{I}$ was in the pantheon, where I climbed up a ladder to see how the roofing progressed; it was not yet concluded, but what was done, was well done. In the four corners small, rather imperceptible copper pipes, were laid for the rain water to make its escape. On my return I dunned the notary Seminario 16 Correo, who was again more than three months in arrears with his rent, and at home lay down for nearly an hour, but found still time to listen to Ricardo's reading to me before breakfast. A decree was published, which said that the Government made itself responsible for the payment of 85,000 Soles notes of the Banco Anglo Peruano which were considered to be in circulation; the bank paying the same amount [521] to the Government, in billetes autorizados, or notes of the four associated banks, for whose payment the Government had made itself responsible.

Sunday, $2^{\text {nd }}$ of December 1877 . At 7 precisely Bryson and I started from the bridge and ascended San Cristoval, straight up from the Descalzos. We rested twice, and I reached the summit a little fatigued. We descended to the saddle behind the convent, and then turning to the right returned by the valley of Lurigancho. A little past 9.30 I was back in my house, bathed in perspiration, though the sun had not been out. I undressed, went to bed, slept for nearly an hour, breakfasted, and attended to my customary occupations. When Bryson was gone, Limpricht and I played chess in the corredor till nearly dinner time, four games: the first and fourth, long ones, he; the second and third, very short, I gained. In the evening Ricardo read to me from the German Rundschau (look around), Prescilla we had finished.

Monday, $3^{\text {rd }}$ of December. From the Leipzic Gazette Ricardo read to me an article on a famous French astronomer, Leverrier, who born in 1811 had died in September last. From astronomical calculations made by him in 1846 he deduced that there must necessarily exist a planet, hitherto unknown in our planetary system, and this conclusion he drew from the irregularities in the motion of the planets Saturn and Uranus which were too great to be produced by the attraction of Jupiter. He actually pointed out on the Heavens were in 
his opinion this new planet should be, and in September 1846 it was actually discovered by a German astronomer Galle near the very spot where Leverrier had been certain that it would be, that is to say still further from the Sun than the planet Uranus. In his private character he had been proud, overbearing, choleric, and disagreeable to all those to whom he had taken a dislike and of them there were not a few, whilst he could make himself very agreeable to all such as pleased his fancy. A well known [522] [_]man actress and authoress, Caroline Baur, had also departed this life; she was born in 1808; in 1829 was morganatica[_] married to Prince Leopold of Coburg, from whom she was divorced when he ascended the throne of Belgium, whereupon she married another German nobleman. Nearly the whole forenoon I had to run about. I went out at about 12.45 first to Carlos Elizalde, whom I asked if the Insurance Coy. Lima had made any insurance upon the "Atacama", belonging to the P.S.N. Company, which was lost in the night from $30^{\text {th }}$ Novr. to $1^{\text {st }}$ Decr., by striking upon a rock called caja-chica in the latitude of Caldera. She had left Valparaiso on the $28^{\text {th }}$ with about 200 persons on board, of whom only 23 were saved. The insurance company had not taken any risk upon her. From Elizalde I went to Juan Gallagher who was ill in bed, and remained with him about half an hour; thence to the secretary of the first chamber of the Superior Court, where I learned that the expediente relative to my claim against Juan Aliaga was in the hands of the Vocales. Next, I called upon Doña Irene, Dr. Munoz's wife with whom I stayed about half an hour; and whom I told that we were going out to Chorrillos, where we should be most happy to see her and her husband, whensoever it might be convenient to them; with the same object I called upon Rafael Velarde's wife and daughter. Then to the Concejo Departamental, where, at last, after having been at it for a fortnight or three weeks I obtained that my patente for this year, of $S / 1000$ was not only reduced to $S / 608$, but that the surplus I had paid for last six months was actually returned to me. All with whom I had to do were very polite, but the dilatoriness in their proceedings was beyond conception. Now I was at home for about a quarter of an hour, and then had again to go to the secretary of the first chamber, who notified to me the sentence of the Superior Court, which confirmed that given by Quiroga in my favour. [523]

Tuesday, $4^{\text {th }}$ of December 1877. About this time [_] needle was much spoken of in the European, and sometimes also in the Lima papers. I learned from the same that this so-called "needle" was one of two obelisks which in times long gone by stood in front of the temple of On in Egypt, and which, seven years after the death of Cleopatra, say 23 years before Christ, were removed to Alexandria. In 1820 the needle was presented to the English nation by the Pasha Mehemit Ali, but only in September last its conveyance to England had been attempted, 
not by the English government but by a private individual Mr. Dixon; he had a vessel built on purpose, which was towed by a steamer, the "Olga". About the middle of October during a violent gale in the Bay of Biscay, the two vessels were severed from each other, and that with the obelisk on board was met by a screw steamer, the "Fitzmaurice", which again took her in tow, and brought her safely into the port of Ferrol, where she lay as per last advices.

This day at 2 O'clock Enriqueta with the little girls and the servants left for Chorrillos, our servant Juan with the luggage having preceded her yesterday. I followed her at 5 . It was 6.30 before we could sit down to dinner in the corredor; we were: Garland, Enriqueta, Antonio, the little girls and I. Enriqueta was knocked up, so hard had she been working the whole day. The two servants, Juan, and my Chinaman Ayao had had a dreadful quarrel and beaten each other like wild beasts, the blood streaming from their faces; however, Guillermo had easily separated them and tranquillity was restored. After dinner Garland sat in the corredor, Enriqueta, as already said, was very tired. Geraldo came in for a moment, and one with another it was a very tedious evening.

Wednesday, $5^{\text {th }}$ of December 1877. I ascended to the cross on the summit of the Moro Solar; when there I rested for five minutes. The expedition took me an hour and thr $[\ldots][524][\ldots]$ much fatigued. Ricardo began reading to me a new German book, the continuation of the political novel Mines and Counter mines, Crown and sceptre, and the two Imperial crowns. This was called "The Cross and Sword", and opens near Dusseldorf in September 1869. I went to town by the 11.15 train, and returned by that of 5 O'clock. After dinner Ricardo read to me the above mentioned book, and towards 9 we had some visitors, Luis, the son of John Bryce, with his young wife Grimaneza, daughter of Grimeneza Cotes, and Doña Jacinta Sotomayor, at present on good terms with Enriqueta, as if I had never carried on against her such a tenacious lawsuit as that from February 1864 to the latter end of 1869 . I hastened to bed at 10 O'clock.

Thursday, $6^{\text {th }}$ of December. Ricardo read to me. I did not go out before breakfast. This day the Supreme Court sentenced the case between Silvestre Guiroy and the Banco Hipotecario relative to the Cedulas of this bank transferred to Paris, of the merits of which case I gave the details at the time that Oyague, Dionisio Villate and I were called in by the Directors to give our opinion whether a "transacion" proposed by Enrique Barreda y Osma, the principal holder of such cedulas should be accepted or not. I alone was then in favor of the proposal. All others insisted on carrying on the lawsuit. Silvestre Guiroy held but a few Cedulas of this description, but of course the sentence given in his case would also be valid for Enrique Barreda's. The Vocales who voted were Drs. Oviedo, Mariano Cosio, Melchor Vidaurre, Eusebio Sanchez, Jervacio Alvarez, and two "Conjueces" who were called in, the other members 
of the tribunal being impeded for some reason or other. They had not been unanimous; "habia discordia", but it was not known how the votes had been divided.

Immediately after dinner, say at 7.15 went per train to Lima, Bryson read to me from 8 to 9.30 and at 10 I went to my dormitory. [525]

Friday, $7^{\text {th }}$ of December 1877. By the 8 train [...] to Chorrillos, and after breakfast again to town by that of 11.15 . Thermometer at 3 p.m. $78^{\circ} \mathrm{F}$.

Of the seven judges, Alvarez, the two "conjueces" Loli and a certain Garcia had voted in favor, the other four against the bank.

In Chorrillos, Middendorf and Doña Jacinta Sotomayor dined with us. Ricardo read to me.

Saturday, $8^{\text {th }}$ of December. Dia de la Concepcion. I took a cup of tea, ate a little cold meat and went to town by the 9 train. Thermometer at noon $79^{\circ} \mathrm{F}$.

On my return to Chorrillos by the 2 O'clock train accompanied by Limpricht, I found in the rancho Dr. Dorado of the criminal court, who, a good natured man paid us such a long visit, that I almost despaired of his ever leaving us. When he was gone, Limpricht and I played two games at chess; the first I lost the second I gained; they took up our time till nearly 6 O'clock. Doña Jacinta Sotomayor was again with us at dinner, also Urquhart and Limpricht. Afterwards it was rather tedious, and as soon as those for Lima had left, I went to bed.

Sunday, $9^{\text {th }}$ of December. Like yesterday I took the 9 O'clock train for Lima. Thermometer at 11 a.m. $79^{\circ} \mathrm{F}$.

I returned at 2 O'clock, went to see Eliza, Guillermo's wife, who was very ill of an inflammation in the throat which prevented her speaking, and only allowed her to take milk for nourishment. Next I looked in at Ruden's where I found them playing at rocambor, that is to say: Ruden, Eggert, Carranzas, editor of the Comercio, and Manuel Costas, whilst Alejandro was looking on. At another table sat Col. Mendez and Dubois, partner of Graham Rowe \& Co., also playing rocambor at two, an extraordinary game they say. I did not remain long and till dinner time listened to Ricardo's reading. When we issued from our [526] [_] we found a pretty large party assembled to celebrate Geraldo's birthday. Of the family, Alejandro, Juan, and Antonio were wanting; instead of them, Limpricht, Urquhart and Julio Benavides, a son of Manuel Francisco, and colleague of Geraldo in the late embassy to Japan and China. There were also Melchor Velarde and Doña Jacinta, together fourteen in number. At a later hour Henry Higginson called; I talked with him and with Limpricht and thus the time till 10.30 passed away less tediously than on the previous evenings.

Monday, $10^{\text {th }}$ of December. At 9 a.m. I bathed, and was hardly two minutes in the water, which to me did not feel particularly cold. For some time past it had been the cherished idea of the Peruvian Government to bring about a 
uniformity in the laws of the South and Central American Republics. To attain this end, negotiations had been carried on with the respective cabinets, even with those of Mexico and Haiti, and the result had been the resolve to form a Congress of Legists which was to meet in Lima. For this purpose six or seven lawyers delegated by their Governments had gradually arrived and this day they held their first session in the Congress Hall where they elected for their President the Peruvian Dr. Antonio Arenas, Vocal of the Supreme Court of Justice in Lima.

At dinner I had not the slightest appetite, and ate hardly anything; I went to town by the 7.15 train, and Bryson read to me till nearly 9.30, half of the time Motleys Dutch Commonwealth, half Zanoni by Bulwer. I went to bed without loss of time, and awoke about midnight with an insupportable heartburn, which kept me awake for some time. I fell asleep again, awoke at 3 when I vomited and purged.

Tuesday, $17^{\text {th }}$ of December. I went to Chorrillos by the 8 train far from well; on my arrival I went to bed, and slept till [527] 11 O'clock, then, after taking a little broth and a [...] tea without milk I returned to town by the 12 train, and at a later hour suffered again from heartburn. At 5 , back again to Chorrillos. I ate very little, and Ricardo read to me a considerable while in our German novel by Zamarow; we had come to November 1869, when mention is made for the first time of the Prince of Hohenzollern-Siegmaringen, elder brother of him who is Prince of Wallachia and Moldavia, as a fit person for the Spanish thrones.

Wednesday, $12^{\text {th }}$ of December 1877 . I took a very short bath at about 8 , then a walk, listened to Ricardo's reading, went to town, and was again perfectly well. Thermometer at $1,81^{\circ} \mathrm{F}$.

Thursday, $13^{\text {th }}$ of December. My way of living was now regularly established. I took a short bath in the sea between 7 and 8, then a walk, listened to Ricardo's reading, breakfasted at 10.30 , generally in company with Doña Jacinta, sometimes with La Rosa, and with the one or the other of Garland's sons, went to Lima by the 11.15 train, if necessary to the Justice Hall, remodelled the old diaries - we were now in November 1869 - returned at 5, dined at 6.30, and again listened to Ricardo's reading. Cipriana, one of the daughters of Dr. Anibal de la Torre had come to Chorrillos to keep my daughter company for a few days.

Friday, $14^{\text {th }}$ of December. Thermometer at $1.3082^{\circ} \mathrm{F}$. Last night great disorders occurred in the meeting of the members of the Concejo Departamental. They had been convened to elect a President and two Vice Presidents for the ensuing year. Melchor Velarde told me that the Government party wanted to have Manuel Fco. Benavides named President; the Civilistas, Ramon Ribeyro. When the members were assembled the national party pretended that the suplentes, ten in number, should not vote, because even without them a sufficient number 
was present to form the quorum; when put to the vote they lost the question by a majority of 38 to 32 . Then the "Barra" began to make a [528] [...] President Buenaventura Elguera instead of ordering them to be quiet, thought proper to leave the hall, accompanied by the Vice President and some of his party, thus no decision could be come to.

A telegram had been received, dated Bucharest $10^{\text {th }}$ Decr., which advised the surrender of Plevna, and of the Turkish army enclosed within the fortifications to the Russian forces. In its proper place I mentioned the departure of George Elster, for San Francisco, but I omitted to say that he was the Russian Consul in Perú, and that as such he had requested our Enrique to take charge of the Consulate during his absence. This, Enrique had agreed to at the time, little expecting that it would give him so much extra occupation as it now did, owing to the arrival in Callao of the Russians man-of-war "Crysser", to whose officers and their wants he had necessarily to attend. The evening of this day I remained in Lima.

Saturday, $15^{\text {th }}$ of December. At 6.30 I walked out to the pantheon, where they had nearly concluded roofing the chapel. Almost every slate they had to cut to its proper size, and as the slate was extremely brittle, this cutting, or rather sawing, cost a deal of trouble, and took up much time. I walked back to Lima, dunned the notary Seminario without success, and took the 9 train to Chorrillos. There I bathed, breakfasted, and was again in Lima by 12 O'clock. Before going to my house I looked in in the Justice hall. Aliaga had appealed to the Supreme Court about the valuation of $\mathrm{N}^{\circ} 11$ and 13 Polvos Azules. In Chorrillos Dr. Middendorf dined with us. He propounded to me two puzzles: the one; why do white sheep eat more than black sheep? I answered at once, because there are more of them. The other puzzle was the following: At 12 O'clock exactly the two hands of the watch cover each other, at what hour will they again do it? This I was not able to solve at the moment. He told us also an extremely pretty pun of Ruden's; at the time that Gibbs [529] had the guano business, there was a friendly dis [...] presence whether they or Baring ranked higher in the mercantile world; then Ruden said very seriously: "I have known Gibbs for twenty years, and have always found them over-bearing".

Sunday, $16^{\text {th }}$ of December 1877. I was up, and bathed before seven, took my usual walk, listened to Ricardo's reading, looked over with Guillermo two months in my cash-book that he might enter them in my cash journal during my absence, and went to Lima by the 11.15 train. Thermometer at $12.3082^{\circ} \mathrm{F}$. On my return, when alighting from the train I met Dr. Anibal de la Torre, his wife Fidelia, their daughter Caroline, and their little boy Enrique. They spent the whole day in our rancho; but the Doctor was certainly disappointed, because as Garland did not come in till near six he could have no rocambor; otherwise 
he was very agreeable and talkative, and the time passed quickly enough till they left with the 10.30 train. In the day time I called upon Drs. Dorado and J. M. Perez, neither of whom was at home; at the former's I had to talk with his married daughter, at the latter's with his wife. In the evening we had a visit from Luis Bryce and wife.

Tuesday, $18^{\text {th }}$ of December. Thermometer at 1 p.m. $83^{\circ} \mathrm{F}$.

King Alfonso of Spain, born in 1857 , son of the dethroned Isabel was engaged to marry his cousin, daughter of the Duke Montpensier, son of Louis Phillippe and Luisa, sister of Queen Isabel. This being the birthday of Mariano Ignacio Prado, he gave a lunch in Amancaes to some of his most particular friends, amongst whom were mentioned Gregorio Benavides, Pedro Saavedra, Dionisio Derteano, J. Asambuja, Chargé of the Brazilian, and Dr. Lührsen of the German Empire.

Little Guillermo Garland completed his first year. Guillermo, and his wife Eliza, who was just recovering from a bad quinsy, and who resided with Henry Higginson and wife in their Chorrillos rancho, asked to dine with them. [530] [_] and some of his sons went; Enriqueta, Cipriana la Torre, Ricardo and I did not.

Wednesday, $19^{\text {th }}$ of December. The papers stated that last night the Pierolistas arrested in San Francisco de Paula tried to make their escape; some doors were found open; that leading to the street was shut; they returned, and were fired at by the guard, none was wounded. The affair of the Cedulas del Banco Hipotecario transferred to Paris gave Garland immense trouble, the more so as John Gallagher, his fellow manager, continued ill and could not leave his house. With Calderoni, who represented Silvestre Guiroy, and with M. G. Chavez, who had full power from his half brother Gordillo in Paris, of whose death advice had just been received, and who were holders of comparatively speaking small quantities, he had come to a friendly understanding upon the following terms, and accordingly the suits carried on by them in the Supreme Court, had been put a stop to. For S/30,00o in Cedulas, of which 4 of S/1000 ea. were redeemed, and for $22 \%$ interest upon the same, say for 3 instalments in 1875 , and 8 in the two years 1876 and 1877 , together 11 at $2 \%$, both Cedulas and interest payable at the exchange of $4 \mathrm{fcs} 64 \mathrm{cts}$ he paid $£_{5000}$ Sterling. One with another the Cedulas had still to run 15 years, but at the end, all would have to be paid at par, and in the same manner the interest, of course decreasing every year, when a Cedula is redeemed, must be paid until all the Cedulas are redeemed and both the one and the other at the exchange of fcs 4.65 had this arrangement not been made and the suit been decided against the bank. It was very difficult, if possible at all to make an exact calculation how much this transfer of the Cedulas to France at 4.65 if carried out to its last extremity, 
would have cost the bank, as little, how much was saved by the arrangement. $£ 5000$ at $22 \mathrm{~d}$ cost $\mathrm{S} / 54,545$, whilst the capital of $S / 30,000$, without taking the interest into consideration, at fcs 4.65 and reduced at the exchange of 2.35 into

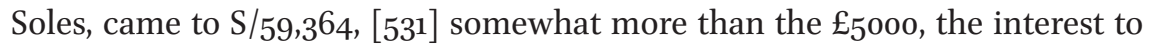
pay of $[\ldots]$ as well as that until the extinction of the whole debt, not being taken into consideration. On the other hand it may be argued that there was a possibility of Exchange improving in the course of fifteen years; very true, but it might also get worse. With Enrique Barreda, who had two hundred and odd Cedulas of the same description, Garland had not yet been able to come to terms.

Thursday, $20^{\text {th }}$ of December 1877. The Nacional of last night gave some interesting details relative to the Nitrate of Soda business as it was carried on at present. It will be recollected that Government had bought a great many, but not all the Nitrate establishments in the Province of Tarapaca; for those purchased, the Government had given certificates of $S / 1000$ each which gained an interest of $8 \%$ annually, payable every three months at the exchange of 44 pence to the amount of more than seven million Soles. The greater part of these salitreras were not worked, others were worked by their late owners such as Gibbs and Gildemeister, and these had hitherto put the nitrate on board on account of the Government, at $S / 1.70$ at present, at $S / 1.53$ at $42 \mathrm{~d}$. It was calculated that including this original cost, freight, insurance, all expenses, and sales commission, the cwt of nitrate cost on shore in England 11/6 to 11/9, and consequently if sold at a higher price than this original cost, the surplus was so much gain to the government. Nevertheless, the "Nacional" said that of 83 cargoes sent to Gibbs on account of the Government, nine had left losses, and the gain for 1 year to 30 Novr. had come to £10o,608. Those who had not sold their establishments, and who shipped on their own account, "los libres productores", had to pay duty of $\mathrm{S} / 1.25$ at $40 \mathrm{~d}=5 \mathrm{od}$ the quintal, and notwithstanding this high export duty, they continued shipping, a proof that the selling prices of $15 / 3$ to $15 / 6$ still left them a profit. The quantity of nitrate

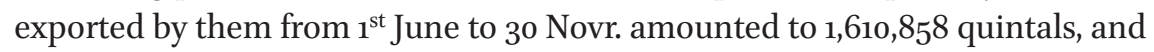
the duty received by Government [532] [...] expenses, to S/3,104,267.

The management of the Nitrate business was placed into the hands of the four associated banks, which as per contract were entitled to charge $5 \%$ commission for collecting the export duty and $5 \%$ commission upon the amount sold in England of which $5 \%$ they allowed one half to Gibbs. The four banks had chosen two delegates for each bank, and these eight, with Francisco Garcia Calderon as the President, and Luis Benjamin Cisneros as their paid secretary managed the entire business. They also gave, every three months the drafts on Gibbs, for interest on the certificates. 
I received a note from the Gerentes of the Banco del Perú informing me that the Directory had unanimously chosen me Director, and from Ruden I learned that the vacant place was that left by M. G. Chavez, just embarked for Paris. I answered, accepting the nomination.

Friday, $23^{s t}$ of December. Having been cited to a meeting of the Directory of the Banco del Perú, I went past 1 O'clock. It lasted full half an hour, before all were assembled. Emilio Althaus presided; to his left sat Carlos Elizalde, Vice; Manuel Candamo, secretary, Enrique Ayulo, Cesar Canevaro, one of the Gerentes; opposite Althaus, at the other end of the table, Calderoni; opposite César Canevaro, Ruden; opposite Ayulo, I; an empty chair, and finally J. P. Escobar, the second gerente, opposite Elizalde and to the right of Althaus. I of course took little part in the discussion, being the newest member, but could not help observing that those here assembled were men of clearer understanding than the generality of the Directors of the Banco de Lima. The question under discussion was of importance. The Banco de Lima being in liquidation, had offered to the other banks, "Peru", "Providencia", and "Nacional", the amount due to the same by the Government, payable in conformity with the president's verbal promise, at the exchange of $42 \mathrm{~d}$, also its interest in the nitrate business managed by the Delegates [533] and its gains to the end of the year in this [_]. The three banks had agreed to pay 612,00o Soles, the Banco del Perú having made the sine qua non condition that the exact amount of the debt of the Government should be ascertained, and a decree be given that it was payable at $42 \mathrm{~d}$. The two other banks, or to speak more properly Garcia Calderon and Dionisio Derteano, who had an overwhelming influence, the first in La Providencia, the second in El Nacional, did not consider this necessary, consequently the majority, two to one, did not insist on this condition, and therefore it was now discussed by the Directory whether it would be advisable to take this one third share in the business, or not. All agreed not to take any interest, and this the more so, because some of the Directors even feared that some day or other the administration of the nitrate of soda business would arbitrarily be taken from the banks by the Government, of the good faith of which I clearly saw none of those present entertained any high opinion; neither did they seem to be well inclined towards Calderon and Derteano. In Chorrillos I learned to my great surprise from Garland that the Directory of the Banco Hipotecario had decided in a meeting held this day, not to come to a friendly understanding with Enrique Barreda, not even on the terms hitherto offered to him, but to carry on the lawsuit.

This was no doubt owing to the influence of Jose Vicente Oyague who was on bad terms with the Barredas, and to whom the entire Directory, in fact a poor set, looked up with a, in my opinion, exaggerated deference. There had also been a meeting of shareholders, of which Garland had not told me a word, 
and the object of which had been to name two shareholders to examine the accounts of this year, but as there had been no sufficient number to form a quorum, the meeting was postponed to the $27^{\text {th }}$ inst. Dr. Middendorf came to dinner when I showed him the following solution of the problem spoken of on the $15^{\text {th }}$ inst.: $\mathrm{x}$ is the unknown of the minutes which the large hand requires to overtake the [534] [...], which moves one minute whilst the large moves 12, consequently when the large hand had moved from 12 O'clock all round the dial, to 1 O'clock, the small had moved the five minutes from 12 to 1 , and $5 / 12^{\text {ths }}$ of a minute more; now the unknown number $\mathrm{x}$ is to be added to 65 minutes made by the large hand, and the twelfth part of $x$ to the $655 / 12$ minutes made by the small hand thus:

$$
\begin{aligned}
& 65 \mathrm{~m}+\mathrm{x}=655 / 12 \mathrm{~m}+\mathrm{x} / 12 \\
& 780 \mathrm{~m}+12 \mathrm{x}=785 \mathrm{~m}+\mathrm{x} \\
& 780 \mathrm{~m}+\mathrm{x}=780 \mathrm{~m}+\mathrm{x} \\
& 11 \mathrm{x}=5 \mathrm{~m} \\
& \mathrm{x}=5 / 11 \mathrm{~m}
\end{aligned}
$$

In other words the large hand overtakes the small one in $5 / 11^{\text {ths }}$ minute past one. Proof: $655 / 11 \mathrm{~m}=655 / 12 \mathrm{~m}+(\mathrm{x} / 12+5 / 11=655 / 12 \mathrm{~m}+5 / 132=655 / 11$.

By the 7.15 train I returned to town, where Bryson read to me till nearly 9.30, and Johannes Limpricht till 10 letters received by him from Germany. His sister Elizabeth continued very poorly, and the medical men were of opinion that she should return from Montreaux, in Switzerland to her children in Moers, where she would be well taken care of and attended to. My bedroom was hot to suffocation so that I passed a rather sleepless night till

Saturday, $22^{\text {nd }}$ of December 1877 at 6 p.m. when I rose, dressed, and walked out to the pantheon, where they had not yet concluded the roof. By the 9 train I went to Chorrillos to breakfast. Melchor Velarde who dined with us related that in the previous evening in the Concejo Departamental, his friends the Civilistas had been completely defeated. A considerable portion of them influenced by the Government had stayed away. On the other hand the other party mustered strong, and one of them, Carlos Paz Soldan, moved that the resolution taken in the last meeting, that the Suplentes had a right to vote, should be reconsidered. The Civilistas [_]posed this reconsideration, but were outvoted and then in a [535] body left the hall. The Nacionales, thirty in [...] it now all their own way, and chose M. F. Benavides, President, the lawyer Alejandro Arenas Vice, and Dr. Lucio Barrios, $2^{\text {nd }}$ Vice.

Sunday, $23^{\text {rd }}$ of December 1877 . An early sea bath, a light breakfast, a drive per train to Lima, and the remodelling of my old diary - we were now in 1870 were, as on other Sundays and holidays, the occupations which took up my 
time, till 1.30, but then when walking to the terminus I was so completely lost in my thoughts that when recollecting myself I had far passed it, and was unable to reach it before the 2 train had left. Now, having given the key to my apartments to Bryson so that he might not have to wait for me on the following day, I had nothing better to do than to perambulate the streets of Lima till 4 O'clock when the train left. In Chorrillos we were but few at dinner, for a bull fight in the Plaza de Acho, and a lunch given in the Exposition palace to the President by some of his friends had attracted many people. Thus at dinner we were only Garland, Enriqueta, the two little girls, Enrique, Limpricht, who had expected me to play chess, Ricardo, and I.

Monday, $24^{\text {th }}$. The 200,000 tons of Guano to Mauritius and other islands, the consignment of which for perhaps two years had been in the hands of the associated banks, and which had been resumed by the Government since it made itself responsible for the notes in circulation, were now offered for sale.

Felipe Varela, to celebrate the birthday of his first born, a boy one year old, gave a numerous party in his Chorrillos house, to which fête he had invited Garland and the two little girls, who however preferred staying at home, and thanks to Enriqueta's kindness Maria and Corina did not weep nor repine, for they, like all the members of the family, the servants included, received their Christmas presents prettily laid out, in the room used by my son Juan as his dormitory when here.

Tuesday, $25^{\text {th }}$. In Chorrillos I called upon General Pezet [536] [...], and Luis Bryce, but finding no one at home, merely left my card. At Henry Higginson's the attention of the entire family and all their thoughts, were concentrated upon Guillermo so that it was really a very stupid visit. With Doña Paula Benavides, I remained a considerable while. Varela's party had been magnificent; the children, of whom there had been a great many, had received their presents, the grown up people had danced, played cards, and broken up at a late hour.

By the 4.30 train arrived from Lima Dr. Jervacio Alvarez, his daughter Asuncion, and her daughter Maria, also Johannes Limpricht; Gregorio Benavides came in uninvited and whilst he, Garland, and the Doctor played rocambor I had time to play a game at chess, which, after a tenacious fight I had the good luck to gain; at dinner we were a numerous party; those already named and all the children except Alejandro. Dr. Alvarez, who sat between Enriqueta and myself, was rather silent, as it was his habit, but being otherwise an agreeable, and clever man, the conversation did not flag, and the time passed pleasantly enough. All left by the 8.45 train.

Wednesday, $26^{\text {th }}$ of December. As soon as arrived in Chorrillos I changed my dress and again took the train for Barranco, where I called upon the Canon Bandini, who was not in, and upon Dolores Puente, who resided with the 
Marriott's. I stayed with them a pretty long while, and then slowly walked back to Chorrillos. The number of houses had much increased since my last visit to the Barranco; it had now its market-place but as yet gaslights and the tubes for conveying water to each separate dwelling, were wanting. Dr. Middendorf was at dinner and at a later hour we had a call from Alfred Böhl. Of our entire family only Enrique went to the ball given by José Basagoytia in Lima in honor of his eldest daughter Filomena, who for the first time put on "su traje largo", which here is a great event in the life of a young girl. In the Supreme Court of Justice a very important [537] lawsuit was decided. Some time ago two lan [...] in the valley of Chicama, near Trujillo, whose sugar estates lay contiguous to each other, the one, Albrecht, a German, who many years backs had for some time served me as lector, the other, a certain Cavada, had made a contract, to the faithful and exact fulfilment of which they had bound themselves under a heavy fine. Albrecht had taken upon himself to put up within a certain time, casualties excepted, a large machinery for grinding sugar cane. Cavada on the other hand had promised to have all his sugar cane ground at Albrecht's, paying him a certain remuneration, stipulated in the contract. The vessel which brought out the machinery from Europe was either lost, or obliged by stress of weather to put into a port, where she underwent repairs; at all events she did not arrive by the time that Albrecht had counted upon and the machinery was not ready for grinding on the day fixed upon in the contract. "Now", Cavada said, "I am free of my engagement, and can grind my sugar cane where I like." "No", replied Albrecht, "the casualty has been provided for in the contract, moreover, you have ordered out your own machinery, and even purposely spoiled the ovals which lead through your to my estate, so that even had the vessel arrived when I counted upon her, the machinery could not have been put up in time, and you must pay me the fine", amounting perhaps to more than half a million Soles. How the inferior tribunals had sentenced I did not learn. In the Supreme Court, Vidaurre, Sanchez, Leon, and Oviedo gave their opinion for Cavada, who was backed by the influence of Dreyfus' house to whom he owed S/70o,ooo for Albrecht, voted Cosio, Muñoz, and Alvarez; a conjuez Loli, was called in, who sided with the three latter, whereupon, after his vote was known, but not yet publicly declared, Cavada recused him and appealed to the tribunal de Responsabilidad where his appeal was not admitted. Another conjuez was called in, a certain Garcia, unknown to me and as upon [538] [...] depended the decision, it was generally supposed that neither party had been sparing, either in money or promises. Finally, he gave his vote against Cavada. By a rough calculation the money laid out by the two litigants on this occasion in the Supreme Court and in the Tribunal de Responsabilidad, amounted to at least $S / 100,000$. I was also assured that when the firm of Dreyfus saw that 
the suit looked rather black for Cavada, they made over the debt to the Banco Nacional, which establishment and not they, was now Cavada's creditor. Albrecht's correspondent was Gildemeister. He was also indebted to the Banco Hipotecario for several hundred thousand Soles, but paid his three-monthly instalments with the greatest regularly.

Thursday, $27^{\text {th }}$ of December. Nothing worth mentioning.

Friday, $28^{\text {th }}$ of December. I went by the 7.15 train to Lima when J. M. Cardenas took his seat near me, and we conversed the whole time; he confirmed to me what I had already learned from other quarters that at present not even the two banks La Providencia and El Nacional would make the purchase from the Banco de Lima of which I spoke detailedly on the $21^{\text {st }}$. He added that he was doing his utmost to induce the President to have this purchase made by the Government if the banks would not do it. It would be an excellent thing for the Banco de Lima if this were brought about, but I doubted it. Cardenas was further of opinion that the President, notwithstanding his repeated promises would never sign the decree which ordered the balances due to the banks to be paid at 42 pence. In Lima Bryson read to me till 9.30 when I conversed with Limpricht for more than half an hour and then went to bed. From him I learned that Charles Willink's widow, the St. C[?] lady, had died in Hamburg.

Saturday, $29^{\text {th }}$. I was up early, and at 7.15 in the pantheon where I did not find a single man at work [539] [_]n the chapel. It was a very disagreeable [morning], $[\ldots]$ as if we were in the month of July, the foot pavements were wet, and the carriage roads nothing but mud. On my return I looked in at Seminario's, of course again fruitlessly. Also in Chorrillos it had rained a good deal, and instead of bathing I undressed and lay down on my bed for my trousers and boots were thoroughly wet.

In Lima we had a meeting of the Directors of the Banco del Perú, all present except Ayulo and Calderoni. We had been convoked to determine whether to go to law with the testamentaria of Eduardo Villate, in former years the banks agent in the Cerro de Pasco, and which owed 6o,ooo Soles, or whether we would content ourselves with S/15,00o which they offered. All considered this second alternative the more advisable. Whilst we were together a letter was brought in from the Delegates of the banks in which they requested the Banco del Perú to present an account of what the Government owed them, without reducing the amount to pounds sterling. This gave rise to a very long discussion for several, I of the number, feared that such a simple statement might be looked upon by the Government as a renunciation of our right to the $42 \mathrm{~d}$. At last it was agreed that an answer should be given, stating that the amount to the credit of the bank was on the 17 Augt. so many soles, and that immediately after this 
was done an interest account should be presented to the end of the year, at 42 pence.

In my suit against Aliaga I was told in the secretary's office of the Supreme Court, that Aliaga's procurador had taken the expediente para fundar la nulidad, and that today was the last day for him to return it. Dr. Palacios kept me a long time in his office telling me of the various amounts of money which he expected to get in from the one or other quarter, and with which he intended to pay his debt to Garland. I however placed little reliance upon his asseverations. [540]

Sunday, $30^{\text {th }}$ of December. A morning like the previous one; nevertheless I took my early bath. We saw by the papers that in the Superior Court in that chamber of which Anibal de la Torre was President Enriqueta had lost her suit against the Frailes of San Francisco, the sentence being that the premises were again to be brought to the hammer. I went to Lima by the 10 O'clock train and returned at two, together with Limpricht, with whom I played chess till nearly dinner time. I gained the first, and lost the second game. Limpricht was the only one at dinner except the family Garland, and of them, Alejandro, Geraldo, Juan, and Antonio were wanting.

Monday, $37^{\text {st }}$. I bathed early, and then ascended to the cross; the sun was out and it was an excessively hot and fatiguing job. Thermometer at 1 p.m. in my office $82^{\circ}$ F. I saw by the papers that José Silva Santistevan had made a contract with the Government to conclude on his own account the Pacasmayo railway to Cajamarca, thence to Gualgayoc, and from Gualgayoc to Chiclayo. At about 5 p.m. a loud clap of thunder was heard by the greater part of the inhabitants of Lima; some said that they had also seen the lightning. Thunderstorms are frequent occurrences in the mountainous regions of Perú; also from Lima the lightning in the Cordillera is sometimes seen, but a clap of thunder on the coast is quite as rare an event as an earthquake in northern Europe. Ricardo read to me Zamarows (Von Meding's) political novel till 10.30, when I went to bed but his playing the piano kept me awake till past midnight and thus I began the new year of

1878

Tuesday, st $^{\text {st }}$ of January 1878. Advices from Europe to about the middle of December said that the President of France Marshal Mac Mahon had formed a new cabinet consisting exclusively [541] [...] so that complete harmony prevailed between the executive and [_] Chamber of Deputies, which body, it was rumoured, had determined not to vote the budget if the President had 
persisted in keeping his previous cabinet, whose members were known for their monarchical tendencies.

Yesterday, for the fourth time the monthly burning of S/300,000 billetes took place in the Plaza Mayor. In the evening, new year's eve, many Germans had met in the house of Dr. Lührsen, the German Minister, where they were always treated with the greatest hospitality, had a light supper, and remained together till 2 or 3 O'clock this morning. There was also a bull fight in the Plaza de Acho; and a ball in the Club de la Union, which lasted till 5 or 6 O'clock.

This forenoon I had a call from Eduard Knauer who came to congratulate me. In Chorrillos it was rather dull. I went to see Alfred Böhl, and J. A. Lavalle and family in both houses the street door was locked. At Ruden's they were playing rocambor: Ruden himself, Manuel Costas, Manuel Candamo, and Dr. Carranzas, editor of the Comercio. In the house of Federico Luna, close to ours, occupied last year by Federico Panizo, I went to see the family of Manuel Alvarez Calderon, but only found the unmarried daughter, an agreeable young lady. At dinner we had with us Federico Palacios, a grandson of the old Doña Ignacia; Jorge Valle, a son of the deceased Vocal, Urquhart, and Johannes Limpricht, whose birthday it was; of the sons, Guillermo, Alejandro, and Juan were wanting. I was very low spirited, and taciturn as I frequently was. I learned in the course of the day that J. F. Lembcke, one of the founders of the Banco de Lima, Director, and its leading gerente, had thrown up his post, and entirely withdrawn from the management of the bank.

Wednesday, $2^{\text {nd }}$ of January. About 7 or 8 in the evening quite unexpectedly, the Administrador of Meiggs' farm, Villegas and Juan Garland, who but seldom showed his face in our rancho, made their appearance, the latter with his left eye dreadfully lacerated. Their account and I suppose a [542] [...], was that they had been hunting in the neighbourhood of San Juan de Matucanas, that at 4 p.m. a dense fog had come on which had covered every object, and that in this obscurity a thorny branch of a tree which overhung the road had wounded his eye. This morning they had come to town, Juan had seen Dr. Middendorf who had prescribed leeches, for the eye was much swollen, and the continual bathing with certain liquids. Juan went to that bed which had been provided for Cipriana de la Torre, and poor Enriqueta was with her son the whole evening and night, nursing him, hardly sleeping a wink.

Thursday, $3^{\text {rd }}$ of January. This morning Juan was somewhat better, but with the wounded eye could not see anything. We saw by the Panamá Star and Herald that it was on the $9^{\text {th }}$ December when Osman Pasha made an energetic sally against the Russian fortifications in the direction of Widdin; he did so because though he had still powder, shot, and provisions in Plevna, an epidemic disease had broken out, and was carrying off his soldiers in great numbers. The Turks, 
though fighting with desperate valour were repulsed by the Russian grenadiers and when they attempted to re-enter Plevna, it was already in the hands of the enemy. In last night's Nacional the Peruvian antiquarian Ricardo Palma narrated as authentic facts that on the $16^{\text {th }}$ April 1803 , and again in Novr. of the same year, thunder was heard in Lima, and lightning seen in the town itself. According to a chronicler, Moreno, the same phenomenon had occurred on the $13^{\text {th }}$ July $155^{2}$, and again in 1720 and 1747 , but Palma did not seem to believe in the correctness of this statement.

Five of the Directors of the Insurance Coy. Lima had their usual monthly meeting in the Company office when we resolved that of the $S / 58$,ooo net gains of last year, 40,000 , equal to $20 \%$ on the paid up capital of $S / 200,000$ should be divided amongst the shareholders, and 18,0oo be added to reserve fund, which was now about 190,000 Soles. We raised a trifle the salaries of the two clerks Valdivieso and Cudlip, and ordered [543] the gerente to pay each a gratification at the end of the year and, what to me appeared of great significance, we requested the gerente to demand payment of a pagaré of Scheel's for S/30,000 which fell due this month, unless he gave better security than that which we held, viz.: Shares in Dreyfus contract. By this days South Steamer embarked for Chile, Mariana Barreda, wife of Manuel Pardo, with several of her children; also with destination for Puno, Manuel Costas, wife, and two daughters together with Miguel San Roman. Costas and the two daughters took their leave of us a few days back. In the evening Urquhart and the Administrador of Villegas came to our rancho to see how Juan was. I learned from the latter that they had not been out hunting, but that they had been to a mine, and that on their return to Matucanas they were overtaken by the darkness. Whilst walking along a very narrow path, a high mountain on the one, and a precipice on the other side, an Indian guide leading the way, next the administrador, then Juan, and another North American, the mules one by one, and finally the muleteer. Juan had been struck by a thorny branch, and would have probably fallen down, the precipice, if he who walked behind him had not taken hold of him. In this manner they proceeded for a great part of the night when at 3 or 4 in the morning they lay down on the wet ground, to rest till daybreak, and reached Matucanas a few hours later.

Friday, $4^{\text {th }}$ of January 1878 . After the taking of Plevna by the Russians Servia had also declared war to the Turks.

Saturday, $5^{\text {th }}$. The papers stated that Agustin Edwards, the rich banker and miner, a native of Chile, had died in Valparaiso on the $2^{\text {nd }}$ inst. His father, an Englishman, had laid the foundation to his own and his son's wealth by working copper mines in the neighbourhood of Coquimbo. Further, that in the Island of Cuba the Vice President Francisco J. Cespedes had placed himself at the head 
of the revolutionary party, also called the patriots; the President had fallen into the hands of the Spaniards several months before and [544] [_] carried to the Peninsula. At dinner Enrique gave us the [_] that England had declared war to Russia. Juan wrote me by last steamer from Nizza, that the English and French holders of Peruvian Bonds had once more begun a lawsuit against the firm of Dreyfus in Paris, to make them pay the interest overdue on these bonds, as well as the bonds which should have been redeemed. Enriqueta went to bed, suffering from headache, Ricardo did not come to Chorrillos before 10.30 and I thus spent a miserable evening for the greater part lying asleep on the sofa.

Sunday, $6^{\text {th }}$. In the forenoon I was occupied with dictating my letter to Juan, went per train to Chorrillos, descended at the station, called Buen Pastor at the beginning of the village, and walked to the rancho of Baltazar Aranivar to congratulate him on his Saints day, for the $6^{\text {th }}$ January is dia de los Reys': Gaspar, Baltazar, and Melchor; or the Holy Epiphany. The site was a present from the family Goyeneche to Don Baltazar, and the house covered a great extent of ground. It contained more than 20 large rooms, even an oratory with an adjoining for the dressing and undressing of the officiating clergyman, but it was evident that money had been wanting to conclude it; even furniture was scarce. When I reached my rancho I felt so weak that I first lay down upon my bed, then undressed, and turned in. The family of Anibal de la Torre and various others dined with Enriqueta, also Dr. Middendorf, who after having taken my pulse, gave it as his opinion that I had a violent fever. I ate nothing, perspired profusely, for four hours, from 6 to 10, and slept soundly till

Monday, $7^{\text {th }}$ of January, when by the Doctor's advice I neither bathed, nor went to town. Through Ricardo I begged Bryson to come out, who was with me for a few hours, but had also to leave off, for the terciana came upon him. It was a very tedious time till 6.30 when we as usual sat down to dinner. In the evening Garland, who was by no means well, for he suffered from an oppression on the heart, and Enriqueta went out to pay visits. José Canevaro called, who told me amongst other things [545] that he, Candamo, and Derteano, had hitherto made [?] progre[_] in their acquisition of the shares of the Eten Railway, and in the arrangement with the different persons who had given their guarantee for the one million Soles Bonds frequently mentioned.

Tuesday, $8^{\text {th }}$ of January 1878 . Though extremely weak I went to town, and paid to the Compañia de Fomento, hard up for money, $\mathrm{S} / 2500$ on account of the chapel, and thus only S/50o remained unpaid. In Chile had died, full of years and honors, the Vice-Admiral of the Chilian fleet Mr. Robert Simpson of whom I spoke in my diary of 1824, Vol. 1 page 6o, when he was but Captain, and I saw him occasionally with Moens and others. Here in Lima we had the sudden death of Guillermo Pfeiffer, the youngest son of Don Federico. Of 
late he had been employed in the Callao Custom house, then again he had gone to the Pabellon de Pica for the guano loading company, but one with another he could have left but little money to his widow, a French lady whom he had married, when for a great part of his life he had resided in France. By submarine cable advice had also been received from Chile of the death of Dr. Don Domingo Mendoza, Vocal of the Superior court in Lima, who having been cured about eight or ten months ago, of a very dangerous liver complaint by Dr. Alarco, went to Chile to recover his strength, but there breathed his last. He was a very good and moral man, upright, but not particularly clever judge, for the entire Mendoza family, of the bluest blood, is rather short of intellectual capacity: the mother, Doña Manuela, who without doing her any injustice may be called silly; her son Manuel, the Mayorazgo, and her two daughters Emilia and Catalina. Don Domingo left a widow, Cristina, daughter of the late Dr. Prada, but no children.

Early in the morning our neighbour Don Manuel Alvarez Calderon came and invited Garland and myself to dine with him, to celebrate his birthday. Garland had already gone to Lima, but Enriqueta accepted the invitation for him whilst I begged to be excused, because as it was really the ca[_] [546] [...] go into society. After dinner we were quite by our[_] and as Ricardo did not come till 10.30 when he still read to me for half an hour, the time passed rather heavily.

Wednesday, $9^{\text {th }}$ ofJanuary. The heat was excessive, thermometer at 3 p.m. $85^{\circ}$ F. I felt very weak, and rather unwell.

Thursday, $10^{\text {th }}$. Thermometer at $2.3085^{\circ} \mathrm{F}$. As regards myself the same as yesterday. I received via Panama a present from Corina Cordes consisting of an oil portrait of my dear Mariquita painted from the photograph taken in Paris in 1863. Though I was not able to distinguish it well I believed it was a good likeness of how she then looked, but certainly not of her features in the last years of her life.

Friday, $17^{\text {th }}$. Thermometer at $1.3085^{\circ} \mathrm{F}$. I felt a little stronger than yesterday. Since the last few days I went to Chorrillos by the 6 p.m. train for Bryson did not leave me till past five. In Chorrillos we had after dinner a visit from Rafael Velarde and family, who thought of removing to Callao there to spend the hot season. As superintendent of the Callao Custom House Don Rafael had a house in the Port, which the Government placed gratis at his disposal. The notorious Dr. Fernando Casos, with whom Garland had formed some kind of intimacy, was also present.

Saturday, $12^{\text {th }}$. I heard that the Banco Garantizador had presented itself before the Supreme Court of Justice against the Government, complaining of "Despojo". The Executive had some time past given a decree to the effect 
that all the notes of the Banco Garantizador should be recalled by the $1^{\text {st }}$ April. The bank sustained that the Government had no right to give such a decree, because: "la industria es libre", and further because as there exists no law relative to banks, everyone can issue notes, and it only depends upon the public whether they take them or not. In my opinion the bank was in the right. At 1.30 I was in the Banco del Perú, where the Directors assembled. The last acta was read by César Canevaro when I observed that nothing was said in the same on the [547] subject of the letter written by the Delegates to the banks in wh $[\ldots]$ hey asked for the exact amount which the Government owed. The answer given me was that as no resolution had been come to at the time it had not been thought necessary to take any note of it in the Acta. I asked whether the Delegates had paid the interest on the Government's debt since the middle of Augt. till the end of the year at 42 pence; I asked what arrangement had been made with the estate of Eduardo Villate of the Cerro; to both questions I was answered that nothing had been done. The object of our meeting was to discuss the wording of an answer to be given to the Government which had passed a note to the Banco del Perú, in the same manner as it had done to La Providencia, in which it asked for the delivery of four millions and odd of Soles in billetes resellados which they purposed exchanging in the fiscal offices for the notes without the Government's Stamp. None of us was inclined to deliver this large amount of billetes, apprehensive that the Government might put them into circulation without exchanging them for other notes, and if this were done, the amount of notes in circulation would perhaps be the double of what it ought to be. An answer had been drawn up by the lawyer Ramon Ribeyro and the Gerentes; it was read, but not approved by the Directors; a great deal was talked, many suggestions were made; none of the Directors would take upon himself the drawing out of another answer, and thus we had to leave the work to the gerentes who would have again to call us, in order to lay before us the result of their lucubrations.

Sunday, $13^{\text {th }}$ of January 1878 . With Bryson I occupied myself remodelling the old diary of 1870; at 1 O'clock Eduard Knauer came, who read to me two letters which he had received from his mother. I then went to Chorrillos by the $2 \mathrm{t}$ [rain]; on my arrival there I dressed, and paid visits to our neighbours, the family of Manuel Alvarez Calderon, and to the Coxes, also to Mrs. Manuel Candamo, where everything was locked up, and to Antonio Lavalle. Already when [_] Coxes a shive[_] [548] [...] upon me and when sitting in the corredor in our rancho I felt so cold that I had to hurry to my bedroom, where I quickly undressed, lay down, and requested Enriqueta to throw over me as many bedclothes as she possibly could. From that moment I lost all consciousness. 
I knew of nothing that happened to me until about two hours and a half later when the Doctor and Enriqueta came to my bedside, and I awoke in the firm belief that only a few minutes had passed since I lay down. Meanwhile Basagoytia and some of his family, Federico Palacios and wife, and a few others, had been dining with the Garlands in the corredor; I felt very miserable, vomited, again fell asleep and did not awake till

Monday, $14^{\text {th }}$. Through Ricardo I sent a message to Bryson, requesting him to come out, and though I managed to occupy myself with him, and to listen to his reading, I had fever the whole day long, and ate nothing. Dr. Middendorf came in the afternoon, was not at all satisfied with the state in which he found me, and prescribed for the next day Seidtlitz powders, and after them a considerable dose of quinine. I passed a bad night.

Tuesday, $15^{\text {th }}$. Bryson again came out, I took my medicine, and spent the day exactly like the previous one.

Wednesday, $16^{\text {th }}$ was passed in the same manner, with the exception that Bryson remained in Lima to copy what we had remodelled. At 4 p.m. I fell asleep, perspired profusely, and when I awoke at 6 O'clock the fever was gone.

Thursday, $17^{\text {th }}$. Bryson was again with me, and now and then I was strong enough to listen to Ricardo's reading. The nourishment I took was confined to some strong broth and two cups of tea daily. I continued taking quinine.

Friday, $18^{\text {th }}$. I got up, but my weakness was extreme. In the course of these few days all kinds of news had been received from Europe; also in Lima, events had occurred, worth being chronicled. On the $8^{\text {th }}$ January died Osman Pasha, the heroic but unsuccessful defender [549] of Plevna. On the $9^{\text {th }}$ expired, struck by apoplexy, Victor [_], the first King of United Italy since the times of Odoacer and Theodorico. He was born in March 1820, succeeded his father Carlo Alberto, who abdicated in his favor in 1848, married the daughter of Regnier, Austrian Viceroy of Lombardy and Venetia, brother of the Emperor Francis I, and after her death married again, but morganatically. On the $10^{\text {th }}$ January he was succeeded by his eldest son Prince Umberto; and on the same day capitulated the Turkish garrison of the fortifications of Shipka, which capitulation was followed by an armistice between the belligerent parties. By the Lima papers, I saw that the firm of Dreyfus had lost its suit against the Supreme Government, but I had not been able to learn what the question was which had been decided. In the "Comercio" of $17^{\text {th }} N^{\circ} 13,887$ a decree dated $14^{\text {th }}$ January was published which said that the Government acceded to a proposal made to the same by the Delegates of the Banco de Lima, that the Government would deliver on the $27^{\text {th }}$ May $£ 20,00090 \mathrm{~d} /$ st. on London; on the $27^{\text {th }}$ June $£ 20,000$; and on the $27^{\text {th }}$ July $£ 16,966$, which three deliveries, calculated the 
first at $27 \mathrm{~d}$ the second at $28 \mathrm{~d}$ and the third at $29 \mathrm{~d}$, made a total of $\mathrm{S} / 465,825$ which payment not only cancelled the Government's debt to the Banco de Lima with interest since the $17^{\text {th }}$ August, but also put the Government in the place which the Banco de Lima had occupied hitherto in the administration of the Nitrate business, and in the consignment of guano to Mauritius, and not only this, but the profits made to the end of the year were likewise ceded to the Government. In virtue of another decree Juan Martin Cardenas was named one of the Government's Delegates in the Nitrate and Guano negotiation in lieu of Gustavus Heudebert who had filled the post for the Banco de Lima. Focion Mariategui, the other Delegate of the Bank kept his situation on account of the Government, both he and Cardenas with a salary of S/300o. Yesterday the so frequently discussed question whether the Banco Hipotecario should "tranzar" with Enrique Barreda his claim for the payment of the Cedulas transferred to Paris [550] [...] suit should he carried on, the Fiscal Dr. Teodoro de la Rosa having already given his vista in favor of Barreda, was again brought before the Directors, who had invited to be present at their deliberations, and to give their opinion, Jose V. Oyague, Dionisio O. de Villate; Aurelio Denegri; and myself, who unable to attend, begged Alejandro to go instead of me. The Gerentes told these gentlemen when assembled, that Barreda was ready to desist from the suit on receipt of $£ 40,000$ Stg. Aurelio Denegri was the first who spoke recommending strongly to accept the proposal. Villate said that he would vote with the majority of the Directory; Oyague hemmed and hawed, and talked a great deal, giving to understand that he was against the proposal, but did not venture to speak so decidedly as he had done on the previous occasion, because he clearly saw that the majority was against him. Alejandro said that if they did not now pay $£_{40,000}$ they might have to pay a few weeks later $£_{50,000}$ if not more. The Directors themselves said but little, but after the others had left, they authorized the gerentes to close the affair with Barreda, and so this question which for such a length of time was pending, was brought to a conclusion. Garland went this day to Barreda to arrange with him the dates when the payments were to be made, for it stood to reason that the drafts for $£_{40,000}$ could not be handed him at once. His Cedulas transferred to Paris amounted to 236 of S/1000 each, of which 22 were redeemed.

Saturday, $19^{\text {th }}$ and Sunday, $20^{\text {th }}$ of January. Bryson remained in Lima. The state of my health was like the two previous days, without fever, but extremely weak. Saturday in the morning and evening Ricardo read to me a little, and so he did on Sunday, on which day Federico Palacios wife and father-in-law, also Urquhart and Limpricht dined with the family Garland. I took my dinner by myself in the sala, and nearly the whole of both days, lay or sat on one of the sofas. Limpricht kept me company for a [551] short time, and Dr. Middendorf, 
who came at a $[\ldots]$ cribed some ointment with which to rub the right hip, where I felt rheumatic pains.

Monday, 21 ${ }^{\text {st }}$ of January 1878. J. M. Cardenas refused to accept the Government delegateship in the Saltpetre and Mauritius Guano business.

Bryson came by the 10 O'clock train. I felt like the day before, very weak and with rheumatism.

Tuesday, $22^{\text {nd }}$. I was gradually getting better, and without fever, but always weak. Ricardo read to me from the Leipsic Illustrated Gazette an article relative to the gigantic cast-steel foundry, the property of Mr. Alfred Krupp, near the town of Essen, in the Ruhr district, Westphalia, the most perfect, and most extensive establishment on the globe, of its kind. One year before the birth of its present owner in 1811, the foundation was laid by his father, after whose death he continued to work, first on his mothers, then on his own account, and gradually raised it to its present height. In the coal and iron mines, also his property, 6000 men were daily at work; in the foundry 8500 ; for smelting the ore, and for raising the steam required to put in motion the numberless machinery, 44,000 cwt of coal were consumed daily. The establishment included many miles of Railways, with their corresponding locomotives, waggons etc., also many carts drawn by horses; 3200 houses, in which dwelt the higher employés, workmen, and their families, telegraphic, lithographic, and photographic establishments; a printing press, a bakery, which produced monthly 390,000 lbs of bread, slaughtering houses, shops in which meat, all kinds of groceries, and manufactured articles of general use were sold, a hospital, druggist shop, a chemical laboratory; an hotel; 6 beer halls, four schools for children; one for grown up girls; another for married women who were inclined to work; even a life Insurance Company; in short, nothing was wanting for the comfort of this colony. The sound produced by the falling of the main hammer upon the mass of Cast-steel was like the [552] [_] of a heavy piece of artillery; Mr. Krupp's own dwelling house not far off trembled, and the windows rattled. At a later period he removed to a country palace built on the banks of the Ruhr. The principal products of his foundry were cast-steel pieces of artillery of which he had made more than 15,000 of all sizes for the different potentates of Europe; of late the Emperor of Russia had given him extensive orders, in order to compete with the Turks, who had been ahead of him in this respect; he also made propellers for steamers, rails, steel hoops for wheels, axles, in short everything where caststeel can be employed, and to secure the best material he had purchased iron mines in Biscay, where, it is well known, the best iron is found. The Emperor of Germany offered him the diplomacy of nobility, which he declined, but accepted the order of the second class of the Red Eagle of Prussia, which the Emperor himself handed him at the time of his visit. 
This morning died here in Chorrillos General Manuel Martinez Aparicio, native of Santa Marta, Nueva Granada, one of the oldest generals in the Peruvian Service. Col. Juan Salaverry had also breathed his last in Lima. He was a natural brother of the notorious General Felipe Santiago Salaverry. For many years past my good friend Charles Pflücker had been carrying on a lawsuit with this Salaverry relative to the Silver mines in Castro Vireyna, which, worked by his sons, were producing large amounts of rich ore, and which were claimed by Salaverry as being his, he pretending that the Pfluckers had possessed themselves of the same by illegal means.

In the evening when Garland and Enriqueta had gone out to pay some farewell visits, and Ricardo was reading to me, it was exactly five minutes past nine, a very severe shock of an earthquake was felt. I actually thought that the walls of my rancho would be overthrown; one of the windows came down [with] a loud crash, and several panes were broken; shortly afterwards Mr. and Mrs. Manuel Candamo, very nice people, entered, whom in the absence of Enriqueta I had to receive; they remained but [...] minutes. [553]

Wednesday, $23^{\text {rd }}$ of January 1878 . Bryson was with me from [_] ill somewhat past 4.30. In the evening Garland sat in the corridor, then went out; Enriqueta, accompanied by Ricardo, made several calls, and thus I was all by myself till 10 O'clock, with pains above my right thigh, which were so severe that if once seated, it was with difficulty I could get up. At this late hour first came Peta, the wife of Carlos Paz Soldan, deaf as a post; next, Eliza, with her mother Doña Mariquita Higginson, not particularly interesting and finally Mr. Pinto, a very agreeable gentleman.

Thursday, $24^{\text {th }}$ of January. This morning we were all up at an early hour, to get ready for our return to Lima. Castagnini, the Italian druggist, had sent us word through Geraldo that he wished me to let him my rancho, because one of his daughters was ill, and that he would pay me any price. Yesterday a young man came out sent by him to whom I showed every room and who seemed much pleased. The rent I asked was to the $30^{\text {th }}$ April S/1000, or to the $31^{\text {st }}$ May S/1200. He promised to send an answer to Mr. Garland at the Banco Hipotecario and at all events to return this morning by the 9 train. We waited and waited, but he did not come. The curtains were taken down and everything shut up in our rooms; and Enriqueta, Antonio, the two little girls, their friend Maria Palacios, and I, went to town by the 12 train. I was again installed in my office, and felt quite well, but for the disagreeable pains above the right hip. I saw by the Nacional that the Government had allowed to Pedro Telmo Larrañaga an unlimited issue of a new kind of bank notes, under the name of "Boletos de Pasaje, para los ferro-carriles en el Departamento de la Libertad"; further that Juan Revoredo had obtained a judicial order for embargoing all the proceeds of the Oroya Railway, because La Compañia de Obras Publicas y Fomento, which 
by the by had issued the entire $S / 5,333,333$, refused to pay two bonds known as those of Meiggs, each of S/50,0oo, held by Revoredo.

The remainder of the day, I did not leave the house.

Friday, $25^{\text {th }}$ of January. Antonio Bazo died at 8 a.m. [554] [...] Manzanilla. Already on the $30^{\text {th }}$ September, the [_] of Henry Meiggs decease, he was believed to be on the point of death; it may easily be conceived what his sufferings must have been since then, and what care and attention all around him, particularly his sister Pepa, had bestowed upon him.

In the course of the day I had necessarily to go out to see how things were going on in Lima. In the office of the Escribano Escobar I learned that the judge Quiroga had fixed the public sale of Juan Aliaga y Puente's finca, Calle de Polvos Azules, for the $11^{\text {th }}$ Feby., he, Aliaga, presenting meanwhile the title deeds. This sentence had been notified to Aliaga on the $7^{\text {th }}$ January, and as he had not yet presented these documents I gave in an escrito when the judge resolved that Aliaga was to exhibit them in two days, under pain of having guards placed at the street door of his house. From the Salitrera Barrenechea, I received the dividend of $20 \%$ upon eight shares of S/500 each, belonging to Dr. Palacios which he had placed in my hands as prenda pretoria for a loan of S/2700 made him by me on the $29^{\text {th }}$ August 1873 . Of these 800 , four hundred corresponded to me, the other half to Rosa, Juan and Enriqueta. I had to walk extremely slow and nevertheless, I felt much pain in the muscles round my hip bone. Dr. Middendorf prescribed a mustard plaster which was put on when I was in bed. The Canon Mora, Urquhart, and Limpricht had spent the evening with us, sitting in the comfortable nook on my side of the corredor.

Saturday, $26^{\text {th }}$ of January. The plaster had done me neither good nor harm. I slept last night better than I had done for a long time past, and had this morning not the slightest fever. A telegraphic dispatch published in the Comercio said that the Agente fiscal in Europe had by order of the government embargoed the guano existing in the hands of Dreyfus whilst the Lima firm published an article in which it affirmed that this telegram was not correct. Johannes Limpricht came and asked me for a loan of S/10,000 at $7 \%$ with an escritura upon the contents of his shop Calle de Mercaderes. [555] I agreed, though reluctantly, to lend him $\mathrm{S} / 8000$ at $8 \%$. At a later hour, Constantino Rehder came, and closed my account with Rehder \& Co., which I had open since the death of John Renner; he paid the balance of the principal, and interest, so that they did not remain owing a cent. With great difficulty I walked as far as Gibbs' house, to bid good by to Eggert who left by his steamer for Europe, but did not find him in. The object of his visit to Lima had remained a secret.

After Bryson was gone I took my usual seat in the corredor, Enriqueta kept me company till bed time. Garland sat with us for an hour, without opening his mouth. Ricardo went to the Church of Cocharcas, whether Antonio 
Bazo's corpse had been carried from Manzanilla, and then accompanied it, together with several friends of the deceased, to the Church of La Merced, where this day

Sunday, $27^{\text {th }}$ of January, the funeral was solemnized. The Municipality had decreed that henceforth the dead were to be carried out directly to the pantheon, and that this was to be done within 24 hours after the decease, in my opinion the most imprudent, cruel, and improper measure, for it is but too well known that deathlike trances sometimes last more than 24 hours, and thus the chances of persons being buried alive are still greater than they have been hitherto in Perú, where, as far as I can judge, it has always been the custom to bury the dead much too soon. Middendorf came this morning, took my pulse, and declared that I had no fever. At my suggestion he ordered a "parche poroso" to be put upon my painful hip, and there was no doubt that I could walk to day with more ease than yesterday. When Bryson was gone at 1.30, Limpricht and I played two games at chess, which I lost; it was nearly five before we left off. He and Urquhart were with us at dinner. From 9 to 10 Ricardo read to me Zamarow's book; till bed-time Enriqueta and I were as usual in the corredor.

Monday, $28^{\text {th }}$ of January. The fever was gone, and the pain in my hip-bone was decreasing. In the forenoon I went out to see what was going on in the world. In the office of the Banco de Lima Cucalon gave me the exact details of the arrangement between [556] [_] Bank and the Government, somewhat different from those mentioned on the $18^{\text {th }}$. The gains which had arisen from the administration of the Nitrate business, and the guano to Mauritius which would probably amount to $S / 130,000$ remained with the bank. They were not ceded to the Government. The amount of $S / 465,825$ which the bills to be received from Government, calculated at 27, 28, and 29 pence per Sol, came to, was exactly the sum which the Government owed on the $17^{\text {th }}$ August, thus the interest since that date was lost, but on the other hands as there was a probability of the $£ 56,000$ being sold at 23 or 24 pence, there would then be a handsome profit for the bank.

From the two Insurance Companies I received the dividends for last year: from the South American S/200, 12 1/2\% on my S/160o; from the "Lima" S/400, $20 \%$ on my $\mathrm{S} / 2000$.

The South American

The Lima

The South American

The Lima

The South American

The Lima made last year on

made last year on

made last year on

made last year on

made last year on

made last year on
Sea risk

Sea risk

Fire risk

Fire risk

in interest

in interest
$\mathrm{S} / 48,815$

$\mathrm{S} / 11,211$

$\mathrm{S} / 45,343$

$\mathrm{S} / 16,705$

$\mathrm{S} / 53,700$

$\mathrm{S} / 44,696$ 
and notwithstanding these considerable differences in favor of the South American, the "Lima" paid a larger dividend, which arose from the circumstance that it had suffered no loss worth mentioning in 1877, whilst the South American had to pay for three heavy losses, viz.:

Silver bars lost on board the steamer San Francisco

Loss by fire in the shop of Luis Biggio

$\mathrm{S} / 39,000$

$\mathrm{S} / 5000$

Loss by fire in the store of Denegri Herm.

$\mathrm{S} / 50,840$

$\mathrm{S} / 94,840$

The Capitals of the two Companies stood as follows:

South American

$$
\begin{aligned}
& \text { Capital paid up } \\
& \text { Reserve Fund } \\
& \text { Fund for covering loss on securities held } \\
& \text { Further fund for meeting losses } \\
& \text { Known, but amount not yet ascert. }
\end{aligned}
$$

$$
\begin{array}{r}
S / 160,000 \\
S / 240,000 \\
S / 80,000 \\
S / 10,000 \\
S / 490,000
\end{array}
$$

$[557]$

Insurance Coy. "Lima”

$$
\text { Capital paid up }
$$$$
\text { Reserve fund }
$$

$$
\begin{array}{r}
\mathrm{S} /[?] \\
190,000 \\
S / 390,000
\end{array}
$$

The last telegraphic dispatches from Europe went to the $22^{\text {nd }}$ January when the English Government had passed a note to that of St. Petersburg, expressing a hope that the Russian troops would stop their further march onwards, which if done would be a proof that Russia did not intend to aggrandize its territory at the cost of Turkey, an on the other hand it was stated that Russian troops were accelerating their march to Gallipoli to take possession of that port before the arrival of the English fleets. The Ministers for Foreign Affairs for Perú and Bolivia were at present in a disagreeable correspondence on the subject of the Peruvian import duties, which had been considerably raised since the first of this month, and to which the Bolivians objected, because as the greater proportion of the imports by the port of Arica, and also part of those by Mollendo, were consumed in Bolivia, the Bolivians suffered by these increased duties whilst the advantage was exclusively for the Peruvian Exchequer. Hitherto Perú had paid to Bolivia annually $\mathrm{S} / 400,000$ as a compensation for the duties on imports destined for the Bolivian markets. Since at noon the sea 
in Callao Bay had been much agitated; the waves came from the North, from hour to hour they increased in size and violence, and had done much injury to the Port, mostly to the Muelle Darsena, which was said to have suffered very considerably. Last night towards evening the sea gradually went down. Eggert embarked on board of the steamer, whilst a sailing vessel, on board of which for his health Antonio was to make a trip to Chile, put off her sailing from day to day.

Tuesday, $29^{\text {th }}$ of January 1878 . Nearly the whole forenoon I was in the street. First, I went to see Rafael's wife and daughters whom the Callao waves had frightened up to Lima. Then I went to a meeting of the Directory of the Banco del Perú, where the yearly report of the gerentes Escobar and Cesar Canevaro was read. One point in the same gave rise to a serious and protracted discussion. The bank had of late been purchasing with the unanimous consent of the Directory, before I formed part of it, a considerable number of their own shares, at various rates which gave an av[_] [558] [...], the gerentes said, by means of this purchase we annul so many shares, worth to the bank $100 \%$, and consequently there is a gain of $37 \mathrm{1} / 2 \%$, upon which we are entitled to our commission of $10 \%$ jointly. Candamo, with whom and Ruden I had previously spoken on the subject, moved that this purchase ought to be considered as any other investment, that an account should be opened for these purchased shares, and place the cost of them to the debit of the account. I developed this idea saying that any dividend to be received on these shares should be placed to the credit of the account, and then carried to Profit and Loss. I further said that it was quite preposterous to carry off the gain of $371 / 2 \%$ because it was impossible to know before hand whether at the time of liquidating the bank would give $100 \%$. On the other hand Canevaro and Calderoni were quite as certain in their opinion that the shares being now in the hands of the bank, and consequently the number of those upon which dividends had to be paid to other persons, had decreased in the same proportion, the gain was actually made, and the gerentes entitled to their commission upon it. Althaus proposed as a middle course that we should take the value of the shares bought, at $75 \%$, their present market rate, and that the difference between $621 / 2$ and 75 should be carried to the credit of Profit and Loss. This, Candamo, who by the by spoke much better, and more eloquently than I, as well as myself, agreed to. However, the others were not satisfied; Ruden, who sided with Candamo and myself, did not say much, neither did Elizalde, and it was as late as 3.30 before we resolved that the question should be laid before the shareholders in the next general meeting, when I was certain that the majority would be against Candamo and myself, not because we were in the wrong, but because if this supposed gain between $621 / 2$ and 100, did not go to the credit of Profit and Loss, then the 
dividend for last year would not be 12 , but only $9 \%$. Thence I went to the Banco de Lima where I received $30 \%$ of my capital of S/50,000 say one hundred shares of $S / 1000$ each $50 \%$ paid up, viz.: S/12,00o in nitrate certificates at par, and [559] $\mathrm{S} / 6000$, Internal debt at $50 \% \mathrm{~S} / 3000$, together [...]. In the evening Bryson read to me Motley's Dutch Commonwealth and Paul Clifford by Bulwer. Limpricht kept Enriqueta and myself company in the corredor until bed time.

Wednesday, $30^{\text {th }}$ of January. To Alejandro I sold the S/6ooo Internal Debt at $50 \%$, and bought of him S/300o Nitrate Certificates at 95\%. I then went to Notary Escobar's office, where I learned to my great annoyance that Aliaga had recused Escobar as notary, and that he had no further title deeds than the escritura de la formacion del Mayorazgo drawn out in 1500 and odd, before a certain Perez, Notary of His Catholic Majesty. Quiroga had named Prieto instead of Escobar, to whom I was introduced by Orbegoso, the latter's clerk. In Dr. Palacios' office I had to wait nearly two hours before he dictated a short escrito in which he demanded that the judge would be pleased to fix a day for the public sale of the finca in Polvos Azules, and hardly had I come home when I had a long visit from Lembcke.

In the evening we had with us a clergyman, Aguila. Limpricht read to me in his room the last letters received by him from his sister, brother, and sister-in-law.

Thursday, $37^{\text {st }}$ of January. The Directory of the Banco de Lima had named provisionally Cipriano Correa, Gerente, instead of Lembcke. The Electric wire told us that in Pisagua the sea had also been much agitated, and done some injury to the establishments on shore. In Iquique it had remained quiet. On the $23^{\text {rd }}$ in the evening severe earthquakes were felt in Tacna and Arequipa. The European news via Valparaiso went to the $26^{\text {th }}$ or $27^{\text {th }}$ January. Earl Derby and Lord Carnarvon had resigned their posts in Queen Victoria's Cabinet. Negotiations for peace between Russia and Turkey were actively carried on. Antonio bade me good by, the vessel in which he intended taking the trip to Chile, would leave to-day, a proof that also in Callao the sea had gone down. I took from Garland three Nitrate Certificates of S/10oo each which he had received from the Banco de Lima upon the shares which were formerly [_] [56o] [...] his. I paid him at 95\%, and placed the S/2850 against the pagaré of Pedro Bernales, which years ago I discounted to Garland.

Friday, $7^{\text {st }}$ of February. Thermometer at 12.30 , a little above $85^{\circ} \mathrm{F}$. This was the New Year's day of the Chinese, who had closed their shops, and let off crackers the whole day long, from early in the morning till 10 or 11 at night. When I went to the Banco del Perú, where I opened an account, I found Ruden, Calderoni, and Escobar consulting whether it would be advisable to sell the large amount of internal debt which the bank held and which cost $70 \%$ at the current rate. 
Calderoni and I thought it would be well to do so, Ruden and Escobar were not inclined, and as this was a casual meeting, the decision was put off till the next session of the Directory. Meanwhile, Alejandro came in who purchased a few thousand Soles of this Debt, at $54 \%$ and a few moments later Calderoni, two or three thousand at $541 / 2 \%$. It was rumoured that the Government had made or was about making an arrangement with the Delegates of the Banks, in virtue of which they were to bind themselves to "hacer el servicio" of the Internal Debt, on condition that the Government left the consignment of guano to Mauritius etc. in their hands, and this had been the cause of the sudden rise in the value of this paper.

A telegraphic dispatch had been received by the Government from the Prefect of Cuzco, which advised the discovery of an immense treasure of gold and silver in the convent of San Francisco amounting according to some, to seven, to others eleven million Soles. In the evening the letters by the North steamer were delivered; Juan wrote from Nizza that he continued to suffer from piles, which made him lose a great deal of blood, and that he had given up the idea of returning to Perú and of building a rancho in Chorrillos, which had been his plan when last here. Rosa wrote Enriqueta that her husband had had a fainting fit, which for the moment had made her fear for his life, but that he had recovered. Further, that Schwank, a native of German [561] Switzerland, in former years clerk, then partner of [...] Manchester, and afterwards one of the two liquidators of the South American Company in London, had died on the $16^{\text {th }}$ December, at the age of 39 in London, leaving but a small fortune to his surviving wife and children.

Saturday, $2^{\text {nd }}$ of February. Candlemas. When Bryson was gone I started to make a few visits; firstly to the family of Dr. Gervacio Alvarez, where I always met with a very friendly reception; secondly, to Doña Josefa Prada, to whom I expressed my grief, for the loss she had sustained by the death of her son-in-law Domingo Mendoza. She was particularly agreeable, and so was Doña Manuela Portillo, with both which ladies I remained a considerable while. Irene, Dr. Munoz' wife, was prevented from receiving me by a severe headache. At Don Diego Masias' the doors were shut. At Doña Manuela Mendoza's nobody was in the drawing-room, and upstairs I was received by Don Manuel, not by his wife Isabel Barreda. When conversing with him I was confirmed in the idea which I had always formed of him, that he was certainly no bright genius.

Garland was the whole day in Chorrillos, and when he came home he told us that he had been assured by General Buendia that the story of the treasure discovered in Cuzco was an entire fabrication. This seemed to me very strange, because the evening before Buendia's niece, Fidelia, Anibal La Torre's wife, related to Enriqueta that her uncle himself had seen the telegraphic dispatch 
received by the President from Cuzco. Where the falsehood lay I could not determine. Federico Palacios, with his wife Mercedes Villacampa dined with us and remained till 10.30. Though both were very agreeable yet a visit of from seven to eight hours was rather too much of a good thing. Fortunately I could absent myself for about an hour when I listened to Bryson's reading Paul Clifford.

Sunday, $3^{\text {rd }}$ of February. The time that Bryson was with me was taken up with my dictating a letter to C. W. Schutte [562] [_] Limpricht and I played chess in the corredor. I gained the first game after an hour and a half's hard fighting, whilst he beat me the second in less than a quarter of an hour. Whilst we were playing I had a short visit from Dr. Alvarez. At dinner we had Urquhart with us, and from 8 to 9 Ricardo read to me.

Tuesday, $5^{\text {th }}$ of February. The newspapers published a decree signed by the Minister of Finance, and provided with the usual flourish or rubrica of the president, from which it was evident that the Government was firm in its resolve to exact from the firm of Dreyfus the payment of twenty two million Soles, which in their opinion was due to them, whilst on the other hand as far as I could understand these intricate accounts Dreyfus made a counterdemand for twenty one millions. In Piura, Catacaos, La Huaca, and Payta, the heavy rains which had fallen towards the end of December and the month of January, and the consequent rising of the rivers, had done much damage, mostly to La Huaca; and from Arequipa they wrote that contrary to what is usually experienced in that town and its environs, no rain had as yet fallen in the month of January. From Iquique and Pabellon de Pica they wrote that on the $23^{\text {rd }}$ at 8 p.m. a severe earthquake had been felt in both places. A sambo woman, servant to Magdalena the President's wife, who this day had been with Enriqueta, assured her that there was not the slightest doubt of the discovery of the Cuzco treasure, but that the Government wanted to keep it secret.

This day the Lima Water Company sent me $21 / 4 \%$ dividend due $31^{\text {st }}$ March, and $1 \%$ on account of the capital. The clerk who brought me the check told me that Andrés Rey, the manager, had been struck by apoplexy about a fortnight back, whilst sitting at his desk in the office, and that he had been conveyed to his house, where he was now lying dangerously ill, hardly able to articulate a word.

Garland, Enriqueta, and the girls dined at Federico [563] Palacios'. Urquhart and Meeker, adminis [...] chacra Villegas, sat down with Enrique, Ricardo, Juan, and myself. Juan and Meeker were great friends; they had planned a business for providing Lima with ice from the Sierra. They made contracts for purchasing and selling, without having the necessary funds, and now that these were required they were nowhere to be procured. Garland, the father, had been 
good enough to give his son the 25 shares in the Banco de Lima, Noml. S/25,000 paid up S/12,500 formerly Bernales' upon which the bank had just paid 30\%, and upon which in course of time 30 or $40 \%$ more might be forthcoming, but as was to be expected, nobody would advance any money on such security.

Wednesday, $6^{\text {th }}$ of February 1878. Juan Aliaga y Puente had stated in one of his late escritos that the title deeds of his small finca 11 and 13 Polvos Azules were included in the foundation [_] the Mayorazgo in 1570, before the notary of His Royal Majesty Estevan Perez; the whole morning I tried to find where the archives of this notary were, when I discovered that no such notary had existed, and consequently Dr. Palacios dictated an escrito in which I demanded that Juan Aliaga y Puente should rectify his indication as to the whereabouts of the title deeds.

Thursday, $7^{\text {th }}$ of February. In one of the daily papers an extract from one of the London Times was published which said that up to the $30^{\text {th }}$ June 1877 the Peruvian Guano Coy. (Ld.), London had made very little progress in the sale of guano, and that the Peruvian Government owed them at the time about $£ 1,600,000$. If this were correct, as in all probability it was, there was little chance of the resumption of payment of interest on Peruvian Bonds on the $1^{\text {st }}$ January 1879 as promised in the contract concluded between the said company and General Prado about the middle of 1876 .

Friday, $8^{\text {th }}$ of February. At 12 O'clock I was in the office of the notary Prieto, and had to wait full half an hour till his confidential clerk came, who against my receipt allowed [_] [564] [...] the expediente, which I showed to my lawyer. In conformity with my escrito of the $6^{\text {th }}$ Dr. Quiroga had ordered Juan Aliaga y Puente to point out distinctly and clearly where the deeds were to be found. On the other hand he had presented an escrito in which, "para evitar futuras complicaciones y para poner su conducta en salvo", he thought proper to make known to me that the house which I had embargoed he had not only mortgaged to me, but also to Pedro Villavicencio and to Dionisio Derteano, to the former for S/30,000, to the latter for S/50,000. Now Dr. Palacios, in order to reply to this escrito required a list of all the mortgages which weighed upon Aliagas' house in the Calle de Palacio, and to obtain this I went to the office of his brother, the notary Francisco who has the register of mortgages under his charge. I told him what I required and received for answer that he could not get it drawn out till the following day.

It was now 1.15, high time to be at the meeting of the Directors of the Insurance Company Lima. Present were, the Gerente Elizalde; Gil, vice; instead of Chavez; Robertson, I, and the two newly elected, Isaacson of Bates Stokes \& Co., and Menchaca, a Spaniard, owner of the extensive iron monger's shop in the Calle del Correo. Elizalde informed us that he had received advice of two losses, for which the Company would erelong have to pay the amounts insured 
to the parties interested. The one, $S / 10,000$ on hides and silver bars shipped for Hamburg on board the German steamer Karnak which had run aground not far from Montevideo; the other S/16,00o on freight per Esther from Callao to Liverpool, which vessel had been obliged by stress of weather to put into the port of Valparaiso. Mr. Isaacson, whose firm had a branch establishment in Montevideo and Robertson of SawersWoodgate \& Co., who had his in Valparaiso promised that they would write to their friends and request them to furnish all the details which could be of interest to the Company. We further learned from Elizalde that Cudlip, the junior clerk, to whom at the end of the year we had given a small [565] gratification, and raised his salary, had [embezzled] S/6oo which had only just been discovered. When taking money to La Providencia he had occasionally delivered less, and falsified the number both in the book and the receipt given. I need not say that he had been dismissed, and that Elizalde had written to his brother, the husband of the widow of Francisco Calderon, at present in Europe, asking him whether he would make good this amount to the Company. Thence I had to hurry to a meeting of the shareholders of the Banco Hipotecario; after the acta of the last meeting had been read and approved, the report for the last year, printed copies of which had been sent round to all the shareholders, was hardly discussed and quickly approved. Then the President of the Directory, the Spaniard Lorente, said that he wished to say a few words in order to give an idea of the excellent condition in which the bank was at present, but what he spoke was such a farrago of words, such a confusion of ideas, such a mixing up of numbers, that I was quite certain when he had finished nobody was a bit the wiser than before. A repartition of the profits came now under debate; an amount equal to $10 \%$ on the capital would be distributed in Cedulas at par. Someone rose to make an observation on the subject, but he was quickly silenced, it being proved that the late arrangement with Barreda had absorbed all the cash, and that nothing better could be done than pay the dividend in Cedulas. After the necessary sum had been carried off to reserve fund there still remained a balance of $S / 14,000$. What was to be done with it? Loayza and Agustin Escudero, the latter the gerente who had succeeded Calderon, proposed that this sum should also be carried to reserve fund. Manuel Candamo moved that it should be distributed in the same manner as a similar balance at the end of last year, viz.: S/3000 as an extra remuneration to the gerentes; $S / 2000$ to the clerks, and $S / 2500$ to the Directors. This motion was approved of. Finally the choice of new Directors came on. I made out my list, and left the room. I afterwards learned that the follo[_] [566] [...] een chosen. Sebastian Lorente; Manl. M. Galvez; Melchor Velarde; Pedro Correa y Santiago; Enrique Witt; and Suplentes: Pedro Helguero, Francisco Paz Soldan and George Elster. 
Thence I went again to Francisco Palacios, but the certified list was not ready; thus the whole day passed. In the evening Enriqueta and I had a short visit from Dolores Puente, whom I accompanied home.

Saturday, $9^{\text {th }}$ of February. From 8 till 10 a.m. I dictated to Enrique Garland a letter which he as Consul had to write to the danish Government. When Bryson came we occupied ourselves a short time with remodelling the old diary. Then in the heat of the day I had to walk to the office of Fernando Palacios, to that of his brother Francisco, and back again but the certificate I required was not yet ready. At about two I was in the locality upstairs in the Banco del Perú where I took my seat amongst the Directors to the left of Emilio Althaus, the president, and to the right of César Canevaro, one of the Gerentes. Althaus, who made an excellent chairman, read the yearly report drawn out by the gerentes, and signed by the Directors. Cipriani was the first to rise, and said that though on former occasions he had censured the acts of the Directory, he could now only praise the purchase which they had made of the Bank's shares. Oyague then spoke, and was of opinion that the profit between the cost price and par was actually made, and that he saw no reason why this profit should not at once be divided. Elizalde followed in the same track. Candamo was not present, and I, seeing that the general opinion was against me, kept silent. Consequently, the dividend of $12 \%$ was declared. Francis Bryce moved that the report should always be printed and sent round to the shareholders a fortnight before their meeting. It was however proved to him that this would be very impolitic because it was by no means desirable that everybody, not a shareholder and especially the Government and Municipality [567] became acquainted with the sources of the profits and their amount; and this they would of course be if the report was printed. Consequently the motion was lost. Then eight new Directors were chosen, the old ones who remained in being M. Candamo, and J. Calderoni. The choice fell upon the following: Enrique Ayulo, Carlos Elizalde, Alexander Ruden, Emilio Althaus, José V. Oyague, myself, Jose Unanue, and Francis Bryce. Of these, the six first named had more or less the same number of votes, the two last named considerably less. It was now nearly 4 and again I hastened to Francisco Palacios who was occupied with drawing out the certificate. When he had done I took it to my lawyer, when we found that the principal mortgage, that of Derteano, had been omitted; again I hurried to Francisco's, who had no time, because he was going to Chorrillos. This morning Camagli, an Italian, married to a sister of the Denegri's, lost his life in a frightful manner. In his estate of Bocanegra he had put up a new machinery for grinding sugar-cane, part of which consisted in a very large iron wheel, with which he was not satisfied. The distance between the wheel and the wall was hardly nine inches; he ordered some of his men to ascend, and to place themselves upon some of the spokes, to make the wheel move; he did the same, slipped, fell 
into the space between the wheel and the wall head foremost, and, the wheel having just then begun to move, was crushed to death. His suffering must have been dreadful.

Another accident occurred in the dead of last night. The large acequia or canal which put in motion the Tocuyo manufactory situated just before you come to the Alameda de los Descalzos which by negligence had been allowed to fill up with sand, overflowed its banks, and inundated a large number of houses in the vicinity. We hear only of one dog having lost his life, but much damage had been done to the houses, and more to the furniture.

Sunday, $10^{\text {th }}$ of February 1878. After Bryson was gone I paid several visits, which were more agreeable than these visits usually are, viz.: to Doña Isabel Coloma, widow of Carlos [568] [_], where the mother having gone out I was received by her elde[_] daughter Juanita, an agreeable young lady; next, to Mrs. Macandr[_], then to Virginia La Torre, widow of Domingo Valle Riestra; and finally, to Emilia Lopez, J. P. Escobar's wife. At Dr. Muñoz's, neither he nor his wife was in. Don Teodoro de la Rosa, though his porter said that he was upstairs, sent word that he was not at home. At dinner we were but few; Garland and the little girls had gone to Chorrillos, and Limpricht dined in Miraflores.

Monday, $11^{\text {th }}$ of February. The corpse of Camogli was conveyed in the funeral hearse, direct to the pantheon, in conformity with the present municipal regulations. At last I obtained the necessary certificate from the notary Palacios, of which the following is a translation:

Mortgages on the house, stores, and shops of Don Juan Aliaga y Puente Nos. 24 at 38 Calle de Palacio

\begin{tabular}{|c|c|c|c|c|}
\hline Date & Amount Soles & Mortgage on & Creditor & Notary \\
\hline May 141869 & $\$ 14,400$ & House 24.26 & P. Villavicencio & Palacios \\
\hline Augt. 231869 & 7200 & House 24.26 & E. Witt & Palacios \\
\hline June 231874 & 3200 & House 24.26 & $\begin{array}{l}\text { Margarita } \\
\text { Aliaga }\end{array}$ & Palacios \\
\hline Augt. 91872 & 8000 & $\begin{array}{l}\text { Shops } 24 \cdot 30 \cdot 32.34 \\
36 \text { and } 38\end{array}$ & $\begin{array}{l}\text { Pedro } \\
\text { Villavicencio }\end{array}$ & do. \\
\hline Augt. 11874 & $5^{0,000}$ & do. & $\begin{array}{l}\text { Dionisio } \\
\text { Derteano }\end{array}$ & Suarez \\
\hline May 301876 & 1000 & Un departamento & A. San Martin & Palacios \\
\hline Jany. 111877 & 4000 & House and Shops & $\begin{array}{l}\text { Evaristo Gomez } \\
\text { Sanchez }\end{array}$ & do. \\
\hline
\end{tabular}




$\begin{array}{ll}\text { Dec. } 121874 & \text { Security given to } \\ & \text { For the validity of the sale of a } \\ & \text { house in Madrid made by Aliaga do. } \\ & \text { to him. }\end{array}$

His brother the lawyer then dictated an escrito in which he set [569] forth that the mortgages upon the house of Juan Aliaga [...] in the Calle de Palacios came to $\$$ dollars 109,250 , but that of this amount only $\$ 18,000$ to Pedro Villavicencio dated May 1869 was previous to my $\$ 9000$ of 23 Augt. of the same year. I dictated my letter to Juan. We remodelled the old diary and thus one with another I was so occupied that I had no time to go to the meeting of the Directors of the Banco del Perú.

Tuesday, $12^{\text {th }}$ of February 1878 . Before breakfast I went out to the pantheon, where I had not been for the last five or six weeks. The interior of my chapel was painted with a pretty whitish oil color; however, as it was not yet sufficiently dry the painter would have to wait several days before he could put the finish to his work.

On my return I met a hearse followed by many carriages which converged to the pantheon the corpse of Enriqueta Elespuru, about 50 years of age, one of the handsome daughters of the once beautiful Natividad Pinillos, wife of General Elespuru who died on the $20^{\text {th }}$ January 1839 in the battle of Ancachs. She and her elder sister Benjamina had married two brothers, cousins of theirs; Benjamina Alfonso; Enriqueta Agustin Gonzales. Both were bad and faithless husbands; Alfonso died several years back of a cancer in the tongue. Agustin was still alive; but he and his wife had been living separate for many, many years. Enriqueta's conduct had not been blameless either, but for the errors of her youth she had atoned by dreadful sufferings. For a long series of years she had been paralytic, unable to move a step, and blind into the bargain; since she had abandoned her husband or her husband abandoned her she had been living with Benjamina, mother-in-law of Gustavus Heudebert.

A telegram from Europe brought the news of the death of Pius IX on the $7^{\text {th }}$ February. He was born on the $13^{\text {th }}$ May 1792 in the town of Sinagaglia, and raised to the Pontifical dignity in June 1846. My health was at present good; the pains in my right hip and left knee had not entirely gone, but so trifling were they that they could easily be borne. Last night there was a great festivity in [570] [_] the malecon, which had been considerably widened in conformity with the plan of the present Alcalde Federico Peze[_], and which now occupied the entire breadth to the very foot of the house of Candamo, Ruden and others was inaugurated, that is to say nobody was allowed to enter, without paying two Soles. There were three bands of music which played the whole evening till it 
was time to return to Lima by the last train, and the very first society, ladies and gentlemen, promenaded up and down in the most elegant attire. This was the only amusement. The President and wife were at José Unanue's, just opposite the malecon. From 4.30 to 5.30 p.m. I had to wait at notary Prieto's, when I learned that my escrito had not been dispatched by Judge Quiroga.

Wednesday, $13^{\text {th }}$ of February. As a sign of grief for the death of Pius IX, for four days successively all the flags in Lima had to be hoisted half mast high, and on Saturday next the funeral service would be held in the Cathedral. Count Palikao, a French general, who earned his title in the last war of the French and English against the Chinese, and whose name had also twined up in the Franco-German war, had departed this life. The same had I to say of the Italian General de la Marmora who commanded the Sardinian troops in the Crimean war. At about 3 O'clock I went to the Banco Hipotecario where the new Directory assembled, viz.: Lorente, Pedro Correa y Santiago, Dr. M. M. Galvez, Melchor Velarde, and I. The first thing to be done was to chose the chairman and Vice; for the former, Lorente had 3; I, 2 votes; for the latter Correa y Santiago, 3; Galvez, 2. I broached the important point of Marcone's debt and insisted that something should be done. Correa expressed his dissatisfaction with the present lawyers of the bank; and thought it advisable that others should be named in their stead. Gallagher said that the Marcone affair had long taken up his and Garland's thoughts, and that next meeting he would lay before us their ideas on the subject. He also informed us of an offer of Garcia Calderon's to [...] [571] which he had guaranteed for Simon Soyer, and to the payme[_] of which he was sentenced by the Supreme Court. Lorente had to absent himself before 4 , and thus we broke up before having come to a decision on this question, and agreed to meet again within a day or two. At the notary Prieto's I learned that Dr. Quiroga had not yet dispatched my escrito.

Thursday, $14^{\text {th }}$ of February 1878 . On account of the Pope's death theatrical representations were prohibited for four days. On the $5^{\text {th }}$ instant I said a few words about Juan Garlands and Meeker's project to provide Lima with ice from the mountains in the neighbourhood of San Juan de Matucanas. Yesterday in the Concejo Departamental a majority disapproved the contract concluded by them with the Municipality of the said place. I had no idea what Juan would now do. He and Guillermo liked to go their own way without taking anybody's advice which accounted for the many false steps they had already taken, young as they were. Guillermo was however by far superior to his brother.

From 8.30 p.m. when Bryson left me till past 10, I was quite by myself in the corredor. Garland had gone to Chorrillos to dine with Malinowski. Limpricht did not leave his room. Enriqueta with the little ones had gone to Anibal La Torre's. 
Friday, $15^{\text {th }}$ of February. After waiting nearly an hour before Dr. Palacios came to his office I went with him to Dr. Quiroga to whom he explained in a few words the exact state of the mortgage I had upon Juan Aliaga's house. Via Valparaiso we had telegrams from Europe till the $7^{\text {th }}$. The German parliament had been opened, and the speech from the throne breathed a pacific spirit. The English fleet had passed the Dardanelles, because Russia had declined to look upon the negotiations to be opened in Vienna as a basis of peace with Turkey. At last Quiroga dispatched my escrito: "The Certificate of the mortgage on Juan Aliaga y Puente's house was to be added to the autos; what I had said was to be borne in mind in due time, and [...] inst. in which he ordered Aliaga to [572] point out exactly where the title deeds were to be was to be notified to him."

Saturday, $16^{\text {th }}$ of February. The Exequies of the Pope were this day celebrated at the expense of the Papal Delegate Moncenni in the Church of La Merced. The Banco Hipotecario was closed, otherwise all banks and shops and stores were open. The Archbishop had ordered that as the Conclave for the election of the new Pope opened this day in Rome, daily prayers were to be said in all churches, for the enlightenment of the Conclave by the Holy Ghost.

At 1.45 I walked out to the farm of Manzanilla where I found Doña Pepa in the bedroom with her eldest son Vicente, who had been most dangerously ill of typhus fever; he was now out of danger, but so weak, that he could hardly speak and not stand upright without assistance. I remained full half an hour, and was back before 3.30 . When at a later hour I went to the notary Prieto's I was told that notwithstanding the promise given me the previous day that Aliaga should be notified, it had not yet been done. The Canon Mora dined with us and remained till near 10; Doña Jacinta Sotomayor also came, and it was difficult to decide who was the more tedious of the two.

Sunday, $17^{\text {th }}$ of February. To Bryson I dictated a letter to Sieveking. From 2 till 4 O'clock I played chess with Limpricht in the corredor; he gained the first, which I gave up, in less than twenty minutes. The second was a drawn one; only one more was wanting for him to make a queen, when I had the good luck to place my king and castle in such a position as to give continual check to his king, which, as everybody knows, makes the game a drawn one. He and Urquhart dined with us. Of the young men only Ricardo. In the evening the reading of Schutte's and Juan's letters took up some time. The latter, still in Nizza, complained of loss of blood owing to the piles, of great general debility, of weak sight, and of a very bad cold. Schutte, Rosa [573] wrote, suffered frequently fr $[\ldots]$ inting fits.

Monday, $18^{\text {th }}$ of February 1878. Ricardo read to me the Star and Herald, which contained many interesting news. The Chinese had taken possession of Kashgar, a town of Central Asia, and the dispossessed Emir had laid his 
complaints before the Czar of Russia. The Russian armies were approaching Adrianople, and the negotiations for peace were likely to begin in a place between this town and Philopopolis. The demands of Russia, if acceded to, and I believed the Turks would be obliged to grant them, would reduce European Turkey to a mere nothing, to a strip of land from West to East between Bulgaria to the North and Greece to the South. Servia was to be independent. Bosnia, Herzegovina, and Bulgaria to have the right of governing themselves; the territory of Montenegro to be enlarged, and the frontiers at the mouth of the Danube to be rectified. The free passage through the Dardanelles to be allowed Russian men-of-war, and a war indemnity to be paid by Turkey of £20,000,000 Stg. either in money or in territory, and until this money were paid, the Russians would keep possession of Batum, Kars, and Erzerum. The English fleet had not entered the Dardanelles as above said, but been recalled at the last moment and had returned to Besika Bay. The marriage between Alfonso, King of Spain, with his cousin Mercedes, had been celebrated with great pomp. Cleopatra's needle had reached London and would be put up on the Thames embankment at the top of the Adelphi stairs. The Earl of Derby had withdrawn his resignation and was again in the cabinet, whilst Lord Carnarvon had not followed his colleague's example.

Last night Guillermo returned from his trip to the Ganzas copper mines, a short distance from Ica, which did not look so promising as had been expected. In Ica and its vicinity the vintage had completely failed.

George Elster and Peter D. Gallagher had come back from San Francisco, where they had not succeeded in their object to procure Chinese labourers for the Peruvian Sugar estates. I went to the notary Prieto, where I learned that Aliaga had been [574] [...] Saturday, after my having been in the office, thence to José Basagoytia's, who was lying ill, and finally, walked as far as the convent of los Descalzos, a proof that I had completely recovered the strength of my legs. Mrs. Lührsen called, accompanied by her friend the North American teacher Miss Kate, and Enriqueta not being ready to receive them I had to do so in her stead. Mrs. Lührsen told me that two German men-of-war were daily expected, the one, the "Ariadne", to come to Callao; the other, the "Leipsic", to proceed to Nicaragua, there to demand satisfaction for an outrage said to have been committed against the German Consul Mr. Eisenstuck.

Tuesday, $19^{\text {th }}$ of February. In the northern departments of Perú the unusual rains had done much injury, whilst along the Southern coast the uncommon roughness of the sea and frequent shocks of earthquake kept the inhabitants in continual alarm. At somewhat past 1 O'clock I went to the meeting of the Directors of the Banco del Perú. Enrique Ayulo as usual did not attend. We were informed that Oyague and Francis Bryce had declined accepting their 
nomination as Directors of the Bank, and that José Unanue who had accepted his was indisposed. We were therefore under the necessity of naming a provisional Director and our choice fell upon John Bryce. José F. Canevaro, Second vice President of the Republic, wished to have an audience. He proposed to the Directory in the name of President Prado that the Banco del Perú ceded to the Government their interest in the administration of the nitrate business, hitherto managed by the Delegates of the Banks, the Government having already bought the share belonging to the Banco de Lima. The profits made by the four banks had in two years come up to about $S / 850,000$ of which $S / 280,000$ corresponded to the Banco del Perú. These $S / 280,000$, and about $S / 20,000$ paid by the Banco del Perú to the Delegates, together somewhat more than $S / 300,000$ were still owing to the bank by the Delegates. Besides, the Government was owing to the Bank about S/700,00o, [575] the Banco del Peru's proportion of the amount due [to the four] after deducting the fifteen million Soles in notes, for the payment of which the Government had made itself responsible; from the original loan of eighteen millions. Now the Government, through Canevaro, proposed in compensation for the session of the Bank's interest in the Nitrate Administration, to pay the $\mathrm{S} / 300,000$ either in billetes or in bills on England at the current exchange, and the $S / 700,000$ on bills at $42 \mathrm{~d}$. We were unanimously inclined to accept this proposal, but with the sine qua non condition that the payment of these sums as proposed to us, should be assured in a manner which would not admit any doubt of its being carried out. Althaus was named to treat personally with the President. When Canevaro was gone we chose the President and Vice President of the Directory, and the choice fell upon Emilio Althaus and Carlos Elizalde; but as the former decidedly declined to continue as President, Manuel Candamo was named in his stead. Then there was a very long discussion whether the two Delegates of the Banco del Perú, Althaus and Calderoni, who were again chosen, should receive the salary of $S / 250$ each for the month of January and February, which had been fixed upon in a session of all the Delegates, and which were as yet deposited in the bank. We resolved that the money might be paid over to them. To the meeting of the Directory of the Banco Hipotecario I had no time to go, and for want of number there was no meeting.

Wednesday, $20^{\text {th }}$ of February 1878 . Some time was taken up by my receiving from the Banco del Perú, $12 \%$ dividend on Schutte's S/60,00o and my own $\mathrm{S} / 5000$, and from the Banco Hipotecario $10 \%$ payable in Cedulas, on my $\mathrm{S} / 66,000$ on Rosa's $\mathrm{S} / 17,000$, on Juan's $S / 3000$ and on $S / 10,000$ which I held as security from Melchor Velarde.

Last night the friends of Juan Garland made an attempt to have the cancelment of his contract with the Municipality of San Juan de Matucanas, 
reconsidered in the Concejo Departamental. The majority was however against him. [576] [...] mac was much swollen, and threatened [_] overflow its banks; also the Chorrillos railway had suffered a little from accumulation of water, and about the latitude of Miraflores part of the terraplen had been washed away. On the $23^{\text {rd }}$ December the volcano Izluga, in the department of Tarapacá, close to the Bolivian frontier had thrown out stones and lava, and done damage to several villages in its vicinity. They wrote from the province of Castilla, in the department of Arequipa that the very high mountain called Corpuna, hitherto invariably covered with snow, gave signs of being a volcano, the snow had melted, and in one of the sides a crater was said to have opened. In the Banco Mercantil, into which the Anglo Peruano had merged, and the gerente of which was Oscar Heeren, a considerable theft had been committed. Daniel Dorado, of whom his father Don Mariano had lately spoken to me in very laudatory terms, had made off with 33,211 Soles.

Friday, $22^{\text {nd }}$ of February. Thermometer at noon $84^{\circ}$ F. Juan Garland returned from his trip up the Oroya line which, he told me, had in several places suffered much damage, owing partly to the falling in of the embankments partly to the action of water which had gushed out in some places where it had never been seen before. A considerable distance he had been obliged to go on foot, where there was neither train nor beast to be had.

I went to bed as soon as Bryson had done reading, and spent a most miserable night, hardly sleeping at all till

Saturday, $23^{\text {rd }}$ of February. On awaking I felt so weak and poorly that I thought best to send for Dr. Middendorf who, having taken my pulse gave it as his opinion that I was suffering from a slight attack of fever and ague. The infallible quinine, prescribed by the Doctor, was at once taken and thanks to the same, thanks to a strong chicken broth prepared by Enriqueta herself, and to a little port, in the evening when going to bed at the usual hour I again felt all right. In [577] the course of the day I had had to attend a meeting of [_] Directors of the Banco del Peru, convened at the request of Emilio Althaus. John Bryce had accepted his nomination, but was not present, as little as Unanue, still indisposed. Ayulo was there. When we were seated round the table Althaus gave us a detailed account of his conference with the President Prado who had by no means been inclined to enter into the plan proposed by Canevaro on the $19^{\text {th }}$ inst., and he now wished to know what he was to do as he had been cited to another interview on the $25^{\text {th }}$. Then Canevaro came in, and gave us to understand in his usual polite, smooth, and convincing manner that the President was as desirous as before to buy the bank's shares in the Delegation, but that the conditions had necessarily to be modified. He explained how this might be done, and then the discussion commenced, in which Althaus took 
the lead, Calderoni, the other Delegate, occasionally making his observations when he thought that Althaus statements were not quite correct. Canevaro replied, Candamo, who was in the chair, now and then said a few words; so did Ruden, but his remarks were little to the purpose, and hardly heeded. Ayulo, Elizalde, and I kept silent, I however listening with undivided attention, and the more so as owing to the quinine I had taken I was a little deaf on my right ear, with which I generally hear quite well. Finally, Althaus was authorized to treat with his Excellency for the sale of the bank's interest in the Delegation, on the following terms: The S/700,00o due by the Government to the bank were to be calculated at two exchanges, at the exchange of the day, and at 40 pence. The pounds sterling, resulting from the first operation to be secured to the Bank in such a manner as to leave no doubt of the payment; whilst the balance between the first and second operation, might be taken in Certificates or promises for the delivery of bills in the first months of the year 1879. As to the other debt of $\mathrm{S} / 300,000$ [578] [...], Althaus thought that it might be cancelled by means of drafts on England at the current exchange, to be given by the Delegation to the bank every time they made a shipment of nitrate at the rate of 3 pence per quintal. This idea was approved by all, and full power given to Althaus to make such an arrangement if feasible. In the course of these debates I learned that hitherto the Delegates had furnished the bank notes which the Government required for the monthly burning or "incineration" as it is called here, of $\mathrm{S} / 300,000$ - and this was to me a strange piece of news, because Rafael Velarde, the head manager of the Callao Custom House, had assured me that of the duties monthly received, a similar amount had regularly been put aside for the same purpose. Now Prado had again applied to Francisco Garcia Calderon, President of the Delegation, for a like sum, to be burned at the end of the month, which Calderon had this time not been able to give him, and hence the coolness which about this time was known to exist between him and the President of the Republic.

Per telegraph advice had been received from San Juan de Matucanas that the Rimac had overflown its banks this morning at about 5 O'clock, and done great damage to the town. The train could not go higher up than La Chosica. I continued in good health. Middendorf came in the evening, and said I was without fever.

Sunday, $24^{\text {th }}$ of February. I awoke quite well. I finished my letter to Mr. Schutte, and after Bryson was gone at about 2, Limpricht and I played our chess in the corredor, and this day I was so fortunate as to beat him twice. For more than half an hour we were interrupted in our play, firstly, by Macandrew, next, by Mr. Richard Gibbs, the North American Minister, a pleasant off hand gentleman. At dinner we were very few. Maria and Corina had been taken by Federico [579] 
Palacios to the bull-fight, which I look upon [...] mo[_] improper spectacle for young girls.

After dinner Ricardo read to me Zamarow's novel. We had now come to that part where he gives a no doubt overcharged, but vivid and interesting description of the state of Paris from the time of the Commune in March till May 1871.

Advices were received that the place of Chicla, not far from the summit of the Cordillera, had also suffered considerably from the overflow of waters. Enrique was very uneasy about it, for he had at the railway station there a considerable quantity of silver ore belonging to one of the mining companies, of which he was not only the manager, but one of the principal partners. And this ore, owing to the interruption in the line it had not been possible to send to Lima.

Monday, $25^{\text {th }}$ of February. Dr. Middendorf came and prescribed me some more quinine; he told us at breakfast that the population of London amounted to 4,268,00o; of the United Kingdom to 33,000,000; that of London he made me remark was greater than that of the Kingdoms of Saxony and Wirtemberg, and the Grand Duchy of Baden, taken together. Berlin had 1,200,000. In the course of the day advices were received that also in the valleys of Supe and Barranca the rivers had done damage by overflowing.

At 5.30 p.m. died Dr. Bravo, a man of an advanced age and looked upon as one of the most experienced medical men in Lima. A telegram was received, and published in the papers which made known that the choice for the new Pope had fallen upon an Italian Cardinal, Joaquin Pecci, 68 years of age, who had taken the name of Leo XIII.

Tuesday, $26^{\text {th }}$ of February. Near the Martinete gate the Rimac had done some trifling injury, which however had been immediately repaired.

When Dr. Middendorf came I had to tell him that I suffered a little from diarrhea, whereupon he prescribed [580] [...] medicine to stop the evil, and ordered me to be[_] for the whole day. I however rose again at 2 and went to the Banco Hipotecario, where all the members of the Directory were present, and where we were joined by Dr. Ramon Ribeyro, the lawyer of the bank. The principal point which we discussed was the heavy debt of Marcone. It was Dr. Francisco Garcia Calderon who made him the loan of more than $\mathrm{S} / 300,000$ about five years back. Marcone failed six months after the loan was made, without having paid a rial. A certain Bustos was named Sindico of the Concurso; then the creditors, and particularly Riva Agüero when he reentered as the gerente of the bank, were not satisfied with him, and named other sindicos. Bustos however refused to give up his post, and to this day it had been impossible to turn him out, and he in the meanwhile had collected the rent of 
the immovable property mortgaged to the bank. The gerentes now proposed, and we all, including the two lawyers M. M. Galvez, and Ramon Ribeyro, agreed with them that the only thing to be done in order to get some money from this debtor was to come to terms with Bustos, offer him a large commission upon the sums that the bank might recover, and in this manner induce him to withdraw his opposition. The Gerentes were accordingly empowered to treat with him.

Wednesday, $27^{\text {th }}$ of February. Not having been able to attend, yesterday at the meeting of the Directors of the Banco del Perú I went to Carlos Elizalde to enquire what had been the object of the meeting. He told me that the Delegation of the Banks having refused to Prado the S/300,00o for which he had applied to them in order to burn them on the $28^{\text {th }}$, he, through José Canevaro, had made a like application to the Banco del Perú, offering as security, certificates for bills to be drawn on the Peruvian Guano Coy., Ld. London for May and June next, at 28 and 29d. Canevaro had declared himself ready to take half of the business whereupon the Directors Althaus, Calderoni, Ruden, Candamo, and Elizalde [581] had resolved to accept the proposal. Ayulo alone had been of the contrary opinion.

At a later hour I went with Dr. Palacios to the offices of various notaries to discover where the testimonio of the foundation of Aliaga's Mayorazgo really existed, he having said in an escrito that it was with the Juez Olivares in the hands of a notary, Flor, which notary did no more exist. We went from notary to notary and were at last assured by Casavilca, who attended the judge Puente Arnao, that for the present this testimonio was in his hands. Besides the German Corvette "Ariadne", the "Leipsic" carrying twelve guns had also been in Callao, and again left for the North.

Thursday, $28^{\text {th }}$ of February 1878 . As on this day the exequies of the Pope were to be solemnized in the Cathedral, the authorities had ordered that it should be kept as a civic holiday, nevertheless all shops and stores were open; only Bryson left me to witness the ceremony.

Ricardo in the evening finished reading to me Zamarow's series of novels. The last chapter contains a description of the death of Louis Napoleon on the $9^{\text {th }}$ January 1873 and the last words are: "He will judge him." After dinner Bryson read as usual Motley's Commonwealth, and Paul Clifford.

Friday, $7^{\text {st }}$ of March. I presented an escrito, requesting Don Quiroga to fix a day for the sale of Juan Aliaga y Puente's house, Calle de Polvos Azules. In the Banco del Perú all the Directors except Unanue were present. The S/300,000 in bank notes which the government required for their monthly incineration had been delivered to the treasury, and the Government certificates for Bills on England to be drawn on the $27^{\text {th }}$ Augt. at $29 \mathrm{~d}$ were in the hands of the gerentes. 
Althaus moved that the Gerentes should be authorized to effect gradual sales of La Deuda Interna at not less than $53 \%$, to which we all agreed, for the reasons given by him were in our opinion unanswerable. At about 5 I went to the office of the notary Prieto when I [582] [...] great disappointment that though in the morning myself had placed the escrito into Dr. Quiroga hands, he had not dispatched it.

Saturday, $2^{\text {nd }}$ of March. This morning Ricardo began reading to me another work by Zamarow, called "The death of the Hanoverian Legion", written in the same style as the previous ones. In the course of the forenoon I went three or four times to the office of the notary Prieto, also to the Juzgado of Dr. Quiroga but after all my escrito was not dispatched.

This being the birthday of the new Pope Leon XIII, hitherto Joaquin Pecci, it was celebrated by the hoisting of flags in the public offices, and in the houses of the Diplomatic and Consular Agents resident in Lima. Also in Obrajillo damage had been done by the overflowing of the waters. From China had arrived a Belgian steamer, the "Perusia" with Mr. Geary of Oliphant's house on board. She brought mainly cargo, also some Chinese as passengers, how many I had not learned, but no Chinese labourers. In the office of the Compañia de Obras Publicas y Fomento, Enriqueta who had sent her receipts for the rent due $1^{\text {st }}$ February and $1^{\text {st }}$ March amounting to S/1200 received for answer that they could not pay, for their chest was empty, but that they would send up the money as soon as the Government paid them.

Sunday, $3^{\text {rd }}$ of March. First Carnival day. I did not leave the house. At 2 Limpricht and I sat down to chess. It took me an hour and a half to gain the first game, whilst the second I lost in half an hour. After dinner we had a long visit from Diego Masias which made the time pass away very pleasantly, for though only half what he says can be believed, he is a very amusing talker. Sometime back he had obtained in public sale the privilege for providing the farmers in the departments of Arequipa and Moquegua with the guano which they required for their agricultural pursuits. Accordingly, he had of late been in all the Southern guano depts., and now gave it as his [583] opinion that the guano would at the very utmost [...] longer. He added that some guano shipped from the Pabellon de Pica was of superior quality and contained as much as $18 \%$ ammoniac. In this he was certainly mistaken, for the guano of the Chincha Islands, which had always been considered the best ever exported, had never contained more than $14 \%$. The guano in Pabellon de Pica, he said, is in some places covered with a layer of earth, sand, and stone, 70 feet high, for which reason the shipping was connected with great difficulty. Fifteen hundred tons was the utmost which could be embarked daily. The contractors for the loading were: Canevaro; Petrie, Grace of Callao, Emilio Althaus, and 
perhaps one or two more. Andres Alvarez Calderon obtained the carguio in public sale at 67 pence per ton, and transferred it to the said individuals at 60 pence, but of the thus arising profit of 7 pence he had had to share about $31 / 2$ with J. A. Garcia y Garcia, Francisco Garcia Calderon, and other leeches of this description. This was Masias' version. The object of his visit was to invite our family to his house for the next two days, where the Carnival would be played in the Orthodox Arequipa fashion. They were preparing not less than four large botijas of Chicha.

Monday, $4^{\text {th }}$ of March. Second Carnival day. Once more I did not leave the house. Bryson and I made good progress in the remodelling of the diary of 1871. With Limpricht I played one game at chess from two till 4 which ended in being a drawn one; each remained with the king, one castle and one pawn.

Ricardo concluded reading an excellent article in a German Review on the Civil war in the United States, in which it was clearly demonstrated that the Southerners had succumbed, not for want of courage, but for want of physical means. Already in the years 1864 and 1865 their forces were to those of the Northerners as one to two, and this disproportion went on increasing from year to year. The death-blow to their cause was struck by the extraordinary [584] [_] of [_] through Georgia to Savannah, and then north to South Carolina and Charleston. He kept strict discip[_] but subsisted on requisitions and foraging; on his whole march, the railways were thoroughly destroyed; Atlanta was burned to the ground. According to this writer the two men who excelled by their intellect and genius were in the North General Sherman, in the South General Lee, who died on the $10^{\text {th }}$ October 1870 . Lincoln, Grant, Machellan, Thomas, Beauregard, Stonewall Jackson, and others, were all excellent men of their kind, but did not rise much above mediocrity.

In the evening Bryson finished Paul Clifford. Little Maria who came home from the Masias at 9.30 told us that the so called Carnival-playing had been carried on there in a downright brutal manner; to dip each other in the well filled with water, had been the very least; the rooms ran with water, and if water was not at hand, chicha, beer, and eau de Cologne were used for the same purpose of wetting each other. The letters from Juan and Mr. Schutte contained little of importance; from the former I learnt that Dreyfus was not the least afraid of the claims made against him both by the Peruvian Government and the Peruvian Bondholders.

Tuesday, $5^{\text {th }}$ of March. Third carnival day. Again at home the whole day. When Juan Bazo was with his wife in Europe several years back, Mr. Schutte lent him $£_{300}$ to enable him to return to Perú, of which debt Bazo had not paid a cent though in the meanwhile he had filled the lucrative post of Prefect in Callao. Schutte of course dunned him, and by the last steamer he enclosed to me a 
letter to Bazo, written in the most insulting terms. This I had thought proper to keep back and dictated this morning a polite letter to Bazo, demanding the payment of £1oo on account. Bryson and I then occupied ourselves with Gibbs' account current for last year, closed with a balance in my favor of $£_{5400}$ but showed only one dividend of $£ 400$ on my Columbian Bonds, and of course none on the Peruvian, and for the last hour remodelled [585] the diary of 1871.

Ricardo read to me from a German Review a not over interesting article on the Prussian Ministry, presided over by Von Auerswald, which in the month of March and April 1848 had been unable to withstand the democratic tendencies of the national assembly then sitting in Berlin. From 4 to 5.30 Limpricht and I played one game at chess, which I gained with the king and two pawns against his king. At dinner we had with us Limpricht and Urquhart, which latter told us that on the previous evening J. A. Garcia y Garcia had given a very pleasant dance in Chorrillos, and that another would be given this evening by J. F. Canevaro. At about 8.30 p.m. Garland, who had been ailing for the last two or three days, without complaining, as it was his habit, had a very severe nervous attack, which however did not affect his heart. Middendorf was sent for, and remained with us till the remedies prescribed had the desired effect of calming his agitation and facilitating his breathing.

Wednesday, $6^{\text {th }}$ of March 1878 . This morning Garland felt better. The European news which I took from the Star and Herald of Panamá confirmed upon the whole the conditions of the armistice between Russia and Turkey, given by me on the $18^{\text {th }}$ February. The fortresses of Rustschuk and Silistria had been given up to the Russians, and their army was but a short distance from Constantinople and Galipoli. The English fleet, consisting of fire ironclads, against the will of the Turkish Government, had passed the Dardanelles, and entered the sea of Marmora, to protect British lives and interests in Constantinople. A large majority in the House of Commons had voted $£ 6,000$,ooo for extraordinary war expenses.

The following occurrence was likely to give rise to serious complications between the United States and the State of Panama. A certain Scrafford had made himself guilty of forgery in the state of Kansas; he fled to Perú, but in virtue of a treaty of extradition existing between the two Republics, was given up to the North American Chargé. Under the charge of Mr. Clayton, North American Vice- [586] [...] lao he embarked on board the steamer "Amazonas" for Panamá, and on his arrival at said port proceeded to the house of Mr. Long, United States Consul; jointly they delivered Scrafford into the hands of a subaltern in the Panamá police office, who received him and gave a provisional receipt. This was done on the afternoon of the $20^{\text {th }}$ February, and on the following day Scrafford was placed in liberty, by order of the President 
of the State of Panamá. On Mr. Clayton's complaining of this proceeding he received for answer that Scrafford had been placed in liberty because he had committed no offence on Columbian territory, and secondly because there existed no treaty of extradition between the United States and Columbia.

Thursday, $7^{\text {th }}$ of March. Last night's Nacional published a telegram dated London $16^{\text {th }}$ February, which said that part of the Russian army had entered Constantinople.

The use of the newly-invented Telephone, which forwards the sound of the human voice by means of an electric wire, made great progress. By means of the same Von Bismark whilst on his estate, Varzin, in Pomerania, conferred with his subordinates in Berlin. Between Inverness and Aberdeen in Scotland a successful trial had been made. In a coal mine in England the apparatus had been introduced and the miner's voice from the bowels of the earth had reached the surface and been understood. The Nacional said that a trial had also been made between Chorrillos and Lima, with a satisfactory result. Garland, who had yesterday been able to go to the bank had apparently recovered his health.

Little Corina who since the second carnival day which she spent in the house of Jesus Elias in company of her friend Maria Palacios had suffered from cold, became gradually worse and at about 7 or 8 p.m. had a violent, and even dangerous asthmatic attack; Dr. Middendorf who came at eleven, found her very ill; a mustard plaster applied to the chest did her immediate good; nevertheless he did not leave till 12.30 and I was not asleep before 1 O'clock. [587]

Friday, 8 $^{\text {th }}$ of March 1878 . This morning Corina [...] of danger. Advices received from Trujillo said that the overflowing of the rivers had done much damage in all the neighbourhood, especially in the valley of Chicama. At 1 O'clock I went to a meeting of the Directors of the Insurance Company Lima. Before we sat down round the table, Moscoso Melgar of La Providencia told me that there was a probability that the Government would come to some arrangement with the three banks Nacional, La Providencia, and Garantizador, as to their paying the interest on the internal debt, as well as the monthly redemption of the same, against the Govt.'s concession to them of the consignment of guano to Mauritius etc. This coincided in some measure with the rumour afloat that the Government intended issuing six millions more of the Internal debt, wherewith to pay their debt to the Compañia de Obras Publicas y Fomento. In the Lima Insurance Office the only thing of importance was that Graham Rowe \& Co. who had hitherto given all their insurances to the South American Company, had promised to give henceforth the preference to the "Lima" Coy. With the former they had had a dispute, in which, in the opinion of Mr. Macandrew, the head of the firm, the South American had been in the wrong. 
Insurance against sea-risk always includes the risk from land to land, that is to say it includes the risk of launches, or boats from shore to the vessel, and vice-versa. Some merchandize had now been lost in a steam launch from the steamer to Pabellon de Pica, which the South American Insurance Coy. had refused paying, because the steamer had been anchored uncommonly far out. Whether the Company finally made good the loss was not stated, but Graham Rowe \& Co., in order to prevent similar difficulties in future had added a clause in their policies which explained the expression of risk from land to land. The Company had not objected to this clause, but raised the premium from 1 to $11 / 4 \%$, and this had finally brought about the rupture.

Saturday, $9^{\text {th }}$ of March. Little Corina, though some[_] [588] [...] ed in bed. At 1.30 the Directory of the Banco del Perú, Althaus excepted, was assembled. The Gerentes had, with the consent of the Director de Turno, John Bryce, sold $\mathrm{S} / 52,000$ Deuda interna, at $54 \%$ less $1 / 2 \%$ brokerage, but since then Bianchi had come into the market with very large amounts, which he offered at lower rates, for which reason they had stopped selling, which we approved of. They supposed that this internal debt now offered for sale, belonged to Scheel; I thought that it might be the property of the Banco Nacional. The negotiations between the bank and the Government relative to the transfer of the bank's interest in the Delegation, to the Government, were completely broken off. The object of the meeting was to inform us that the Government proposed to pay to the bank the Beneficencia's debt of more or less $\mathrm{S} / 220,000$ by certificates for bills to be drawn in October, November, and December, at 26 pence. It was Prado's idea to make of Santa Ana a barrack and as this building was mortgaged by the Beneficencia to the bank, the Government had to cancel this mortgage in order to have the free disposal of the building. It was our unanimous opinion that though the exchange was low, though the security was by no means of the best, yet as the Beneficencia itself would never pay us, and as it would be a difficult matter to bring the building to the hammer, it was thought advisable to accept the Government's proposal, and the gerentes received the corresponding authorization. They were however particularly instructed, and I insisted especially upon this condition, that the certificates for the bills should be endorsed by the Beneficencia. The news which Garland had given me one or two days before, viz.: that J. M. Cardenas suffered from Mental derangement, was confirmed by César Canevaro and José Calderoni. Cardenas was certainly a clever man, but his vanity was unbounded. In the Banco de Lima he had been a troublesome shareholder, and afterwards an equally disagreeable Director. He had expected to be made Fiscal, afterwards Vocal de la Corte Superior, and being disappointed in both, it was thought that this had been the cause of his, it was to be hoped only temporary [589] insanity. 
Sunday, $10^{\text {th }}$ of March 1878. Enriqueta kept her bed with a dreadful migraine. Thermometer at noon $80^{\circ} \mathrm{F}$.

After having dictated a letter to C. W. Schutte I went by the 2 train to the Barranco where I called upon the Canon Dr. Bandini, upon the family of the vocal, José Antonio Ribeyro, and upon Doña Dolores Puente, who resided with her sister Mrs. Federico Marriott. Though I was everywhere very politely received I did not find the same pleasure in such visits as I had done in previous years. It was past 3.30 when I set off on foot for Chorrillos, but lost my way amongst the cultivated field, had to climb over many tapias, to pass through dry ditches, and was thus glad when I again emerged on the railway, when I walked back to the Barranco Station where I waited for half an hour and returned to Lima by the 5 train. For a long time past I had not been so low spirited as I was this day. At dinner we were only Garland, Enrique, Ricardo, Maria, Urquhart, and I. Enriqueta and Corina still kept their beds. Ricardo read to me Zamarow's novel.

Monday, $17^{\text {th }}$ of March. Last night, or early this day died El Gran Mariscal Don Gutierrez de la Fuente, at a very advanced age, and after one or two days' illness. In the first numbers of my diary his name has frequently occurred; from his very youth he had taken an active share in the continual political dissensions which distracted the Republic. He never was Constitutional President, but over and over again just one step from reaching the top of the political ladder. In 1868 during the short time of Pedro Diez de Canseco's administration, he was Alcalde of the Municipality of Lima, and this was the last time he appeared in public life. Ever since Manuel Pardo took the reins of Government, also during Prado's rule, he had but seldom shown his face in the palace. Little Corina was quite well. Enriqueta out of bed.

Guillermo told me this morning in strict confidence that he had closed Alejandro's books till the $31^{\text {st }}$ December wh[_] [590] [...] showed to the credit of Stock account the hands[_] sum of S/73,00o. It was really wonderful how Alejandro had known how to make so much money, notwithstanding his own heavy house-keeping expenses, and the large amount he had to pay for interest.

I found in the Star and Herald a few words relative to George Cruikshank, the great caricaturist, only inferior to Hogarth. He died on the $1^{\text {st }}$ February of the present year 86 years of age. According to the said Panamá paper he had a quick and acute perception of everything ludicrous, of everything that was wrong and wicked, and which required the lash of satire and irony, but on the other hand he had no idea of the beautiful, as a proof of which it is affirmed that amongst his numberless sketches not a single beautiful face can be found; neither was there anywhere, anything indecent, not even improper, which 
certainly could not be said of Hogarth, and thus Cruikshank's caricatures were seen and passed from hand to hand in every English family circle.

Tuesday, $12^{\text {th }}$ of March. Juan Bazo paid the $£ 100$ on account of C. W. Schutte, to whom I remitted $£_{500}$. At about nine O'clock passed our house the funeral procession of General La Fuente to the pantheon. A considerable number of troops followed the hearse.

Last night's Nacional published a short, not very flattering biography of the deceased; also reproduced the different documents which in June 1829 had been published in Lima relative to him. It was then that he and Gamarra carried out the nefarious conspiracy against General La Mar whom Gamarra betrayed in the battle del Portete de Tarqui whilst La Fuente, a few weeks later turned out in Lima the Vice-President Salazar. The cuttings go affixed in appendix under $\mathrm{N}^{\circ} 24$ and 25. At 1.30 I started for the ascent of San Cristoval, which I accomplished though not with such ease as in former years. I climbed up from the Descalzos, rested twice, sat down for a few minutes on the big [591] stone on the top, and again rested when descending. The Sun was not out, so that I did not suffer much from heat. The whole took me two hours twenty minutes, twenty minutes longer than formerly.

In the evening of this day as well as

Wednesday, $13^{\text {th }}$ of March 1878 in the first hours of the day there was an extraordinary stir in nitrate certificates, it being affirmed as a fact, though only known to certain persons that Gibbs and the Government had signed a contract for the payment of the interest and the gradual redemption of the debt itself. Alejandro had bought largely on the preceding day at 100, 101 and resold the greater part this morning at 105 and 107; he however remained with $\mathrm{S} / 30,000$ on hand. I had given an order to purchase four certificates of $\mathrm{S} / 1000$ at $108 \%$ but was in time to retract, for at about 2 or 3 p.m. it was already known that the Government and Gibbs had not come to terms, and accordingly the certificates again declined. At 3 O'clock I went to the Banco Hipotecario, where we were Lorente, Correa, Melchor Velarde, and I. We got through a good deal of work, rapidly, and unanimously, refusing to accept several proposals as to the cancelment of outstanding doubtful accounts. Garland, in the absence of Gallagher, who was ill, informed us that the bank had been under the necessity of buying in public sale the mill of Otero, formerly known as Pfeiffer's Mill, which had been mortgaged to the bank by the present owner Colletti, who owed seventy odd thousand Soles, and for which (the Mill) the bank had now paid $\mathrm{S} / 43,000$. The salaries of the clerks we increased a trifle.

Thursday, $14^{\text {th }}$ of March. Last nights papers gave the news that peace had been signed between Turkey and Russia. 
The "Nacional" said that the Interest on the Nitrate Certificates came to $£ 14000$ monthly and that the selling price of 16 / in Liverpool, which was the last quotation, left a net profit of $4 / 4$ quintal.

Friday, 15 $5^{\text {th }}$ of March. I saw by the Nacional of last [592] [_]ght that the Peruvian Consul in Hamburg had communica[_] some important news to the Peruvian Minister of Foreign Affair[_]. Firstly, that the Telephone would be made use of in the German Army to communicate with the advanced guard, and small piquets still further ahead. Secondly, that subterranean telegraphs had been, and were about being laid from Berlin to Konigsberg, Stettin, Hamburg, Cologne, Strasburg, Frankfurt on the Maine and Breslaw; and thirdly, that a certain Strousberg, of whom Limpricht had lately spoken to me as the German Railway King, had proposed to make a canal, I suppose for deep going vessels, from Berlin to the mouth of the Oder, for $£ 8,000,000$ Stg.

In the forenoon I had two long visits, from Evaristo Barrios and from Vicente Gonzales. This latter merely came to enquire of me how the Pasco Railway Company stood, and I told him that $19 / 10^{\text {tho }} \%$ was the only dividend which had been, and would be forthcoming. Barrios' visit was disagreeable. After the customary preamble that I would allow him to speak his mind frankly, he told me that he and many of his friends were displeased with my having been elected Director of the Banco Hipotecario, not as far as regards myself personally, but because I was father-in-law of the Gerente Garland, and because Melchor Velarde, another relation, was likewise Director. He said that it was quite a family party, and if this time it was allowed to pass, such a precedent might on other occasions be detrimental to the Company; he therefore counselled me to withdraw quietly, and call in one of the suplentes in my stead. I answered rather annoyed that he had been sent by Oyague, which he of course denied; that I understood from him that if I remained in as Director, the gerentes would not be rechosen in September next, which he assured me was by no means his and his friends intention, and, thirdly, that I should certainly not absent myself, because I had been chosen without having spoken to anybody on the subject, and that if they did not wish me to be Director they might turn me out. [593] By and by I became cooler, and when he left we were ag[_] on good terms.

Saturday, $16^{\text {th }}$ of March 1878 . Last night Garland had three friends with him to play rocambor which had not been the case for about two years. They were: Dr. Middendorf, Melchor Velarde, and a Mr. Braun, born in Bolivia, son of that German who as General, and finally as Gran Mariscal, was General Santa Cruz's right hand in Bolivia. After Santa Cruz's fall he left Bolivia and returned to his native country Hesse Cassel where he married a country-woman of his, his first wife, Doña Justa Rivero of Arequipa having died some years previously. I went to bed at 11.30; full an hour later Garland passed through when I was still wide awake; soon after, I rose and went to the rooms close by, the parlour and 
drawing-room, not that I expected, not that I believed I should see anything supernatural, but as Garland had more than once positively assured me that in those rooms he had seen an apparition many years back I thought there might be a possibility of my dear Mariquita shewing herself to me but I stared, and stared, and saw nothing but the darkness. When again in bed, erelong the clock struck three. Now I recollected that it was Friday night; ninety five weeks had elapsed since the $20^{\text {th }}$ May 1876 ; purposely I kept awake till 4; all around was quiet and tranquil. I began to calculate, to run over the list of the Roman Emperors, but sleep did not come to my eyes. It struck 5; day broke, Aurelia came to take away my cloths; she brought them back, bandaged my knee, and I rose before seven without having had a wink of sleep. The sleepless night and various unpleasant things which turned up, made me pass a very disagreeable day.

Sunday, $17^{\text {th }}$ of March. A great many hours in the forenoon I was busy with Guillermo; everything was quite as annoying as the occurrences of the previous day. With Limpricht I played a game at chess, which I gained. He gave me the Kings gambit and from the very beginning I had the advantage. I must [594] [...] that he returned to me one bad move. From 8 till 10 p.m. whilst Garland and Enriqueta were at the Basagoytia's, Ricardo read Zamarow's Death of the Hanoverian Legion.

The Pierolistas, Pedro Calderon, J. M. Echenique, and one or two more, unknown to me, had at last been placed at liberty, in a bad state of health if the papers could be believed. Last night whilst I was so fast asleep that I did not awake from 8 p.m. on Saturday till 6 a.m. on Sunday, an earthquake was felt at 9.30 p.m.

Monday, $18^{\text {th }}$ of March. I borrowed from J. P. Escobar the manuscript of the report given by the secretary Luis Benjamin Cisneros, to the Delegates of the Banks, from which I extracted the following particulars.

The Export duty which the Delegates collected on nitrate shipped by the free producers, from $1^{\text {st }}$ May 1876 to $31^{\text {st }}$ Decr. 1877 , including some other trifling items came to $S / 8,771,814$ which were distributed in the following manner:

For maintenance and conservation of Salitreras 200,218 Delegate's Commission of $5 \%$ 438,590

To the Banks, for the interest on S/18,500,00o till the $17^{\text {th }}$ August 1877 at $6 \%$ $1,333,936$ To the same a/c redemption of principal to the $30^{\text {th }}$ June $1,173,676$ Paid to, and by order of the Caja Fiscal $5,453,009$ Interest at 12 and $6 \%$ p.a. on advances 16,781 Petty Charges 
Profit and Loss Account on the $31^{\text {st }}$ December 1877 stood as follows:

Gastos

Perdidas y Ganancias

Ganancia Neta

$\begin{array}{rlr}\text { S/163,292.86 } & \text { Comisiones } & \mathrm{S} / 573,606.11 \\ \mathrm{~S} / 7,232.48 & \text { Cambios } & \mathrm{S} / 343,114.69 \\ \mathrm{~S} / 896,497.02 & \text { Descuentos é } & \\ & \text { Intereses } & \mathrm{S} / 150,301.56 \\ \mathrm{~S} / \mathbf{1}, 067, \mathbf{0 2 2 . 3 6} & & \mathrm{S} / 1,067,022.36\end{array}$

The Salitreras sold [595] to the $3{ }^{1 \text { st }}$ December 1877 came to

Less to be deducted for various causes

for which certificates were signed, bearing an annual interest of $8 \%$, and at the exch. of 44d payable every three months

Retained in the hands of the Banks

Still to be delivered

66,007 $\quad \mathrm{S} / 17,753,901$

S/12,513,042 already delivered 577,459 $4,597,391 \quad \mathrm{~S} / 17,687,893$

In the evening Garland had again one rocambor table. I was however with Enriqueta on my side of the corredor till I went to bed, at eleven.

Tuesday, $19^{\text {th }}$ of March. San José. My health upon the whole was good; the rheumatic pains in the left hip were gone, and I had taken off the porous plaster; only my left knee was always a little weak and I feared would remain so the few years I still had to live.

The papers about this time were filled with bitter invectives against the Government; some articles were signed by Segarra, others by the Banco Garantizador. The former, who had been Peruvian Chargé in Santiago at the time of the "Huascar" question, directed his shafts against the Minister for Foreign Affairs, whose conduct, according to him, had been highly improper at that critical period. The bank complained of the injustice of the Minister of Finances, who would not allow their notes to circulate; and at the same time they made known that at their office their notes would be exchanged for the notes of those banks the circulation of which was authorized by the Government.

I occupied myself with Bryson in revising the diary of October 1871. When he was gone I got ready to make a few calls, but it was three before I left my house. At the Alvarez I was always received with the same kindness. At José Basagoytia's I only saw a sister of his wife's; his daughter Filomena, just grown up to womanhood, and one of his younger children. None of the females of this family could boast of a particularly bright intellect. [596] [...] hand I was much pleased with my visit to Doña Josefa, the widow of Prada, and finally, with that to Doña Trinidad La Fuente, wife of General Pedro Cisneros. This 
family after having resided for a series of years in Cucalon's large Rancho in Chorrillos had at last come to town, and rented part of the first story of the large house Calle de Santo Domingo, where the Bergmanns used to life. At dinner we had Urquhart and Doña Jacinta Sotomayor, Doña Juana Carbajal who came in before we had risen; and all three I still found with Enriqueta on my side the corredor after Bryson had done reading to me.

Wednesday, $20^{\text {th }}$. The papers affirmed that the North American Mackie, the principal owner of the Klomstock Mines in Nevada had a revenue of $£_{5}$ per minute, equal to an annual income of 2 1/2 million Sterling.

When Manuel Pardo was president he gave much of his attention to education; for the lower classes of society he founded the Municipal Schools. For the higher classes he called hither several females belonging to the Congregation of the Sacred Heart of Jesus, an order which superintended various colleges, not only in the Catholic Churches of Europe, but also in England. To those who came to Lima, for the greater part English, he ceded the vast premises belonging to the Church of San Pedro, hitherto occupied by the few brothers of the Congregation of San Felipe de Neri, there to establish a college similar to those in Europe. The repairs and alterations which these buildings required, and which had been entrusted to the Compania de Obras Publicas y Fomento, had been finished within the last few days, and this day the President of the Republic, Don Mariano Ignacio, opened the college. He rode thither in his uniform of General, with his big boots higher up than the knee, and accompanied by his escort of splendidly dressed hussars, altogether rather ridiculous for the inauguration of an establishment like this, presided by nuns, and destined for the education of young girls. Enriqueta placed her two daughters in this college; she did so, though reluctantly, because she knew from experience that Maria was of such an indolent disposition [597] as to preclude $[\ldots]$ her deriving any benefit from private $[. .$.$] the other hand she$ was in hopes that in a public school the example of her companions would serve as a stimulus, and she might thus learn something, at all events more than she would do at home. At 1 O'clock she herself took them there, and at 5 Garland brought them back. They told us that there were from one hundred and fifty to two hundred girls of different ages, that they had been playing all the while, and thus, this, the first day, they were quite happy and content.

In the meantime I had been in the Banco Hipotecario, where the Directors, Dr. Galvez excepted, were assembled. Gallagher, who had recovered his health, occupied his usual seat, and in less than an hour's time we got through a good deal of business. I mentioned to the President Lorente that I knew from Evaristo Barrios that the last day he had acted as Director, he had moved that it was highly improper that any one who was related to the gerente, should be Director. This was clearly pointed at me, and I therefore begged that this 
motion might be discussed as soon as possible. Enriqueta was again in bed with a fearful migraine. Both Bryson and Ricardo read to me in the evening; with pleasure did I listen to them, but my sadness was always the same.

Thursday, $27^{\text {st }}$ of March 1878. At 1 I went to the Banco del Perú, where the Directory, Ayulo excepted, were present. Under date $15^{\text {th }}$ the Government had given a decree which ordered that the banks should send Delegates to the capitals of the different Departments, for the purpose of changing the old notes for those provided with the Government's stamp. The decree did not say who was to pay the commission, the freight, the insurance on the billetes sent and exchanged; neither, who was to run the risk by land and sea. All this was detailedly discussed and the gerentes authorized to represent to the Government, in unison with the gerentes of the other banks, the incompleteness of this decree, and to propose various modifications.

In the evening Garland had again a few gentlemen to play at rocambor. I went to bed at past eleven.

Friday, $22^{\text {nd }}$. Juan's letter from Nizza, of $15^{\text {th }}$ February contained nothing of importance. C. W. Schutte's was dated Paris $14^{\text {th }}$. From what he wrote, and from what was read to me from [598] [_] of $15^{\text {th }}$ Feby., from the Star and Herald of $12^{\text {th }}$ March, and from the "Nacional" of last night, I made the following extract.

When Admiral Hornby first demanded from the Sultan permission to pass through the Dardanelles, he received a negative answer; he then telegraphed to Lord Derby, who replied that he was to enter at all hazards. He did so, and without experiencing any hostility from the Turks, entered the sea of Marmora on the $13^{\text {th }}$ in the evening. His fleet consisted of twelve ironclads and ten cruisers. Whether the Russians had entered Constantinople or not, it was impossible to make out; my opinion was, they had not; as little was it known for a certainty, whether peace had actually been concluded between the belligerents. England and Austria were making great warlike preparations. The former power was sending man-of-war after man-of-war to the Mediterranean, and had bought three new ironclads, two of which were building for Turkey on the Thames, close to London; the other, called "The Independencia", just concluded for the Emperor of Brazil. Lord Napier of Madgala was named General-in-chief of the land forces, and Sir Garnet Wolseley Chief of the Staff. Telegrams to the beginning of this month were however again of a Pacific nature.

In Japan seventy eight millions of dollars, in size and intrinsic value, similar to the North American dollar had been coined within the last three years. The Mexican dollars hitherto in circulation there were gradually disappearing. About this time an Artesian well was being sunk in the neighbourhood of Perth, which had reached the hitherto unprecedented depth of $95^{\circ}$ metres, where water of a very hot temperature was found. 
Ricardo Palma, the Lima antiquarian, affirmed in an article published in the Nacional, that not only Bolivar himself, but also his intimate adviser and minister Monteagudo was in favor of a monarchical government. The latter was assassinated on the $30^{\text {th }}$ January 1825 , by a negro, Candelario Espinoza, who in all probability was nothing but an instrument [599] in the hands of the ultra Republicans; whilst to Sanchez [_] who belonged to this party, prison had twice been administered; the first time he escaped from its effects, the second time he fell a victim to the same.

At about 2 O'clock I went to Dr. Lührsen, the German Chargé, to congratulate him on the Emperor of Germany's birthday, who this day completed his $81^{\text {st }}$ year. The Doctor was by himself in his study, and I remained about half an hour. He was of the same opinion as I, that the Russians had not entered Constantinople, and that there would be no war between Russia, and England and Austria. The little girls came from their college quite as happy as on the previous day, especially Corina did not cease chatting and relating to us how she had amused herself.

Saturday, $23^{\text {rd }}$ of March. This morning on the contrary when Enriqueta came home, she told me that Corina had been weeping bitterly when at the door of her college, that she had clung to her gown, and begged and prayed to be taken back to her own house. However, Enriqueta had to be hard-hearted, and made her enter. A day or two back returned to China, the Belgian steamer "Perusia", taking with her, but a small cargo. On board of her embarked as Peruvian Envoy to China and Japan Frederic Elmore who, it was said, had secretly an interest in the business of Oliphant \& Co. The object of his mission was to remove if possible the obstacles which for many years past had been raised mainly by the English authorities, in China to the immigration of Chinese coolies to the Coast of Perú. This Elmore, brother of Mr. Jerningham's widow was one of the many sons of the late Mr. Elmore. He had received a very good education in Europe, was brought up to the law, and for a year or so worked in the study of Dr. Fernando Palacios, where many a time I paid him four, six, or eight rials, for writing an escrito dictated by the Doctor. All of a sudden he disappeared; being well acquainted with the English language, the Peruvian Govmt. had appointed him secretary to Don Mariano Alvarez, sent as Envoy to the United States. Since then he had occupied various situations under Government and when Manuel Pardo na[_] [6oo] [_] Garcia y Garcia, Ambassador to Japan and China, Elmore again went with him as secretary and for the same reason as above given, for Garcia knew as little of English as Alvarez. Geraldo spoke very highly of him. At past two I went to the office of the Lima Water Company, where a meeting of the shareholders was convened, but, as usual, we had no quorum. I learned from young Rey, whose father was not yet able to attend, that the excavations 
for water, somewhat further up than the pantheon, commenced several years back when I was Director, and which were indispensable for supplying the necessary quantity of water, and the cost of which had run up to $S / 150,000$ had been suspended, owing to an absurd interference of the Municipality. As the earth where they were digging was of a yellow colour and clayish nature, the water which came to the town was occasionally turbid, and therefore the Municipality had made known to the Company that the first time this happened again they would have to pay a fine of S/100o. Very naturally they at once stopped the work. I bought from Alejandro for Rosa £650, for Juan $£_{150}$ Graham Rowe \& Co. on their Liverpool firm, at 23d 3/4, for myself $£_{500 \text {, }}$ Government on the Guano Coy., at 24d.

About eighteen months or two years back, appeared in Lima a Frenchman, who called himself Lemale, and who was only known to Luis B. Cisneros, who had probably seen him at the time he was Peruvian Consul in Havre. Cisneros introduced him to some of his friends, and erelong he had formed a numerous circle of acquaintances, and succeeded in establishing a club or commercial association, the members of which were for the greater part shop and storekeepers. They rented some apartments in the large house of Terry, opposite Gibbs, and took the name of La Junta Mercantil, and, presided by Juan Revoredo, had their meetings, made their motions, took their resolutions, in fact, acted as an independent body of which more than once I have made mention in the preceding pages. But how did Lemale gain his livelihood in the meanwhile? This nobody knew. At last his true [6o1] character came out. To the firm of Serdio Herm [...] he bill on Chile, which was protested and turned out to be a forgery, whereupon he was clapped into prison, from which about this time he had made his escape in the disguise of a friar. I myself had never exchanged a word with him, nor did I know him by sight. With Enriqueta I went to fetch the little girls from the college. They came home quite merry; but in the evening when in bed little Corina again began to weep, and begged her mother not to send her to college again.

Sunday, $24^{\text {th }}$ of March 1878. This morning Corina went to the college in a very sad mood, but did not weep. Guillermo balanced and closed my books, with which he had been occupied every morning for more or less a week. The result was very unsatisfactory. My expenses, rent, board, and lectors, presents made by me, actual losses, patente, and medical attendance, and above all the deterioration in the value of my property, estimated much too high on the $28^{\text {th }}$ February 1877, reduced my Stock account since last balance by S/2,291.90ct, and what was much worse, owing to the continual rise in exchange, which from 30 pence, twelve months back had risen to 24 pence, my fortune had in reality decreased $£_{12,000 \text {. }}$ 
It was really a sad thing to observe how my fortune which since I separated from Gibbs in 1842 had gradually gone on increasing, had within the last years, without my fault, and owing to the unfortunate exchange, dwindled away in a frightful manner, as the following statement will shew.

1843

April 30

Decr. 31

Decr. 31

Decr. 31

Decr. 31

Decr. 31

April 30

April 30

[602]

April 30

April 30

April 30

April 30

April 30

April 30

April 30

April 30

Augt. 31

Augt. 31

Augt. 31

Feby. 29

Feby. 28

Feby. 28

Feby. 28

Feby. 28

Feby. 28

Feby. 28

Feby. 28

Feby. 28

Feby. 28

Feby. 28

Feby. 28
Dollars

$\$ 172,694$

$\$ 197,846$

$\$ 207,157$

$\$ 217,758$

$\$ 233,861$

$\$ 257,549$

$\$ 264,500$

$\$ 270,000$

$\$ 275,000$

$\$ 374,000$

$\$ 402,137$

$\$ 430,000$

$\$ 450,000$

$\$ 477,000$

$\$ 508,000$

$\$ 542,000$

$\$ 634,000$

$\$ 672,000$

$\$ 700,000$

$\$ 709,000$

$\$ 747,000$

$\$ 797,000$

$\$ 847,000$

$\$ 897,000$

$\$ 929,000$

Soles

$\mathrm{S} / 781,200$

$\mathrm{S} / 771,200$

$\mathrm{S} / 812,201$

$\mathrm{S} / 932,280$

$\mathrm{S} / 492,291$

$\mathrm{S} / 490,000$
Exchange 44d

Exchange 44d

Exchange 44d

Exchange 44d

Exchange 44d

Exchange 44d

Exchange 44d

Exchange 45d

Exchange 45d

Exchange 45d

Exchange 43d

Exchange 44d

Exchange 41d

Exchange 41d

Exchange 4od

Exchange 4od

Exchange 37d

Exchange 37d

Exchange 37d

Exchange 36d 1/2

Exchange 36d 1/2

Exchange 37

Exchange 36

Exchange 36

Exchange 36

Exchange 44d 1/2

Exchange 43d 1/2

Exchange 3od

Exchange 3od

Exchange 3od

Exchange 24d
$£_{31,660}$ Stg. $£_{36,271} \mathrm{Stg}$. $£_{37,978 \text { Stg. }}$ $£ 39,733$ Stg. $£_{42,874 \text { Stg. }}$ $£ 47,211$ Stg. $£ 48,492$ Stg. $£_{50,625} \mathrm{Stg}$.

$$
\begin{array}{r}
£_{51,650} \\
£_{70,125} \\
£_{72,048} \\
£ 78,833 \\
£ 76,875 \\
£ 81,477 \\
£ 84,666 \\
£ 90,333 \\
£ 97,740 \\
£ 103,600 \\
£ 107,916 \\
£ 107,827 \\
£ 113,565 \\
£ 122,870 \\
£ 127,050 \\
£ 134,55^{0} \\
£ 139,35^{0}
\end{array}
$$

$£ 146,519$

$£ 139,780$

$£ 101,525$

$£ 116,535$

$£ 61,536$

$£ 49,000$ 
To Bryson I dictated a letter to C. W. Schutte, and then remodelled the old diary of November and December 1871. With Limpricht I played two games at chess. The first, in which he gave me the Kings gambit, ended after many ups and downs in a drawn game, he giving everlasting Check; the second, which I began, I gained with comparative ease. The little girls, though it was Sunday, had to be in college to 4 O'clock. Corina, when in bed, wept as she had done the previous evening.

Ricardo read to me Zamarow. Enriqueta and I seldom retired from the corredor before 11 O'clock.

Monday, $25^{\text {th }}$ of March. Holiday. La Anunciacion. At [603] 7 I started for the summit of San Cristoval. I ascended from [_] side of Los Descalzos, rested half way up, and when I came to the steep part, had to climb on all fours for a few yards. I descended leisurely and easily and calculated upon being home in two hours, but when walking along the narrow path on the side of the mountain I stumbled over a stone and had a bad fall. I wonder I did not roll down to the bottom. When I got up I felt a severe pain in my left thigh; fortunately nothing was broken, but I was so completely unnerved that I had to rest over and over again and when in town took a coach, in which I drove to my house where I lay down for a few minutes on my bed, breakfasted, and somewhat later felt quite well, excepting the pain, which was however not acute.

I dictated my letter to Juan, and at about 3 O'clock went out to pay a few visits which were all unusually agreeable; firstly, to Dr. Muñoz and wife, who were both at home, next to the family of Masias, not in, then to Doña Isabel Coloma, where I found young Alfredo, son of Manuel Francisco Benavides of Arequipa, who was engaged to Maria, second daughter of Doña Isabel, whose mother, a Salazar, belonged to one of the noblest families in Lima, of which she was not a little proud, whilst her father General Coloma was a nobody who came to the surface in the course of the many political dissensions which had distracted this country ever since the Independence; her husband was Carlos, a natural son, cousin of the ex President Pedro Diez Canseco. Thence I directed my steps to Manuela Portillo, who had gone out, but in lieu of her, her granddaughter Amalia Alayza, widow of Manuel Ferreyros, and mother of three little girls, received me; she was quite as agreeable as her grand-mother. Doña Francisca Castañeda, Melchor Velarde's wife, was by herself and whilst I was with her we ran every moment to the balcony to have a look at the cars of the just finished tramway, or, as it is called here, ferro-carril urbano, which had been inaugurated on the preceding day by the President of the Republic. The trunk line runs from the terminus in the Paseo de Aguas, passes the Church of San Lazaro and then in a straight line over the bridge la Calle de Palacio [604] 
alongside the [_] de Escribanos as far as the Exposition. There it retur[_] the same way as far as the Faltriquera del Diablo, where it turns off to the right, straight up to the Chorrillos Station, and once more in a straight line trough Filipinas, La Coca, Bodegones, passes the steps which lead up to the Cathedral, La Pescaderia, where it once more turns to the left, behind the Palace, and rejoins the trunk line close to the bridge. Inside the fare is one rial per person, outside, half a rial. I closed my round of visits at José Pablo Escobar's. Maria and Corina had as usual been in the college; the latter began crying when we were at dinner; she would not eat, she went to her mother, to me, I could not stand it, and left the table. "Mama Qui would not have sent me to college, I am sure she would not have done so." She was taken to bed, and wept herself asleep. Even whilst sleeping her little breast heaved convulsively, as if she were sobbing.

Garland had now regularly, every Monday and Thursday his rocambor, to which sat down, he himself, José Basagoytia, Melchor Velarde, and Dr. Middendorf. Past eleven I went to my bedroom.

Thursday, $26^{\text {th }}$ of March. I took a walk through the town, for though my thigh pained me, it did not prevent my walking. When I came back I was glad to hear that Corina had gone to college without weeping, the servant girl Virginia, not their mother, had taken the children thither.

The parties interested in the street tramway were: Eduardo de las Carreras, a gentleman from Uruguay, who had made all the disbursements; Mariano Borda, and Geraldino, whom I had known as Agentes de Pleytos, and the former of whom, who obtained the original concession I had seen supervising the laying of the rails, Pedro Saavedra, Alcalde, and perhaps a few more.

At 1.30 the Directors of the Banco del Perú, Althaus excepted, assembled. Candamo read a letter directed to him by the book keeper, in which he made some requests and complaints. I, to whom Escobar had spoken yesterday on the subject, said that my opinion was the clerks should address themselves to [605] the immediate superiors, the Gerentes, and not to the Directory [_] the President. This observation, at first unheeded, was afterwards taken up by Ruden, and finally approved unanimously. Next, Escobar said that the Gerentes were quite at a loss what to do about the sale of the Internal Debt, because there were so many conflicting rumours afloat, and nobody knew what to believe. Calderoni proposed that the sale should be suspended till next meeting, when Althaus, who was supposed to be better informed than anybody else, should be particularly requested to attend. The discussion was long and animated; when the motion was put to the vote I and Ayulo voted with Calderoni; against Ruden, Bryce and Elizalde for the sale. Candamo, the chairman, had now to 
give his casting-vote; and voted for the suspension. The two little girls when coming home from the college, were quite happy and satisfied. I was so sleepy that I went to bed at 9.30.

Wednesday, $27^{\text {th }}$ of March 1878 . Corina went at 8 without crying but apparently sad.

In the forenoon I merely went to the Banco del Perú for the purpose of signing the motion made by me on the previous day and which the gerentes had had to write in clean, but which César Canevaro, who had gone out, had locked up in his desk. Escobar offered me bills drawn by Gibbs of Lima, on Gibbs of London, of which the bank had several for sale at $24 \mathrm{~d} 1 / 4$. I took one of $£_{300}$ on my own account.

The papers spoke of great armaments being made by Austria, of extraordinary supplies voted by the Chambers, and of continual misunderstanding between Russia on the one, and England and Austria on the other side. Now Berlin was mentioned as the place where the meeting of the plenipotentiaries of the European powers was to be held. In the United States a so-called Silver bill had passed, which I suppose meant that this country had adopted both silver and gold for its monetary standard. They had begun coining silver dollars.

Thursday, $28^{\text {th }}$ of March. At last it seemed as if little Corina had made up her mind to go to school without crying, when comi[_] [6o6] [...] p.m. both were in good spirits. In the forenoon the Directory of the Banco Hipotecario, Dr. Galvez excepted, was assembled for hardly an hour. We agreed upon the terms in which a letter written by Riva Agüero to the President Lorente should be answered. We authorized the Gerentes to make a small loan to Vivanco, a natural son of the late General, upon the mortgage of a valuable farm of his called Mata Lechuzas, close to the village of Magdalena, and lastly to borrow forty or fifty thousand Soles, which they said they required to make up the sum wanted for the payment of the interest on the Cedulas on the $1^{\text {st }}$ April, various sums, upon the receipt of which they had firmly counted, not having come in, and this want of regularity on the part of the debtors was owing in a great measure to the damage done to the sugar estates by the late rains. Garland had his three rocambor players with him in the evening.

Friday, $29^{\text {th }}$ of March. Now that we had no more trouble with little Corina, her mother was again ill of migraine. Juan Garland I had not seen for at least a fortnight; I did not know whether he still worked as clerk in the Compañia de Fomento, I did not know whether he slept at home, or where he took his meals, and his parents knew as little of him as I.

In the Banco del Perú all the members except Ayulo were assembled. Althaus gave it decidedly as his opinion that we should go on with the sale of the deuda interna, because he was convinced that months would elapse 
before the Government could find anyone merchant, or bank, who would bind himself to "hacer el servicio". Calderoni was of a different opinion, and when Althaus made the motion that the Gerentes should be authorized to sell, S/200,000 Nominal, not below 54\%, I observed that this authorization should be limited to $S / 100,000$ but all others sided with him. Next, all were unanimous in approving the purchase of shares of the bank itself, if they could be bought at $75 \%$ or less. The discussion whether part of the funds of the bank should be invested in Nitrate Certificates, was postponed till next meeting, and finally, we resolved to make a loan of $\mathrm{S} / 300,000$ to the Delegates of the Banks for one [607] month at $1 \%$ against their placing into our hands good [_] on England for the same amount. This sum the Delegates required to hand over to the Government for the monthly incineration.

In appendix under $\mathrm{N}^{\circ} 26$ goes affixed a cutting from the Nacional containing biographical sketch of Bernardo Monteagudo and Faustino Sanchez Carrion, written by Ricardo Palma.

Enriqueta was ill the whole day. Middendorf came twice.

Saturday, $30^{\text {th }}$ of March 1878. She was somewhat better, but the doctor insisted upon her changing climate; she was to go to La Chosica, she was to go to Arequipa; easily said, but difficult to be done.

Sunday, $33^{\text {st }}$ of March. Enriqueta was up, but extremely weak.

Here follow a few gleanings from German papers read to me by Ricardo. The distance from Holyhead to Dublin, across St. George's Channel is 67 English miles, and by means of the telephone a conversation had been carried on between the two named places. In the South of the Kingdom of Saxony many trials had been made with the telephone at a distance of 190 kilometres, but the result had not been satisfactory; the sound, it is true, travelled the entire distance, but at the other extremity it had lost its distinctness, and no intelligible word had been heard. At the mouth of the Tay in Scotland, a railway had just been concluded at such a height above the level of the river that sailing vessels could pass under it. On the $31^{\text {st }}$ Decr. 1875 the railways all over the Globe measured very nearly 300,00o kilometres, equal to 40,000 geographical German or 160,00o English nautical miles. Their cost was estimated at 65,000,000,000 Imperial Marks equal to $£_{3,250,000,000}$ Stg. The walls round Vienna had been demolished, and the open space between these walls and the suburbs formerly called the "glacis", was now transformed into one beautiful street "the ring", one of the principal features of which was the large square the four sides of which were occupied respectively by the Parliament house, the University, the town house, and the Imperial theatre. If these building were not yet concluded they would soon be so. A garden, or park, was to fill up the inner area of this square. [6o8] [_] England the density of population was such that upon each square 
kilometre live more than 100 persons, in Germany 79; in France 68; in Austria 57. It is a pity the paper did not say whether by the word "England" was meant the United Kingdom, or merely England and Wales, and in the same manner whether Austria was confined to the German Austria, or whether it included the Hungarian Austrian Empire. In Germany the production of grain was not sufficient for its consumption, 20,000,000 quintals were imported annually. From a report presented to the House of Commons by a committee specially named for the purpose, the following details were drawn. Europe produced annually 200,000,000 tons of coal, of which falls to the share of England, 127,000,000; and 90\% of this production was consumed in the country; France consumed annually double, even triple the quantity which it produced. According to some the deposits of coal in Europe were not likely to last more than one century, according to others, two centuries, and the most hopeful extended the time to four centuries. It is supposed that there are layers of coal below the present mines, but these can in all probability never be worked, because the intensity of the heat in the bowels of the earth increases from metre to metre, and at the depth of 1200 metres it cannot be supported by human beings.

By the 2 O'clock train I went to Chorrillos where I made a few calls. At General Pezet's, who was always very polite, I met the family of Don Diego Masias. Dr. J. M. Perez, who was by himself was as taciturn as usual, and only thawed up when he began to speak of the suit which he carried on against Mathison for having raised the price of the gas in Chorrillos from eight to ten Soles per thousand cubic feet, which latter price he and many others would not pay. Luisa Soyer, the wife of José Canevaro, was by herself. Everybody knows that she is a very pleasant and pretty young lady. José V. Oyague, who gave himself his usual airs, was however very polite towards me, and asked me to remain to dinner, which however I declined. At Felipe Barreda's nobody was visible. Mariano Felipe Paz-Soldan [6o9] showed me the telephone he had. It was a very plain [_], something like a short tube, with a small hole at the one end, into which he who sends the message speaks, the sound puts into a vibrating motion a very small, thin round plate of iron, which when moved by the breath of the speaker touches a magnet, or magnetized iron, distant perhaps a line. Every time the magnet is touched, magnetism is produced which again produces electricity in the metallic wire which is affixed, and which runs to the other extremity where the listener holds to his ear a tube exactly similar to the other; here the electricity of the wire again produces the magnetism in the magnet and this attracts and repulses a small bit of iron exactly similar to that on the other end, and this emits the same words which have been spoken into the tube by the sender of the message. Don Mariano Felipe made several 
trials with his son Carlos who was in a distant room, and they understood each other perfectly. I also made an attempt, and though I placed the tube to my right ear, with which I hear perfectly well, only indistinct sound, mixed up with an occasional distinct word reached me. Don Manuel Alvarez Calderon also invited me to dine with him, but I preferred returning to town. My last call was upon Anibal Gonzales, and his wife Josefa Bazo, who lived miserably in a few rooms belonging to the hotel of Don Pedro. I was home by 6.45, dined and afterwards listened a little to Ricardo's reading.

Monday, $7^{\text {st }}$ of April 1878. I, being this month Director de Turno in the Banco del Perú, went thither at 9.30 a.m. and found there the two gerentes, and Lecca, a commissioner named by the Government to inspect every month the accounts of the banks. He, I, Cesar Canevaro the Cashier, and another clerk, descended to the vault, where we counted, or at least Lecca did, for I could not see, the billetes contained in a number of boxes and chests, that is to say the parcels of billetes, for to count all the billetes themselves would have taken more than a week. Again I went at about twelve, when Canevaro read and explained to me the balance of the various accounts which formed the balance sheet, which provided [_]ith my signature was to [610] appear in the [_] papers. In the evening when Dr. Middendorf came to play his usual rocambor he brought the news that Graham Rowe \& Co. had just received a telegram with the significant words "war imminent". Limpricht told me that on Saturday before last all negotiations between the firm of Dreyfus in Lima, and the Government, had been decidedly and irrevocably broken off, and that the former were taking steps to diminish their hitherto heavy expenses. Perhaps they thought of liquidating.

Tuesday, $2^{\text {nd }}$ of April 1878. I received long letters from C. W. Schutte and Juan, the former from Paris to the $1^{\text {st }}$ March; the latter from Nizza. Both complained of their want of health and certainly both were sufferers, though Schutte's ailings were of a far more serious nature than Juan's. Rosa wrote that her husband was very melancholy and that he frequently wept. The political news which they communicated was not, and could not be of any great interest, for its substance was always anticipated by previously received telegrams. Those letters also brought the advice of the death of Mrs. John Hayne, and of Mr. Hermann Schwartz. Somewhere in my diary I must have mentioned how about the year 1834, Mrs. Hayne, then Miss Baynton, came to this country with her sister Charlotte; both were very very poor, but agreeable and well educated, and how they then had the good luck to marry, the elder, Jane, Mr. John Hayne; the younger, Charlotte, Mr. George Thomas Davy, both partners of Gibbs' establishments on this coast. Hayne left a fortune of $£ 400,000$ the interest on part of which his widow had enjoyed in conformity with his will. 
The remainder, by far the greater proportion, had gone to his four children: Jane, who married Mr. Döring, John, George, and Charles, who as Mrs. Schutte wrote, had managed to get through with this handsome fortune in the course of the thirteen or fourteen years which had elapsed since their father's death. Herman Schwartz was a native of Thorn in Polish Prussia; he came as clerk [611] to Gibbs, and rose in a short time to be partner. I think [_] was in 1845 that he was in Tacna, managing the branch there when Mr. Schutte and I paid him a visit. Charles Eggert, a native of Dantzic, just arrived, was then clerk with Schwartz. This latter retired with a handsome fortune; in 1863 I dined with him in Hamburg, and afterwards he bought an estate somewhere in Austria; he was upon the whole a very agreeable man; amongst his friends he occasionally made a boast of his voracious appetite. The quantity he could swallow at a sitting exceeded all belief; he died unmarried. Telegrams from Europe said that Earl Derby had resigned his post as Minister for Foreign Affairs and that on the $1^{\text {st }}$ April the Queen was to have made known to parliament in a speech from the throne that the English army was to be placed on a war footing.

Wednesday, $3^{\text {rd }}$ of April. I was called to the Banco del Perú as Director de Turno, to give my opinion as to the sale at $541 / 2 \%$ of S/200,000 Noml. Internal Debt, of which the gerentes would not dispose though authorized to do so by the Directory. Besides me, Calderoni and Bryce were there, and we decided that the sale should be made. Through Alejandro I sold to Mr. Charles Watson, Gerente y Director of La Compañia del Ferro-Carril a La Oroya y Mineral de Pasco, my S/12,00o privileged obligations of the Pasco Railway Company at $57 \%$, and the old shares, both Juan's and mine, of the same company, at $5 \%$. I considered it a good sale, but it had the drawback that it was at three months credit the documents remaining meanwhile in my hands as security. Last year, 1877, the gross revenue of the Railway from the United States to California, had been twelve million American Dollars, the expenses somewhat above five millions. In India 191,000,00o inhabitants who occupied an area of 900,00o English square miles, were subject to the sceptre of Queen Victoria. In the Grand Hotel of Paris a dreadful accident had occurred; a foreign lady, a baroness, who had a room in the fifth story, ordered the person employed for the purpose to lower her in the machine called the elevator, to the ground floor; two other persons of the male sex [612] [...] at the same time. All of a sudden a dreadful noi[_] was heard in the hotel; the elevator had come down with a frightful rapidity, and the three persons in the same were corpses. Two extraordinary walking matches had come off in England, the one as to who could walk the greatest distance in twenty-four consecutive hours; he who obtained the first prize had completed nearly 129 miles, the second $1251 / 2$. The other consisted in 2000 miles being walked in 1000 hours, with the condition, 
two miles in every hour; here the difficulty did not lie in the number of miles walked, but in the want of uninterrupted sleep.

Thursday, $4^{\text {th }}$ of April. The temperature was getting somewhat cooler in the morning and evening. At $4.30 \mathrm{p} . \mathrm{m}$. thermometer $801 / 2^{\circ} \mathrm{F}$. Again I was called to the Banco del Perú. The Bank had S/30,00o Shares in the Chilete Mining Coy., which sum years back they had had to take from Bianchi in payment of a debt of his, and which were valued in their books at nothing. Now the question was whether the Gerentes should pay a new call of $6 \%$ upon the $S / 30,000$ or sell the $\mathrm{S} / 30,000$ for which José Canevaro had offered $5 \%$. Elizalde who was called in, and I, voted for the sale. Ayulo, who was there by chance said it was quite indifferent to him, and Bryce did not give his opinion. At 2 I had to go to the Insurance Company "Lima", where nothing worth mentioning was transacted. I bought from Elizalde about $£_{3} 00 \mathrm{go} \mathrm{d} /$ st., interest on nitrate certificates, that is to say, bills drawn by the Delegates on Gibbs, London, at $25 \mathrm{~d} 1 / 2$. This year the patente to be paid by me had again been fixed at $S / 500$ every six months, and I of course again presented my escrito to have it reduced to the $\mathrm{S} / 304$ half yearly paid by me in 1877 .

This morning at 1 a.m. the rancho inhabited in Miraflores by Mr. Young, manager of the Chorrillos and Callao lines, was forcibly entered by four individuals, guided by a boy who was acquainted with the arrangement of the house. One of the four, a negro, went into Mrs. Youngs bedroom, and not finding her [613] husband there, proceeded to his, where he found him in bed, [_] threw himself upon him, revolver in hand, and before he could fire it off Mrs. Young pulled him back by the hair; then the shot went off, and the ball slightly grazed Mr. Young's body; hereupon Mr. Young also took hold of the negro, who however managed to escape, together with the three who had been waiting outside. Another accident occurred in consequence; the shots fired, and the noise made roused some of the neighbours who came en masse; from another side arrived the Gobernador of the village, with his followers; he went up to the roof of Mr. Young's house, was seen there, believed to be one of the burglars, was shot at and dangerously wounded. Garland's rocambor party increased in number; there were this evening Dr. Middendorf, José Basagoytia, Melchor Velarde, Ramon La Fuente, an elderly man, son of the late Basilio La Fuente of Arequipa, Col. Mariscal, an intimate friend of the Basagoytia's who in 1865 came hither with Prado, to whom he, together with his companions, the Colonels of the other battalions, offered the Dictatorship, and finally Johannes Limpricht. This latter merely played though he did extremely well, to make up the number required; his losses or gains he divided with Enriqueta.

Friday, $5^{\text {th }}$ of April 1878. I recommenced taking my early morning walks. For the remainder of the day I did not leave the house. 
Saturday, $6^{\text {th }}$ of April. The Directory of the Banco Hipotecario had a meeting of two hours. All were present, as well as the lawyer of the bank, Dr. Ramon Ribeyro. Much was done, and the various questions laid before us by Gallagher, were quickly dispatched, some in the negative, some in the affirmative. Dr. Ribeyro was henceforth to be the sole lawyer of the bank and to have his study in one of the rooms belonging to the same. Dr. Felipe Varela would be dismissed. The gerentes were authorized to make if possible some arrangement with Bustos, who, as said a few pages back, was the Sindico of the estate of Marconi.

Last nights Nacional reproduced an article from the [_] [614] which said that Dreyfus and Raphael \& Co. had at last come to a friendly understanding, to the effect that henceforth they would both [_] the guano, which contained at least $7 \%$ Azoe, at $£ 12.10$.

Sunday, ${ }^{\text {th }}$ of April 1878. The papers gave further details of the arrangement between Dreyfus and Raphael. The guano to be sold at £12.10 had to contain besides $7 \%$ Azoe, $14 \%$ Fosforic acid, and such parcels of guano as were of an inferior quality were to be mixed up with those of a superior, so as to produce a guano of the just stated average quality. The capital of the Peruvian Guano Company was doubled, and accordingly raised to £1,60o,0oo. La Société Generale, and various powerful groups of capitalists, both in London and Paris, had entered into the business. Of the annual proceeds, $£_{700,000}$ were to be put aside for the Peruvian Government as hitherto; next the proceeds of fifty thousand tons, whether actually sold or not, would be applied to the payment of a very small interest on the Peruvian Bonds. Maria and Corina continued to go to their college without any difficulty. Enriqueta was by particular permission admitted to the mass, which was said in the chapel of the college and which all the children attended; she said that nothing could be better conducted, and that the children behaved with admirable devotion; the playing of the organ, accompanied by the singing of the teachers, las madres, pleased Enriqueta above all.

To Bryson I began dictating a long letter to Juan, and when he was gone I played with Limpricht four games of chess in somewhat more than two hours. I gained the first and second, he the third, the fourth was a drawn one, both remaining with king and queen. Afterwards I had a short call from General Pedro Cisneros; at dinner we had Limpricht and Urquhart. From 8 to 9 Ricardo read Zamarow's Death of the Hanoverian Legion, which never sl[_]s in interest. Monday, $8^{\text {th }}$ of April. Thermometer at 4 p.m. $79^{\circ} \mathrm{F}$.

Tuesday, $9^{\text {th }}$ of April. Last night when Garland had his rocambor players with him, I sat down with Limpricht to a game of chess. [615] We began near 10 and left off near midnight. He gave me the [_]gambit, and beat me. 
At midnight Enriqueta had chocolate served. I took a cup, but owing either to this, or to the excitement of the chess playing, frequently awoke during the night.

I saw by the papers that on the Northern frontiers of Bolivia, custom house buildings were in progress of construction, which measure on the part of the Government of that Republic, was a natural consequence of the differences which about this time existed between the two Republics with regard to the import duties levied in Perú on merchandize destined for the Bolivian markets. See what I said on this subject page 557 of this Volume. This day Eulogio Higueras, formerly cashkeeper to José Canevaro, gave me his cheque for S/250 - the amount for which I had sold my S/5000 shares in the Chilete Mining enterprize in doing which I had followed the example of the Banco del Perú, and of Emilio Althaus.

Page _ I spoke of the outrage committed in Nicaragua on the person of the German Consul, Mr. Eisenstuck. Though in my opinion this gentleman was by no means blameless, a German man-of-war had been sent thither to demand redress which we now saw by the papers had been obtained. The authorities had written a deprecatory letter to Mr. Eisenstuck, saluted the German flag, and paid the said Consul an indemnity of $\$ 30,000$.

Wednesday, $10^{\text {th }}$ of April 1878. Enriqueta persuaded me to go a little before breakfast to the Cathedral, to hear the preaching of an Italian called Moro; this Moro had been a Dominican friar in Quito, been expelled, and now lived with his co-religionists here. Ricardo was my guide. He took me to the choir, which being empty I sat down on one of the canon's seats, but as here I could not well hear, I went somewhat nearer the pulpit. Moro pronounced Spanish so well that I could not believe him to be a foreigner; on the contrary I thought him a Serrano for more than once he gave to the "o" the sound of "u". His sermon was directed against the Rationalists whom he taxed with "atheism", and disbelief in the immortality of the soul. His reasoning was the following: in nature everything is mystery to us, we cannot explain [616] [...] move, we cannot explain how the plant grows from the seed; we cannot explain electricity, not the many wonders of chemistry, and yet we believe in them. If we do believe these mysteries, why do we disbelieve the mysteries of the Church, the incarnation, the resurrection, the transubstantiation, etc., in my opinion a very erroneous reasoning. That what he called the mysteries of nature we have before us, we see them, we cannot doubt them, and thus we cannot but believe; the other mysteries we have not before our eyes; we are merely told that such a thing had occurred, but we cannot be certain of it. In the evening Bryson read to me from the Star and Herald, afterwards, Ricardo from the Leipsic Gazette, for Enriqueta, again suffering from headache had gone to bed early. 
In Turkey the dignity of Grand Vizier had been abolished. The Sultan had now his Cabinet, consisting of responsible ministers for the Interior, for Foreign Affairs, finances, war, justice, etc., the same as in Western Europe. The trial made for ascertaining whether there was a possibility of constructing a tunnel under the channel, proceeded satisfactorily; as far as the diggings went, the ground had been found to consist of a compact chalk.

I have said a few pages back that in the grand hotel a baroness lost her life in the fall of the elevator; her husband de Schack had made a claim upon the owners of the hotel, for an indemnification of half a million francs, this being the amount of the fortune which he pretended he lost with her.

Thursday, $17^{\text {th }}$ of April. I bought this day through Alejandro $£ 500$ drawn by Mathison on Mathison \& Beausire Liverpool at $27 \mathrm{~d} £_{3} 00$ for Rosa; £10o for Juan, and £10o for myself. In the evening Garland had his rocambor players and I played two games of chess, which I gained, but as from both sides moves were given back, I did not look upon them as fairly gained.

Friday, $12^{\text {th }}$ of April 1878 . Chess playing excited my mind in an unusual manner; last night I went to bed at midnight, but had hardly a wink of sleep before four in the [617] morning. I was again up by seven, and walked to the Calle [...] a Polvora, far distant from our house in the vicinity of San Bartolomé. Here a Mrs. Ponce, widow of a criminal judge, and sister of the wife of Dr. Muñoz had died, and it was only on account of the intimacy which I kept up with the Doctor, that I went thither. In the saloons, uncommonly well furnished, assembled somewhat about twenty gentlemen who sat there without speaking a word.

Mr. James Bryson, who had been with me since October 1874, see vol. 5, page 88 , told me on $30^{\text {th }}$ December 1879 , that, as his brother had to absent himself from Lima, he had to attend to his business and could therefore no more come to my office; on the $3^{\text {st }}$ December he was with me for the last time and on $1^{\text {st }}$ January $188 \mathrm{o} \mathrm{Mr}$. Neat Ladd took his place.

Continuation of $12^{\text {th }}$ April 1878 . It was about 8.30 when the hearse drove off, and we followed in the coaches which were waiting in the street; an old gentleman and I entered one, which turned out to be the private carriage of Dr. Mariano Alvarez, the son of my wife's good friend and my acquaintance, the late Dr. Mariano Alejo. I, of course, did not recognize him but he knew me and was extremely polite. When we had arrived at the pantheon we walked straight on to one of the niches where the coffin was immured without any religious ceremony whatever. Dr. Alvarez and I returned alone in his carriage and drove back to Ponce's house where we presented ourselves and shook hands with Dr. Muñoz, the chief mourner; Dr. Manuel Morales, the Minister who stood to his 
left, and a young man, one of Ponce's sons, to his right. Before 10.30 I was back in my house, very sleepy.

I saw by the papers that the negotiations relative to the Internal Debt which had been pending many weeks had at last been brought to a close, not with the three Banks, "Providencia" 50\%, "Nacional" 33 1/3 and "Garantizador" 16 2/3, but with Schmolle, Calderoni \& Co., represented by Juan Calderoni [...] [618] [...]

Schmolle, Calderoni \& Co. obtain the consignment of 200,00o tons of guano to Mauritius etc., for six years; they charge $5 \%$ commission, $6 \%$ interest on outlay and are re-imbursed at the exchange of 4 od. On the other hand they bind themselves to pay on the $1^{\text {st }}$ May all the interest overdue on the Internal Debt and to continue paying the tri-monthly interest till the $31^{\text {st }}$ July 1880 ; also the redemption overdue, amounting to \$267,900 and henceforth every monthly redemption with $\$ 89,300$. On no account is the Internal Debt to exceed $\$ 20,000,000$ and the amount redeemed is not to be re-issued.

I further saw by the papers that hitherto the Salitreras bought and paid for came to $\$ 16,000,000$, that perhaps 3 millions more might have to be disbursed to purchase the remainder and that the amount of Certificates hitherto issued was somewhat above 12 millions.

Saturday, $13^{\text {th }}$ of April 1878. The Directors of the Banco Hipotecario, except M. M. Galvez, were assembled at 1 o'clock, and in an hour's time we had gone through with our business. Francisco Garcia Calderon who had given his simple guarante[_] for \$620,00o due by Simon Soyer, and who had hitherto refused paying, had made an offer to cancel his debt with Cedulas at par; Lorente, Melchor Velarde and I were at first inclined to accept the offer, but changed our mind when Correa represented to us that abatements might be made to debtors who could not but certainly not to such as could and would not pay. Consequently, we resolved to put off giving a decisive answer until the re-opening of [...] ceedings, when we expected that Garcia [619] Calderon would be sentenced to pay the $[. .$.$] um without any abatement, or allowance$ for interest, which he also claimed.

Guillermo did not come to town from Chorillos, having fallen ill of fever.

In the evening Enriqueta and I went out to pay a visit to Doña Dolores Puente, yesterday having been her saint's day; she was not at home and we then went to Raphael Velarde's whose family had returned from Callao after a stay of 3 months: he continued "Superintendente" of the Custom House.

Whenever Enriqueta was well, she and I were generally together on my side of the corredor till near eleven: at about 10 Limpricht was in the habit of coming; Ricardo also came, Garland Senr., hardly ever; he played "rocambor", either at home or in other houses, or went to bed early. 
The little ones continued to go to college without any trouble or difficulty; Maria learned with the greatest ease, whilst Corina, as she could not read, had to be assisted by her mother and father; the latter teaching her English words at 7 in the morning.

Sunday, $14^{\text {th }}$ of April 1878 . The temperature was decidedly getting cooler, particularly in the morning and in the evening. Thermometer at noon $85^{\circ} \mathrm{F}$.

With Bryson I was occupied revising the diary of July 1872; from 2 to 4 I played chess with Limpricht, each gaining one game: I then called upon Doña Dolores Puente, took a walk as far as the gate of Guadalupe and was back by six.

Doña Juana Carbajal and the Canon Mora, neither of whom particularly agreeable, kept us company; also Limpricht dined with us. Ricardo read to me a little, and about 11 we separated.

Monday, $15^{\text {th }}$ of April 1878. On the $6^{\text {th }}$ and $7^{\text {th }}$ inst. [...] [620] [_]ulars of, [_] my opinion very satisfactory arrangement made between the Peruvian Guano Co. and Dreyfus of Paris. The Government's decree of $10^{\text {th }}$ inst. suspended the approval of this arrangement, because two fiscal agents (José Aranivar and Emilio Althaus) were about being sent to Europe to settle the numerouse affairs relative to Peruvian finances, which were still pending.

I learned from J. V. Oyague, whom I casually met in the street, that the insurrection of the Cubanos was not yet totally suppressed, and that in the eastern part of the island they continued in arms. The sale of Guano was exlusively limited to the western half.

Tuesday, $16^{\text {th }}$ of April 1878. Last night when Bryson had done reading to me I went to the house of Dr. Bernardo Muñoz, to pay my visit of condolence, "para dar el pésame", for the death of the late Señora Poncé. The saloon was somewhat darkened; on one of the sofas sat Doña Irene with one of the children of her late sister in her arms; two other ladies were with her; on the other sofa, the Doctor with three gentlemen, of whom I recognized Raymundo Morales. I shock hands with Doña Irene, sat down on the sofa near the Doctor, conversed on the topics of the day, and returned home at 9 .

Here Garland's "rocambor" players had already come; only one table was formed, Mariscal was a looker-on, and with Ramon La Fuente I played two games at chess: perhaps he did not play quite as well as I, nevertheless as I undervalued his strength I lost the first game; the second I gained. It was nearly midnight when we left off, and though I went to bed at so late an hour, to my surprise I slept well. [621] Limpricht was unwell from a slight fev[_] from which Guillermo and Geraldo were also suffering.

Wednesday, $7^{\text {th }}$ of April 1878. I had completely recovered from the pains caused by the fall I had on San Cristoval three weeks ago, on the other hand the left knee was always weaker than the other and would probably continue so. 
Thermometer at $3 \cdot 30,80^{\circ} \mathrm{F}$. I saw from an article on the famous or notorious Hobbes, in the American Encyclopaedia, that he has said somewhere in his writings that the Christian Scriptures were not received by the Church as of divine authority till the settlement of the Canon by the council of Laodicea, A.D. 364. I should like to know whether this assertion of Hobbes' is correct or not.

Thursday, $18^{\text {th }}$ of April 1878. The papers made known that Climaco Basombrio, Gerente of the Banco Nacional, had presented a petition to the Government, in which he said that the representatives of the three Banks, Nacional, Providencia and Garantizador, had seen with great surprise that the Government had concluded a contract with Schmolle, Calderoni \& Co. for the consignment of guano to Mauritius etc., and that they, the three Banks, Nacional, Providencia and Garantizador, could not give up the right which, in their opinion they had to the contract. The Nacional even offered to pay its proportion of the net proceeds, half in authorized bank notes, half in coined silver or gold. The newspaper "El Nacional" further informed its readers that one of the employés in the Ministry of Finance had refused to sign the new "Vales Consolidados" which the Government was about to issue, because "he would not make himself guilty of an action contrary to the law of the country; and finally, that the "Concejo Dep[_]tam[_] [622] [_] disapproved the contract concluded between the "Providencial" and the "Compañia de Obras Publicas" for covering the carriage road of 200 streets (cuadras) of Lima with the brown earth "Ripio", which was brought from the Sierra.

An article on the Bank of England in the American Encyclopædia says that on the $27^{\text {th }}$ February 1797, an order of Council, afterwards approved by Parliament, ordered the Bank of England to suspend cash payment. This was to be a temporal measure, but the resumption of cash payment was postponed from year to year; gradually the notes became depreciated, or, as it was said, bullion rose to a premium of from 14 to $15 \%$. After the fall of Napoleon, 1815 , the premium went down; in 1819 the resumption of cash payment was seriously thought of, and measures taken accordingly. By and by $£ 14,000,000$ in sovereigns were coined, and on the $1^{\text {st }}$ May 1823 cash payments were resumed without any remarkable disturbance in the commercial world. To-day was Holy Thursday, at 1 p.m. thermometer $79^{\circ} \mathrm{F}$.

Within the last few days Charles Pflücker's wife had died of consumption in San Mateo, whither he had removed with his second family, and built there a comfortable house, for both to him and to his wife the Lima climate was injurious. She was buried in the pantheon without my knowing anything about it, for otherwise I should have attended at the funeral.

The closing of C. W. Schutte's a/current, the calculation of days, interest etc., took up Bryson's and my time to 2 o'clock; shortly after he had gone [_] went 
to the house of Charles Pflücker, Calle de [623] Plumeros de San Agustin, but found every do $[\ldots]$ hut, and no servant visible. Afterwards, Ricardo read to me Zamarow's "Death of the Hanoverian Legion".

The author Von Meding, who, I believe, depicts the high personages whom he introduces in their true colours, shows clearly that Napoleon the Third was decidedly averse to the war against Prussia, but, being of an irresolute character, he was driven into it by the war party around him, at the head of which stood the Empress Eugenie.

After dinner I waited in vain for Bryson, but the time was whiled away by my listening to Enriqueta's reading to me Schutte's and Juan's letters just received. At about nine, José Basagoytia was the only one who came of the "rocambor" players, and thus he, Enriqueta and Garland had to converse whilst Limpricht and I played two games at chess, toughly contested; the first was drawn; the second I gained, but did not consider myself to be the true victor, he having given back to me more than one important move.

We left off at 11.30, but felt so hot that to cool ourselves we walked the corridor some time in the beautiful moonlight; and I had to plunge my head into cold water before going to bed.

Friday, $19^{\text {th }}$ of April 1878. Good Friday. It was three in the morning before I fell fairly asleep. My cousin, Frances Cresswell, of Winchmore Hill, whose letter Bryson read to me this morning, wrote that her husband's mother, old Mrs. Cresswell, the widow of Dr. Richard, would complete on the $29^{\text {th }}$ May, 88 years, and that her mental faculties were so unimpaired that she was still able to read the papers, in which she took great delight.

Frances' son Frank would be 17 on the $11^{\text {th }}$ May, and seemed to be very clever in mechanics; the daughter Henrietta was an artist in painting. Thermometer at noon $78^{\circ} \mathrm{F}$. We, Bryson and I, occupied ourselves in revising the old diary until two o'clock. [...] [624] [_] hen Bryson was gone I dosed and calculate[_] in my chair, and, for perhaps an hour, Ricardo read.

At dinner, it being Good Friday, Enriqueta placed no meat on the table, Urquhart, also the little girls, who since yesterday, had been home from college, were with us. In the evening Bryson read to me from the "Eclectic" a very interesting short article taken from "Blackwood", called "A Ride for Life", being an episode from the great Indian rebellion in 1857.

Saturday, $20^{\text {th }}$ of April 1878. "Sabado de Gloria". At about nine we had the usual noise of crackers being let off all around us. Enriqueta had ordered her servants to open her saloon and clean it out; when I saw the furniture placed in the corridor, I recollected that my dear Mariquita was in the habit of having the same done to our saloon; as she was certain to have many visitors on Easter 
Sunday, whom she always received there. To-day all was shut up on my side of the house.

At about twelve I went in search of Charles Pflücker who had taken up his provisional lodgings in the house, Calle de San Pedro, where Ramon Ribeyro had his study. Not finding him at home, I walked through the streets of Lima, which, at this hour, always afford some shade, as far as the Gas works. Here I had not been for a long time, and found great changes. No vestiges were left of the gate, neither of the two mounds of earth on both sides of the railway line to Callao, where many years back when Juan Garland was a child, he and I used to take our station to see the trains pass. Everywhere the ground was enclosed with "adobe" walls.

I returned home and at 4 o'clock, again went to see Mr. Pflücker; he was not in, but soon came; at the same time Dr. Lührsen entered, his brother Julius was there, and when several visitors and the family of the house had left, we four conversed for some time. [625] The reason of Charles Pflücker's [_]part[_] soon after the death of his wife was the presence of a medical adviser, Dr. Velez, on board of the steamer who accompanied José Aranivar, a great glutton, one of the two fiscal agents dispatched by the Government, Pflücker not having forgotten the sudden death of Sigismund Salter, which had taken place a few months back on his passage from Colon to Jamaica. On my observing that Mr. Pflücker had still much to do, for he had not even begun packing, Lührsen and I rose at the same moment, but I allowed him to leave the room before me. When Pflucker and I shook hands we were both overpowered by our feelings; I could not refrain my tears, and hurried out of the room.

In the evening Garland and Enriqueta went by invitation to the Basagoytias, and I was by myself in the corredor from 8.30 till 10.30, when Ricardo brought the little ones, and then read to me for an hour.

Sunday, ${ }_{27}{ }^{\text {st }}$ of April 1878. Easter Sunday. To-day embarked in Callao to continue their voyage from Colon by the French Steamer "L' Amerique" to St. Nazaire, Charles Pflücker with his son Federico and three or four daughters by his second wife; Emilio Althaus with his wife, children, sister-in-law Maria Rosa Dartnell, and his secretary Manl. Alvarez Calderon; José Aranivar, also with his secretary and Dr. Velez; the wife of Le Maitre of the house of Thomas, Lachambre \& Co.; Electro Corso with his rich Guayaquil wife, and perhaps one or two more.

Last year as well as 1876 the weather changed suddenly on the $21^{\text {st }}$ April; this year we had no such sudden change. Thermometer at noon $76^{\circ} \mathrm{F}$.

I paid the following visits: to Dr. Gervacio Alvarez and family, to Doña Josefa Prada; to Mrs. Macandrew with whom I conversed in English, and who told 
me that a brother of hers by her father's first marriage, Hy. Read Jr., in Gibbs' Iquique establishment for some time [_] [626] [_] now in England, would be here about July, when he was to be junior partner in Gibbs' house in Lima, Böhl continuing the first. He would bring his young wife with him, daughter of a Mr. Jones, who, she added, had been a short time in the employ of the London Mexican Bank in Lima, and grand-daughter of old Mr. Bates of the firm of Bates, Stokes \& Co. Next I went to Dr. Teodoro La Rosa's, to Gibbs' house where I left my card for James Hayne, just arrived from Europe, who had gone out. The same I did at Mr. Gibbs', the North American Chargé; and finally I spent about twenty minutes with old Doña Manuela Portillo, who was indisposed, and her grand-daughter Amalia.

At dinner we were by ourselves, and afterwards I was with Enriqueta and Ricardo in the corridor, till about 10.30 .

Monday, $22^{\text {nd }}$ of April 1878. Easter Monday. To Bryson I dictated my answer to the letter received by last steamer from Frances Cresswell, and went by the 2 o'clock train to Chorrillos, where I had many calls to make. I first went to Henry Higginson's rancho, where I passed a short time, in a not particularly interesting manner, with Mrs. Higginson and her daughter Eliza. Dr. Morales, Minister of Justice, lived in a very small rancho. I conversed with him a considerable while. He told me that he had been the only of the council who had opposed the mission of Aranivar and Althaus. I also learned from him to my surprise, that he, the Minister of Justice, had not been invited by Prado to the dinner given this day in Chorrillos to the Legists from the different South American Republics, at present assembled in Lima; neither had he been present at another dinner given the previous [_] to the French Admiral and to the two French Char- [627] gés, the one coming in, the other going out. At Dr. Dorado's everything was shut up, which I was not sorry for; at Vicente Gonzales' I only found his daughter, the wife of the engineer Dubois, a particularly pleasant young lady, with whom I remained about half an hour. Doña Carmen Barreda was also very agreeable, with her was one of her grandchildren, Victoria Pardo, a pretty child about two years old. At Doña Juana Guise's, I met her never failing companion Dr. Melchor Vidaurre and Virginia, the widow of Admiral Valle-Riestra. Whilst I was with them came in the second son of Lembcke, partner of Prevost \& Co. with his wife, a daughter of Miguel Valle-Riestra, one of the brothers of Doña Juana. Here I learned that on board yesterday's steamer embarked also the Procurador of the Superior Court, Diego Lopez Aliaga, with his daughter, who was consumptive. My last visit was to the Pinto's, who have taken up their quarters on the very last house of the Rivera, the property of Manuel Costas; just when I entered, the Papal Delegate Monceni, accompanied by my good friend, the bare footed Italian friar Fray Luis, were taking leave. The Delegate, dressed in a purple tunic, was a tall thin man who held himself up 
uncommonly straight; his complexion rather dark. Till 5.30 I remained with Mrs. Pinto and her daughter Leonor, both very nice people. When walking to the train I was stopped by Oyague, who was standing at the door of his house, he invited me to dine, which I declined; the 6 train took me to Lima, and round the dinner table at Enriqueta's I found besides the family Limpricht, who had returned from his trip to La Chosica, the curate Aguilar from Moyabamba, perennial deputy of that province, Dr. Middendorff, Federico Palacios and Guillermo. After dinner the "rocambor" players came, also Mrs. Rafael Velarde with her two daughters, Don Raf[_] [628] [_] dining with his Excellency. I played with Limpricht one game of chess, which lasted an hour and a half and which I lost: it excited me in an extraordinary manner, and it was long before I fell asleep.

Tuesday, $23^{\text {rd }}$ of April 1878. Prado gave again a dinner party, this time to those whom he called his particular friends. In the list published in the papers called "Las Noticias", Garland and John Gallagher's names appeared, but neither of them had received an invitation.

Wednesday, $24^{\text {th }}$ of April 1878. Before eight I walked out to the Pantheon. When in the street, "Las Maravillas", which runs due east, the sun was very troublesome. In my chapel I was glad to see that some progress had been made. The floor was inlaid with those small coloured clay tiles which came from England, and which form a kind of mosaic; those used here are for the greater part a sombre tint, black, brown and of a brownish red. What was done looked very well. A considerable part of the forenoon I was in Dr. Palacios' study, where I waited for him in vain. I also spoke a few words with the Juez de $1^{a}$ Instancia Dr. Quiroga, who promised to dispatch my "escrito" which had been in his hands since Saturday before Carnival, the day when all Courts of Justice had been shut up. Yesterday they were re-opened, and, by the message read by J. A. Ribeyro, President of the Supreme Tribunal for last year, that Court had dispatched in the twelve months, between nine hundred and one thousand cases, and had been sitting only 263 days.

Thursday, $25^{\text {th }}$ of April 1878. The "Comercio" affirmed that the Government would not listen to the new proposals of the three banks, and would carry out the contract concluded with Schmolle, Calderoni \& Co., which [_] it was said had furnished the £10,400 required [629] for Aranivar and Althaus, each one half. Thermometer at noon, $77^{\circ} \mathrm{F}$.

In the course of the forenoon I received from the Banco de Lima $20 \%$ on my capital of $\$ 50,000$, in the following manner:

6 Nitrate Certificates of S10oo each

and 4 Cedulas del Banco Hipotecario of \$10oo Total

\section{$\$ 6000$}

S4000

\$10,000 
The Certificates stood in the market at somewhat above par: the Cedulas were worth $821 / 2 \%$. From Garland I received on a/c of the 60 Cedulas of Banco Hipotecario of \$10oo each, lent by me to him, and by him to Dr. Fernando Palacios, 8 Cedulas; thus the number hitherto received by me was 16 . He also paid the interest on $\$ 52,000$ with $\$ 1840$ due since the $1^{\text {st }}$ inst.

I went to the Concejo Departamental, which had its offices on the ground floor of the house, which was formerly Antonio Salinas', opposite the Church de la Concepcion, where I spoke with the President Manuel Francisco Benavides about my "patente", which had again been fixed at \$50o every 6 months, and which I wanted to have reduced to \$304, as last year. At the notary Prieto's I learned that at the foot of my "escrito" Dr. Quiroga had decreed that he, Prieto, had to go in person to the office of the notary Casavilca and examine whether the title deeds of the "finca" in Polvos Azules, were really there as affirmed by Juan Aliaga y Puente.

The meeting of the Directory of the Banco del Perú was presided over by Carlos Elizalde, Candamo being absent owing to indisposition. The first thing we did was to choose a new Delegate in lieu of Althaus gone to Europe. Carlos Elizalde had four votes, and was consequently chosen, Manuel Candamo one, and Ayulo one. Next, Calderoni brought a message from the Delegates, to which body the bank had lent $\$ 300,000$, about a month back. He said that the Delegation was unable to pay at the moment, and proposed to deliver to the bank, instead of $\$_{300,000}$ in bank notes [630] [...] of first-rate bills on England, for the greater part Gibbs' drafts, at the exchange of 30, which was acceded to. Finally, Ayulo asked Calderoni, the Delegate, what steps had of late been taken in the Delegation with regard to a certain number of bills on England. The answer was, that in order to prevent a further sudden improvement in exchange on London, £40,00o had been sent to Gibbs' and order given them to return the same, by steamer, in coined sovereigns. This operation was disapproved of by Ayulo in very strong terms. I was the first to give my assent to what Ayulo had said: Bryce, Ruden, and Elizalde were all of the same opinion, and Ayulo drew out a motion in which he blamed the Delegates, and protested against what they had done. This seemed to me too severe, and I altered what Ayulo had written more or less in the following terms; which I dictated to the gerente César Canevaro: "The bank disapproves the above operation of the Delegation; in case there is still time counter orders should be given to Gibbs of London; and thirdly, the bank orders its Delegates to oppose in the Delegation, every operation similar to the present one, and (this was Ruden's amendment) every other operation which might contribute to impede the improvement in exchange." This was unanimously approved. 
Friday, $26^{\text {th }}$ of April 1878 . Again a meeting in the Banco del Perú. Candamo was in the chair, Ayulo was absent. The first thing we did was to authorize the gerentes to sell the bills received from the delegation without loss of time, however at no worse an exchange than zod. Then it was made known that Gibbs of Lima had received a telegram from their London friends stating that the sovereigns were already shipped; whereupon Calderoni said that the Delegation wanted a loan of 300,000 sols from the three banks, which sum the Government required, more or less, for the usual monthly incineration, and offered as security [631] the sovereigns already on their way from [_]. I said that if the state of our cash permitted I saw no objection to our lending the \$10o,ooo asked for from the Banco del Perú. After some slight discussion this was agreed to. Now came the main point. Calderoni stated that Garcia Calderon, the President of the Delegation, had communicated to him that it was the plan of the Delegation, in conjunction with some London firm, to ask the Government to concede to them the Nitrate Consignment. One of the Directors, having made an insignificant observation, I, after a short preamble said it would not be prudent to enter into the business as long as the Delegation was constituted as at present. This was certainly a bold step, but to my great joy all were of the same opinion, for it was evident to me that none of the Directors had any predilection either for Garcia Calderon or Derteano, who had an illimited influence in the Delegation. It was I who had broken the ice. In the discussion which ensued I took very little part, and the result was an authorization given to our Delegates to ask from the Delegation a sketch of Garcia Calderon's plan, which would then be laid before the Directory, and be discussed by the same. But at the same time we considered it indispensable that the sketch should come accompanied by the statutes of the Delegation, which though drawn out, had not been approved of, nor ever been acted upon. These statutes stated amongst other things that the presidency of the Delegation was to go by turns, and thus, if acted upon, it was hoped that Garcia Calderon would be turned out from the chair he had so long occupied. We then broke up.

Saturday, $27^{\text {th }}$ of April 1878. For some time I was with M. F. Benavides, the President of the Concejo Departamental on the subject of my "patente"; also a few moments with the Notary Prieto about the title deeds, but neither with the one nor the $\left[63^{2}\right][\ldots]$ any progress. Part of the forenoon was taken up with finishing my letters for Europe. I bought through Alejandro from the Banco de Londres, Mexico \& S. America, on their firm in London, £6oo, $90 \mathrm{~d} / \mathrm{st}$. at 29d, of which I remitted $£_{400}$ to C. W. Schutte and $£_{200}$ on my own account, to A. Gibbs \& Sons. I was told that the Banco del Perú had begun to sell at $29 \mathrm{~d} 1 / 4$, and that Government Bills were to be had at 3od, some said even at 3od 1/2. 
Sunday, $28^{\text {th }}$ of April 1878. Antonio arrived this morning from Chile, after an absence of about three month[_], much pleased with his trip; his fever was gone.

Juan Martin Echenique, who, after the recovery of his health, had presented himself to the officer in San Francisco de Paula, and had again been arrested, was now set at liberty. The difference between Perú and Bolivia regarding the Custom-house question was not yet settled. A commission of French astronomers had arrived on this coast for the purpose of taking observations in Paita, where the atmosphere is never clouded, of the transit of the planet Mercury across the disc of the sun, which would take place on the $6^{\text {th }}$ May. Now the Peruvian Government had named a commission with the same object to embark on board the "Huascar" for the said port. Camilo Carrillo was its chief. Amongst the subalterns I found the names of Jorge Velarde, Melchor's son, and of Fermin Canseco, son of the late Carlos Canseco and Isabel Coloma. These two young mariners had returned about a month back from a cruise of eleven months' duration on board the French man-of-war "La Magicienne". Thermometer at noon $77^{\circ} \mathrm{F}$.

The whole forenoon was taken up revising and correcting the old diary of September 1872. From 2 till 4.30 Limpricht and I played chess in my corridor. The first game I fairly won; in the second he gave me [633] back a move by which would have [_] my quee[_], and I again gained by one pawn; in the third towards the end we were so evenly matched that we could make no impression the one upon the other, and thus we gave it up, without having it decided; he and Urquhart dined with us; the latter remained till past 9, conversing in the corridor. Limpricht had bought a bill from Canevaro on the London Guano Co., at $29 \mathrm{~d} 1 / 2$.

The Municipality of Paris, according to calculation made by the same, would have to disburse for the General "Exposition" to be opened on the $1^{\text {st }}$ May, fortyfour million francs. The proceeds, arising mostly from the sale of tickets for entrance, were likely to come up to thirty three million francs.

Monday, $29^{\text {th }}$ of April 1878. Thermometer at 11.30 in my office, $77^{\circ} \mathrm{F}$. In the course of the forenoon it became known in Lima that, at a late hour last night, the President Prado had come in from Chorrillos and visited the different barracks; also that Admiral Haza had gone on board the "Huascar", moored in Callao bay, that he had made some alterations in her crew, and sent her off for Paita without loss of time. These measures were attributed to a secret advice said to have been received by Prado, purporting that a plot was hatching in Callao, that Lizardo Montero was implicated in the same and that the first thing the conspirators had intended to have done was to have seized the "Huascar". 
At one in the morning the Intendente with some soldiers had been at the street door of General Echenique's. Rufino rose and let them in; they wanted to see whether Juan Martin was in his bedroom; he was not. He had come from Chorrillos in the same train as the President and had gone to the club to sup.

But hardly had he learned that he had been looked for when he presented himself to the Prefect [_] [634] [_] $\mathrm{m}$ that he might quietly go home as there was no order for his arrest.

Twice I went to the Concejo Departamental; the chairman Benavides had signed the decree which reduced my "patente" to 304 sols half-yearly; however they were too busy to receive my money. In the evening Bryson read to me the annual report of the Lima Gas Company, which was very unsatisfactory. Six per cent dividend had hitherto been paid, and four more would be given, two immediately, and two when the state of the Cash would permit it. The expenses in the year had run up to 110,000 sols. The Municipality was owing for street light \$171,00o and moreover this debt increased monthly \$200o. Besides this running a/c there was still another debt owing by the Municipality and a third due by Government, and, whilst the result was so unfavourable in every respect, Prentice still received his \$3500 annually for doing nothing in England, the Directors had for the first time received their pay of \$500o, say $21 / 2$ per cent upon the amount distributed, and, finally, all salaries had been raised on account of the depreciation of the bank notes.

Thursday, 30 ${ }^{\text {th }}$ of April 1878. Last night Garland had his one rocambor table. Extra visitors were Böhl and James Hayne; with the latter who did not play I had a long and pleasant conversation. On my observing to him that people said he had come to make some arrangement about the Guano business he answered neither in the negative nor in the affirmative and remarked that it was very difficult to do anything with this Government because they required such enormous advances. The Chilian nitrate, he said, was not so good as the Peruvian. The "caliche" was [_] ht by train to their establishment in Antofagasta, [635] perhaps 12,000 quintals a day; 3000 quintals [_] more or less, were produced daily. He further said that he might perhaps return to Valparaiso, there to take his share in the business of the house. Of my old friends he told me that F. A. Eck had sold his estate, Hollybush House in Ayrshire, and that he now resided in London, where he occupied himself with forming a valuable collection of ores.

George Rodger with whom in November 1842 I stayed about a week on his farm "Bridgelands" near Selkirk had died. Thomas Gray was still alive but in a miserable state of health, he was paralytic, unable to stir, and had to be moved about in a rolling chair from one place to the other. Of the children of his 
uncle John Hayne, only the daughter Jane had preserved her fortune. When she married, it had been tied up in such a manner that neither she nor her husband could get at the principal.

During the night I had very confused dreams. In one of them I saw for a second or so, her whom I have lost, in a reddish-brown dress which fitted close up to the throat, and which Enriqueta told me this morning she had actually worn now and then, though I myself had no recollection of it. How strange that in our dreams we can see things which when awake we do not remember!

Bryson suffering from a sore throat left at an early hour, and I was the greater part of the day in the street. At 2 o'clock I went to the Gas Company, where I received the $2 \%$ upon \$270,0oo, Schutte's, Juan's and my shares in that company. Before three I was once more in the Concejo Departamental, where, my cheque in hand, I had to wait nearly three quarters of an hour, and was then told that there was a signature wanting in my "expediente", and that I might return after the civic [_] [636] [_]. I went back to the Gas Company, where many of the Shareholders were assembled, and Marriott was reading a report signed by Dr. Loayza, one of the three gentlemen who had been named to give their opinion on Isaacson's protest against the resolution taken on the $6^{\text {th }}$ of April last year. Dionisio Villate and Enrique Prevost, named jointly with Dr. Loayza, had been absent, the one in Chile, the other in the United States, which accounted for their not having affixed their signatures to the document. Dr. Loayza confirmed the resolution just referred to, whereupon Oyague observed that the resolution was an infringement of the Statutes, that the Statutes could not be altered except by the unanimous votes of two thirds of the Shareholders, and that on the $6^{\text {th }}$ April last year, such two thirds had not voted for the resolution. The Statutes were then referred to, the votes given on the $6^{\text {th }}$ April were counted, and, certainly, they had not come up to two thirds of the shareholders. Consequently, Loayza withdrew his report, the whole affair fell to the ground, and all the time employed in the same was lost. Finally, a new Directory had to be named, and the following were chosen: Oyague, Mathison, Ruden, Böhl, John Bryce, Manuel Villate, the same as hitherto, and instead of Dr. Galvez, Dr. Arosemena.

During my absence the last year's report had been read, and been approved; not a single observation had been made on the enormous expenses, on the useless remuneration of Prentice, on the heavy outstandings etc.; had I been there, I should not have allowed those items to pass unnoticed.

Wednesday, $7^{\text {st }}$ of May 1878. Bryson came at the usual hour. Thermometer at noon $76^{\circ} \mathrm{F}$. On the preceding day 214,000 paper sols, not 300,000 as hitherto, [637] had been burned. The Directors of the Banco Hipotecario were together 
for about an hour and a half, and dispatched a good deal of business. In my opinion Don Pedro Correa y Santiago was without doubt the most efficient of us five.

Enriqueta was very ill of migraine.

Thursday, $2^{\text {nd }}$ of May 1878. Anniversary of the repulse which the Spanish fleet experienced in Callao bay in 1866. At six in the morning I heard the firing of the cannons in Callao. Thermometer at noon $75^{\circ} \mathrm{F}$.

Bryson had an attack of fever and ague and went home a little before one. Limpricht wrote my clean cash, which being done, we played one game at chess, which I fairly won, for I neither took nor gave back a single move. In the evening Garland had one rocambor table. Enrique, one of the sons of Don José Basagoytia, asked me to play chess with him; I did so, and, of course, gained both games, though in the first game he attacked me so fiercely that I had to take great care of myself; however, my mind became by far not so excited as when playing with Limpricht.

Friday, $3^{\text {rd }}$ of May 1878. Last night the members of the Club "La Union" gave a ball, at which Lizardo Montero, as president of the Club, and his lady, and some intimate friends of theirs, received the guests. It had always been the custom to ask the government for a few soldiers to keep order at the street door; this time policemen were sent for the purpose, which gave rise to some suspicion. At about half past five this morning, just at the moment when Montero and his lady were entering their coach, some of the young men, members of the club, he[_]d the sound of a whistle, which they did not like; they also observed that a major of the police was standing at the corner, and they therefore thought proper to tell Mr. and Mrs. Montero, that if they would walk home instead of availing themselves [638] [_] ge, they would find great pleasure in accompanying them. This offer was willingly accepted and the whole party left together. When they came to the corner of the Calle de Nuñez and the Banco del Herrador, an officer of the police, Paredes, addressed Montero very politely and told him that he had received order to arrest him. Rosa Elias would not allow her husband to be taken from her side, her brother Jesus, Ignacio Tavara, Federico Palacios who with his wife had driven alongside the party, surrounded Montero. A certain Flores, a particular friend of his, drew a dagger, Paredes begged him to spare his life, and, in the midst of this turmoil, Montero was pushed by his friends into the postern of Juan Valdeavellano's house, which already stood open at this early hour; as soon as he was inside the patio, the door was shut, the bolt pushed in; Montero made his escape over the roofs of the houses and had probably found an asylum in the house of Dr. Lührsen, German Chargé. Geraldo, who had been present, gave us all these particulars; 
Rosa and her mother Isabel Elias had, he added, resolved to go to Chorrillos to tell Prado their opinion on the share which he must have had in this, as they thought, unwarrantable attempt to arrest their husband and son-in-law.

Bryson, unwell, did not come in the evening; Ricardo was not in, and I had a very heavy time [_]f it till I saw Limpricht enter, to whom I proposed to play a game at chess, which he acceded to; we played in his room and I lost the game fairly, no move being taken back on either side.

Saturday, $4^{\text {th }}$ of May 1878. It had been the intention of Enriqueta to accompany me to Chorrillos, there to be present when Castignini gave up to me my rancho. She was however too unwell to go, and I though I had been cited to a mee [...] $\mathrm{f}$ the Shareholders of the Water Co., and to another, [639] [_] urgent", of the Directory of the Banco del Per[_], went out together with the servant Juan by the 12 train. We were met there by a young man, the nephew of Mr. Castagnini, who delivered the keys; we found everything in the very best order; only a milkjug and a padlock of the kitchen were wanting, of which trifling deficiencies I declined to take any notice.

Apprehensions were entertained by some that the Custom House question with Bolivia might lead to a serious misunderstanding between the two republics.

Thermometer at $4.30 \mathrm{p} \cdot \mathrm{m} .75^{\circ} \mathrm{F}$.

At dinner we had a pretty numerous party: Federico Palacios, his wife, Guillermo, Eliza, Basagoytia and Urquhart; of the family only Juan and Alejandro were wanting. I, however, rose when Bryson came, and listened to his reading to me Palgrave's very interesting journey through Arabia, in the disguise of a medical man from Damascus. He was a Captain in the Bombay Army, and says at the very beginning that he spoke Arabic quite as fluently as English, and that the latter language he understood perfectly. When I returned to Enriqueta's parlour I found the music master Castañeda playing the piano. Basagoytia's wife, her sisters-in-law and daughter came, and immediately afterwards all sat down to play Monte at cards, at very low stakes. I then went to Limpricht's room, gained one and lost two games at chess. At 1/2 past 11 o'clock I retired to my bedroom; the party broke up an hour later.

Sunday, $5^{\text {th }}$ of May 1878. For the first time this year we had a cool, somewhat moist, not rainy morning.

Thermometer at noon $74^{\circ} \mathrm{F}$. Bryson and I made good progress in revising the diary of November and December 1872. At 2 o'clock I went out, and called first upon Augusta Bergmann, Miceno Espantoso's wife, who had removed to a handsome, lately rebuilt house in the Calle de Gremios, formerly Armeros' [_] [640] [...] property of that Meliton Porras of whom I spo[_] on the $15^{\text {th }}$ December 1872, next upon the family of Dr. Jervacio Alvarez, upon Manuel 
Francisco Benavides, where I was received by a rational young lady, daughter of his by his first marriage, then upon the Minister Dr. Manuel Morales, Dr. Bernardo Muñoz, Rafael Velarde, where nobody was at home, and finally, upon Doña Dolores Puente, with whom I found to my surprise, besides Sagastabeytia, Amancio Castillo, whom I never before had seen there. Probably his pretended sanctity had been his passport to Doña Dolores' society. I learned from Sagastabeytia that he knew for a certainty that Gibbs' negotiation with the Government on the subject of the Nitrate business, had come to nothing. Gibbs, he said had insisted that the contract should be made out ad referendum, and be laid before the Congress for their approbation, to both which conditions the Government had been unwilling to accede. After dinner Ricardo read to me and at a later hour came Rafael Velarde with his wife and two daughters. Garland was in bed with fever.

Monday, $6^{\text {th }}$ of May 1878. Garland, though not quite well, went to the bank. This being the first Monday in the month, Maria and Corina did not go to their college, and Doña Josefa Bazo, Gonzales' wife, with some of their children, breakfasted with us. Lizardo Montero had taken refuge, not at Lührsen's, but at Godoy's, the Chilian Chargé.

From my niece Elizabeth Bobertag I received a letter dated Moers, $24^{\text {th }}$ March in which she congratulated me on my birthday. She, herself confessed that her last year's residence in Switzerland had done but little good to her pulmonary complaint; she called herself a decrepit old woman, her exact age being no more than 55 . Not only were her lungs in a diseased state but she also suffered [_] debilit[_] and rheumatism. She did not live in the [641] same house as her daughter Maria, married to [_] professor at the college, and mother of two children, but in a separate house together with her unmarried daughter Emma. The temperature had suddenly become much cooler, thermometer at noon $74^{\circ} \mathrm{F}$.

In the course of the forenoon I went to the Banco del Perú, and to the office of Carlos Elizalde, and enquired in both places what had been resolved on Saturday last in the meeting of the Directory of the Banco del Perú. I was told that the Delegates, Calderoni and Elizalde, had on that day laid before the Directory a proposal made by the Government to the Delegates, in virtue of which the Delegation was to have the total management of the Nitrate business on very advantageous terms, but with the following onerous conditions: The Delegation was to take upon itself the payment of 8 per cent annual interest, and 4 per cent annual redemption upon $£ 6,000,000$, equal to $£_{720}, 000$ annually, and moreover a heavy advance more than the stipulated interest was required for the first six months. The Salitreras actually bought, but not paid for, were said to amount to $£ 4,000,000$, and for $£ 2,000$, 000 more, new certificates, which, 
one might say, have no solid fecundation whatever, the Government intended issuing; with the proceeds of which it was supposed they would pay part of their debt to the Compañia de Obras Públicas y Fomento, which establishment

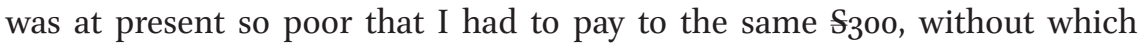
assistance Umlauff, the bookkeeper, assured me they were unable to pay the duties and expenses on the bronze work just arrived from the United States, and destined for my chapel in the cemetery. The Directory of the Banco del Perú had declined unanimously to enter into the Nitrate Business if subject to the above conditions. In the evening I had no inclination to go to Enriqueta's parlour, where the rocambor players were, but on receiving repeated messages, I could not avoid going. I gained three games at chess from Enrique B[_] [642] [_], and was in bed about midnight.

Tuesday, $7^{\text {th }}$ of May 1878 . Thermometer at noon $74^{\circ}$ F. At 2 p.m. I took a walk down the two Alamedas and ascended the lower range of San Cristoval intending to descend on the other side near the former "paseo de aguas", but owing perhaps to my weak sight, perhaps also to alterations being actually made, I could find no convenient path downwards, and returned the same way I had come. The walk took me about two hours.

From the Concejo Departamental I at last obtained my "patente" for the first six months of this year for which I paid \$304, the same as last year. In the evening Limpricht and I were with Enriqueta till near eleven. Garland had gone to Basagoytia's. Enriqueta related to me that she had been told by Doña Jacinta Sotomayor, who had it again from her friend Rosa Elias, that she, Rosa, and her mother Doña Isabel had actually gone to Prado's rancho in Chorrillos, where they had been received by his wife Magdalena, who to their question whether the order had been given to take Montero dead or alive, had replied that no such written order had been given by her husband. The two ladies Elias had called Prado by all kinds of names such as "bruto", "billarero", (for it is said that in his youth he had been a billiard-marker in Huanuco), "ingrato", and I do no knew what else.

Wednesday, $8^{\text {th }}$ of May 1878. Last night's "Comercio" said that the transit of the planet Mercury across the disc of the sun had been observed in Callao, as far as the imperfect instruments used there would permit. It first touched the disc at 10.4 a.m., but, owing to the cloudy state of the atmosphere, could not clearly be seen till 10.20 a.m. Its course was from west to east with a slight inclination Southward till [_]1.20 p.m. when it turned northward, and at 2.50 p.m, to the [Northwest]. At 5.30 p.m. it had completed its passage. [643] At 2 o'clock I went to the office of the Ins[_] Company, "Lima", where the Directors Mathison, Isaacson, Robertson, I, Valentin Gil as Vice in the chair, and the 
Gerente Elizalde had assembled. The President Moscoso Melgar was absent, having to attend a meeting in the "Providencia" on the subject of the project proposed by the Delegation, see $6^{\text {th }}$ May. In our Insurance Co. nothing of particular importance was transacted. Our profits this year were about \$10,00o less than last year; there was a trifling decrease on interest and on premiums, both for fire and sea risk.

A considerable while back the German steamer Karnac ran aground not far from Montevideo. We had insured on her cargo to the amount of about 10,000 sols, hides, account Alberto Larco, silver ore account of Schröder, both articles destined for Hamburg. Though we insured only against total loss and general average I feared that in this occasion the latter would come to about four thousand "soles".

The evening we passed like the previous one. Garland played rocambor at M. F. Benavides.

Friday, $10^{\text {th }}$ of May 1878. Last night Garland had only one rocambor table: he, Limpricht, Dr. Middendorff, and Colonel Mariscal. I went to bed at 10.30. The "Comercio" contained a translation of the treaty of peace between Turkey and Russia concluded in San Stefano on the $19^{\text {th }}$ February old $/ 3^{\text {rd }}$ March new style. The following were the principal conditions: Servia, Montenegro, and Rumania to be independent states; the limits of the two former to be rectified, in other words, their territory to be enlarged at the expense of Turkey. In Herzegovina and Bosnia, reforms to be introduced. Bulgaria, which comprises a large territory, South and North of the Balkan, to be tributary to Turkey, but to have its own Government under a Christian prince. The war indemnity which Russia claimed under various pretences ran up to 1,410,000,00o Roubles; it was not said whether paper or silver, but as the Sultan was unable to pay this sum, Russia would be satisf[_] it [644] [...] of territory Merchant vessels allowed to pass the Dardanelles and the Bosphorus in time of peace. The prince of Bulgaria would most likely be a German Count Von Battenberg whose father was Alexander, a younger brother of the father of Louis the present GrandDuke of Hesse-Darmstadt married to Alice, daughter of Queen Victoria. Von Battenberg's mother was a noble Polish lady. A sister of the father of Grand Duke Louis was married to the Emperor Alexander II of Russia, and, consequently, Von Battenberg was cousin of the Grand Duke Nicholas, General-in-chief of the Russian Army in Turkey. I further saw by the same paper that the "Eurydice", an old wooden frigate in the British navy which served as a training vessel for ablebodied seamen, and which had just returned from a cruise to the West Indies, had been capsized by a sudden squall, accompanied by a heavy fall of snow near the Isle of Wight on Sunday $24^{\text {th }}$ March, at 4 p.m.: the Captain's orders to 
shorten sail had been given just too late. On the lee side the port-holes were open, and there, the water rushed in. Of 320 human beings on board only two were saved.

Ricardo, who had accompanied the mortal remains of a certain Clementina Frias to their last resting place, a niche in the Pantheon, told me, on his return that Painters were at work in the interior of my chapel and that, in his opinion, they would soon finish their task. This Clementina who was of a very respectable family in the republic of Ecuador had, when a child, been a schoolfellow of Enriqueta with whom she had kept up her friend[_] relations until death put an end to her existence upon this earth, an existence which, to judge from appearances, had certainly not afforded her many pleasures or enjoyments. She had always been poor, always proud of her family connections; frequently she had been in ill health and fi [...] suffering from a cancer which had caused her [645] death. To her this earth had been, as the Span[_] say "un valle de lagrimas". Let us hope that she will fare better where she is gone to!

Sunday, $11^{\text {th }}$ of May 1878. My Birthday. I was awake by 6 a.m and a quarter of an hour later, when it was hardly full daylight, and the weather foggy, was on my way to ascend San Cristoval, which I did, though not so easily as on former occasions, from the Lurigancho side, at the end of the paseo militar. My want of sight, not weakness of legs or lungs, was the great impediment. The path alongside the mountain by which I descended to the Alameda de los Descalzos had become almost dangerous, owing to it being partly covered by the earth and sand washed down from the mountain side. I was back at 8.45 and lay down till ten. Enriqueta, Enrique, Guillermo, Ricardo, Antonio, all congratulated me on my birthday. The first named sent in presents in her name and in that of the two little girls, whom I did not see: they having gone to college; also Limpricht came to congratulate me. On the $11^{\text {th }}$ May last year I gave an account of how I was then in the habit of spending my time; this year there was hardly any change. My left leg was much stronger than it then had been, though not so strong as the right one. At dinner Guillermo was now frequently with us; Alejandro and Juan, never. At night it had become too cold to sit in the corridor, and Limpricht sometimes kept Enriqueta and me company. Garland, if he had not rocambor at home, was generally out to play in the houses of his friends.

Exchange had again risen. Canevaro who had drawn by last steamer at $29 \mathrm{~d}$ did so by this steamer at $28 \mathrm{~d} 3 / 4$, and real good bills were not to be had. Alejandro offered me $£_{500}$ Scheel on Dreyfus, with the endorsement of the National Bank, which I would not take for Schutte, who had some money to his credit. A decree had been given, in virtue of which Schmolle, Calderoni \& Co. remained with [_] [646] [_] of Guano to Mauritius etc., they being obliged 
to "hacer el servicio" of the Internal Debt for a certain length of time, as mentioned on the $12^{\text {th }}$ April.

Without my knowledge Enriqueta had invited a few friends to dinner; a turkey was served with which it was her custom to celebrate the birthday of one of the family. We were, all the Garlands, without Alejandro and Juan, but with Eliza, Dr. Middendorff, Melchor Velarde, Urquhart and Limpricht. When we rose from dinner it was nearly time for the "rocambor" players to sit down. I conversed with Enriqueta, Urquhart and Antonio till near eleven, when I went to my bedroom.

Sunday, $12^{\text {th }}$ of May 1878 . The little ones had left off going to college on Sundays because the nuns had had to give way to the importunities of a great number of the mothers, backed by the Delegado Apostolico, who had represented to them that working on Sunday was a sin. Enriqueta was much displeased with this new arrangement and had obtained from the Superior of the college permission to send her children there to hear mass.

Bryson and I revised my old diary of beginning of 1873; hardly was he gone when Edward Knauer came to congratulate me on my birthday, and to read to me two letters from his mother, in one of which she related an occurrence which had taken place in Altona, and which I think worth while to reproduce here to show that before the Prussian law their is no distinction of persons. Mr. Vogler, the active partner of the well-known firm of John Henry Schröder \& Co. of Hamburg, who had had to apply on some business to a judge in Altona, had not been received with the deference which he had expected, of which he complained to other judges superior to the first one; all these negatived his complaint. Another gentleman who had been similarly treated by the first judge, but not applied to [...] published an article on the subject in the [647] daily papers, which induced Mr. Vogler to do the [_], but in his narration he omitted to state that he had fruitlessly appealed to the superior judges. For this incomplete and consequently inexact publication he was fined six hundred Reichsmark. His wife, Margaret, a daughter of my old good friend Theodore Elmenhorst, probably considering this an injustice, committed the imprudence to direct anonymous defamatory letters to the various judges; enquires were set on foot, and it was soon discovered that Mrs. Vogler was the writer. She was cited before a tribunal: in person she went round to the judges assuring them of her repentance and prayed for forgiveness, but in vain; she was condemned to imprisonment for a certain length of time, and, as Mrs. Knauer wrote, she, a lady of the most respectable connections, would actually have to go to prison unless some person high in power interfered on her behalf.

Hardly was Knauer gone and Limpricht and I were on the point of sitting down to chess, when José Basagoytia came also to congratulate me. He begged 
us to continue playing, which we did; Limpricht gave me the King's gambit, and with the greatest difficulty I gained the game; one move I took back as it clearly arose from my want of sight. It was now 4 o'clock and I had still time to call upon the family of Dr. Ribeyro, just come in from the Barranco; upon Federico Panizo and wife, not at home, and upon Mrs. Escobar. In the evening Ricardo read to me a little; Enriqueta and I were by ourselves until eleven.

Monday, $13^{\text {th }}$ of May 1878. In the course of the forenoon I walked out to the pantheon where, notwithstanding what Ricardo had told me the other day, I found that my chapel was in the same incomplete state as it had been for several months. Mould, the architect of the Compañia de Obras Publicas, excused himself with saying that he did not consider it prudent to begin the painting of the inside until [_]e bronze door had come up from Callao which he would [648] [_] ately put in its right place in the chapel; and then being able to lock the same, the painter might begin his work.

In the evening Garland had only one rocambor table, and I was in bed by 11 o'clock.

The five Ministers had resigned, viz.: Buendia for the Interior; Rospigliosi, Foreign Affairs; Morales, Justice; Haza, War; Garcia, Finance.

Tuesday, $14^{\text {th }}$ of May 1878. At 9.30 I was with Dr. J. A. Ribeyro to whom I explained the merits of the case between Enriqueta and the monks of San Francisco. Ignacio Távara in his Vista-Fiscal had clearly set forth that Enriqueta's purchase of the locality in the convent had to stand good, that the posterior offer made by another party was null, and that there was no reason why the property should again be brought to public sale. On the previous evening, Garland accompanied by Enriqueta had been first with Dr. Muñoz and lady, then he by himself with Dr. J. Alvarez; and to-day at a late hour he went out to Chorrillos to see Dr. Manuel Cisneros; all three visits were with the same object, to make clear to the Vocales that in the suit which Enriqueta was carrying on against the prior of San Francisco justice was decidedly on her side. Everywhere they had met with a friendly reception; also through the medium of General Pedro Cisneros and his wife Trinidad, Enriqueta had obtained from Dr. Oviedo, President of the Supreme Court, the promise that he would postpone the case till Saturday next, which delay would enable Garland to engage a lawyer, Dr. Fernandez, for pleading; Espiritu Cisneros, Alejandro's lawyer, who had hitherto defended the case, being absent in Europe.

In the course of the day I was present at the meeting of the two Directories, of that of the Banco [Hipotecario], and of that of the Banco del Perú. In th[_] [649] former, the Bank's lawyer informed us that [...] not yet been able to come to an understanding with Bustos in the Marcone affair; the Gerentes laid 
before us some applications for loans, of which we granted one or two and refused the greater number. When I joined the directory of the Banco del Perú, they had already authorized the Gerentes to sell our "internal debt" at $60 \%$ or better, in case this figure were obtainable. The Gerentes then informed us that the Government had requested the Bank to sell to the same some of our banknotes for which we had no employ, in order to replace with them an equal number of notes of the Banco de Lima which were in such a state as to be hardly recognizable. After a short debate we resolved to give an answer in the negative because we feared that the Government would put the one into circulation without withdrawing the other, and in order to preclude the possibility of a similar request in the future, we ordered the immediate burning of our useless notes. Finally, the Gerentes were empowered to make loans and to discount, to no individual for a larger amount than $\$_{25}, 000$, nor for a longer period than three months, and this only as long as there existed in the chest at least one half of the amount which stood to the credit of accounts-current, including deposits at sight. From the Delegation no information had been received as to how the saltpetre negotiations stood with the Government.

Thursday, $16^{\text {th }}$ of May 1878 . The temperature became perceptibly cooler from day to day. At noon the sky was overcast, and the thermometer stood at $71^{\circ} \mathrm{F}$.

Yesterday at 6 p.m. Lizardo Montero, provided with a passport and accompanied by Godoy, the Chilian Chargé, and about forty of his friends, went per train to Callao, where he embarked on board the steamer for Valparaiso.

In the forenoon I went to Gustavus Heudebert's, and begged him de empeñarse with Dr. Leon in the suit [...] [650] [_]ghter against the Convent of San Francisco. In the evening Garland, Dr. Middendorff, Colonel Mariscal and José Basagoytia played at rocambor; Enriqueta, Federico Palacios, his wife Doña Mercedes, the Curate Aguila from Loreto, Urquhart and Enrique, at vingt-un. When they began, I went to bed.

Friday, $17^{\text {th }}$ of May 1878 . Also this morning I went on a similar errand as on the $14^{\text {th }}$; to Melchor Velarde, whom I requested to interest himself with Felipe Coz, a particular friend of the Vocal Eusebio Sanchez. In the meeting of the shareholders of the Water Company, convened for the third or last time, there were only four Directors, of whom I knew Oyague, the provisional director Luis Rey instead of his father, and I. The accounts of last year had been examined and approved by Roca Pratolongo, but on my expressing a wish to learn some particulars, I found the accounts to be made out in such a beyond measure detailed manner that I could hardly form a clear idea of them. Nevertheless, I understood that in the course of last year somewhat more then \$180,00o had been collected for water furnished to the inhabitants of Lima, that a dividend 
of 10 per cent upon the capital of about 1,500,000 pesos had been paid to the shareholders, and that at the present moment there were $\$ 46$, ooo to the credit of the Company in the Banco del Perú. The daily consumption of water in Lima amounted to six million gallons. The new directors were named; the same as hitherto, with the exception of José Basagoytia, who, at my suggestion was chosen instead of Andres Rey, whom illness had forced to withdraw. To examine the accounts of the present year we named Dubois, the North American engineer, son-in-law of Vicente Gonzales y Pinillos. On the previous day $\$_{420,000}$ of the Internal Debt had been redeemed at 55 1/4 per cent.

Saturday, $18^{\text {th }}$ of May 1878 . The Directory of the Ban[_] [651] Hipotecario authorized the Gerentes to make s[_] arrangement or other with the notorious Dr. Fernando Casós who had proposed to purchase Marcone's debt; Melchor Velarde was at first opposed to it, but came round to the opinion of the majority, when Dr. Ramon Ribeyro explained to him how the affair really stood. Also the debt of Silva Santistevan we authorized the Gerentes to sell to the same Casós if it could be done at a fair price. In the granting of loans we proceeded with the same prudence as we had done for some time past.

My diary of the first months of 1873 states that at that time rocambor was played at very high stakes in Chorrillos. This year the same had occurred, particularly in the houses of the President and $2^{\text {nd }}$ Vice President of the Republic.

I had a letter from my friend Sieveking, dated Altona, $5^{\text {th }}$ April, who narrated more or less the same story as that which Edward Knauer had communicated to me on the $12^{\text {th }}$, and added that his son Charles, the lawyer, whom Mr. and Mrs. Vogler had engaged, had succeeded in inducing the judges to let the affair drop. Had they carried it on, either a fine of 6000 Reichsmark or the incarceration would have been the unavoidable consequence. His son Johannes, who had been here in Lima a year back, continued in Puno in the employ of Thorndyke.

Sunday, $19^{\text {th }}$ of May 1878. I had now made it my rule to remain at home one Sunday to play at chess with Limpricht; to go out the other. To-day was the going out day; accordingly I paid my visits: to the family of Dr. Jervacio Alvarez where I was told that the old gentleman, though he had gone out, was in reality very much indisposed. Next to the first Vice President General La Puerta, always very polite; to Dr. Lührsen and wife, neither at home; to the wife of José Maria Peña, just returned from Arequipa where the entire family had been for many months; she, [_]self subject to rheumatism, had derived great benefit from [_] [652] [_] baths of Jesus and of Yura; to Cipriano Corr[_] family, Dolores Puente and Rafael Velarde.

Monday, $20^{\text {th }}$ of May 1878. The fatal anniversary. I awoke in the middle of the night; looked at my watch, it was a quarter past three. I again feel asleep, but 
rose early and went out to the pantheon, where to my great pleasure I found that the bronze work sent from the States had actually arrived, and would be put up in the course of the week. The door, though certainly handsome, especially the upper part, was however not of such exquisite workmanship as Mr. Mould, the architect of the Company, had led me to expect.

In the course of the day Enriqueta had several visitors who recollected the day it was; in the evening José Basagoytia came, accompanied by his wife; also Gregorio Benavides; I saw none of them because I preferred to remain in my bedroom and to lay down at nine. Limpricht, I was told, had played chess with Doña Juana Rosa, and beaten her, though not so easily as he had believed he would.

Tuesday, $27^{\text {st }}$ of May 1878. The Directors of the Banco Hipotecario assembled at one, and the principal thing we did was to listen to a proposal made by Casós to purchase four of the worst debts, amongst which that of Marcone, amounting to $\$ 440,000$, at 25 per cent discount. We [_]rrived at no decision, but all seemed inclined to accept the offer. Then we had to wait for the shareholders who were convened to meet, and it was past three before the session was opened, Pedro Correa, Vice, in the chair instead of Sebastian Lorente. After the last "acta" had been approved, the Gerente John Gallagher read aloud a motion made by Evaristo Barrios, the first article of which was [_] the effect that no one should be Director who was of the [_] amily of or related to the one or the other of the two Gerentes. A [_] pause ensued; I was the first to break the silence [653] saying that this first article was expressly directed against Melchor Velarde and myself; for all present knew that we two stood in some relationship to Mr. Garland; I added, that a few days back, one of the shareholders had been with me and advised me in his name and in that of some of his friends to throw up my post as director and to call in one of the suplentes; this however I was not inclined to do, because being chosen by a majority of the shareholders I would not retire at the behest of two or three of them.

Nobody replied; then the discussion commenced, it lasted a considerable time, and the first article was thrown out by a considerable majority. Next the report of the lawyer Galvez on this clause, which was in fact an amendment, was read; he proposed that in future no shareholder could be chosen director who was connected with either of the gerentes by affinity or consanguinity in any of those degrees which were specified by the law of the country in analogous cases. This amendment passed by a majority of two; and be it said, en passant, neither Melchor's nor my relationship with Garland came within these forbidden degrees. The other articles of Barrio's motion of little importance were unanimously approved with slight modifications. The principal spokesmen in this debate were Evaristo Barrios, who of course 
defended the plan, J.V. Oyague, who had undoubtedly inspired Barrios with his ideas, Aurelio Denegri, Dionosio Villate, Alejandro Garland, of the Directors, Pedro Correa, the gerente Gallagher and, finally, a certain Noel, this latter with much bitterness and violence, the others in a quiet, proper and dispassionate manner. According to the statutes, they could only be altered by two-thirds of the voters present, and in two consecutive meetings, therefore we would probably again be cited within a few days.

Wednesday, 22 ${ }^{\text {nd }}$ of May 1878 . The Directory of the B[_] [654] [_] decided many important points: Firstly, the Gerentes were ordered to instruct our agent in the Cerro, one of the sons of Andrés Rey, to discontinue the "habilitaciones" to the miners, which meant that he should no more make them advances upon silver to be delivered within [_] certain time. This system which had been acted upon by the bank for many years had cost the same a great deal of money. Secondly, the Delegation had placed in the hands of the bank 13,00o coined sovereigns as a security for the last loan of \$100,000. Now the Delegation asked the Bank whether it preferred to take these sovereigns at \$9.35 [?] in payment, which price they said the sovereigns stood in, or whether the Delegation should continue to sell them, which they would not do for less than 10 sols, and pay off the bank with their proceeds. In the debate about the Cerro de Pasco I had taken no share, not being acquainted with the merits of the case. Now I was the first to speak, and said I was opposed to the bank taking these sovereigns on its own account at \$9.35 [?]. The majority went with me. In the minority voted Elizalde. Finally the Nitrate of Soda consignment was again brought on the tapis. At first we confirmed our last resolution to take a share in the consignment as proposed by the Government, as long as the Certificates did not exceed four million pounds sterling. In the course of the debate one of the Directors said that the Banco Nacional was willing to take an interest if the certificates did not amount to more than $£_{5}, 000,000$, and that the "Providencia" had gone as far as $£ 6,000,00 o$. Hearing this I came upon the idea that it might be advisable to join the Nacional in the $£ 5,000,000$, thereby to prevent the emission of the enormous sum of $£ 6,000,000$ which would be ruinous $[\ldots]$ interested. This was relished by the [655] [_]thers, but modified by Calderoni in so far that [_] $£_{5,000,000}$ should be our last offer in case of need, and that on the meanwhile our Delegates should limit themselves to $£_{4,000,000 \text {. There was }}$ no doubt that great abuses had been committed in the purchase of Salitreras, which the "Comercio" had first brought to light. One "parada", which means an extent of Nitrate of Soda plain, without any regular machinery, had been

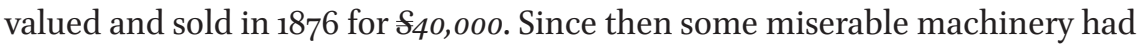
been put up, and now it appeared as resold to the Government for \$300,ooo. 
Thursday, $23^{\text {rd }}$ of May 1878. Our winter had set in. The mornings were foggy, and to-day the sky was overcast from morning to night. Thermometer at 3.30 p.m. $71^{\circ}$ F. At somewhat past twelve Sebastian Lorente, Pedro Correa y Santiago, Dr. M. M. Galvez and I, also Dr. Ramon Ribeyro and the two gerentes, assembled in the office of the Banco Hipotecario, and after Dr. Ribeyro had given his opinion, in accordance with that entertained by the Directory, the Gerentes were authorized to close the bargain with Casós.

In the evening, Garland had two rocambor tables, whilst the Curate Aguila, and afterwards Urquhart, Enriqueta and I conversed till midnight, when I withdrew to my bedroom. Urquhart told me that Charles Watson had made an arrangement with three of the children of the late Henry Meiggs, viz.: with Minor, Henry, and Fanny, married to Robertson, the fourth party, the widow of Manfred, who resided in Chile, not being included, in virtue of which arrangement the three said heirs of Henry Meiggs transferred to Watson all the assets they had inherited from their father, he on the other hand taking upon himself the responsibility of all the father's debts, and paying to them moreover a certain sum, it was said one million sols, in instalments; he, no doubt, expected when making this bargain to receive ere long from the Government [co]nsiderable sums either in documents of the Internal Debt or [_] Nitrate Certificates. The Compañia de Obras Publi[_] [656] [_]nto, Urquhart added, would have to liquidate, but possessed ample means to pay all they owed as this Company was at present the owner of the greater part of the landed property, formerly Meiggs's, situated between Lima and Callao to the right of the carriage road. The other Company founded by Meiggs before his death for working the Cerro de Pasco mines continued in full vigour.

Friday, $24^{\text {th }}$ of May 1878 . Before breakfast I walked to the pantheon where I found the high bronze cross placed on the top of the chapel, also the bronze door in its place.

In the office of the Banco Hipotecario, Lorente, Correa, Galvez and I, together with the lawyer R. Ribeyro were assembled not half an hour, but quite long enough to give our opinion as to the impossibility of accepting Casós' offer, because he only presented a real guarantee for the first fourth to be paid in cash; whilst for the other three fourths to be paid in six, twelve, and eighteen months, he had offered as guarantee the amounts which he expected to collect from the various debtors, and which he promised to deposit with the bank as soon as received. This in fact was no security whatever. The "Nacional" of last night published a telegram which made known that on the $13^{\text {th }}$ May, a fortunately unsuccessful attempt had been made upon the life of the Emperor of Germany. It also published a decree signed by the Finance Minister, which 
ordered all such persons as owned salitreras on the province of Tarapacá, and who had not yet offered them for sale to the Government, to do so before the $2^{\text {nd }}$ of July; and, secondly, raised the export duty on Nitrate of Soda to three sols silver, more or less equal to ten shillings sterling, from the $15^{\text {th }}$ of August

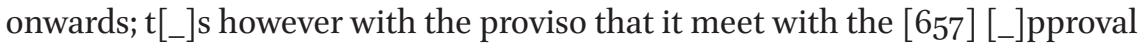
of the Congress.

Saturday, $25^{\text {th }}$ of May 1878. We were again in the Banco Hipotecario, including Melchor Velarde and Doctor Ribeyro. The Gerentes communicated to us a new proposal of Casós, which, as in our opinion it did not present a sufficient guarantee, was again rejected. I had been able to obtain for Mr. Schutte, through the medium of Alejandro, a bill of $£_{500}$, Fletcher, Ryder \& Co. of Arequipa on Fletcher \& Rider Liverpool, payable in London, at 27d; I now required $£_{150}$ more to balance Schutte's account, but could not get them at the same exchange. A few thousand pounds, Sawers Woodgate \& Co. on their London firm had been sold through the brothers Cox at $27 \mathrm{~d} 1 / 4$.

In the evening Enriqueta had with her Julia Cavenecia, the widow of Federico Bergmann, a good-looking, good-natured, but silly little woman. With her came her daughter Anita, 13 or 14 years of age, and the music-master Castañeda, whose object was to show to our little girls the progress which Anita had made on the piano under his tuition, and who, Enriqueta told me, really played very well for her age. This Castañeda, Benjamin, only son of the late Don Domingo, had, when a young man, been sent by his father to Europe to be educated. He made progress, especially in music; on his return to his native country, after the death of his father, he quickly dissipated a fair inheritance, married the natural daughter of one of the Baltas, and now was able to maintain himself and family in a decent manner, thanks to his skill on the piano.

Sunday, $26^{\text {th }}$ of May 1878. An article in last night's Nacional stated that, by the peace of San Stefano, European Turkey lost, in population, 4,200,00o souls; of whom 3,800,00o went to the new Principality of Bulgaria; and the remainder were distributed between Montenegro, Servia, and Roumania.

Thermometer at 12.30 in my office, $70^{\circ} \mathrm{F}$.

Exchange was a year back 23d; to-day 27d. F[_] [658] [_] to 4.30 Limpricht and I played chess, each of us gained one game. We were interrupted by Josefa Bazo, José Maria Peña and Francisco Sagastabeytia whom I received on my side of the corridor, for Garland with Enriqueta and the little girls had gone out to Chorrillos. Last night there was a large party in the German Club, in honour of Captain Von Bedecke and the officers of the German corvette "Elizabeth", now in the port of Callao. Dr. Lührsen and lady were present, and dancing was kept up to an early hour in the morning.

Monday, $27^{\text {th }}$ of May 1878 . At noon the Directory of the Banco Hipotecario again assembled; Dr. Casós, who was also present, explained, in a few words, 
the basis of his offer for the purchase of several large amounts due to the bank, of difficult, if not doubtful, recovery. When he was gone, we once more discussed the matter, and there was now some chance of our coming to terms.

The young Garlands said that the exchange was $26 \mathrm{~d} 3 / 4$, at which rate I refused to buy a small bill, equivalent to the amount which I still owed to Mr. Schutte. Coined silver 65\% premium. Bar Silver, fineness 993, S15.30 [?] to S15.50 [?] the mark.

Thermometer at $3 \mathrm{p} \cdot \mathrm{m} .70^{\circ} \mathrm{F}$.

In the evening, Garland had with him his rocambor friends, whilst Enriqueta and I had to converse for two hours, with Enrique Gibson of Arequipa, rather deaf, and not particularly interesting. He was one of the sons of James Gibson, deceased, whom I mentioned in volume I, page 105; his mother was still alive; he, married to one of the daughters of the late Mr. William Möller, was established on his own account, and did some business with Alejandro. In our conversation we touched on the dreadful accident which had befallen [...] Englishmen who ascended the "Misti". [659] They were a certain Mr. Ryder, (employed [_] the office of Fletcher, Ryder \& Co., successors of Jack Bros., and younger brother of that Ryder who was my companion in March or April 1859 on my ride from Islay to Arequipa) and a Mr. Rothwell, a young man come out to South America for the benefit of his health; these two, with a third who had safely returned to Arequipa, reached the summit of the mountain probably from the Cangallo side, where I ascended in 1825 . When on the summit the two determined to cross, and to descend on the other side, towards the river; here, in all probability, they lost themselves amongst the precipices, and died of fatigue, hunger, and perhaps, cold. Ryder's corpse had been found in a reclining posture, sitting upon a stone, the eyes turned upwards; his open watch lying alongside of him: the corpse of Rothwell had not yet been discovered.

Tuesday, $28^{\text {th }}$ of May 1878 . The Directors of the Banco Hipotecario met, once more, at 2 o'clock, to confer on the subject of Dr. Casós's proposal, but as neither Sebastian Lorente, our President, nor the two lawyers Ribeyro, and Galvez, one of the Directors, attended, we put off the discussion to the following day. There was also to have been a meeting of the shareholders, but, as only few of them came, this likewise was postponed for a week.

At dinner we had with us Enrique Gibson, Dr. Middendorff and Melchor Velarde; so that I could not rise to listen to Bryson's reading. From Gibson I learnt that Paula Zavalaga, the widow of John Moens, who, when I first arrived in Arequipa, was a young lady full of pretensions, and who I well remember showed off her graceful dancing at a ball given to the Libertador Bolivar in 1825, had gone to her long home after having been paralytic for many years.

Wednesday, $29^{\text {th }}$ of May 1878. At last the affair with Casós [_] brought to a conclusion by the Directory of the Banco Hi[_] [66o] [_], in the presence and 
with the advice of Dr. Ramon Ribeyro. The Minuta of the Escritura drawn out by this lawyer was approved with a few insignificant alterations. Dr. Casós's name did not appear; the purchaser was a certain P. J. Zavala from Tarapacá; the bank sold to him the debt of Marcone, amounting originally to $\$ 400,000$,

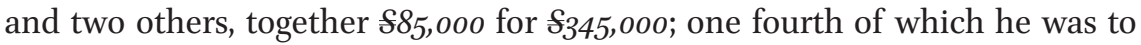
pay in cash when the escritura was signed, the other three fourths in three instalments of eight, twelve and sixteen months; moreover, he had to place in the hands of the bank \$1oo, ooo Nitrate Certificates, as security for the payment of the three other dividends. If one dividend were not paid, then the rights to the different fincas which were hypothecated to the bank were to be resumed by the same; in such a case the bank continued to collect whatsoever might be wanting to complete the purchase money, say $\S_{345,00 o}$ besides interest at one per cent monthly, the judicial expenses incurred, and a fine of $\$ 40,000$ for nonfulfillment of the contract. The insertion of the fine was exclusively my idea; at first it was rejected, finally adopted.

Hardly had we finished the job, when Luis Roca y Boloña entered and harangued for a considerable while on the subject of a claim ceded to the bank by Simon Soyer, and secured by a mortgage on the large building and garden behind the convent of the Prado, and known as the "huerta de Jimenez". This was so intricate an affair, there were claims and counter claims; one of which was that to which Agustin Escudero pretended to have the right for \$39,000, that to me it was impossible to make head or tail of it. When Roca was gone, the lawyer Galvez held forth to shew the injustice of Escudero's pretensions. Then we were told that José Basagoytia had offered the bank for its claim 16,0oo sols nominal in cédulas. Whereupon I, [_]h as already said, knew little of the justice or injustice of [661] the respective claims, proposed that we should [_] Basagoytia that we could not take less than \$20,00o in Cedulas, to this the others agreed.

News from Europe were at last of a pacific nature. England had made great warlike preparations, Austria also had armed, and, more than once in the course of the last few months, war had been imminent. I, however, had always been of opinion that the two powers England and Russia would not come to blows, and now it might be considered almost certain that a Congress of the Great Powers would meet in Berlin, at which Prince Bismarck would preside. This statesman, always a friend of Russia, had however of late give[_] to understand that some day or other a stop had to be put to the pretensions and encroachments of this power, and perhaps this occult threat had been one of the causes of the present pacific tendencies.

I learnt from Limpricht that Mr. Charles Watson had given warning to all the clerks, both in Meiggs's establishment, and in the Compañia de Obras Publicas, that from the $1^{\text {st }}$ of June onwards he would not require their services. 
Thursday, $30^{\text {th }}$ of May 1878. Ascension Day. Thermometer at noon, $70^{\circ} \mathrm{F}$, the sky over-cast. I dictated a letter to Sieveking, and this being the holiday when it was my turn to go out, I called firstly upon the family Ribeyro where I was received by the Doctor, the ladies being still dressing; he complained bitterly of his poverty, and added that though he had been serving the public for 42 years, for at the age of 22 he had begun his career as Agente Fiscal, he had not made a fortune: four or five times he had been Minister of Foreign Affairs, once of the Interior. Next, I went to Dr. Alvarez; who was very ill, and I much feared that he would not recover. He received me in the inner room, and said that even now he had fever, 104 pulsations per minute. He much regretted that in all probability [_] would not be [...] [662] [...] o conclude his universal history, at which compilation he had been working for many years. Dr. Lührsen and lady I found at home and stayed with them more than half an hour; the Doctor told me that he had seen in the Hamburg paper, "The Correspondent" that the banns had been published for the marriage of Gustavus Adolphus Schön and Corina Schutte, widow of F. Cordes, not by the ecclesiastical, but by the civil authority. Of my visit to Doña Dolores Puente and Dr. Muñoz I had nothing to say. Finally, I went to the house where Rufino Torrico and his wife Maria Araoz, just arrived from Paris, had taken up their quarters. It was a miserable building, the property of a certain Tadeo Barrios, whose wife, an elderly lady, was Torrico's aunt, and with whom I remained a few minutes.

In the evening, Garland had his rocambor players, and I, apprehensive that there might be a large party with whom I did not like to mix, went to bed at nine.

Friday, $33^{\text {st }}$ of May 1878 . I rose pretty early and walked out to the pantheon where the four smaller crosses had been placed on the four corners of the roof of the Chapel; the covering with slate was nearly finished, but after all, I thought that the workmen were making but little progress. It was a fine sunny morning; at noon the thermometer stood at $70^{\circ} \mathrm{F}$; the sky overcast.

In the evening, after Bryson was gone, I played chess with Limpricht, for Enriqueta was in bed with her customary migraine. I gained one game and then feeling that my eyes were much strained preferred listening to his reading to me from a German book called "Winged Words", which contained short sentences in different languages, known over the civilized world, and which in course of time had become what one might call indispu [...]. Besides these sentences of which a few [663] examples follow, the book gives their origin: [...] s right"; "Jurare in Verba Magistri"; "Toujours Perdrix"; "Les extrêmes touchent"; "Blut und eisen"; this last an expression of Bismarck's, made use of in one of his speeches to the Chamber. "Crescentem cura sequitur pecuniam." This last is in my opinion not founded on fact. Care follows the decrease, not the increase of fortune. 
Saturday, ${ }^{\text {st }}$ of June 1878. One hundred and seventy thousand sols, "billetes", were burned, and the redemption of the Internal Debt came off at $5^{21 / 2}$ per cent.

I was for a great part of the morning in the office of Adolfo Prieto, without having the good luck to see him. On the $25^{\text {th }}$ January I gave in my first escrito, demanding from Juan Aliaga y Puente the exhibition of the title deeds of the house 11 and 13 Polvos Azules which I had embargoed, and up to this date he had not presented them. Some time back the notary Ordoñez declared that he held a receipt of Dionisio Villate for these deeds; Villate declared in an escrito that he held no title deeds belonging to Aliaga. The judge Quiroga ordered Ordoñez to present the receipt, which I could not, myself, obtain from him then, nor since. Enriqueta, unwell, went to bed early.

Ricardo brought the letters received per North steamer. Juan's from Nizza was unimportant; Schutte's from Paris, extremely long. He gave me as a reason for the probable peacable adjustment of European difficulties, firstly, the bad state of the Russian finances; the daily expenses of that Government being, as he affirmed, seven to eight million francs, without having any probability of raising a new loan; secondly, the dissatisfaction with the Government prevalent in many parts of Russia, in confirmation of which he enclosed a cutting from the "Saturday Review", which goes affixed in Appendix under $\mathrm{N}^{\circ} 26$.

Sunday, $2^{\text {nd }}$ of June 1878. Mrs. Garland was very unwell this morning; the Doctor said it was fever and a[_]ue from which [_] [664] [_], and came three times in the course of the day to see her. In the evening she felt somewhat better, when Garland, who had not stirred the whole day long, went to Basagoytia's to play at rocambor.

In the forenoon I had two visitors, both of whom I received in my corridor: Rufino Torrico and Dr. Manuel Morales, Minister of Justice. The former told me that Mr. Schutte in Paris was completely paralysed in his legs, so that he could hardly walk three or four steps; in his apartments he was rolled about in an arm chair. The game at chess which Limpricht and I played lasted till past five, I gained by my last pawn being made queen one move before his reached the opposite end of the board. After dinner Ricardo read to me a chapter from Zamarow's "Die Romerfahrt der Epigonen", anglicé, Our successors' visit to the Romer; the name given an old building in Frankfort where the German Emperors in former times used to be elected, and sometimes crowned. Von Meding, the author, had given this name to his book, because it treated on the meeting of the German sovereigns, and burgomasters of free towns, (the king of Prussia excepted, who refused to come) convoked thither by the Emperor of Austria, Francis Joseph, in the year 1863, for the purpose of forming a new German constitution, which plan turned out [_] total failure. 
Monday, $3^{\text {rd }}$ of June 1878. Enriqueta remained in bed the whole day. In the evening Garland had his rocambor players, whilst I played a game at chess with Limpricht. I gained it, but not exactly in the proper manner because he allowed me to take back two moves, which I also occasionally [_]d to him.

Tuesday, $4^{\text {th }}$ of June 1878 . Enriqueta was so far better that she was able to leave her bed. The "Nacional" gave an [_]t of the accident which occurred about the middle of May [665] to the Englishmen who ascended the Misti, and of [_] I spoke on the $27^{\text {th }}$ May; it will be found in the Appendix, under $\mathrm{N}^{\circ} 27$.

The Universal Exhibition in Paris was opened on the $1^{\text {st }}$ May, with great pomp by the President of the Republic Marshal Mac Mahon, accompanied by the Prince of Wales, Amadeo, Ex-King of Spain, and the Crown Princes of Denmark and of the Netherlands.

There was but little doubt that the Congress of the Great European Powers would meet within a month or so in Berlin under the Presidency of Prince Bismarck, though, on the other hand, a loan of fifty millions of roubles, which the Russian Government had succeeded in raising with the assistance of a number of Berlin Bankers, afforded new means to the Czar to continue the war, should he be inclined to do so. Some differences had also arisen between the Russians and Turks as to the giving up of the fortresses in Bulgaria, which the latter seemed little inclined to do.

Here in Lima the rumour was current that ere long some of the sugar planters in the Northern departments would receive a supply from San Francisco of from four to five hundred Chinese coolies.

Dr. Palacios had succeeded in obtaining from the notary Ordoñez the receipt spoken of on the $1^{\text {st }}$ inst., which I immediately delivered to the notary Prieto. At one o'clock I went to the Banco del Perú, where the Directors, Ayulo and Ruden excepted, had assembled. The discussion on the Cerro de Pasco affairs was postponed until the Gerentes had had an interview with Rey, the agent in the Cerro, who was expected in the evening. At the earnest request of the two gerentes, though against my own conviction, it was decided that the bank should take in payment of the \$10o,ooo owing by the delegation coined sovereigns at \$9.35 [?] each. José Canevaro asked for a loan of \$200,00o upon the security of Certificates of Government bills deliverable in November at 34d. It was conceded to hi [...] [666] [...] per cent interest, and on condition that 20 per cent of the gain should be for the bank.

Thence I went to the Banco Hipotecario where the second general meeting of shareholders had been convened to decide on Barrios's motion. Not many were present. By 3 o'clock only Melchor Velarde and I of the Directors, so that I had to preside until Lorente came. Gallagher explained that according to statutes no alteration could be made in them if such alteration were not 
approved in the first general meeting by two-thirds of the shareholders then present, and as two-thirds in the last meeting had only approved one clause of Barrios's motion, the remainder naturally fell to the ground. I agreed with him, so did Aurelio Denegri, almost the only spokesman. Barrios tried to make some objections but was over-ruled, and when Lorente had come, that one clause was unanimously approved which declared that the Company was only responsible for the amount paid in by the shareholders, say three million soles; completely unnecessary, because the commercial code itself contained this law; and in this ridiculous manner Barrios's grand motion came to an end.

Thursday, $6^{\text {th }}$ of June 1878. Many hours of the forenoon I was in the Banco del Perú, when we discussed whether the banks should take a share in the Nitrate of Soda consignment proposed by the Government to the three banks, Nacional, Perú, and "Providencia". The debate was animated and interesting; I took but little share in it, listening to the arguments on both sides of the question. With the exception of Ruden, who was decidedly opposed to our entering into the business, we resolved to take a share on the express condition that the one million of pounds sterling Nitrate Certificates which the Government wanted to issue over and above the four millions, more or less the cost of the Salitreras bought, should be certificates of a different kind, and the servicio [...] that is to say 8 per cent interest and 4 per cent [667] redemption annually, should only be obligatory $[. .$.$] banks if there existed surplus funds sufficient for this object.$ Whilst here a hollow tooth began to give me pain, and as soon as I reached my house I went to bed without eating anything; was however able to listen to Bryson's reading to me, "Lockart's life of Walter Scott", who called playing at chess a sad waste of the brains. A little cotton wool, dipped in laudanum I put into the tooth; with a similar liquid I rubbed the gums, thus I fell asleep, and on

Friday, $7^{\text {th }}$ awoke without pain. Before breakfast I was, however, already at the dentist's, who cleaned out the tooth, put something into it and requested me to return the next day; the pain was gone.

In the Insurance Company "Lima" we were only Moscoso Melgar, President, Menchaca, I, and the Gerente. The gains this year until to-day were $\$_{4000}$ less than those of last year, which arose from a falling off in the interest. We instructed the Gerente how to proceed with various pagarés which fell due in the course of the month; the one he was ordered to collect, for the other he was instructed to ask for better security and so on.

Saturday, $8^{\text {th }}$ of June 1878 . Before breakfast I was again with the dentist Lince; he continued his operation, which he did with a great dial of skill, put some paste into the tooth, which he assured me would become as hard as stone, and charged me ten sols. At noon I was in the Banco Hipotecario, when the Directory granted some loans, and refused others. Gallagher made known to us 
that Casós had discovered that of the various properties which Marcone had hypothecated to the bank and which we had transferred to Zavala as explained on the $29^{\text {th }}$ May, Marcone, with the consent of the then Gerente Francisco Garcia Calderon had sold one house, probably without the knowledge of the Directory, to an Italian for \$10,00o. We were unanimously of opinion that the shameful transactions of Calderon's did not at all concern the bank, for the "escrit[_] [668] [...] Zavala was of such a nature as to free us from all responsibility, and Zavala or his lawyer Casós might if they thought proper sue Calderon for the value of the property improperly disposed of.

In the Banco del Perú we were again a long time together. Thursday's debate was continued. Ruden was more opposed than ever to the Nitrate business. Calderoni defended it with great skill and vehemence; Candamo spoke in a very rational way; Elizalde also, in favour of our entering; Ayulo, Bryce and I, said but little. At last, Ruden excepted, we took the following resolution: the Bank would take the fifth part in the company likely to be established with a capital of eight hundred thousand pounds sterling for the purpose of administering the consignment of Nitrate to Europe, on the conditions proposed by the Government, but with the same proviso about the "servicio" as set forth on Thursday last. To my vote in the affirmative I added the condition that the Government's debt to the Bank, which calculated at $42 \mathrm{~d}$ came to £130,ooo, was to be considered as part payment of the $£ 160,000$ the Bank had to contribute. If the Company with a capital of $£ 800,00 o$, could not be formed within a month after the Government had agreed to our proposal, then the Government might dispose of the consignment as it thought proper. Accordingly, our two delegates, Calderoni and Elizalde, were authorized to treat with the delegates of the other two Banks upon the preceding basis. Next, Rey the Bank's Gerentes in the Cerro was called in, who gave it as his opinion that by proper management, the 145,000 sols due by Pasco miners to the bank might be reduced to a very small sum by the end of the year, and he was therefore empowered to take the necessary steps to bring about this result.

Garland and Enriqueta dined with [669] Federico Palacios and his wife in the [...] father Antonio Villacampa, thus at our dinner-table, we were only, I, Ricardo, Antonio, and the little girls who were very sad owing to their mother's absence. Bryson, then Ricardo, read to me, and when, at about ten, I went to the parlour, I learned to my great dismay that the Supreme Court had sentenced against Enriqueta in her suit versus the friars of San Francisco. The property in that convent rented by Enriqueta would now again be brought to the hammer.

Within the last few days died Rosa Zevallos, sister of the Doctor Don Manuel. About thirty years ago, she, though considerably older than Enriqueta and her contemporaneous companions came much to our house, for she played the 
piano extremely well, also sang, and knew a good deal about music; afterwards, she married Espinosa, a native of the Republic of Ecuador; they, however, did not long live together, for she pretended that she could not stand the climate of Quito; he, that that of Lima was injurious to his health; gradually, she became estranged from all her previous friends. After Espinosa's death, she took up her residence in Callao, and finally married a son of Raborg (many year secretary of the Lima Exchange Rooms), a young man young enough to be her son.

The "Nacional" of the $6^{\text {th }}$ June gave the details of an extraordinary verdict pronounced by a Russian jury in St. Petersburg: In July of last year the prefect of St. Petersburg, General Trépoff, had ordered the flagellation of an individual, Bogolinboff, detained in one of the prisons of St. Petersburg, which chastisement, it was generally supposed, had not only been an arbitrary act on the part of the prefect, but also been inflicted with undue severity. A woman, Vera Sassolitch, who as appeared by her confession, was not acquainted with Bogolinboff, and who belonged to the secret society of the Nihilists, took upon herself the "vindication of outraged humanity" [670] [...] pretence or other she was admitted into General Trépoff's presence, fired a revolver at him and wounded him severely. She was arrested, tried, confessed her crime, and was absolved by the jury!! - an evident confirmation of the opinion on Russian affairs, expressed in the "Standard" - see the cutting in Appendix under $\mathrm{N}^{\circ} 26$. The "Nacional" of Friday and Saturday published a very interesting translation of an article in "La Revue des Deux Mondes" by which I saw that the Principality of Bulgaria, the result of the St. Stefano treaty, would be of an extent equal to two-thirds of the area of France, and that it was situated in such a manner as completely to separate Constantinople from the few provinces which still remained to the Turkish empire in Europe, viz.; from Herzegovina and Bosnia on the one hand, and from Albania on the other.

Sunday, $9^{\text {th }}$ of June 1878. I dictated my letter to Mr. Schutte of Paris, then made a few calls: on Henry Higginson, wife and daughter; on Dr. Alvarez, apparently much better; on Doña Juana Guise, Dolores Puente, and Mrs. Rafael Velarde. Ricardo, as usual on Sunday's, read to me after dinner, Enriqueta and Garland went to the Basagoytia's.

On the $7^{\text {th }}$ inst. the Finance Minister had published an absurd decree which began with stating that the accounts of the house of Dreyfus with the Government of Perú had been duly examined by the "Tribunal de Cuentas", and that this examination had given the following result; firstly, that the house of Dreyfus had no right to claim the sum of about $\$ 19,000,000$ which according to their account appeared to the debt of the Peruvian Government; secondly, that the house of Dreyfus owed to the Peruvian Government, (a) about \$700,00o, (b) the amount of a cupon improperly charged and never [_] by them, and (c) 
an indefinite amount arising from [671] the savings introduced by them in the Guano busi[_]; and thirdly, in consequence of the two preceding articles the account between Dreyfus, Bros. \& Co. of Paris and the Peruvian Government was cancelled. In this manner the Government constituted itself Judge in its own cause, without heeding the arguments of the other side.

Monday, $10^{\text {th }}$ of June 1878. Whit-Monday. This forenoon a religious ceremony was solemnized in the Church de la Concepcion at the request of some English Catholics resident in Lima, in order to celebrate the re-establishment of the Catholic Hierarchy in Scotland. The Apostolic Delegate was present, Canon Bandini sang the mass, and an English clergyman Strongarm read a sermon in the Spanish language.

After Bryson had gone, Limpricht and I played chess till half-past five, two games in three hours, which I gained with the greatest difficulty. He and Urquhart dined with us. Garland had two rocambor tables, I beat Enrique Basagoytia one game at chess easily; and retired to my bedroom at somewhat past eleven.

Tuesday, $n^{\text {th }}$ of June 1878 . Thermometer at 4 p.m. $69^{\circ} \mathrm{F}$. Of this day I had nothing to write. In the evening Garland was at home, and we were all very taciturn and low-spirited.

Wednesday, $12^{\text {th }}$ of June 1878 . The evening of this day was spent like the previous one. Limpricht was with us for about an hour. Exchange on London, $25 \mathrm{~d} 1 / 2$, at which I remitted $£_{150}$ to C. W. Schutte; at the last moment there was a slight tendency for improvement. From the Banco del Perú I bought fiftysovereigns of the lot they had taken in payment from the Delegation at \$9.35 [?] each.

Thursday, $13^{\text {th }}$ of June 1878 . Though it was a gloomy and wet morning, before breakfast I walked out to the pantheon, where I found my chapel locked up. As far as I could distinguish, the inside walls were not yet painted.

The latest news from Europe per tele[_] [672] [_] the [_] inst., were of a pacific nature, and the Congress would probably have been opened in Berlin on the $11^{\text {th }}$ of this month.

Doña Mariana Barreda, wife of Manuel Pardo, with some of her children had returned from Chile, where she had resided for several months.

George Elster and family left this day, viâ Panamá for Europe, and Enrique Garland had again taken charge of the Russian Consulate hitherto held by Elster. Other passengers by the steamer were, for London, Federico, the only son of General Pezet, with his wife, the daughter of an English brewer, who was so addicted to the use of spirituous liquors that it was hardly expected she would reach her destination; and for France, Mercedes Castañeda, widow of Emeterio Villamil of La Paz, accompanied by her son, who after a short stay in 
Lima returned to Versailles where she had resided many years for, as she used to say, after having once enjoyed the convenience of life in France one cannot bear living in Perú.

Gonzalez and his wife dined with us; afterwards, the curate Aguila, Urquhart, Limpricht and I kept Enriqueta company, whilst Garland had his rocambor players with him except Basagoytia who gave a party in his own house to celebrate his mother's, Doña Antonia's saint's day.

Friday, $14^{\text {th }}$ of June 1878. The tenants of $\mathrm{N}^{\circ s} 11$ and 13 Calle de Polvos Azules being notified that they had to pay their rent to the Depositario Alejandro Garland, replied; he of $\mathrm{N}^{\circ} 11$, called Melchor N., that he paid \$2o monthly, but that he had advanced the rent to Aliaga till the $6^{\text {th }}$ October; the other in $\mathrm{N}^{\circ} 13$ that his name was Frank, and that his brother, now in Europe, had made an escritura with Aliaga for four years which would expire in 1882, and that the rent had been paid in advance, but that he did not [_] know the amount nor the date of the escritura drawn [673] out in the office of [_] Palacios.

Whensoever I had not to attend a meeting of one of the three Directories of which I was a member, I generally took a walk in the forenoon to allow Bryson time to copy the old diary, with which we had now progressed as far as the end of 1873. This day I walked out to Santa Sofia; the entrance was locked up, and, as far as I could observe, nobody was at work; there was only one living being, a small watch-dog.

Antonio left on a visit to Arequipa. I gave him \$25 to defray part of his expenses. The commander of the man-of-war "Limeña" had made him an offer of a free passage to and back from Mollendo, which he of course had readily accepted.

Sunday, $16^{\text {th }}$ of June 1878 . The "Nacional" mentioned that twelve enormous guns were about being cast in the foundry of Armstrong, eight for the Italian, four for the English Government. Each was to weight 100 tons, for loading 485 lbs powder of first quality were required, the ball weighing $2000 \mathrm{lbs}$ would travel at the rate of 496 metres the second.

A considerable amount of debts left by the late king of Italy, Victor Emmanuel, Il Galantuomo, his son and successor, the present King Humberto had declared would be paid by him, and this out of his private fortune.

Victor Emmanuel's last morganatic queen was, as Limpricht told me, a pretty peasant girl raised by him to the rank of Countess delle Millefiori.

Thermometer at noon $68^{\circ} \mathrm{F}$. When Bryson was gone I went out to make some calls: in four houses, those of J. N. Vargas, Pinto, Joseph Macandrew and J. V. Oyague, nobody was in. With the widowed lady, Mrs. Minks, sister of the brother Cox, I remained about half an hour. So did I at Rafael Velarde's, and with the wife and daughters of Melchor Velarde. Thus the t[_] passed from two 
till past five. [674] Enriqueta was unwell and part of the day in bed. The little girls had with them Sofia Velarde and Maria Santillana; Garland took them to the Exhibition Park, which in the winter season was much frequented on Sundays and holidays. Urquhart was with us at dinner. Ricardo read to me for an hour till near ten, I then kept Enriqueta company, for Garland was gone to Basagoytia's, and about eleven I went to my room.

In this quiet and simple manner I was in the habit of spending my Sunday in Lima.

Monday, $17^{\text {th }}$ of June 1878 . Before breakfast I went to the pantheon where I found the painter in my chapel. The work went on slowly, I calculated that it would be concluded in the course of a week, or thereabouts.

In the evening Garland had with him seven rocambor players: Melchor Velarde, José Basagoytia, Colonel Mariscal, Pinto, Rafael Canevaro, Dr. Middendorff and Jorge Valle, forming two tables. With Enrique Basagoytia I played three games at chess, giving him the king's bishop, gained two, lost one. At 11.30 I was in bed.

At 2.30 in the morning of this day had died Federico Riglos, of good connections but indolent habits. Only five months back he had married the rich widow of a certain Llerena, one of the daughters of J. M. Varela. On Saturday last he confessed, yesterday he took the communion, and though he felt somewhat unwell in the afternoon, had as was his habit played rocambor in the apartments of his brother-in-law Felipe Varela, on the ground floor of the same house in which he occupied the first story. They broke up at about one, and whilst he and his wife were undressing he complained, took some beverage prescribed by his physician, said that his sight was failing him, and expired; the cause of his death was heart complaint.

Tuesday, $18^{\text {th }}$ of June 1878 . Last night's papers [675] contained all kinds of news.

[...] Russell, the statesman known for his liberal principles had died at a very advanced age. The Emperor of Germany had again been fired at; and this time been slightly wounded. The two German Ironclads King William and the Great Elector had had a collision in the English Channel off Folkestone; the latter went down with the greater part of her crew. The well known steamer "Tasmanian" on her voyage from Colon to Southampton ran aground on a sandbank, 4 miles to the south of Porto Rico. On the $28^{\text {th }}$ May advice of this misfortune was received in St. Thomas, when the "Arno", belonging to the same Company was dispatched, which brought off all the correspondence, the passengers and treasure.

Juan's letter was dated $14^{\text {th }}$ May from Monte Carlo, a very pretty place a little to the eastward of Nizza. In the evening when Bryson was gone I found Mercedes, 
the wife of Federico Palacios, with Enriqueta, but not feeling inclined to keep them company I went to my bedroom, and soon lay down.

Wednesday, $19^{\text {th }}$ of June 1878. At 12 o'clock I was in the Banco Hipotecario, with Pedro Correa who presided in the absence of Lorente, Melchor Velarde, Dr. M. M. Galvez, and the two gerentes. Gallagher, who was the spokesman of the two, laid many questions before us of more or less importance. At 1.30 we had done with our work, some loans were conceded, others denied.

I saw by the "Nacional" of last night that the "Tasmanian" ran upon a stony sand bank at the entrance to the road-stead of Puerto Rico at 8.40 p.m. on the $27^{\text {th }}$ May. The sea was very calm, the passengers went quietly to bed, slept, and breakfasted on the $28^{\text {th }}$ as usual. On the same day at 4 a.m., a Spanish man-ofwar from the port came to render assistance. At a later hour the "Arno" from St. Thomas as yesterday relat[_] [676] [...] In the United States Congress, after long debates, a commission of eleven persons had been named to investigate the frauds said to have been committed at the election of the present President Hayes, in the states of Louisiana and Florida.

The liquidation of the accounts between the Government and the former company for loading Guano showed a balance in favour of the latter of $\S_{2}, 801,000$ which debt had been recognized as correct by a decree lately issued. At 3.30 thermometer in my office between $69^{\circ}$ and $70^{\circ} \mathrm{F}$., a disagreeable, gloomy day.

At 5 p.m., when I went as it was my custom to the office of Dr. Palacios, I was told by his amanuensis that he had been called to the palace, there to take his oath as Minister of the Interior or "de Gobierno". His colleagues were Dr. J. G. Loayza, a very respectable lawyer, Minister for Foreign Affairs under Balta, now Minister of Justice and President of the Council; J. M. Irigoyen, Minister for Foreign Affairs, he was rather an insignificant man and owed his rise to his marriage with Mercedes, niece of Doña Pancha, Ramon Castilla's widow. More than once under different administration he had filled the post as Peruvian Envoy at Foreign Courts and in his political opinions he was believed to lean towards Pardo's party. General Pedro Bustamante, still more insignificant than Irigoyen, Minister for War. A certain Barinaga, for many years employed in the Tribunal de Cuentas, said to be very honest, Minister for Finance. Doctor Palacios was certainly very clever and astute, but of his uprightness I had not the very highest opinion. He owed his nomination solely to the intrigues of José Basagoytia, with whom he was very intimate. He was a sworn enemy of Aranivar, just gone to Europe, and, like Loayza, an adherent of Nicolas Pierola.

Thursday, 20 ${ }^{\text {th }}$ of June 1878. Corpus Cristi. [677] At 11.30 when on my way to Dr. Palacios' house, I met Basagoytia who told me that he was not in his office, 
having gone to the palace to accompany the President in this day's procession. He further told me that the Doctor would continue to superintend his business as lawyer, and that he had chosen Enrique Perla to work under him. This appeared to me to be by no means a good election, for Perla, when Gerente of the Banco Territorial, had suddenly been turned off - a deficit in the cash having been discovered for which he could not account.

When I reached home I engaged a young Englishman, Alfred Brierly, clerk in the London Bank of Mexico and South America, to read to me in the evening from 7.30 to 9; to begin on the $1^{\text {st }}$ July next, for other occupations prevented Bryson from doing so any longer. I then dictated a short letter to Mr. Schutte of Paris, and from past two to past five played three games at chess with Limpricht, gained two and lost one. Then Ricardo read to me, and it was about 6.30 when we sat down to dinner: Garland and Enriqueta, Enrique and Ricardo, the two little girls and I, Limpricht, Urquhart, Federico Palacios and wife, with their illmannered little daughter Maria. I did not find any pleasure in these and similar parties; however good breeding did not allow me to rise as soon as I should have liked. At about nine some rocambor players came, amongst whom José Basagoytia, with his wife, two sisters-in-law, daughter Filomena, and son Enrique; with the latter I played a game at chess, which at all events whiled away the time; the others played Monte; and I was in bed by eleven, but could not sleep till near one, when I heard the party break up.

Friday, $27^{\text {st }}$ of June 1878 . At about nine I went to Dr. Palacios, whom I found in his office, and congratulated on his nomination; he assured me that my suit should be well taken care of, for he would co[_]ti[_] to superintend it [...] [678] [...] named in his stead was not Enrique Perla but a certain Eygurren.

Saturday, $22^{\text {nd }}$ of June. Enriqueta was once more ill, and kept her bed. Maria and Corina returned to their college after having been at home since Monday last, because the nuns and the elder girls in the college had had to confess and to take the communion.

We had telegraphic dispatches from Europe to the $17^{\text {th }}$ inst.: On the $13^{\text {th }}$ the Congress of European plenipotentiaries was opened in Berlin, prince Von Bismarck presiding. The Emperor was doing as well as could be expected; this last time he had been struck, not by a single ball, but by shot, which had wounded him in many places both in arms and face.

In the evening Ricardo finished reading to me Von Meding's "Romerfahrt", so that I had now concluded his various very interesting political novels.

Sunday, $23^{\text {rd }}$ of June 1878. In the "Comercio" a letter or "oficio" was published which Focion Mariategui, late sindico of the Municipality or Concejo Provincial, had directed to Benavides, President of the Concejo Departamental, in which 
he had laid open all the arbitrary acts and defraudations which had been committed by Pedro Saavedra, Alcalde or President of the "Provincial", and his clique.

When Bryson was gone I paid a few visits: Dr. Jervacio Alvarez was not at home, but his family told me that he continued very unwell. Doña Virginia La Torre with whom I found Enrique Ayulo, was very agreeable, as she always was. I remained some time with Dr. Valeri, a clergyman, a Roman by birth, and resident in Lima, who had lately returned from a voyage to Europe. He had been in Rome at the time of the death of the King Victor Emanuel, of the pope Pio IX, and [_] the election of the new pope, which latter, Cardinal [679] Pecci, formerly not much known, [...] for his excellent conduct during the short time, about a fortnight that he filled the post of Camerlengo, that is to say, supreme chief of the Church in the interval between the death of the one and the election of the new pope; and, of this conduct, Valeri gave me the two following instances: King Humberto had sent a deputation to the Camerlengo expressing a wish to be present at the funeral of Pius the Ninth, to be celebrated in the Sixtine Chapel; Pecci replied that he should be most happy to see a deputation of the King present on the occasion, but that the chapel was so small that he could only give them a place in the same gallery with Foreign Princes, which indirectly gave to understand that he considered the King of Italy as a foreign prince, and, consequently, King Humberto sent no deputation to the funeral. The ambassadors of the four Catholic powers, Austria, France, Spain and Portugal had represented to Cardinal Pecci that they expected he would recognize the right which their respective countries had to the veto, which means that each of the four sovereigns had a right, before the election of the new Pope, to exclude from the list of persons likely to be elected any certain person obnoxious to him. Pecci's answer was, "This privilege of the veto was conceded to the four powers on condition that they should stand up for the defence of the Pope. Have you done so? You have not. Pio Nono was deprived of the temporal power, and you did not lift up a finger. Judge yourselves; as you have not fulfilled that part of the Contract which corresponded to you, say the defence of the Pope, whether you have now a right to demand a veto which was conceded to you in the expectation of you doing your duty." Consequently, none of the four powers exercised its right of veto at the time of the new pope's election.

After dinner Ricardo read to me Goethe's drama "Götz von Berlichingen" till past nine, when I in the beli[_] [680] [...] gone out, went to Limpricht's room and played with him a game at chess, which I lost and which I should have lost much sooner than I did had he not given back to me a move which exposed my queen. 
Monday, $24^{\text {th }}$ of June 1878. San Juan. Before 2 o'clock I went out, and had done with my calls by 4.30. With Dr. Mariano Dorado, Juan Bazo, José Basagoytia, Josefa Bazo de Gonzales and Antonio Lavalle, I merely left my card. I stayed a short time with Doña Juana Rosa Moreyra, and somewhat longer with Doña Juana, widow of the notorious General Felipe S. Salaverry with whom I had not been for years. At Dr. Juan A. Ribeyro's it was like a bee-hive; so visitors went in and out.

The Alameda de los Descalzos and its vicinity were, like last year, filled with ladies and gentlemen, in coaches closed and open, private and public, on horseback and on foot, some moving about, others standing, others sitting on the marble seats in the Alameda.

At dinner we had Dr. Middendorff and Urquhart. At a later hour I waited for Bryson, but in vain; then came the usual rocambor players, also the clergyman Aguila. I conversed a little with Urquhart, and at eleven retired to my bedroom.

Tuesday, $25^{\text {th }}$ of June 1878 . Both Maria and Corina were unwell and did not go to college. In the middle of the day I walked out to the pantheon to have a look at the chapel. The painters told me that they had just finished their work. The inside walls were painted with a light bluish-grey colour with borders above and below; those above I could not distinguish; those below, brown with a yellow design, did not please me much.

The Compañia de Obras Públicas y [681] Fomento had at last paid to [...] for which they had been in arrears up to the $30^{\text {th }}$ inst. by means of an acceptance of Charles Watson due on the said day; at the same time they had advised her that they ceased to be her tenants from that date, but that they expected that Charles Watson, as Director of the Company formed for working the Cerro de Pasco Mines, would continue to occupy the premises hitherto rented by them.

Wednesday, $26^{\text {th }}$ of June 1878 . I awoke with a sore throat, and was not quite well the whole day long. The little girls also continued unwell, and Garland suffered from a violent cold. Hitherto it rained but little, but the temperature was rather cold.

Thursday, $27^{\text {th }}$ of June 1878 . Thermometer at noon $67^{\circ} \mathrm{F}$, very low compared to last year. We learned per telegram that the German Parliament or Reichstag had been dissolved because that which had hitherto been sitting would not pass a bill introduced by the Executive against the Socialists and their associations.

The Directory of the Banco del Perú met at a little past twelve. Ruden and Ayulo did not attend. The Delegates Elizalde and Calderoni informed us that the Government persisted in its pretension that the banks or the Company, or whosoever obtained the exclusive consignment of Nitrate of Soda, had to take upon themselves the obligation to pay the interest of 8 per cent annually, and 4 per cent annual redemption, not only on the $£ 4,000$,ooo at $44 \mathrm{~d}$, value of 
the Salitreras sold, but also on the $£ 1,000,000$ at $44 \mathrm{~d}$, which the Government wanted to hand over to the Compañia de Fomento, in part payment of its debt. I was the first to speak, and said that in my opinion we should not give way from what we had resolved in our last meeting, viz.; that we could only bind ourselves to hacer el servicio upon the 4 millions, and upon the one million if there was a surplus. Calderoni answered that the sales of the Nitrate [_] [682] [...] for the service of the $£ 5,000,000$. If that was the case, I replied, the Government lost nothing by our proposal, but insisted that we ought to adhere to our last resolution. Then the discussion commenced, in which, as it was my custom, I took no active share, but had the satisfaction that finally my opinion was accepted unanimously, and our Delegates authorized to communicate our decision to the Delegation. It was near two when we separated.

My cold was as bad as the day before; nevertheless I went to Rafael Velarde's to congratulate Zoyla on her birthday, who had received splendid presents from the $1^{\text {st }}$ Vice President La Puerta, a valuable diamond ring, and a large golden visiting card upon which were engraved the words, "Felicitaciones á Zoyla Velarde, de Luis La Puerta", or other words to that import.

In the evening Macandrew and wife had their first reception; nevertheless Enriqueta's little party was pretty well attended. I stayed up till 11.30 taking great interest in the game at chess played between Johannes Limpricht and Enrique Basagoytia, the former giving to the latter one or two figures; and yet gaining more games than he lost.

Friday, $28^{\text {th }}$ of June 1878 . At 3 p.m, thermometer $68^{\circ} \mathrm{F}$. My cold was somewhat better. I sold to the Banco del Perú, C. W. Schutte's 120 shares in this Bank, say $\$ 60,000$ paid up, at $80 \%$; exactly the figure at which by last steamer he had authorized me to sell. In the Banco de Lima I received $10 \%$ on my 100 shares or $\$ 50,000$ paid up capital, which $10 \%$ completed the $60 \%$ until now received from the liquidators.

Saturday, $29^{\text {th }}$ of June 1878. San Pedro y San Pablo. My cold was getting better. Little Corina continued unwell, and kept her bed; particularly at night she suffer [...] something like asthmatic complaint and for seve- [683] ral hours her mother had regularly to a [...] Last night the Concejo Departamental, M. F. Benavides presiding, held a meeting which was not without interest. The Concejo Provincial, or Municipality of Lima, had let some months ago the wooden shops opposite the market place, known as those of Paz Soldan, to one of the Dinegros, at a ridiculously low price, whilst they might have obtained at least double as much. The minority of the Municipality appealed to the Concejo Departamental, and last night a majority of two, say 19 against 17, resolved that the contract with Dinegro should be annulled. In the majority 
voted amongst others; Melchor Velarde, Colonel Mariscal, Carlos Paz-Soldan, Juan José Moreyra, Tadeo Terry, Gustavus Heudebert, and Ramon Alzamora.

When Bryson was gone I made a few calls of which the most agreeable was that to Doña Petita, Manuel Pardo's mother. I found with her Nicolas Rodrigo, and one of the Delgados. When I asked her about the return of her son, she said it was uncertain and depended upon circumstances. Petita, the deaf wife of Carlos Paz-Soldan, received me in her negligé; nobody else was with her. At José Pablo Escobar's I found Dr. Ribeyro and one other visitor. At Doña Petita Marriott's there was a pretty large circle, her husband in bed with a cold.

In the evening, Bryson read to me from the Eclectic Magazine an article in which an account was given of the attempts made by the North American Missionaries to introduce Christian religion and western civilization into European and Asiatic Turkey, but to judge from what they themselves said, the progress hitherto made had been very insignificant. I wondered that the Turkish government tolerated the establishment of these Christian schools and seminaries.

Enriqueta had with her Fernando Casós and his daughter: afterwards, till near midnight, Federico Palacios and his wife; I did not join them, but went to bed early in low spirits and with a bad cold. [684]

Sunday, $30^{\text {th }}$ of June 1878 . Till past twelve I waited for Bryson, but as he did not come, I called Ricardo, who fortunately was at home and who read to me Goethe's "Götz", which I did not much admire. It gives no doubt a good idea of the medieval manners in the last years of the reign of the Emperor Maximilian I. The language also is very natural, but the plot is very simple, and it is written in direct opposition to the laws of unity. In time it extends over I know not how many months, and the place shifts with every scene, which sometimes in the book does not even occupy one single page. Now we are at Bamberg, then at Heilbronn, again in Jaxt-hausen, in the Spessart, in the open country, in a forest, in a tower, with gipsies, everywhere in the circuit of a good many miles. With Limpricht I played at chess, lost two, gained one game. Garland was unwell. Doña Juana Carbajal looked in. Everything was very dull and sad.

Monday, ${ }^{\text {st }}$ of July 1878 . It was a gloomy, wet day; thermometer at noon, $67^{\circ} \mathrm{F}$. Rafael Velarde had thrown up his post as Superintendent of the Callao Custom-House; he said he had done so because he had to take many steps in order to be elected Deputy for the next Congress, his dual or competitor was San Roman who belonged to the Civilistas or Pardo's party. He had also had a violent dispute with an employé in the Custom-House which might have influenced his resolution. 
In the evening at 7.30 came for the first time Mr. Alfred Brierly whom I had engaged to read to me every day an hour and a half. He read to me Lockart's Life of Walter Scott.

Tuesday, $2^{\text {nd }}$ of July 1878. At 1 p.m. I was in the office of the Banco Hipotecario. Pedro Correa did not attend owing to his father's recent death. The Gerentes $[\ldots]$ tainly very hard work for scarcely a week elapsed with [685] out their discovering new irregularities which [...] place in former times, even loans had been made upon inadequate security. It seemed to me as if Francisco Garcia Calderon had been the gerente who had made the greatest number of such loans, and in him it was the less to be excused, because, being a clever lawyer, he knew what he was about, and what he did he did with his eyes open, merely to gain his commission, and now we, the Directory, had to consult with the Gerentes what allowances, more or less heavy, were to be made in order to save the remainder of these debts.

In the evening, besides reading Lockart, Brierly began the "Tempest" by Shakespere.

Bryson read to me from the Eclectic a pretty little anecdote: A Yankee democrat met a clergyman. How are you, priest? was the question; how are you, democrat? - How do you know that I am a democrat? - how do you know that I am a priest? - I knew you by your dress - and I, you by your address.

This day $\$ 170,000$ in bank notes were burned in the Plaza.

Wednesday, $3^{\text {rd }}$ of July 1878 . My cough was nearly well. A telegraphic dispatch brought the advise of the death of the young queen of Spain, Mercedes, daughter of the Duc de Montpensier, which took place on the $26^{\text {th }}$ June.

The Editors of the "Nacional" had been accused of a libel against the Government by the agente fiscal Dr. Estevan Guzman, or to speak more correctly, not the editors, but the person who had signed and guaranteed the article complained of; but contrary to expectation the grand jury, which consisted of persons, not belonging to the Civilistas, declared unanimously "que no había motivo para formacion de causa". In other words, they absolved the accused, who, after many months detention, had now to be placed in liberty.

The daily paper "La Patria", hitherto the organ of Dreyfus's firm, had passed into the hands of the Pierolistas with P[_] [686] [...] as chief editor.

Yesterday Antonio returned from Arequipa much pleased with the kind manner in which he had been received by Enriqueta's friends; he said that there was no doubt that smoke was actually issuing from the crater of the Volcano "El Misti".

On the $18^{\text {th }}$ June the Judge Quiroga had ordered the notary Ordoñez to present the title deeds of Juan Aliaga y Puente's finca, and only to-day Ordoñez's 
reply was notified to me, in which he said that the deeds were in possession of Dionisio Villate. Ordoñez's silence had been caused by his long absence on the estate of "La Estrella" of which he gave judicial possession to Francis Bryce, who, as everybody knows, had laid out an enormous deal of money on the same, but who, Heaven knows why, not only had allowed a certain Llona, whom he had taken for partner, to administer it, but even to sign Llona \& Co., without any mention of the name of Bryce. Llona's name stood on the engines, the machinery; everywhere; Bryce's nowhere. A month or so ago, Llona a married man, suddenly left, accompanied by his mistress, a Frenchwoman, and Bryce, aware of the imprudence he had committed, now tried to secure his interest by taking judicial possession of what in reality was already his. A lawsuit was likely to be the result of these various proceedings.

In the evening Brierly did not come, being as he had told me, in expectation of the arrival of a young German lady to whom he was engaged, a Miss Schaum, some time ago governess to Sattler's children.

Thursday, $4^{\text {th }}$ of July 1878 . We received our letter by North Steamer. Corina Schutte had been married to Gustavus Adolphus Schön on the $28^{8 \text { th }}$ May in the Mairie with the greatest secrecy, without even the presence of Mr. Schutte, prevented from moving by his swollen [_] and on the $31^{\text {st }}$ of the same month quite as quietly [687] in the Church. On the same evening they had [...] ut for Berlin, to return to Paris within three or four weeks. By the same steamer I received a letter from Henry Sieveking Jr. who informed me that his father, my very good friend, had been at death's door, but that he had fortunately recovered. My niece Elizabeth Bobertag wrote her brother Johannes to the same effect. She had applied to Henry the father for some pecuniary assistance which I had authorized him to led her have on my account, but it had been the son who had answered her letter. She, herself, was in a miserable state of health. To afford some relief to her weak lungs her medical advisers had sent her to Southern Switzerland, whence she had returned without having being benefited by the change of climate. For many years past she had never been entirely free from rheumatic pains, some times they had been excruciating, and finally the muscles of her neck had relaxed to such a degree that she could not keep her head up, it always rested upon her left breast; and, not withstanding this doleful plight in which she was, she had resolved to remove for a few weeks to a small place in Holland where existed an establishment which enjoyed a great reputation by the cures there effected by the kneading process, and of this she was desirous to make a trial.

Advice was also received of the suicide committed on board the steamer on the other side of Colon by Federico Pflücker who was on his way to Europe together with his father and half sisters. $\mathrm{He}$, of a melancholy and suspicious 
character, was always complaining that the young folks on board and even the lawyer, Manuel Alvarez Calderon, were making fun of him. Four days after leaving Guadalupe, at 3 p.m. he entered the berth of Calderon, who was lying asleep on his bed, his hands folded upon his breast. Federico, without saying a word, discharged his revolver at him; fortunately the ball merely broke one of his fingers; Alvarez Calderon awoke and said, Que haces Federico? Pflucker then went quietly to his own berth [_] [688] [...] into his mouth, fired, fell and expired.

In the evening Brierly again stayed away; I however received a note from him in which he begged me to excuse him, his bride having only arrived this day.

Garland had a few rocambor players with him, but I remained with Enriqueta, who suffering from migraine kept her bed.

Friday, $5^{\text {th }}$ of July 1878. The Emperor of Germany's would-be assassin was a certain Nobeling, 32 years of age, professor of philology, and one of the editors of a radical socialistic newspaper in Berlin. On the $2^{\text {nd }}$ June at 2 p.m., when the Emperor was driving in his open carriage to the Thiergarten, he was fired at from the second story of $\mathrm{N}^{\circ} 18$ Unter den Linden. Between thirty and forty small shot entered his face and arm. The wound on the wrist close to the artery was the most dangerous, and the extraction of so many pieces of lead very naturally caused a great loss of blood. After the first shot had been fired the feldjäger, who sat on the box near the coachman, jumped off, threw himself upon the Emperor, and thus covered him with his body; the papers did not say whether this faithful man was wounded or not. The police could hardly prevent the populace from rushing upstairs to wreak their vengeance upon the criminal; Noveling barricaded the door, the report of a shot was heard within, the door was broken open, and he was found, not dead, but severely wounded and not likely to live long; in this condition he was conveyed to prison. On the $6^{\text {th }}$ the Emperor named his son Frederick William Regent of the Empire. The Ambassadors who formed the Congress sitting in Berlin were the first statesmen of Europe, viz.;

For Germany: Prince Von Bismarck, Prince Hohenlohe, and Count Von Bulow.

For Great Britain: Lord Beaconsfield, First Lord of [_] Treasury, Marquis of Salisbury, Secretary for Foreign [689] Affairs, and Odo Russell English Minis $[\ldots]$.

For Russia: Gortschakoff, Prime Minister, Count Schouvaloff and Prince d'Oubril.

For Austria: Count Andrussy, Prime Minister, and Baron Haymerle. 
For France: M. M. Waddington, Minister for Foreign Affairs, and De Vallier. For Italy: Conti, Minister for Foreign Affairs, and Count de Sirnay, and finally, For Turkey: Sadyk Pasha, Karatheodoro Effendi, and Mehemet Ali Pasha, a Prussian by birth.

From 7.30 p.m. to 9 Brierley read to me, but neither of the two books with which we were occupied pleased me much. In Lockart's life of Walter Scott we were in the years 1803 and 1804 which treated on Antiquarian researches, very uninteresting to me. In Shakespeare's Tempest we were in the first scenes, which were neither to my liking.

Saturday, $6^{\text {th }}$ of July 1878 . Thermometer at noon $67^{\circ} \mathrm{F}$.

This morning a procession of wild beasts and equestrian performers, male and female, belonging to the International Circus of Cooper \& Co. of New York, paraded some of the streets of Lima. I did not see it though I was assured it was well worth looking at: there were three camels, one dromedary, five elephants, two lionesses and one lion with their tamer in an iron cage, a tiger, not in a cage, but tied with an iron chain lying at the foot of his tamer; four particularly pretty ponies, etc., etc. In the evening they gave their first performance in an extensive building erected for the purpose opposite the Exhibition Park.

Sunday, $7^{\text {th }}$ of July 1878 . This morning I was at the funeral of a natural daughter of Rafael Velarde, Maria, who, twenty-four years old, had died of consumption in the rancho of Baltazar Aranivar in Chorrillos, where she had been well nursed by the excellent Doña Goya. At 7.30 a.m. I walked with Garland, Enrique, Ricardo, and Ant [...] [69o] [...] os [_]minus, whence at about 8 we started for the pantheon. I was requested to take hold of one of the ribbons, hanging down from the coffin when it was carried from the terminus to the hearse. Francisco Garcia Calderon, and Jorge Velarde, (the eldest son of Melchor, who was prevented by a bad cold from attending,) held two other ribbons. After the corpse had been placed in the niche we looked at my chapel, which was now nearly finished, only the windows were not yet put in. We were back before breakfast.

Of my this day's visits I had nothing particular to say. From past 9 p.m. till past 10 Ricardo read to me Goethe's "Egmont", certainly by far superior to his Götz.

Monday, $8^{\text {th }}$ of July 1878. In the distribution of my daily occupations, a notable change had been introduced. At 11 o'clock came a certain Thos. E. Davies, a Colombian by birth, who, notwithstanding his English name and his English education, had a faulty pronunciation; he merely read to me. Bryson, who was with me from two to past five, devoted himself almost exclusively to the writing of my remodelled diary, and of my letters. Brierley read to me 
in the evening from 7.30 to 9. With Davies I had commenced the "Five Great Monarchies of the Ancient Eastern World" by George Rawlinson, from which I learned that the Ancient Chaldea was a country hardly as large as the present Portugal; it occupied the land in Lower Mesopotamia. Its northern frontier was undefined; its southern was the Persian Gulf. When in its glory it extended westward [o]ver the Euphrates to the Deserts of Arabia. The Euphrates from its source to its mouth measures about 1700, the Tigris about 1100 English miles.

From the Eclectic of June of this year I saw [...] the year 1867 the Imperial [691] British Parliament had allowed to the [_], and other territories in North America, an independent Government, that is to say, their own parliament, which met in Ottawa, and their own Cabinet, of which the first Prime Minister was Sir John Macdonald, a Conservative. The seven Provinces which constitute British North America are: Upper Canada, now called Ontario; Lower Canada, or Quebec; Nova Scotia; New Brunswick; Prince Edward's Island; British Columbia, which includes Vancouver's Island; and part of the Hudson Company's territory, called Manitoba. The annual revenue was about twenty million hard dollars. The island of Newfoundland did not seem to be included. Brierley finished reading Shakespeare's "Tempest", in which I for my part found nothing to admire.

Tuesday, $9^{\text {th }}$ of July 1878 . The Directory met in the Insurance Company "Lima", without Moscoso Melgar and Isaacson; a knotty point was discussed. On board the German Steamer "Karnac" through the Straits, Larco had shipped a parcel of salted hides, for Havre, the "Karnac" ran aground not far from Montevideo. The cargo, worth $£ 60,000$ was saved and shipped on board another steamer for Hamburg, the salvage amounting of £24,0oo. Now Elizalde asked for instructions as to what was to be done with the hides if the steamer did not touch in Havre and took them direct to Hamburg. Should the hides be sent from Hamburg to Havre, there to be held at the disposal of the consignée, or be sold in Hamburg on account of the underwriters, in this case our Insurance Company? In the discussion all took their share, and it was finally resolved to forward them to Havre if they were at all in a fair condition, if entirely spoiled to sell them in Hamburg.

I saw by the papers that a jury had absolved Ricardo Palma who was accused by General Pedro Silva for having libelled him when speaking of him by the nickname of Pata de Gallina. The Deputies and Senators for the Congress were fast arriving from all parts of the Republic and last ni [...] he P[_] [692] [...] ny of them in the Palace. Basagoytia had been there, and came afterwards to Garland's, about ten o'clock.

It had become known that the Banco Nacional had lent to the Government against orders on the Custom House, either 200,000 or 300,000 soles in coined 
sovereigns, which the Government had paid to its employés at \$9.35 [?], whilst in the market they were not worth more than from \$8 to \$8,40 [?].

The blind ex-king of Hanover, who called himself George V, had died.

Thermometer at $4 \mathrm{p} \cdot \mathrm{m} .66^{\circ} \mathrm{F}$.

Wednesday, $10^{\text {th }}$ of July 1878. Last night Brierley read to me "Julius Caesar" by Shakespeare, with which I was much pleased. The papers said that the Government had received back from its employés the sovereigns paid at \$9.35 [?], and given them their value at this rate in bank notes. My dividend in the Pacific Steam Navigation Company, 4 per cent upon 11 shares of $£_{50}$ each, say $£ 22$, were paid me in coined sovereigns.

To to-day's meeting of the shareholders of "La Providencia", I went by mistake too late. Moscoso Melgar, the Gerente, told me that 6 per cent would be paid to make up a dividend of 12 per cent for the preceding year, and that in the meeting the broker Zavaleta had made a motion, which had passed, to the effect that henceforth the Directors were to be remunerated in proportion as they attended the meetings. Eight per cent upon the capital was first to be distributed amongst the shareholders, and of the nett surplus 25 per cent to be divided amongst the Directors.

Little Corina had been very unwell on the pre[ce]ding day, and had passed a bad night. To-day she was a little better, but kept her bed.

About 9.30 when Limpricht and I were sitting [_] E[_] eta in h[_] bedroom, Dr. Middendorff came, and [693] to our great surprise was very tipsy. [...] to me in German till near eleven, said that I did not occupy in Lima the station which I ought, that I should give dinner parties and unite round me the most accomplished of the Lima gentlemen. He asked me with whom I was acquainted, objected to some, noted down the others; in short made himself very ridiculous.

Thursday, $11^{\text {th }}$ of July 1878 . Little Corina was still unwell. At noon I went to Dr. Palacios' office where Dr. Eygurren, left by him in his stead, dictated an "escrito" once more demanding the exhibition of the title deeds by Juan Aliaga y Puente.

Exchange had undergone extraordinary fluctuations; four or five days ago bills were sold at 29d; Canevaro drew $£_{30,000}$ at $28 \mathrm{~d}$ 1/2, I had bought some trifle for Schutte, Juan and myself, at $28 \mathrm{~d} 1 / 4$, and to-day the exchange was $27 \mathrm{~d}$.

Friday, $12^{\text {th }}$ of July 1878 . Last night I made an exception to the general rule and stayed up till nearly 1 o'clock; I, first, gained three games at chess from Enrique Basagoytia who understood very little about it; then conversed with Enriqueta and Urquhart. The rocambor table was formed by Garland, Mr. and Mrs. Basagoytia, and Jorge Valle. To-day Corina was out of bed.

Saturday, $13^{\text {th }}$ ofJuly 1878. At 12 the Directors of the Banco Hipotecario without Melchor Velarde were assembled, and all we did was to treat on the steps to be 
taken for reducing the great mass of doubtful debts, which of course could not be done without great sacrifice.

I learnt from the interesting work of Rawlinson that already in the beginning of the $4^{\text {th }}$ century before Christ, when Alexander the Great was in Babylon, Chaldea[?] astronomical table had been presented to him which dated 1900 years back. The tables have not come down to us but this their existence at the time of Alexander proves that forty centuries back the Chaldeans were already acquainted with astronomy. Inscriptions in simple characters have been discovered, they were made in moist clay which was the [_]ll[_]ed t[_] $\mathrm{dr}\left[\_\right]$[694] [...] arge buildings, probably temples, certainly two, perhaps three stories high, each story of smaller dimensions than the lower one. They were constructed inside of sun-dried bricks, called in Lima, "adobes", with a very thick facing of kiln-baked bricks. Their sepultures were three fold; the first, small vaults of bricks about seven feet in length and of corresponding width and height. In them the skeletons, well preserved, but crumbling to dust when exposed to air, were found stretched out on the ground, sometimes a mat below them, and always turned a little to the left; generally only one or two, in one instance 11 skeletons, in the same vault. Secondly, the skeletons were discovered lying on the ground covered with a kiln-dried bell, exactly in the shape of a dish-cover, the outside adorned with some indentures, and of course large enough to cover the corpse. Thirdly, the corpse had been put into two large jugs, the mouths of which were soldered together with bitumen.

Sunday, $14^{\text {th }}$ of June 1878 . The rains had set in and the streets were beyond measure wet and muddy, especially the carriage roads which, the former stone pavement having been removed, had been covered with the so called Oroya cement. Thermometer at noon $64^{\circ} \mathrm{F}$.

We saw by the papers that yesterday the preparatory sessions of the Senate and the Chamber of Deputies had begun, and that everything had gone off in a quiet manner; the former was presided over by Dr. Rosas, Pardo's Minister of the Interior; the latter by Dr. Chinarro, likewise a decided civilista. It was also announced that the Banco La Providencia for itself, for the Banco Nacional, and various capitalists had closed with the Government for the Nitrate of Soda consignment for five years. The "Nacional" added that the Nitrate [ce]rtificates would be increased one million pounds sterling, [...] $\mathrm{m}$ four million to five million. Garland further [695] told me that the Government had paid [...] ion eight hundred thousand soles due to the former Guano Loading Company with bonds of the Internal debt. Thus, just before the opening of the Congress the Executive had increased its debt with nearly nine millions of soles.

After Bryson had gone Limpricht and I played three games at chess; the first, which I gained, lasted nearly two hours. The fate of the two others was decided 
in less than half an hour, I lost one, and gained the other. I still had time to go to Rafael and Melchor Velarde's, who had both caught a bad cold, a disease very prevalent at present. Geraldo, with a sore throat, kept his bed the whole day.

At dinner we had Josefa Bazo with her two sons, Vicente and Belisario, and Urquhart. At a later hour Ricardo read to me one act of Goethe's "Egmont". Upon the whole it was a very dull day.

Monday, $15^{\text {th }}$ of July 1878 . The weather was quite as disagreeable and cold as the preceding day. Davies continued reading the Chaldean History.

At 2 p.m. I went to the Banco Hipotecario and witnessed the drawing of the numbers of the Cédulas to be redeemed at the end of the year. Of the Directors there was only Pedro Correa besides myself. Of shareholders, José Jimenez and Clemente Noel. First, Gallagher, then Correa called out the numbers, which were drawn by a clerk and placed upon a table. Jimenez fixed his eyes upon them to convince himself that they were called out correctly, Garland noted them down, so did Noel and a clerk of the establishment. The whole lasted about one hour and a half.

In the evening there was but one rocambor table, at which played Garland, Dr. Middendorff, Jorge Valle, and Colonel Mariscal. José Basagoytia and his son Enrique came later, the former having first been in the palace, where the president was in the habit of receiving on Monday evenings; also the Ministers, with the exception of the finance minister [_] [696] [...] evenings; but none, not even that in the palace, was so well attended as Riva Agüero's parties on Tuesdays and Fridays, he being at present the centre of the civilistas, which party was as strong and compact as ever.

Tuesday, $16^{\text {th }}$ ofJuly 1878 . In the Chamber of Deputies, the civilistas numbered at least forty-five, the Nacionales or Prado's friends, twenty-five. In the Senate the disproportion was still greater, twenty-eight or twenty-six against six or eight; consequently, only civilistas were qualified, and their number increased from day to day. Amongst others Aurelio Garcia y Garcia had been qualified as Deputy for Tumbes; Julius Pflucker y Rico for Castro Vireyna, Augusto Althaus, Senator for Ancachs; all three, decided friends of Pardo,

My lector Brierley, having been married on Sunday last in the office of the German Chargé Doctor Lührsen, did not come to read to me neither yesterday, nor this day. Ricardo took his place. We finished Goethe's "Egmont", and began his "Clavigo". Davies and Bryson came regularly. The Chaldean history continued to interest me much. The first of their kings was Nimrod, the great hunter before the Lord; about 2300 B.C. He founded the town of Ur, or Hur. Babylon was of a somewhat later date.

Wednesday, $17^{\text {th }}$ of July 1878. All the Directors and the Gerentes of the Banco del Perú assembled. We were informed that Garcia Calderon had proposed to 
the bank to take an interest in the Contract which the Banco La Providencia had concluded with the Government, and of which the following were the principal conditions: The "Providencia" was allowed to form a company with a capital of $£ 800,000$ in 1000 shares of $£ 800$ each. The "Providencia" took 20 per cent, Banco Nacional [...] cent, Benito Valdeavellano who represented a group of [697] capitalists, 40 per cent, of which he offered 20 [...] del Perú; 10 per cent, Dionisio Derteano, and 10 per cent, Francisco Garcia Calderon. The Company was to have the exclusive consignment of all nitrate, except that for the United States and Canada, which had been conceded to Oliphant \& Co. for five years. It was to pay to the producers of nitrate, 6 shillings the quintal; it charged the Government for all expenses, Freight, Commission, Landing, Storing, Store-rent, Fire Insurance, etc., etc., $£_{4}$ the ton. If the freight exceeded $£_{2}, 15 \mathrm{~S} /$-, the surplus was to be on account of the Government. Insurance against sea risk on account of the Government; for chartering vessels the Company charged the customary commission. Interest pro and con, six per cent. The company had to advance to the Government $£_{3} 60,000$ in six monthly instalments to begin with the $1^{\text {st }}$ July. After the six months £20,000 monthly. The certificates would be increased from four to five million pounds, the last one million to be issued gradually within the next two years; this million was destined for the payment of the Government's debt to the Compañia de Fomento. No difference was made between the old and new certificates which might even be increased to six millions. These certificates would be converted into bonds, which would pay the same interest of 8 per cent at $44 \mathrm{~d}$ as hitherto, and 4 per cent would be redeemed annually not at par, but by sealed tenders. The Company was bound to hacer el servicio of these bonds. The quantity of Nitrate to be shipped annually not to exceed 6 millions and not to fall short of 5 million quintals. So far all looked well, but quite at the end, a condition was introduced which to the holders of certificates was extremely disadvantageous; it said that these different payments would be made as long as the stock of nitrate on hand enabled the Company to do so. Thus there was nothing certain for the payment of the interest of the certificates, for if the proceeds of the Nitrate sold did not suffice, then of course the interest on the certificates would decrease in proportion, and consequently the old $£_{4,000,000}$ certificates were much prejudiced by the emission of the new $£[$ [_] [698] [_] other conditions were of less importance. The Company would be administered here in Lima by five Directors, a gerente, and the necessary number of clerks; the Directors to have each a salary of $£ 800$. We resolved unanimously to take no share in the business. To me it was clear that none of those who were present liked to have anything to do with Garcia Calderon and Derteano. We were further of opinion that the holders of Nitrate 
Certificates should apply to the Congress and demand the cancelment of this contract.

Thursday, $18^{\text {th }}$ of July 1878 . We saw by the papers that the conference in Berlin had been closed, and that some modifications had been introduced into the treaty of San Stefano. The particulars I shall specify as soon as published.Turkey, it was said, had ceded the Island of Cyprus to England. From Rawlinson's work Ilearned that ancient Assyria in its widest extent had the following frontiers: to the south it bordered on Chaldea; to the north it was confined by the mountains of Niphates; to the east by those of Zagros, to the west by the "Euphrates". Thus it included Upper Mesopotamia, which was however of less importance than a tract of land to the left of the Tigris, its size was more or less double of that of Portugal.

In the evening Garland had two rocambor tables; with young Enrique Basagoytia I played four games at chess giving him the king's bishop, and played so badly as to lose two of them. Then conversing with him, Urquhart and Enriqueta I remained up till midnight, much too late to my taste.

Friday, $19^{\text {th }}$ of July 1878 . The papers published an order of the Government which said that the Nitrate certificates which were to be handed by the "Providencia" to the Compañia de Obras Públicas, and which were to form a total of $£_{1,000,000}$ were not to exceed $£ 42,166$ monthly.

To Dr. Quiroga's reiterated order to Juan Aliaga [699] y Puente to exhibit the tittle deeds of his finca of which [_] small house in the Calle de Polvos Azules embargoed by me is a part, he gave in an "escrito" in which he said that he could do no more than what he had done, viz.: to name the notary Eusebio Perez in whose office in the year 1560 odd the Mayorazgo of the family Aliaga had been founded, and that consequently he appealed from Quiroga's sentence to the Superior Court; this appeal having been conceded to him I went to my lawyer, who dictated a very proper "escrito" in which he explained that such and such an article of the Codigo de Enjuiciamientos said that a debtor had to declare where the title deeds are, and that consequently Aliaga y Puente ought to state in which of the archives of the present notaries the deeds were to be found, it not being sufficient that he should name a notary who lived three centuries back.

Saturday, $20^{\text {th }}$ of July 1878 . From Rawlinson's history I learned that to judge from the numberless ruins found in the land which in ancient times was known as Assyria, the whole country had been studded with towns of different sizes. The author gives the names and sites of many of them. I will only mention Nineveh, the largest of them all, situated not far from the present Mosul, to the south of it Kala or Nimrod, still further south Asshur, and to the east of Nineveh, Arebil, the Greek Arbelar, all four to the east of the Tigris. 
My letters from Juan and Schutte contained little of importance. Juan said that the Paris Exhibition had been visited on one day by 198,ooo persons and that 15,000 had remained outside for want of tickets. Schutte was in a very poor state of health, and his legs had again swollen considerably.

The cutting from an English newspaper, affixed in Appendix under $\mathrm{N}^{\circ} 28$, gives an interesting account of the opening of the Berlin Congress. This day in the Senate Lizardo Montero, who had already embarked in Valparaiso for Callao, was [...] [700] [...] ra. The Civilistas preponderated to such a degree that the opposite party offered no resistance whatever, and there were not a few who pretended that even the President favoured them at present.

Sunday, $27^{\text {st }}$ of July 1878 . The streets were dry, no rain fell. Thermometer at noon $65^{\circ} \mathrm{F}$. I got through with nine visits, of which I only specify that to José Canevaro, who was beyond measure polite, in my opinion more than he should be, considering that he was the second Vice-President of the Republic. His wife, he told me, had gone to Chorrillos to see her sister Victoria, who the day before had returned from Europe with her husband Carlos Pividal, who, it will be remembered, had been sent by Prado to settle the differences between Dreyfus and Raphael, in which he had succeeded, but what he had done was not approved of by the Lima Government. He had now come back, having been superseded by Althaus and Aranivar. Canevaro also introduced me to his brother Napoleon, who at an early age had entered the Italian naval service and who was now in the Port of Callao, as Captain of the Italian man-of-war Cristofero Colombo; he appeared to me to be a puny little fellow, as all the Canevaros are. Yesterday a lunch had been given in honour of him and of his brother officers in the Exhibition Park by the Italian Minister, to which had been invited the Diplomatic and Consular Bodies, the Minister of Foreign Affairs, the Alcalde of Lima and other personages, amongst whom Enrique, as Danish Consul.

In the evening Ricardo read to me one act of Goethe's "Clavigo".

Monday, $22^{\text {nd }}$ of July 1878 . The sun was out. Thermometer at 2.30 p.m. $65^{\circ} \mathrm{F}$.

I was present at a meeting of the Directors of the Banco del Perú when we authorized the Gerentes [...] up the shares of the Bank if they could [701] be had at 90 por ciento. Esc [...] had been informed that a vital alteration would be made in the contract between the Government and the Banco de Providencia, of which I gave the Particulars on the $17^{\text {th }}$ inst. Viz.: That the "Providencia" or the Company to which the Nitrate business might be transferred would take upon itself the unconditional payment of the interest on and the redemption of the Nitrate Certificates.

On my return from my customary walk to give Bryson time to copy my diary I received a message from Böhl requesting my presence at a meeting of owners 
of nitrate establishments and of holders of nitrate certificates, which was to be held in the Exchange rooms at 4.15 p.m. I went, by and by from 20 to 30 gentlemen entered of whom I hardly recognised a single one; they took their seats round the table; I, mine, next to Böhl who read "una solicitud" addressed to the Government in which the petitioners after referring to the contract lately concluded with the "Providencia" requested the Government to suspend the emission of the last one million pounds sterling of Nitrate certificates. I was the first to speak, and said that the Government would never make this concession, because they wanted the money to pay La Compañia de Obras Publicas, and that we should content ourselves with asking that this one million of pounds sterling were secured by the second mortgage on the Salitreras, the original four millions having the first. Oscar Heeren coincided with me. Böhl gave no opinion of his own and merely expressed a wish that, whatsoever was decided, as many signatures as possible might be affixed to the petition. Others, amongst whom Pratolongo, said that we ought to concede nothing, but stand upon our right, and that we should always have to lay our complaint before the Congress. This opinion prevailed, and an amendment of Pratolongo's was approved of, which said that this emission should be suspended until the original four millions were paid off. With this addition the document was to be placed on the following $[\ldots][702][\ldots]$ change Rooms to be signed by all such a[_] might be inclined to do so, and then to be presented to the Minister of Finance by a commission consisting of Pratolongo, Mathison, and a certain Ugarte, a Salitrero in the province of Tarapacá. When walking home with Böhl he told me that Gibbs held certificates to the amount of \$1,250,000, for which they had sold their "salitreras" to the Government.

In the evening Garland had only Valle and Pinto to play rocambor. I went to my bedroom at eleven. This was the saint's-day of Magdalenas, the President's wife. She and her husband had gone up the Oroya line and would not return till this evening. To-day Antonio went for the first time to Gibbs's store as clerk.

Tuesday, $23^{\text {rd }}$ of July 1878. Little Corina's birthday, who completed her $8^{\text {th }}$ year. She was overwhelmed with presents of all kinds; mine consisted of 20 hard soles and a pair of pretty diamond earrings. Davies came at eleven to tell me that a very bad toothache rendered it impossible for him to read to me. I remained at home, lying on the sofa for the greater part of the time till Bryson came.

The sun was out. Thermometer at $4 \mathrm{p} . \mathrm{m} .67^{\circ} \mathrm{F}$. The papers said that the Executive had cancelled the concession made to the brothers Ramos for the construction of a railway from Lima to Pisco, and that to Bedoya of Islay for the irrigation of the Pampas of Tambo, and the construction of the railway from Islay to Mollendo. 
At dinner we sat down not less than twenty-one persons. Garland and Enriqueta with all their children except Alejandro and Juan, the former of whom had ceased coming to the house, the motive of which was that Enri- [...] to see his wife; of Juan I knew nothing [703] whatever; they said that he was in his room, $[. .$.$] that at this time Enriqueta was sending his breakfast and dinner$ to him. Besides the said nine of the family, the children had their friends the two Lacroix, Sofia Velarde, and two daughters of Colonel Vargas; further, there were also Castañeda, the music master; Dr. Middendorff, Jorge Valle, Urquhart, Limpricht, and I; dinner was very nice, as Enriqueta always had it whensoever she celebrated the birthday of one of the family. We had however to rise before dinner was over because Enriqueta had to receive several ladies with their daughters who had been invited at Castañeda's particular request in order to take part on what he called "un concierto infantil", of which the programme drawn up by him will be found in Appendix under $N^{\circ}$ 29. At 8.30 they began playing the piano. The best performer was undoubtedly Maria Jesus Ballen, Anita Bergmann also played very well; these, like Maria and Corina, were pupils of Castañeda; Maria Theresa and Maria Santillana played twice; all of course were much applauded, and as far as I could judge, I really believe that considering their age they did very well. The other guests present were Aurora, the grown up daughter of Asuncion Santillana; her brother Gervacio in the Peruvian naval service, a brother of Anita Bergmann, two young Basagoytias, Maria Mendoza, and Mr. Rand, a North American, belonging to the staff of the Oroya Co., a great friend of Corina's, with whom I had a long conversation, in which he gave me a glowing account of the Machinery bought by Mr. Cilley in San Francisco, and which was to be put up in the Cerro de Pasco for the purpose of crushing and amalgamating the desmontes.

Garland sat down with Valle and Middendorff to play rocambor. Enriqueta only gave tea, and, at a late hour, chocolate. All seemed to be well pleased. The young folks with their mothers left at about eleven. I was in bed by midnight; the rocambor players were still at their work.

The great news of the day was a telegram received from Valparaiso, which said that the Chilian C [...] [704] [...] lation, till the $31^{\text {st }}$ August of next year, of the notes issued by the various privileged banks established in Chile; and secondly, the unanimous qualification[_] of Don Manuel Pardo as Senator for the Department of Junin, by 40 votes. Of his "dual" General La Cotera no mention whatever had been made.

Wednesday, $24^{\text {th }}$ of July 1878 . Once more a sunny day. At 4 p.m. thermometer in my office, $68^{\circ} \mathrm{F}$. As had been expected, Rafael Velarde was not qualified in the Chamber of Deputies as Deputy for Arequipa. His dual, M. San Roman, was, by a large majority. 
Thursday, $25^{\text {th }}$ of July 1878. With my colleagues, Sebastian Lorente, Pedro Correa and Melchor Velarde, I was at two in the office of the Banco Hipotecario. We treated on various subjects, the only one of which worth noting was that of the debt of a certain Gonzales del Riego, amounting to \$50,000, secured by a mortgage upon an estate of his in the neighbourhood of Santa, who since he received the loan had never paid a single real; after due consideration we authorized the gerentes to sell it for \$15,000 if this sum could be obtained, of which there was still a doubt. It was Riva-Agüero who had made the loan at the time he was gerente.

Garland and Enriqueta dined with Feder[_] Palacios and his wife. On their return the former was very sad because the physician Almenava, who had closely examined little Corina, had declared that in his opinion she had a great propensity to become asthmatic. He strongly advised change of climate.

In the evening, to my great surprise, the Brazilian ex-chargé Asambuja made his appearance to play at rocambor without, as Garland told us, being invited by him; Pinto, Basagoytia and Garland were the three others. Colonel Mariscal, Valle and Limpricht were also present, [...] played. [705] The Civilistas passed from victory to victory. Aurelio Garcia was qualified as Senator for Ayacucho; Carlos Paz-Soldan thrown out as Deputy for Contumazá.

Friday, $26^{\text {th }}$ of July 1878 . I took a walk over the lower range of San Cristoval, ascending from the side of El Paseo de Aguas, and descending near the baths of Altazar. I accomplished it in an hour and a half.

I saw by the papers that the Diplomatic Body had conceded to Moncenni, the Papal Delegate, the precedence as an act of courtesy towards him, not as his right. When they had met to treat on this subject, Gibbs for the United States and Lührsen for Germany had absented themselves; only three, viz.: Vorges for France, Uriburu for the Argentine Provinces and Pinto for San Salvador, had voted that the Delegate should be looked upon as their Senior, or Decano; the remainder being of the contrary opinion. A protocol was drawn out giving these particulars, as well as the above concession made to him and which had been moved by Godoy, the Chilian Minister and hitherto Decano, to which Gibbs gave his written assent; Lührsen abstained from taking any part.

Saturday, $27^{\text {th }}$ of July 1878. I was in the Banco del Perú from 12.30 till near four. All the Directors were present. The report to be laid before the shareholders in the next general meeting was discussed. It had been drawn out by J. P. Escobar, and been much modified by Manuel Candamo, the President. After giving an account of the present state of the Bank, and of the operations of the same in the first six months of the year, 41/2 per cent interest was declared. The shareholders were told amongst other things that the Directors had thought prudent to take no interest in the Nitrate of Soda contract. And, that they had 
continued to buy up shares, so that the amount of the shares in circulation was reduced to three million soles. Next, the shareholders were to be asked whether they would liquidate the bank or continue on a new system, because the bank had ceased to be a bank of emission and had now a paid up [_]ital [...] [706] [...] six thousand shares of \$500 each. Should the latter be resolved upon then the old statutes had to be completely altered, and with this alteration we were occupied for a length of time without coming to a conclusion. Every one of us took his share in the discussion. We were told that Carlos Elizalde had been named one of the Directors of the new Nitrate of Soda Company, as representative of Gaston of London, uncle of Benito Valdeavellano, who was of the group of capitalists interested for 40 per cent and he, Elizalde, could therefore not continue to be one of the Delegates of the Bank. The Gerente Escobar was named to accompany Juan Calderoni in the Delegation. César Canevaro, the other Gerente, Deputy for Huarochiri, who had left us for a few minutes, told us on his return that in the Senate Manuel Pardo had been chosen President, and Riva-Agüero, Vice; in the Chamber of Deputies, Camilo Carrillo, a naval officer, Director of the naval school in Callao, Minister under Balta and again under Pardo, President; Ricardo Wenceslao Espinosa, son of Don Narciso of Payta, whom I remembered as one of Gibbs's correspondents, 40 years back, Vice; and Julius Pflücker y Rico, son of Don Carlos, second Vice. Apprehensions had been entertained that the party which called itself "Nacional" would have raised disturbances in the course of this day, but the Minister of the Interior, Fernando Palacios, and the Prefect Lara had taken the necessary steps to prevent an outbreak. In the Cabildo a few of them had met, made an attempt to harangue the people without having been listened to, and had then drawn out a petition to the government demanding a plebiscite. It was said that a turbulent sambo carpenter called Aguilar had been arrested.

Sunday, $28^{\text {th }}$ of July 1878 . From an article in the "Eclectic" of 1877 , read to me last night by Brierley, I learned that amongst the Mussulmans there exists a schism. The one party, which calls itself the "Orthodox" and to [707] which the Turks belong, are called the [_]. [_] consider the three immediate successors of Mahomet, viz.; Abu Beker, Omar and Othman to have been legitimate, whilst the schismatics, the Shiites of whom the Persians are the most important, call these three successors Usurpers, and affirm that the first true successor of Mahomet was his son-in-law Ali.

On the $24^{\text {th }}$ inst., early in the morning, when sleep is not so sound as in the first hours of the night, I was awakened by the sound of the word "quien" loudly pronounced by a voice exactly like that of my dear wife. I knew full well that this was a mere illusion of my imagination, but at the same time it was a proof 
that I had her fresh in my mind, her, whose image I was confident would not fade from my recollection as long as there was breath in my body.

An important alteration had been made in the Nitrate of Soda contract. On the $26^{\text {th }}$ inst. the Government decreed that the 4 per cent annual redemption was to be made by paying every six months, two per cent of the capital, by which means every certificate, or bond, if the certificates should be changed for bonds, would annually decrease 4 per cent. Secondly, on the same date the Minister of Finance addressed a few words to the Gerentes de la "Providencia" saying that the Government considered the obligation which the "Providencia" had taken upon itself to make the payments enumerated in the contract, was á firme; in other words, that the "Providencia" had to make these payments at all events - even if the sales of the Nitrate did not furnish them with the necessary funds. The reply of the "Providencia" was not yet published.

When Bryson was gone at $2 \mathrm{p} \mathrm{m}$, Limpricht and I sat down to play at chess. We played till near six, allowing ourselves to be interrupted only for a short time, when Enriqueta called us to see the President return from the Congress, which had been opened this day. The first game I lost; the second was a drawn one, I remaining with the king, two pawns and the king's bishop, Limpricht with the same less one pawn. In [...] [708] [_] we found but few lookers-on: Melchor, his youngest daughter Maria, Guillermo, Eliza, Federico Palacios, his wife, and a young Pezet. The streets were lined with soldiers; the President was preceded by the Jueces de $1^{\text {a }}$ Instancia, the greater number of the members of the Superior and Supreme Courts. With him were his ministers, one or two generals, other military men and some civilians. General Rivarola on horseback commanded the troops who in gala uniform followed. The last were the small body of "Cabos" who had for such a length of time been drilled by the late Antonio Bazo.

At dinner we were again not less than twenty-one. The whole family (except Guillermo, Alejandro and Juan), Federico Palacios, wife and little girl, Melchor and youngest daughter, Zoila and Sofia Velarde, Doña Juana Carbajal, Enrique Basagoytia, Urquhart, Limpricht, Castañeda and I. The conversation was much more lively than on other occasions; also after dinner I talked a good deal with Melchor and Palacios; however near eleven o'clock I felt so sleepy that I had to go to bed, when all were gone except the Palacios'.

Monday, $29^{\text {th }}$ ofJuly 1878 . Ricardo read to me the message which the President had read yesterday in the Congress. It gave an account of the progress, which according to him, the Country had made in every respect; he said that all financial difficulties were solved, excepting the interest on the external debt which had not been paid for several years, but which he promised to do for 
the future if possible. He also declared that the Country required a new manof-war, more powerful than any of the vessels which constituted the present Peruvian navy.

This day being considered a holiday, Davies did not come, in lieu of him Bryson, who remained to past two. Besides remodelling the diary of 1874 , we were occupied [...] the corrected one of December 1868. [709] From 2 to 4.30 p.m. Limpricht and I played ch[_]. I gained two games, he one. At the end of the second, which I gained, we had both, the king, four pawns, one castle and one knight; so that apparently we were equal, but I had the advantage in being the first to make the attack.

I then took my usual walk to the Chorrillos gate and met the greater part of the so-called civic procession on its return; there were the fire brigades, several groups representing various American Nationalities with their respective banners, boys and girls from the Municipal schools and several bands of music playing the national hymn. The foot pavements were crowded to excess, with I should think two to three thousand persons. A drizzling rain fell, and it was a disagreeable afternoon.

At dinner we had Anibal Gonzales with his wife and three of his children: Irene, Vicente and Maria. I got up from dinner at 7.30 and listened to Brierley's reading till nine. From the $3^{\text {rd }}$ Scene of the $3^{\text {rd }}$ Act of Hamlet I copied the following sentence: King. "My words fly up, my thoughts remain below; Words, without thoughts never to heaven go."

Two rocambor players came rather late, Valle and Basagoytia. With them, Garland and Gonzales sat down. Dr. Middendorff came still later; I went to my bed-room at eleven.

Thursday, $30^{\text {th }}$ of July 1878 . Horse races were held at the race ground half way between Lima and Callao, to which the seven sons of Garland, Juan and Ricardo excepted, went.

Wednesday, $3^{\text {st }}$ of July 1878. Again horse races like yesterday. However the greater part of the shops and stores, also the foreign houses and Tribunals, were open, only the banks closed. From the London "Times" of $7^{\text {th }}$ June I took the following particulars of the collision of the two German iron-clads, "Der Grosse Chürfurst" ("The Great Elector") and the "King William", and the consequent fatal loss of the former. It took place on the $3^{\text {st }}$ May last in the morning when the weather was exce $[\ldots][710][\ldots]$ y clear, the sea smooth, and a slight breeze blowing from the East. They steamed westwar[_] at about 9 knots an hour, in two columns, the starboard being formed by the "Great Elector", the larboard by the "King William" and "Preussen", but according to the opinion of the "Time" much too near to each other. When they were abreast Sandgate, close to Folkestone, three miles from the coast, sailing vessels went across their 
bows. To avoid them they manœuvred, came in contact with each other, the "King William" ran her ram into the "Great Elector", which went down in, some say six, others ten minutes. Of 497 human beings on board 213 were saved, amongst whom the Captain Count von Montz and the first lieutenant. She was a vessel of 6623 tons and in 1875 was launched in Wilhelm's-hafen. The "King William" was considerably damaged by the shock, and the Admiral Bartsch made the best of his way for Portsmouth where the damage was to be patched up, and thence she was to proceed to Wilhelm's-hafen for complete repair. She measures 9925 tons, was built on the Thames, originally for the Turk[_] Government and cost $£_{508,000 \text {. }}$

The "Eclectic" for April 1878, in the article called "March of an English Generation through Life" contains the following interesting statistics as to the average mortality in England. Of one million human beings born, one fourth are calculated to die before 5 years of age. Of the remainder, 161,200 reach the age of 75, 38,000, 85, and 220, 100 years. Farmers and field-labourers upon the whole live longest, also carpenters and joiners enjoy long life. On the contrary, amongst publicans the mortality is greatest, next amongst butchers and fishmongers. Liverpool and Manchester and their vicinity may be locked upon as the most unhealthy spots of England, or at all events there [ $t$ ] he mortality is greatest. London, notwithstanding its [_] population is not unhealthy. Consumption is [711] the disease which carries most persons to the grave.

In the evening the literary club gave a more than usual grand soirée in the Exhibition Palace. Some members read treatises written by them, a lady for instance one on the glory of Bolivar. Mrs. Lührsen was likewise there, and favoured the party with several songs. Enrique, as Danish Consul, had received an invitation but did not go. The Hall was crowded, but the company not very select.

Thursday, $7^{\text {st }}$ of August 1878. I went to see Moscoso Melgar, and asked him what answer the "Providencia" had given to the Government's note relative to their doing the servicio á firme. His answer was that the bank had replied that they had made over the contract to a Company, and that the Company he believed would take upon itself el servicio á firme except in "casos fortuitos", such as war, earthquakes, cessation of the production of Nitrate, and similar unforeseen events.

Friday, $2^{\text {nd }}$ of August 1878. Before breakfast Dr. Palacios came to see Garland. I asked what news there were from Arequipa. His answer was that the disturbances there were of a very serious nature, and that both there and in Puno the Prefects could not keep down the populace, which asked with one voice for the dissolution of Congress and the meeting of a constituent assembly, because, according to them, the qualifications here had been illegal 
in every respect, which in my opinion, in some instances, had certainly been the case, for, as we well knew, only Pardo's friends had been qualified. Palacios added that two ways were open to the President; the one to act in concert with the Congress and to be overwhelmed by general dissatisfaction which he thought would spread to the departments of Cuzco and Ayacucho, or, to dissolve the Congress. It was clear to me that he inclined to the latter. On the $28^{\text {th }}$ when the Congress opened its sittings about 20 of the so-called Nacionales had abstained from attending in the expectation that by doing so the number would be so reduced as not to form a quorum. Then the Civilistas had called in the Suplentes, which measure, one party said, was in every respect illegal [_] [712] [_] Deputies were in Lima, whilst the other party defended its legality.

At 12 o'clock I was in the Banco Hipotecario with Correa, Galvez, and Melchor. Lorente did not attend. The Gerentes told us that in their opinion it was necessary to make an alteration in the annual redemption, and Gallagher read the plan which they had drawn out. Correa proposed, that in order to discuss it we should call in several of the principal shareholders, to which we others consented. J. V. Oyague, Aurelio Denegri, Manuel Candamo, Dionisio Derteano, José Jimenez and Dionisio Villate were the six whom we thought of calling in.

The President held this day a review of the troops in Amancaes. There was also the feast of "La Porciuncula", when in the convent of Los Descalzos provisions are distributed to all the poor who present themselves. On my going to the Alameda to witness this distribution of provisions I was surprised to see an uninterrupted stream of persons, particularly women, enter the Church at one door and come out at the other. On my enquiring what was the cause of this, I was told that all those who on this day, the "dia de los Angeles", say a certain number of certain prayers in the Church of Los Descalzos are certain to gain great indulgences.

Saturday, $3^{\text {rd }}$ of August 1878. Last night Rafael Canevaro and his wife Inéz Laos gave a ball as a farewell party before leaving for Europe on the $8^{\text {th }}$. Of our whole family only Antonio went.

This morning I received a note from the Gerentes of the Banco de Lima in which they informed me that the bank ceased to allow interest in account current. Accordingly, I withdrew my small balance and closed the account which I had had open since the establishment [of] the Bank in January 1870. The number of the clerks [...] en reduced to two: Polo, who now also kept the books, [713] and Sanchez who received and paid the [...] $\mathrm{n}$ and went out.

When I went to the Banco del Perú, the Directory was already assembled. The report of the Gerentes, now corrected and modified, was again read and approved. Before we rose I said I was sorry I had again to revert to a point 
on which I did not agree with them, viz.: on the remuneration which in the new statutes had been allowed to the five Directors, \$15,000 annually, after all expenses as well as 9 per cent interest to the shareholders had first been deducted from the gross gains, which I thought to be too large a sum. Not one sided with me. Candamo and Ayulo kept silent, Elizalde, Calderoni and Ruden tried to convince me that I was in the wrong. At last I said, "Me callo; pero no estoy convencido."

In the evening Brierley did not come. Enriqueta was in bed suffering from migraine; Ricardo came home late and thus I spent a few dull hours. The "Nacional" said that a telegram had to-day been received from Mollendo which brought the news that Belisario Suarez, Prefect of Arequipa, had declared himself Dictator.

Sunday, $4^{\text {th }}$ of August 1878. Last Sunday I played chess, thus it was to-day my turn to pay visits. I went to Doctor Alvarez's, to condole for the loss the family had sustained by the death of Mariano Velarde Alvarez, the Doctor's nephew, who had expired in Ayacucho, at the age of 40 years, on the very day when in the Senate he had been qualified as Senator for his department. At the time that Pardo, Ureta and Arenas were candidates for the Presidency of the Republic he sided with Ureta; but on Pardo's election he joined the Civilistas heart and soul.

From J. V. Oyague I learned that the $\$_{2}, 800,000$ due by the Government to the late Guano Loading Co. had been cancelled; \$1,700,00o which the Company owed to Drey [...] [714] [...] had debited them and credited Dreyfus, whilst the balance of \$1,100,000 the Company had received some bonds of the Internal Debt at 75 per cent. He further told me that the loading of Guano had become a difficult operation, for it was at present found at a great depth, was frequently very hard, and almost invariably mixed up with stones and pieces of rock. He thought that 71 pence per ton which the Government allowed them could leave no profits to the loading Company.

Everywhere the news received from Arequipa was the topic of conversation, and it was now known as a fact that the telegram received by Manuel San Roman was at all events incorrect. Arequipa was agitated, the populace not satisfied with the present Congress, but the Prefect was hitherto faithful to the Government.

At dinner we had Jorge Valle, Urquhart, and a young Hamburgher with whom the Garlands had been at school in Schüler's establishment. He was the son of the Danish Consul-General in Hamburg, Pontoppidan, and was travelling for pleasure. Not being conversant which the Spanish language he was rather taciturn, for he had the seat to Enriqueta's right; English he spoke well having been for several years in New York. I conversed with him in German. From 9 to 
10 I played a game at chess with Limpricht, which was toughly contested. He had by far the better of it and was on the point of gaining, when owing to an oversight of his I succeeded in mating him.

Tuesday, $6^{\text {th }}$ of August 1878. When I went to the office of the Insurance Company "Lima", where the Directors had been cited to their usual monthly meeting, I found none of them. After a few moments however Mathison came, and Elizalde proposed to us two insurances against sea-risk, which Isaacson had already approved, the one on a steam-tug of [_] Guano loading Company for one year, the other a cargo [715] of sugar by German vessel Alfred from [_] o New Sealand We agreed to take these risks, the former at the lowest, 5 per cent per annum; the latter, §30,000, one half of the value of the cargo, at $11 / 4 \%$. Thence I went to the Banco Hipotecario, where, besides the Gerentes and the three Directors, Lorente, Correa and I, the following gentlemen, shareholders, and holders of Cédulas, whom we had requested to join us, viz.: J. V. Oyague, Aurelio Denegri. Manuel Candamo, Dionisio Derteano, Dionisio Ortiz de Villate, José Jimenez, and Alejandro Garland, joined us. Gallagher read to them the same report, which in our last meeting we had approved, and which explained that it was impossible for the bank to continue the redemption of the cédulas in the same manner as had been done hitherto, and which had caused an extraordinary outlay, amounting at the end of this year to $\$ 1,500,000$. $\mathrm{He}$, in the name of himself and his co-gerente, proposed that the redemption should henceforth be made in conformity with the Schedule to be found in the Appendix under $\mathrm{N}^{\circ} 30$; which would redeem each cédula in the course of twenty years, from the date of its being issued, which was all the holders could demand, and that from the amount to be redeemed each six months, las amortizaciones extraordinarias, that is to say the cédulas paid in by the debtors of the Bank, should be deducted. This plan presented only one difficulty viz.: that the amortizacion extraordinaria of one half-year might absorb the entire amount to be redeemed for the public; to obviate which it was further proposed that in such a case it should be left to the prudence of the Directory and the gerentes what proportion of la amortizacion extraordinaria was to be applied to the current half-year, and how much was to stand over till the next halfyear, so that a fair amount would always be redeemed for the public. The plan was unanimously approved, the spokesmen being Oyague, Villate, Denegri and Derteano. Candamo and Alejandro said a few words, so did Garland Senior. Gallagher gave all the expla[_] [716] [...] not speak; Correa, likewise, was more silent than usual. Lorente spoke, not much to the purpose. Denegri went so far as to propose that we should take measures to get back the one million and a half improperly disbursed; this was opposed by all present. Nevertheless, a commission consisting of Denegri and Derteano was named to re-examine the 
accounts of the Bank and to report to the Directory the possibility [_] nonpossibility of recovering the above mentioned amount.

In the course of the day it became known that the news received by San Roman on Saturday last, as to the Dictatorship of Colonel Suarez in Arequipa, was correct, and that the cable having been in possession of the revolutionary party, the false telegrams speaking of tranquility prevailing in Arequipa had been purposely sent, in order to lead the Government astray.

The steamer from Panamá, due since Saturday last, had not yet arrived; and nothing whatever was known about her. The agent of the Company in Callao, Noel West, had sent the "Santiago" in search of her. The itinerary of the steamers to Colon and from Panamá hither, had been completely altered of late. Mr. Noel West gave the following reasons: The contract between the Company and the British Government, in virtue of which the latter paid to the former a very considerable subvention annually, had expired. The Government having entered into the cheap universal postage league, had reduced the subvention to one sixth, and consequently, the Company had to make up for this loss by touching at more ports than hitherto, in order to make more passage money and freight. Moreover, as long as the large subvention was in force, the Company's steamers were bound to arrive and depart at certain dates, which was [n] ow done away with, and therefore the changes were made, $[. .$.$] agreeable to the$ Lima Mercantile community. [717] We had now a steamer every Thursday, [...] very month corresponded with the Royal Mail for Colon.

Mr. and Mrs. Federico Palacios dined with us, the latter had assisted Enriqueta in sewing dresses for the two little girls which they required for the $9^{\text {th }}$, as will be seen in due time.

The Superior Court sentenced that Juan Aliaga y Puente had not to exhibit the title deeds as I had demanded, because he had done his duty in indicating the office of the notary where they were originally drawn out, and lists were in existence which showed where the archives of notaries of former centuries were deposited at present. I went to make enquiries in the office of the Notary Francisco Palacios where they could not throw any light on the subject. A young man asked me S1oo to find out the title deeds; I turned my back upon him and walked to the notary Iparraguirre's, who on examining his list at once discovered that the archives of the notary Estevan Perez, before whom in 1576 the Mayorazgo or entail of the Aliaga's had been founded, was in his possession.

As soon as Mr. Brierley was gone I went to bed, for I was extremely low-spirited.

I had found in Carlyle's history of the French revolution the following derivation of the English word "king", which comes from the Danish Kong, or German König, which formerly was Kön-ning, which word had clearly its 
origin in the verb Können, Anglicé to can or to be able, and thus it would mean a man who can do something, or who is powerful.

Thursday, $8^{\text {th }}$ of August 1878. To-day left for Europe by the steamer for Panamá: Rafael Canevaro, his wife Inéz Laos, children, and servants, also Luciano Benjamin Cisneros with his whole family, he as Peruvian Minister in Rome ad honorem.

At a meeting of the Directory of the Banco del Perú, Elizalde and Ayulo did not attend. Calderoni and Escobar had hitherto not been able to come to ter [...] [718] [_] Compañia Salitrera del Perú as to the manner in which the large debt owing to the Bank by the late Delegation, now to be paid by the new Company, was to be cancelled. F. Garcia Calderon was President of this Company, Carlos Elizalde, Vice, and Luis B. Cisneros, Gerente. I spoke first, and said that we should not recede from our original demand of £10,00o monthly, and interest $10 \%$ annually, by which means the pounds sterling debt would be cancelled in 13 months, the debt in Soles to be paid in the same proportion, with the same interest. After all had given their opinion, Escobar and Calderoni were instructed to insist either upon £10,00o monthly, and $10 \%$ interest, $£_{15,000}$ and $9 \%$ interest, or $£_{20,000}$ and $8 \%$ interest, or, as $\mathrm{Mr}$. Ruden suggested, the whole amount cash down, which, of course, was not to be thought of. The debt in soles to be paid in the same proportion. Much was spoken about politics, and all, particularly Calderoni, took a very black view of the present state of things. He said it was quite impossible that a fortnight could elapse without the Government and the Congress coming into collision, the consequence of which could not fail to be anything but complete anarchy. He had last night been in the Palace, when the saloons had been crowded with the so-called Nacionales, not with Civilistas as had been the case of late. Prado had not played rocambor, but been in an inner room, together with Saavedra, and other men of the same clique.

At a later hour I went out to the pantheon to look at the chapel, which the Compañia de Fomento had written to me was finished, and of which I had received the keys; though the key fitted I could not open the door and was thus unable to distinguish whether a crucifix, which the Company had to furnish, stood upon the altar or not.

In the evening Dr. Middendorff, Pinto, [_] V[_]lle, Melchor Velarde, Jose Basagoytia and his two [719] sons, were with Garland and Enriqueta.

I played a game at chess with Limpricht, who by sacrificing a bishop, mated me; the mate was taken back, I being able to defend myself by a proper move, and then Limpricht having one officer less than I, lost the game.

Friday, $9^{\text {th }}$ of August 1878. The Minister of War, General Bustamante, had embarked for Arica with one battalion of soldiers. In his absence Dr. Loayza 
took charge of his portfolio. Lizardo Montero had arrived from Valparaiso and taken his seat as Senator for Piura. The senator Nicolas Hurtado, a friend both of Prado and Pardo, when he came to my office to pay his three-monthly interest, assured me that Arequipa was quiet, and that Colonel Suarez obeyed the orders of the Lima Government.

I saw from an article in the "Eclectic" of July 1878, that the title of Earl of Beaconsfield, conferred upon Mr. Benjamin Disraeli by Queen Victoria, George III had been on the point of granting to Edmund Burke in 1794. It was not done, because, according to the writer of the article, Burke, just at the time, lost his only son Richard, upon whom he had founded all his hopes; but I for my part, could not understand why this, his son's death, could have been the motive for the title having been withheld from him. The son and father are both interred in the Church of Beaconsfield, the latter died in 1797.

This evening, at 9 p.m., were married in the house of Dr. Lührsen, the German Chargé, Mr. George Batchelor, and Miss Catherine Guerin, the North American lady, who, for some time, had been the teacher of Maria and Corina, and who had of late become the intimate friend of Mrs. Lührsen; Mr. Batchelor had some years back been in the firm of H. Moss \& Co. of Callao, and was at present partner of E. Haines \& Co. of Lima. Mrs. Lührsen had requested Enriqueta to allow her two little girls to be of the number of Miss Guerin's bridemaids. Enriqueta though not [...] [720] [...] could not say "No" and had thus for more than a week been hard at work in sewing the dresses which her daughters required for this solemnity, and after all, at the last moment little Corina, always delicate, fell ill and could not go. I, for my own part, was not sorry that it had turned out so, for never before had I heard that such little girls had acted as bridemaids for a lady of not less than thirty. Besides Maria, Antonio went for there was to be a ball after the ceremony, also Guillermo, intimately acquainted with Mr. Batchelor. Dr. Middendorff, who at a later hour came to see Corina, told us that the number of gentlemen present had been very great; and that Mr. Vaughan, the Catholic clergyman, after having performed the ceremony, had made an attempt to deliver a speech, but had failed; stuck fast, could not utter a word, and was carried away under the pretence of fainting. With difficulty had those present refrained from laughing. This Vaughan had been here some time soliciting and actually obtaining some subscriptions for an expiatory monument, to be erected in London, for the sins committed by the English Nation in having fallen off from the true faith. The correspondence and passengers per "Colombia", from Panamá, arrived this forenoon in Callao, on board the "Oroya"; the "Colombia", one of the largest steamers of the Company, with a native pilot on board, had struck on the $29^{\text {th }}$ inst. at 5 p.m. upon a hitherto unknown sunken rock in the bay of Ballenita, a 
little to the north of Guayaquil; she being built in compartments, one of them filled with water, and it was expected that she would be got off, and the cargo, though damaged, be saved.

Saturday, $10^{\text {th }}$ of August 1878. Before breakfast, Enriqueta, Enrique and I accompanied by a Mr. Lund who belonged to the Compañia de Obras Públicas, drove out to the pantheon. The door of the chapel was easily [...] and to my great joy Enriqueta was much pleased [721] with the building. The only defects $[\ldots]$ that the building would look more airy if the roof were a little higher, in which she was certainly correct; and secondly, that the altar was so small that mass could not conveniently be said at it, but this I thought might easily be remedied by having the altar covered with a piece of mahogany or cedar wood neatly worked, and polished, protruding on each side about half a vara, by which means the size of the altar would be sufficiently enlarged. The balance of \$20o which I owed for the building of the chapel I paid to the Company of Obras Publicas.

From the papers I took various news. Cardinal Franchi, the new Pope's

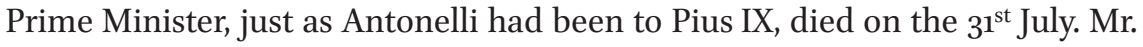
Baring, of the British Legation in Constantinople, took possession, on the $11^{\text {th }}$ July, in the name of Queen Victoria, of the Island of Cyprus, which would be garrisoned by 10,000 men, mostly of the East Indian army, under command of Sir Garnet Wolseley. Railways would probably be constructed on the Island, and the submarine cable laid from one of its ports to Alexandria. On the $13^{\text {th }}$ July the treaty of peace had been signed, in Von Bismarck's official residence in Berlin, by the respective Ambassadors, each of whom received one copy written out in French, on parchment, and provided with all the signatures. It consisted of 64 clauses, and the contents were immediately telegraphed to London. Turkey, which exclusive of Herzegovina, Bosnia and the two Bulgarias, had still a population of 6,000,00o souls in Europe, and England had formed a strict alliance. Austria was to occupy Herzegovina and Bosnia, (but I supposed only for a certain length of time). Lord Beaconsfield arrived on the $16^{\text {th }}$ in London, and was received in the most enthusiastic manner. The Queen conferred on him, as well as on the Marquis of Salisburry, the order of the Garter.

Sunday, $11^{\text {th }}$ of August 1878. The letter received [...] [722] [...] from Rosa to Enriqueta, gave both a lamentable account of Mr. Schutte's health; he suffered from dropsy, which, their Dr. Acosta said, could not be cured when the patient had reached the age of 75 , which was the case with Mr. Schutte. When in a sitting position the water did not reach higher up than the ancles, but when reclining it rose as far as his knees. Juan who was in Paris, felt rather better than he had done for some time past. 
Here in Lima the monthly burning of bank notes, promised by the President to take place regularly, had not been effected in the month of July, and I doubted it would ever be resumed.

Thermometer at noon $65^{\circ} \mathrm{F}$. Bryson and I busied ourselves revising the diary of September and October 1874. When he was gone, Limpricht wrote my Cash for July, and we then played two games at chess till 5 o'clock - I gained the first, he the second.

At dinner we had with us Bertha, one of the daughters of the late William Möller of Arequipa, with her husband Mr. Vargas, who had come to Lima with five little children, merely with the object to divert themselves. Nothing particular had I to say of either of the two. It had been expected that this day would not pass over without disturbances; the party opposed to the Civilistas had disseminated loose sheets in which they called their adherents to a popular meeting round the monument of the Dos de Mayo. I was told that about 300 had assembled, and twenty of the most unruly had been arrested. In our quarter of the town everything was quiet.

Monday, $12^{\text {th }}$ of August 1878. A meeting of the shareholders of the Banco del Perú had been convened for 1 o'clock.J. V. Oyague, owner of 340 shares, made us all wait for him as was his custom; without him [_] had not a sufficient number of shareholders to form [723] the quorum, say one above the half. [...] of the Gerentes was read, and passed without any observation. An interest of $41 / 2 \%$ for the last six months was declared. Then Manuel Candamo who presided read a short discourse drawn out by him, in which he asked the shareholders whether they wished to liquidate the bank, or continue with a capital of 3,000,000 soles, divided in 6000 shares of \$500 each, all paid up. Oyague said a few words in favour of the continuance of the bank; next, the liquidation was put to the vote, rejected unanimously, and with the same unanimity the continuance of the bank was voted. As the statutes would now have to be altered, and this could not be done without the assistance of two-thirds of the shareholders, those present were earnestly requested to attend the next meeting, which would shortly be called together.

Yesterday, early in the morning, arrived from Arequipa a certain Diego Butron whom I had heard frequently mentioned as Gibbs's most active collector and contractor for wool in the Interior. At present Alcalde of the Arequipa Municipality he had been sent hither as their delegate. On his arrival he went to the Palace, and breakfasted with his Excellency, but otherwise not the slightest notice had been taken of him.

Tuesday, $13^{\text {th }}$ of August 1878 . The Directory of the Banco Hipotecario met without M. M. Galvez, who as Deputy had to attend the sitting in the Lower 
Chamber, the few questions laid before us were of hardly any importance, and required no notice.

Here follow in my original the principal conditions of the Berlin treaty which I think proper to omit in this my revised diary, because a few days later there will be found in the appendix a cutting from the "Times" containing a translation of the entire document.

Little Corina, who had been very unwell since Thursday last, to-day for the first time sat down with us to dinner. [724] [_] Opinión Nacional said in an article cop[_]ed from an European paper that in the year 1875 the income tax, not more than three-pence in the pound, had been le[_]ied in the United Kingdom upon an income of $£ 571,000,00\left[\_\right]$sterling, which sum did not include the incomes of less than $£ 100$ annually, which are not subject to the income tax.

Wednesday, $14^{\text {th }}$ of August 1878. To judge from various articles published in the "Nacional" of last night, there seemed to be not the slightest possibility that the house of Oliphant \& Co. would be able to comply with the engagement it had taken upon itself to procure Chinese Coolies for Perú. The cause of this was that the English Government had prohibited their being shipped in Hong Kong.

Thursday, $15^{\text {th }}$ of August 1878. From an article in the "Eclectic" for August 1875, I took the following sentences "If, as Helmholtz says, the duration of life on our earth is but the minutest ripple in the infinite ocean of time", etc. What an idea of the inconceivable immensity, or rather infinity of the universe do these words give!

The papers said, that Quiñones, the Prefect of Puno, had been arrested by Falconi, the chief of the gendarmes; also that Rafael Velarde's resignation of his post as Superintendent of the Callao Custom-House had been accepted, and Pepe Izcue, hitherto one of the principal employés in the Ministry of Finance, named in his stead. What Rafael would now do, and what he would live upon, I could not conceive. He had no money of his own, nor any fixed income whatever.

Bryson, being otherwise engaged, left me before twelve. I walked the corridor, dressed, and went out early. Doña Manuela Portillo, Doña Dolores Puente, and Rufino Torrico, and his wife Maria Araoz, I did not find at home. I had a long chat with Mr. and Mrs. Rafael Quiroz, and with Doña Josefa Bazo. [725] Rafael Velarde told me that his [_]son [_] having given in for the fourth time his renunciation of his post in the Callao Custom-house was that he had been displeased with some of his subalterns, and that the Government refused to remove them. I remained but a short time with the two ladies whom I had to congratulate, this being their saint's day, viz.: Transito Llosa, and Asuncion Santillana, which latter I presented with a handsome Chinese embroidered 
white crape shawl. Neither did I remain long with Doña Bertha Möller, who with her husband and family had taken up her quarters in a lately established hotel at the corner of Santo Domingo, apparently far superior to the old one of Maury in Bodegones, for she was about leaving to go to a monster concert of 300 musicians given in the Exhibition palace, the proceeds of which were destined for the new hospice about being established for beggars.

In the church of Jesus Maria there was also a great festivity; an altar with the image of the Señora de Lourdes being inaugurated with great splendour at the expense of Isabel Soyer, wife of José Vicente Oyague.

In the evening, though holiday, Brierley came as per agreement. Each time he was with me, he read one act of Shakespeare's most renowned tragedies. We were now with King Lear, but I must confess, perhaps to my shame, that I could not admire them so much as one was in duty bound to do.

Friday, $16^{\text {th }}$ of August 1878 . This morning at about 5 a.m. the shop of a hairdresser opposite Maury's hotel was destroyed by fire. I heard nothing of the noise made by the whistling of the celadores and the rattling of the fireengines, and only learned it in the course of the day.

The "Comercio" said in the morning edition that General Bustamante had telegraphed from Arequipa to the President that in both the Departments of Arequipa and Puno tranquility prevailed. [726] [_] Bank-notes burned by order of the Government, from September last to June of this year inclusive, amounted to $\$ 2,654,000$.

Saturday, $17^{\text {th }}$ of August 1878 . From the Leipsic Gazette I took the following: The individual who had attempted the assassination of the Emperor of Germany was called Karl Nobeling. His father was a farmer of a Royal domain in the province of Posen. He was born on the $10^{\text {th }}$ April 1848; had received a very good education, been studying in one or two universities, and obtained the diploma of Doctor-at-law; but already at school his fellow-pupils had disliked him for his thoroughly selfish character. After concluding his studies and having travelled a little he entered both in Berlin and Dresden a Government statistical office, but seemed not to have given satisfaction. In the beginning of this year he removed to Berlin where he mixed with the socialistic societies and listened with satisfaction to the most subversive doctrines of which the attack upon the Emperor's life was the result. Two of his brothers were in the army, and they as well as all his relations who bore the name of Nobeling had changed it into that of Adeling. The German papers affected to call the German Emperor, "Whitebeard", in contra-position to Barbarosa or "Redbeard", the famous Hohenstauffen Emperor.

The day before yesterday, embarked for Buenos Ayres as Peruvian Minister, Anibal La Torre with his entire family. In the evening I received letters from Juan and Schutte, of $15^{\text {th }}$ July. The swelling in the legs of the latter had considerably 
decreased, owing to the use of the mineral waters of Marienbad. Limpricht, who in the evening was with me for about an hour, whilst Enriqueta was in bed with her head-ache, told me that Mrs. Knauer of Altona had written to her son Edward [727] that my friend Henry Sieveking [...] ffering [_] ully from asthma, and that apprehensions were entertained for his life.

Sunday, $18^{\text {th }}$ of August 1878 . The "Nacional" published a letter addressed to the Editors of the "Comercio" by their correspondent in Mollendo who wrote that Falconi, the chief of the gendarmes in Puno, had been obliged to give way to the superior forces of Prefect Quiñones, who had proclaimed Pierola, and had consequently by order of the Minister of War Bustamante, then in Arequipa, retired with 170 men under his command to the port of Mollendo. Prefect Suarez of Arequipa, it was said, was faithful to the Lima Government.

Yesterday, bank notes to the amount of 170,000 soles, were burned in the plaza, which corresponded to the month of July.

I dictated my letters to Juan and to George Shattuck, to go by the steamer of the $22^{\text {nd }}$. Limpricht and I played three games at chess in as short a time as two hours. I lost the first, gained the two others, and then took a long walk to the Descalzos; thence to the Chorrillos gate, and home. I found them at dinner with Urquhart and Jorge Valle, both very agreeable young men. Of the sons, only Ricardo and Antonio were present, the former of whom read to me after dinner the Leipzic gazette till it was bed-time.

Monday, $19^{\text {th }}$ of August 1878. Last night's "Nacional" stated that Falconi, who it seemed to me, had done his best to sustain the established authority in Puno, had in Mollendo been deprived of his command by order of General Bustamante who had named a certain Juan de Dios Rivera in his place.

Little Maria's birthday, who therefore did not go to school. My present to her was exactly like that to Corina on $23^{\text {rd }}$ July. We had at breakfast Guillermo and Eliza with their boy Guillermito, Pepa Bazo with her daughter Irene, and Goya Velarde with her grand-daughter Maria Aranivar.

From various papers I copied the following [_] [728] [...] note issued by the Bank of England on the $20^{\text {th }}$ February 1743 was returned to the same on the $23^{\text {rd }}$ September 1846. Rafael's painting of the virgin of the Candelabros had been sold in London in public sale for £20,00o. The first monarch of whom it was known that he had his portrait engraved on the current coin of the country was Alexander the Great; Augustus, the first Roman emperor, had done the same. The statue of Roland, of which I made mention when travelling in Holstein in 1855, without then knowing its object, was in the Middle Ages in Germany the symbol that the town where it was erected had its own judicature.

At dinner a large party sat down; besides Maria and Corina, two little Lacroix, two of the late Frederick Bergmann's girls, Sofia, Rafael's, and Maria, Melchor 
Velarde's daughter. Moreover, Jorge Velarde the marine cadet, Urquhart, Limpricht, and Castañeda, the music-master. I rose at 7.30 to listen to Brierley's reading of an article in the "Eclectic" of November 1877, entitled Popes and Cardinals, of which I intended to give an abstract when time would permit. On my return to the salita Castañeda amused the little ones with sleight of hand; afterwards he made them play other games, and kept them in excellent humour till past eleven, when they went home. Dr. Middendorff and Jorge Valle played rocambor with Garland. The curate Aguila, Federico Palacios and wife were also present. Rafael Velarde, who came to fetch his daughter home, spoke of a meeting of the Municipality at which he was to attend on the following day, and the general opinion was that disturbances would be unavoidable if the Congress did not reconsider the qualification which it had made on Saturday last of J. J. Helguera, Senator, and Manuel Candamo, Ignacio Osma, Ramon R[_]o and José Unanue, Deputies for Lima, all five the [729] staunchest friends of Manuel [...] he Civilistas there was some want of union. In the Senate they voted on Saturday last that the Electoral college of the city of Lima, presided by Riva Agüero, had been illegal, whilst in the Deputies they resolved the contrary. This day in the United Congress, Dr. Bernardino Leon was by a large majority chosen Vocal of the Supreme Court instead of Mariano Cossio who had retired on a pension of his entire appointment after 50 years service.

Tuesday, $20^{\text {th }}$ of August 1878 . At 12 o'clock I went to the juzgado of Dr. A. Puente Arnao, where part of the convent of San Francisco, which Enriqueta had rented for a number of years, was to be disposed of by public sale, emphiteutically, for 150 years. I returned there at 1.30 and was present when at 2 precisely it was knocked down to Ramon Patron for the laudemio of $855^{\circ}$ soles and a monthly canon of \$180. Enriqueta had el derecho de retracto, of which however she would probably not avail herself as it would be paying too dear for it. The streets were quiet; troops were ordered out to protect the Congress; I saw a company at the corner of Goyeneche's new house.

At 3 o'clock I went out to attend a meeting of the shareholders of the Banco Hipotecario to elect the gerentes. The first thing which struck my eye was a company of gendarmes at the corner of the street; another, more numerous, stood at the entrance of the Plaza from the Calle de Arzobispo. They however let me pass. The Rivera from the Palace door to the Calle del Correo was crowded with people, and a good many were assembled before the Cabildo. I stopped, and heard a certain Colonel Pereyra perorate from the balcony of the Municipality. I distinguished the words "Congreso Constituyente", "Reforma radical en toda la Republica", which were received with great applause. Without any hindrance I walked under the Portal de Escribanos to the corner of Mantas where also a [...] [730] [...] ioned, who allowed everybody to go 
out, but none to enter the plaza. The coaches which usual[_] had their stand here were drawn up in the Calle de Mercaderes. On the tramway the coaches did not run; and, in the centre of the town many stores and shops were closed.

Wednesday, 2 ${ }^{\text {st }}$ of August 1878 . I saw by last night's papers that several persons, Buenaventura Elguera, M. F. Benavides, Alejandro Arenas, Dr. Pasós and Rafael Velarde, who had all lost their election in the Congress, and several others, had harangued the people from the Municipality. Also Prado from his windows had addressed a few words to the multitude and told them that in the same manner as the Government had to perform a duty towards them, they had their duty towards the Government, and this was, quietly to disperse and go home. P. J. Calderon the Piérolista, at present Editor of the "Patria", likewise spoke to the people assembled in the Calle de Palacio.

Yesterday in the Chamber of Deputies, a great majority resolved that the elections for the Lima Deputies should be reconsidered.

Thursday, $22^{\text {nd }}$ of August 1878 . On the $20^{\text {th }}$ inst., in the Banco Hipotecario only a few were assembled, we remained till $3.30 \mathrm{p} . \mathrm{m}$, and then separated. I then continued my walk to the Chorrillos gate. On my return home at about 4.30 p.m. of that day nobody was stopped anywhere, the speechifying had come to an end, but the crowd of people which came in the direction from the bridge was so dense that I could hardly make my way against them. I knew not whence they came. Near the Prefectura stood a company of gendarmes.

Last night's "Nacional" published the acta, which on the $20^{\text {th }}$ instant, fifty individuals whom this paper called the plebiscitarios, had signed and presented to Prado. After a tremendous tirade against $t$ [_] Civilistas the document said that they did not recog- [731] nize the present Congress, and that they [...] Executive to call together without loss of time a constituent Congress, and to introduce a complete reform in the electoral laws. Besides the persons already mentioned, I found the names of J. G. Basagoytia, Carlos Paz Soldan, Evaristo Gomez Sanchez, Lucio Barrios, Ignacio Tavara, etc. Rafael Velarde's name was not down.

In the evening when the two rocamboristas, Valle and Basagoytia, came, Limpricht playing on account of Enriqueta, making the fourth, all kinds of rumours which had been afloat in the course of the day were discussed. The only thing certain seemed to be that Colonel Zamudio, who commanded one of the battalions quartered in Lima, had requested the Colonels of other battalions to come to his barrack to take a glass of beer and to treat on weighty matters. Prado was advised of it; he counselled some Colonels not to go, others went, but no resolution inimical to the Congress, which had been Zamudio's intention, was taken. J. J. Helguera took his oath in the Senate.

Friday, $23^{\text {rd }}$ of August 1878 . A gloomy day. Thermometer at 4.30 p.m. $66^{\circ} \mathrm{F}$. The Prefect published a bando or proclamation which prohibited all meetings 
unless permitted by the Government. In the Senate, a motion of Lizardo Montero's passed, that the answers which the other day the Minister of the Interior Dr. Palacios had given to questions put to him by the said Montero were unsatisfactory, and that the doctrines laid down by the said Ministers were unconstitutional and subversive. In both Chambers, Senate and Deputies, a law was given, which amongst other stringent clauses had one which said that military men from General downwards, who took part in public meetings, were to be erazed from the military list. The majority in all three cases was overwhelming.

Saturday, $24^{\text {th }}$ of August 1878 . This morning Enriqueta called together her husband, Enrique, Guillermo, and myself [...] [732] [...] it would be advisable to make use of her derecho de retracto in the case of the property, part of the convent of San Francisco which on $20^{\text {th }}$ August had been sold in public auction to Ramon Patron. A close calculation was made of the outlay, indispensable repairs and other expenses; on the other hand, of the rent likely to be received monthly; and much against Enriqueta's wish it was determined to leave the purchase to Patron. I was certain that we had done right in taking this determination.

Sunday, $25^{\text {th }}$ of August 1878. I dictated a letter to Mr. Schutte. At 2 p.m. I started for a few visits: to Rafael Velarde's family, to Doña Manuela Portillo, whom I had not seen for a length of time, to Colonel Juan N. Vargas, and to the family of Manuel Alvarez Calderon, with whom I had not been since we were together in Chorrillos in the beginning of the year. I only saw the unmarried daughter, with whom I conversed mainly on the accident which had befallen her brother on board the steamer when fired at and nearly killed by Federico Pflücker. At the Pintos I merely left my card. Frederick Marriott I found out of bed suffering from a complaint in the chest. He seemed to be very ill indeed. Within a few days he thought of removing to San Juan de Matucanas or La Chosica, but not before having paid to the shareholders of the Gas Company, six per cent, viz.: $2 \%$ still due since March for the dividend of December $1877 ; 2 \%$ for $3^{\text {st }}$ March, payable $30^{\text {th }}$ June, and $2 \%$ for $30^{\text {th }}$ June, payable $30^{\text {th }}$ September. He told me that the Lima Municipality had paid all they owed till May last in Municipal Bonds at $80 \%$, which, at the utmost, could be sold in the market at 70 . The Directory had resolved to sell them gradually, but not below 70, and meanwhile to take up $\$ 80,000$ on interest, [...] to pay the dividends. I was convinced they would [733] have to let them go at less than [...] pality bonds gained $8 \%$ annual interest, and had $4 \%$ annual redemption. Also Melchor Velarde was ailing, for five days he had not left the house.

At dinner we had Urquhart; Antonio came in in high spirits, for in the foot races held in the Exhibition park he had gained four times, and the cups he presented as trophies were five in number, four beautifully plated, gilt inside, 
and a small one pure silver. The last race of 3 miles he had run in 19 minutes, less a few seconds, in which he had beaten J. V. Oyague, his competitor. After the races they had had lunch, and then dancing till about 5 p.m. He was of course tired though he would not confess it, and went to bed early. Garland went to Basagoytia's to play rocambor; Enriqueta retired to her bedroom, and I was also very sleepy.

Monday, $26^{\text {th }}$ of August 1878 . Thermometer at 2 o'clock $66^{\circ}$ F. Exchange on London, $25 \mathrm{~d} 3 / 4$ to $25 \mathrm{~d} 1 / 2$. Silver soles, 55 per cent premium, Bar silver, fineness 993, S15.20 to $\mathrm{S}_{15.40}$ [?].

Manuel Costas's wife had died in Puno, the Prefect Quiñones had forced him to pay, though in the shape of a loan, the sum of ₹2ooo.

Tuesday, $27^{\text {th }}$ of August 1878. At twelve I went to the office of the notary Prieto, who notified to me an order of Judge Quiroga's, for the sale in public auction of Juan Aliaga y Puente's small house Nos 13/11, Polvos Azules, exactly one year after I gave in the first escrito in which I demanded the sale to be made. At two I went to the Banco Hipotecario, where the Directory had been cited, but as only Pedro Correa was present besides myself, and Lorente did not come till three, we had not time to do anything, because a meeting of the shareholders had been fixed for the same hour. Very few were present, but as this was the second meeting for the same object, when any number of shareholders sufficed, we proceeded to the election of the gerentes, and Garland and Gallagher were unanimously rechosen. [734] [...] of last night gave the result of the elections held in Germany of the members for the new parliament or Reichstag. Nine of the members were believed to be socialistic tendencies, twenty-eight belonged to the party of progress, ninety-seven to the Liberal Nationals, at whose head stood Benningsen the Hanoverian; one hundred and ten were Imperialists or staunch partizans of Bismarck, ninety-nine ultramontanes, and fifty-four called themselves Independents.

Little Corina was again very unwell, and in bed. Maria was prevented from going to school yesterday by a bad cough.

It was a fine sunny day, thermometer at 5 p.m. $67^{\circ} \mathrm{F}$.

Wednesday, $28^{\text {th }}$ of August 1878. At twelve, Lorente, Pedro Correa and I were in the Banco Hipotecario. Gallagher laid before us various questions which we disposed of granting one loan, refusing the other, authorizing the gerentes to make the best arrangement they could with bad creditors, and so on. For a long time past we had insisted upon the lawyer of the bank, Ramon Ribeyro, having his study in the same house where the Banco Hipotecario was, because his advice was required every moment by the Gerentes. He had always put off the removal, but to-day we insisted upon his declaring what he intended to do. 
Corina very ill. She was extremely weak, ate nothing, vomited continually, and spoke not a word.

In the evening Rafael Velarde came with his family, and told us that he had been named by the President the Government's interventor in the Nitrate contract with the "Providencia", with a salary of \$6ooo annually, a post for which he was the most unfit person imaginable, for he did not understand anything about accounts.

Thursday, $29^{\text {th }}$ of August 1878 . I collected this [_] the six percent dividend from the Gas Company, [735] of which Marriott [_] spoken to me last [...] to \$16,200, of which for me, only \$1440, the remainder for Schutte, Rosa and Juan.

Dr. Ribeyro, the father, accosted me in the street and complained bitterly that we in the Banco Hipotecario were hostilizando su hijo.

Corina continued ill. Thermometer at 5 p.m. $66^{\circ} \mathrm{F}$.

In the evening only one rocambor table: Garland, Dr. Middendorff, Valle and Basagoytia. Enriqueta retired early, being worn out with four bad nights at her daughter's bedside. Limpricht and I played one game at chess which lasted till past half past eleven, and which I gained. Very different were these Thursday evenings from those of 1874 and 1875 , when my dear Mariquita, though she was always the loser, liked to try her luck at roulette. When ten or twelve persons sat and stood round the table, when there were eight, sometimes twelve rocambor players, and when young folks danced till about one in the morning.

Friday, $30^{\text {th }}$ of August 1878. Santa Rosa. Corina was much better, she had eaten a little and spoken a few words. The sun was out; thermometer at noon, $65^{\circ} \mathrm{F}$.

This day was a counterpart of Santa Rosa of last year. At Basagoytia's in the evening, there was a little dance, and rocambor playing; Garland Senior went for the latter, Antonio for the former.

Saturday, $3^{\text {st }}$ of August 1878 . Corina had been able to leave her bed, whilst her mother had laid down with a bad migraine. Thermometer at 5 p.m. $66^{\circ} \mathrm{F}$.

Advices had been received from Europe of the death of the ex-queen of Spain, Maria Cristina, the spouse of Ferdinand VII of Spain, afterwards married to the Duke of Rianzares.

A telegram brought the news of the decease of Pedro Galvez, Peruvian Envoy in London and Paris, brother of D [...] [736] [...] on the 2[_] May 1866 in Callao, and of Dr. Manuel Maria, son-in-law of Nicolas Rodrigo. He left no children, but a widow, the amiable Magdalena Peralta, who when a child used to come to our house in the Calle del Correo to play there with Corina and Amalia.

Sunday, $7^{\text {st }}$ of September 1878. Corina was quite well, and sat down to breakfast, whilst Enriqueta continued in bed with a head-ache. 
I received letters from Juan and Schutte, dated respectively $31^{\text {st }}$ July and $30^{\text {th }} \mathrm{July,} \mathrm{which} \mathrm{did} \mathrm{not} \mathrm{contain} \mathrm{anything} \mathrm{of} \mathrm{importance.} \mathrm{Thermometer} \mathrm{at}$ noon $66^{\circ} \mathrm{F}$.

I dictated to Bryson part of a letter to my cousin in Winchmore Hill, then, when he was gone, Limpricht read to me a letter from his sister Elizabeth, dated Bonn, whither she had gone to consult some first-rate physicians, friends of her brother Henry, under whose direction a machine was being made which consisted of leather well padded, into which small steel stays were introduced, the whole for the purpose of gradually raising her head, which was completely sunk down upon her left shoulder, and which she could not lift. To defray these and other expenses, she had had to apply for the money required to Sieveking \& Co., who would pay it on my account.

Limpricht wrote my Cash of August, which took him till near four, and afterwards I gained two games of chess from him. I then took a quick walk to where formerly the Barbones gate stood, and came home quite in the dark, when Garland, Enriqueta, Enrique, Juan, Ricardo, the two little girls, Jorge Valle, Urquhart and Limpricht had already sat down to dinner. When all were gone, Ricardo read to me.

Monday, $2^{\text {nd }}$ of September 1878. Guillermo told me at breakfast that he, his brother Alejandro, and several [_]men from Chorrillos had left that place per train [737] at a very early hour for Callao, in or [...] Manuel Pardo, who had arrived between seven and eight from Valparaiso; from Lima also many of his friends had gone, Guillermo thought perhaps 600 persons in all.

They had accompanied him to his house in Lima, which was completely crammed, and where he had to shake hands with and embrace them all the one after the other.

At about one, when Davies had done reading to me, Edward Knauer entered my room with the words: "I have bad news to give you", and certainly bad news they were; my good friend Henry Sieveking had died. Knauer read to me the letter from his mother dated $29^{\text {th }}$ July, which she had begun with saying, "I have just returned from the funeral of my good friend Sieveking, who in the night from Friday to Saturday last (that is to say, in the night from the $26^{\text {th }}$ to the $27^{\text {th }}$ July) very quietly breathed his last." She requested her son to communicate this to me, and also the death of my cousin Theodore Hugues, the Calvinist clergyman in Celle. I was much affected by these advices. Sieveking I had been acquainted with since I was about 8 or 10 years of age. We played together in our childhood, danced and rode out together in our youth, for a short time lived together in Kennington near London, and to the very last kept up a friendly intercourse. I affix in the Appendix a small cutting from the Altona paper, also a short sketch of his life, written by me, under $\mathrm{N}^{\text {os }} 32 / 31$. Of my cousin Theodore, of whom I have spoken in my diary in my visits to Celle, I was 
also very fond; he was an extremely pleasant and excellent man, my younger by a few years, for he was born on the $19^{\text {th }}$ May 1803 .

At about two p.m. I went to see Don Manuel Pardo who was in his drawingroom, not many persons with him; he introduced me to General La Puerta, with whom I was previously acquainted, and to a certain Osorio, Vocal de la Corte Superior of Tacna; these two sat on the sofa; there were three or four mor[_] [738] [...] and whom he did not mention to me. As to myself, he embraced me and led me carefully to an arm-chair near him; asked for Juan, and then continued the conversation which I had interrupted. It turned on Nitrate of Soda, when I said that I hoped he would set that affair right; to which he replied that he would see what he could do in the Congress. It was well known that Pardo was not a sincere man, but at all events he was very agreeable, and I liked him much. I hardly remained a quarter of an hour, and rose when a lady came in who called him her compadre. Thermometer at 5 p.m. $65^{\circ} \mathrm{F}$.

To my surprise, M. F. Benavides, who had not been in the house for many months, made his appearance in the evening, he did not join the rocambor players, and left at about eleven. It was not at all unlikely that he and Basagoytia, who belonged to the party of the Nacionales, had appointed Garland's rooms as a rendezvous. Basagoytia had come from the palace, and they had some private talk.

Tuesday, $3^{\text {rd }}$ of September 1878. I was awake nearly the whole night, from two till daybreak. At noon Lorente, Correa, Melchor Velarde and I were in the office of the Banco Hipotecario. We dispatched some routine business, which being done, I told them in a few words the gist of my conversation with the Vocal Ribeyro. It was however resolved that we could not allow ourselves to be influenced by the threat which Ribeyro had held out to me in a covert manner, nevertheless, at Lorente's request the answer to Ramon Ribeyro's letter, in which he threw up his post as lawyer of the bank, was once more deferred till Thursday. Correa and I did not see the slightest reason for this postponement, but ceded to Lorente's desire.

The newspapers related that on Saturday [...] when said Ramon Ribeyro accompanied by some [739] friends walked along the street of [...] leven at night, an individual armed with a dagger came upon him. He and his companions having no arms with them escaped into an apothecary's shop.

From the "Panamá Star and Herald" I learned that the Marquis of Lorne, eldest son of the Duke of Argyle, married to Louise, one of the daughters of Queen Victoria, had been named Governor-General of Canada. In Herzegovina and Bosnia, the Austrian troops had met with great resistance from the natives.

At about one, when leaving the Banco Hipotecario I looked in in the Banco de Lima, where the two gerentes Manuel Cucalon and Cipriano Correa told me that at present they had nothing else to do but to defend themselves against 
the lawsuits which rained upon them from all quarters; from the Salitrera Esperanza, from various parties interested in this salitrera individually, and even from Lembcke, who claimed his commission upon the gains of last year; whilst, according to the gerentes, the bank had sustained a heavy loss during that period.

Yesterday again \$170,00o paper were burned in the Plaza, and the Internal Debt was redeemed at $491 / 2$ and $493 / 4$. Thermometer at 5 o'clock this afternoon, $67^{\circ} \mathrm{F}$.

This day being Garland's birthday, Enriqueta had invited several friends to dine with them; and I therefore begged her to excuse me, because I disliked to mix with so many persons. There were Basagoytia, M. F. Benavides, John Gallagher, Limpricht, Valle, and Urquhart. As I had first thought of being present at the dinner, I had written to Brierley not to come, and thus, after having taken first a long walk till past seven, then dined by myself in my salita, I remained thinking and ciphering in my head till about nine, when I went to bed, and slept the whole night through, no doubt owing to the previous sleepless night.

Wednesday, $4^{\text {th }}$ of September 1878 . This morning I went out to the pantheon, and opened the chapel, the interior of [...] [740] [...] the sun shone prettily through the painted windows.

I saw by the message of the Finance Minister to the Congress, that there was actually a deficit in the Peruvian Finances of 24,000,000 soles, and that the sales of guano were diminishing considerably in Europe. Also in the United States the sales of Guano did not diminish the debt due by the Government to the consignees.

Last year the Custom-houses gave an income of $\$ 6,800,000$, and of the paper money in circulation on account of the Government \$2,654,00o had been burned, up to the date of the message, so that at the present moment $\$_{17}, 679,333 \cdot 30$ [?] were still in existence.

A sunny summer day. Thermometer at 5 p.m. $68^{\circ} \mathrm{F}$.

Last night's "Nacional" contained a dispatch signed by Pantaleon Falconi, chief of the gendarmes of Puno, from which it appeared that the two Prefects, Quiñones of Puno, and Suarez of Arequipa, had been evidently conspiring against the President Prado, and that their machinations had been crossed by the unexpected opposition of Falconi and his gendarmes. It was said that Suarez was about being superseded by a certain Colonel Bezada, not in active service, a great friend of the President and owner of the chacra "Flores" in the valley of Lurigancho; a man of dubious reputation.

At 9.30 p.m. the President's wife, accompanied by her brother-in-law Carlos Von der Heyde, paid a visit to Enriqueta. Garland was about going to bed; and Limpricht and I made our escape when she was announced. 
Thursday, $5^{\text {th }}$ of September 1878. At 12.30 all the Directors of the Banco Hipotecario were assembled, and we agreed to Galvez's proposal to write a note to Ramon Ribeyro for the last time in which the gerentes were to tell him [_] if he was not inclined to transfer his study to the [741] rooms allotted to him in the Banco $[\ldots]$ would be under the necessity of accepting his resignation.

From the continuation of the Minister of Finance's message, I saw that on the $3{ }^{\text {st }}$ July 1876 , when Manuel Pardo ceased to be President, the Internal Debt amounted to $\$ 24,600,000$, and that, on the $31^{\text {st }}$ July 1878 , it had been reduced by six millions, without however taking into consideration the floating debt of $31^{\text {st }}$ July 1876 , not yet liquidated, and the amount of billetes in circulation for which the Government had become responsible.

In the evening Seminario of Piura, Colonel Mariscal, José Basagoytia, and Melchor Velarde came rather later than usual, they having been detained in the Concejo Departamental, where the lease of the so-called shops of Paz-Soldan to Enrique Dinegro had come again under consideration, and as those who wanted to annul the lease, which was miserably low, saw that if the question had been brought to the vote, they would have had the minority, the president Alejandro Arenas, who was one of them, had adjourned the session on the plea of the lateness of the hour.

Friday, $6^{\text {th }}$ of September 1878. I saw by the "Nacional" that the concession which the Government had made in December last, to Dr. José Silva Santistevan for the conclusion of the railway to Cajamarca, for the construction of a branch to Hualgayoc, and another to Lambayeque, had been annulled because Santistevan had not complied with the conditions of the agreement.

When at 1 o'clock I went to the Banco Hipotecario there was no meeting of Directors, as yesterday agreed upon, because Dr. Ramon Ribeyro had at last given in, and agreed to transfer his study to the bank. Also in the Banco del Perú to which I had been cited, there was nothing of importance to be transacted, we did not even take our seats round the table. It was however resolved that the Bank should contribute \$25 monthly for the sustenance [_] the $b[\ldots][742][\ldots]$ ished in Lima. Likewise in the Insurance Co. "Lima", where the Directors, except Gil and Robertson, were present, we had hardly anything to treat on. We mostly conversed, and each gave his opinion on the various financial projects which were published in the papers, one of which proposed that import duties should be paid in silver or gold coins, or in bank notes with an increase corresponding to their depreciated value in the market, and that this premium upon the silver and gold should be exclusively employed in purchasing silver bars which should be coined, and with the coined silver, the bank-notes be gradually redeemed. Another project was that an export duty should be levied on the produce of the country, and the proceeds be employed more or less in the same manner as indicated in the previous one. The third, 
Cudlipp's, referred to the coinage of silver rials and two rial pieces of a very low standard, wherewith to exchange the dirty and torn small bank-notes which were in circulation.

Saturday, $7^{\text {th }}$ of September 1878. Last night in the Theatre a favourite actor and comic singer, Sanchez Osorio, was fined S1oo by the Municipal Censor, for having sung a few lines which did not originally stand in his part, viz.:

\author{
En la Caja de Pandora \\ Dijo el amigo Buxó: \\ El Mesias está en Chile \\ Y el Mesias ya llegó.
}

La Caja de Pandora was a political farce which had been acted some time back; Buxó was the name of an actor, and the word Mesias of course applied to Manuel Pardo. Consequently this couplet was received with great applause, and the Actor had to repeat it, which so much incensed the Censor, a certain Macedo, that he ordered the fine to be levied. The President Prado had been present in his box.

To-day Manuel Pardo took his seat in the [743] Senate as Senator for Junin, and delivered a [_] hort sp[_] as President of this Chamber. It was generally believed that the Nitrate of Soda contract between the Government and La Providencia would be annulled by the Chambers. Moscoso Melgar, the Gerente of this bank, had made known that Goyeneche in Europe was not interested in this business, whilst on the other hand James Sawers \& Co. of London had taken a share. All this combined had caused a rise in the Certificates from 91 to $97 \%$ in a day or two.

Sunday, 8 $^{\text {th }}$ of September 1878 . I dictated my letter to Juan. At past two I went out. The first three ladies upon whom I called were extremely talkative; Zoila Velarde expatiated on last Thursday's soirée in Macandrew's house, where she had been present, and amused herself extremely well. Secondly, Ernestina Pflucker, just returned from Europe with her husband Felix Dibos, gave me an animated account of where she had been, how she had travelled about, what she had seen, how the different members of her family were getting on, in what a friendly manner she had been received by Hermann Rodewald of Bremen, how he had enquired for me, etc. Irene, Dr. Muñoz's wife, was quite as communicative as the two others, but on another subject. She spoke of the many subscriptions to which she had had to contribute for pious and religious institutions, and shewed me a newly finished Oratory with the image of the Virgen de Lourdes on the altar. 
On the other hand, Dr. Jervacio Alvarez was very taciturn, owing perhaps to his ill-health. At Higginson's, whose wife's saint's-day it was, I was not much pleased either, whilst with Vargás from Arequipa and his wife Bertha Müller, I stayed perhaps half an hour, well contented.

Tuesday, $10^{\text {th }}$ of September 1878. Last night's "Nacional" said that in the Session of the Chamber of Deputies, to which the Minister of Finance, Dr. Barinaga, had been called, the injunction, voted by a great majority, had been laid upon him, not to deliver any Nitrate Certificates to the Compañia de O[_] [744] [...] decision [_] taken by the two Chambers on the Nitrate business in general.

At about one the Directors of the Banco del Perú sat down. Enrique Ayulo, on account of another person, had asked for a loan of 120,000 soles for six months on the security of $\$ 150,000$ Nitrate Certificates. We agreed to make the loan either for five, or seven months; in the first case, two cupones of the $1^{\text {st }}$ October and $1^{\text {st }}$ January, the bank kept as payment of interest; in the second case, one cupon more, that of $1^{\text {st }}$ April. Ayulo could not decide whether he for whom he acted would accept these conditions. Next I learned that the Company to which the "Providencia" had made over the Nitrate Contract with the Government was in so far dissolved that Goyeneche and Gaston had withdrawn from the same, and that its capital of $£ 800,000$ was at present represented by the Banco Nacional and Banco Providencia, each $£_{320,000}$, Francisco Garcia Calderon and Dionisio Derteano, each $£ 80,000$. Hereupon it was communicated to us that the Delegates offered to pay the Delegation's debt to the Bank in fourteen instalments, allowing interest at 6 per cent annually. This we rejected, and authorized the Gerentes to demand immediate payment of the entire debt, and if the Delegates were not willing to pay, then to make a representation to the Government demanding payment, for the Government had been the original debtor. The lawyer of the Bank, Ramon Ribeyro, was present at the discussion. I heard from Alejandro that the machinery purchased by Cilley in San Francisco, for working the Silver mines of the Cerro, had arrived; and that Watson had told him that, if the Government did not pay him part of what they owed, he would have no money wherewith to pay the freight. He had also [_] d Alejandro that as soon as he had any funds, he [745] would pay the pagaré I held of him.

Thermometer at $5 \mathrm{p} \cdot \mathrm{m} .67^{\circ} \mathrm{F}$.

Wednesday, $17^{\text {th }}$ of September 1878. The Directors of the Banco del Perú again assembled with Carlos Elizalde in the chair, instead of Manuel Candamo, whose wife had suddenly been taken ill. Dr. Ramon Ribeyro read the rough draft of the representation of the Government on which we had decided yesterday. On reconsideration it was however thought more advisable to present ourselves 
at once, judicially against the Delegation, demanding the liquidation of the Company formed by the associated banks, and the immediate payment of the amount due to the Banco del Perú, say on the $30^{\text {th }}$ June last, about $£_{130,000 \text {, }}$ and more or less $\$ 400,000$ in bank notes. I remitted by this mail £10oo to C. W. Schutte, $£_{300}$ to Juan; bills drawn by the London Bank of Mexico and South America on their London firm, at $26 \mathrm{~d} 1 / 2$. Thermometer at 5 p.m. $67^{\circ}$ Fahrenheit.

Julian Zaracondegui had died.

Guillermo left this day for Ica, in the neighbourhood of which place are the mines of Canzas, which, believed to be very rich in copper ore, had some years back been the property of Tomás Solar Reyes, then fallen into the hands of Henry Meiggs who had left them to his son Minor, who, being without the funds to work them had just sold them to Alejandro. Alejandro recognized the right of 25 per cent ceded to Guillermo by Minor, and had given 15 per cent to Geraldo in the same. On the other hand I learned from Limpricht that the price in England of $£ 61$ the ton, at which Chilian copper was quoted, at present, was so low that it did not answer the purpose of the Chilian miners to work their mines.

Thursday, $12^{\text {th }}$ of September 1878. From an article in the "Eclectic" of August 1878, written by Richard A. Proctor in the Cornhill Magazine, I took the following particulars regarding the planet Mercury. Its diameter, which measures 3300 miles, compared to that of the moon is as $11 /[$ [_] to 1 co[_] ared to th $[\ldots][746][\ldots]$ surface is one sixth of the surface of the earth. In a second it moves 30 miles; the earth in a second $181 / 2$. The earth's mean distance from the sun is $921 / 2$ millions of miles, Mercury's, when furthest off, is 42 millions, when nearest, $281 / 2$ millions. Mercury makes its circuit round the sun in 88 days; its axis inclines from the perpendicular 70 degrees, the earth's no more than $231 / 2$. The amount of heat and light which Mercury receives from the sun is from $41 / 2$ to $101 / 2$ times greater than the earth receives, for which reason the writer is of opinion that it is utterly impossible that a being bearing the least resemblance to those who people the earth, can exist upon the planet Mercury, the heat produced by the rays of the sun, notwithstanding the atmosphere, consisting of aqueous substances, which surrounds the planet, being equal to that of boiling water.

Thermometer at 5 p.m. $67^{\circ} \mathrm{F}$.

Sunday, $15^{\text {th }}$ of September 1878 . From the daily press I took the following news: On the $4^{\text {th }}$ inst. Dr. Piedrahita, an Ecuatorian, who had been in Lima in the capacity of Envoy from his Republic, was assassinated in his hacienda, called "La Palestina". At 8 p.m. he walked to his dwelling house, and whilst clearing away some branches which he found lying in the path, he was fired at; the ball 
entered his belly, and he died immediately. On the $16^{\text {th }}$ of August, Emil Hoedel, 21 years of age, the first of the two who made an attempt on the life of the Emperor of Germany, had been decapitated. Nitrate had declined in London to $13 \mathrm{~s} 6 \mathrm{~d}$. When Bryson was gone, Limpricht and I played three games at chess in somewhat more than two hours, of which I gained two, he, one. I had still time to take a long walk before dinner.

In the evening, Enriqueta and I as usual by ourselves. Garland at Basagoytia's. Monday, $16^{\text {th }}$ of September 1878. Davies began reading [747] to me a life of Bolivar in Spanish, [...] music-master Castañeda. As far as we had come, it was nothing but a fulsome panegyric. In the evening when Brierley was gone I was so low spirited that I did not enter the parlour where the rocambor players were, and went to bed before ten.

Tuesday, $17^{\text {th }}$ of September 1878. Davies begged to be excused as he was suffering from pleurisy. I therefore started for a pretty long walk over the lower range of San Cristoval. On my return I looked in at Urquhart's who was very unwell of an ulcer or boil in the throat.

In the Banco Hipotecario, Correa, Melchor and I discussed a request repeatedly made by José Sevilla, viz.: that the Cédulas which are al portador, might be transferred to the name of him who wished it to be done, and that the cedulas thus transferred might be registered in a book opened for that purpose. Dr. Ramon Ribeyro, who had at last removed his study to the bank, had given his written opinion that such a transfer was quite legal. I was the first to speak, and said that I saw no objection why we should not comply with Sevilla's desire, but with the condition that for each transfer the bank should charge $1 / 4 \%$. Correa thought that we should not charge more than 1 per mil, to which Melchor and I agreed. An advertizement to this effect would now be inserted in the daily papers, but, before doing so, it had to be laid before the Directory in our next meeting.

To-day was Enriqueta's birthday and I presented her with \$30o. Some presents had been sent in the course of the forenoon; visitors also came to offer their congratulations, amongst whom I was glad to observe Alejandro. More and more presents came in, particularly all descriptions of sweetmeats. A very pretty plated basket for keeping visiting cards from Enrique and Geraldo, a really valuable piece of furniture with a small aquarium and some gold-fish in it from Mercedes Palacios; Juan Garland made his reappearance on [_] his [_] [748]

[...] dinner: the family, except Guillerm[_] absent in Ica, and Alejandro, whose wife had presented him last night with a little girl; Eliza, with her sister Maria Luisa Higginson, Anibal Gonzales with his wife Pepa Bazo, Dr. Middendorff, Limpricht, and Jorge Velarde, the young naval cadet. As I did not 
leave the table, I had to send word to Brierley that I could not receive him, and whilst we were at dinner there came in successively José Basagoytia, Doña Jacinta Sotomayor, Gregorio Benavides, and Seminario the Senator; after dinner Ramon La Fuente and Jorge La Valle, so that Garland had his rocambor. It was $1 / 2$ past eleven when I went to my bedroom.

Wednesday, $18^{\text {th }}$ of September 1878 . Early in the morning I met in the street the carriages which followed the hearse conveying to the pantheon the body of Andrés Alvarez Calderon, whose name has been mentioned once or twice in my diary, certainly not in laudatory terms.

I saw by the "Nacional" that the Banco del Perú had presented itself against the Delegation as we had agreed upon last Tuesday, and that Garcia Calderon had declined the jurisdiction of Dr. Quiroga, because both plaintiff and defendant being mercantile establishments we should have sued them before the Consulado, not before a Juez de $1^{\text {a }}$ Instancia.

In the course of the day Dr. Palacios handed in 25 Cedulas, which Garland immediately brought to me, so that of the loan of 6o Cédulas made him in August 1876, only 10 were still pending. Then again Garland had returned to him six of his diamonds; the two remaining being in the hands of Gregorio Benavides, who had been instructed to raffle them.

Davies again did not come, and I, not feeling inclined to go out, spent some dull hours till Bryson came at [_]. Enriqueta again had some lady visitors. [749] At dinner our guests were: [_]s, wife [_] Federico Palacios, Doña Jacinta, Middendorff and Alejandro. I, however, managed to get away at 7.30 and had as usual Brierley with me till nine. Troops had been embarked for the North; because, as it was said, Iglesias was again causing disturbances in Cajamarca.

Thursday, $19^{\text {th }}$ of September 1878 . Davies once more stayed away. I went to see him in his house. He was of course in bed, and I hardly thought would be able to come before Monday.

At past one, the Directors of the Banco del Perú were assembled. The gerentes were present, as well as Dr. Ribeyro; the only thing discussed was whether the two Delegates of the bank, Calderoni and Escobar, should still be present at the meetings of the Delegates, as the bank had sued them. I did not say a single word because I did not consider myself competent to give an opinion; by Dr. Ribeyro's advice, they would go to-morrow to a meeting of the Delegates to which they were cited, but this should be the last time. I was also glad to hear that though Garcia Calderon had declined the jurisdiction of Quiroga, he had not been able to impede the retention of the funds which Gibbs might hold belonging to the Delegates, and which retention had been duly notified to them. In the evening I did not enter Enriqueta's parlour where the rocamboristas were, but went to bed at ten o'clock. 
Friday, $20^{\text {th }}$ of September 1878. Davies did not come, neither did he on

Saturday, $27^{\text {st }}$ of September 1878 . The entire morning till 2 p.m., I was at the Justice Hall, for the sale by auction of Juan Aliaga's house, 11 and 13 Calle de Polvos Azules, was fixed for this day. It had been valued in $\$_{7} 826,2 / 3^{\text {rds }}$ of which, at which according to law it might be sold were \$5,217.33 [?]. Pedro Villavicencio offered \$5300, for which price it was knocked down to him, but I feared that he would retract as soon as he learned that the upper story was let till December 1881, and that the rent for the same up to this date had already been paid to Ali[_]. [750] [...] Banco de Lima had quitted its old establishment in Calle de Mantas, and taken two rooms in Heudebert's house, for which it paid a, comparatively speaking, low rent.

By the letters received from Europe I had no particular news, only Sieveking's eldest son Henry advised me of the death of his father.

It was a disagreeable rainy morning, now at 4.30 p.m. the sun was out, thermometer in my office $68^{\circ} \mathrm{F}$.

Sunday, $22^{\text {nd }}$ of September 1878. I dictated letters to Juan and Schutte. At 2.30 I went out. My first call was upon Delfina, the eldest daughter of the late Tomás Davila, who had lately got married to a certain Jimenez; she was by herself, and I remained a pretty long time with her. My visit to Rafael Velarde's wife and daughter was short. Ramon La Fuente I did not find at home. With Macandrew I was a pretty long time, and for at least three quarters of an hour I chatted with old Mrs. Pfeiffer. Also with Doña Dolores Puente I was for more than half an hour.

In the evening Garland was far from well; he suffered from an oppression on the heart, and lay down at an early hour; on the other hand Urquhart was well enough to dine with us. Dr. Middendorff had cured him in a day or two, whilst his former physician Deutz only had made him suffer.

Monday, $23^{\text {rd }}$ of September 1878. Dr. Palacios, the Minister for the Interior, was regularly in his office at about nine; I went to see him this morning, and he instructed young Eygurren, who was with him, to draw out an escrito to the Juez de $1^{\text {a }}$ Instancia demanding that Juan Aliaga y Puente should point out one or two shops in his house Calle de Palacios to be embargoed by me, because the amount of $[\ldots]$ the house Calle de Polvos Azules did not cover [751] half of my demand. This was [...] ingly [_]bout noon, and I took the escrito to the notary's office.

To-day the weather was pleasant and warm, thermometer at 5 p.m. $68^{\circ} \mathrm{F}$.

Already last night Limpricht had told me in the greatest secrecy that three or four merchants in Lima had received telegrams from Europe to the effect that William Scheel's drafts on Dreyfus Bros. \& Co., of Paris, had been protested for non-acceptance, but that in all probability they would be paid when due. 
In the course of the day this news spread all over the mercantile world of Lima; but in the evening Limpricht again told me that the house of Dreyfus would assist Scheel, and prevent his failure. Further that Dreyfus offered their bills on their Paris house, payable in London, at 28d.

Tuesday, $24^{\text {th }}$ of September 1878. Dia de las Mercedes. At an early hour I went to Dreyfus's office and bought two bills at the above rate, £420 for C. W. Schutte, $£ 220$ for Juan Diez.

Thermometer at 2 p.m. $68^{\circ} \mathrm{F}$.

In the course of the day I paid the customary visit to Mercedes Guise, widow of Dartnell, and made several other calls, amongst which one upon Dr. Manuel Morales, whom I congratulated on his having been chosen, though only provisionally, Vocal of the Supreme Court. He was always very agreeable. Dr. Ribeyro was also in good humour; neither had I any reason to complain of Dr. Muñoz.

In the evening, Enrique Barreda, son of Don Felipe, married Amalia, daughter of Domingo Laos, a rich landed proprietor in the North, who went by the name of Caballero Laos, and of whose want of intellect many stories were afloat. He was one of the few hacendados who were not indebted either to the Banco Territorial or Banco Hipotecario, and of late he had bought the large house opposite the Church of La Concepcion, formerly Antonio Salinas's. Two hundred persons or more were present at the ceremony. [752]

Wednesday, $25^{\text {th }}$ of September 1878. The Cojo Larrañ[_] had again been arrested, for he had returned from his banishment without permission. Cudlipp's motion in the Chamber of Deputies, to replace the small bank notes with low silver charge, had been rejected.

Thursday, $26^{\text {th }}$ of September 1878 . At 1 p.m. Sebastian Lorente, Pedro Correa, and I were in the office of the Banco Hipotecario. The advertisement regarding the registration of Cédulas was read and approved, with trifling alterations. One loan asked for, though recommended by Lizardo Montero, was refused; whilst we agreed to make another to a certain Schreibmüller in the valley of Chicama in case the property he offered to mortgage was really worth as much as he said it was.

One table with rocambor players, Garland was generally able to make up. This evening he, Pinto, Basagoytia, and Dr. Middendorff were the players, Melchor Velarde looked on. Enriqueta, Limpricht and I usually retired between eleven and half past.

Friday, $27^{\text {th }}$ of September 1878 . A pleasant sunny day. Thermometer at 4.30 p.m. $69^{\circ} \mathrm{F}$.

Coined silver was at a premium of $52 \%$, last year 9o; bar silver this year $\mathrm{S}_{15}$ to $\$ 15.20$, last \$2o; Exchange this year $26 \mathrm{~d} 1 / 2$ to $27 \mathrm{~d}$ per sol, last year 20 to 21 . 
The improvement was considerable, but I doubted that if ever we should again reach 30 this rate could be maintained for any length of time.

Sunday, $29^{\text {th }}$ of September 1878. Bryson and I occupied ourselves with remodelling the diary of 1875 and indexing that of 1869 . From about 2.30 p.m. to 4 Limpricht and I played three games at chess; the first he gained, the two others I. I then took a long walk till half past six, which made me somewhat sleepy after dinner. However, as Garland went to José Canevaro's to play [...] mbor, Antonio with him to dance, I remained up with [753] Enriqueta till near eleven.

Little Corina was never well. She had not enjoyed perfect health for nearly the last three months. She coughed a good deal, had always saliva in her mouth, sometimes she had fever, occasionally a difficulty in breathing, and finally, her weakness was great.

Monday, $30^{\text {th }}$ of September 1878 . In the Supplement to Appendix under № 33 is affixed a cutting from the "Times", containing the Berlin Treaty of Peace of $13^{\text {th }}$ July 1878 . On the $4^{\text {th }}$ June, the English Ambassador Layard signed, in Constantinople, with the Turkish Minister for Foreign Affairs, a treaty for a defensive alliance between the two countries, in which treaty the Island of Cyprus was ceded to Great Britain on condition that it be returned to Turkey as soon as Russia would restore Kars and Batoum. In the Supplement to Appendix under $\mathrm{N}^{\circ} 34$ will also be found the advice of the death of my cousin Theodore Hugues. I saw by the papers that Andrés Zavala had instituted a suit for divorce from his wife Josefa Prada.

This day, in the church of La Merced a religious ceremony came off in celebration of the first anniversary of Henry Meiggs' death. The singing and music were fine, and the concourse was great.

Böhl, manager of the firm of Gibbs, bought this day in public sale, 600,000 Soles Nitrate Certificates, belonging to the bankrupt Salitrera "Rimac", at 94 1/2\%. Alejandro and the brothers Cox also bid, but retired when they observed that Böhl was intent upon having them.

Thursday, ${ }^{\text {st }}$ of October 1878. At 12 o'clock, Enriqueta, Enrique and I drove to the pantheon to be present at the removal of the coffin with my dear Mariquita's mortal remains from the niche in which it had hitherto been deposited to the sarcophagus to the right of the altar in my chapel.

The entire management I had entrusted to a certain Lund, belonging to Mould's staff. Ale[?]ria the [_] [754] [...], was also on the spot. I delivered to him the document which shewed that I had bought $\mathrm{t}\left[\_\right]$niche, which now again became the property of the Beneficencia. The marble slab was removed, the niche opened, and the coffin carried to the chapel. Dr. Middendorff had dissuaded Enriqueta and myself from having it opened, for he assured me, 
that not much more than two years having elapsed, the corruption was not yet complete, and we should therefore see death in its most revolting stage. In the chapel Lund had erected some scaffolding with pulleys to lift up the lid of the sarcophagus of very great weight, for doing which the united forces of several strong men were needed. The coffin was then lowered down, but with its wooden mouldings it was a few lines too long for the interior of the sarcophagus, and we had thus to place it in a slightly slanting position. The lid was then carefully lowered, and the interstice covered over with a little chalk to prevent insects from entering. This chalk could easily be cut open if some day or other we should again be inclined to raise the lid.

Enriqueta, who, as was to be expected, was extremely sad, and weeping the whole while, had taken flowers with her which she threw upon the coffin, and placed a wreath upon the lid of the sarcophagus. The scaffolding was then removed, the floor and the outside of the sarcophagus washed, and we drove home. It was a melancholy duty which we had had to perform; but nevertheless I was glad that we had decided upon building this chapel with its two sarcophagi. The altar had been enlarged by means of a polished cedar board, nicely wrought, placed over it. In this board a small stone said to contain the relics of some martyr, which we had obtained from Dr. Gregorio La Rosa, [_] up in a piece of linen, was inserted; for without [755] these relics it would be no altar, merely a [...] onry, at least this is the belief in Roman Catholic countries.

Wednesday, $2^{\text {nd }}$ of October 1878. In the Chamber of Deputies, Chinarro moved that the Minister of Finance Barranaga should be asked whether there was any truth in the rumours which were afloat, and which said, firstly, that the Government had lent to Charles Watson \$9oo,ooo in Nitrate Certificates, and secondly, that five hundred thousand soles notes of the Compañia de Fomento y Obras Publicas, not provided with the Government's stamp, had been put into circulation by the Government. A certain Oviedo spoke of frauds committed by the Government in the purchase of Salitreras which ought to be looked into. At a little to one five of the Directors of the Banco del Perú took their seats. The object of their meeting was to determine who should take the place of Rey, who had thrown up his post in the Cerro. However, as long as I was there, for I had necessarily to go to the Banco Hipotecario, the conversation ran solely on the two facts, not rumours, of which I spoke above, and Candamo assured me that the amount of notes put into circulation by the Government was not $\$_{500,000,}$ but $\$ 1,600,000$. If this were true, which I did not doubt, what was the use of burning the bank notes? On the $1^{\text {st }}$ S170,00o had again been committed to the flames, including which the total burned came up now to $\$_{3,140,000 \text {. }}$ 
In the Banco Hipotecario I learned that the loan to Schreibmüller, of which I spoke on the $26^{\text {th }}$ September, had not been made, because upon enquiry it was discovered that the [_] tates he wanted to mortgage were not worth as much as he had stated. Gallagher read a proposal made by Alejandro Garland, at present the largest shareholder in the Banco Hipotecario, which, if acted upon he believed to be beneficial to the establishment. I shall give the details as soon as they are laid before the shareholders in a general meeting. In the meanwhile we resolved that [_] [756] [...] udy them in his own house, to form his opinion, and that we should discuss them in the next meeting.

Saturday, $5^{\text {th }}$ of October 1878 . We were again together in the Banco del Perú, when we resolved to decline an offer made us by the Delegates to pay us the amounts they owed the bank, both in Pounds sterling and soles, in thirteen month[_] by instalments, but this only when the question about the Salitreras, pending in the Chambers, was decided. We further resolved that the Gerentes should address a letter to Francisco Garcia Calderon, President of the Delegation, and request his answer within a day or two to the question put him, whether he had actually delivered to Charles Watson \$9oo,ooo in certificates or not; to which was added that the Delegates of the Banco del Perú knew nothing of such delivery. The lawyer Dr. Ramon Ribeyro wrote the letter in rough.

Sunday, $6^{\text {th }}$ of October 1878. Bryson having gone to Ancon on the previous day did not come in the forenoon. Ricardo read to me from the Leipsic Gazette some details regarding the Turco-Russian War. When he had done I had a visit from Knauer who again brought me bad news. His sister Maria, married to Arthur Donner, who, perhaps a year ago, had had a cancer cut out of her breast, and who had since then been suffering from various maladies, had died on the $23^{\text {rd }}$ August, 49 years of age. I knew her in 1843 , when she was a very nice, pretty young girl. Her eldest son had died in the Franco-German-War of wounds received in the battle of Mars la Tour. When Knauer was gone, I made some of my usual calls, upon the family of Rafael Velarde, upon Doña Manuela Portillo, and Doña Dolores Puente. Frederick Marriott, the Gerente of the Gas Company, was always ailing, now he had removed to [_]. After dinner Ricardo again read [757] to me about an hour.

Monday, $7^{\text {th }}$ of October 1878. This morning I met Dr. Palacios in the street who told me that it was not at all unlikely he would shortly resign, because he would on no account sign any decree to the prejudice of Dr. Quiñones, Prefect of Puno, and Colonel Suarez, ex prefect of Arequipa, against both of whom the Chamber of Deputies had been thundering. They demanded the deposition of the former, and the erasure of the latter's name from the military 
list. Dr. Palacios pretended that the object of Falconi, the chief of the Puno gendarmes, had been to bring about a revolution in favour of Pardo, to which Manuel Costas had given the money; in my opinion, a fabrication without the slightest foundation.

In the previous week the young folks had had many opportunities to dance, of which Enrique and Antonio had mostly availed themselves, viz.: Tuesday and Wednesday at Basagoytia's, rather dull. On Thursday at Macandrew's, his usual weekly party, with which all who went there were extremely well pleased; on Friday a great ball had been given in the house of the late Don Pedro PazSoldan, and finally, last night a very pretty concert and dance at Dr. Antonio Arenas's. Garland was hardly at home a single evening in the week; he was always on the look out for rocambor.

The "Star and Herald" informed us of a dreadful accident which had occurred on the Thames. On Sunday, $1^{\text {st }}$ September, when an excursion steamer, the "Princess Alice", was returning from Gravesend, with nearly 800 persons on board, mostly of the middle and lower classes, amongst whom a large proportion of women and children, at about 8 in the evening when it was getting dark, she came into collision with another large steamer coming down the river; her bow was stove in, and in about five minutes she heeled over and went down in deep water; perhaps $15^{\circ}$ persons were saved [...] [758] [...] of the other steamer. The "Tasmann" which went down some time back in Ponce Bay, Porto Rico, will likely be raised, an expedition for that purpose having been sent out from Norfolk in Virginia.

Tuesday, $8^{\text {th }}$ of October 1878. I was cited to the Insurance Company "Lima", went at the appointed hour, one o'clock, and was joined by Moscoso Melgar and Menchaca. Though we formed no quorum, we authorized Elizalde to purchase more of less $\S_{30,00 o}$ in Nitrate certificates, so as to complete the round number of 100, if they could be obtained at $92 \%$. Money was very abundant, and it was difficult to place large amounts, with good security, even at $10 \%$ annually.

Wednesday, $9^{\text {th }}$ of October 1878 . Fernando O'Phel[_]n, whom I had told that I had some money disposable, (the $\mathrm{S}_{48,000}$ of C. W. Schutte's) came to me this morning and wanted \$20,000 for a certain Seguin, giving as security \$70,000 of the documents called Pardo's debt, upon which I refused to make the loan. This so-called Pardo's debt consisted of certificates given by the Caja Fiscal for the amounts owing by the Government to its creditors at the time when Pardo's period as president had expired and when he was succeeded by Prado, say, on the $2^{\text {nd }}$ of August 1876 . These were quoted in the market at about $40 \%$, and Alejandro had bought large quantities of them.

Last night Enrique had had again an opportunity of amusing himself, at a dance given by Henry Higginson, in celebration of the birthday of his eldest son Enrique. 
Thursday, $10^{\text {th }}$ of October 1878 . This morning between 7 and 8 a fatal accident occurred on the Lima and Chancay line. General Rivarola, who had ordered a private conveyance for himself, had left the station near [_] Barranca at about 7 in a small railway car- [759] riage attached to a corresponding [...] "El Caballito"; before reaching the Portada de Guias they came into collision with a heaving steam-engine pulling a waggon with labourers, at a spot where the line makes a curve. When they came in sight of each other, both drivers did their utmost to stop the engines, but in vain, they rushed on; the lighter conveyance was thrown off, and the occupants hurled to considerable distances. The engine driver Andersen was killed on the spot, the brakeman had his legs amputated and was likely to die, General Rivarola, so much and severely wounded that his life was despaired of. The driver of the large engine had fled. Various individuals were arrested, and their declarations were to be taken. Adrian Bielich, who had rented the line from the Government, had been fined \$10,000.

Garland, Enriqueta and the two little girls went to Chorrillos to have a look at the upper story of Luna's rancho, close to ours, because Dr. Middendorff wanted Corina to change climate; but neither of them was pleased with the conveniences it afforded.

Friday, $11^{\text {th }}$ of October 1878 . At about 3 p.m. when, as it was my custom, I took my walk to give Bryson time to copy the remodelled diary I looked in at Melchor Velarde's to enquire about his health, his second daughter Herminia told me that her father was pretty well, but that her brother Jorge, an excellent young man, midshipman in the Peruvian navy, had spat blood; he was in bed with a blister on his chest. I was afterwards told that when on board he had ordered the carpenter to put out of the way a large piece of iron which was lying on the deck; the carpenter had said, that it was too heavy. "What! too heavy?" replied Jorge, "lift it up with me." They did so, and instantaneously he felt some pain in the chest.

Saturday, $12^{\text {th }}$ of October 1878 . The Directors of the Banco del Perú sat down at about $1.30 \mathrm{p}$.m. In our last meeting of $5^{\text {th }}$ inst. we had resolved that a letter should be addressed [...] [760] [...] ion on the subject of the \$9oo,ooo Nitrat[_] Certificates delivered to Charles Watson. This had been done accordingly; he had not answered; on the $10^{\text {th }}$ a duplicate had been sent him through a notary, whereupon he had cited a meeting of the Delegates, at which, on the part of El Banco del Perú, Calderoni and Escobar had been present. He had defended his delivery of the $\$ 900,000$ on the plea that the Delegados were only administrators on account of the Government, and that he had had to obey the orders of the President. The first written order for $\$ 500,000$ was dated $1^{\text {st }}$ May, signed by Minister J. F. Garcia, and provided with the flourish of the President. The second was dated $8^{\text {th }}$ June, for $\$ 400,000$ and odd, and signed by J. D. Rivero, 
chief of one of the sections of the Finance Ministry. Derteano, in the name of the Banco Nacional, had protested that he did not know a word about such delivery. Albarracin had done the same for the Providencia; and Calderoni and Escobar had insisted upon an answer to the letter, which Calderon said he would send. I was the first to speak, and said that on no account could we wait for the answer longer than Wednesday next, and that we must then take some decisive measure. I also asked whether we had not resolved that Calderoni and Escobar should demand the destitution of Calderon as President of the Delegation, to which Calderoni answered that if they had done so they would always have been in the minority. Moreover, that in reality the Delegation did no longer exist; it was in liquidation, and the new Nitrate Company, to which the Providencia had made over the late contract with Government was now attending to the Nitrate business; and of this new Company Garcia Calderon was again the President.

In the Senate and Chamber of [761] Deputies, much was said about the [...] ivery of these S9oo,ooo; of a non-authorized emission of half a million of bank notes of those signed by the Compañia de Fomento; also on the subject of the illegality of the Nitrate Contract with the Providencia; however no decision had as yet been taken.

Rivarola was likely to escape with his life from the wounds received on the Chancay railway.

From Europe we learned that Nobeling, who made the attempt on the Emperor of Germany's life, had died in prison a natural death. In the German Empire very severe measures were being taken to eradicate the Socialist societies. The Austrians, though always victorious, met with strenuous resistance from the natives of Herzegovina and Bosnia, who defended every inch of ground. In the Southern parts of the United States of North America the yellow fever was committing great ravages.

Sunday, $13^{\text {th }}$ of October 1878. Accompanied by Antonio, I ascended the Cerro of San Cristoval which I did not do so easily as in former years, then I used to climb up without stopping; to-day I had to rest three times. From our house to the foot of the mountain at the end of the paseo militar, it took us half-anhour, to the summit, 35 minutes; the descent into the valley of Lurigancho, 20, thence back to our house in Calle de Zarate, less than half an hour; altogether about two hours and a half. At home I lay down, and slept more than half an hour.

When Bryson was gone, Limpricht wrote up my cash for September, and we then played two games at chess, which lasted till 5.30, and which I lost.

At dinner we had the two little girls of Isabel Aliaga, widow of Lacroix, Maria and Isabel, very well brought up. In the evening Enriqueta, Limpricht $[\ldots][762]$ Garland having gone to play rocambor at Basagoytia's. 
Last night were married Alfredo, one of the sons of M. F. Benavides, to Maria, second daughter of Isabel Coloma de Canseco, who had sent me a note inviting me to be present at the ceremony, to which I gave a negative answer because for the last two years I had entirely withdrawn from large parties. Garland, Enrique and Corina were the only ones of the family who went.

Monday, $14^{\text {th }}$ of October 1878 . Little was the progress which I made in the lawsuit against Aliaga. Upon his escrito in which he said that he could not approve the sale of the house $\mathrm{N}^{\mathrm{os}} 11$ and 13 Polvos Azules, Dr. Quiroga had decreed "traslado". I refuted Aliaga's arguments, and at the same time demanded that his house 26 Calle de Palacio should be embargoed, because the proceeds of the sale of 11 and 13 Polvos Azules would not cover my claim, and also asked that he who had bought the said 11 and 13 should deliver the purchase money to me. Quiroga reapproved the sale, but gave no reply to my two other petitions. To-day I presented a new escrito reiterating my demand for the embargo of 26 Calle de Palacio.

In the course of the morning I called on Manuel Cucalon and Cipriano Correa, liquidators of the affairs of the Banco de Lima, who had now only one clerk, Polo; they were involved in an infinity of lawsuits, arising mostly from the old debt of the Salitrera Esperanza, of the ultimate result of which they could as yet form no idea. José Muro was the prime mover; his lawyer was Fuentes, "El Murciélago"; the bank's, Isaac Alzamora.

In the meeting of the Banco Hipote [...] 12 o'clock, all the Directors, and the lawyer [763] Ramon Ribeyro, were present. [...] project, of which I have already made mention, was brought forward and thoroughly discussed; as yet, no resolution taken, and Ribeyro was requested to give his written opinion as to the legality of the same. At all events we decided that it should be presented to the shareholders in the next general meeting as a project of one of the shareholders, Alejandro Garland, not as a project of the Directory, so that, if adopted, no responsibility could ever be attached to the latter.

Thursday, $15^{\text {th }}$ of October 1878 . Whilst Bryson was copying the remodelled diary, I went out to the pantheon, opened the chapel, and for about five minutes sat down on the step of the altar, thinking of her who lay so close to me, and yet was so far away. I was very low spirited the whole day.

Wednesday, $16^{\text {th }}$ of October 1878 . The temperature was this year less warm than it had been in the same month of last year; then we used to spend the last hours of the day in the open air on my side of the corridor; this year it was as yet too cold to do so. Thermometer at 3 p.m., in my office, $701 / 2^{\circ} \mathrm{F}$.

From the Star and Herald of $3^{\text {rd }}$ inst. I took the following details, copied from the Saturday Review, about the ancestors of Benjamin Disraeli, Earl Beaconsfield, at present Prime Minister of Great Britain. Till the end of the $15^{\text {th }}$ century they, of Jewish persuasion, lived in Spain; then removed to Venice, 
where under the mild and tolerant government of that Republic, they traded in peace until the year 1747, when the grandfather of the present Earl settled in London. His father Isaac, in every respect a literary man, and imbibed with the principles of Voltaire and Rousseau, quarrelled with the synagogue about the payment of a penalty imposed upon him, which led to his withdrawal from the Jewish communion in 1817. Benjamin was born in the $21^{\text {st }}$ December 1804

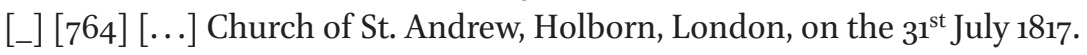

From other papers I learned the following. The number of letters which in 1876 had passed through the Post Offices of Great Britain and Ireland came to 1,019,000,00o more or less. In the same period five millions pounds and odd in gold, silver and bronze money had been coined. Of the last two metals a very small proportion. In the same year the coinage in Sydney and Melbourne reached nearly four millions of pounds.

Thursday, $17^{\text {th }}$ of October 1878. I was dressed by 8 o'clock, walked as far as where the Chorrillos line leaves the town, and on my return home looked in at the office of the notary Prieto, where I was told that Judge Quiroga had ordered Juan Aliaga y Puente, de ampliar el embargo, under my responsibility. Fearing that this expression might have some sinister meaning I went to Dr. Palacios's office, who was already there; he told me that I need not trouble myself about the words "my responsibility".

At 9.30 I was home, when Ricardo read to me till breakfast an article in the "Leipzic Gazette", which enabled me to form a clear idea of the late TurkishRussian war; and from the "Nacional", which paper treated detailedly on the important nitrate question.

At past ten we sat down to breakfast, I to the left of Enriqueta. I only took, as it was my custom, broth with yuca, and an egg, a few slices of fried plantains, a cup of tea, and hardly any bread. Maria used to breakfast in her college, Antonio at Gibbs's, Geraldo frequently with his brother Alejandro in Chorrillos. Guillermo was absent in the Cansas copper mine near [_]. From past eleven till past one, Mr. Davies [765] was regularly with me. [...] as Tomás Mosquera, once or twice president of Colombia. We were still occupied with reading Rawlinson's "Ancient Monarchies", in which we had come to that of Media, whose king Cyaxares overthrew the empire of Assyria about the year 630 B.C. The original Media was situated more or less to the west of the southern part of the Caspian Sea, and of the salt desert of Persia; to the north it was confined by the Araxes, to the west by the ridge of the Sagros, to the south the limits were rather undefined. Davies likewise read to me the "Eclectic". We had just finished one article in the September number, on the eccentric, one might say half crazy wife of William Lamb, Viscount Melbourne, whose maiden name was Caroline Ponsonby, and who died $26^{\text {th }}$ January 1828 , in her forty-second 
year. Another article treated on Freemasons, of whom it was calculated there existed at present about 450,000 all over the globe. There were more than 5000 lodges in the United States, 1600 in England and its colonies, and 400, very numerously attended, in Germany. For many centuries back the common masons had their guild in Germany, whence the present freemasons have their origin. About the beginning of last century the freemasons sprung up in England. According to this article their object is exclusively charity.

Till Bryson came at two, I was by myself. With the old diaries we were as far as May 1875. For the last 20 minutes he read to me Carlyle's French Revolution, written in his usual whimsical style.

Of the half-hour till dinner I generally availed myself to take a quiet run as far as Cinco Esquinas. From 7.30 to 9 Brierly was with me. We were reading "Memoirs of Mary, Queen of Scots", by Miss Benger; and George Elliot's "Daniel Deronda", which I wished I had done with, so tedious was it to me.

This being Thursday evening Garland [_] [766] [...] I did not enter the room, and was in bed by ten.

This was my usual way of living on a week day; occasionally I had to spend an hour or so either in the Directory of the Banco del Perú or that of Hipotecario. To-day I lent to Calixto Pfeiffer, through the intervention of the broker Gabriel Saco, on account of C. W. Schutte, for 3 months at $10 \%$ annual discount, $\$_{3} 6,000$, on sufficient security.

Sundays and holidays Davies did not come; Bryson from 11 to 2; on Sundays in the evening he was not with me, on holidays he was. The time from 2 to 5 on these days I alternately played chess or paid visits.

Friday, $18^{\text {th }}$ of October 1878 . When at 9 o'clock I was with the notary Prieto, he told me that Aliaga had given in an escrito appealing to the Superior Court, against what he called the unwarrantable sale of his house 11 and 13 Polvos Azules. At about 5 p.m. I was again with the notary, when Quiroga's decree which admitted the appeal was notified to me.

Saturday, $19^{\text {th }}$ of October 1878. The king of Assyria whom Cyaxares defeated and dethroned was Ashur Banipol, whose predecessors had sat upon the Assyrian throne for perhaps ten centuries. To the common reader he is known by the name of Sardanapalus, who, unable to withstand the enemy, part of the fortresses of Nineveh having been destroyed by a sudden rise of the Tigris, set fire to his palace, and was burned with his courtiers, wives and concubines. He had ordered a general of his, who was Governor in Babylonia, called Nabopolassar, to attack the invading Medes from the South, whilst he himself opposed them in front, but the Babylonian passed over to Cyaxares, who rewarded him [_] his treachery by re-instating him as King of Baby[767] lonia, and by giving his daughter [...] ge to Nabopolassar's son, called 
Nebuchadnezzar. Cyaxares, after having overrun the whole of Assyria, came in hostile contact with Allyates, king of Lydia, situated somewhat more to the Westward. Their formidable armies fought for one or two days without either gaining any advantage, when an eclipse of the sun put a stop to the carnage. They formed an alliance, and the Lydian king's daughter married Astyages, the mild, unwarlike, and luxurious son of the conqueror Cyaxares. Thus, united by matrimonial alliances, the subjects of the said three kings enjoyed for about fifty years the blessings of peace and tranquility. According to some writers, Persia was at that time an independent kingdom; according to others, a dependency of Media; but whatsoever it may have been, Atradates, father of Cyrus, of the family of Achoemenida, ruled Persia, either as king or satrap. War was once more kindled, this time between Astyages and Cyrus. The Persians, defeated more than once, gained at last a decisive victory. Astyages was made prisoner, and Cyrus became king of the Medes and Persians. This happened about 558 B.C. Meanwhile Nebuchadnezzar had died in Babylon, and his son been murdered by his brother-in-law, which accounts for the Babylonians having withheld their assistance from the Medes in their conflict with the Persians. The kingdom of Media existed but 70 years.

In the Chamber of Deputies, the Minister of Finance Barinaga gave the following answers to the questions put to him. The exact amount of nitrate certificates handed to Charles Watson, as representative of the heirs of the late Henry Meiggs whilst J. F. Garcia was Minister, was 97 of \$10,000 each. Further, that his predecessor had authorized the illegal circulation of $\$ 500,000$ in billetes; that he himself had given the decree for the circulation of $\$ 1,600,000$ more, and that [768] [...] about \$9oo,ooo of these \$2,100,00o still remained in circulation. The same Minister, Barinaga, had given in his resignation.

Exchange on London by the steamer of the day before yesterday was 24 to 24 1/2 pence. Discount there, per last advices, $6 \%$.

In the Banco Hipotecario the five Directors, with Ramon Ribeyro the lawyer, and Alejandro Garland, were present; they were together from 12 to 3 . This latter's project was discussed. Its outlines were the following: Ever since the establishment of the bank, the redemption of the Cédulas had not been made with due exactness, the consequence of which had been that at present about 11/2 millions of soles had been redeemed more than there should have been, by which means the holders of cédulas had been improperly benefited, and the shareholders prejudiced. Now Alejandro proposed that one million of cédulas be emitted, and that these one million be divided amongst the shareholders in payment of one third of their shares, so that the capital would be reduced to two millions of soles and the cédulas be increased to 8 millions, in exact accordance with the statutes, which said that the capital must be at least equal to one fourth of the cédulas. The first point to be discussed was, 
whether it was a legal transaction. Dr. Ribeyro gave in his written opinion to the effect that it was legal, and the opinion of each Director was asked after very long debates. Lorente still entertained some doubts, whilst we four others declared that it was legal. Then came the second question, whether it was convenient. Now I with all my might spoke against it, because if this project passed, the bank would take upon itself the obligation de hacer el servicio on one million Soles of cédulas more than hitherto, that is to say, an [_]al payment of \$130,00o, whilst as long as there [769] existed the one million in shares, [...] to pay the dividend which it could pay, and which perhaps might be nothing at all, and that thus without any necessity it would take upon itself an additional obligation for the payment of \$130,00o. Secondly, if the Capital was two millions, and the cédulas came to 8 millions, our hands were tied, and we could not make any loan whatever, for the limited capital of two millions did not allow us to issue one single cédula more than the 8 millions. To these two objections I received the following answer: The annual collections of the bank were quite sufficient to pay this extra $\$ 130,000$, and as to the making of new loans, the state of the country was such that it would not be advisable to make any loans whatever for a length of time to come. These answers did not convince me and I persevered in my opposition. Lorente went with me. Correa, Melchor, and Dr. Galvez voted for the convenience; Galvez however said it was convenient for the shareholders; he did not say for the bank.

On my coming home, a telegram from Juan, dated $17^{\text {th }}$ inst., received from Valparaiso on the $18^{\text {th }}$, was handed me, containing these words: "Sell my Gas shares, market-price; Diez." It will be found in supplement to Appendix, under $\mathrm{N}^{\circ} 35$. I had now to act in conformity with these injunctions, though I had no idea what might be the motives of them.

Sunday, $20^{\text {th }}$ of October 1878. Dr. Palacios, Minister of the Interior, had given in his resignation. The "Comercio" made known that there had been another illegal payment to Watson of $\$ 500,000$ in Certificates and one million of soles in silver, and that in a secret sitting of the Chamber of Deputies this payment had been denounced by Julius Pflücker. In last night's "Nacional" Watson published a letter declaring that he had received no such certificates, nor silver; and Pflücker in another letter, to the editors of the "Comercio", said that he had not been quite correctly informed of what had occurred when making the above state[_] [770] [...] Deputies. Within the last few days a note addressed by Francisco Garcia Calderon, president of the new Nitrate Company, to Barinaga, Minister of Finance, had been published, in which he had stated that this new company had made the following advances to Government:

Three monthly instalments of $£ 60,000$ each; Something on account of the instalment of $1^{\text {st }}$ Novr., and $£ 64,000$ interest, paid $1^{\text {st }}$ October on the Nitrate Certificates. 
A motion had been made in the Chamber of Deputies, the object of which was to annul the 97 certificates delivered to Watson, or what is the same, to declare them of no value, as regards the present holders of them, it was said that they might claim the amount disbursed by them where and when they considered it to be for their interest to do so. This motion if it had passed, which it did not, would have been a flagrant injustice, for how could bona fide purchasers be made to suffer for any illegal act committed by the President of the Republic? Geraldo told me that even Felipe Barreda, known as the most cautious man in Lima, was the holder of a considerable number of these nitrate certificates. Within these last days the "Perusia", Oliphant's steamer, arrived in Callao. She brought a cargo of Chinese goods, also twenty-one Chinese passengers, but no labourers; and notwithstanding the poor prospect of receiving coolies for the sugar estates, the shares in the Banco Hipotecario had risen, owing solely to Alejandro's project, which had transpired. John Bryce had bought some at $671 / 2$, and now they could not be had at less than 70 .

I made some calls which required no notice. At dinner we had Jorge Valle, Juan Urquhart, and Johannes Limpricht. In the salita, [...] Corina and Maria we played with them some [771] stupid game of cards, and at past [...] xcept Enriqueta, Limpricht and myself.

Monday, $27^{\text {st }}$ of October 1878 . At breakfast I heard of the decease of Charles Higginson, who had died in London at the age of about 67 or 68 . He was the eldest brother of the Higginsons, the name of which family had occurred sometimes in my diary. One of his brothers is Enrique, port agent in Callao, and father-in-law of Guillermo Garland. When at the end of 1845 I returned from England viâ Panamá, his father, British Consul in Payta, was still alive, and to him I owed the passage on board H.B.M. Steamer "Cormorant" to Callao. Charles Higginson Junior was for many years clerk at Gibbs's. When his father died he removed to Payta, where he did some business, which he afterwards made over to Alexander Blacker, married to his sister Eliza. Higginson kept always a share in the business, which enabled him to live in Europe, mostly in London, in one of the club houses in the west end of the town. He died a bachelor.

Tuesday, $22^{\text {nd }}$ of October 1878 . At somewhat past 8 I walked to the house of M. F. Benavides, not far from the Callao gate, the ground floor of which was occupied by Francis Bryce and family. His mother-in-law, Doña Carmen LopezAldana, had died one or two days back, and I had received an invitation to be one of the many who accompanied the body to the pantheon. When I entered the room of course I distinguished no one; Mr. Bryce however rose and shook hands with me. Afterwards, Manuel Pardo came in, and took his seat near me; 
in the course of our conversation I asked him his opinion about Alejandro's project regarding the Banco Hipotecario; his answer was that Alejandro had consulted with him, and that he looked upon the new issue of one million soles cédulas as correct. In the patio I shook hands with Heudebert, Vicente Oyague, and Henry Higginson; to the pantheon I had a coach to myself. When there I had time to go to my chapel where I found [_] [772] [...]

Davies did not come; I waited till past twelve, and then, not being quite certain whether I had locked the chapel, I again went out to the pantheon, this time on foot, which I did in an uncommonly short time.

In the Banco del Perú the Directors discussed a letter addressed to Francisco Garcia Calderon, written in rough by Ramon Ribeyro, the object of which was to induce him to lay down the Presidency of the Delegation of the Associated Banks. Ruden, Candamo, Ayulo and I were not pleased with the style of the letter, Calderoni and Escobar defended it, Bryce did not give his opinion. Whilst we were discussing we experienced a pretty severe earthquake, and before we had taken a resolution, Ruden, who had been called out by Calixto Pfeiffer, re-entered with the news that James Sawers \& Co. of London had suspended payment. This put an end to our debate; we separated and agreed to meet again the following day. The news of Sawers' stoppage spread like wildfire, and the natural consequence was that everybody believed exchange would rise.

Wednesday, $23^{\text {rd }}$ of October 1878. Davies came as usual; yesterday he had been indisposed. In the Banco del Perú, at about one, the Directors, except Ruden, were assembled. Candamo proposed that a letter should be written to Calderon in which the Gerentes were to tell him that the Delegation was in liquidation, that it was advisable he should make this known in the papers, and that we had seen an acceptance of the Delegation without the words "en liquidacion" being added. Candamo's object was to prevent the Delegation from making a new contract with Gibbs for the consignment of Nitrate to them, because the "Codigo del Comercio" does not allow a firm in liquidation to enter into fresh business; and this end being obtained, he hoped that the Government would consign their Nitrate [_] to Gibbs, without intervention of the Delegation; [773] though the majority was of opinion [...] would be a prudent measure, it was violently opposed by Calderoni, who thought that it would be entirely useless. Ayulo, generally one of the silent members, was this day particularly eloquent, and insisted upon the necessity of our remaining quiet for a day or two until the horizon cleared up, by which he meant that we should wait till we knew whether Gibbs would admit the consignment or not; and this would not be determined until the arrival of James Hayne from 
Valparaiso, who was expected on Sunday next, for Böhl of Gibbs's house would not take any decision until he had conferred with his partner.

Exchange on London 23d; Nitrate Certificates $911 / 2$, in demand. I made another loan for Mr. Schutte, of $\$ 7800$, to G. Saco, for 3 months, at $10 \%$ discount. Thermometer, at $3 \cdot 30,70^{\circ} \mathrm{F}$., 7 less than last year.

Thursday, $24^{\text {th }}$ of October 1878 . Politics became more complicated from day to day. In the Chamber of Deputies two motions had been made yesterday; the one to accuse J. F. Garcia, the other, both Garcia and Barinaga, before the Senate, for the fraudulent issue of Nitrate Certificates and bank notes. On the other hand a letter was published in the papers, addressed by Charles Watson to the President, demanding the immediate payment of part of the amount due to the Company which he represented, and threatening to put a stop to the traffic on the railways between Mollendo and Arequipa and other places, if such money was not forthcoming.

The last advices from England quoted Nitrate at $13 \mathrm{~s} 6 \mathrm{~d}$ the cwt, and silver at $48 \mathrm{~d} 1 / 4$ the ounce Troy.

At 2.30 I was in the Banco Hipotecario where all the Directors and a good many shareholders were assembled. Lorente opened the session, and made a short speech. Gallagher read Alejandro's project, the opinio [...] [774] [...] about its legality, the opinion given by the book-keeper of the Bank, and the last "acta" of the Directory, which recapitulated the opinions emitted by the same. The project met with considerable opposition; the spokesmen were Dionisio Villate, Noel, Agustin Escudero, all opposed to it. Evaristo Barrios said that a statement of the pecuniary condition of the bank ought to be drawn out and laid before the shareholders. Alejandro defended his project calmly, and very properly. I said a few words, but not of much importance; at last it was resolved that all the above documents should be printed, a copy sent to each shareholder, and moreover, a committee named with the object of giving its opinion within a fortnight after the copies were sent round. I proposed as members of this committee, Dionisio Villate, who at once refused to accept the nomination, Manuel Candamo, and J. V. Oyague. Lorente named me. I declined, because, as Director, I had already given my opinion; and finally, Pedro Helguero, Evaristo Barrios, and Dr. M. M. Galvez were fixed upon. Thence I hurried to the Secretaria of the first chamber of the Superior Court, which was already shut up; next, to Rafael Velarde's house, to congratulate him on his Saint's Day. He, being indisposed, was not visible.

Thermometer, at $5 \mathrm{p} . \mathrm{m}, 69 \mathrm{1} / \mathrm{2}^{\circ} \mathrm{F}$.

In the evening there were two new rocambor players: a certain Madrid, an Ecuatorian, introduced by Jorge Valle; and Luis Bryce, son of John Bryce, married to Grimaneza, daughter of Grimaneza Althaus, widow of M. M. Cotes, 
resident in Paris. He was one of the two gerentes of the United States Guano Company. The usual players were: Dr. Mid[_] Jorge Valle, José Basagoytia, M. F. Benavides, [775] and Pinto.

Friday, $25^{\text {th }}$ of October 1878. The obnoxious Prefect of Puno, Dr. Quiñonez, had been removed, and had been named Peruvian Chargé in La Paz, in lieu of Bruno Bueno. The prefectship was entrusted to José de la Torre, Colonel of Hussars. At 1.30 the Directors of the Banco del Perú were again assembled. Calderoni made known that Garcia Calderon had offered the bank a share in the Nitrate Company, which offer was unanimously rejected. Then a great deal was spoken about the steps which the bank had to take if the Nitrate business were again to fall into the hands of the Delegation, which would naturally come to pass after the dissolution of the present Nitrate Company; this was our general opinion, and we were confirmed in it by César Canevaro, who, as Deputy, was better acquainted with many particulars than we Directors were. No resolution was taken, but we all agreed on one point, viz.: to insist upon the removal of Calderon from the Presidency of the Delegation.

Saturday, $26^{\text {th }}$ of October 1878 . Bruno Bueno and J. R. Izcue were to-day sworn in as Ministers, the former for the Interior, the latter for Finance. Pepe Izcue, as he is usually called, is the son of J. F. Izcue of Lima, and Inés Gutierrez of Arequipa, sister of the mother of Prado's wife, and, consequently, the new Finance Minister and Mrs. Prado were cousins. He, together with the sons of Charles Pflücker, the daughters of Julius Pflücker, and Corina and Amalia Schutte, were all in their time pupils of a certain Zyla, a native of Silesia, who taught me latin about the years 1840 to 1842 . Thus Izcue and Julius Pflücker, to whom the Finance Ministry had also been offered, but not accepted, were co-disciples.

Tomás Mosquera, 81 years of age, ex-President of New Granada, and leader of the Democratic party in that Republic, had died.

On the $26^{\text {th }}$ August a severe earth[_] [776] [...] north-eastern part of at 9 a.m. It had lasted from 7 to 8 seconds, and if the accounts received from Cologne could be believed, must have been very severe; its centre point seemed to have been the Aar valley and the mountain ridge of the Eifel. It was said to have extended as far south as Strasbourg, as far west as the Seine, to the North-east as far as Osnabruck.

The sentence of Dr. Quiroga as to the validity of the sale by auction of Juan Aliaga y Puente's house, 11 and 13 Polvos Azules, having been confirmed by the Superior Court, I went to the office of the Secretary of the first Chamber, where the corresponding notification was made to me.

Sunday, $27^{\text {th }}$ of October 1878 . Enriqueta was once more very ill of her usual migraine; she did not come to breakfast, at which meal I learned that Derteano 
owed to the firm of Dreyfus Bros. \& Co., Frs. 7,100,00 and that he was gradually reducing this debt by regular payments of \$50oo sterling monthly.

The Peruvian Saltpetre Company had advertized in the papers that the bills drawn on the $3^{\text {rd }}$ inst., for the cupones of the nitrate certificates on James Sawers \& Co., would be duly accepted by another firm, the name of which it did not give as yet.

When Bryson was gone I played two games of chess with Limpricht, from 2.30 to 5.30 . The first, which lasted two hours, I lost; the second of one hour's duration, was a drawn one. I then took a quick walk to where Barbones gate once stood, and was back before 7, when we dined, Urquhart with us, Enriqueta still in bed. When we were at the meal, Anibal Gonzales with two of his children, and his wife Josefa Bazo, came in. Doña Josefa kept Enriqueta company [_] Anibal remained with us, till about 9 when all left; [777] Garland went to his rocam [...]. Ricardo read to me in German from the Rundschau, an interesting article on ancient Gaul.

Monday, $28^{\text {th }}$ of October 1878. To-day in the Banco Hipotecario only Correa, Melchor and I were present. It now appeared to me as if Gallagher were opposed to Alejandro's scheme. Also Correa, hitherto a defender of the same, had changed his mind a little. Two proposals were laid before us, the one from Francisco Garcia Calderon, the other from Simon Soyer, both as to the cancelment of their debts; the first was rejected, the latter accepted with [_] tain modifications.

In the evening I did not go to the salita, but remained at Enriqueta's bedside till 10.30. There were again two new rocambor players, Juan Gallagher and Dr. Ricardo Zevallos.

Tuesday, $29^{\text {th }}$ of October 1878 . At 8 a.m. I was with the dentist Lince to have two of my teeth plumbed, for within these last few days I had felt some pain in them.

Thermometer, at 5 p.m., $72^{\circ} \mathrm{F}$.

Wednesday, $30^{\text {th }}$ of October 1878 . I had to repeat my visit to the dentist.

We read an advertisement in the papers which said that, as the firm of Dreyfus was about liquidating, henceforth Mr. F. Ford was the only representative of the house; the advertisement was signed by him, Derteano and Scheel.

Thursday, $37^{\text {st }}$ of October 1878. At 12 o'clock Enriqueta, myself, with Corina and the servant woman Aurelia, drove to the pantheon. Enriqueta took with her wreaths of flowers, which the servant Juan, who had gone by train, fixed on the sarcophagus, after having first swept and dusted the interior of the chapel.

Carlos Pividal, with his wife Victoria Soyer, had returned to Europe by the steamer of the $24^{\text {th }}$. It was supposed that the Government had instructed him to make, if possibl [...] [778] [...] London or Paris with the Peruv[_] Guano 
Company, limited, with Dreyfus, or with La Socié[_] Générale, so as to ensure the payment of the Cupon on the Anglo Peruvian Bonds, due $1^{\text {st }}$ January 1879.

Alejandro expected that this would cause a rise in the price of the bonds, and I had therefore, at his request, and on his account, given a letter of credit on A. Gibbs \& Sons for £200o sterling in favour of Carlos Pividal, who would avail himself of it if convenient to him. It was to remain in force till the $28^{\text {th }}$ February of next year.

In the evening Garland had two rocambor tables; at the one, M. F. Benavides, Manuel Seminario y Váscones of Piura, Luis Bryce, and Jorge Valle. At the other, Garland, José Basagoytia, Colonel Mariscal, and Madrid. I went to my bedroom at eleven.

Friday, ${ }^{\text {st }}$ of November 1878 . All Saints' Day. When Bryson was gone Limpricht wrote my cash for October. I had a short visit from Dr. Jervacio Alvarez, and from 3.30 to 5 my nephew and I played a game at chess, which I again lost. It was now clear to me that he played a little better than I.

At dinner we had the Canon Mora, Jorge Valle, and Urquhart; of Garland's sons only Juan, Ricardo and Antonio. Enrique was gone to his mines somewhat higher up than Chicla. When Brierley had read to me, and I went to the salitas, all the guests were gone. Enriqueta then read to me Juan's and Schutte's letters, and we remained together with Limpricht till eleven.

Saturday, $2^{\text {nd }}$ of November 1878. At 9 a.m., I was in the Banco del Perú where, as Director de Turno, I, jointly with Lecca, who came on account of the Government, exa[_]ed the cash, also an extract of the balance sheet to be [779] published in the papers, which [...].

Two conspicuous characters had died in Europe: Peterman the renowned geographer, in Leipzic, who, the papers said, had hanged himself; and Dupanloup, the ultramontane Bishop of Orleans.

I saw by Rawlinson's History that ancient Babylon was surrounded by a quadrilateral wall, forty-one English miles in circumference. The vast area enclosed by this wall and intersected by roads was however not completely built over. It is supposed that within the same much ground was either covered with trees or with corn, and that part was used for gardens. The width of the wall was given differently by different authors, from 85 to 32 feet; the height, from 375 to 73 . The ruins cover a great extent of ground. They are however merely mounds of earth mixed up with sun-baked and kiln-dried bricks, entire and broken.

In the course of last year 14,000 new houses had been built in London, and the new streets laid out in the same time measured 39 miles.

I went to the Justice Hall to enquire whether Juan Aliaga y Puente had appealed to the Supreme court, but to my surprise, found all the offices shut 
up, to-day being All Soul's Day. Hereupon I walked out to the pantheon, which presented exactly the same aspect as last year, then described by me. Before the door of my chapel there was always a crowd of people. I entered, and put some flowers, a present from Doña Juana Carbajal, upon the cold sarcophagus.

At dinner I felt so sleepy, a little unwell, also low-spirited, that I did not at all regret when I received a note from my lector Brierley, in which he said that indisposition prevented him from coming.

I went to bed at a little past eight, and awakening only for a few minutes, slept the whole night through till daybreak of [780]

Sunday, $3^{\text {rd }}$ of November 1878 , a proof that I had actually required some repose.

From the "Star and Herald" I took the following: In the year 1827, a boy was born in Magdeburg, whose father called Detroit, a descendant from the French refugees, was a trumpeter in a regiment of cuirassiers. The boy, when 13 or 14 years of age, ran away from his home, found his way to Rostock, embarked on board of a Mecklenburg vessel bound for the Levant, and on his arrival in the Bosphorus threw himself into the sea and swam on board of a Turkish man-of-war commanded by Ali Pasha, to whom he said in his broken French, that he was a Christian but wished to become a Mussulman. Ali Pasha took him under his protection; afterwards he studied in the military academy in Constantinople, entered the army, rose from grade to grade, distinguished himself on several occasions, acted, as Mehemet Ali Pasha, a prominent part in the late war against Russia, and was sent by the Sultan as Turkish Ambassador to the Berlin Congress, where it is said Von Bismarck did not always treat him with the deference which he deserved, and addressed him sometimes in German as Herr Detroit, which, if true, I look upon as a want of good breeding. On his return Mehemet Ali was sent by the Sultan to Albania to quell the revolt which had broken out there, and in September last he and about twenty of his followers were murdered by the insurgents.

Having played at chess last Sunday, this Sunday I had to make my calls. I went to see the family of Dr. Ribeyro, where I conversed a short time with the daughters; then to Rafael Velarde's, where Zoila received me. These two calls were not particularly agreeable. Better pleased was I with those on D[_]s Puente, and on Ernestina Pflücker, Mrs. Dibos, [781] at both places I remained a cons $[\ldots]$.

At dinner we had the two little La Croix, also Doña Goya Velarde. Garland spent the day in Chorrillos, and in the evening went to play rocambor at Basagoytia's. We amused ourselves with the little ones who made an attempt to represent "Titeres", (Punch and Judy). At a later hour Limpricht came in as usual. 
Monday, $4^{\text {th }}$ of November 1878. From Europe we heard of the stoppage of the Glasgow Bank, whose liabilities came to ten million pounds sterling. Discount in London was $6 \%$. Nitrate down to $13 \mathrm{~s} 3 \mathrm{~d}$ to $13 \mathrm{~s} 6 \mathrm{~d}$. Bar Silver to $48 \mathrm{~d} 1 / 2$. This last quotation was dated the $18^{\text {th }}$ October, on which day the German Parliament had passed Von Bismarck's bill against the Socialists and their societies.

About 1.30 p.m. the Directors of the Banco del Perú were assembled, when Candamo communicated to us that Manuel Pardo had expressed a wish that the three banks "Providencia", Nacional, and Perú, should each name one of their Directors to confer together on the most proper measures to be taken, in order to come to a satisfactory understanding with regard to the Nitrate business. I asked Candamo whether Pardo himself would be present at the conference of these three Directors, to which he replied that he did not know, but that it did not seem to him unlikely. The "Providencia" had named for this purpose, Menchaca; "Nacional", Pedro Correa; who was now to represent the Banco del Perú? Candamo said that Pardo had particularized Calderoni and myself. I excused myself on the plea of my want of sight. The reply was that if I could not see, I could hear. However at last my excuse was admitted. Candamo and Elizalde also begged to be excused; then Calderoni said as everybody else seemed afraid, he [...] [782] [...] first Chamber of the Superior Court, I was told that Juan Aliaga y Puente habia interpuesto nulidad.

In the evening I did not go to the salita where rocambor was played, but remained with Limpricht till past eleven. He read to me letters from his sister Elizabeth, in Moers, and from his brother Henry, in Greifswalde. The former wrote that her lungs seemed to be in a better state than they had been for some time past, but that her head leaned over to her left shoulder quite as much as before, and that the apparatus she wore gave her pain, without doing her good. Henry wrote that his daughter Maria, hardly 21 years of age, who had been married, perhaps a year or eighteen months back, had been obliged to keep her bed since March last, owing to a disease in the abdomen, and that though she was gradually getting better, she would certainly not be able to rise before Christmas. Johannes calculated that his brother Henry, as professor of Chemistry, had an annual income of about 15,00o Reichsmark, upon which he could live decently, not extravagantly, in Greifswalde.

Tuesday, $5^{\text {th }}$ of November 1878 . In the Secretaria I was notified that the Tribunal had admitted Aliaga's appeal. This morning it was very cool. At 4 p.m. the sun was out, Thermometer $77^{\circ} \mathrm{F}$.

Wednesday, $6^{\text {th }}$ of November 1878 . At a quarter past one I received a telegram, which will be found in supplement to Appendix, under $\mathrm{N}^{\circ} 36$, dated Nizza, $5^{\text {th }}$ November, 9.50 a.m., it contained the following words: "Carlie over buy bark Diez." I was much puzzled by these words and took them to Garland, who 
thought [_] meant: "Crisis over buy back.", which interpretation [783] I believed was correct, and accordingly [...] make no further sales of Juan's gas shares, neither to buy back any which I had sold; the reason for this my determination I gave him in my letter of this date. With Alejandro I drove to the cable office, where they were likewise unable to decipher the first word, and promised to telegraph back in order to learn what it really meant.

Thursday, $7^{\text {th }}$ of November 1878 . The Papers had an advertisement from the Peruvian Nitrate Company which said that the bills drawn on Sawers for interest on certificates at the beginning of the month, would be taken up by Graham, Rowe \& Co. of Liverpool. In the Insurance Company "Lima" we were: Moscoso Melgar, Valentin Gil, Messrs. Isaacson and Mathison, I, and the Gerente Carlos Elizalde. José Gregorio Garcia of Callao, from whom we held as security for his debt of twenty thousand and odd soles his shares in the Bellavista Corndepôt buildings, had declared himself unable to pay the principal when it fell due. We therefore authorized the Gerente, at his own suggestion, to place the pagaré, without loss of time, in the hands of Dr. Antonio Saldaña, for recovery. This same Garcia had owed me \$10,00o for several years, and, as I had charged $11 / 4 \%$ monthly interest, he had preferred to pay me the money, and to take it up at $1 \%$ from the Insurance Company. What a fortunate escape! Next, the Gerente informed us that Valdeavellano \& Co. wanted \$30,00o for 3 months at $1 \%$ monthly discount, placing into our hands as security a Nitrate Certificate for \$10,00o and a promissory letter directed to them by Antonio Prada, the owner of a valuable sugar estate, in which he bound himself to ship a considerable quantity of sugar within a certain time. I spoke first, and said that I was opposed to make the loan because I knew that Prada was not at all exact in his payments; to which Melgar replied that he had nearly cancelled his debt to "La Providencia", and that he was also up to the day with the Banco Hipotecario [_] [784] [...] at he and Elizalde were favour[_] inclined towards Valdeavellano. After a pretty long discussion, Gil, then Isaacson and Mathison said "Yes". As the majority was now in favour of the loan, my opposition was useless. Melgar as President did not vote.

Friday, $8^{\text {th }}$ of November 1878. In the Banco Hipotecario I learned that Prada was so far in arrears with his three-monthly payments that the Gerentes had thought proper to sue him, and had obtained the sentence for bringing his estates to the hammer. I ran to Elizalde to give him this advice, but the loan to Valdeavellano had already been made, and he, Elizalde, had the conviction that the pagare would be paid when due.

In yesterday's Session of the Senate, J. A. Garcia y Garcia brought forward the following project: the Government was to be authorized to sell the present Railways to the best bidder not for less than their costs, and to take in payment the Internal or External Debt, at par, including as a further payment the amount 
of interest which might be due on the respective documents at the date when the payment was made, the preference to be given to the external debt.

The actual cost of the railways was put down as follows:

From Paita to Piura

From Pacasmayo to Magdalena

From Salaverry to Trujillo

From Chimbote to Huaraz

From Callao to the Oroya

From Lima to Chancay

From Pisco to Ica

From Mollendo to Arequipa

From Arequipa to Puno

From Juliaca to Cuzco

From Ilo to Moquegua

[...
$\mathrm{S}_{2,500,000}$

$\$ 6,000,000$

$\mathrm{s}_{3,500,000}$

\$10,000,000

\$27,000,000

$\mathrm{S}_{4,000,000}$

\$2,000,000

$\$ 12,000,000$

$\mathrm{S}_{25,000,000}$

$\$ 10,000,000$

$\$ 6,000,000$

$[\ldots]$

[785] The plan appeared to me a very [...] had omitted two main points; in the first place he had not said whether the soles were paper or silver, and secondly, at what Exchange the pounds sterling were to be calculated.

Saturday, $9^{\text {th }}$ of November 1878 . Before breakfast I walked out to the pantheon, and put some fresh flowers upon the sarcophagus. As the sun was out I felt very warm, and the walk made me extremely sleepy. In the evening Brierley read to me Mahon's History of England. It was at least the third time that I listened to the reading of this splendid work. The author, when speaking of the notorious Cardinal Dubois, called him in one place: an accomplished knave; in another, a statesman without honour, a cardinal without religion. In a third he related that when the Prince Regent, the Duke of Orleans, his former pupil, had made him Councillor of State, and he was about taking his seat, the duke told him in a friendly manner: "Now my dear Abbé, try to be a little honest". Voltaire said of Görtz, Minister of Charles XII of Sweden, that he was as lavish of gifts and promises, as of lies and oaths. Pretty characters these two!

By the French steamer I received a letter from Juan dated $5^{\text {th }}$ October, in which he enclosed a cutting from the Daily Telegraph, see Supplement to Appendix $\mathrm{N}^{\circ} 37$, which treats in a very clever manner on the little profit, if not actual loss, which the bank "La Providencia" or the Company to which it had transferred the Nitrate Contract with the Peruvian Government derived from this contract.

The "Tribunal" said that the Banks "La Providencia" and Nacional had to place into the hands of Graham, Rowe \& Co. all their reserve funds of coined gold and silver before this firm would take upon itself the obligation to honour 
the drafts on James Sawers \& Co. It would of course be paid for its outlay by consignments of Nitrate. The present Directory of the Peruvian Nitrate Company consisted of [786] [...] President, Albarracin and Harismendy, all three of "La Providencia", and Derteano and Basombrio of the "Nacional". Of course these gentlemen did only what Garcia Calderon and Derteano wished them to do. Juan further wrote of a bad fall which Mr. Schutte had had, but which fortunately had had not fatal consequence. He had attempted to walk a few steps without assistance. His forces failed him, and he fell.

Sunday, $10^{\text {th }}$ of November 1878. Bryson and I revised my old diary of August 1875, at which time the dispute between Riva Agüero and the Banco Hipotecario was at its height. I then dictated my letter to Schutte, gained two games at chess from Limpricht, walked out to the pantheon, and in the evening was quietly at home playing with Enriqueta, Urquhart, Limpricht, Ricardo and the two little girls, some game at cards or other only to amuse the latter. We left off at past nine and I went to bed at past ten.

Monday, $17^{\text {th }}$ of November 1878 . To-day the heat made itself felt for the first time. Thermometer in my office at 2 p.m. $73^{\circ} \mathrm{F}$.

In the evening Garland had two rocambor tables; round the one, he, M. F. Benavides, J. Basagoytia, and Luis Bryce. At the other, Basagoytia's wife, Jorge Valle, Gregorio Benavides, the best of all players, and Antonio Garland, who, though knowing least of the game, had the good luck to gain go odd points, at 25 cents each. Enriqueta had to keep one of the sisters-in-law of Basagoytia company till as late as 12.30, which was beyond measure tiresome to her. I went to my room at eleven.

Tuesday, $12^{\text {th }}$ of November 1878. Dr. Manuel Mor[_] of the Supreme Court came and asked me for a loan of \$200o at 1 year's credit. [...] To Juan I remitted $£ 160$, J. Cane [_]Peruvian Guano Co. Ltd. at 24d 1/2. [787]

Thursday, $14^{\text {th }}$ of November 1878. [...] Brierley finished reading to me the novel Daniel Deronda, by Miss Evans, who wrote under the name of George Elliott, and I rejoiced that we had finished it, for hardly ever before had I read a novel more uninteresting than this; and this was certainly strange, for the critics had passed high eulogiums on it. Intrigue there was hardly any, striking incidents none, except the drowning of Sir Henry Grancourt. Some of the characters were carefully delineated, especially Glindowlen who in fact was more the heroine than the Jewess Mirah, the beloved of the hero Daniel, "le chevalier sans pareil et sans reproche", such a non plus ultra of virtue and exalted feelings, without the smallest alloy of badness or weakness, that in my opinion he was a character as improbable as tedious. I wonder how he managed to fall in love with Mirah. The book close, not with the lovers' marriage, but with the death of Ezra, the high minded brother of Mirah. Of the 
ulterior fate of the other dramatis personae we remained completely ignorant. The introspection into the minds and souls of the main actors in this novel was probably that part of it which, filling pages after pages, was admired by many, and upon which the authoress seemed to pride herself most; but to me it was frequently unintelligible, and if intelligible, highly tedious.

A clever novelist should relate the actions of his heroes, and let the reader draw the conclusion as to his motives and feelings. So Walter Scott and Bulwer do, but Miss Evans dissects and cuts up the sentiments and the motives, into the very smallest particles, which may be very clever, but is surely not amusing.

To-day José Canevaro and his wife Doña Luisa embarked for Europe viâ Panamá. A very numerous party, amongst whom the President went down with him to Callao. It was said that the object of his voyage was to bring about by his personal influence and connections some arrangement or other with London or Paris Ba[_] ker to ensure the payment [...] [788] [...] vian Bonds, due $1^{\text {st January [_] }}$

Friday, $15^{\text {th }}$ of November 1878 . I affix in supplement to Appendix, under $\mathrm{N}^{\circ} 38$, a sample of the Lima circulating medium. Thousands of similar little bits of paper which pass from hand to hand, were not all of them in such an utterly irrecognizable condition as my sample, for it cannot be made out whether it represents five cents or ten cents, or half of a note for twenty cents. The larger notes, if not torn right through, were some times very dirty, and small pieces torn off, but at all events could be recognized.

Saturday, $16^{\text {th }}$ of November 1878 . Long before breakfast I walked out to the pantheon and took my flowers to the chapel.

Mr. Davies read to me various interesting articles from the "Eclectic" of October. One, a description of a trip to Iceland; another which gave an account of a North American actress, Miss Cushman and a third, which treated on the various races which under Turkish rule inhabit Asia Minor and Syria. They are said to number about sixteen millions, and are: Turks, 10 millions, Armenians, 2 millions, Curds, Arabs, Greeks, Syrians, Circassians, Turcomans, Jews, Tartars, Gipsies, etc.

After Davies had left, at about half past one, whilst I was walking up and down the corredor, Enriqueta came from her rooms with the words "hay cierrapuertas", and further said that in the Plaza de Bolivar, she distinguished an unusual number of gentlemen in black, probably Senators and Deputies; at the same moment Juan Garland came up the stairs shouting "han asesinado a Pardo." I went into the street, which was already crowded with people. It must have been ten or fifteen minutes to two. All agreed in saying that $[. .$.$] had$ been the assassin; some added of the bat- [789] talion Pichincha, a company of $[\ldots]$ guard at the Senate House. The one said that Pardo had been shot 
at the moment he alighted from the coach, others when he passed through the passage. The ball had gone right through his body, and there was not the slightest hope of his escaping with his life. I was beyond measure affected; and the first thing I said to Enriqueta was: "ahora es tiempo de dejar al pais." The President came, and towards the Plaza de Bolivar, our street was nearly choked up with people. Enriqueta and Urquhart said that they had heard some people shout, "Viva Piérola." At about fifteen minutes to three a monk of Santo Domingo passed with the Santos Oleos, but probably he would come too late. At 3.30 I walked out to see how the town looked. All shops and stores were locked, the streets filled with groups of people in eager conversation. Pardo's house was guarded by two or three policemen. His family, both wife, daughters, and mother, it was said, had been removed by their friends. In Mercaderes I met Johannes Limpricht and Evaristo Barrios; the latter accompanied me home. The four corners of La Plaza Mayor were guarded by soldiers, and nobody was allowed to pass. Cavalry piquets patrolled the streets. Also at the corner of my street, de Zarate, the entrance was prohibited, and I was only allowed to pass when I told the officer that the corner house was mine, and that he might see me enter. In our balcony Enriqueta had Urquhart, Vargas from Arequipa, Juan, Antonio, and several of their friends. The President, strongly escorted, passed by on his return to the palace. The murderer had been arrested, and at five o'clock the town was apparently quiet. This was a dreadful blow to the country. The Civilistas had now no one to whom to look up and to direct their movements. I, myself, though never intimate with Pardo, knew him, and was very fond of him. He had always bee [...] [790] [...] we had met. The last time [_] had seen his father-in-law Felipe Barreda was near the Botanic Garden, when he said to me: "here I am building a row of small houses, un callejon, for my daughter Marianita, that she may never be in want." Marianita was Pardo's widow, mother of a numerous family, the youngest of whom was one or two years of age, and at this time she was again in the family way.

Alejandro came; he was extremely sad... He had been in the Senate the whole time whilst Pardo was in his last agonies. Several senators, as well as Dr. Bambaren had been crying like children. Mariana Barreda had been admitted and swooned as soon as she saw her husband. Also Doña Carmen, her mother, had come in search of her daughter. The Confessor had arrived whilst Pardo was still alive, but certainly there had been little time for confession. His last words it is said had been, "mucho debo, perdono á todos." From twelve till near two he had been in the printing office of the "Comercio" correcting the proof sheets of the speech which on the 14 and $15^{\text {th }}$ he had delivered in the Senate, of which he was President, to prove the necessity of laying a new 
impost on merchandize imported, and produce exported, which impost was to serve for the gradual redemption of the paper money. At a few minutes before two he had ordered a coach, and had driven to the Senate together with Dr. M. M. Rivas, Senator for Ayacucho. They walked through the passage alongside of which stood the guard, which presented arms as it was the custom. At the end stood the sergeant Melchor Montoya, and the lieutenant Ulloa. There the passage turns to the left and narrows a little; and at the moment that Pardo passed the turning, the serjeant, who was but a few steps off, fired his rifle; [_] ball of a long [_]ical sh[_] and weighing an [791] ounce, went through the [...] and lodged in the wall, where in the evening I saw the small hole it had made. Pardo had merely time to say "Me han muerto" and fell into the arms of Rivas. Dr. Adan Melgar, who walked behind them, grappled with the serjeant, whilst the lieutenant and the soldiers stood immovable. The sergeant escaped to the street, but was taken hold of in the plazuela by a sergeant of gendarmes, taken back to the Senate, and kept prisoner. A criminal judge, Arbulú, was summoned, who without loss of time took his declarations. Pardo expired at near 3 o'clock, and was, shortly after, embalmed.

We kept our street door closed all day. Brierley did not come in the evening, nor did I expect him. At 8.45 Enrique and I went to the Senate Hall, whence the body was to be carried to Pardo's dwelling-house. We were shewn, as above said, the hole made by the ball in the wall, and the spot where Pardo had fallen. For some time we stood with some other persons in the open yard, where we were joined by Sagastabeytia and one of the Prévosts; but when Seminario the Senator came he took us into the apartment where his colleagues and the Deputies were assembled. Here I saw amongst others Jesus Elias. After a short time we walked surrounded by a crowd to the hall where the Senate usually met, and here lay Don Manuel in an open coffin, dressed in black. I, of course, could not distinguish him. The coffin was raised, and carried in slow procession to his house, the accompaniment being by no means so numerous as I had expected. Of the vocales of the Supreme and Superior Courts, for instance, only Eusebio Sanchez was present. At the corners of all the streets through which we passed policemen were stationed to prevent interruption from the cross streets. In Pardo's house the coffin was deposited in the room to the right of the patio where his study was. [_] [792] [...] clock.

Sunday, $17^{\text {th }}$ of November 1878 . This morning I saw at the barber's César Canevaro, the Deputy, who told me that in his opinion not only the guard of the Senate, but also that in the Chamber of Deputies, had been tampered with. A sergeant of the latter, Armando Garay, had fired his rifle, and shouted "Viva el Pueblo." Moreover all had shewn a kind of vacillation, as if they were 
in expectation of something. As soon as it could be done they were relieved by two companies from the battalion Ayacucho, stationed in San Lázaro and commanded by Prado's nephew.

I affix, in supplement to Appendix under $\mathrm{N}^{\circ \mathrm{s}} 4 \mathrm{0} / 39$, a part of last night's and a part of to-day's "Nacional", which contain many interesting details.

The Directors of the Glasgow Bank which failed the other day for $£ 10,000,000$ had been arrested and judicial proceedings been commenced against them.

I called upon the family of Doctor Jervacio Alvarez, upon Rafael Velarde's family, upon Doña Dolores Puente, who had her room closed - no doubt on account of Pardo's death, to whom she was distantly related, and upon Muñoz and his wife. Except with Mrs. Velarde, the great event of the day was the sole topic of conversation.

Whilst I was thus employed, the Congress held its session, and the Council of Ministers was cited. They were interrogated, but after a few questions had been asked, Riva Agüero who now presided as Vice, thought proper to convert the session into a secret one. However, as the door was not completely shut, much of what was said was heard by those who stood outside, and we learned by the papers that, with the exception of three [_] had been declared that la Patria está en peligro, [793] and extraordinary powers were [...] which is equivalent to the suspension of the Habeas Corpus Act in England; also public meetings were prohibited. Various members declared that they had no confidence in the present Ministry, especially in the Minister for War, General Bustamante. Another exclaimed that the Municipality was the focus of assassins, and Pedro Saavedra, the Alcalde, who was present as Deputy, did not say a word in the defence of this body.

Monday, $18^{\text {th }}$ of November 1878 . At one I went to the Justice Hall, and found the Tribunals open. The banks were closed. All public spectacles were prohibited. The Government buildings had the Peruvian flag hoisted at half mast, which example had been followed by the foreign Diplomats and Consuls.

Pardo's corpse was to be transferred from his house to the Church of Santo Domingo. Accordingly I went at 2.30 to the former. I met Ruden; together we entered the patio, which was so crowded, and the heat so stifling, that we preferred to go into the street. Whilst we had been in the patio, the coffin hitherto open had been closed and locked. More and more people came. Several acquaintances joined us: Lorente, Evaristo Barrios, Francisco Bohorquez, J. P. Escobar, Dr. Ramon Ribeyro, Böhl, and James Hayne, the last named lately arrived from Chile. He and I kept together the whole time from 3.30, when the procession put itself in motion, till past four, at which time we reached the Church of Santo Domingo. From Pardo's street we turned into the street of Filipinas, Coca, Bodegones, La Plaza Mayor, and the Calle del Correo. 
The papers gave an account how this procession was arranged. In my opinion, the number of private gentlemen who followed was at least 2000, whilst others spoke of no more than five to seven hundred. All were of course in deep mourning. The streets were lined with lookers-on, so were the balconies [...] [794] [...] to the Cathedral the throng was immense. When we had reached the Church the crowd was such that we could hardly move. Enrique Ayulo and J. N. Hurtado who came out of the Church said to me: "No se esponga Ud. Don Enrique"; and the former almost thrust me out. I was home by five.

At rocambor Garland had M. F. Benavides and José Basagoytia. Also Gregorio Benavides came who related that the sergeant Montoya had been tortured in a horrible manner, in order to make him confess. This nobody believed, for Don Gregorio belonged to the party of the Nacionales, and I told him, "si lo han hecho, bien lo merece un tal criminal"; he did not reply, and merely stared at me.

Tuesday, $19^{\text {th }}$ of November 1878. It was generally believed that Pardo's murder had been only one link of a vast conspiracy. At least it was affirmed that it had been the intention of the conspirators to kill many of the Senators and Deputies, if not all of them, which work was to be done by the guards who were on duty at the doors of the two chambers, and who belonged both to the battalion Pichincha. The officer who stood close to Montoya, and who remained impassable when Pardo was struck down, was Ulloa, a younger brother of Dr. Ulloa, ex editor of "La Patria", formerly Dreyfus's organ, and married to a sister of the brothers Cisneros. A sergeant, Gomez-Sanchez, also deeply implicated, they said was a natural son of Evaristo Gomez-Sanchez, who had been arrested. The sergeant Garay was a natural son of the clergyman Garay, whose other natural son was Bentin, who was one of the first arrested, together with Astete, a lieutenant Dufoo, and the notorious sambo carpenter Aguilar. Last night [...] the Prefect Captain Lara, went to the house [795] of the wife of Nicolas [...] ff to the Intendencia where she remained a prisoner. She insulted the Prefect, and all who came near her, using the most abusive language, and the "Comercio" affirmed that in her possession a key to a cypher had been found which corresponded with a cypher Bentin had. The arrest of Carlos Paz-Soldan was doubtful. The judge Arbulú worked day and night with indefatigable activity.

Telegrams had again been received which said that Dreyfus's firm had refused acceptance, but it was not quite clear, whether of the drafts of the firm of Dreyfus of Lima, or of those of Scheel, probably it referred to those of the latter.

Thursday, $27^{\text {st }}$ of November 1878 . This being Mariquita's birthday, Enriqueta, the two little girls and myself, drove to the pantheon at 8 o'clock, taking with 
us a considerable quantity of flowers and wreaths bought by Enriqueta. Our servant sat on the box. In the chapel we removed some of the flowers which had faded, and replaced them with so many fresh ones that the sarcophagus had actually a cheerful appearance. The chapel was well swept and dusted, and we were home just in time for breakfast, which this day was placed on the table at ten precisely.

I put on my dress coat, with the Dannebrog ribbon which I had not worn for more than three years, also white kid gloves; and thus, in strict etiquette dress, I was, without difficulty, admitted by the officer who was on guard at the entrance to the Church of Santo Domingo, which was still empty. The interior hung for the greater part with black drapery, upon which were silver spots representing tears, presented a mournful appearance. At the extremity of the nave stood the coffin upon an elevated and ornamental platform, which I could not see. Firemen in their gala uniform kept watch. The whole ill [...] [796] [...] lustres, in which wax light[_] were burning-torches, and big vases with burning spirit of wine. I met Menchaca, the ironmonger, with whom I kept company. By and by the church filled. There came the relations of Pardo: J. A. Lavalle, Enrique Barreda, Ignacio and Javier Osma, J. V. Oyague, Enrique Canaval, J. J. Moreira, and few more. Then the monks of the different Lima convents, more firemen, who kept a clear passage in the nave, the canons with the archbishop, also the papal delegate, and others whom I did not know. I suppose it was about twelve when the president came with his cortège, the Ministers, the members of the Courts of Justice, the diplomatic and consular bodies, and heaven knows how many other corporations. They entered the Church, and after a few minutes walked out again, and began the procession towards the Cathedral. The coffin was carried by Senators and Deputies. This procession walked along the Calle del Correo, the portal of Escribanos, that of Botoneros, and thus to the Cathedral. I suppose that the first had already reached the Cathedral when the last, amongst whom was I with a great many other gentlemen, walking two by two, left Santo Domingo. In the plaza I was joined by Sagastabeytia, and on our reaching the Cathedral, he took me up to the choir, where at first everything was so dark that I could not see anything. When my eyes got accustomed to the obscurity, I saw that all around sat the Canons, and several monks of the barefooted friars. Before them, many officers; at all events I distinguished the epaulettes. But for us there were no chairs. High mass was sung, in which professional singers took their part, who were accompanied by musical instruments. It may have [...] but I was no judge of it; moreover, soon [797] [_] tired with standing so long, [...] Enriqueta had decided upon not admitting anybody to the balconies, because it was the anniversary of her mother's birthday. Nevertheless several came whom she could not turn out: Asuncion 
Santillana, with her two daughters, José Basagoytia's wife with her two sisters and her daughter Filomena, Eliza, Guillermo's wife; Vargas of Arequipa with his wife Bertha Möller, Antonio and some of his friends. However, neither Enriqueta nor I shewed our faces. I remained in my rooms, I was low spirited, and sleepy. Bryson, with my consent, had not come. I think it was past four when the servant woman Aurelia called me to see the funeral cortège pass by, and I went to Enrique's room, where I looked out through a broken pane. First came four soldiers on horseback who go by the name of "batidores", which we may render with rangers, then General Buendia, who commanded the entire force, with his aides-de-camp, the artillery, the President's escort, the hearse drawn by four mules walking step by step, the coffin carried by the President of the Chamber of Deputies, Carrillo; the Minister of Justice, Loayza; General J. Rufino Echenique; the President of the Supreme Court, Oviedo; the Minister of the Interior, Bruno Bueno; the President of the Senate, Riva Agüero. These were soon relieved, but the whole way to the pantheon the coffin was always carried by gentlemen, not by common porters. Next followed the three other Ministers; aides-de-camp of the President, who, himself, had returned from the Cathedral to the Palace; the members of the Senate, the Deputies; the members of the Supreme and Superior Courts, and judges de $1^{\mathrm{a}}$ Instancia; also the members of nearly all the corporations and clubs of Lima, and private gentlemen who actually formed a sea of black coats. Two Government coaches each drawn by four horses and the troops garrisoned in Lima, except those left in their respective bar [...] [798] [...] the troops a small number of carriages. The visitors left and we dined by ourselves.

In the evening, this being rocambor night, Juan Gallagher also came, who gave us the following particulars: When the cortège was passing the Maravillas gate, women of the lowest classes who were standing on the top had poured down chicha, which had wetted and soiled the dress of several gentlemen. On the arrival at the pantheon the members of the Beneficencia, under whose care the pantheon was, were there to receive them, and several of them carried the coffin from the entrance to the chapel, where it was deposited, and left under a guard of soldiers. Many speeches were made: by J. A. Ribeyro, Rector of the University; by Riva Agüero, whose speech Gallagher described as having been a very poor one; by J. A. Garcia y Garcia, Senator; by M. M. Galvez, Deputy; and by many others. Those who did not return by train came home nearly in the dark.

Friday, $22^{\text {nd }}$ of November 1878 . The sermon preached yesterday in the Cathedral by Antonio Roca, who had been chosen for the purpose by the President himself, was read to me this morning by Davies. It did not eulogise the deceased because the preacher, as he said, abstained from touching 
on politics, and his sole purpose evidently was to recommend the assassin, Melchor Montoya, to the clemency of the Government. The artisan who was arrested was not the notorious Aguilar, but a certain Aymach, uncle of Montoya, who had a shop as second class tailor in the Calle de San Gerónimo. Carlos Paz-Soldan had not been arrested. The arrest of Evaristo Gomez-Sanchez was doubted. It was however certain that my lawyer, Dr. F. Palacios had hid himself, his conscience must [799] have accused him; [...] Balta's time was Peruvian Minister to Ecuador had been taken up, so had been Generals Fermin Castillo and Vargas Machuca. The former, after a few hours detention, was set at liberty on parole, the latter remained in prison. La Señora Piérola had been removed from the Prefectura, first to the police office near the gate of Barbones, then to the barrack of San Francisco de Paula, where political offenders are usually kept.

In December 1860 I had a short correspondence with Pardo, who at that time was Sindico of the estate of Pedro Landáburu, who was my debtor for \$30oo and I being, if I mistake not, the only one whose debt was secured by a mortgage was the first to be paid. By chance I have kept Pardo's letters, which I now affix, together with my answers, in supplement to Appendix, under $\mathrm{N}^{\text {os }} 44 / 41$.

Saturday, $23^{\text {rd }}$ of November 1878 . Before breakfast I went out to the pantheon; the flowers in the chapel were still in a fair state of preservation; also the floor was not covered with dust, though it could easily pass through the railing of the door.

The battalion of Pichincha was dissolved by order of the Congress; more than 400 soldiers would be sent to their homes; the remainder, less then 100 had been drafted into the other battalions. What had become of the officers I did not learn. One of them, a natural son of Rafael Velarde, lieutenant, who at the time of the murder was on duty in the Guadalupe barrack, had been deprived of his commission.

At about 1.30 the Directors of the Banco del Perú were together. Escobar laid before us the conditions upon which he expected to come to an understanding with the delegates of the banks so that the entire debt to the Banco del Perú, say about $\$ 300$,ooo paper and one hundred and thirty odd thousand [...] [800] $[\ldots]$ interest in instalments, to begin on the $1^{\text {st }}$ April 1879 , before the end of that year; these payments being moreover guaranteed by the two banks "Nacional" and "Providencia"; and asked our authorization to close on these terms, which was readily given him. Other questions of minor importance were quickly dispatched without any discussion. One was that from the $1^{\text {st }}$ January 1879 the bank was not to allow any interest upon the surplus over and above \$100,00o which might stand to the credit of any single individual or establishment. 
Pardo's death was more than once adverted to, and all agreed that there was nobody in the country who could replace him. There was every probability that the Peruvian Nitrate Co. would keep the contract at least for two years. Thermometer, at $4 \cdot 30,74^{\circ} \mathrm{F}$.

Sunday, $24^{\text {th }}$ of November 1878 . I received [t] he letters per steamer from Juan and Mr. Schutte dated the middle of October. Juan, through the intervention of the Paris Jeweller Fontana, had at last sold the diamond necklace which I had bought several years back for 12,000 Soles, when paper soles were still as good as coined silver. When I divided my property with Mariquita's children it was valued at its full cost, but in my own valuation of property I put it down at a discount of $162 / 3 \%$, say at \$80oo. It was now sold for 20,000 francs, which, at the exchange of $25 \mathrm{~d}$ was equal to $\$ 8000$ paper. What a tremendous loss! Rosa wrote to Enriqueta that since Mr. Schutte had had the fall, of which I wrote a fortnight ago, he had become extremely deaf, and in every respect his health was much worse than it had been a few months previously. The young king of Spain had been fired at [...] th of October, but not hurt. This last [801] steamer brought the advice [...] had been made upon Humberto, king of Italy, who had been wounded in the arm. The king of the Netherlands, William III, 62 years of age, was about marrying a princess of Waldeck, 20 years old. A telegraphic dispatch brought the news that the Indian Government had declared war to Shere Ali, Ameer of Afghanistan, who, after refusing admittance to an English Embassy, had rejected the ultimatum.

I played with Limpricht two games of chess, which I lost, another proof of his decided superiority over me. At dinner we had the Canon Mora, Urquhart and Maria, the youngest daughter of Doña Asuncion Santillana. Afterwards we amused the children, playing at cards with them.

Monday, $25^{\text {th }}$ of November 1878. Geraldo related to us at breakfast that on the previous day there had been quite a theatrical display in the palace. The President Prado had summoned the leaders of the two political parties which divided the Republic, of the Civilistas there had come: Dr. Rosas, the two Garcia y Garcia, Lizardo Montero, Riva Agüero, M. M. Valle, co-editor of the "Nacional" and others; of the Nacionales: Macedo, Tadeo Terry, Pedro Saavedra, and so on. When they were assembled, Prado had addressed them in a short speech, in which he told them that his object in having called them together was to bring about a reconciliation. He begged them to renounce their party distinctions, and to gather under the banner of "Los Liberales"; he recommended peace and harmony, without which the Republic ran the greatest danger. Not only had the last conspiracy been a terrific one, the complete consummation of which had only been prevented by a fortuitous accident, with which all present were acquainted, but the eternal conspirator Nicolas de Piérola was also again on 
the move; he had appeared in M[_]tevid [...] [802] [...] Then Prado, as a proof of his resolve to make up differences with those with whom he himself was not on the very best terms, embraced Lizardo Montero and one or two more, which touching appeal to the sensibility of the bystanders is said to have elicited tears; but our informant had not been told that the President's example had been followed. I, for my own part, was convinced that such a sudden and violent patching up of old feuds could and would not last. The casuality to which Prado had referred was the following:

The Conspirators had fixed upon the $16^{\text {th }}$ November because they knew that on that day, between twelve and half past twelve, the hour when Pardo used to go to the Senate, the gendarmes quartered in the barrack close by, who were not implicated, would be absent, being occupied in the river washing their clothes; but Pardo, having been detained in the office of the "Comercio" correcting the proof sheets of the speech delivered by him on the two previous days, did not come till 1.45; and this had altogether disconcerted the plan of the plotters, for when the fatal shot was fired and when Garay discharged his rifle, the faithful gendarmes, returning from the river, were already in the Calle del Tigre, close to the Plaza de Bolivar, where, on hearing the reports, the commanding officer ordered his men to run, and in the nick of time they appeared on the spot. It was a gendarme who, as already said, took hold of the assassin.

Tuesday, $26^{\text {th }}$ of November 1878 . When I went at past one o'clock to the office of the Banco Hipotecario, the other four Directors were already assembled; they had approved the acta of last meeting, and rejected various petitions for loans. I asked the gerentes [_] they were getting on with several of their debtors [803] who where either much in [...] he bank was involved in law-suits; such as the Judge Wenceslao Rospigliosi; the lawyer Garcia Calderon, Simon Soyer, Carlos Elias, Antonio Prada, Enrique Canaval, and Arizola of Callao. The reply was that all these accounts were more or less in the same condition as they had been for several months.

The Civilistas had determined not to give up their party-name, which they looked upon as an heirloom from Pardo.

Wednesday, $27^{\text {th }}$ of November 1878. Davies read to me this morning an article from the "Eclectic" of November 1878 on Giordano Bruno, and Galileo Galilei. The former was born in Nola about the year 1550; when a lad he entered a convent of Dominican friars, which he soon left, and for many years travelled all over France, England and Germany. As an itinerant and disputant philosopher he maintained the most heterodox opinions. After having paid his obeisance to Luther's statue in Wittenberg, he wrote a panegyric on this reformer in which he expressed himself about his holiness in the following terms: "Who is he whose name I have hitherto passed in silence? The Vicar 
of the Tyrant of Hell, at once fox and lion, armed with keys and sword, with fraud and violence, hypocrisy and ferocity; infecting the Universe with a superstitious worship, and an ignorance worse than brutal. None dared oppose themselves to that devouring beast, when a new Alcides arose to restore this fallen age, this degraded Europe, to a purer and happier state." And after having given utterance to such invectives he was fool-hardly enough to venture again across the Alps, and found his way to Venice, where, at the request of the Pope Clement VIII, the Doge Pascuale Cicogna delivered him up, and in the year 1600 , when the Eternal city was crowded with believing devotees, who had come thither to celebrate the jubilee, he was burned alive as an Arch [...] $[804][\ldots]$

Last night the Señora Piérola wa[_] set at liberty. In the department of Cuzco the Pierolistas were creating great disturbances. The Deputy Velasco, a decided Civilista, had been murdered by them.

Thursday, $28^{\text {th }}$ of November 1878 . Thermometer in my office at 5 p.m. $73^{\circ} \mathrm{F}$.

Alejandro brought to-day to his mother his little girl two months old, who had just been baptized Eloida Corina, Eloida being the name of the mother.

A large number of Senators and Deputies were with the President in the Palace, instead of attending in their respective chambers. The object was to consolidate the fusion between the two parties Civilistas and Nacionalistas, but that this was actually brought about was more than doubtful.

In the evening I did not go to the salita where the rocamboristas were, but lay down at 10 o'clock. Garland was far from well.

Friday, $29^{\text {th }}$ of November 1878. Garland went to the bank, came home early, went to bed, and Doctor Middendorf was sent for. He had fever, and pains all over the body.

Saturday, $30^{\text {th }}$ of November 1878. Garland remained at home.

Sunday, ${ }^{\text {st }}$ of December 1878. In the morning before breakfast I went to the chapel and adorned the sarcophagus with many flowers, mainly red roses. After having done so, I sat down on the steps of the altar, and thought of times gone by.

The advice of Pardo's assassination, which took place on the $16^{\text {th }}$, reached Europe on the $17^{\text {th }}$ in the evening. On the $18^{\text {th }}$ it was telegraphed $[\ldots]$ on the $19^{\text {th }}$ in the morning it was known at Panamá. [805] Thermometer at noon [...]

This being my visiting Sunday, I made some calls; firstly, I went to Gibbs's house, where I found Charles Eggert, just arrived from England viâ the United States; James Hayne from Chile, who had been here for perhaps three weeks, and Böhl, the head of the Lima firm, together with two visitors, General Nicolas Freyre and Pinto. Eggert had been in Boston where he had seen Amalia looking well, in very good health, and by no means thin. The conversation turned of 
course on Pardo's assassination, when Freyre held forth for a long time in a rather prosy manner. At Dr. Ribeyro's I found two of the daughters and Manuel O. de Villate. At Dr. Alvarez's, the old gentleman, unwell and taciturn, together with his grand-daughter Aurora Santillana. Dolores Puente, very sad for Pardo's untimely end. With Rafael Velarde and wife I remained but a short time, and left my card with Dr. Bandini.

At dinner we had a large party, which proved that Garland was again pretty well. He took, as usual, his seat in the centre of the table; to his right sat Doña Mercedes, Federico Palacios's wife, Urquhart, little Maria; Enrique at the bottom, Ricardo, Limpricht, I, Federico Palacios; Enriqueta opposite her husband, to her right Manuel Seminario from Piura, Juan, Corina, an empty chair for Antonio, Jorge Valle, and again Garland. Valle and Seminario kept up the conversation. I spoke a little with my two neighbours, of whom Palacios was not so talkative as usual; he complained of headache. When we rose from dinner it was time for the rocamboristas to sit down to their table. Afterwards Gregorio Benavides came in, who related that in the morning Lizardo Montero had nearly been poisoned. Having felt rather unwell his physician had prescribed a potion which was prepared in the apothecary's shop [...] [806] $[\ldots]$ must have been made, for having taken two spoonfuls a deathlike lethargy came over him; and Dr. Alarco, who was called in, declared that had he taken another spoonful he would infallibly have died. He was restored by strong coffee and other stimulants.

Monday, $2^{\text {nd }}$ of December 1878 . Pinto, who came in the evening to play rocambor, related that a respectable gentleman in Pisagua had written him that Nicolas de Piérola was again on the coast in a steamer named "Santa Lucia", with armament and uniforms. On the $20^{\text {th }}$ October he had left England, towards the end of November Valparaiso. The "Limeña" and "Union" were ready in Callao to go to sea.

Tuesday, $3^{\text {rd }}$ of December 1878 . On the $13^{\text {th }}$ of November the expediente against Juan Aliaga y Puente had been sent up from the Superior to the Supreme Court, to which Aliaga had appealed. This his procurador Suarez had taken from the Secretaria on the $15^{\text {th }}$ November, and up to this day he had not returned it, though the law allowed him only six days. Several times I had complained to the secretary of the Tribunal. To-day at noon, by his advice, I complained to the President of the Court, Dr. Oviedo, for whom I had been waiting in the corridor through which he had to pass when going to the Tribunal. Of course he promised to look after it.

Friday, $6^{\text {th }}$ of December 1878 . Last night the usual Thursday evening party was very numerous. In the large saloon were the family of Rafael Velarde, Federico Palacios, wife and little daughter, Urquhart, and Enriqueta with some of her 
children; they played at Monte. In the salita, at rocambor, G[_]land, Luis Br[_] ce, Valle, and Basagoytia. [807] Standing about and look [...] Dr. Middendorff, Eggert, Böhl and James Hayne, with which latter I conversed a good deal. He related to me that his aunt Mrs. John Hayne had died last year in consequence of a sudden and violent cold. George Rodger, with whom I resided for about a week on his farm near Selkirk in 1843, had also gone to a better home; one of his sons, George, one of the principal consigners to Gibbs of Lima, lived in or near Manchester, and had married one of the daughters of Eck, whilst another daughter of Eck had become the wife of a certain Alexander, no relation whatever of Eck's wife, Janet Alexander.

Yesterday morning I had a call from Oscar Heeren, son-in-law of Felipe Barreda, and consequently brother-in-law of the late Manuel Pardo. Barreda wanted to cancel Pardo's debt to the Banco Hipotecario, but asked for a considerable reduction, which, when the Directory met at one, we did not think ourselves authorized to concede. About six or seven years back Pardo bought a large estate in the north, called Tuman, for which he paid \$340,000 viz.; \$260,00o, which he borrowed from the bank, and \$80,00o, part of the 210,000 dollars which his wife Mariana had received from her father; he had rented it to Solf, for \$19,0oo annually, for 10 years, of which 6 and a half had now

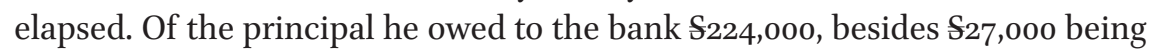
the amount for which he was in arrears with his three-monthly instalments. Barreda offered for the whole debt \$150,00o cash down. We resolved that we could not take less than \$180,000 cash down.

The papers made known that Felipe Pardo, the eldest son, in the name of his mother, had presented to Dr. Adan Melgar and M. M. Rivas, who were with his father at the last moments, some keepsakes; to the former, the buttons of the shirt [_] of the [...] the latter [...] [808] [...] apprehensive of Pierola[_] landing, had sent some troops southward.

Saturday, $7^{\text {th }}$ of December 1878 . Before breakfast I went out to the pantheon with my flowers. At about 1 p.m. I had a visit from Isabel Coloma de Canseco, to whom I had lent on the $1^{\text {st }}$ April last $\$ 300$, and to whom I had written a dunning letter. She was very polite, very thankful, but could not pay. Before August next the rent of a small estate of hers in the valley of Vitor would not be due, and before then she would probably not be able to cancel her debt. I had had of late an uncommon number of applications for small loans, which I could not refuse, and which I did not look upon as particularly safe: to Dr. Morales \$10oo, to Rönacher the watchmaker \$500, to Asuncion Alvarez de Santillana \$200, to Mr. Mould of the Compañia de Fomento \$1oo; besides \$400 paid in advance to Guillermo for bringing up my books to the $28^{\text {th }}$ February next, which last payment did of course not come under the same heading as 
the loans. Guillermo and his family had come in from Chorrillos and rented some apartments in the house belonging now to Carlos Paz-Soldan, Calle de Valladolid; and of course the poor fellow wanted money to pay the expenses arising from this removal. To-day he again went to Alejandro's copper-mine at Cansas near Ica, which promised well; and in which his brother had given him an interest. He took with him an engineer Echegaray, a Cuzqueño, who had studied in Belgium and France.

Sunday, $8^{\text {th }}$ of December 1878. After Bryson was gone, Limpricht was with me. I had a visit from Dr. Puente Arnao, the Judge de $1^{\text {a }}$ Instancia, who had sentenced in my favour in my suit with Leyva about the [_] of the house and to whom I had the[_] presented [809] a tea-service of plaque, which he [...] ccompanied by the letter to be found in Supplement to Appendix, under $\mathrm{N}^{\circ} 45$; the service I afterwards gave to Guillermo.

From Limpricht I gained the first game of chess, and lost the second. It was past 5.30 when we had done; I then took a run to the Barbones Gate. After dinner, at which we had with us Urquhart and the curate Aguila from Moyabamba, Deputy of Congress, I felt so sleepy that I went to bed at 9 o'clock.

Monday, $9^{\text {th }}$ of December 1878. It was rumoured that all the five Ministers had resigned their posts; seven serjeants had been arrested in Callao; other sergeants and some officers been brought hither as prisoners from Cajamarca, and one with another the situation of the country was very critical. The office of the newspaper "La Capital", an organ of the Piérolistas, had been shut up, and three individuals belonging to the same put in the casemates of Callao.

This was the anniversary of the victory of Ayacucho and Geraldo's birthday. He, however, suffered so much from headache that he could not sit down to dinner with us, though Enriqueta, as it was her custom on the birthdays of her sons, had a boiled turkey on the table. Valle and Urquhart were with us; and in the evening Garland had but one rocambor table.

Wednesday, $17^{\text {th }}$ of December 1878. At past twelve I was in the office of the Banco Hipotecario; only Lorente was there, Galvez came in afterwards, when Lorente and I had already resolved to accept, from Felipe Barreda, \$180,ooo, in billetes, in cancelment of the late Manuel Pardo's debt, see $6^{\text {th }}$ December.

Exchange on London $25 \mathrm{~d} 1 / 2$ to $26 \mathrm{~d}$. There was very little demand for bills and every probability of an improvement. Thermometer in my office at 5 p.m. $78^{\circ} \mathrm{F}$.

Thursday, $12^{\text {th }}$ of December 1878 . The Direct [...] [810] [...] meeting. The Gerentes had closed with the Peruvian Nitrate Co. on the terms which we had empowered them to accept on the $23^{\text {rd }}$ November. No escritura had been signed, but the pagarées, of which one was read aloud, were drawn out in the most binding form, signed by Garcia Calderon, President, and Luis Cisneros, 
Secretary; and counter-signed, de mancomun et insolidum, by Moscoso Melgar, as Gerente for "La Providencia"; and by Lucas Oyague for the "Nacional". We further resolved to lower the interest in a/cs current to $3 \%$ from the beginning of next year.

In the evening the rocambor players were only Garland, M. F. Benavides of Arequipa, Manuel Seminario y Vascones of Piura, and Limpricht. Mercedes, Federico Palacios's wife, kept Enriqueta company, and I conversed very pleasantly with the husband, who has seen a good deal of the world, till past midnight. In the "Amazonas" he had sailed and steamed round the earth, and for about 3 months he had been in Calcutta, where his vessel had undergone repairs in the Dock. They thought to leave shortly for Europe, for Marcó, the Peruvian Consul in Paris, had advised Palacios of the death of Manuel Argumaniz, supposed to have left a considerable fortune, one of whose sisters was the mother of Palacios, a natural son of José Maria, one of the sons of the well-known Doña Ignacia, of whom I have spoken in this diary. Manuel Argumaniz had also been mentioned by me, for the first time in Volume VII, page 78 , and again on other occasions.

Friday, $13^{\text {th }}$ of December 1878 . Urquhart came to me with a message from Charles Watson, gerente and Director of the Oroya and Cerro de Pasco Co., to whom I [...] letter in which I demanded the payment [811] of his pagaré of $855^{\circ}$ soles, due [...] Urquhart brought me a bill for \$30,00o, due $1^{\text {st }}$ July 1879 , drawn by the Caja Fiscal on the Peruvian Nitrate Co. in favour of the Oroya Co., and accepted by Garcia Calderon, President, and Luis Cisneros, Secretary, which he begged me to try to discount, and in case I succeeded I might pay myself out of the proceeds. I went to the Banco del Perú, where I spoke with Cesar Canevaro; to the Banco de Londres, where I addressed myself to L'Anson, and to "La Providencia", where I applied to Bolivar, but everywhere I received a negative answer.

At a later hour, first the Directory, then the majority of the shareholders, of the Banco Hipotecario, assembled; Lorente, of course, presiding. The late acta was read and approved; next the report of M. M. Galvez, Pedro Helguero, and Evaristo Barrios, who proposed that one third of the capital of the bank, say one million, should be returned to the shareholders, not in cédulas, as proposed by Alejandro, but in billetes autorizados, and this return of the capital should be made in instalments whensoever the state of the cash of the bank permitted it. This plan was violently impugned by Noel and Agustin Escudero, defended by M. M. Galvez and J. V. Oyague. Gradually the speakers became excited, the talking was loud and fast; many rose from their seats and formed themselves into small knots. Dionisio Villate and Francisco Bohorquez spoke rather against the project; Gallagher read a modification proposed by him and 
Garland. Some left the apartment, the number was less than the half required to form a quorum, and we broke up at five without having come to a resolution.

Saturday, $14^{\text {th }}$ of December 1878. Before breakfast I was, as usual, in the pantheon, and adorned the sarcophagus with a number of red roses.

In the course of the week the Chamber of Deputies had annulled the ele [...] [812] [...] puties for Lima, Manue[_] Candamo, Ignacio Osma, Ramon Ribeyro, and José Unanue, and thus, as it had been the case more than once, the Capital of the Republic was not represented in the lower house. What had been the reason for this step taken by the Civilistas, who preponderated in the Congress, I could not tell. No new Cabinet had as yet been named.

The papers informed us that Cabul had been taken by the English after a short conflict before the walls of the town; further, that Oliphant \& Co. of HongKong, the contractors with the Peruvian Government for the importation of Chinese coolies, had failed; and that the same fate had befallen Pustau \& Co. of Hamburg, and their correspondents Donner \& Co. of London. Pustau \& Co. and Theodore Siemssen \& Co., both of Hamburg, had for a long time past been the first German houses in China; old Pustau, whom I saw in 1851, at Knauer's in Eppendorff and again in the London Exhibition, had already retired from business and been living in Altona in ease and affluence, but had been obliged to return to China not long ago to look after the affairs of his house. The Donner of London would in all probability be one of the grandsons of J. C. Donner, the sleeping partner of Conrad Hinrich, at the time I was in the latter's counting house from 1816 to 1822 inclusive.

Thermometer at 2 p.m. $76^{\circ} \mathrm{F}$.

Sunday, $15^{\text {th }}$ of December 1878 . I made a few visits, of which I only mention that to Focion Mariátegui, who had advised me of his marriage with a Señorita Ausejo. They occupied the altos of the house of Doña Juana Guise; she, a daughter of a wealthy hacendado, was a very young woman, and hardly said a word. He, t[_]lk[_]tive and agreeable confirmed to me what I had [813] previously learned from $[. .$.$] the Banco de Lima in liquidation had to defend$ itself against innumerable lawsuits.

At dinner we had Josefá Bazo, her son Vicente - whom I used to call the fat boy -, the two girls Lacroix, and Urquhart. To please the children we played cards with them after dinner.

Monday, $16^{\text {th }}$ of December 1878. I saw by the "Eclectic" of November that the British Museum had obtained a copy of the Chinese Encyclopædia, consisting of 5020 volumes, and supposed to contain the entire Chinese literature from 1100 to 1700 .

Insane people never weep. If they begin to shed tears, there is some hopes of their recovery. 
Here in Lima the Senate assembled on Saturday last voted unanimously 100,000 soles to be paid to the family of Manuel Pardo; J. A. Lavalle and Ignacio Osma, Pardo's relations, left the hall when the votes were about to be taken.

In the province of Abancay with 118,500 inhabitants there did not exist one single school.

Wednesday, $18^{\text {th }}$ of December 1878 . From what Ricardo and Davies read to me, I learned various things. In Denmark there was hardly a grown up man or woman who could not read and write. The attempt to assassinate Humberto, the young king of Italy, was made on the $17^{\text {th }}$ November - one day after the murder of Pardo. The king and his family together with one minister had entered Naples in an open carriage and had been much cheered, when an individual called Giovanni Passanante with a drawn dagger threw himself upon the king, whom he slightly wounded in the left arm, whilst the Minister who took hold of Passanante by the hair was wounded in his left thigh. The wouldbe-assassin had said in his declaration that he was no friend to monarchs. [814] [...] in Lima the five new Ministers took their oaths. Not one of them was [_] man of distinguished intellect or decided character: Mesones, a lukewarm Civilista, Minister for Foreign Affairs and President of the Council. Juan Corrales Melgar, from Arequipa, a Civilista without energy. General Domingo Solar, Commander-in-Chief of the Artillery, of the same party, but little known. José Rafael Izcue, an excellent employé, of no political party whatever; and Mariano Felipe Paz-Soldan, who belonged to the party of the Nacionales.

In the Chamber of Deputies the grant of \$10o,ooo to the family of Pardo had also passed, as well as another motion for an annual Congress. The Fiscal Delegation in London to investigate the accounts of Thomson Bonar \& Co. and the National Guano Co. had been annulled. Henceforward only one person with a secretary was to carry on the investigation.

At noon I went to the Secretary of the Supreme Court and asked him whether the Fiscal had returned my expediente against Juan Aliaga y Puente. On receiving an answer in the negative I went to the study of the Fiscal Dr. Teodoro de la Rosa, did not find him in, but begged his clerk to expedite the Vista as much as lay in his power.

From the Callao agency of the Pacific Steam Navigation Co. I had received advice about a week ago that the Directory in Liverpool had resolved to return $£ 10$ on each share. I therefore went to Callao by the Oroya line, gave up the shares and receipts of my eleven shares of $£_{50}$ each, and received in return a certificate for 11 shares of $£_{40}$ each, besides [_] bill on Liverpool for $£ 110,90 \mathrm{~d} / \mathrm{s}$. I next [815] paid some accounts I [...] returning by the first train, walked about in Callao, which place had certainly much improved during the last 10 or 15 years. I observed even some hackney coaches, noted two pretty 
squares, a fountain in the middle, shrubs around, the whole enclosed by an iron railing. Some of the streets were wide, the foot pavement convenient, and there were a good many respectable looking houses. The stores in the Calle del Comercio, on the left hand side, were of great depth. I returned by the Oroya line. This day being the Saint's day of the President Mariano Ignacio Prado, I sent him my card; so did Enriqueta and Garland.

At 11 a.m. the marriage between Leonor, the very intelligent and agreeable daughter of Pinto, and Uriburu, the Buenos Ayrean Minister, an elderly man, was celebrated in the church of Belen, in the presence of many persons. Garland, some of his sons, and I, had received invitations, but none of us went.

Thursday, $19^{\text {th }}$ of December 1878. At about 3 o'clock a sufficient number of the shareholders of the Banco Hipotecario were assembled to form a quorum. Pedro Correa presided, instead of Lorente, who was absent, as well as M. M. Galvez. To the left of Correa sat Gallagher; opposite Gallagher, on the other side of the table, Garland; to the right of Correa, I; next to me, Melchor Velarde. The last acta being read and approved, Correa said that the first thing to be done was to name the two inspectors for the annual examination of accounts; the choice fell almost unanimously on Manuel Candamo and John Bryce. Next, the discussion broken off at the last meeting, relative to the return of the Capital, was resumed. Just as last time Noel and Agustin Escudero were opposed to it. Then spoke Dr. Loayza, the late Minister and P[_] [816] [...] the shares of his wife Doña Ramona, widow of Domingo Castañeda. He said that though not acquainted with all the particulars of the case, his opinion was than even were the $\$ 1,000,000$ returned to the shareholders they would always be responsible for this amount and have to refund it in case the revenues of the bank did not suffice to hacer el servicio of the cédulas, because the capital of the bank was 3 millions of soles, and the debtor was not permitted to diminish his capital without the consent of the creditor; in this case the holder of the cédulas. This speech caused an uproar; Escudero and Noel from one side; Dionisio Villate, Alejandro, Helguero, one of the commissioners who had drawn out the report, from the other, all spoke at the same time. Correa had to ring the bell, and begged for regularity in the proceedings. Vicente Oyague now spoke; he said that he had 150 shares and centenares de miles de Cédulas - he meant to say centenares de cédulas de \$10oo cada una - and that therefore he spoke with impartiality. He founded the legality of the re-payment of the \$1,000,00o upon one clause of the statues, which says that the amount of the cédulas issued should not exceed four times the amount of the capital. Consequently, that as at present hardly seven million cédulas were in circulation, the capital could be reduced to $\$ 2,000,000$ without infringing on the statutes, and that this reduced capital would at once stop the issuing of cédulas to a larger amount 
than 8,00o,0oo soles. I thought that his reasoning was not quite correct because, though it was said that for each sol of capital four soles in Cédulas could be emitted, it did not follow that only that part of the capital which amounted to four times the amount of [_]las emitted was responsible, but all the capital which [817] was known to constitute [...] the cédulas. Nevertheless, Loayza, after Oyag[_] had ceased speaking, declared that Oyague had convinced him of the incorrectness of his former view, and that therefore he now withdrew his opposition. Then the votes were taken nominally. Firstly, whether one million should be returned to the shareholders. Secondly, whether this repayment should be made whensoever the Directory were of opinion that it could be done; Gallagher wished to have the words added, "and the Gerentes", but his amendment was thrown out. Thirdly, whether the two million soles, now the capital of the bank should gain an annual interest of $10 \%$, payable $21 / 2 \%$ every three months. Now I rose, and said this article should begin with the words "de las utilidades que hubiesen, se pagarán, etc." From various sides I heard an approval of my motion; however, Correa and Gallagher proved to me by the statutes that, more or less the addition which I wished to be made was already contained in them. Fourthly, that the million to be returned gained the same interest of $10 \%$ until it were cancelled. And, lastly, that the gains of the bank were to be employed in the following manner:

$A$. In paying the interest and redemption of cédulas.

$B$. In paying the $10 \%$ interest on the capital, and

$C$. In the repayment of the million

These different articles were approved by a vast majority, and we separated at near five o'clock.

Thursday, $20^{\text {th }}$ of December 1878 . By telegraph, advice was received of the death of Queen Victoria's second daughter, the Princess Alice, Grand Duchess of Hesse Darmstadt, which had taken place on the $14^{\text {th }}$ instant. She was born in 1843 .

In the evening Garland had two rocambor tables. At the one he, Pedro Correa, and John Gallagher, which last named lost considerably and consequently [...] [818] [...] M. F. Benavides, Luis Bryce, José Basagoytia, and Jorge Valle. The curate Aguila kept Enriqueta company till about eleven. When he was gone, I retired to my bedroom.

Saturday, $27^{\text {st }}$ of December 1878. Early in the morning I was in the chapel of the pantheon, and adorned the sarcophagus with many red roses, which I had brought with me. In the evening the letters per North steamer were delivered. Juan wrote from Nizza; Corina and her husband Schön continued in Berlin. 
The alarm felt by the holders of gas shares owing to Mr. Edison's invention of the divisibility of the electric light, so as to apply it to general illumination had subsided. Juan's second telegram I had understood correctly; its words were: "Panic over, buy back." Schutte ordered me to lay out all his funds in Nitrate Certificates, if the price was not above par; and now I had no money of his disposable, because, according to previous orders, I had employed it in making loans on his account. I had also a very pleasant letter from my cousin Mrs. Kramer, in answer to my letter of condolence, which I had addressed to her in September last on the occasion of the death of her brother Theodore.

Sunday, $22^{\text {nd }}$ of December1878. I rose at $5 \cdot 30$, called Antonio, and accompanied by him ascended San Cristoval from the Lurigancho side, where the Pasco Militar ends. It was hardly daylight; the sky was overcast, and the sun did not come out. Nevertheless, hardly had we climbed up about one fifth of the entire height, when I felt so knocked up that I had to lie down; and several minutes passed before I recovered and continued the ascent. I felt exactly the same as I had done several months back when ascend [...] with Dr. Middendorff. Thenceforward I [819] walked very slowly, and [...] without any further inconvenience; but it was clear to me that my strength had much diminished in the last two or three years. When we had descended to the saddle, instead of turning off to the right to Lurigancho, Antonio saw another descent to the left, which we chose, but which was beyond measure bad; the path led over live rock on which the foot had no fast hold. It brought us to the spot where the French used to fire at a target. Walking along the base of the mountain we passed through the house formerly a chacra, now used by the French club, descended to the Alameda de los Descalzos, and were home by a little past eight, when I lay down and slept.

Enriqueta had the greatest trouble in collecting the rent which La Compañia de Oroya \& Cerro de Pasco owed her for the ground-floor of her house; as well as that from Watson for the store, and for the house in Calle de Aldabas which he occupied. Neither the one nor the other had paid her for last month.

The various persons formerly in the employment of the late Henry Meiggs were at daggers drawn. Watson was looked upon by everybody in Lima as a great rogue. Cilley, on the other hand, just come from the United States, was believed to be an honest man, and he had so far prevailed with his colleagues, that Watson had been deprived of the management, gerencia, of the Company; and Robertson, the late Meiggs' son-in-law, and chief of the firm of Sawers, Woodgate \& Co., been provisionally named in his stead. To him I went the other day with the pagare of $\$ 855^{\circ}$, due $1^{\text {st }}$ July last, and signed by Watson as gerente. His answer was, he knew of this pagaré, but at present he had not the means of paying it. 
Thermometer in my office at noon $78^{\circ} \mathrm{F}$. [820] [...] gone Limpricht and I sat down to play at chess, which we did till near six o'clock. Of three games I gained two and lost one. I had still time to take a quick walk as far as the Cinco Esquinas, and shortly after my return we sat down to dinner, to which Enriqueta had invited Federico Palacios, and his wife Mercedes, who would certainly embark for Panamá on Thursday next, Doña Mercedes' father, Antonio Villacampa, Urquhart and Limpricht. At nine Garland went, as was his habit, to Basagoytia's rocambor, and I walking with Palacios in the corridor, conversed with him very agreeable till near eleven.

Tuesday, $24^{\text {th }}$ of December 1878 . Before breakfast Enriqueta, the two little girls, Ricardo and I drove out to the Pantheon, the servant Juan on the box. Enriqueta had taken with her a large quantity of flowers, with which she adorned the sarcophagus. The faded flowers were removed, Juan cleaned and washed the interior, and when we left it had actually a cheerful look. On our return we suffered much from heat. In the forenoon a great deal of my time was taken up with arranging the payment of a bill which in the month of July I had taken from Enrique, drawn by Sawers, Woodgate \& Co. of Lima, on James Sawers \& Co. of London, and which Gibbs had returned to me under protest for nonpayment. Mr. Robertson, the head of the firm here, declared his willingness to pay, and expressed a hope that I would treat him with great leniency. Many years back $25 \%$ was charged here in Lima for redraft. At the time that the bills upon the South American Company of London were returned under protest for non-payment, the redraft was fixed at $10 \%$, including interest and all [821] expenses. I contented [...] Robertson $1 / 2 \%$ banking commission, the real cost of the two protests sent me by Gibbs, 4 s postage, and 4 months - which was an error, I ought to have charged 5 months - interest at $5 \%$ per annum, for the total of which he promised to give me a good bill on London; but he not being able to obtain a bill, I accepted the amount in billetes calculated at $26 \mathrm{~d}$, after I had bought from Alejandro about the same amount at the same exchange.

This was Christmas Eve. Böhl gave a small dinner party; Basagoytia a ball, to which Garland and Antonio went; and in the Exhibition Palace, some military men a tea, to the President; the Prefect Lara sent Enrique an invitation as Consul. He went, but told me on his return that it had been a very dull party. He and the two Pfluckers had merely walked about in the park, which was handsomely lighted up. In the palace of the Exhibition rocambor had been played. To the open place where the statue of Columbus stands, by order of the prefect, la noche buena had been removed from la Plaza Mayor, which consequently was this evening as quiet as any other evening. At Dr. Lührsen's there was likewise a small party; whilst in our house Enriqueta, Limpricht and I were quietly by ourselves, and retired to rest at the usual hour of eleven. 
Wednesday, $25^{\text {th }}$ of December 1878. Christmas Day. Enriqueta presented me with two black cravats and two pair of black silk gloves. The two little girls, with a small box of chocolate, of which they know I am very fond. I, on the other hand, distributed \$ 36 amongst the servants.

Watson had paid Enriqueta the three-monthly rent of his house, $£_{75}$ at $25 \mathrm{~d}$, and \$250, for one month, due $1^{\text {st }}$ inst., for the store, whilst the Oroya Company [822] [...] lley, had not yet paid the \$30o, for the apartments occupied by them.

The English funeral service says that threescore years and ten are the time allotted to man, and as next year I shall complete my $80^{\text {th }}$ year, it may come to pass that this is the last time I make my regular round of visits at Christmas and on the new-year; and for this reason I will note down to whom I went: to the family of Dr. Jervacio Alvarez, where I found several visitors, amongst whom Dr. J. A. Ribeyro, with whom I conversed a few words in a friendly and jocose manner. Dr. Alvarez was not in. To Mrs. Frederick Marriott, where the door was shut; to José Basagoytia's, where I merely spoke a few words with the young daughter Filomena; the remainder of the family being still asleep and resting from last night's ball; to J. V. Oyague, where I found him, the largest gas shareholder, in earnest conversation with Frederick Marriott, the Gas gerente. Oyague said that he had been well pleased in the Exhibition on the previous evening when the party was given to the President by the officers of the gendarmerie. The illumination had been brilliant, the fireworks pretty; and there had been no rocambor. When Mrs. Oyague came in, I spoke a few words with her, and then left. Upstairs at Lührsen's I found him and his wife at lunch. The lady looked very pale and knocked up; she herself complained that she could not recover her strength; certainly she was much changed for the worse. At Felipe Barreda's, for a wonder, Doña Carmen received visitors. I remained a considerable while with her, she was very agreeable, the conversations treated exclusively on the death of Manuel Pardo, her son-in-law. Doña Dolores Puente, was as [_]ble and Mrs. Rafael Velarde and [823] daughter were as insign [...] he other always are.

At dinner we had Limpricht, Zoila and Sofia Velarde, and Urquhart. We rose very late; afterwards, Rafael and his wife came to fetch their daughters.

Thursday, $26^{\text {th }}$ of December 1878. Till mid-day I waited for Bryson, who did not come. I then occupied myself with examining and counting the various documents which I had deposited in my iron chest, and before two I was again on the move. To the new Minister, Mariano F. Paz-Soldan, where I was well pleased to hear that he had gone out, and that his wife was still dressing; next, to the wife of Melchor Velarde, who had nothing better to say than to give an account of the illness of her husband and three or four of her children. Poor Melchor was certainly very much reduced. Doña Rosa Veyan, wife of Cipriana Correa, though a pleasant woman, was this day rather too talkative. At Dr. 
Dorado's all the doors were shut. At Rafael Quiroz's I was received by his lady, a Señorita Vega of Paris, with whom was Javier Correa, an uncle of her husband's and a very old acquaintance of mine. Of all upon whom I called there was none whom I liked so well as Doña Virginia, the widow of Domingo Valle-Riestra. Her daughter Isabel was also a nice young girl. At Lavalle's all was shut up. With Dr. Manuel Morales I remained a short time. His wife did not shew herself, having lately been confined. At Dr. J. A Ribeyro's I found a large party. I had of course to take my seat near Doña Eulalia, who was amiability personified. My last call was upon Eliza, Guillermo's wife. He was still absent in the mine near Ica; she is a very good creature, not over bright. The apartments they had lately rented in Carlos Paz-Soldan's house are very handsome, almost too extensive for their small family. [824] [...], Brierley came and read to me, which I was very glad of.

Whilst I had been absent in the forenoon, Garland, Enriqueta and the two little girls, had been down in Callao to see off Mr. and Mrs. Federico Palacios, and on their return they had been induced to witness the horse races.

Garland had two rocambor tables; Basagoytia had brought with him his daughter Filomena, Rafael came with his wife and daughters. To please them Enriqueta had to play Monte, and, tired as she was, had to stay up till past midnight. I retired to my room before they were gone.

Friday, $27^{\text {th }}$ of December 1878. In a meeting of the Directors of the Banco Hipotecario, followed by one of the shareholders, the project of the commission for the repayment of one million soles of the bank's capital, see $19^{\text {th }}$ inst., was unanimously approved in all its parts.

Of late the Supreme Court had decided a very important question in the case of Montero Bros. against the Government. The former, who were the owners of the Tarapacá Railways, demanded the payment of passage money and freight in silver, or in billetes with the increase of the premium. The Government would only pay in billetes, at their nominal value. The tribunal had sentenced in favour of Montero. Only Bernardino Leon had given his vote for the Government. The case would probably go to the Tribunal de Responsabilidad. My opinion was that Leon was in the right.

Saturday, $28^{\text {th }}$ of December 1878 . The porter of the Supreme Court advised me that Juan Aliaga y P[_]te habia desistido. He had lost in the first [825] Instance and in [...] fiscal had been against him, and now, just in the nick of time, when the Supreme Tribunal would confirm the sentence of the other courts, he desisted; but by these manœuvers he had succeeded in delaying the suit full two months and a half.

The "Nacional" of last night contained a telegram from Europe, which said that Shere Ali, Ameer of Afghanistan, had fled to Turkestan, that his eldest son Jacub Khan, friendly to the English, had ascended the throne, and that the war 
might be considered at an end. The same paper published some statements signed by Garcia Calderon, President of the Peruvian Nitrate Co., from which I saw that the Salitreras and paradas, purchased by Government, amounted to $\$_{20,012,000,}$ and that those not yet bought were valued in $\$ 618,000$. The export duty for the libres productores was $\varsigma_{3}$ silver. See what I have said on the same subject on the $20^{\text {th }}$ December 1877 . There was now every probability that the contract with the Government and "La Providencia" made over by the latter to a joint-stock company would not be annulled.

Sunday, $29^{\text {th }}$ of December 1878 . I continue to specify the names of those on whom I called in the course of the day. The Roman clergyman Valeri, not at home. Doña Tránsito Llosa, who received me in the house of her brother-inlaw Colonel Masias, absent in the southern departments of Perú, whither his business had called him, he having obtained from the Government in public sale the privilege of supplying the departments of Arequipa and Moquegua with guano. At Mariquita Moreyra's, widow of Stanhope Prévost, I left my card. At her neighbour's Ernestina Pflucker, wife of Feliz Dibos, I remained a considerable while; so did I with Doña Manuela Portillo, both very agreeable; the latter an old lady, the fo[_] [826] [...] ene, Mrs. Muñoz, [_] had nothing to say. With Mariana Moreyra, married to the German Hülsenbech, who lived in Germany, she in Lima, I found the door shut, and left my card, she occupied part of the house belonging to Amalia Riglos, widow of Francisco Moreyra, upon whom, I had not called since her return from Chile. She seemed much pleased that I had not entirely forgotten her. Finally, I went to Josefa Bazo, who was with all her children and her husband Anibal Gonzales, this latter suffering from headache and apparently in bad humour. When Dr. Middendorff and Urquhart came to dine with us, the first thing we learned from them was the duel which early in the morning had been fought between Arturo, the younger son of Dionisio Derteano, and Peter Gallagher. At the last horse race the former had not been satisfied with the award given by John Gallagher, and had animadverted upon it in severe terms, this he had done in the hearing of Peter, who took him up; they had high words, Peter gave him a blow, and Arturo said this affair had now to be decided in a different manner; he sent Peter a challenge by a friend of his, and they fought with rapiers. Derteano inflicted a wound in Gallagher's right breast, which would have been dangerous had it penetrated deeper in. As it was it was of no great consequence. They had fought on the Chacra "La Agustina", close to Manzanilla, outside the Barbones Gate. Gallagher's second had been Carlos Elias, the Deputy, and the young lawyer Manuel Alvarez Calderon, just returned from Europe.

At dinner I seldom took a share in the general conversation, and this day I felt rather [_]k so much so that I rose before the others got up [827] and went 
to bed. The Doctor came to feel my pulse, and said that it was rather agitated; I awoke at eleven, asked for a cup of tea and two biscuits, and slept soundly till day broke on

Monday, $30^{\text {th }}$ of December 1878 , when I felt quite well. I learned in the Secretaria of the Supreme Court, that Juan Aliaga y Puente had asked for several certified copies, which would of course be given him, thus causing a new delay.

Thermometer at 4 p.m. $78^{\circ} \mathrm{F}$.

I allowed Batchelor and his wife to remain in our rancho in Chorrillos till the end of February, at \$30o monthly, unless we should require it for ourselves, in which case I would always give him four days notice.

In the evening a concert was given in the Exhibition Palace, the proceeds of which, \$4 each ticket, were destined for the construction of part of the church called Santa Rosa de los Padres, and especially for that part of the same where the saint is said to have lived and died. The Papal Delegate Moncenni had this work much at heart, and owing to him collections for the same purpose were being made all over the town. I had the good luck not to receive any tickets, and consequently \$12, which I had advanced to Josefa Velarde, to whom I was in the habit of giving this sum every month, were now left with her as a Christmas present, and I was sure that in this way the money had been much better employed. At rocambor Garland had only Jorge Valle, Admiral Lizardo Montero, who had not been in our house for several years, and Limpricht, who was called in to make the fourth.

Tuesday, $3{ }^{\text {st }}$ of December 1878. Little Corina who on the previous day had been running about a great deal in the corredores with the children of Bertha Möller of Arequipa, had been very poorly th [...] [828] [...] I saw by the "Eclectic" of November last that a new crater, 3 miles in length, which previously had not existed, had been discovered in the moon. A crater is never formed without the eruption of a volcano, and thus it is evident that the moon is not so dead and lifeless as has been generally supposed.

1879

Wednesday, $7^{\text {st }}$ of January 1879 . Last night Brierley sent me word that he had to be at work in the Banco de Londres of which he was clerk, and was therefore prevented from coming, which was to me very annoying. Ricardo had gone out, Enriqueta had to attend to little Corina, who was very ill; Garland suffered from oppression on the heart, Antonio, who had gone to a dance at Basagoytia's, came home before eleven feeling indisposed, Enrique was at a party with some North American friends, Limpricht went to spend new year's eve with 
some of his acquaintances, and thus I whiled away the time walking in the corridor, sitting down occasionally, ciphering, and thinking. At 11.30 I went to bed, however kept awake till the clock in my room, a present from Enriqueta to my wife, struck twelve. I then turned round, and was asleep in a few minutes. Meanwhile little Corina had been very ill, feeling great difficulty in breathing. Near one o'clock Garland had gone for Dr. Middendorff, who came, and without loss of time prescribed an emetic. He and Garland went all over the town, but found no apothecary [_] open. Thus they had to tickle the little girl's [829] throat with a feat [...] She vomited freely phlegm and bile, and felt better towards morning. It was as late as four before Enriqueta and Garland could again lie down. In this unpropitious manner did we begin the new year of 1879 . At seven in the morning I walked out to the pantheon, a bunch of red and white roses in my hand, with which I prettily adorned the sarcophagus.

I saw by an article published in the "Tribuna" and reprinted in last night's "Nacional" that in the years 1876 and 1877 the Peruvian Guano Company, Limited, of London (Raphael \& Co. and others) had sold no more than 41,00o tons of guano, which had netted on an average $£_{4}$ is $4 \mathrm{~d}$ each ton. According to Mr. Walker, the English chemist employed by the Peruvian Government in London, the unit of azoe was worth 2os, that of phosphoric acid 5s; according to Raymondi, the Italian chemist resident in Perú, the former was worth 21s, the latter $5 \mathrm{~s} 6 \mathrm{~d}$. Thus the ton of guano, which contains on an average $63 / 4 \%$ azoe and $15 \%$ phosphoric acid, was worth as per Raymondi, £11 4s $3 \mathrm{~d}$.

The Special Commission, Tejeda and Jimenez, named by the Chamber of Deputies to give their opinion whether there was any motive for accusing the ex-Ministers of Finance, J. F. Garcia and Dr. Barinaga, before the Senate, had given in their report. It said that they had rendered themselves guilty of grave crimes (delitos) in having delivered to Charles Watson, Gerente of La Compañia de Fomento y Obras Publicas, Nitrate certificates amounting nominally to \$971,00o, and secondly, in having clandestinely put into circulation the sum of \$1,416,00o in bank notes of same Compañia de Fomento, but as these crimes did not bear the character either of abuso de confianza or of estafa or of defraudacion [_] [830] [...] did not carry in its [_]rain bodily punishment, and as, moreover, the Ministers had derived no personal advantage from these transactions, the Committee was of opinion that there was no reason for accusing the Ministers before the Senate.

Whilst Bryson and I were occupied indexing my corrected diary of 1873, Edward Knauer came in to wish me a happy new year, and remained with me till past two, when I had to go out on the same errand. I first went to see General Luis La Puerta, first Vice President, Pinto was with him, and when 
M. F. Benavides entered I rose and left; next, to Augusta Bergmann, wife of M. Espantoso, with whom I remained but a short time; upstairs, in the apartments of Federico Panizo and his wife, no one was in the saloon. At Enrique Higginson's, I found the whole family, whilst Mrs. Nicolas Freyre was by herself, and the stern widow of Salaverry, accompanied by one of her granddaughters was very agreeable towards me. At Macandrew's where his wife received, the number of visitors was great, gentlemen went in and out, such as Dr. Mola, the Cuban physician, a certain Tudela, Eggert, Hayne, Firth, the new Manager of the Pacific Steam Navigation Co., Dr. Lührsen, and Godoy Chilian Chargé. On the other hand, at the Fiscal's, Dr. Teodoro de la Rosa, I saw only one of his young daughters, who told me that both her father and mother were indisposed. Of Doña Manuela Mendoza, who lived over the way, I have given my opinion more than once; her daughter-in-law Isabel Barreda was more agreeable and talkative than I had ever found her before. She recollected the time when [_] years ago she and her two elder sisters came to [831] my house Calle del C [...] with them and the two Schutte.

At dinner we had several guests: the Canon Mora, Antonio Villacampa, Limpricht, the music-master Castañeda, very agreeable, Jorge Valle, and Urquhart. It was as late as nine when we rose, and at a little past ten I was in bed.

Thursday, $2^{\text {nd }}$ of January 1879 . Little Corina was considerably better, but not yet quite well; she still kept her, or rather her mother's bed. Thermometer at 4 p.m. $78^{\circ} \mathrm{F}$.

In the evening there were two rocambor tables. Juana Rosa, Basagoytia's wife, came with her three daughters, one of whom was Filomena, a grown up girl; thus Enriqueta was kept up till past one, much against her inclination, whilst I hardly shewed my face, and preferred sitting on my side of the corridor, which, as the heat had set in, was again very pleasant in the evening.

Saturday, $4^{\text {th }}$ of January 1879. In the office of the Insurance Company "Lima" all attended except Isaacson. The object of our meeting was to fix a dividend for last year. The accounts stood more or less as follows:

Net premium on sea risk, about

On fire risk,

each about \$20oo less than last year

Interest gained,

about \$200o more than last year.

Net gain, about

\$200o less than last year
\$9100

S14,900

$\mathrm{S}_{46,45^{\circ}}$

$\$_{5} 6,000$ 
The idea of my colleagues was to pay $20 \%$ dividend, whilst I was of opinion that we should give somewhat less, because we should certainly sustain some loss upon J. G. Garcia's debt, as well as upon the Lima Bank Shares which we had been obliged to take in pa[_]ent. Besides [_] had [_] [832] [...] stood in our books [_] par, whilst they were worth at the present time no more than $83 \%$. Also \$100,00o Nitrate Certificates cost \$97,000 and were only worth \$88,500. I was however over-ruled. Especially Elizalde was opposed to my view, and finally it was resolved that the $\$ 56,000$ should be divided as follows: $\$_{40,000}$ or $20 \%$ upon the paid up capital to be distributed amongst the shareholders. About $\$ 9000$ to be carried to Reserve Fund which would then come up to \$200,000; and the balance of from \$600o to \$7000 to be placed to the credit of a new account, "de reparacion", wherewith to make up or repair the losses, to which I had alluded.

On the $1^{\text {st } I}$ spoke of a report given in by the Deputies Tejeda and Jimenez on the subject of the accusation of Ministers. When this report was discussed in the Chambers, another Deputy observed that that article of the Constitution to which they had referred, and in consequence of which the Ministers could not be accused before the Senate was improperly expressed in the printed copies of the Constitution, and that it stood differently in the original manuscript, whereupon both Tejeda and Jimenez withdrew their signatures from their report; which, in my opinion, was now of no value whatever.

Sunday, $5^{\text {th }}$ of January 1879 . When Bryson was gone Limpricht wrote up my cash of December, when he had finished we played at chess till nearly six; one game was drawn, the other I lost. I then took a quick run to the Cinco Esquinas, and on my return found the family at dinner, together with Federico Bergmann's widow and her two little daughters. Eli[_], Guillermo's wife, and her sister also came, but [833] I, not feeling quite [...] my bedroom, afterwards went to Limpricht's room, who read me a letter from his niece Emma. She wrote that she and her mother, who was again very ill, were together in Bonn, where another apparatus was to be fabricated in order to keep up the latter's head, the previous one not having answered the purpose. She was also suffering from an inflammation in one of her eyes. When Limpricht had done reading, we again took out the chessmen, and this time I gained; it was eleven when we left off.

Monday, $6^{\text {th }}$ of January 1879. Twelfth Day. Till near three in the morning I suffered from diarrhea, which kept me continually on the move.

News had been received from Europe that the January coupon on the Peruvian Bonds would not be paid, because the Guano Company had not had one penny surplus wherewith to meet this payment. 
I further learned by the cuttings from various papers sent me by Juan, that for the present the lighting up by gas ran little risk of being supplanted by the Electric light; at least not for domestic purposes.

This was the last day of my Christmas and New Year's visits; first, to Dr. Melchor Vidaurre, who, on account of ill-health, did not receive; next, to Baltazar Aranivar; thirdly, to Melchor Velarde, who was very poorly; fifthly, to the Pintos, where I was received in the "salon" by Rosita, the eldest unmarried daughter, undoubtedly one of the most agreeable and accomplished young ladies in Lima; sixthly, to Manuel Alvarez Calderon; seventhly, to Colonel J. N. Vargas; eighthly, to Oscar Heeren; not one of the three last mentioned was at home; ninthly, to Dr. Puente Arnao, who was particularly polite; with him, his wife, sister-in-law and father-in-law Guimet, the Ban[_] de Lima's debt [...] [834] [...] the same did I with Mr. R. Gibbs, the North American Mini[_] with whom I found a Cubano, Mr. Bravo, an agreeable young man; his, Gibbs's lady from the same island, also made her appearance; but not much was to be said to her advantage; at least as far as her looks went.

At dinner we were very few. In the evening Brierley came, as was his habit; Garland had one rocambor table; and at the usual hour I retired to my room.

Tuesday, $7^{\text {th }}$ of January 1879. During the night I again suffered from loose bowels, neither was I quite well in the day-time. From Alejandro I bought on account of C. W. Schutte 50,00o Soles Nitrate Certificates, which he had agreed to give me at $881 / 2$, but I offered him $1 / 4 \%$ more on condition he would let me have between $£ 500$ and $£ 600$ at $25 \mathrm{~d} 1 / 2$, also intended for Schutte, at which rate no bills were to be had. At the last moment even $24 \mathrm{~d} 3 / 4$ had been paid.

In supplement to Appendix, under $\mathrm{N}^{\circ} 46$, will be found a cutting from the "Comercio" of the $6^{\text {th }}$, which contains the opinion of the "agente fiscal" regarding the various persons implicated in the murder of Manuel Pardo.

Wednesday, $8^{\text {th }}$ of January 1879 . Enriqueta having gone out in the evening I went to Limpricht's room, with whom I played chess. It was now quite clear to me that I did not play so well as formerly; also Limpricht observed it. He gained the first game, and though in the second he gave me back many moves, I could only make a drawn game of it. $\left.\mathrm{H}_{[}\right]$remained with the king, I with king and pawn, [835] which I could not [...]

Thursday, $9^{\text {th }}$ of January 1879 . Thermometer at 4 p.m. $78^{\circ} \mathrm{F}$.

Friday, $10^{\text {th }}$ of January 1879. A meeting of the shareholders of the Banco del Perú had been called together for 1 o'clock. I, no more a Director, for I did not possess the sufficient number of shares required for this office, went at about two and took my seat amongst the shareholders, of whom few were present. Manuel Candamo, President of the Directory, had when I entered 
nearly finished reading the report of the state of the Bank at the end of last year, and of its operations in the course of that period. The result was very satisfactory. After all expenses had been paid, which for the year ran up to the enormous sum of \$86,ooo, after a sufficient amount had been placed to the credit of reserve fund to meet the loss on the Internal Debt held by the Bank and on the doubtful debts in the Cerro, $14 \%$ could be distributed amongst the shareholders, of which $41 / 2 \%$ interest had been paid in the course of the year, $41 / 2 \%$ interest to make up $9 \%$ annual interest and $5 \%$ dividend would now be paid. The Gerentes received besides their salary, each his $5 \%$ on the gains, and after all there still remained \$21,0oo to the credit of Profit and Loss. Hardly had Candamo ceased reading when Leuthold of Canevaro's house rose, and moved that, of these \$21,000, \$15,00o should be distributed amongst the seven Directors of last year. Derteano moved that all the \$21,0oo should be placed at the disposal of the late Directory; Oyague spoke in the same sense, and voted moreover thanks to the Directory, all which was unanimously approved.

Saturday, $17^{\text {th }}$ of January 1879. At 12 I was in th [...] [836] [...] was read. Here the result was very different from that of the Banco del Perú. The losses last year had been enormous, which was already known to us. The entire reserve fund was absorbed, and not a cent of gain remained to the credit of Profit and Loss account. The document, I believe drawn out by Garland, was very well done, and approved, with trifling alterations. Melchor Velarde was not present, being prevented by serious illness. Thence I went to the office of the notary Prieto, whither my expediente against Aliaga had at last returned from the Supreme and Superior Courts. Nearly three months had elapsed since Aliaga had appealed. At all events he had gained time.

When I went to the Banco del Perú I was told that the Directors for the present year had been chosen, viz.: Candamo, Elizalde, Calderoni, Ruden and John Bryce; Supplentes, Ayulo and Chavez. They had not yet agreed as to the distribution of the \$21,00o. Escobar had laid in a claim for \$30oo on account of the Gerentes jointly, which on Candamo asking my opinion, I replied that it ought not to be granted, as they had already received their five percent upon the profits.

Thermometer at 3 p.m. $79^{\circ}$ F. Early in the morning I had been to the pantheon to adorn the sarcophagus with red roses.

Sunday, $12^{\text {th }}$ of January 1879 . When coming from the barber's shop about nine, I was stopped by a gentleman who said that his name was Mariano Osma, and added that he wished to have a conference with me in the name of Juan Aliaga y Puente. I answered that I should be at home on the following [837] day from twelve to $[\ldots]$ 
My usual Sunday calls were but few; at Melchor Velarde's, I was told by his daughter Erminia that though her father was in bed he felt considerably better, having placed himself under the treatment of the physician Alarco, who had ordered a blister to be put on his stomach.

At dinner only three sons of Garland sat down, however, Villacampa, Urquhart and Jorge Valle came uninvited, and thus our table was pretty well filled.

Monday, $13^{\text {th }}$ of January 1879 . Before breakfast I walked as far as where the Guadalupe Gate once stood, which walk, either owing to the heat, or my want of strength, fatigued me much more than I had expected. At about 2.30 I went to the office of the Insurance Company "Lima", where only a few shareholders were present. Of the Directors, Valentin Gil, who presided, Menchaca, Mathison and I, and the Gerente Elizalde. The last acta was read, then the report or memoria for last year; both documents were approved without a dissenting voice, wherupon we proceeded to the election of new Directors instead of Mathison, Moscoso Melgar and myself, who went out by rotation. The number of votes was 69, which were unanimously given for Mathison and Melgar, Directors, Pedro Correa y Santiago, and Charles Prevost, examiners of accounts, and Enrique Calderoni as suplente. I had 63 votes, 6 being given to Leuthold. Who had given these six, it was not possible to find out. Elizalde told me that on Saturday there had been a violent dispute in the Banco del Perú as to the distribution of the \$21,00o. He had told them that the Gerentes were not entitled to any share of the same.

When going home I was accosted by a gentleman whom I did not recognize. It was Vicente Pazos, whom, if I remember correctly, I had last seen in 185[_] in [838] [...] his wife had been very [_]nd and friendly towards Mariquita and myself. He was now quite an elderly gentleman, and, as far as I could judge, with little elasticity of mind or body. By the "Nacional" I saw that the first shipment of 16,00o quintals of Chilian Nitrate of Soda had been made from a port called Taltal. The Government was offering Certificates for Bills to be drawn next April; at what exchange, I did not learn.

Tuesday, $14^{\text {th }}$ of January 1879. In the Banco del Perú, one of the clerks handed

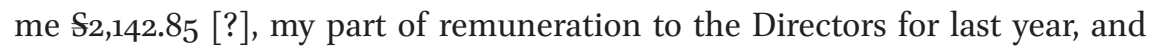
from Elizalde I learned that as the Directors and Gerentes had not been able to come to terms, a letter had been written by them to Derteano, who had said in reply to their question, that when on Saturday last he made the motion then spoken of, his intention had been that $\mathrm{S15}_{5}, 000$ should be distributed amongst the Directors, and the remaining \$60oo amongst the Gerentes and clerks. Accordingly the partition had been made, and the above $\$ 2,142.85$ [?] were one seventh of $\$ 15,000$. 
Wednesday, $15^{\text {th }}$ of January 1879. I saw by last night's "Nacional" that both Chambers had annulled the present Concejos Departamental and Provincial and until the new ones were elected the Prefect Enrique Lara was to attend to what is called in Lima la baja policia.

Espartero had died in Madrid at a very advanced age. He, before the battle of Ayacucho an insignificant Colonel in the Spanish army in Perú, had risen in later years to be Regent [...] la Victoria. Of late he had [839] retired from public $[\ldots]$ bscurity. The English under General Biddulph had entered Candahar, after Cabul the principal town in Afghanistan. Thermometer at 3 p.m. $79^{\circ} \mathrm{F}$.

Saturday, $18^{\text {th }}$ of January 1879 . This morning, as it was now my habit, I walked to the pantheon to adorn the sarcophagus with a bouquet of red roses, the flower which I like best. Though the sun was not out, I came home quite fatigued.

All the declarations taken by the Judge Arbulu in the case of Pardo's assassination had been published in the papers. It appeared to me that at the time of the murder a spirit of discontent had been prevalent amongst the sergeants of the battalion, who had seen by "La Patria", which was their favorite daily paper, that, by a law lately given by the Congress, nobody could be raised to the rank of officer without having passed an examination, and studied in the military school; and thus, to them, illiterate men, all possibility of rising in the army was cut off. Whether this discontent had been such as to make them plan the assassination of Pardo, whom they knew to be the leading man, or whether this idea had been instilled into them by the tailor Poytia, not Aymach, as said on $22^{\text {nd }}$ November last, was not so clear. A particular friend of the assassin Montoya was Antenor Gomez-Sanchez, a lad of 17, also a serjeant, who called himself the nephew, but was believed to be a natural son, of Dr. Evaristo Gomez-Sanchez.

In yesterday's session, the Chamber of Deputies resolved to accuse before the Senate the two ex Ministers of Finance, J. F. Garcia and Dr. Barrinaga; against Garcia the majority was great, against Barrinaga only two, 46 against 44. Man[_] Civilist [...] [840] [...] vote that there was [_] motive for accusing him.

Sunday, $19^{\text {th }}$ of January 1879. Though I gained two games at chess from Limpricht, I had the intimate conviction that he was a better player than I. Juan wrote from Nizza that the winter was rather colder than usual, and that the snow-fall had been very great. The Mont Cenis tunnel was blocked up by masses of snow on the Swiss side, so that the train from Italy had had to return. The tunnel also had filled with smoke, which could not find an outlet. 
From Monday, $20^{\text {th }}$ to Thursday, $23^{\text {rd }}$ of January 1879. On Mondays and Thursdays Garland continued to have with him his rocambor players. Their number was however much reduced, frequently no more than three or four besides himself; Jorge Valle, Luis Bryce, a Chilian Ovalle, were the most regular players; Dr. Middendorff came occasionally, Pinto, very seldom, Limpricht, when sent for to make the fourth. M. F. Benavides and family, also the Basagoytias, had removed to Ancon.

My lawsuit against Aliaga kept me occupied, and hardly a day passed without my going to the notary Prieto; but nothing was as yet decided.

On Thursday a general meeting of the shareholders of the Gas Company had been convened, present were the Directory, with Oyague in the chair; of shareholders not Directors, only Noel West, late Callao agent of the Pacific Steam Navigation Co., Dr. Loayza, Albarracin and I. The last acta was read and approved. The Municipality had cancelled its debt as far as June last, having given in payment Municipal Bonds, which the Company had taken at 80, a few of them [...] at 70 [_] now they were hardly worth [841] 65\%. At pr [...] arrears $\$ 70,000$. About two years ago when my son Juan was here, a motion was made that no shareholder who was interested in business done with the company could be a Director. At that time it passed, but since then it had been found out that it was an innovation of the statutes which could not have been valid without the consent of $2 / 3^{\text {rds }}$ of the shareholders, and as these had then not been present, the resolution had naturally been null and void; this we now confirmed. Ruden thought proper to revive the motion; I seconded him, John Bryce also gave his assent, and after some observations made by Böhl and Loayza, we decided that before the $1^{\text {st }}$ April a new general meeting should be called together, merely for the purpose of discussing this question. To examine the accounts of last year Guillermo Garland was chosen unanimously.

Friday, $24^{\text {th }}$ of January 1879. In the meeting of the shareholders of the South American Insurance Co., who assembled in the office, with Ruden in the chair, and Calixto Pfeiffer, Gerente, everything went off quietly and pleasantly. The last acta was approved; the report or memoria read, Bartolo Figari and A. Polis re-elected Directors, and Bush of Meiggs's establishment and I named by Ruden to examine the accounts at the end of the year. This company had

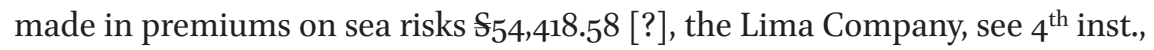
S910o; the South American, premiums on fire risk \$44,424.50 [?], the Lima \$14,90o; Interest, South American, \$42,312.76 [?], Lima \$46,450. After having debited Profit and Loss Account for losses on Maritime Insurance, for all expenses, commission to the gerente, \$80oo remuneration to the Directory, there remained after all a surplus to the credit of Profit and Loss Account of 
\$93,000 of which \$13,000 were carried to the credit of "Fondo para Siniestros", a kind of reserve fund, and \$80,000, say $\$ 40$ or $50 \%$ on each share of 1000 dollars [...] [842] [...] ders; of course a splendid result.

Saturday, $25^{\text {th }}$ of January 1879 . At an early hour I walked out with my flowers to the chapel, and came home much tired.

Sunday, $26^{\text {th }}$ of January 1879 . The "Nacional" of last Wednesday published an official dispatch directed by Izcue, Minister of Finance, to the Chamber of Deputies, which gave a deplorable account of the State of Peruvian Finance for

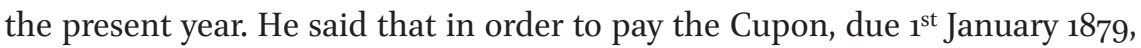
on the Peruvian External Debt, the Government had acquiesced to a proposal made from Europe (probably by J. F. Canevaro) to the effect that of the monthly payments to be made to the Government by the Peruvian Guano Company, Limited, London, £25,00o should be retained monthly, to begin from June next. Consequently, in the course of the whole year the Government would have to receive, according to contract of $7^{\text {th }}$ June 1876 :

Balance due till the $33^{\text {st }}$ May, they having previously disposed of the remainder,

7 months from $1^{\text {st }}$ June to $31^{\text {st }}$ December, at $£ 58,333$ per month,

Less:

To be held at the disposal of Peruvian Diplomatic Agents, $£ 14,400$

Subvention to the Amazon Navigation Company $£ 24,000$ 7 months at $£_{25}$,000 wherewith to pay the cupon,

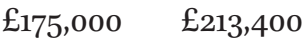
Balance the Government could count upon,

The payment to be received from the Nitrate Company [...] upon the sale of the article, and as the price had [843] declined to 13, such [...] upon with any degree of certainty. From the revenues of the Custom Houses only \$40,000 owing by the Government in the present month of January had to be deducted; but one with another there would be an enormous deficit, which could only be made up for in three ways. Firstly, by reducing expenses, which, Izcue said, could not be done; secondly, by borrowing, which could not be done either, for the country had no credit; and thirdly, by levying new taxes, which, according to Izcue, was the only way left open to the Government.

Yesterday, the wife of Nicolás Piérola left for Valparaiso, where her husband was expected. A considerable number of persons accompanied her to Callao. 
Here in Lima, on the platform, it was Dionisio Derteano, who had given her his arm.

In the course of to-day, Sunday, I made two unusual calls, for which reason I specify them. The one, to Vicente Pazos and his wife, who were not at home; the other, to the old lady Doña Baltazara Calderon, widow of Vicente Rocafuerte, to whom I had paid a visit about a year ago, and of whom I then said a few words.

Monday, $27^{\text {th }}$ of January 1879. At 12 o'clock I was in the office of the Banco Hipotecario, where I had to wait nearly an hour before the two other Directors, Lorente and Pedro Correa, and one or two shareholders came, we then proceeded to draw the numbers of the Cédulas which at the end of the present half year were to be paid at par.

Tuesday, $28^{\text {th }}$ of January 1879 . I saw by last night's "Nacional" that Tadeo Terry had proposed in the Chamber of Deputies to authorize the Executive to issue 6 millions of bank notes, which he believed to be the only way to get out of the present financial difficulties of which I spoke on the $26^{\text {th }}$.

The Minister of Foreign Affairs Mesones had in the name of the Govern [...] [844] [...] year, when the Congr [...] ould again meet, for, as I have already said, the legislative body was at present to meet every year, and not every two years as heretofore.

Exchange on London $22 \mathrm{~d}_{3} / 4$ to $22 \mathrm{~d} 1 / 2$, perhaps even still worse. Premium on coined silver, 75 to $76 \%$.

Friday, $37^{\text {st }}$ of January 1879 . I was cited to a meeting of the shareholders in the office of the Water Company, was there a quarter of an hour later than the hour fixed upon, and only found one of the Prevosts, two gentlemen whom I hardly knew, and young Rey, who acted as provisional gerente during his father's illness. I learned from him that the daily consumption of water in Lima came to eight millions of gallons, and that the waste of water in the present season was very considerable, owing to the streets being continually watered by order of the Prefect, and owing to this the altos of many houses had not a sufficient supply. Of late, the annual increase in the consumption had been from 10,000 soles to 11,000 and the average net gain amounted to 10 or $11 \%$ upon a capital of $\$ 1,320,000$.

Now that the hot season was making itself felt, Enriqueta, Limpricht, and I were frequently on my side of the corridor in the open air till 11 o'clock, our bed-time.

Saturday, $7^{\text {st }}$ of February 1879. Though I had no flowers, I walked out to the pantheon, swept and dusted the chapel, and sat down for a few minutes on the steps of the altar. Thermometer at $2.30,81^{\circ} \mathrm{F}$; about five degrees lower than last year. 
Sunday, $2^{\text {nd }}$ of February 1879 . I was up by six, and [...] hour later walked out to the pantheon, [845] this day with my [...] eturn I got shaved, and was again in bed at half pas[_] eight, when I actually slept till breakfast-time. Garland, Enriqueta, and the two little girls had left the house at about eight in order to go per train to Ancon, there to spend the day with the Basagoytias.

Last night I received per north steamer a few words dated Paris, $31^{\mathrm{st}}$ December, from C. W. Schutte, who now revoked his order for the purchase of Nitrate certificates, which counter order of course arrived too late. They had cost him $883 / 4$, and this day they were at $863 / 4$. Juan, in his letter from Nizza, was again apprehensive of the introduction of the Electric light, and, consequently, authorized me to sell his gas shares, if I could do so without any material sacrifice. They were quoted at $80 \%$, which price I much doubted it would be possible to obtain, especially since the order given by the Prefect Lara that the interest on the Municipal Bonds was not to be paid; and of these bonds the Gas Company held a large quantity, as already stated.

Limpricht wrote up my cash for January, which took him full two hours; we then played chess. In the first game, which he began, he had such an advantage at the fourth or fifth move that I threw it up. The second we had not finished when he left, and it stood over for another time.

The remainder of the day was beyond measure tedious. From Ancon they returned at six. At dinner we had Valle and Urquhart. I did not enter the salita where Garland had his rocambor, and in Enriqueta's bedroom, Ricardo read to me some articles from the German "Rundschau", which interested me but little.

Monday, $3^{\text {rd }}$ of February 1879. I saw by the "Nacional" that the Executive had given its consent or as it is said here [...] [846] [...] Congress, the one [_]ich gave a grant of \$100,00o to the widow of Manu[_] Pardo, the other which ordered the changing of the bank notes for which the Government was responsible, say \$20,333,333.33 [?], less the amount burned, for new notes of a uniform type, none to be of a smaller value than one sol, and upon which was to be engraved that the Government was responsible for their payment. It further said that a committee of seven members was to attend to this change of notes, none of which members should be a Senator, a Deputy, or a Government employé; the President of this committee, the treasurers, and a secretary, to be chosen by the members themselves, were to have an annual salary of \$6ooo each, the others to work gratis. The following were elected by the Congress, not by each Chamber separately, in the sitting of Saturday last: Carlos Maria, the eldest son of Charles Pflücker, Juan de Dios Quintana, brother of Mrs. Elias; Enrique Ayulo; José Maria Cantuarias; Manuel Montero, one of the hacendados of that 
name; Federico Bresani; and Valentin Gil; Suplentes: Ramon La Fuente; José Barron, who had a store in Bodegones; José Maria Santiago y Concha; and Carlos Prevost.

At about two, a small number of the shareholders of the Banco de Lima, amongst whom I noted Cipriano Correa, Aurelio Denegri, J. F. Lembcke, Dionisio Villate, one of the brothers Cox, and Dr. Pró, together with the Directory and the Gerente, were assembled in an apartment on the ground floor of Heudebert's house. Heudebert, who presided, read the acta of the last meeting, at which I had not been present, and which was silently [...] ailed statement memoria, of [847] what the Dire [...] itherto; and finally, a few words signed by Carlos Elizalde and Aurelio Denegri, who had examined the accounts, and who expressed themselves much satisfied with what had hitherto been done. Hopes were held out that besides the $60 \%$ already returned of the capital, $25 \%$ would still be distributed in course of time, which, however, in a great measure depended upon the issue which the many lawsuits begun against the bank would have. All the Directors, as well as the Gerente Cucalon, had each of them, individually and personally, been notified not to distribute any money which they might collect, until the lawsuits were brought to an end. In order to obviate this long detention of the funds, Aurelio Denegri proposed, that, notwithstanding this notification, the Directors should distribute all the money they held; the shareholders being, in conformity with the statutes, responsible to them for the money they had received; and, consequently, would return it if requested to do so. Aurelio, however, did not clearly say whether any new escritura should be drawn out to renew the responsibility of the shareholders, or whether the statutes as they stood were sufficient. The Directors, as might be expected, did not like this idea; neither did I relish it. The lawyer of the Bank, Isaac Alzamora, was called in, and he gave his opinion decidedly against the repayment of any capital as long as the interdiction lasted. Then Denegri withdrew his motion. Next, he and Cox counselled the sale of the Nitrate Certificates which the Directory had bought at from 93 to 95. I opposed it, because I saw no necessity for any sacrifice to be made on these papers.

In the evening Garland had his rocambor players as usual. [848]

[...] My law-suit [_]th Aliaga continued to take up some of my time; on[_] or twice a day I had to look in at the notary Prieto's to see what was going on and to have the notifications made. Quiroga had resolved that the embargo was to be bettered by Aliaga; and had admitted his appeal en un solo efecto, which was in reality equivalent to no admitting the appeal, for the expediente was not sent up to the Superior Court; it remained with the Juez de $1^{\text {a }}$ Instancia, 
before whom the suit continued to be carried on; moreover, Aliaga had to go to the expense of having copies made of all the documents required upon which to found his appeal.

Wednesday, $5^{\text {th }}$ of February 1879 . I presented an escrito demanding once more the payment of the $\$ 5300$ for which sum the house 11 and 13 Polvos Azules had been sold.

Last night at 12 o'clock the Congress closed its Sessions. Before doing so, its President promulgated the law relative to the manner in which the members of the Concejos Provincial and Departamental of Lima were to be chosen hereafter; and to which law the Executive had not put its cumplase. About Nitrate the Congress had done nothing what the Deputies had approved, the Senators had disapproved, and for the present, the Contract with "La Providencia", transferred to a joint-stock Company, remained in force.

The Congress had granted to the Executive extraordinary powers, which was more or less equivalent to the suspension of the Habeas Corpus Act in England. They were to last till the $28^{\text {th }} \mathrm{July}$, when the Congress would again assemble.

The Executive had put its [...] the law which ordered the construction of [849] a mausoleum in the [...] he late Manuel Pardo, and the erection of a statue, representing him in natural size, in the Senate House.

Telegraphic dispatches had been received from Europe, which brought the news that Marshal Macmahon had ceased to be President of the French Republic, and that his place was provisionally filled by M. de Grévy, hitherto President of the Chamber of Deputies. Grévy was born in 1813 in the Department of the Jura. He studied law, and in his political career had always shown himself a decided democrat, more advanced in his opinions than Thiers, more moderate than Gambetta. In the law-suit carried on by the Peruvian bondholders against the firm of Dreyfus he had defended the latter and gained the suit. Thiers was elected President of the French Republic in 1871. In 1873 he was succeeded by Macmahon, who was elected for seven years, and whose constitutional time would therefore not expire till 1880.

Thursday, $6^{\text {th }}$ of February 1879. In the evening, Garland had his rocambor; amongst the players was Federico Panizo; his wife, Manuela Orbegoso, an extremely lively and talkative lady, the Chilian Ovalle, Urquhart, Rafael Velarde, wife and daughter, and Enriqueta, played Monte. I did not shew my face amongst them, and went to bed early.

Friday, $7^{\text {th }}$ of February 1879. There was a meeting of the shareholders of the Banco Hipotecario; the last acta was quietly approved. In the last meeting it had been unanimously resolved that one million, say, one third of the capital, should be returned to the shareholders. Accordingly, in the memoria drawn 
up by the Gerentes and approved by the Directory, printed copies of which had been sent round to all the shareholders, it was said that one third of this million would in the course [...] [850] [...] with interest at [_] per annum up to the day of the payment. It wa[_] further clearly set forth in this memoria that the entire profit made in the year had been absorbed, partly by the loss on the Cédulas transferred to Paris, and partly by the loss on the many bad debts made in former years, and compounded for in the course of 1878 , and thus it was evident that no profit could be divided. The first who rose was Agustin Escudero who said that the losses which had arisen from the bad debts ought to have been carried to the debit of Capital, not to profit and loss, nor to reserve fund, and that consequently there was a profit, which should be divided in the shape of $10 \%$ on the Capital, and no capital be returned. I answered, saying that this was not correct, but that losses ought to be carried either to Profit and loss account, or to Reserve Fund, and never to the debit of Capital. Oyague spoke, but gave his opinion neither the one way nor the other. Bohorquez and Noel backed Escudero, so did Francisco Garcia Calderon, who for a long time past had not been present in these meetings, and who was a debtor to the Bank for \$20,00o, his guarantee for Simon Soyer. I again answered, saying that as there were no profits, no profits could be divided; and that in the manner the entries had been made, the bank was now free from all "manchas" and in a better position than it had ever been before. Calderon replied, this may answer your purpose, but not that of the person I represent who wants his interest and does not wish to see his capital returned. Correa and Melchor did not say a word. Lorente merely put to the vote the question whether the third of the million should be paid or not. The majority was [...] affi[_] tive. The minority was, however, very [851] strong and inclu [...] holders, of course also Riva Agüero, who was represented by one of his sons. Now came the election of the new Directors, for all five went out according to statutes. There were 409 votes, thus the majority, 205. Melchor Velarde had begged me to give my vote for Dr. Loayza, and thus the following stood on my list: Lorente, Correa, Witt, Loayza, Manuel Candamo. Four Directors were chosen: John Bryce, who had most votes; owing, in my opinion, to his very insignificance, for nobody had anything to say against him; next, Pedro Correa, then Dr. Loayza, and, lastly, I, with no more than 208 votes. Candamo had not a sufficient number.

Saturday, $8^{\text {th }}$ of February 1879 . For the last four evenings I had suffered from toothache; several times I had been to the dentist Lince, but only this morning at nine I found him, when he looked at my teeth, and told me that those which he had lately filled were in their proper condition, and that on the other, the right side, where I felt pain, none was decayed, and he therefore merely advised me to rinse my mouth with tincture of Peruvian bark mixed with water. At a 
later hour I went to bid good-bye to Melchor Velarde, who left this day with his wife, one of his daughters, his nephew, and a servant, for Ica, to bathe in the lake of Huacachina close by, the waters of which are of a very stringent nature. Whilst I was with him, Alejandro came in, who told us that he had examined all the votes of the previous day in the Banco Hipotecario, and that he had discovered a deep laid plan to oust the entire present Directory, and to have its place filled by Dr. Loayza, Noel, Lorente, Bryce and Barrios; the four latter mere ciphers. Barrios had been from house to house to secure the votes. Oyague, Loayza, Garcia Calderon, Riva Agüero, Villate, Jimenez, Barrios, and all the small [_] had [...] [852] [...] that if this Direc [...] ad been chosen, they would have proposed a diminut[_] of the expenses, and, consequently, one Gerente instead of two. Garland and Gallagher would have had to resign, and then they would have done their utmost to bring in one of their own clique. My opinion was that this would not so easily have been carried through, for as the two Gerentes had just been named unanimously for three years, they could not have been turned out at a moment's notice.

Sunday, $9^{\text {th }}$ of February 1879. I rose at a little past six and walked to the pantheon with my flowers. The sky was overcast, and even on my return I had but little sun. Nevertheless, I felt tired and slept an hour before breakfast. At noon I did not feel quite well; extremely weak; thermometer $83^{\circ} \mathrm{F}$.

The Executive had promulgated a law given by the Congress, to the effect that all packages which were disembarked and embarked in the ports of the Republic had to pay a small extra impost, viz.: 25 cents for 200 lbs weight, for fractions of $200 \mathrm{lbs}$ in proportion. Moreover, the specific import duty upon liquors, wine, beer, tobacco, cigars, and cards was increased 30 per cent. The two imposts together, it was calculated, would amount monthly to about \$100,000, and this sum was to be paid in to the Commission of which I spoke on the $3^{\text {rd }}$ February. This Commission, as the law said, was to redeem, "amortizar", \$100,00o, bank notes, monthly; it did not say that they were to be burned. See "Nacional" of $6^{\text {th }}$ February. If the new imposts did not produce the S10o,ooo monthly, the Government had to make up the deficit; and if they exceeded the S100,000 then extra redemptions were to be made.

I dictated a long letter to Juan, for the [...] Sp[_]ish, because Rosa had written to En- [853] riqueta that as Juan [...] preferred to read them herself instead of having them translated.

Though suffering a little from tooth-ache I made a few calls. Upon Dr. Alvarez, upon Eliza, Guillermo's wife, and Mrs. Escobar, the latter two not in. Upon Dolores Puente, Mrs. Rafael Velarde, and Dr. Muñoz and lady, which two received me always in a very friendly manner. The Doctor told me that since he had sentenced in my favour in the suit against the Sotomayors the various members of the family had not spoken to him. 
At dinner we were only Garland and Enriqueta, Ricardo, the two little girls, Urquhart and I. Somewhat later, Luis Bryce paid us a visit, and at 9.30 the rocambor players, Valle, Ovalle, and Panizo, came. Ricardo read to me in Enriqueta's bedroom.

Monday, $10^{\text {th }}$ of February 1879. At noon, the four new Directors, Dr. Loayza, Pedro Correa, Juan Bryce, and I, assembled in the office of the Banco Hipotecario. I proposed that Correa should preside, which all agreed to, and said that in my opinion the President and Vice President of the Directory ought not to be chosen until it was completed by the election of the fifth Director. Correa and Loayza thought differently, and we proceeded at once to the election by writing the name upon a piece of paper. We had to choose several times before Correa turned out elected President, with a majority of three votes. Bryce and I had each two for the Vice Presidency. Then lots were drawn; and Bryce's name came out to my great satisfaction. I believe Loayza must have been rather disappointed that every time he was in the minority. This being done we resolved to call together, for the election of one Director and two Suplentes, a general meeting for the $17^{\text {th }}$; the advertisement for the $[\ldots][854][\ldots]$ rected, mostly by [_]ayza.

At two the Directory of the Insurance Company "Lima" met. The routine business was of little importance and quickly got over. We resolved that Valdeavellano \& Co. should pay their pagaré due this month, or give a better guarantee than that we held. We also authorized Elizalde to subscribe to the Pardo monument \$20o at the utmost. The Banco del Perú had subscribed \$1ooo. Then the election of a new President came on in lieu of Moscoso Melgar who had gone to Arequipa. Unanimously, Valentin Gil, hitherto Vice, was chosen. For Vice, Mathison and I had each three votes, but on my representing that my bad sight prevented me reading the documents laid before me, Mathison was elected.

In the evening, Garland had for rocambor players Jorge Valle, Dr. Middendorff, and Manuel Seminario of Piura, Senator of the late Congress. His wife and daughter had also come and thus Enriqueta had to remain up till near one o'clock.

Wednesday, $12^{\text {th }}$ of February 1879 . When going to notary Prieto at about 9 a.m, as it was my custom, I learned that Juan Aliaga y Puente had once more given in an escrito, opposing himself both to the embargo and to the drawing out of the escritura of the sale of the 11 \& 13 Polvos Azules.

From the "Nacional" I took the following news: The claim of the Peruvian Government against Thomson, Bonar \& Co. of London had finally been compounded by the delivery of Peruvian Bonds, amounting to $£ 452,000$. According to [...] had been made by Emilio Alt- [855] haus and Aranivar. [...] three Fiscal Delegates Simon Paredes, Selaya, and Ulises Delboy. It was also 
rumoured that the said London firm was on the point of stopping payment, or had already done so. Secondly, that Gibbs of London had decidedly refused admitting the consignment of Nitrate. Thirdly, that there was some probability that the Governments of England, France and Belgium would interfere in behalf of the holders of Peruvian Bonds; at all events, the Marquis of Salisbury, British Minister for Foreign Affairs, seemed to be well inclined towards them. Fourthly, that in the same manner as about twelve months ago, some shopkeepers of Lima, especially French, had bound themselves to reduce their remittances to Europe, as much as possible, as long as the Exchange was worse than $26 \mathrm{~d}$, also to withdraw their funds from the banks. Limpricht knew nothing of this arrangement.

Garland, Enriqueta, and the little girls went per train to Ancon to pay a visit to Manuel Francisco Benavides who had had a severe attack of liver complaint. When they came home at 6.30 Enriqueta had such a migraine that she immediately went to bed.

After Brierley was gone I went to Limpricht's room, who read to me in German some light writing of a certain Heine, nephew of the well-known Jewish banker, Salomon Heine of Hamburg. This writer, who had always lived in Paris, had found a particular pleasure in deriding everything German; in what Limpricht read to me he ridiculed two German Jews of Hamburg, the one, Mr. Gumpel who in Italy had become Il Marghese Cumpelero, and turned Catholic; the other, his servant Hirsch, now Hyacinthe. Next, he read to me a few pages of a German epic lately published, a paraphrase of the Niebelungenlied. The prologue, or preamble, was such a difficult German that I could hardly $[\ldots][856][\ldots] \mathrm{y}$.

Thursday, $13^{\text {th }}$ of February 1879 . By the eight o'clock train Enrique and I went to Chorrillos, for the plumber Scott had informed me that the Municipality had given orders to lengthen all the waste-pipes so far that the water which ran out of them did not fall upon the cliff, but right into the sea. Enrique saw the necessity of this being done, for if not, the cliff would gradually be eaten away. Mr. Batchelor went by the 9 o'clock train to Lima; with his wife we remained about half an hour.

Garland had as usual his rocambor; Enriqueta, Eliza, Dr. Middendorff, Curate Aguila, Urquhart, and Ricardo played Monte, of course at very low stakes. I was in bed by eleven.

Friday, $14^{\text {th }}$ of February 1879. Serious differences had arisen between the Governments of Chile and Bolivia. Nitrate of Soda produced on Chilian territory by a company, which I believe was that of Gibbs and Edwards, could only be shipped in a Bolivian port, that of Antofagasta. Contrary to previous treaties, the Bolivian Government, whose chief was President Daza, insisted 
upon levying an export duty of 10 cents per quintal which the Company had refused to pay, and was backed in this refusal by the Chilian Government, which had sent some men-of-war to the said port.

Sunday, $16^{\text {th }}$ of February 1879 . I rose at a little past six, and with a large bunch of flowers walked out to the pantheon, and adorned the sarcophagus with them. I also dusted and swept the interior of my chapel as was my habit. The sun was out and it was a warm walk. I went to the barber's, was home by nine, and slept full an hour till breakfast-time. The papers said that the English [...] e defeat in Natal, and had [857] lost 1000 men. [...] Baffres.

With my old diary we had now progressed as far as January 1876, and Bryson's time was taken up with writing the Index of Volume VI. Thermometer at 1 p.m. $81^{\circ} \mathrm{F}$.

With Limpricht I played chess. The first game, which was that which stood over from the Sunday before last, and of which I had taken a copy, I gained for I had a figure more than he. Also the second, I had the good luck to win, but the two others I lost, and became more convinced than ever that I was no more a match for him. We had done by five, and I then sat by myself in the corridor till 6.30, when we, that is to say, Garland, Enriqueta, Dr. Middendorff, Limpricht, Ricardo, Juan, Antonio and I, sat down to dinner. At a later hour, Garland, Middendorff, and Limpricht played rocambor, and I was so dreadfully sleepy that I went to bed at 9.30; even whilst Ricardo was reading I fell asleep.

Monday, $17^{\text {th }}$ of February 1879. A rupture between Chile and Bolivia seemed unavoidable. From the latter country the Minister of Foreign Affairs, Reyes Ortiz, had arrived in Lima on an extraordinary mission.

At somewhat past three a small number of the shareholders of the Banco Hipotecario were assembled in the office of the bank. The greater part of those present held powers from other shareholders, so that more than half of the shares were represented. Pedro Correa presided, the last acta was read, and approved of after an insignificant observation from Focion Mariategui; we then proceeded to elect the fifth Director and two Suplentes. Manuel Candamo was chosen Director, Focion Mariategui and Calixto Pfeiffer, Suplentes; the first unanimously, the third by a great majority; the third Suplente, Francisco PazSoldan, the engineer, one of the sons of $[\ldots][858][\ldots] \mathrm{ng}$.

This being Monday night, G[_]land had his rocambor. I was in bed by eleven.

Tuesday, $18^{\text {th }}$ of February 1879. At twelve, the five new Directors of the Banco Hipotecario assembled, Correa presiding. Little of importance was transacted. Dr. Fernando Palacios asked for a loan of $\$ 15,000$ upon his house in the street Gallinacitos, which he held in emphiteusis for 100 years. I immediately said that I would take no part in the debate, because, if the loan were granted him I should be benefited by it. We others decided that the petition should be laid 
before the bank's lawyer, Ramon Ribeyro. I mentioned not many months ago in this diary that Prince Henry, brother of the King of the Netherlands, fifty odd years of age, had married one of the daughters of Prince Frederick Charles of Prussia. We now heard that the old gentleman had died, and that one of his sisters-in-law was about marrying the Duke of Connaught, one of Queen Victoria's sons. The son of the late blind King of Hanover, who had taken the old title of his family, that of Duke of Cumberland, had married Thyra, the youngest daughter of King Christian IX of Denmark; and the old King of the Netherlands, a widower, who had two grown up good for nothing sons, had taken for wife a young princess of Waldeck.

Wednesday, $19^{\text {th }}$ and Thursday, $20^{\text {th }}$ of February 1879 . Davies, my lector from eleven to one, sent me word that he was suffering from fever, and could not come, thus on both days the time till Bryson came hung very heavily on my hands, and the more so as the great heat prevented my taking a walk. On Thursday however, when the sun was going down, I went as far as the street called La Palma, where [...] bridge had been constructed across the Rimac. [859] [...] e wooden bridge, and had [...] he half brother [_] partner of Emilio Althaus. His object was to have his sugar cane, produced on an estate a short way up the sierra, brought down on the Oroya line, and thence over this new bridge to the Chancay Railway, which passed the estate of Pró, his and his brother's property, where they had the necessary machinery for crushing sugar cane. On my return I had to dress, for Enriqueta had invited a few friends to dinner in honour of Mr. and Mrs. Batchelor. Besides these two there were Luis Bryce, Jorge Valle, Urquhart, Limpricht, Eliza, Zoila, and Sofia Velarde. At my request Enriqueta placed me next to Batchelor, and conversing with him the time passed more pleasantly than was generally the case at such dinners. At a later hour Federico Panizo with his wife, also Rafael Velarde, and the curate Aguila, came. In the salita rocambor was played. In the saloon, Monte, at very low stakes. I was in bed by eleven.

Friday, $27^{\text {st }}$ of February 1879 . Davies came this morning. Enriqueta was once more very ill, suffering from migraine. Yesterday arrived in the port of Callao the German man-of-war "Prince Adalbert", on board of which served in a rank somewhat superior to that of a midshipman, Prince Henry, second son of the Crown Prince of Prussia, consequently grandson of the Empress of India, and of the German Emperor. Though he was only 17 years of age, great preparations had been made for his reception, particularly by the German colony in Lima. A subscription had been set on foot by the club for a theatrical performance and a dance, to which he was to be invited. Fortunately, I was no more a member. Lembcke its President, Gildemeister, Böhl, and Kant who had the beer-shop, had each subscribed \$10o. [860] [...] between Chile an[_] Bolivia had taken a 
very serious [_]. Men-of-[_] belonging to the former were off Antofagasta and Cobija, and in the first of these two ports troops had landed and marched upon Caracoles. In Lima the general opinion was in favour of Bolivia. J. A. Lavalle had been named to go on a special mission to Santiago de Chile to act as mediator between the contending partied if a reconciliation could still be brought about.

Saturday, 22 ${ }^{\text {nd }}$ of February 1879. Gildemeister had placed at Prince Henry's disposal his house beautifully furnished and newly carpeted.

I saw by the papers that on the $30^{\text {th }}$ January Marshal Mac Mahon, the President of the French Republic, had tendered his resignation. The motive which he assigned for this step was that his Ministers had insisted upon his making some alterations in the command of the Corps of his army, which, if made, would, in his opinion, affect the safety of the Republic. Grévy had been chosen in his stead by a vast majority of votes, 536 out of 670 , in the Congress, that is to say, in the two Chambers, the Senators and Deputies united. Most probably Gambetta would be chosen President of the lower Chamber in lieu of Grévy. The removal of the Chambers from Versailles to Paris was also spoken of.

Yesterday afternoon when the notary Prieto had faithfully promised me to lay an embargo upon the house and shops belonging to Juan Aliaga y Puente in the Calle de Palacio, I was received in Dr. Palacios's study with the news that Aliaga had at the very last moment recused Prieto, which stopped all further proceedings for the moment. However, Dr. Eygurren thought proper to dictate an escrito in [...] fuese habilitado, which [861] meant that thoug [...] from to-morrow till Wednesday after Easter, my case against Aliaga might be carried on. I personally delivered this escrito to Dr. Quiroga, who said he would attend to it. However, when I went for the third time to notary Prieto's office at 4 o'clock, I learned that Dr. Quiroga had not dispatched a single escrito, consequently el punto was not habilitado for me, and no notary had been named to take Prieto's place.

Sunday, $23^{\text {rd }}$ of February 1879 I rose at a little past six and went out with my flowers to the pantheon. In the public audience given yesterday to Prince Henry by the President of the Republic, the Prince had addressed His Excellency in English, which of course Dr. Lührsen had had to translate into Spanish. After a short interval the President had returned the visit.

The papers contained the Dispatch directed by Simon Paredes, one of the Delegates in London, to the Minister for Foreign Affairs, regarding the arrangement made with Thomson, Bonar \& Co., £340,000 in bonds, besides 15 per cent deferred interest, was the sum for which the claim had been settled. In 1862 Castilla had made a contract with the National Guano Company, which had named Thomson, Bonar \& Co. their consignees in London. For several 
years no fault was found with the proceedings of this house, however by and by suspicions were entertained that they had made and were making large undue profits, in which the Company was supposed to have their share; consequently, in 1871, Colonel Joaquin Torrico was sent to London as Peruvian Fiscal Delegate to examine the accounts; he was recalled, others were sent, lawyers were engaged, enormous sums were spent, and no result was arrived at. In 1876 the Government [...] [862] [...] and then Government [_]nd Company jointly sued Thomson, Bonar \& Co., and now at last, after the expenditure of many hundred thousands of Soles, the claims had been compounded in the manner just stated, certainly favourable enough for the defendants.

To-day was Carnival Sunday.

I dictated to Bryson a letter to Juan, and from 3 to 6.30, when it was impossible to see any longer, Limpricht and I played chess in my office, whilst Garland, Dr. Middendorff, Basagoytia and Valle were at rocambor on my side of the corridor. The first game I lost, the second, when I tried a new way of beginning, I threw up after four or five moves. The third I gained, and the fourth stood over. The rocambor players and Urquhart remained for dinner. Little Corina had to go to bed suffering from her usual asthmatic complaint, and the remaining hours of the day were as tedious as they usually were when Brierley did not come to read.

Monday, 24 $4^{\text {th }}$ of February 1879. I saw by extracts of Chilian papers republished in the "Nacional" that all of them without exception urged the Chilian Government to energetic measures against Bolivia. The Government of this Republic had ordered the Salitreras to be valued and to be brought to the hammer, because the owners had refused paying the ten cents duty. The territory between the 23 and $24^{\circ}$ south latitude, which contained the salitreras, had been ceded by Chile to Bolivia in 1866, and the limits rectified in 1874 . Thermometer at noon in my office $82^{\circ} \mathrm{F}$.

At somewhat past two Limpricht and I again sat down to chess, to-day in the corridor. [...] one, the next two [863] I lost, he was too strong [...] we were both in a violent perspiration. Garland was nearly the whole day at Basagoytia's playing rocambor. At dinner we were merely Enriqueta, Dr. Middendorff, Ricardo, Maria and I. Corina was getting better. At the usual hour of 7.30 Brierley came, to my great joy. We finished Lord Mahon's History of England, and were getting on with Dickens's "David Copperfield".

Tuesday, $25^{\text {th }}$ of February 1879. Last Carnival Day. In our house everything was as quiet as it possibly could be. Maria and Corina, who had promised themselves great things from the Carnival, confessed that they had passed three most tedious days. I did not leave the house, neither had I done so on the 
previous day. Once more I played chess with Limpricht, gained the first game with the greatest difficulty, and was beaten in the second with much ease. Garland had no rocambor, he dined at home with his wife, myself, Ricardo, and the two little girls. Brierley came in the evening, and began reading Captain Palgrave's Journey through Arabia, to which I now listened for the second time.

The lawyer Felipe Varela and his wife Rosa Orbegoso gave a splendid ball in Chorrillos, to which Prince Henry had been invited, but did not attend; neither did Garland and Enriqueta go though they had also received an invitation.

Wednesday, $26^{\text {th }}$ of February 1879. Ash Wednesday. Both Davies and Bryson came at their usual hours of 11 and 12 respectively. Thermometer at $4.30,82^{\circ} \mathrm{F}$.

Thursday, $27^{\text {th }}$ of February 1879. [...] [864] [...] o that of the notary [_]ieto, but found both shut up. At twelve, Correa, Bryce, and I were in the Banco Hipotecario, and resolved to make some concession to Dr. Francisco Garcia Calderon, who had made a new proposal for cancelling the \$20,00o which he had guaranteed for Simon Soyer. The bank had sued him judicially, had gained in the first and the second instance, but the case had now been lying in the Supreme Court for many months without any chance of sentence being soon pronounced. Zavala, who, about six months back, had purchased various doubtful debts, including the one from Marcone, had paid the first instalment of 8o,0oo and odd soles when the escritura of the settlement was signed; the second had fallen due some weeks ago and had not been paid. He now made some offers how to settle it; such a weighty matter we three however would not decide without the presence of the other Directors Loayza and Candamo.

I learned by the papers that, without an actual declaration of war, hostilities had begun between Chile and Bolivia; the Chilians were in possession of Antofagasta, Mejillones and Caracoles; they claimed the Bolivian Territory as far as the $23^{\circ}$ south latitude, which was ceded by them to Bolivia in treaties of 1866 and 1874 , as said on the $24^{\text {th }}$, but the conditions of which the Chilians pretended the Bolivians had not complied with.

Enrique related this morning at breakfast that all Chilians who had hitherto served in the Peruvian navy had been dismissed. Also that Gibbs of Valparaiso had lent that Government one million of Chilian dollars; this last news was doubtful. [...] evening we had ro- [865] [_]bor in Enrique [...] Basagoytia were also present.

Friday, $28^{\text {th }}$ of February 1879. A very tedious, and if tedious, also a sad day, for, when not occupied, my thoughts referred to former times. The heat was great, which prevented my taking a walk through the streets. At 5 p.m. I went by Dr. Palacios's recommendation to the house of Dr. Quiroga, whom I begged to rehabilitar el punto, (for the meaning of which see Saturday last) merely for 
the purpose of laying the embargo on Aliaga's house in the Calle de Palacio. After some demur he said that I might present an escrito to that effect, dated Friday last, but I much doubted that I should obtain my object.

From the "Nacional", also from Limpricht and Brierley, I learned something of Prince Henry's proceedings of yesterday. In the morning with a large accompaniment, amongst whom Dr. Lührsen, he had taken the Chancay train as far as the hacienda de Infantas, whence vehicles and horses had conveyed the whole party to Canevaro's sugar estate of Caudevilla. Here a splendid breakfast had been provided. Prince Henry took his seat in the centre of the table between César Canevaro and Leuthold, a German Swiss, partner of the firm. Opposite to him Dr. Lührsen, between Captain Maclean, commanding the "Prince Adalbert", and Baron Seckendorf, the Prince's tutor. Afterwards they rode about the hacienda, looked at the sugar fields, the machinery, etc., and returned to Lima by an extraordinary train. Between 9 and 10 p.m. they went by invitation to the German Club, where an insignificant farce was represented, and then dancing began which lasted till near five in the morning. The Prince left at eleven, whilst the suite remained till the end of the feast [...] [866] [...]

Saturday, ${ }^{\text {st }}$ of March 1879. When at a litt[_] past one I went to the Banco Hipotecario the four other Directors were already there, and Gallagher was explaining to them how the Gerentes thought best to arrange with Zavala for the payment of the instalment which had lately fallen due. It was resolved that the Gerentes might return to him the nitrate certificates deposited with the bank, in order that he might obtain a loan upon the same as well as upon about $\$ 40,000$ certificates more which we knew were his, and the amount thus received he should then pay over to the bank. In this manner it was true the bank lost the security of the certificates, but would have received from him about $\$ 170,000$, the half of the purchase money, without having lost its right upon the various immovable property, which, if Zavala did not pay the balance, would revert to the bank.

Correa said that it was rumoured that the Government would henceforth not pay the interest either upon the Certificates or upon the Internal Debt, in consequence of which rumour the former had declined to 84 , and the latter had been redeemed at 49 . I doubted that such arbitrary steps would actually be taken; if they went to war with Chile they would issue paper money: that was my opinion.

Sunday, $2^{\text {nd }}$ of March 1879. At an early hour I went out to the pantheon with my flowers, which were not at all to my liking, for I had no red roses, the season for which had passed.

The whole day long I was extremely weak. When I went out a small fold in my stocking caused me much pain, so that I could hardly walk, and I returned 
home after three insignificant visits to the [...] Dr. [...] Dolores Puente, and Rafael [867] Velarde. I retir [...].

Monday, $3^{\text {rd }}$ of March 1879. To-day I felt much stronger.

The papers contained all kinds of news: Yesterday about eighty electors, all Civilistas, Alejandro Garland of the number, had met in the Cabildo, their object being to choose the members of the Concejos Departamental and Provincial of Lima. However all they did was to name the members of the board of Directors, say José de la Riva-Agüero, President; General Freyre and Juan Bazo, Scrutators; Manuel Maria del Valle, Secretary.

The Agente fiscal had given his vista in the case of Montoya and his accomplices. In his opinion the serjeant Melchor Montoya deserved death. Of the three others, Armando Garay, Elias Alvarez, and Alfredo Decourt, who jointly with Montoya had drawn lots who of them should kill Pardo, one was also to suffer capital punishment, but who that one was to be chance was to decide, they were to draw lots for their lives. The two others to be imprisoned in the penitentiary for fifteen years. The same punishment of 15 years imprisonment was to be inflicted upon the abettors and instigators, Nicanor Gomez-Sanchez, and the tailor Poita, Montoya's uncle. The guilt of Dr. Ampuero, and of several other sergeants, the Agente Fiscal was of opinion had not been proved, whilst the last, Demetrio Aranaga, whose guilt consisted in having uttered improper words against Pardo, Prado, and the Congress, was to be under arrest for six months.

The morning edition of the "Comercio" of this day contained advices from the South, which made manifest that the Chilian Government was resolved to carry on the war, and would not again give up the Bolivian territory which they [...] [868] [...] ded 300 Chilian sol[_]s in Antofagasta, and the National Guard had been called out in that Republic. On the $18^{\text {th }}$ February the Chilian Minister of Foreign Affairs had called together the Diplomatic Agents of Foreign Nations and laid before them the antecedents which had led to the rupture with Bolivia. Present were the Chargés for Germany, England, France, Italy and Uruguay. The French Minister in his name and that of his colleagues replied that they would communicate the contents of these documents to their respective Governments. Those for Perú, Brazil, Portugal and United States had not attended.

At two o'clock I was in the office of the Insurance Company "Lima”. Besides myself there were Elizalde the Gerente, Gil who presided, Mathison and Isaacson. We got quickly through with our business and conversed a long time on the state of the country. The general opinion was that in case of a war the Government would not stop the payment of interest of the Nitrate Certificates and of the Internal Debt, but would issue a new lot of bank notes. In fact they 
could not exist without having recourse to this measure. Nitrate Certificates had been sold at 80 .

Tuesday, $4^{\text {th }}$ of March. Last night Garland had no rocambor. Only Jorge Valle came and we conversed pleasantly till midnight.

During the night of Sunday, the "Prince Adalbert" left Callao for Japan, touching at Panamá. On Saturday the officers on board had given a lunch and a dance to the German Club and to several Peruvians, amongst whom were Felipe Varela, wife, and sister-in-law.

[_] "N[_]l" [_]ve a list of the [869] Peruvian, Bolivian [...] Coast of South America; they are the following: Peruvian: Tumbes, Paita, Sechura, San José, Pimentel, Eten, Pacasmayo, Malabrigo, Huanchaco, Salaverry, Santa, Chimbote, Samanco, Casma, Culebras, Huarmey, Supe, Huacho, Callao, Cerro-Azul, Tambo de Mora, Pisco, Lomas, Chala, Quilca, Mollendo, Ilo, Arica, Pisagua, Mejillones, Iquique, Chucumata, Patillos, Patache, Pabellon de Pica, Punta de Lobos, Huanillos, Chipana, Rio Loa. Bolivian: Tocopilla, Cobija, Mejillones de Bolivia, Antofagasta. Chilian: Blanco Encalada, Taltal, Chanaral, Caldera, Carrizal Bajo, Huasco, Peña Blanca, Coquimbo, Valparaiso, Punta de Curaunilla, Punta de Algarrobo, Punta del Toro, Tolten, Punta Falsa, Carelmapu, Ancud. In Perú, Chancay, Ancon and Islay were at all events omitted; perhaps still others with whose names I am not acquainted.

At dinner Garland told us that Rönacher, the Danish watchmaker, whom I usually employed, had been arrested, because several persons had complained to the Intendente that they could not yet get back from him the watches left for repair. This day a pagaré for $\$_{500}$, which I lent him three months back, fell due.

Wednesday, $5^{\text {th }}$ of March 1879. I went to Rönacher's house, and on enquiry was told by a young man, that his master had gone out, and would perhaps be back by 5 o'clock.

The papers gave the news that the Bolivian Ports of Tocopilla, Antofagasta and Mejillones were occupied by Chilian men-of-war, that from Valparaiso more troops would be sent to the said places, and that Nicolas Piérola had arrived in Santiago across the pampas from Buenos Ayres.

Nitrate certificates had been sold at $78 \%$, and were likely to $[\ldots][870][\ldots]$ um on silver $78 \%$. Thermometer at $5 \mathrm{p} . \mathrm{m}, 81^{\circ} \mathrm{F}$.

Thursday, $6^{\text {th }}$ of March 1879. I went to Rönacher [...] hop and found him in. The pagaré he could not pay for the present.

Last night's "Nacional" said that a telegram had been received from Lavalle in Valparaiso, who said that he considered his mission to Santiago as completely useless, and who counselled the Lima Government to send the entire fleet without loss of time to the Southern ports of Perú; but as the editorial articles of this paper were always written in a warlike strain, I did not give much credence to this news. 
Exchange on London, 2od; premium on coined silver, 90\%.

Thermometer at 2 p.m., $78^{\circ} \mathrm{F}$.

In the evening Garland had his three rocambor players, Dr. Middendorff, Jorge Valle, and Luis Bryce, whilst Enriqueta, Eliza, Ricardo, and I, afterwards with Guillermo and Limpricht, remained together on my side of the corridor till 11.30 .

Friday, $7^{\text {th }}$ of March 1879. Colonel Manuel Velarde, married to one of the nieces of Doña Pancha, Castilla's widow, a staunch Civilista, had been named Chief of the troops which were about being embarked for Iquique.

Premium on coined silver was quoted at 98 per cent.

In the middle of the day I was now in the habit of taking a long, not particularly interesting walk through the streets of Lima, partly to take exercise, partly to allow Bryson time to copy the remodelled diary.

Saturday, $8^{\text {th }}$ of March 1879. Last night the letters per North steamer were brought in, and read to me this [...] the $28^{\text {th }}$ and [871] $29^{\text {th }}$ January, and [...] as shares. I also saw by the "Nacional" that the firm of Fabbri \& Chauncey of New-York, had made a contract with Edison for supplying the whole of South America with Electric light. Schutte had not written, but Juan informed us that he was keeping his bed owing to a dreadful cold. The temperature all over the north of Europe had been very changeable, and an uncommon quantity of snow had fallen everywhere.

Here in Lima the Alcalde of the new Municipality or Concejo Provincial was chosen. Lizardo Montero had one vote more than Ignacio Osma; SubAlcalde was M. M. Valle, one of the Editors of the "Nacional". These particulars I learned from Cesar Canevaro, to whom I applied for bills on London, and who answered that he would let me know the exchange the day after to-morrow. From Alejandro I obtained $£_{300,} 90 \mathrm{~d} / \mathrm{s}$., Braillard of Arequipa on Morris Prevost \& Co. of London, at $19 \mathrm{~d} 1 / 2$. Coined silver was quoted at 110 per cent premium. It was impossible to foresee wither all this would lead us. Gibbs \& Sons' a/c current of $31^{\text {st }}$ December, received last night, shewed a balance in my favour of $£ 81395^{\mathrm{s}} 7 \mathrm{~d}$, which of course did not include my remittances of this year of $£ 500$.

Sunday, $9^{\text {th }}$ of March 1879. I left the house at 6.15. It was a cool morning, daylight, but the rays of the sun did not reach me until I was at the further end of the street of Maravillas. At 8 o'clock I was already at the barber's, and at home, as usual, lay down before breakfast.

Garland, Enriqueta, and the little girls went by invitation to Maranga, a large farm, or small estate, belonging to Federico Panizo, situated between Callao and Magdalena. It was here where President Orbegoso took re [...] [872] I saw by the papers that the plague which had broken out in Astrakhan had made its appearance in Southern Russia, and that the German and Austrian 
Governments were taking efficient measures to prevent its spreading; further, that the Afghan war was at an end, Shere Ali had died, and his soon Yakoob Khan did all the English desired him to do, they intended to keep open the three roads by which they had entered Afghanistan on this occasion; lastly, that on the $4^{\text {th }}$ inst. the house of Marquez, the Peruvian Consul in Valparaiso, had been attacked by a mob, and the escutcheon pelted with stones. The rioters were however dispersed by the police and ample satisfaction given both to the Consul and to the Chargé in Santiago, Pedro Paz Soldan y Unanue.

After having dictated a letter to Juan I went by the 3 o'clock train to Chorrillos, where the greater part of those upon whom I called were more or less unwell. General Pezet dangerously ill with a complaint of the urine; his wife also in bed, so were Mrs. Oyague, the wife of Vicente Gonzales and her daughter Mrs. Dubois. Doña Paula Benavides was "de cuidado", as the servant told me, and Dr. José Maria Perez had removed, his tenants could not tell me to what part of Chorrillos. Consequently only Mr. and Mrs. Batchelor in my own rancho, and Don Mariano Felipe Paz Soldan, the present Minister of Justice, and his lady, received me. With both I remained a considerable while, till it was time to return to Lima by the 5 o'clock train.

Guillermo and Eliza, Urquhart, Enrique and I had to wait till seven before Garland and family returned from Maranga, where they had spent a pleasant day. Garland had been playing rocambor, and [...] down to after dinner with [873] Jorge Valle and [...]

Monday, $10^{\text {th }}$ of March 1879. The papers contained the proclamation of Hilarion Daza, President of Bolivia, and articles from La Paz newspapers. They were filled with expressions of the most eccentric patriotism, and with bitter invectives against the Chilian Nation and the Chilian Government.

At Canevaro's office I was told that they drew by this steamer at $19 \mathrm{~d} 1 / 4$, at which rate I was not inclined to take their drafts on the Peruvian Guano Company, Limited.

Tuesday, $17^{\text {th }}$ of March 1879. At 12 o'clock all the Directors of the Insurance Co. "Lima" were assembled The South American Insurance Company had offered us a fourth part in the Insurance upon all such vessels as were anchored in the port of Huanillos, and were ordered by the Guano Loading Company to Pabellon de Pica; both on the vessels and the freight. The vessels were to be towed from one port to the other in the day time, distance no more than twenty odd miles. No vessel to leave Huanillos unless the previous one had arrived in Pabellon de Pica. Premium 1/2\% against total loss and general average. We all considered it a very good risk, but limited the amount which we insured on each vessel, including freight, to $£_{5000}$. Thence I hastened to Rönacher, where everything was locked up, he having removed, as I was told, with his family to the Barranco. 
At a little past one I was in the Banco Hipotecario with the other Directors. To Mejer we refused a loan of \$10,000 in Cédulas upon a piece of ground measuring nearly 14,000 square varas situated between Santa Sofia and the Exhibition, and ceded to him by the Compañia de Fomento; Fernando Palacios's demand for $\$ 15,000$ cédulas upon his house Calle de Gallinacitos which he had in emphiteusis for 100 years, and upon which there was already [...] [874] [...] proposal [_] ade to the Gerentes by P. J. Zavala. This gent[_]man, it will be remembered, purchased from the bank some time back, and at a considerable discount, a large amount of debts, of which the principal was Marcone's. At the time when the escritura of the sale was signed, he made the first stipulated payment, with the second instalment of \$86,000 he was in arrears, and he now proposed to cancel the entire balance of the debt, say $\$ 270,000$, by handing to the bank an amount of cédulas, which calculated at $80 \%$ would be equivalent to this amount. Forty cédulas of \$1ooo each he had in his possession, and the remainder required, about $\$_{2} 80,000$, he intended to raise form the bank itself, mortgaging to the same all the immovable property which had been made over to him at the time he purchased the debts. This was originally a plan of Alejandro's. Gallagher laid it before us as if it were an idea of the Gerentes, and represented it to us as an advantageous transaction. Correa, Candamo and I were not adverse to it either. Loayza looked upon it in a less favourable light, Bryce said nothing; and we resolved to hear our lawyer's opinion and to meet again in one or two days. It was now past two. I called upon Dr. Lührsen to wish him Good-bye; he, his wife, and children were to embark on the $13^{\text {th }}$, to return, as he said, within ten months.

At Enriqueta's desire I looked in at the Chorrillos terminus to make some arrangement about the carriage of trunks and beds, piano etc., to Chorrillos, but obtained no decisive answer. At home I lay down on the sofa. Batchelor paid me the rent of the rancho, the broker Salcedo [...] me to lend him some money, [875] and so the [...]

Menchaca, whom I met in [...] ffice of the Insurance Company, "Lima", told me that Grace Brothers \& Co. of Callao had taken upon themselves the payment of the interest on Nitrate Certificates until $30^{\text {th }}$ June 1880 inclusive; they giving their drafts on Baring Bros. \& Co. of London, to whom henceforth the Nitrate would be consigned. The last quotation of this article in Liverpool was $13 \mathrm{~s} 6 \mathrm{~d}$ to $14 \mathrm{~s}$. Coined silver had been sold here in Lima at 100 per cent premium.

Wednesday, $12^{\text {th }}$ of March 1879. I lent through the broker Salcedo to Luis Bryce, for 3 months and 3/4\% monthly discount, \$20,000, upon the security of 60 shares Banco del Perú of \$10oo each, 50 per cent paid up; of which \$20,000, \$14,000 account C. W. Schutte, \$6ooo account Juan Diez. I also remitted to them the $£_{300}$ bought on Saturday last, £2oo to the former, £1oo to the latter, 
leaving it to their option to keep them, or to remit them on my account to Gibbs of London.

In the course of the day there was a total reaction in the exchange. There were few takers of bills, and sellers went down to $20 \mathrm{~d}$, even to $2 \mathrm{od} 1 / 2$, but at this last figure little was done. Nitrate certificates rallied, and were up to 80 per cent.

About the war expected between Chile and Perú there was nothing new.

Enriqueta was very busy the whole day long with our preparations for leaving for Chorrillos.

$[876]$ 


\section{Index}

\section{A.D. 1876}

\section{Meetings}

Insurance Company, "Lima”, 2, 12, 17, 33, 57, 86, 132, 168-169, 187, 191, 238

Banco de Lima, 2-5, 23, 25-27, 30, 38-39, 41-42, 49-50, 54-57, $59-61,65-66,70-71,75-79,82,84,86,88,123-124,126,166$, 205-206, 209-210

South American Insurance Company, 7, 14 BancoHipotecario, 8,14,16-17,19, 21,26-27,30-31,42,46,48, $5^{1-52}, 58-59,66,67,69,73-74,83,88,89,172,178,187-188$, 194

Chilete Mining Company, 10-11

Banco Nacional del Perú, 12

Lima Gas Company, 15, 49, 57-58, 207-208

Banco del Perú, 15-16, 169, 181, 200, 226

Directories of the four banks, 32-35, 40

Banco "La Providencia", 214

\section{Deaths}

Count Walewski, 37

Child of Federico Bergmann, 40-41

John Hegan, 42

Dr. Muñoz's son, 46

Joaquin Soroa, 49

José Baron, 49

M. M. Basagoytia, 73

Stewart of New-York, 76

Daughter of Amancio Castillo, 76

Aquiles Allier, 90

Paul Bobertag, 114

Pedro Paz-Soldan, 120

Theodore Elmenhorst, 129

Eliza Semper, 129

Santa Maria, Balta's ex Minister, 149

Carolina Sotomayor, 155

George Sand, the Authoress, 155 
Josephine, Dowager Queen of Sweden, 155

Edward Stubbs, 162

[...] of Charles Pflücker, 188

[877]

\section{Deaths}

M. Sancho Davila, 189

J. H. Menendez, 190

Wife of J. L. Gomez Sanchez, 193

Admiral Blanco Encalada, 199

Colonel José Panizo, 208

Dr. Grau, 231

Dr. Tomás Davila, 243

Cardinal Antonelli, 255

Duchess of Aosta, 255

Mariano La Fuente, 268

General Torrico, 270

\section{Marriages}

Felipe Varela with Rosa Orbegoso, 50

Julia Carrillo with Catalina Valle, 73

Oscar Heeren with Ignacia Barreda, 104

Selaya with Juana Valle-Riestra, 108

Alexander Robertson with Fannie Meiggs, 196

Dr. Loayza with Ramona, widow of Castañeda, 265

Ascents of San Cristoval, 59, 74, 79, 108-109, 111, 118, 128, 139, 145, 153, 166, 173, 180, 194, 196, 199, 212

1876

January $\quad 21 \quad$ Stay in Chorrillos, till $26^{\text {th }}$ January

24 The Supreme Court fixes Schutte \& Co.'s remuneration to F. Garcia Calderon at $\$ 20,000$

25 My resignation of my post as Director in the Banco de Lima (6) - not admitted (14-15)

26 Danish vessel "Conrad" 
27 Exequies of Manuel Ferreyros

28 Riva Agüero Peruvian Minister in France and Belgium

30 Pardo's reforms in the administration of Callao Custom House

$31 \quad$ Repairs required in my Chorrillos Rancho

February $2 \quad$ How C. W. Schutte of Paris was circumstanced

7 Loss of the law-suit carried on by Zavala of Bolivia against C. W. Schutte

11 My suit against Leyva lost in the Superior

Court

16

15 How I spent this day

$[878]$

$[\ldots]$ ment

$19 \quad$ My wife's codicil

21 Closure of Huth's house and departure of Mr. and Mrs. Westphal

24 Credits opened by me in Hamburg for Limpricht and Becker

25 Prado's arrival from Valparaiso, and my visit to him

29 Carnival play in my house

March 5 Purchase of Caudevilla by the Canevaros

$8 \quad$ Gil's house sold to C. M. Pflucker \& Bros.

25,33

9 Chorrillos rancho placed at Prado's disposal

12 Baltazar Aranivar's rancho in Chorrillos

17 My wife's relapse

41,50 , $66-67,72$, $74,78,83$, 86,89

18 Ten thousand soles present to Rosa Schutte

22 General Prado's departure for Europe

25 Visit to the Barranco

$31 \quad$ Vega é Ibañez of Paris 
18 Accident which befell Alexander Robertson

65

22 State of trade and finance

$67-68$

May 7 Elections in Lima and other parts of the Republic for President of the Republic and $80-81$ others

11 My birthday

16 Hilarion Daza President of Bolivia

20/22 Mariquita's Death and Funeral

22 I dismiss Achipe and take my meals with the Garlands

24 Strength of Continental armies in Europe

[...] Directorships

25 Something abou [...]

26 Further particulars about my wife's last hours, and some details of her life

Interest received on my Pasco Railway Preference Bonds

Details about the Banco de Lima

June

Dethronement of the Sultan Abdul Azis

6 Antonio Martinez y Velarde, and his brother Luis

$8 \quad$ Knavery of the Franciscan Monk Pardini

$9 \quad$ Family of the Romanoffs

12 Contract between General Prado and

Rhaphael of London

114, 118,

126 ,

142-144

$115-116$

22 Unsuccessful revolutionary rising in Cuzco

23 Suit between Alejandro Garland and the Banco Anglo-Peruano

24 Opening of the Oroya line between Lima and Callao

28 Capitals of Banks established in Perú

28 Export Duty on Nitrate raised to 5o cents Arminius's monument near Detmold 
15 My visit to the Exhibition Park

17 Details about the Suez Canal

139-141

19 General Prado's arrival in Lima

23 General Silva, Inspector General of the Army, dismissed by President Pardo

24 Holck, a Dane, sent home

24 Pardo's new proposal to the four associated banks

28 Opening of the Congress

29 President Pardo's message

$$
[\ldots]
$$

5 Something about Post Offices and correspondence

7 General La Puerta made Vice President of Perú

16 Rafael Velarde is not qualified in the Chamber of Deputies

17 Juan Garland starts as clerk for the Lobos Islands

17 José F. Canevaro proclaimed $2^{\text {nd }}$ Vice President of Perú

20 Serious riot in Lima directed against Pardo

24 Supposed revenue of Perú for the two years

26 Resignation of Ministers Arenas and Benavides, La Cotera and La Rosa named in their stead

28 Loss of my lawsuit against Leyva in the Supreme Court

29 Something about telegraphs by land and under sea 
31 Rapid journey from New-York to San

Francisco by rail

September 5 The Finance Minister makes known that about $\$ 5,000,000$ due by Government on $2^{\text {nd }}$ August 1876 would not be paid for the present

Contract between J. G. Meiggs and Peruvian

Government for Bolivian Nitrate

Doña Angela Villena left us

10 Queen Victoria Empress of India

14 Tribunal de Alzadas abolished

16 The Empress Eugenie's influence brought on the Franco-German war

19 Contract for the building of my chapel in<smiles>[CH]1[CH]C=C1</smiles>

New revolutionary attempt of Pierola, see above

New system regarding the formation of the sun and planets

18 Statistics relative to Russia

23 Some particulars about Guano

29 Walk to the sugar estate of Villa

Arctic Expedition of Captain Nares, and return

November 6 The resignation of my Danish Consulship

6 Contract between Peruvian Government and Oliphant \& Co.

14 I fell ill with water in the knee

28 Departure of Dr. Palacios and Basagoytia for 
5 Seizure of the "Montezuma" by Leoncio

Prado

$7 \quad$ Census of Perú

8 Robbery committed by Dr. Casós in July $1872 \quad 25^{8}$

12 Crime committed by the Curate Diandéras 259

13 Dispute between C. W. Schutte and

G. Garland

260

Baron Hübner's voyage

Dispute between the Alcalde of the

Municipality and the Minister of the Interior

261-262

Mrs. Garland's dispute with the friars of San

Francisco

18 Birth of Guillermito Garland

263-264

21 Foundation [...]

[882]

$\begin{array}{llr} & {[\ldots]} & 2\left[\_\right] \\ 31 & \text { Geraldo's account of the Mikado of Japan } & 278\end{array}$

A.D. 1877

Meetings:

Insurance Company, "Lima”, 290, 304, 331, 356, 375-376, 407, 427, 473, 491, 509-510, 517

Banco Hipotecario, 301, 416-417

Banco del Perú, 309-310, 443-444, 532-533, 539

Banco de Lima, 310-311, 445, 454-455, 483-484, 508-509

Lima Gas Company, 353-354, 429-430, 437

Banco “La Providencia”, 398, 433-435, 443

Chilete Mining Company, 413, 422-423, 499-500, 513, 519

Deaths:

General Valle-Riestra, 280

Juan Martin Larrañaga, 290

Henry Swayne, 297 


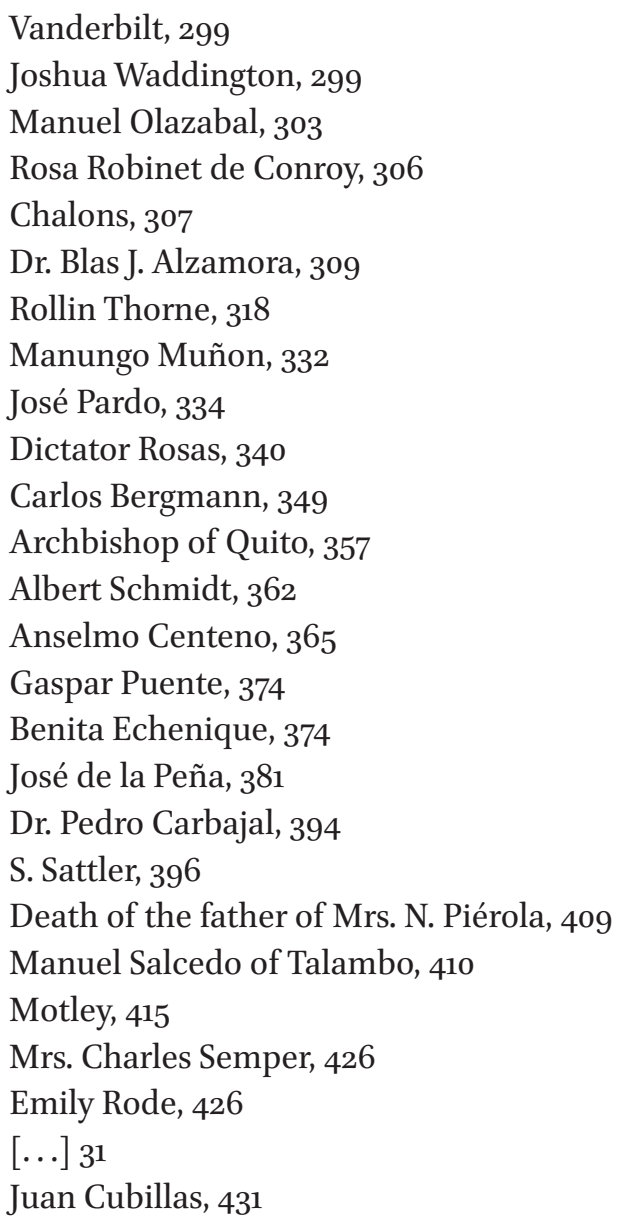

\section{Deaths:}

[_] sabel Loyola de Caravedo, 436

Louis III, Grand Duke [_] Hesse Darmstadt, 470

General Steinmitz, 471

Adolphe Thiers, 475

Brigham Young, 479

Captain Semmes, 480

Henry Meiggs, 484

J. R. Mendivil, 488

Villafañe, 488

Pinto's son, 501

J. M. Costas, 512

Caroline Baur, 522 


\begin{tabular}{|c|c|c|c|}
\hline & & $\begin{array}{l}\text { Gordillo, } 530 \\
\text { Mrs. Charles Willink, } 53^{8}\end{array}$ & \\
\hline & & $\begin{array}{l}\text { Marriages: } \\
\text { Felipe Barreda Junr. with Amalia Bolivar, } 285 \\
\text { Carlos Ferreyros with Rosa Ayulo, } 303 \\
\text { Carlos Pividal with Victoria Soyer, } 340 \\
\text { Charles Cudlipp with the widow of Francisco } \\
360 \\
\text { Maria Pflücker with M. G. Cuadros, } 367 \\
\text { General Buendia's, 428-429 } \\
\text { Noël West with George Petrie's daughter, } 433 \\
\text { F. Umlauff with Señorita Igarza, } 473\end{array}$ & alderon, \\
\hline & & $\begin{array}{l}\text { Suit against Juan Aliaga y Puente, 449-454, } 456 \\
463,471-472,476-477,490-491,495,497,500 \text {, } \\
5^{20}, 5^{22}, 5^{28}, 539\end{array}$ & $\begin{array}{l}457,461 \\
515,519-\end{array}$ \\
\hline 1877 & & & \\
\hline January & 2 & Troubles in Mexico, and in Bolivia & 280 \\
\hline & 4 & $\begin{array}{l}\text { Baron Hübner's travels in Japan } \\
\text { in China }\end{array}$ & $\begin{array}{r}280-282 \\
288,290, \\
292-293\end{array}$ \\
\hline & 5 & $\begin{array}{l}\text { Return to Lima from Chorrillos, my infirm } \\
\text { knee not completely cured }\end{array}$ & 283 \\
\hline & 6 & Removal of my office to Mariquita's boudoir & 283 \\
\hline & 8 & $\begin{array}{l}\text { The Peruvian bondholders cast in their suit } \\
\text { against Dreyfus in England } \\
\text { and in France }\end{array}$ & $\begin{array}{r}284-285 \\
293-294 \\
401-402\end{array}$ \\
\hline & 9 & Juan Garland's return from Lobos Islands & 285 \\
\hline & 10 & Enrique and Carlos Cox & 286 \\
\hline & 12 & Stoppage of Luzarraga's firm in Guayaquil & 287 \\
\hline & & $\begin{array}{l}{[\ldots] \text { overnment for working of Cerro de }} \\
\text { Pasco mines }\end{array}$ & $287,2[-]$ \\
\hline & 14 & How I spent the time & 288 \\
\hline & 22 & $\begin{array}{l}\text { Stoppage of Luzarraga's firm in Guayaquil, } \\
\text { see } 12^{\text {th }} \text { January }\end{array}$ & \\
\hline & 22 & Stoppage of Manuel Quintana in London & 294 \\
\hline & 25 & Banco Anglo Peruano liquidates & 295 \\
\hline
\end{tabular}




\begin{tabular}{|c|c|c|c|}
\hline & 27 & Mahomet and his genealogy & 296 \\
\hline & 3 & State of the Banco de Lima & 302 \\
\hline January & 28 & $\begin{array}{l}\text { Assassination of French plenipotentiaries } \\
\text { at Rastadt }\end{array}$ & 297 \\
\hline \multirow[t]{18}{*}{ February } & 7 & Sketch of Robert von Mohl & 305 \\
\hline & 11 & I suffer from general debility & $307-309$ \\
\hline & 18 & Turkey, a constitutional Monarchy & 312 \\
\hline & 18 & Queen Victoria, Empress of India & 312 \\
\hline & 18 & Details relative to Sugar and Nitrate & $312-313$ \\
\hline & 18 & Details about Turkey & $313-314$ \\
\hline & 19 & Details about Chilete Silver Mine & 315 \\
\hline & 21 & Details about the Samoa Islands & 317 \\
\hline & 24 & Statistics relative to gold and silver & $318,3^{24-}$ \\
\hline & & & 325 \\
\hline & 26 & Two extraordinary decrees of Aranivar & $319-320$ \\
\hline & 26 & Shipwreck of the Bremen steamer & \\
\hline & & "Deutschland" & 321 \\
\hline & 26 & Unsuccessful plan to blow up the steamer & \\
\hline & & "Moselle" & 323 \\
\hline & 28 & $\begin{array}{l}\text { Dispute between the Municipality of Lima } \\
\text { and the Minister of the Interior }\end{array}$ & $\begin{array}{l}323-324 \\
328-329\end{array}$ \\
\hline & & & $334,343^{-}$ \\
\hline & & & 344,357 \\
\hline \multirow[t]{8}{*}{ March } & 4 & Hayes and Wheeler, President and Vice & \\
\hline & & President of the United States, respectively & 327 \\
\hline & 6 & Nares' Arctic Expedition & 329-330, \\
\hline & 6 & $\begin{array}{l}\text { Emissions of Bank Notes by the Compañia } \\
\text { de Obras Públicas }\end{array}$ & $\begin{array}{r}372 \\
328-329 \\
331,333 \\
336\end{array}$ \\
\hline & 7 & Partition of my wife's "gananciales" & $330-337$ \\
\hline & & between her three children & 341-343, \\
\hline & & & $354-355$ \\
\hline & 13 & New Pradista Municipality & 335 \\
\hline & & {$[\ldots]$} & \\
\hline$[-] \mathrm{ch}$ & 15 & $\begin{array}{l}\text { Middendorff proposes to try electric[_] on } \\
\text { my weak knee }\end{array}$ & $\begin{array}{l}335,337 \\
339-340 \\
343-344 \\
345-346\end{array}$ \\
\hline
\end{tabular}


15 Salitrera Barrenechea

18 Duchess of Berri

20 Disagreement between Schutte and

Garland relative to the latter's debt to the former

21 Contract between Oliphant \& Co. and the Government

30 Bishop Pedro de la Gasca

$31 \quad$ First mention made of Nitrate Certificates

[?] Epidemic in Lima

17 J. V. Oyague's new Guano contract for Cuba

20 Turco-Russian war

21 Pedro Bernales' defraudations and 364-367, bankruptcy

25 Fresh Dispute between the Minister and the 
Piérola's new revolutionary attempt, aided by the "Huascar"

10

Rising of the sea along the Coast and in Callao

[886]

[_]ay

June

17 Meeting of Lopez Hurtado's creditors

29 Mrs. Garland's law-suit against the [_]ing about the North American Civil War

$1\left[\_\right.$How I spent my time

20 Arrival in Lima of J. P. Sieveking

24 My will and that of Enriqueta

Franciscan friars in the Superior Court

30 Naval combat between the "Huascar" and the "Shah" and "Amethyst" and causes for the same

$31 \quad$ Failure of Bamberger, Castendyk \& Co.

$31 \quad$ Disturbances in Lima and Callao

1 Resignation of the Ministry

5 Unsuccessful attempts in favour of Manuel Pardo

$7 \quad$ New Ministry

17 Sequel of Garland's loan to Dr. F. Palacios

17 Manuel Pardo's departure

18 Corina Schutte's engagement to G. A. Schön

18 Johannes Bobertag's request for money

19 Discussion about the "Huascar" in the Chile Lower Chamber, and correspondence on the subject

19 Change in French Ministry

20 Turkish parliament
379-381, 384-388, $391,394^{-}$

395 ,

398-399,

402-403 381-382, 385-388,

$3[\ldots]$

383 383-384 389

392-394

395

397

399 ,

406-407, 410-412 400 400-401, 403 401 404-408, 418,420 , 436 408 412 412 412-413, 427 413

413-414, 418 $415-416$ 
21 Banco Hipotecario, on the subject of cédulas

416-417, transferred to Paris

$443,45^{2}$,

$524,530-$

531, 533

23 Meeting on the subject of exchange

418-419

24 Sentence of Supreme Court on Monk Pardini

419

26 Williams's contract with Government for building a Custom House in Iquique

26 Rise of the price of Gas in Lima [...] not carried out

426-427,

442

[887]

27 Attempt to arrest Manuel Pardo in [_]

$42[-]$,

$42[-]$

30 José Canevaro releases me from my

guarantee of Eten Railway bonds

423-424,

436,441

July

Henry Meiggs's proposal to issue fifteen million of soles in bank notes

424

A meeting of retailers in Le Male's

Commercial Rooms

425

$5 \quad$ Misunderstanding between Daza, President of, and San Roman, Peruvian Minister in

Bolivia

9 Drive to Chacra "Manzanilla"

427-428

430

11 Luis Oyague named Gerente of the Banco

Nacional

12 Interview between the President and the Gerentes of the four banks

14 J. Riva Agüero, Grand Cross of the order of Leopold

17 Difficulties arising from the issue of Meiggs's bank notes

18 Wreck of the Pacific Steam Navigation Company's Steamer "Eten"

437, 439, 440,446 , $45^{\circ}$

19 Entrance into Lima of "Los vencedores del Huascar" 


\begin{tabular}{|c|c|c|c|}
\hline & 23 & Corina Garland's birthday & \\
\hline & 24 & Differences in accounts between the & \\
\hline & & Peruvian Government and Dreyfus & 442,515 \\
\hline & 28 & Exhibition of pictures, etc. in "El palacio de & \\
\hline & & Exposicion" & $446,45^{2}$ \\
\hline & 28 & Laying of the first rails of the Tramway & 447 \\
\hline & 29 & "Procesion civica" & $447-448$ \\
\hline & 31 & Report drawn out by J. V. Oyague, Casimiro & \\
\hline & & Tudela and myself & $449-45^{0}$ \\
\hline August & 1 & $\begin{array}{l}\text { I present my first escrito in the suit against } \\
\text { Juan Aliaga y Puente [...] }\end{array}$ & \\
\hline [888] & & & \\
\hline [_]gust & & [...] ion of [_] John, New Brunswick, by fire & $45^{1}$ \\
\hline & 9 & $\begin{array}{l}\text { Murder of Hortencio Escobar by Enrique } \\
\text { Lopez }\end{array}$ & $456-457$ \\
\hline & 14 & $\begin{array}{l}\text { The Supreme Court sentences in favour of } \\
\text { Mrs. Garland in the suit against the friars of } \\
\text { San Francisco }\end{array}$ & \\
\hline & 15 & Alterations made round Lima & $459-460$ \\
\hline & 15 & $\begin{array}{l}\text { Rafael Velarde named "Superintendente" of } \\
\text { Callao Custom house }\end{array}$ & \\
\hline & 18 & $\begin{array}{l}\text { Decrees of the Government, which makes } \\
\text { itself responsible for fifteen millions of soles } \\
\text { in bank notes issued by the four banks, and } \\
\text { five millions, three hundred thousand by the } \\
\text { Compañia de Fomento, etc. }\end{array}$ & 462,464 \\
\hline & 19 & Maria Garland's birthday & 463 \\
\hline & 20 & $\begin{array}{l}\text { Meetings of "bajo" and "alto" Comercio on the } \\
\text { subject of the late decree of the Government }\end{array}$ & $\begin{array}{r}464-465 \\
469\end{array}$ \\
\hline & 23 & Arrest of some Piérolistas & $465-466$ \\
\hline September & 2 & $\begin{array}{l}\text { Pecuniary assistance rendered by me to my } \\
\text { niece }\end{array}$ & 471,488 \\
\hline & 2 & Enrique Garland, Danish Consul-General & 471,484 \\
\hline & 5 & $\begin{array}{l}\text { Alejandro gains his suit against the Banco } \\
\text { Garantizador }\end{array}$ & 472 \\
\hline & 6 & Arrest of J. M. Puente & 472,474 \\
\hline & 12 & Electioneering quarrels & $476-478$ \\
\hline & & & $\begin{array}{l}400,402, \\
484-485\end{array}$ \\
\hline & & & $491-496$ \\
\hline
\end{tabular}


13 Banco Garantizador institutes a "causa 476, 478, ordinaria” against Alejandro Garland $\quad 511,514-$

17 Arrival of Johannes Limpricht

19 Letters from Priscilla to Sabina in German

480-481, $[\ldots]$

485,492 481, 489,

[889]

[_]ber

28 Paraff's swindling transaction in [_]

$4[-]$

$30 \quad$ Burning of bank-notes

485,504 ,

520

October $1 \quad$ Sketch of Henry Meiggs's life

486-487

3 Funeral, etc. of Meiggs

487-489,

492

10 Railway from Mexico to Vera Cruz

491

12 The premises in the Convent of San

Francisco knocked down to Mrs. Garland

493

18

Arrival of Carlos Eggert

496

$21 \quad$ Elections

497-499,

501-503,

513-515,

517

Details regarding the Copper mines of

Canzas

500

25 Arrival of a Japanese vessel in London

501

$27 \quad$ Stoppage of Alexander Cross \& Co. of

Valparaiso

502

28

P. Gallagher and G. Elster start for San

Francisco to procure coolies

November 2 My visit to the pantheon

502-503

505

3 Discovery of the mortal remains of

Columbus

506

4

Differences between the Diplomatic Body and the Papal Delegate

4 How I spent my time

$507-508$

$7 \quad$ Sketch of Emilio Castelar's character

510

8 Another revolutionary attempt of Piérola's

511

19 Manuel Pardo chosen Senator 


\begin{tabular}{|c|c|c|c|}
\hline & \multirow[t]{2}{*}{20} & Banco de Lima liquidates with Directors as & \multirow[b]{2}{*}{$515-516$} \\
\hline & & liquidators & \\
\hline & 23 & $\begin{array}{l}\text { How the London Guano Company was } \\
\text { constituted }\end{array}$ & $517-518$ \\
\hline & \multirow[t]{2}{*}{30} & Banco Anglo-Peruano merges into Banco & \\
\hline & & Mercantil & $5^{20}$ \\
\hline \multirow[t]{4}{*}{ December } & 3 & Astronomer Leverrier's genius & $5^{21}$ \\
\hline & 3 & $\begin{array}{l}\text { Loss of Pacific Steam Navigation Company's } \\
\text { steamer "Atacama" }\end{array}$ & $5^{22}$ \\
\hline & 4 & Cleopatra's needle & 523 \\
\hline & 4 & Our removal to Chorrillos & $5^{23}$ \\
\hline \multicolumn{4}{|l|}{ [89o] } \\
\hline \multirow[t]{11}{*}{ [_]mber } & & $\begin{array}{l}{[\ldots] \text { ment of Congress of American }} \\
\text { Jurisconsuls }\end{array}$ & 526 \\
\hline & 13 & How I spent my time whilst in Chorrillos & $5^{27}$ \\
\hline & 14 & Disputes in Concejo Departamental & $5^{27-528}$ \\
\hline & & & $534-535$ \\
\hline & 20 & Details about Nitrate business & $531-532$ \\
\hline & 20 & $\begin{array}{l}\text { I chosen one of the Directors of the Banco } \\
\text { del Perú }\end{array}$ & 532 \\
\hline & 21 & Solution of Dr. Middendorff's puzzle & $533-534$ \\
\hline & 26 & Albrecht gains the suit against Cavada & $536-53^{8}$ \\
\hline & 30 & The premises in the Convent of San & \\
\hline & & Francisco must again be sold & 540 \\
\hline & 31 & Thunderstorm in Lima & 540 \\
\hline
\end{tabular}

A.D. 1878

Meetings:

Insurance Company, "Lima”, 542-543, 564-565, 587, 612, $643,667,691,714-715,742,758,783-784$

Banco del Perú, 547, 557-558, 560, 566-567, 574-575, 577-578, 580-581, 597, 604-6o7, 611-612, 629-631, 641, 649, 653-655, 665-668, 681-682, 696-698, 700-701, 705706, 713, 717-718, 722-723, 741-742, 744-745, 749, 755-756, 759-76o, 772-773, 775, 781, 799, 800, 810 Banco Hipotecario, 549-550, 565-566, 570-571, 580, 591, $597,606,613,618-619,637,648-649,65^{2}-653,655-661$, 666-668, 675, 684, 693, 695, 704, 712, 715-716, 722, 729-730, 733-734, 738, 741, 747, 752, 755-756, 763, 769, $774,777,802-803,807,809,811,817,824$ 
Water Company, 6oo, $65^{\circ}$

Lima Gas Company, 636

Banco "La Providencia", 692

[891]

$[\ldots]$

[_]ustin Edwards, 543

Admiral [...] son, 54[_]

Guillermo Pfeiffer, 545

Dr. Domingo Mendoza, 545

Osman Pacha, 548

Victor Emanuel, King of Italy, 549

General Aparicio, $55^{2}$

Colonel Juan Salaverry, $55^{2}$

Antonio Bazo, 554

Schwank, 56o-561

Camogli, 567

Enriqueta Elespuru, 569

Pope Pius IX, 569

Count Palikao, 570

Dr. Bravo, 579

General La Fuente, 589

George Cruickshank, 590

Mrs. John Hayne, 610

Hermann Schwartz, 610

Mrs. Ponce, 617

Mrs. Charles Pflücker, 622

George Rodger, 635

Clementina Frias, 644

Paula Zavalaga, 659

Rosa Zevallos, 669

Federico Ri[g]los, 674

Earl John Russell, 675

Pedro Correa y Garay, 684

Mercedes, Queen of Spain, 685

Maria, natural daughter of Rafael Velarde, 689

King George V of Hanover, 692

Mariano Velarde y Alvarez, 713

Mrs. Manuel Costas, 733

Cristina, ex Queen of Spain, 735

Pedro Galvez, 735

Henry Sieveking, 737 
Theodore Hugues, 737

Julian Zaracondegui, 745

Dr. Piedrahita, 746

Andrés A. Calderon, 748

Mrs. Arthur Donner, 756

Nobeling, 761

Charles Higginson, 771

Doña Carmen Lopez-Aldana, 771

Tomás Mosquera, 775

Petermann the geographer, 779

Dupanloup, Bishop of Orleans, 779

Manuel Argumaniz, 810

Princess Alice, 817

Marriages:

Alfonso, King of Spain with his cousin Mercedes, 573

A. Brierley with Miss Schaum, 694

George Batchelor with Catherine Guérin, 719-720

Enrique Barreda with Amalia Laos, $75^{1}$

Alfredo Benavides with Maria Canseco, 762

Focion Mariategui with a Señorita Ausejo, 812

Uriburu with Leonor Pinto, 815

[892]

$[\ldots]$ 745, [_] $75^{2}, 768,773,786,809,821$

My suit against Juan Aliaga y Puente, 554, 559, 563-564, 568-569, 571-574, 581-582, 628-629, 663, 665, 672-673, 686, 693, 698-699, 717, 733, 749-751, 762, 764, 766, 776, $782,806,814,824-825,827$

Mr. C. W. Schutte's bad state of health: $722,726,786,800$

1878

January

Republican Ministry in France

540-541

Burning of Bank Notes

541 ,

$636-637$,

663,685 ,

722 ,

726-727,

739,755

Accident which befell Juan Garland 
6 B. Aranivar's rancho in Chorrillos

10 My wife's portrait received from Corina

Schutte

18 Arrangement between Government and Banco de Lima

24 Return from Chorrillos to Lima

27 Municipality orders corpses to be conveyed direct to the Pantheon Results of Lima and South American Insurance Companies compared import duty $[\ldots]$

Antonio leaves for [...]

5 Disputes between Government and Dreyfus $560-562$ about accounts

$562,670^{-}$ Marcone's debt to Banco Hipotecario

18 Probabilities of peace between Turkey and Russia

18 Cleopatra's needle

18 Gallagher's and Elster's return from San Francisco

20 Theft [c]ommitted in Banco Mercantil by Daniel Dorado 


\begin{tabular}{|c|c|c|c|}
\hline March & 3 & Diego Masias’s opinion on Guano & $5^{8}$ \\
\hline & 4 & Some particulars of the civil war in North & \\
\hline & & America & $583-584$ \\
\hline & 5 & Juan Bazo's debt to C. W. Schutte & 584,59 \\
\hline & 7 & Progress of the use of the telephone & 586,59 \\
\hline & & & $607,6 c$ \\
\hline & 9 & J. M. Cardenas's temporary derangement & $588-58$ \\
\hline & 12 & Ascents of San Cristoval & $590-59$ \\
\hline & & & 603,64 \\
\hline & & & 761,81 \\
\hline & 14 & Peace signed between Turkey and Russia & \\
\hline & 14 & Subterranean electric Telegraphs & \\
\hline & 15 & Evaristo Barrios wished me to retire from & $592-59$ \\
\hline & 15 & the Directorship of the Banco Hipotecario & $\begin{array}{l}59 z^{-5} 5 \\
597,65\end{array}$ \\
\hline & 16 & Garland recommences his rocambor parties & \\
\hline & $16 / 17$ & Sleepless night, and annoyances of which & \\
\hline & & details are not given & \\
\hline & 18 & Nitrate accounts & $594-5$ \\
\hline & 20 & Annual income of Mackie the North & \\
\hline & & American & \\
\hline & 20 & Enriqueta places her two daughters in the & \\
\hline & & college of the Sagrado $[\ldots]$ & \\
\hline [894] & & & \\
\hline [_] $\mathrm{ch}$ & 22 & [_]ssination of Monteagudo & \\
\hline & 23 & Departure of Frederick Elmore for China & \\
\hline & 23 & Le Male, a Frenchman & $600-6$ \\
\hline & 24 & Diminution of my fortune & $601-6$ \\
\hline & 25 & Completion of Lima tramway & $603-6 c$ \\
\hline & 27 & The United States recommence the coinage & \\
\hline & & of silver dollars & \\
\hline & 31 & Construction of Tay Bridge & \\
\hline & 31 & Improvements in Vienna, and production of & \\
\hline & & Coal & $607-60$ \\
\hline April & 1 & Examination of the cash and accounts of the & $609-61$ \\
\hline & & Banco del Perú & \\
\hline & 3 & Sales to Charles Watson of Cerro de Pasco & \\
\hline & & Railway Shares and Bonds & \\
\hline
\end{tabular}


$3 \quad$ Fatal accident in the Grand Hotel of Paris

611-612,

616

$4 \quad$ Unsuccessful attempt to rob Mr. Young in Miraflores

612-613

$7 \quad$ Friendly arrangement between Raphael and

614 Dreyfus as to the sale of Guano

$619-620$

$9 \quad$ Sale of my shares in Chilete Mining Company

Redress obtained for the insult offered to

Eisenstuck, German Consul in Nicaragua

18 Suspension and resumption of Cash

payments by the Bank of England, 1797 to 1823

Departure for Europe of [...] J. Aranivar and others

28 Transit of the planet "Mercury" across the disc of the sun

28 Paris Exhibition

29 Supposed attempt at revolution

7 Reduc[tio]n of "patente" from \$10oo to $\$ 608$ annually

10 Treaty of San Stefano between Russia and Turkey

12 The Prussian law makes no distinction in persons

17 State of Lima Water Company 


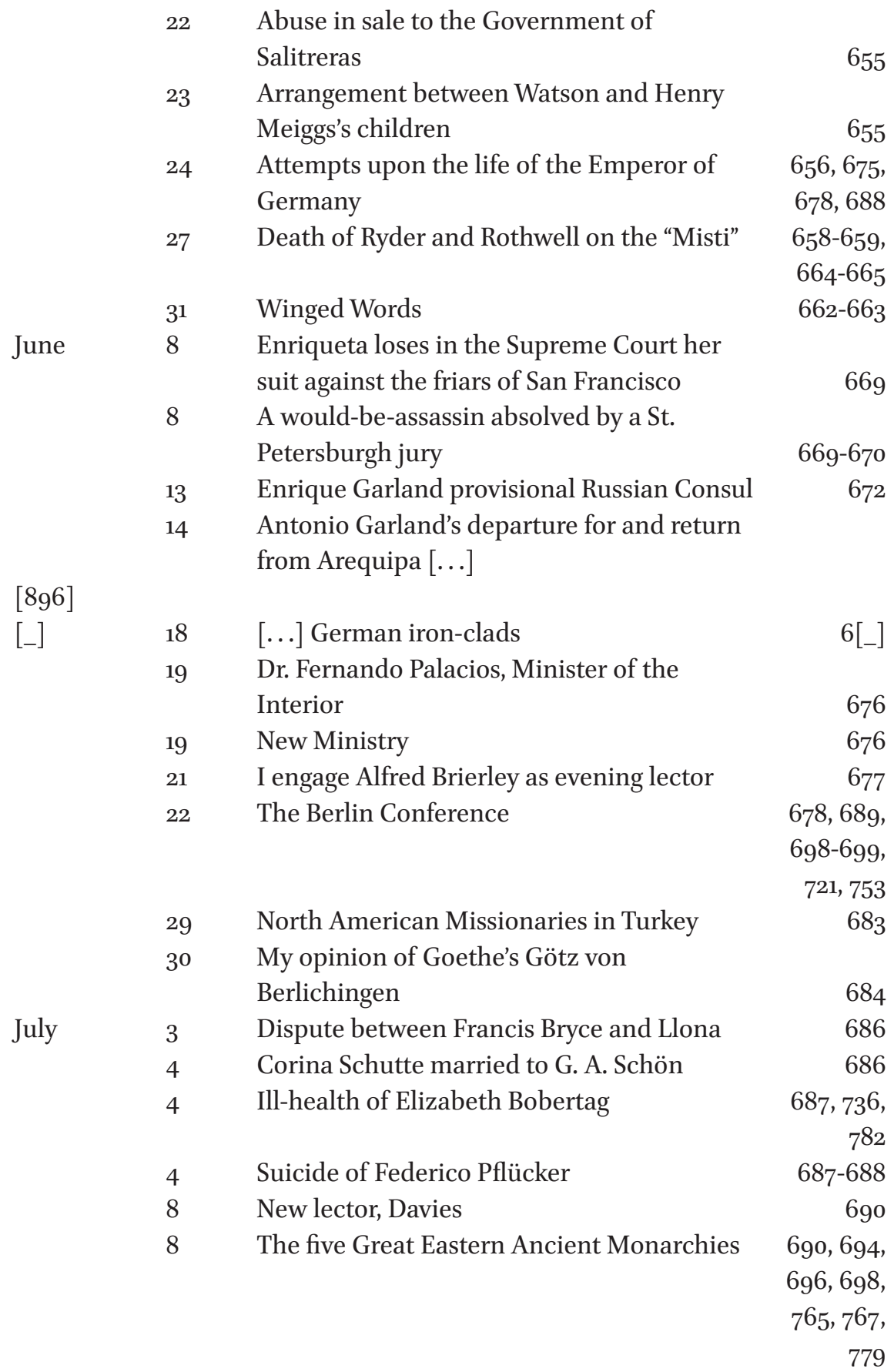


22 Meeting on the subject of Nitrate

Certificates

23 Corina's birthday, Children's concert

23 Manuel Pardo, Senator for Junin, and

26 Diplomatic Body cedes precedence to Papal

Delegate

706

28 Schism amongst the Mussulmans

706-707

28 Opening of the Congress

[...] England

I close my account $[. .$.$] de Lima$

9 Expiatory monument to be erected in London

10 Island of Cyprus taken possession of by the English

15 J. R. Izcue Superintendente of Callao Custom House in the place of Rafael Velarde

17 Nobeling's attempt to assassinate the Emperor of Germany

18 Prefect of Puno declares for Piérola

19 B. Leon Vocal of the Supreme Court in place of M. Cossio 
27 Members of the German Reichstag

734

28 Rafael Velarde, Government's interventor in the Compañia Salitrera

Pecuniary assistance rendered to E. Bobertag

Manuel Pardo's arrival from Chile

State of Peruvian Finances

Alejandro Garland's purchase of the Copper Mines of Canzas, and Guillermo Garland's departure thither

[...] of Mariquita's mortal remains from the niche to the sarcophagus in the Chapel

Watson

7 Collision between two steamers on the "Thames"

19 A. Garland's project relative to Banco Hipotecario

765 $765-766$ 768-769, 773-774, 811,817 ,

26 Bruno Bueno, Minister of the Interior, J. R. Izcue, of Finance 
9 Walks and drives to my Chapel in the

785,788 , Pantheon

795,799 ,

804,808 ,

811,818 ,

820

12 My opinion of "Daniel Deronda"

787

16 Assassination, etc. of Manuel Pardo

788-799,

802,804 ,

813

24 Sale of diamond necklace

800

24 Attempts to kill the Kings of Spain and Italy

801,813

24 War with Afghanistan

801,812 ,

825

25 Attempt to reconcile the Civilistas and [...]

802-804

[899]

[_]er

27

Giordani Bruno

[_]mber

Pierola's revolutionary attempt

[-]

806,809

6

Manuel Pardo's debt to Banco Hipotecario

807,809

14 Failures of Oliphant \& Co. of Canton, Pustau

\& Co. of Hamburg, and Donner \& Co. of

London

812

814

18 New Peruvian Ministry

818

26 Departure of Mr. and Mrs. Federico Palacios

for Europe

824

29 Duel between Arturo Derteano and Pedro

Gallagher

826

A.D. 1879. From $7^{\text {st }}$ January to $12^{\text {th }}$ March

inclusive

Meetings:

Insurance Company, “Lima”, 831-832, 837, 854, 868, 873

Banco del Perú, 835

Banco Hipotecario, 835-836, 843, 849-851, 853-854,

$857-858,864,866,873-874$

Lima Gas Company, 840-841

South American Insurance Company, 841-842

Water Company, 844

Banco de Lima, 846-847 


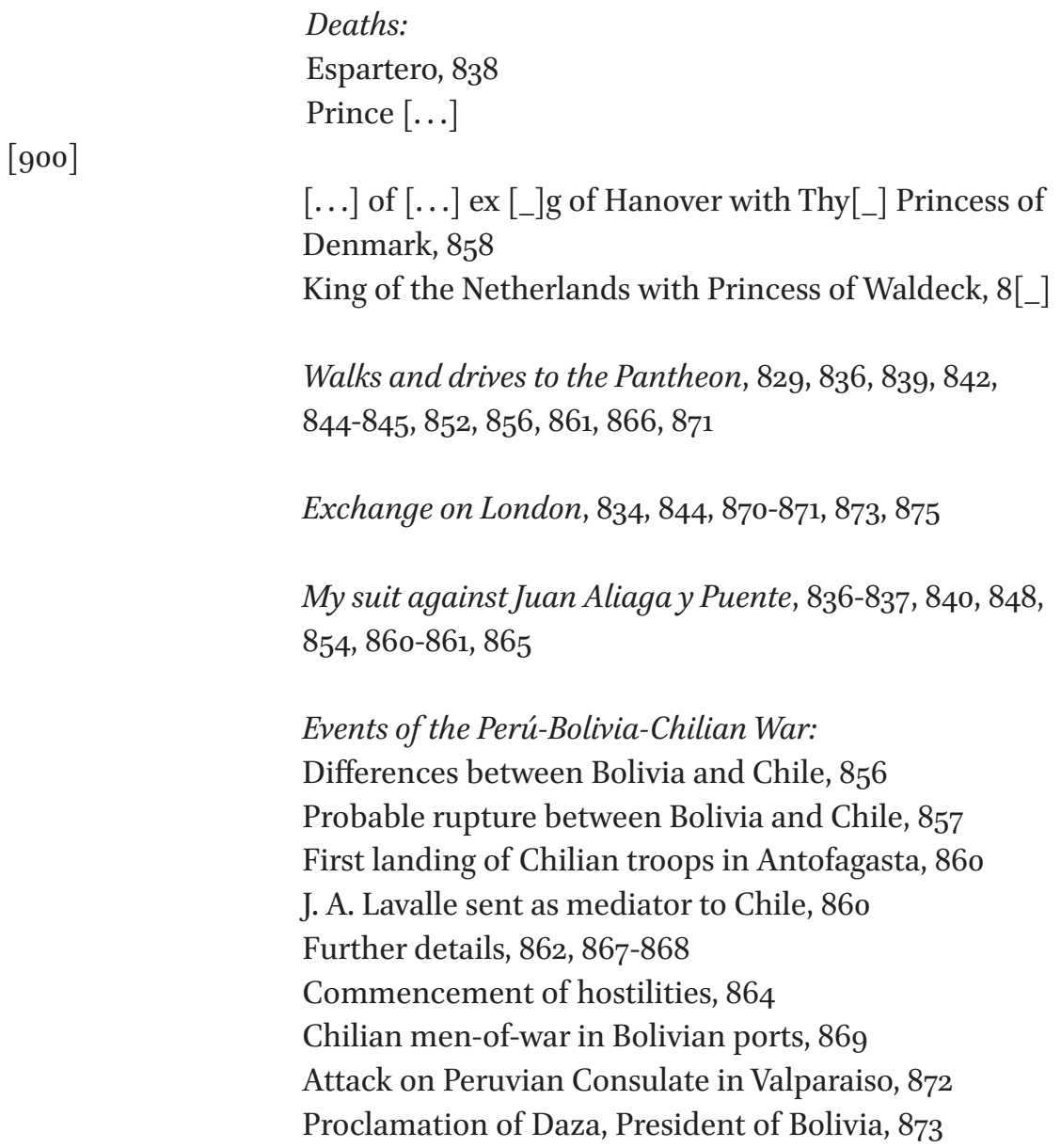

Deaths:

Espartero, 838

Prince $[\ldots]$

[900]

[...] of [...] ex [_]g of Hanover with Thy[_] Princess of Denmark, 858

King of the Netherlands with Princess of Waldeck, 8[_]

Walks and drives to the Pantheon, 829, 836, 839, 842, $844-845,852,856,861,866,871$

Exchange on London, 834, 844, 870-871, 873, 875

My suit against Juan Aliaga y Puente, 836-837, 840, 848, 854, 860-861, 865

Events of the Perú-Bolivia-Chilian War:

Differences between Bolivia and Chile, 856

Probable rupture between Bolivia and Chile, 857

First landing of Chilian troops in Antofagasta, 860

J. A. Lavalle sent as mediator to Chile, 860

Further details, 862, 867-868

Commencement of hostilities, 864

Chilian men-of-war in Bolivian ports, 869

Attack on Peruvian Consulate in Valparaiso, 872

Proclamation of Daza, President of Bolivia, 873

1879

January

Miserable commencement of the new year

828-829

Something about Guano

829

New-year's visits

$830-831$

New-year's visits, concluded

833

838

13 First shipment of Chilian Nitrate

15 Closure of Lima Concejos Departamental

and Provincial

838

17 War with Afghanistan

18 Assassins of Manuel Pardo

839,872

839,867 
$26 \quad$ State of Peruvian Finances

$842-843$

[901]

[_]y

3 Sundry laws:

S100,00o to be paid to Mrs. Pardo

$845^{-846}$

Old bank notes to be exchanged for

Government notes

846

Pardo's mausoleum and statue

A new impost, for cancelling bank notes

848-849

$85^{2}$

$5 \quad$ Closure of Congress

848

5 Grévy, President of French Republic in lieu of Mac Mahon

849,860

12 Claim of Peruvian Government against Thomson, Bonar \& Co. compounded

$854-855$,

$861-862$

16 Defeat of the English in South Africa

$856-857$

21 Arrival of Prince Henry of Prussia in the 859,861 ,

"Adalbert", entertainments, etc.

$863,865^{-}$

866,868

March 4 Ports on the Coast of Perú, Bolivia and

Chile

869

$5 \quad$ Piérola's arrival in Santiago de Chile

869

$9 \quad$ Plague in Southern Russia

872 


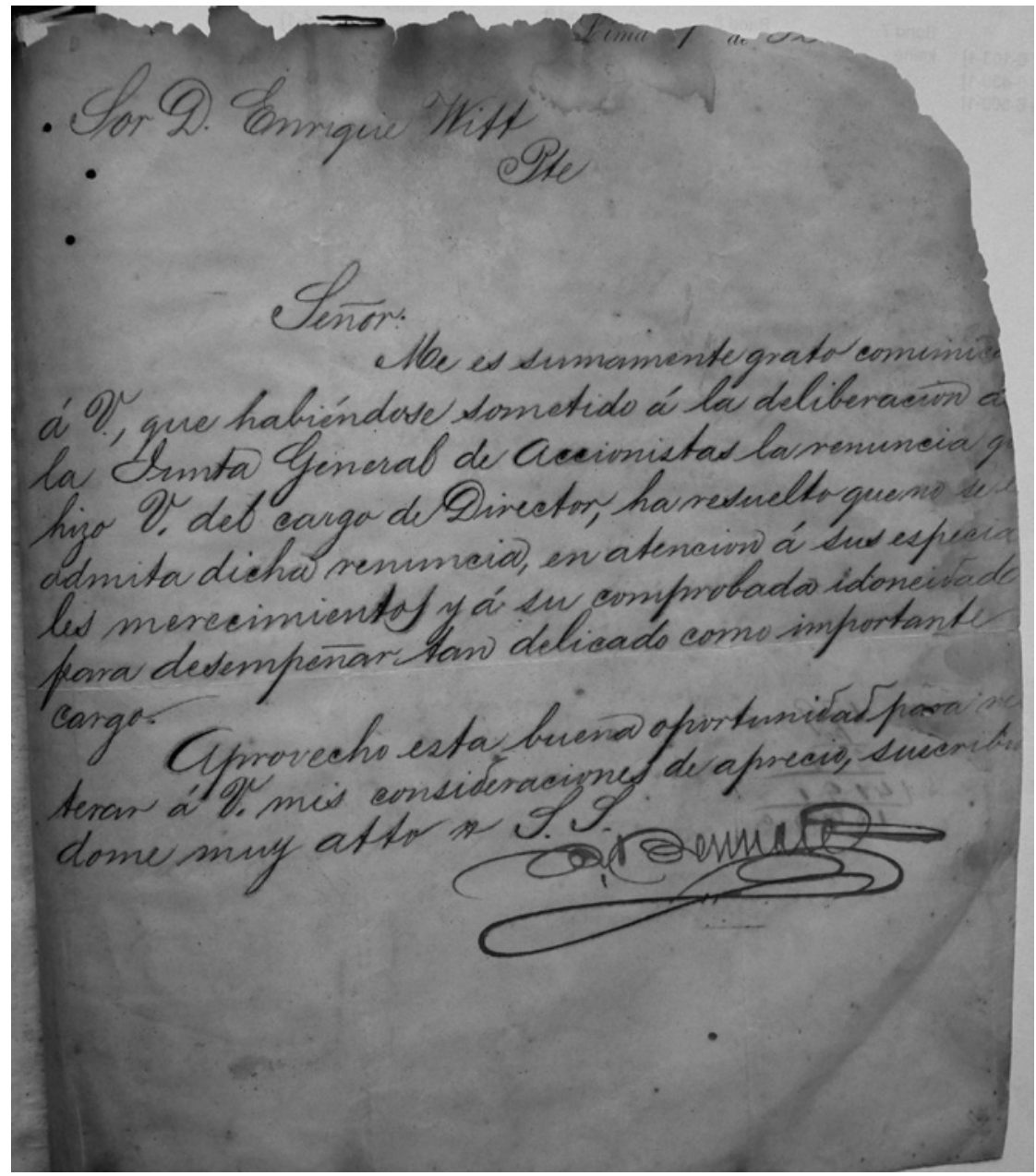

A-8-1. OA-8-1-1 


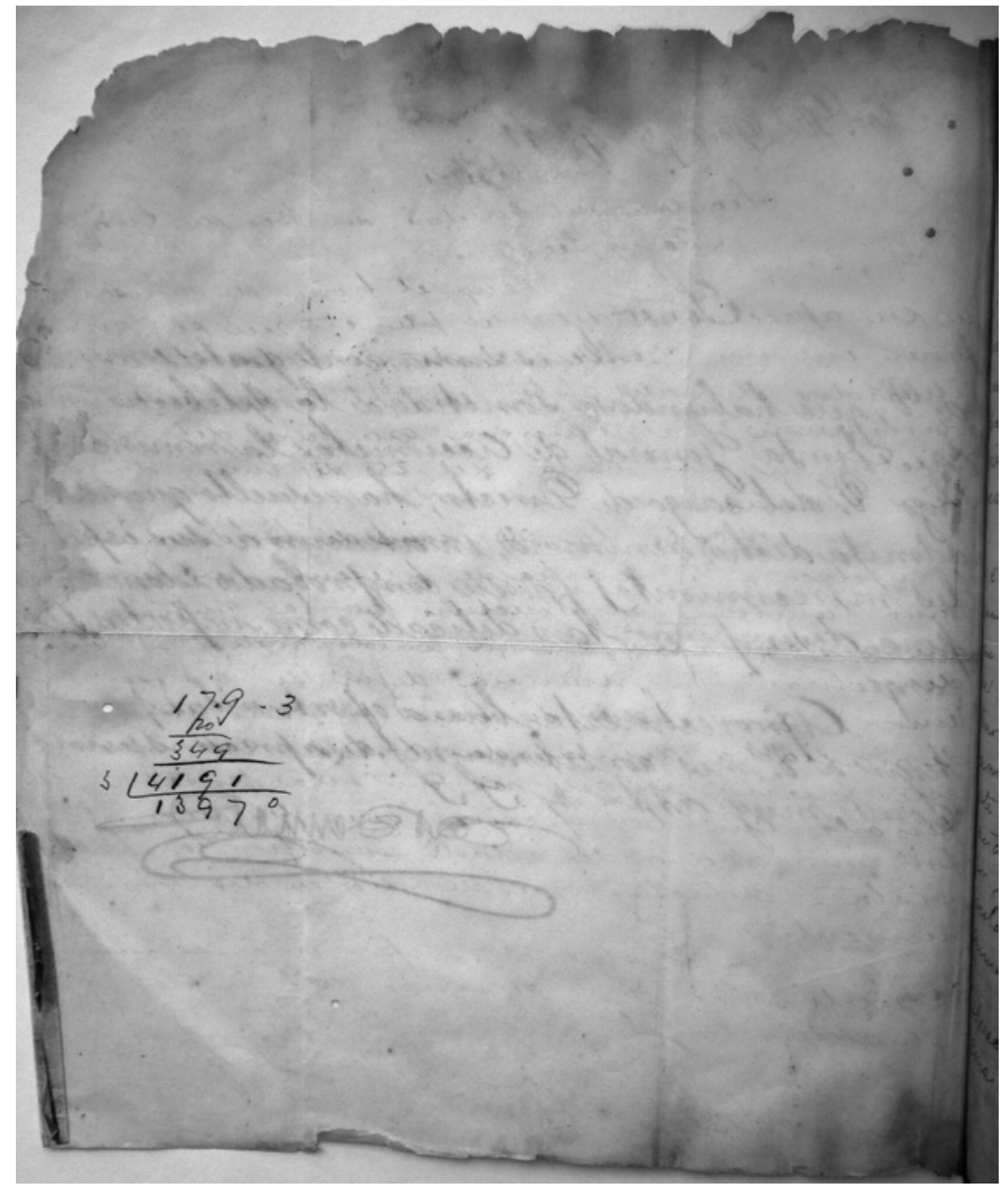

A-8-2. OA-8-1-2 


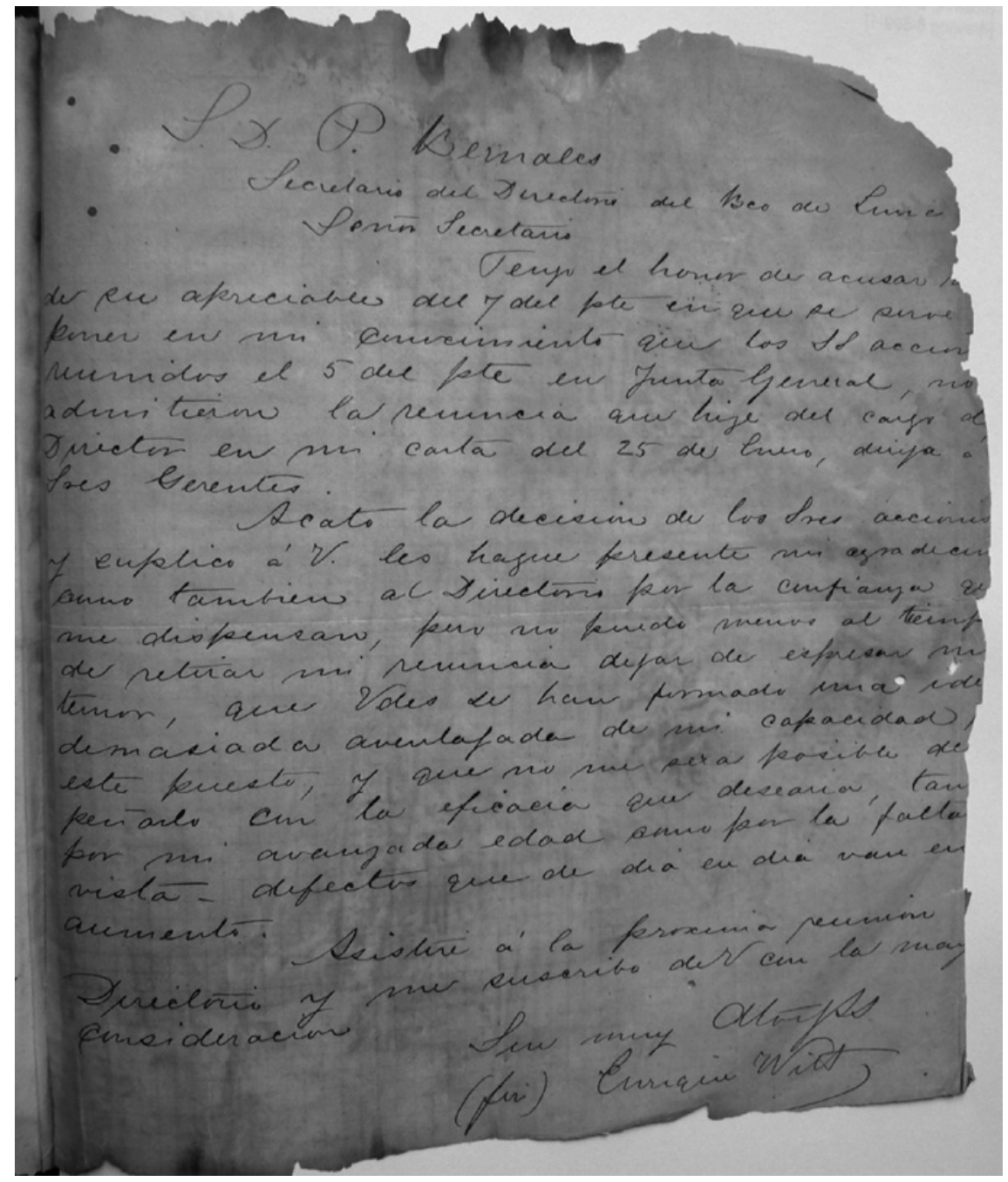

A-8-3. OA-8-2-1 


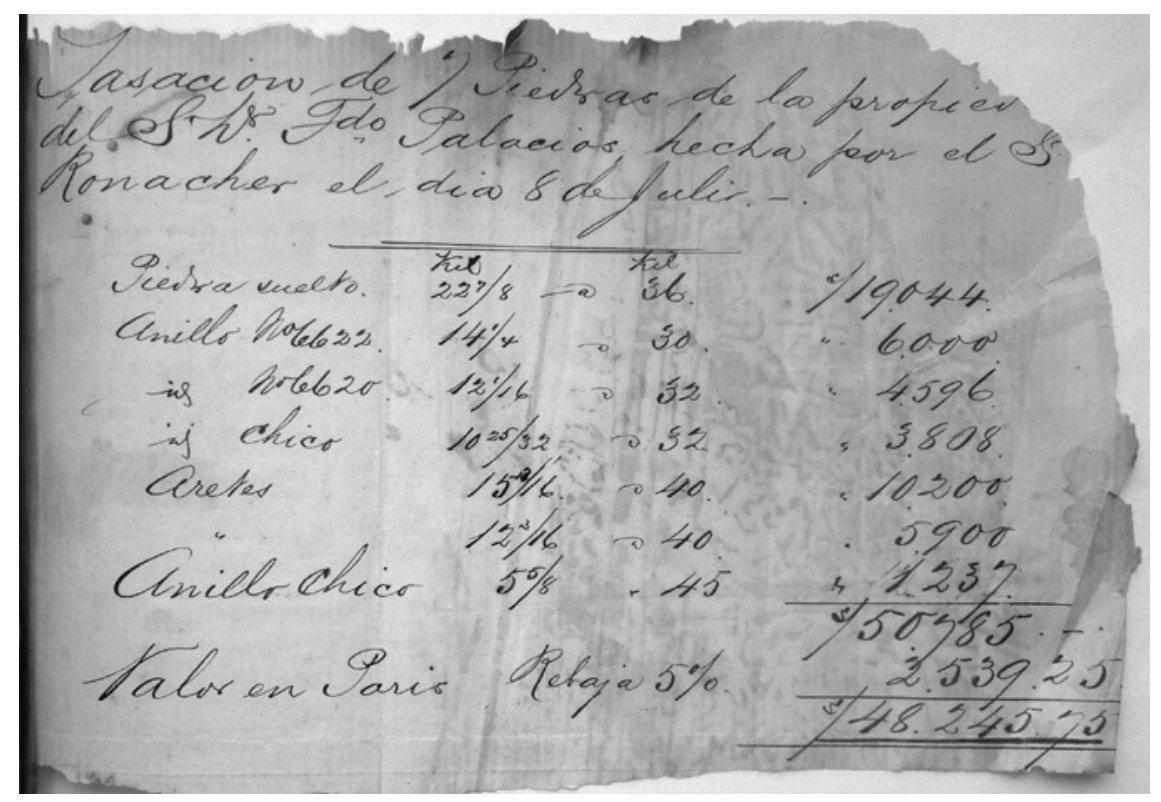

A-8-4. OA-8-6-1 


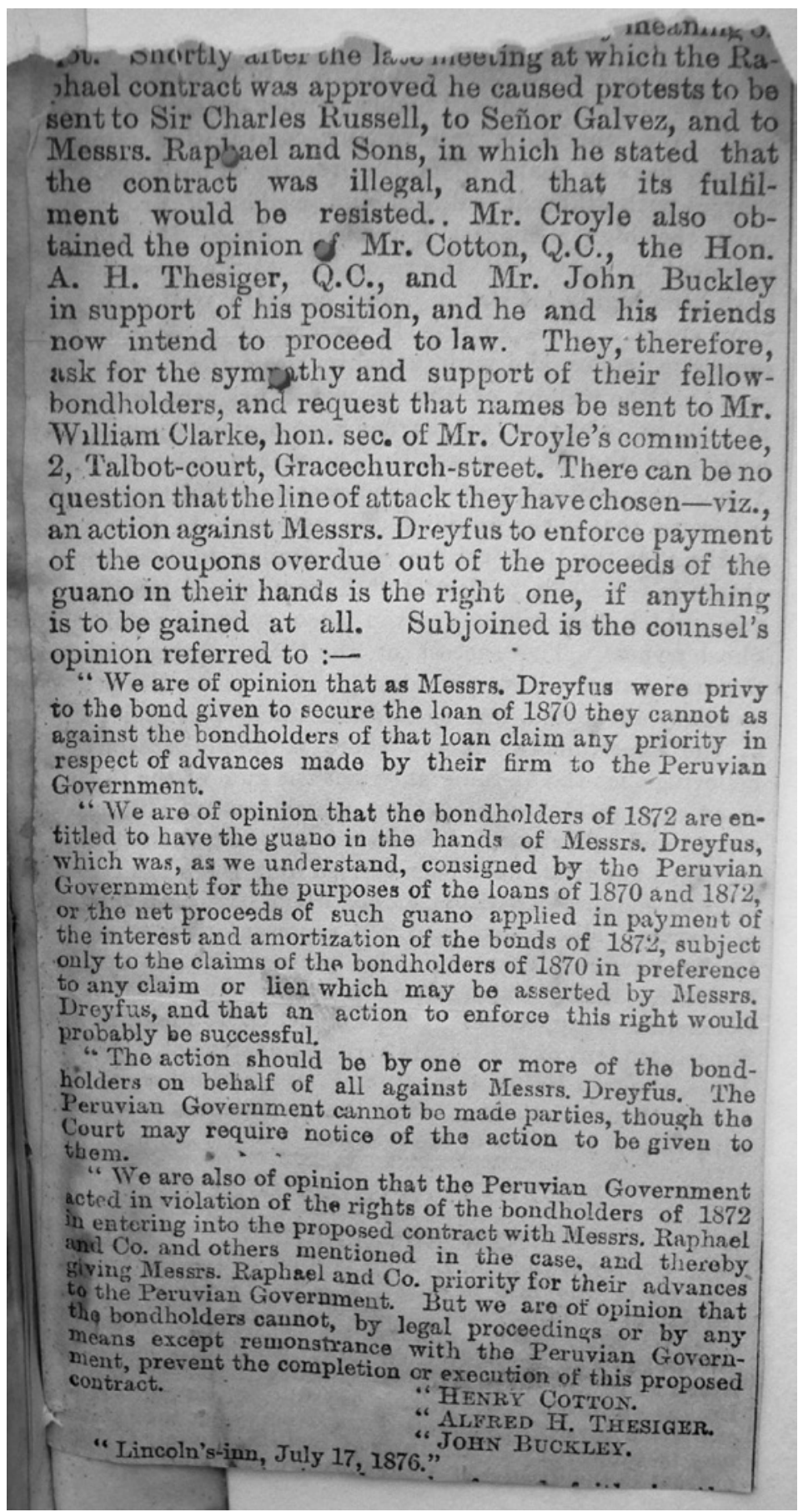

A-8-5. OA-8-7-1 


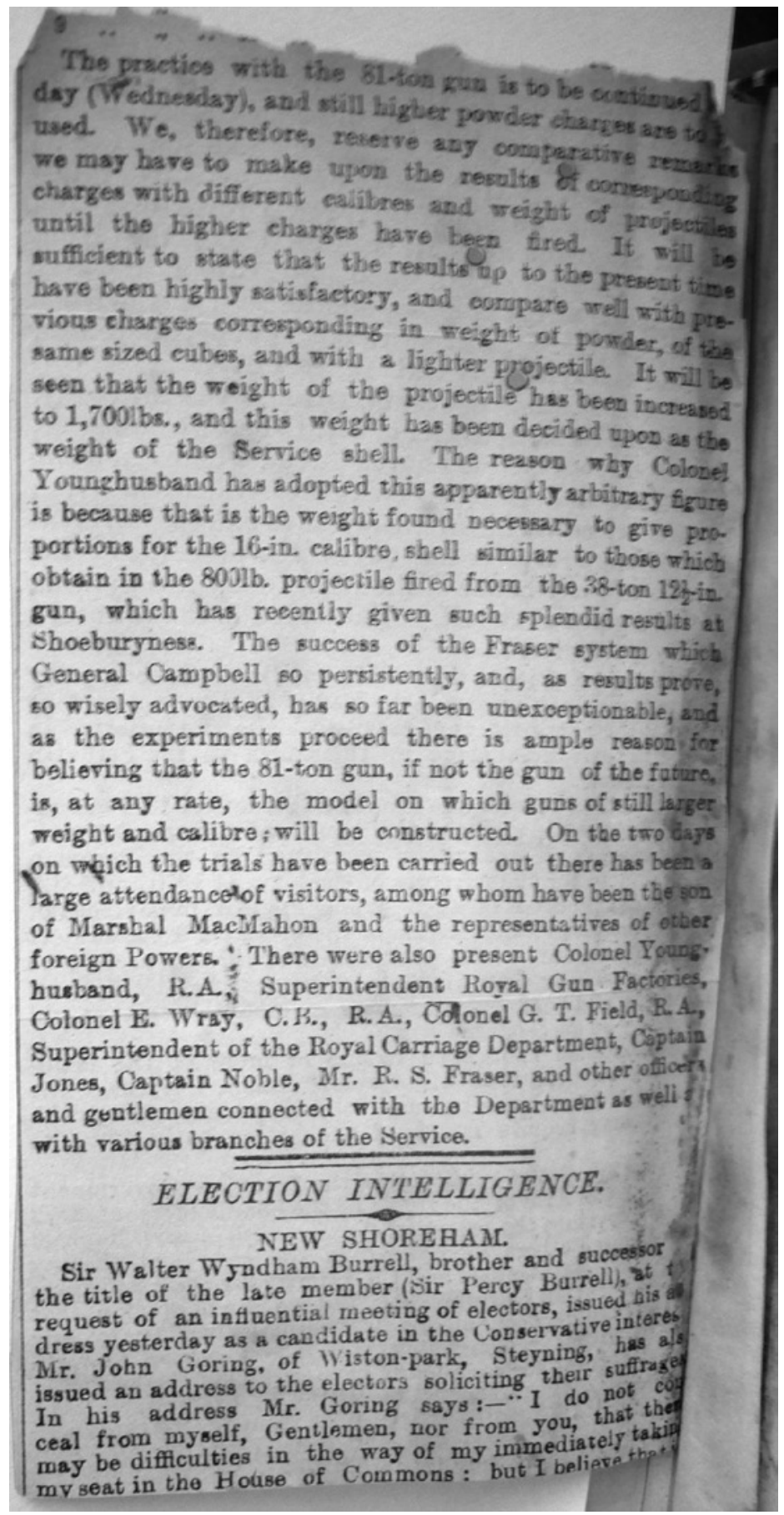

A-8-6. OA-8-7-2 


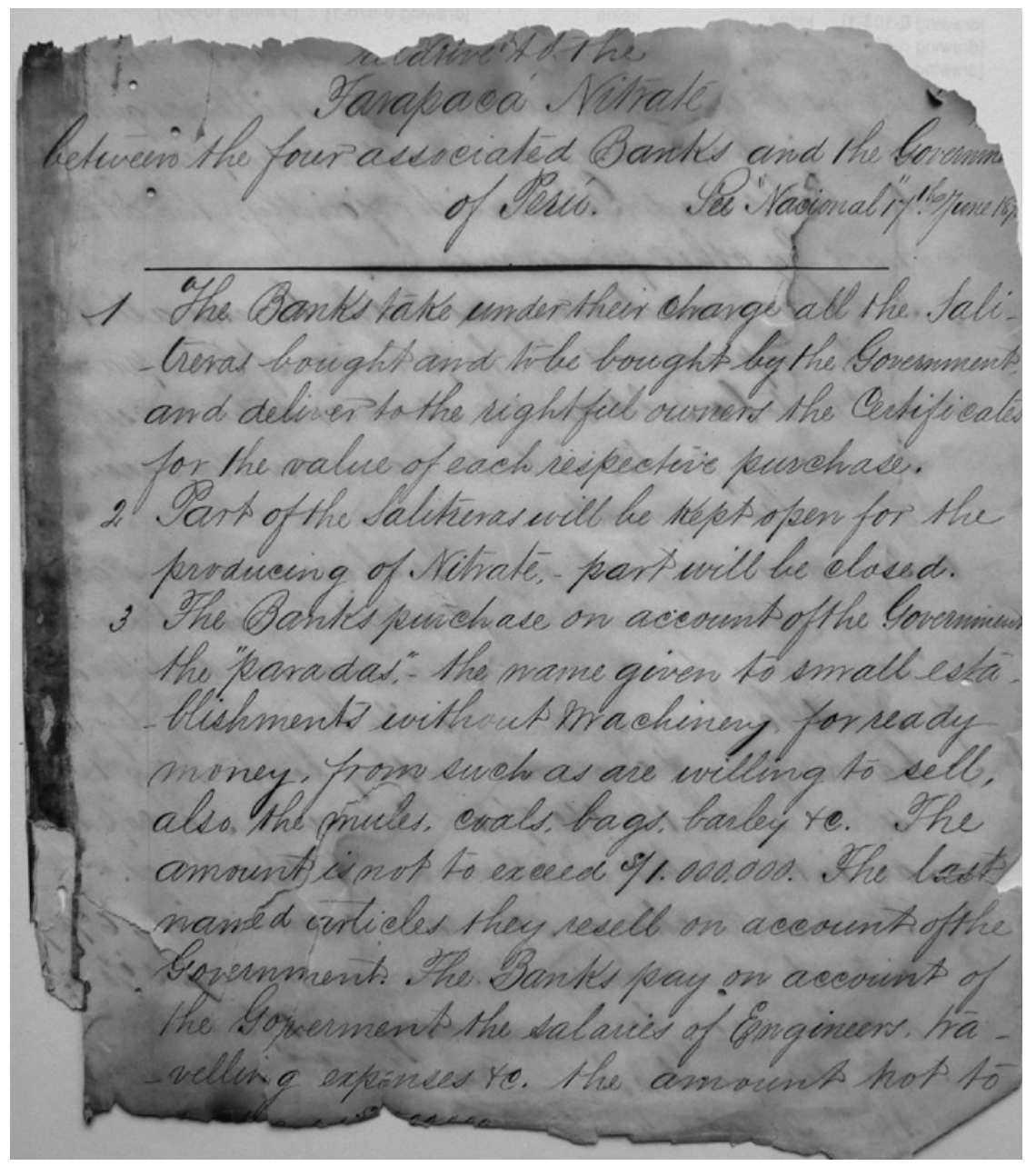

A-8-7. OA-8-9-1 


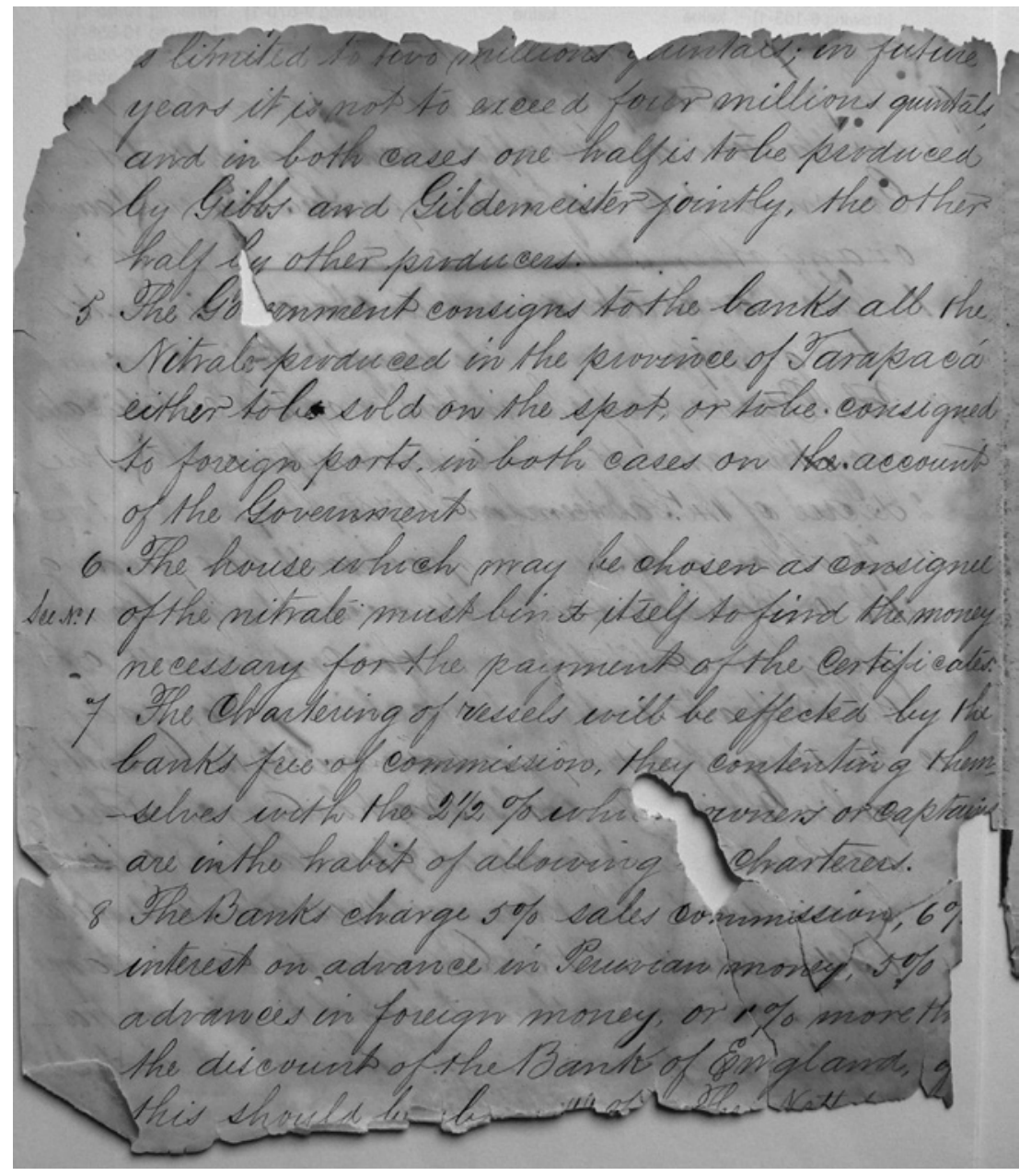

A-8-8. OA-8-9-2 


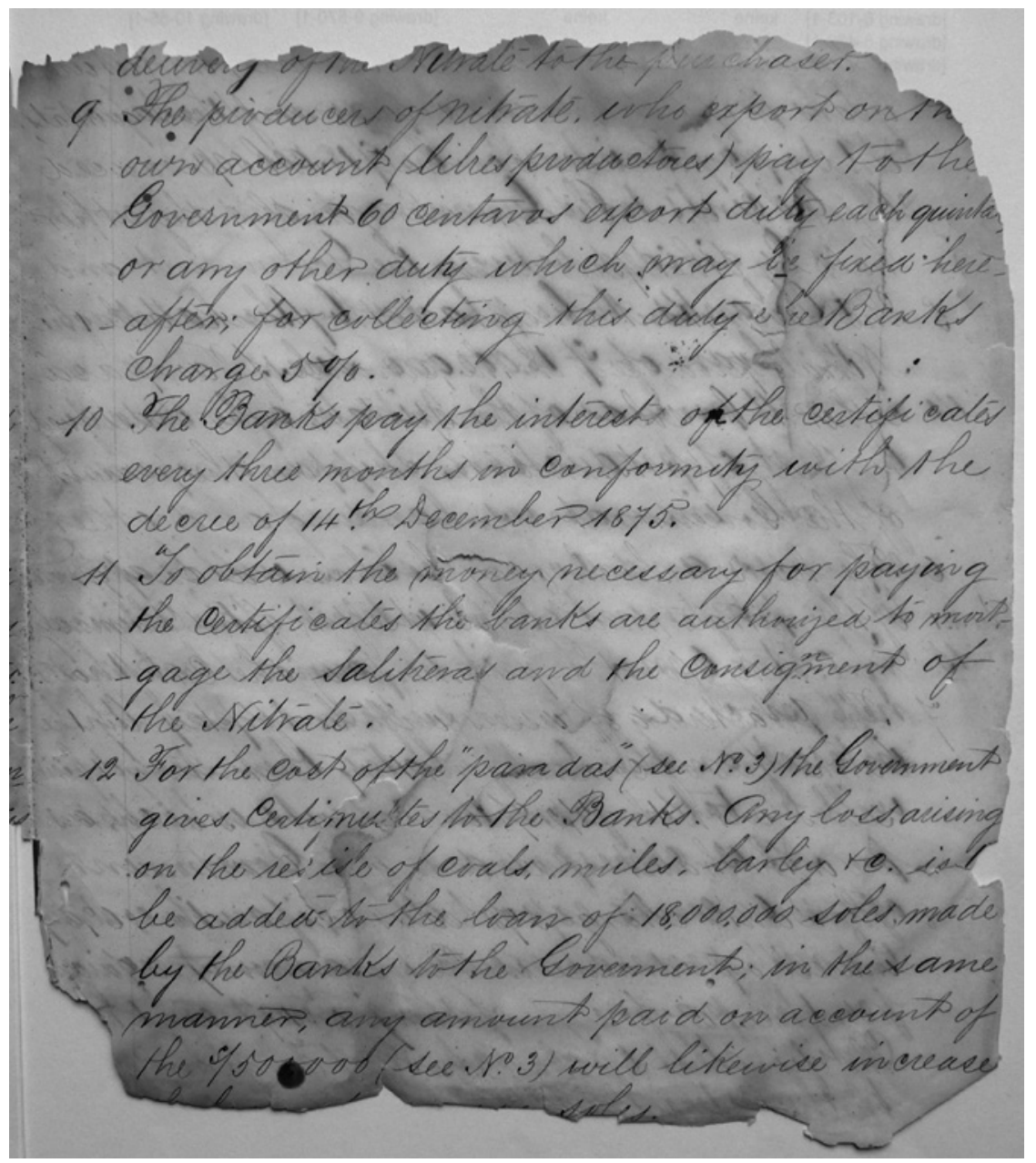

A-8-9. OA-8-9-3 


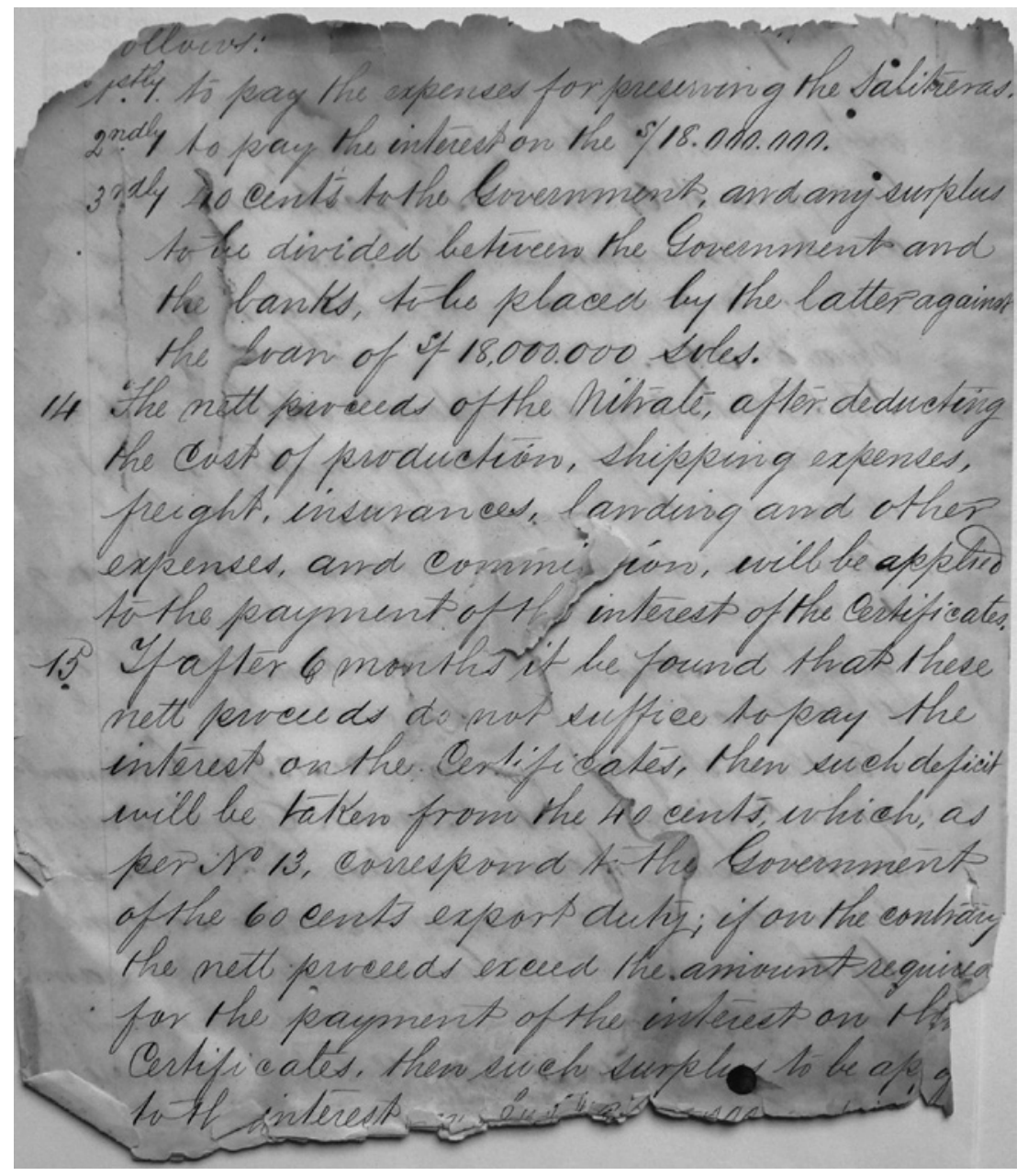

A-8-10. OA-8-9-4 


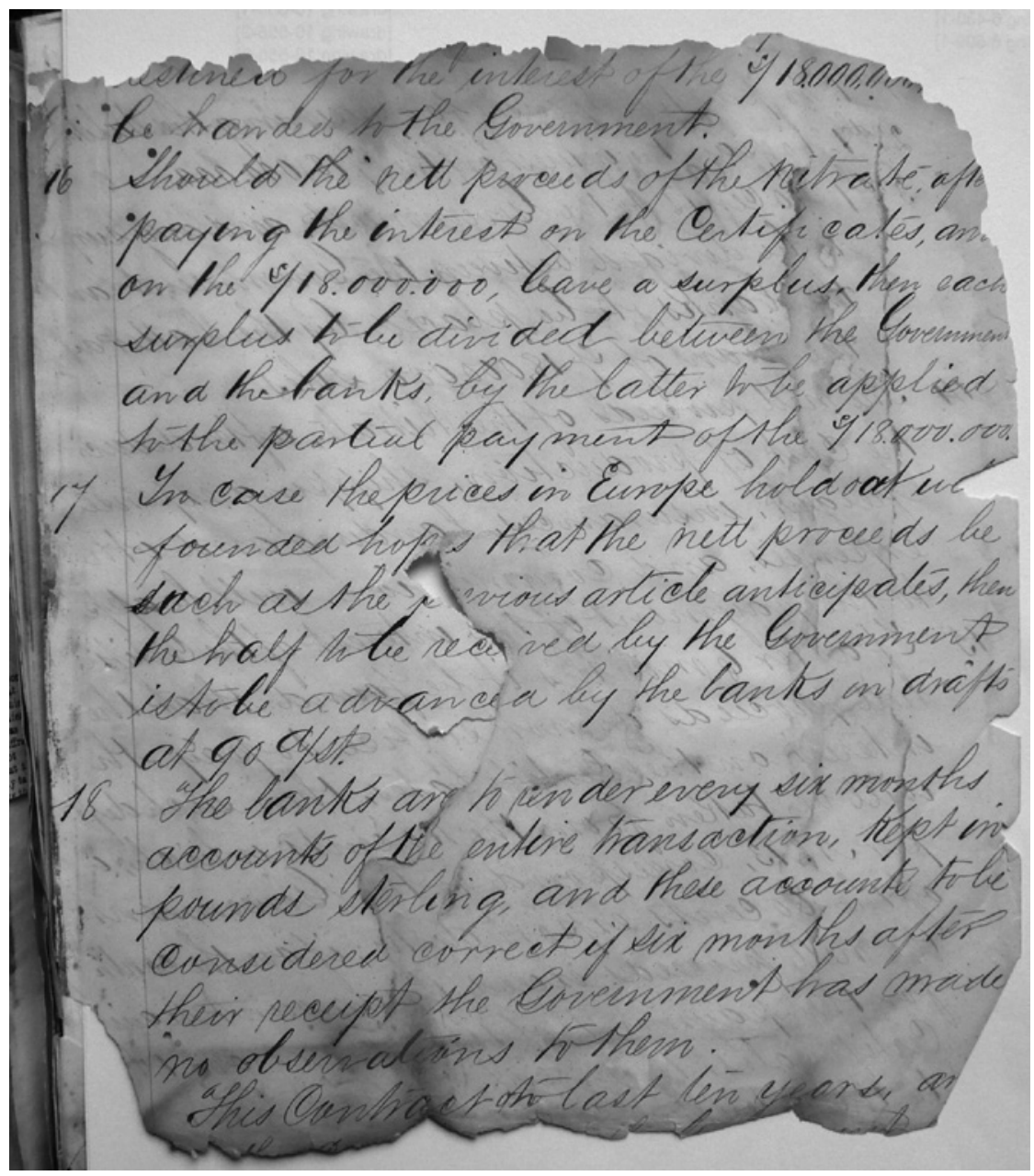

A-8-11. OA-8-9-5 


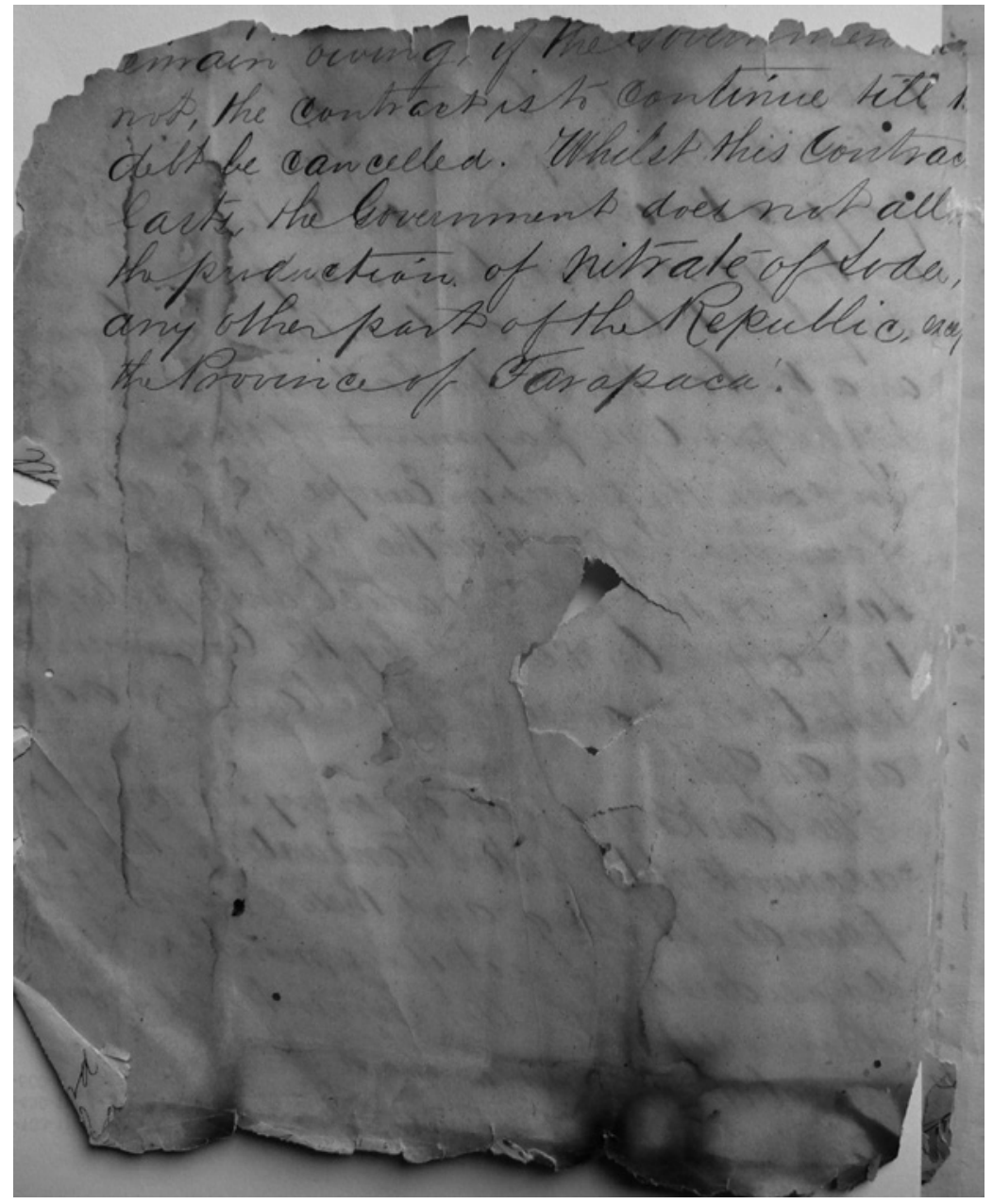

A-8-12. OA-8-9-6 